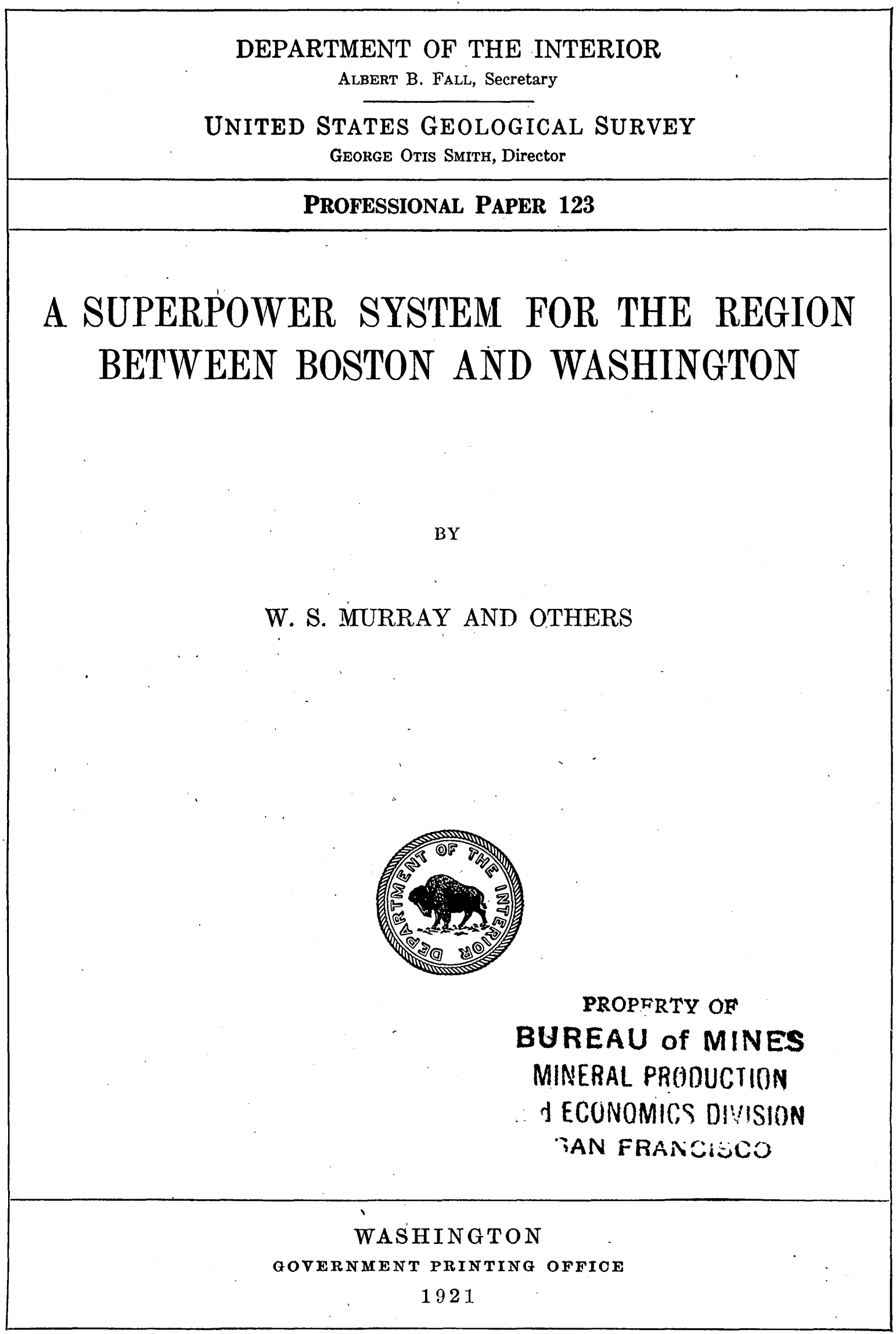




\author{
DEPARTMENT OF THE INTERIOR \\ Albert B. Fall, Secretary \\ UNited STATES GEOLOGICAL SURVEY \\ George OTIS SmITH, Director
}

Professional Paper 123

\title{
A SUPERPOWER SYSTEM FOR THE REGION BETWEEN BOSTON AND WASHINGTON
}

BY

W. S. MURRAY AND OTHERS

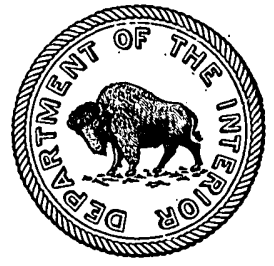

WASHINGTON

GOVERNMENT PRINTING OFFICE

1921 



\section{CONTENTS.}

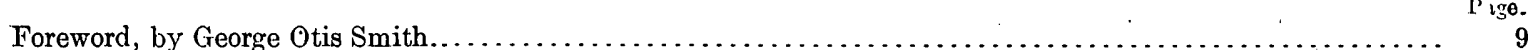

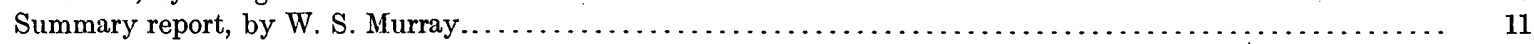

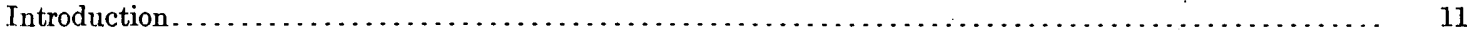

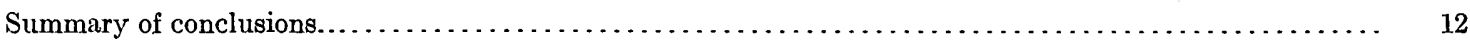

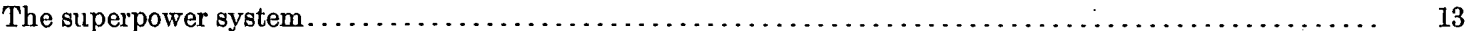

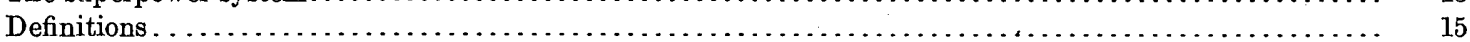

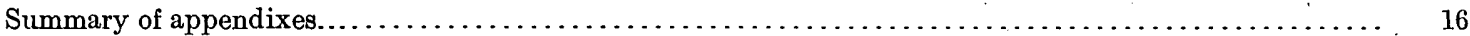

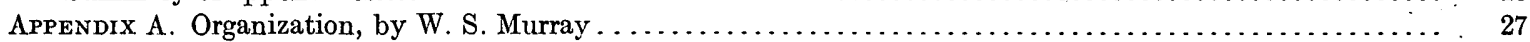

APpendix B. Electric utilities in independent operation in the superpower zone in 1919, by L. E. Imlay, T. B.

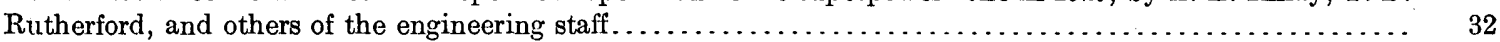

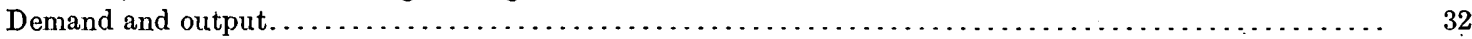

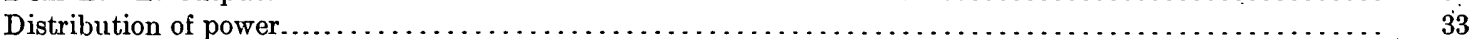

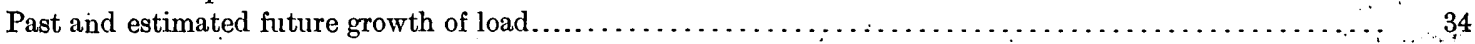

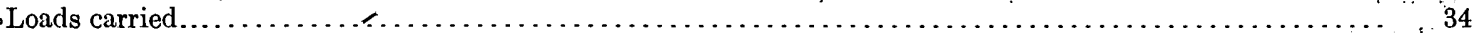

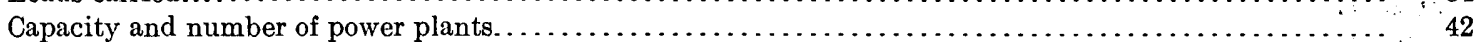

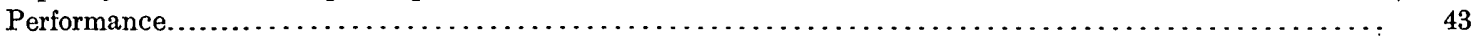

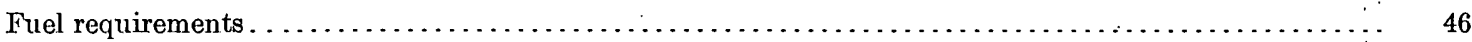

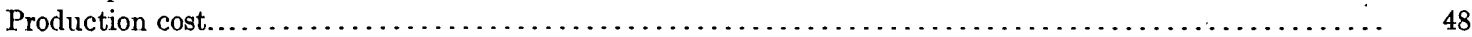

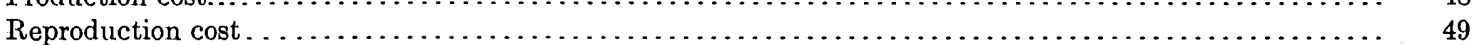

Appendix C. Proposed electrification of heavy-traction railroads in the superpower zone, by C. T. Hutchinson,

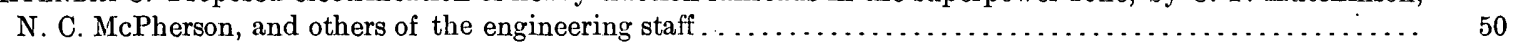

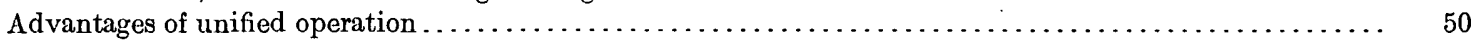

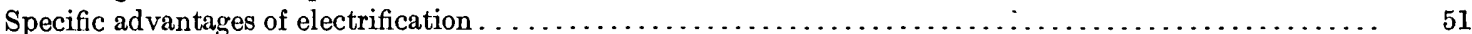

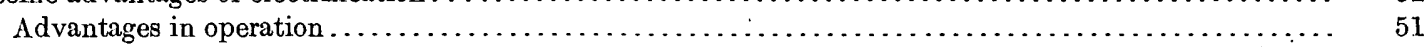

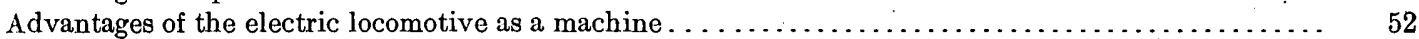

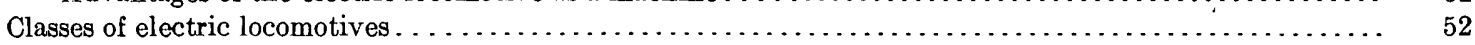

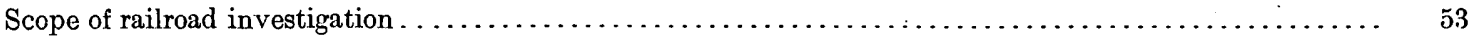

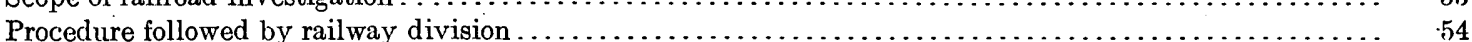

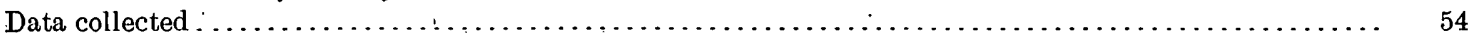

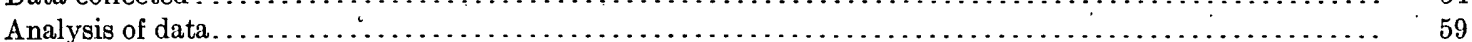

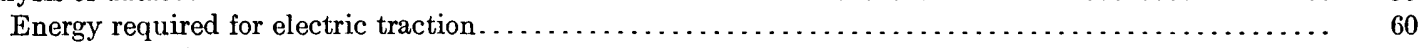

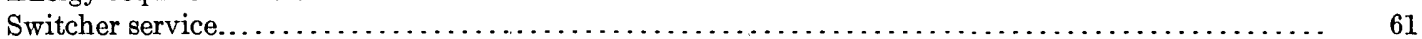

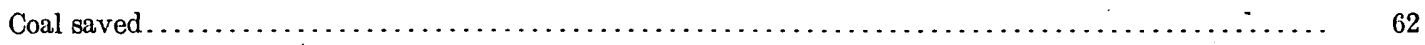

Efficiency . . . . . . . . . . . . .

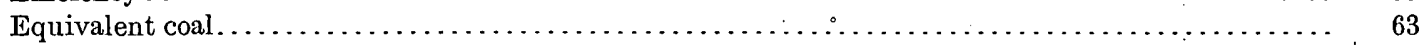

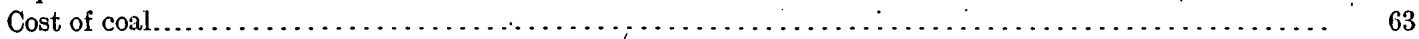

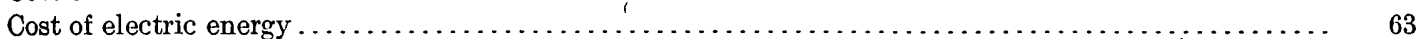

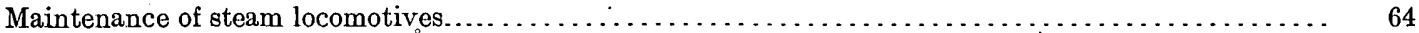

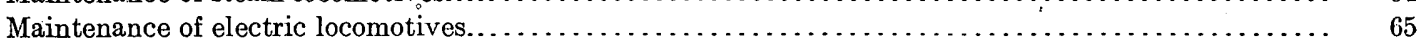

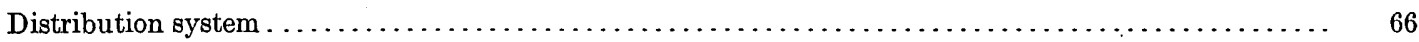

Maintenance of substations. . . . . . . .

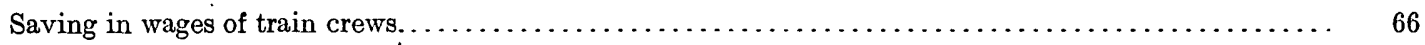

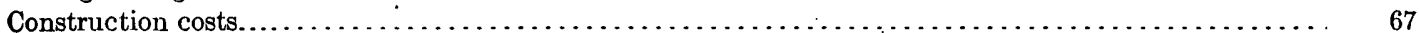

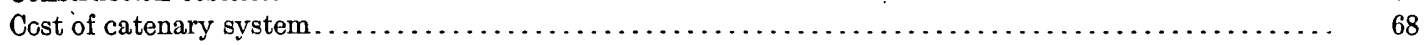

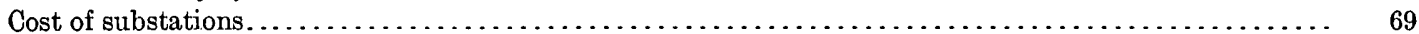

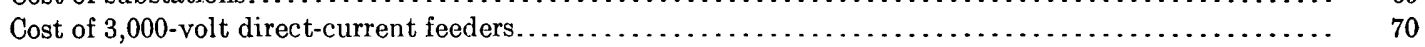

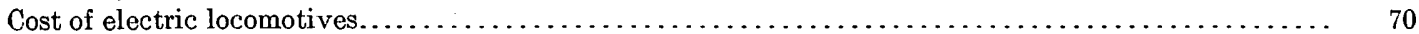

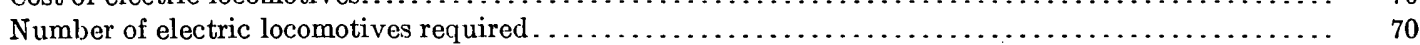

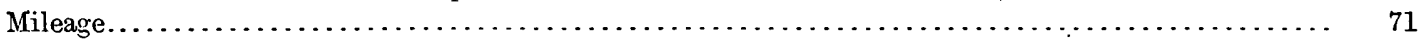

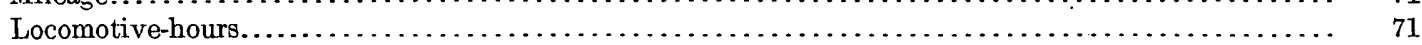

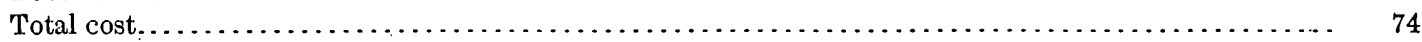

Engineering, contingencies, and interest. . . . . . . .

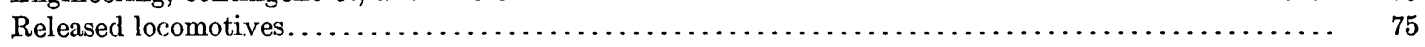

Conclusions. 
ApPeNDIx D. Industry in the superpower zone, by H. W. Butler, H. Goodwin, jr., and others of the engineer-

ing staff.

Conclusions.

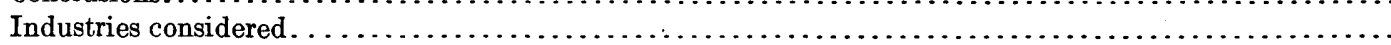

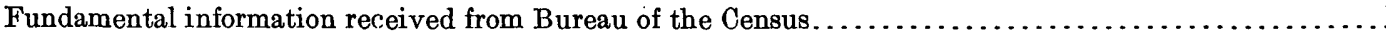

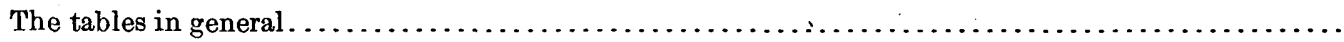

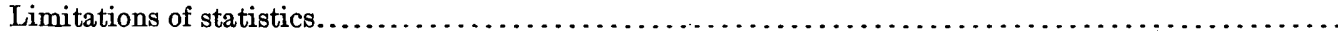

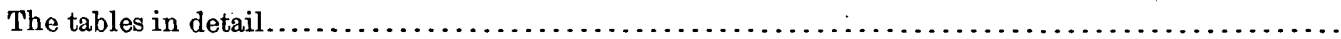

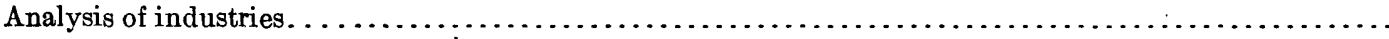

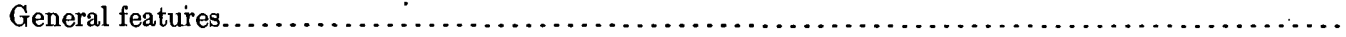

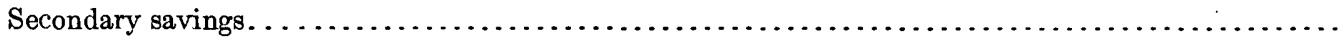

Waterworks. . .

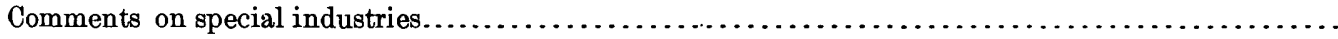

Energy required by load centers.

Prediction of future load.

Cost of industrial power.

Isolated plants.

Central stations.

Saving in cost of power to industries.

Appendix E. Performance and cost of the superpower system, by Henry Flood, jr., A. R. Wellwood, and others of the engineering staff.

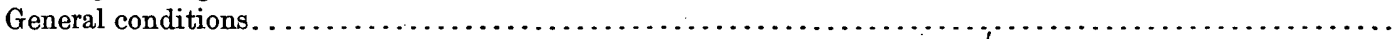

Demand and energy.

Frequency

(1).............

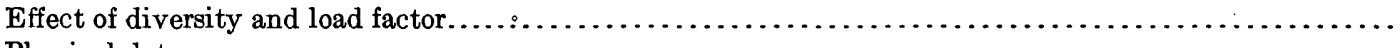

Physical data.

Production facilities.

Transmission lines

Substations.

Fuel requirement

Investment cost:

Cost of power.

Cost of power delivered to the load centers from the new power plants and the transmission system of the superpower system.

APPENDIX F. Steam-electric plants for the superpower system, by Henry Flood, jr., and others of the engineering

Existing plants to be retained

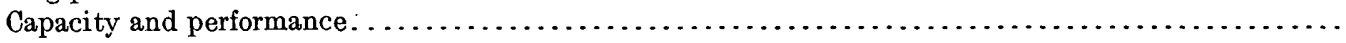

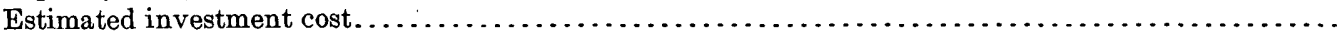

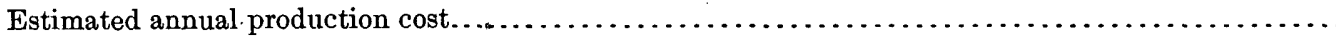

New base-load plants.

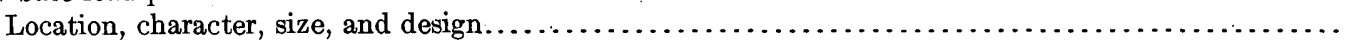

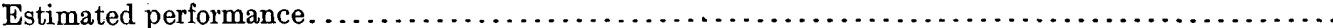

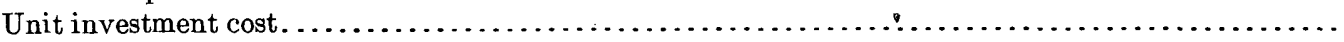

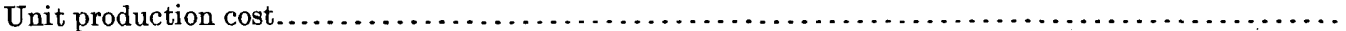

Location at tidewater and on inland rivers.

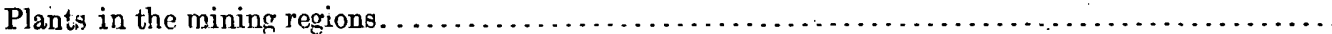

Anthracite fields.

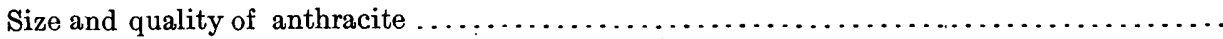

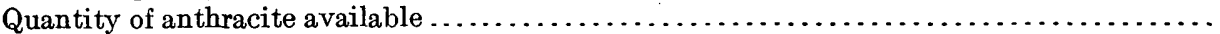

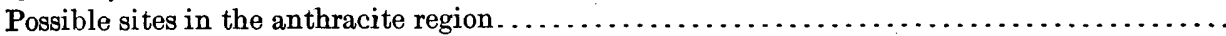

Cost of energy from plants in the anthracite region. . . . . . . . .

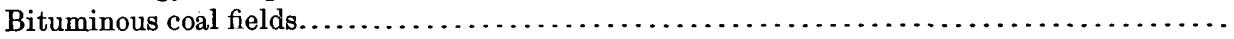

General conditions .

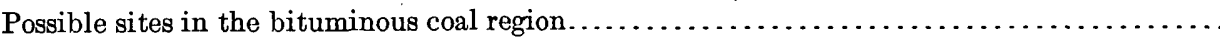

Appendix G. Hydroelectric plants for the superpower system, by L. E. ImIay, L. A. Whitsit, B. J. Peterson, and others of the engineering staff.

The use of hydroelectric plants..........

Potential hydroelectric developmènts.

Potomac River.

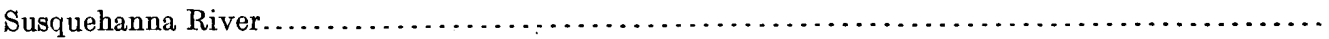

Delaware River. 
APpendrx G. Hydroelectric plants for the superpower system-Continued.

Poteutial hydroelectric developments-Continued..$\quad$ Page.

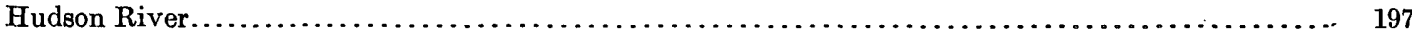

Raquette River. . . . . . . . . . .

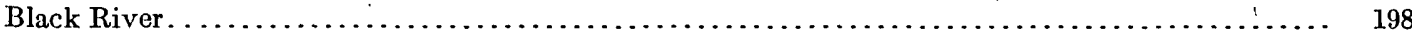

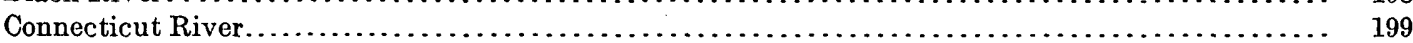

St. Lawrence River........................................................... 200

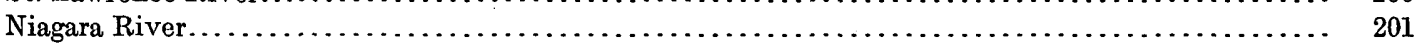

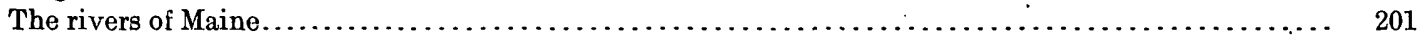

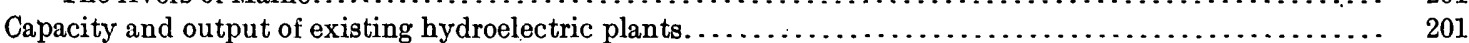

Unit and total investment cost. . . . . . . . . . . . . . . . . . . . . .

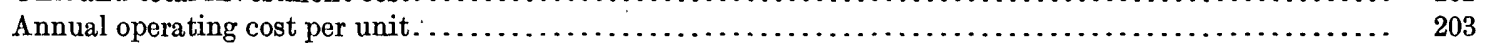

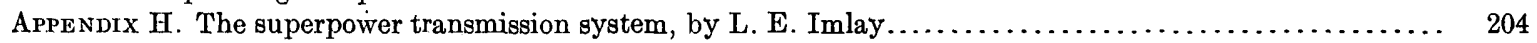

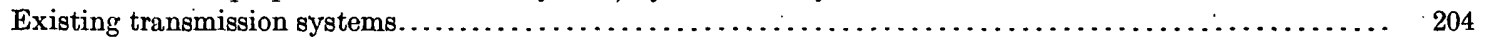

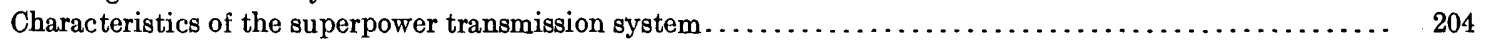

Interconnecting lines....................................................... 204

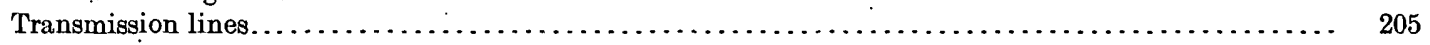

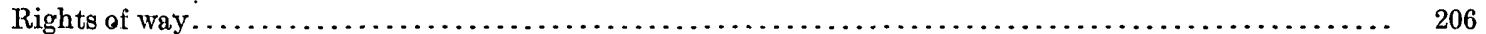

Performance of transmission lines.............................................. 207

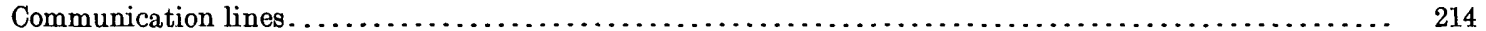

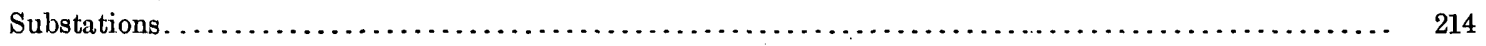

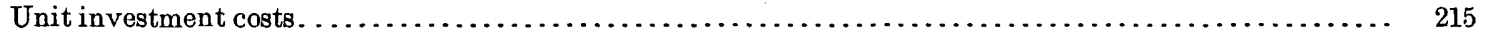

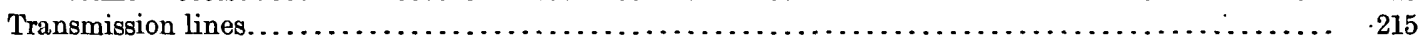

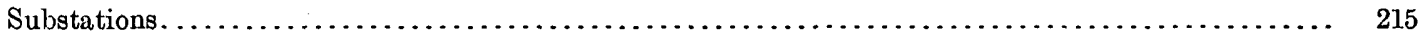

Synchronous-condenser stations. . . . . . . . . . . . .

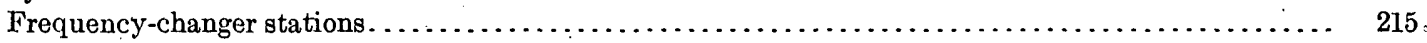

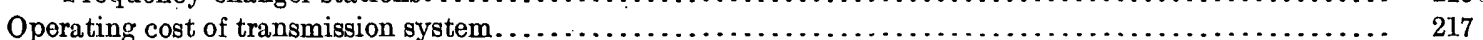

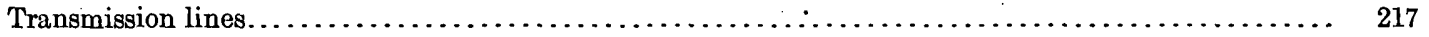

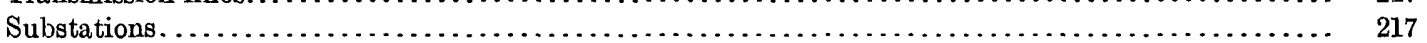

Appendix I. Reliability of service, by L. E. Imlay and others of the engineering staff............... 218

Appendix J. The relation of coal and coal-delivery routes to the superpower system, by C. E. Lesher, F, G.

Tryon, and others.

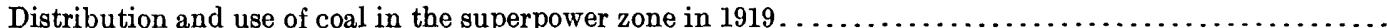

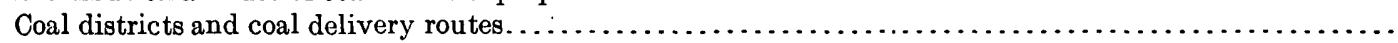

Cost of coal.

Cost of coal at the mines

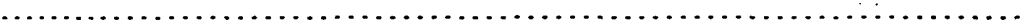

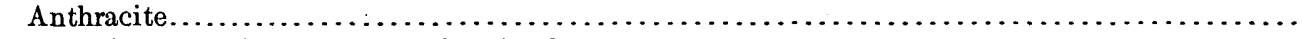

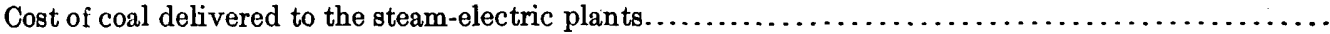

Ownership of coal mines.

Coal storage.

APPENDIX $K$. Use of process fuels and pulverized coal for base-load steam-electric plants, by $0 . P$. Hood and others of the engineering staft...

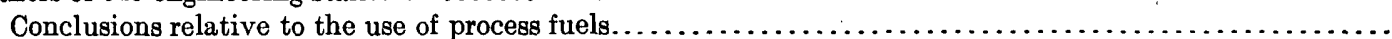

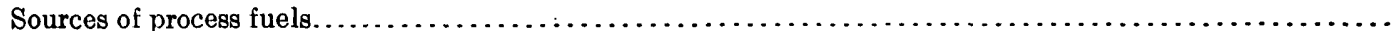

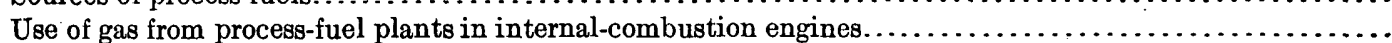

Pulverized coal.

Cost.

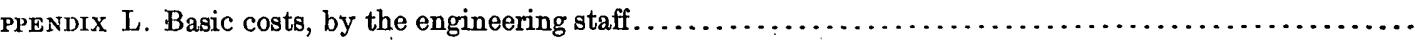

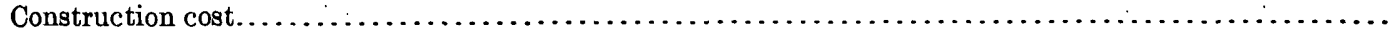

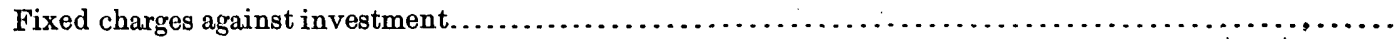

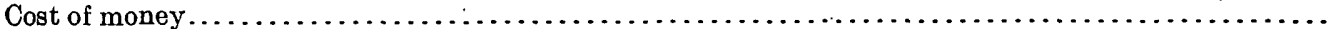

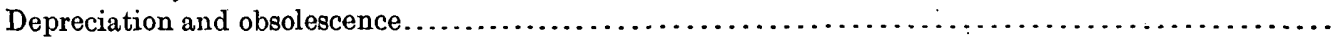
Taxes and insurance.

General expense.

Overhead charges against construction.

APPENDIX.M. Stations and transmission lines of electric-power companies engaged in public service, by $\mathbf{A}$. $\mathrm{H}$.

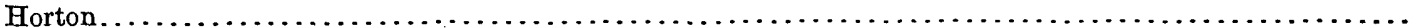

Index.... 


\section{ILLUSTRATIONS.}

PLATE I. Map of the northeastern United States showing superpower zone and geographic divisions..........

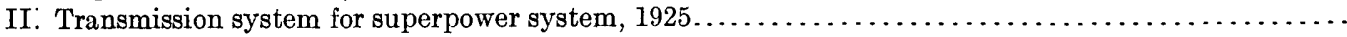

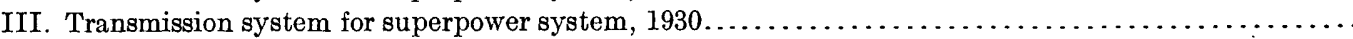

IV. Past and estimated future growth of load of electric public utilities in superpower zone, 1910-1930.

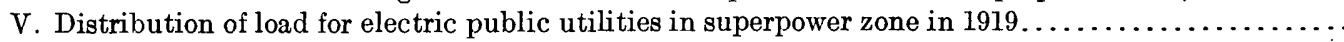

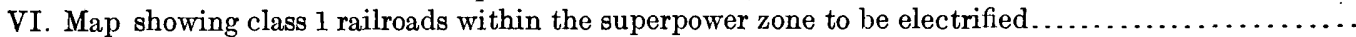

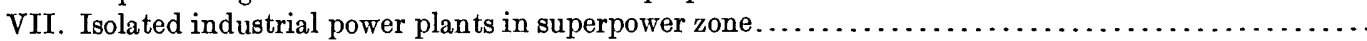

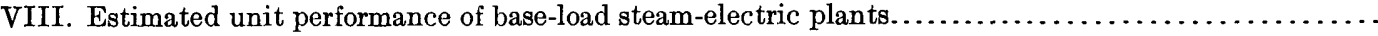

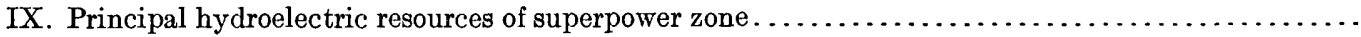

$X$. Location of principal coal-delivery routes from bituminous mining regions to base-load steam-electric plants in 1930 .

XI. Map of the northeastern United States showing power stations and transmission lines used in public

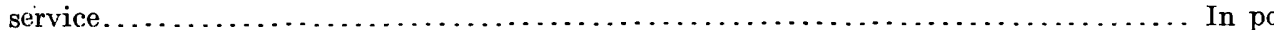

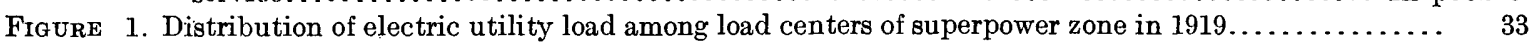

2. Typical seasonal loads of electric utilities in eastern New England division in $1919 \ldots \ldots \ldots \ldots \ldots .35$

3. Typical seasonal loads of electric utilities in western New England division in $1919 \ldots \ldots \ldots \ldots \ldots . . . \ldots$

4. Typical seasonal loads of electric utilities in Mohawk and Hudson divisions in 1919............ 37

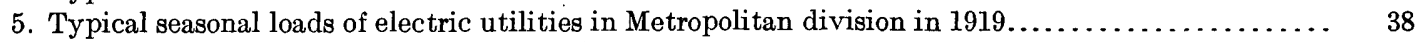

6. Typical seasonal loads of electric utilities in Anthracite division in $1919 \ldots \ldots \ldots \ldots \ldots \ldots \ldots \ldots . . . \ldots \ldots$

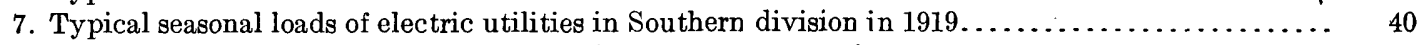

8. Typical seasonal loads of electric utilities in superpower zone in $1919 \ldots \ldots \ldots \ldots \ldots \ldots \ldots \ldots \ldots . .41$

9. Number of generating plants of different capacities owned by 280 of the electric-utility companies

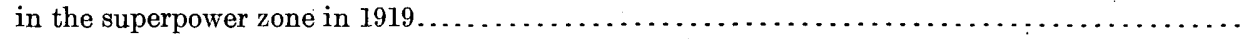

10. Number of generating units of different sizes over 500 kilowatts owned by the electric-utility com-

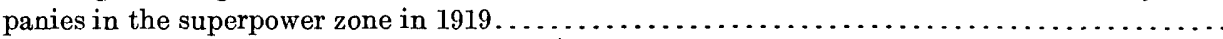

11. Fuel performance in 1919 per plant and per unit of 196 electric-utility plants in the superpower zone that used bituminous coal.

12. All operating costs in 1919 , except that of fuel, per plant and per unit for 196 electric-utility plants

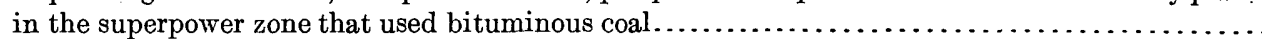

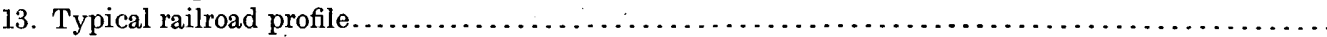

14. Saving effected by electrification of heavy-traction railroads, in percentage of construction cost, not

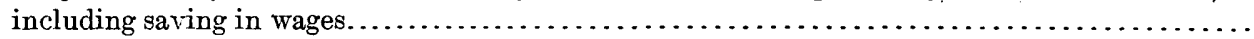

15. Saving effected by electrification of heavy-traction railroads, in percentage of construction cost, including saving in wages.

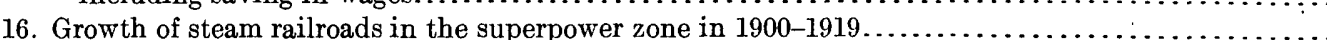

17. Past and predicted future mechanical power-supply equipment used by industries in superpower zone, 1870-1930

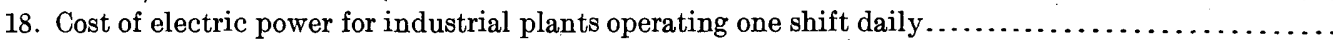

19. Cost of electric power for industrial plants operating three shifts daily $\ldots \ldots \ldots \ldots \ldots \ldots \ldots \ldots \ldots \ldots \ldots \ldots \ldots$

20. Distribution of load among load centers of the superpower system for 1925 and $1930 \ldots \ldots \ldots \ldots . . . .$.

21. Load at the several load centers in 1919 and 1930, in percentage of load at New York.............

22. Sales of 25 -cycle and 60 -cycle generators in the superpower zone, $1914-1919 \ldots \ldots \ldots \ldots \ldots \ldots \ldots$

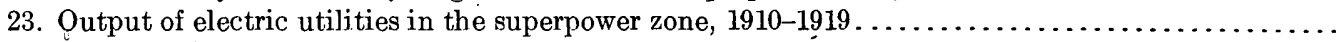

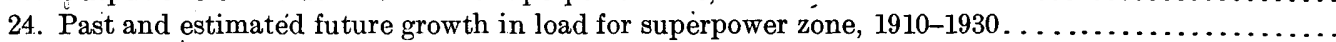

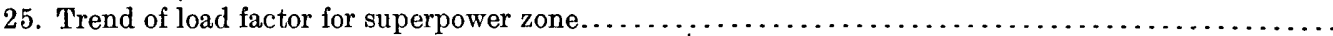

26. Average performance of existing steam-electric plants to be retained in the superpower system....

27. Estimated unit investment for existing steam-electric plants as if constructed in midyear of 1919 . .

28. Estimated average production and operating costs for existing steam-electric plants burning bituminous coal to be retained in the superpower system.

29. Estimated average cost of production and operation for existing steam-electric plants burning

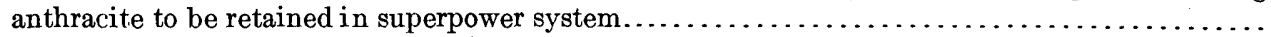

30. Estimated unit investment cost of base-load steam-electric plants burning anthracite...........

31. Estimated unit investment cost of base-load steam-electric plants burning bituminous coal..........

32. Estimated annual cost of maintenance, labor, and supplies for base-load steam-electric plants......

33. Estimated annual production and operating costs for a plant of type B-3, capacity 300,000 kilowatts. . 6 
FIGURE 34. Estimated annual production and operating costs for a plant of type A-3, capacity 300,000 kilowatts.. 188

35. Conditions justifying the use of a plant of type B-1 or B-2 instead of a plant of type B-3....... 188

36. Estimated power available from proposed hydroelectric development of Potomac River for 1925 ... 194

37. Estimated power available from proposed hydroelectric development of Potomac River for 1930 ... 194

38. Curves showing duration of flow of Susquehanna River at Harrisburg, Pa . . . . . . . . . . . . .. 195

39. Estimated power available from proposed hydroelectric development of Delaware River for 1925 $\therefore \quad 196$

40. Fstimated power available from proposed hyaroelectric development of Delaware River for 1930.. 196

41. Estimated power available from proposed hydroelectric development of Hudson River for 1925 ... 198

42. Estimated power available from proposed hydroelectric development of Hudson River for 1930.... 198

43. Estimated power available from proposed hydroelectric development of Connecticut River for 1925. 199

44. Estimated power available from proposed hydroelectric development of Connecticut River for 1930. 199

45. Curves showing duration of power on Connecticut River at Bellows Falls, Vt.............. 200

46. Unit cost for complete hydroelectric equipment installed for different operating heads in midyear of 1919 .

47. Unit operating cost of 58 selected hydroelectric plants in the superpower zone, 1919, according to size of unit.

48. Unit operating cost of 58 selected hydroelectric plants in the superpower zone, 1919, according to capacity of plant.

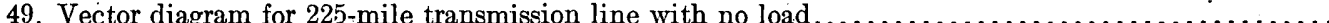

50. Vector diagram for 225 -mile transmission line with normal load of 75,000 lilowatts on each circuit. .

51. Vector diagram for 225-mile transmission line with emergency load of 150,000 kilowatts on cach circuit.

52. Energy delivered over 225 -mile transmission line

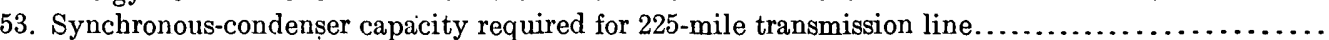

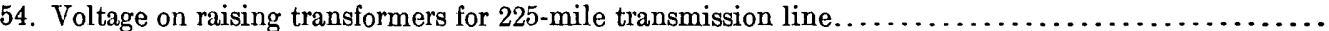

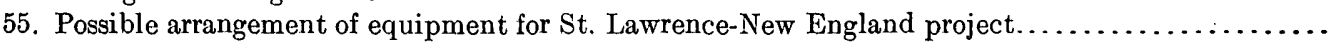

56. Unit cost of 110,000 -volt 60 -cycle substations with low-tension secondaries in midyear of $1919 \ldots$

57. Unit cost of 220,000 -volt 60 -cycle substations with low-tension secondaries in midyear of $1919 \ldots \ldots$.

58. Unit cost of 220,000 -volt 60 -cycle substations with 110,000 -volt secondaries in midyear of $1919 \ldots \ldots$

59. Estimated cost per kilovolt-ampere of capacity of 60 -cycle synchronous condensers in midyear of 1919

60. Unit cost of frequency-changer stations in midyear of 1919.

61. Relation of general expense to annual gross revenue for 60 electric-utility companies in the superpower zone. 
rer 


\section{FOREWORD.}

\section{By George Otis Smith.}

In December, 1918, President E. G. Buckland, of the New York, New Haven \& Hartford Railroad Co., at the instance of Mr. W. S. Murray, consulting engineer, of New York City, urged upon Secretary of the Interior Lane a survey of the sources of energy in New England and on the Atlantic seaboard as far south as Washington. 'Secretary Lane's response was that general and local studies of the country's available power had been pushed with vigor by the Geological Survey as a war measure and that the continuation of this work was already planned under a special appropriation asked from Congress, but as the plans had not contemplated work on the scale suggested by Mr. Buckland the Secretary invited conference and advice, for he at once saw the advantage of making this intensive analysis and working out a plan to provide for the ever-growing energy requirements of this industrial region.

On January 27, 1919, the Secretary of the Interior sent to Congress a supplemental estimate of " an appropriation in the sum of $\$ 200,000$ for a special investigation and report on the power supply for the Boston-Washington industrial region, to be made during the fiscal year 1920." Explanatory letters in which a constructive national power policy was urged were addressed to the chairmen of the committees on appropriations. "The country," said Secretary Lane, "is now passing through a period of transition, which, I firmly believe, will soon be followed by one of industrial activity and expansion. The enormous development of war industries had created an almost insatiable demand for power, a demand that was overreaching the available supply with such rapidity that, had hostilities continued, it is certain that we should now be facing an extreme power shortage. Happily such a crisis was averted by the signing of the armistice, and the ensuing curtailment in the demand for war materials has carried us past immediate danger of a power famine in the industrial districts of the Northeast."

The Director of the United States Geological Survey was heard on the proposal January 30 before the Appropriation Committee of the House. The proposal excited interest but lacked - wide support, and the committee failed to report the item for further consideration by Congress.

During 1919 the subject of power conservation was fully discussed before engineering societies and trade and commercial bodies and in the technical and financial journals, so that the appropriation item was better received at the next session of Congress. Mr. Murray, who had accompanied Mr. Buckland in the earlier conference with the Secretary of the Interior, was foremost in winning both popular and professional support for the idea, and the strongest presentation of the subject to the House Committee on Appropriations was made by a committee appointed by the Engineering Council, of which Mr. Murray was chairman and L. P. Breckenridge, professor of mechanical engineering, Yale University; D. C. Jackson, professor of electrical engineering, Massachusetts Institute of Technology; and M. O. Leighton were the other members.

An appropriation of $\$ 125,000$, carried in the sundry civil appropriation act for the fiscal year 1921, among the items under the United States Geological Survey, authorized the proposed investigation in the following language:

For the survey of power production and distribution in the United States, including the study of methods for the further utilization of water power, and the special investigation of the possible economy of fuel, labor, and materials resul ting from the use in the Boston-Washington industrial region of a comprehensive system for the generation and distribution of electricity to transportation lines and industries, and the preparation of reports thereon, $\$ 125,000$. The Secretary of the Interior is authorized to receive any sums which may be contributed for this purpose. Such sums shall be deposited in the Treasury and credited to the appropriation herein made and be available for expenditure for the purposes thereof. 
The work was promptly organized, and a strong engineering staff was selected by Mr. Murray, who had been appointed by the Secretary of the Interior as the logical man to head this engineering study. The engineers appointed to assist Mr. Murray have met every expectation, and great credit is due to them for their tireless enthusiasm for the work, inspired by both professional and public spirit, and to Mr. Murray for his wise choice of associates. Chief Hydraulic Engineer Grover, of the United States Geological Survey, and Chief Mechanical Engineer Hood, of the Bureau of Mines, became members of the engineering staff, so as to coordinate this special study with the current investigations of the Federal bureaus. This special short-period study was administered as a unit under the water-resources branch of the-Geological Survey.

Secretary of the Interior Payne added to the driving force of this intensive study an advisory board consisting of men of vision and experience, representing our railroads, both steam and electric, and manufacturing, engineering, and chemical industries. These busy men held eight meetings during the year-a service that has added value to this report as now presented. The legal and financial aspects of the superpower project formed the subject of discussion at several of the meetings of the advisory board, but the formulation of conclusions on these aspects was deemed inopportune without further consideration, which it is proposed may be given by the board under authority of new appointments by Secretary of the Interior Fall.

The cooperation of all the industries affected by the proposed larger electrification was unstinted. Engineering aid was freely given, data were promptly furnished, and money was generously contributed as needed. No "dollar-a-year" men were engaged on this work, but under the specific authority of Congress $\$ 26,000$ was contributed by 36 corporations and individuals representing utilities and industries in the zone.

The advisory board, under the leadership of Prof. Breckenridge, was kept fully informed of each step in the engineering study of the problem, and the active interest of many of the members led to constructive criticism, but no further responsibility for the conclusions here reported can be placed upon the advisory board. For the work done in the engineering staff a division of responsibility and credit is necessarily difficult, as here a group of workers has thoroughly coordinated its endeavors. In the appendixes to the report the responsibility of authorship has been indicated so far as possible, but the credit for the successful issue of the year's work must be given to the staff, as a whole.

The investigation was begun on July 1, 1920, and the report was completed on June 30, 1921, as contemplated by Congress, a result in itself creditable to all connected with this special study.

June $30,1921$. 


\title{
A SUPERPOWER SYSTEM FOR THE REGION BETWEEN BOSTON AND WASHINGTON.
}

\author{
By W. S. Murray and others. \\ SUMMARY REPORT.
}

By W. S. Murray.

\section{INTRODUCTION.}

On first presenting the subject considered in this report to the late Secretary of the Interior, the Hon. Franklin K. Lane, I used the word "superpower" to describe a system that would furnish power to the railroads and the industries within the territory between Boston and Washington that has now become more familiarly known as the superpower zone. (See Pl. I.) The system in turn has become known as the superpower system, and as the investigation has progressed it has taken the form of a proposed entity capable of incorporation as either one or more superpower companies.

My association with the power business during the last 15 years in the electric utility, railway, and manufacturing fields had so forcefully impressed upon me the unnecessary waste of money, labor, and material incident to the present form of power production by unassociated units that it seemed a constructive move in the interest of large national economy to present a plan for coordinated power production which would prevent this waste.

In reading this report two things should be kept in mind-first, that the economy in power production and distribution thus far attained has been due largely to the electric public utilities; second, that the failure to attain the highest possible economy has been due largely to restrictive policies that have inhibited the expansion of electric public utilities.

If this report accomplishes nothing more than to show the saving in labor, material, and money that could be effected by the installation of a power system adequate to serve both the railroads and the industries in the superpower zone, then, by the token of this saving, I plead in the name of national economy for a broad policy in legislation, regulation, financing, and management that may not only remove the existing inhibition but may give positive encouragement to the expansion of electric utilities, especially within this zone, so that adequate, reliable, and cheap power may become available to permit the normal expansion in our industries, together with economical expansion in the capacity of our railroads to handle the increased tonnage incident thereto.

The physical details of the plan proposed are given under the heading "The superpower system" (pp.13-15); but, in order that the true objective may not be lost and that the functioning of the whole, with its total result, may be comprehended, it should be remembered that the superpower system is nothing more than a superutility. All its parts will be fashioned similarly, like the parts, for example, of the New England Power Co., with its 12 power stations and its 750 miles of transmission lines; but owing to the greater capacities and distances involved.in the superpower system, its generating units and transmission lines will be larger and more efficient than those now in use. It will make no difference whether the system is a single great superutility or several utilities built up separately and functioning in close relation to one another. In applying the principles to be set forth in this report the superpower system should be visualized as one great power project serving the superpower zone. 


\section{SUMMARY OF CONCLUSIONS.}

The market for superpower energy will be furnished by the electric utilities, the industries, and the railroads. The estimated requirement for energy supplied through the electric utilities for municipal, private, industrial, and railroad purposes in 1930 is $31,000,000,000$ kilowatthours. This energy could be supplied by a coordinated power system such as is described in this report at an annual cost of $\$ 239,000,000$ less than by an uncoordinated system such as is now in use. This amount represents the net saving after the necessary fixed charges on total capital expenditure have been deducted. The cost of uncoordinated power production in 1930 is computed from the cost of the present system in 1919. The total investment in generating and transmission facilities for the superpower system will be $\$ 1,109,564,000$, of which $\$ 416,346,000$ will represent the value of existing facilities to be incorporated into the system.

A study of the 96,000 manufacturing establishments operating within the superpower zone shows that by 1930, through the maximum economical use of purchased electric energy, they can save $\$ 190,000,000$ annually above the fixed annual charges against a capital investment of $\$ 185,000,000$ to provide the motor equipment necessary to receive and use this power.

The combined capital investment necessary for the electric utilities and the industries as of 1930 therefore amounts to $\$ 1,294,564,000$, and this total investment will yield annually above the fixed charges the sum of $\$ 429,000,000$, or 33 per cent on the investment.

Within the superpower zone there are 36,000 miles of railroad measured as single track-that is. including each track of main lines, yards, and sidings. Of this total about 19,000 miles can be profitably electrified, so as to yield by 1930 an annual saving of $\$ 81,000,000$ as compared with the cost of operation by steam. The capital expenditure necessary to electrify the 19,000 miles would be $\$ 570,000,000$, and the average return upon the investment would therefore be 14.2 per cent.

As defined in another section of the report, the superpower system begins at the generating stations connected to its lines and ends at the busses of existing electric utilities. Therefore, the cost of power discussed in this report means cost at the busses of the electric utilities and must not be confused with the cost to the ultimate consumer, which is necessarily much greater, owing to the added cost incident to secondary distribution systems.

Studies of the operations of each load center have shown that a large quantity of coal could have been saved had superpower facilities been available in 1919 . On comparing the coal rates of power production in 1919 with those of the superpower system and applying the difference to the load that will exist in 1930 we find that the coal saved annually under the superpower system may be estimated as follows:

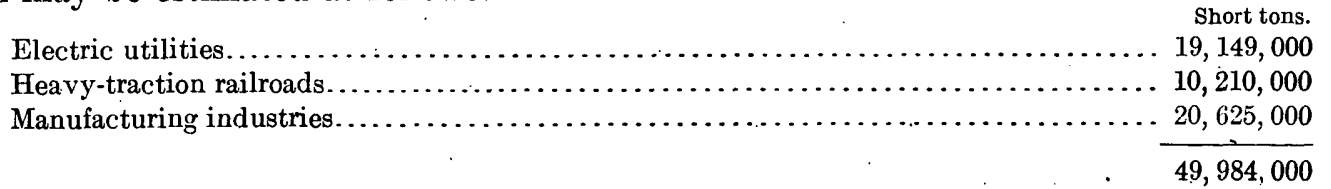

The order in which the superpower steam-electric and hydroelectric power plants and transmission systems should be constructed must depend (1) on the present industrial demand for energy that can not be satisfied because of the difficulties of the local electric utilities in financing extensions; and (2) on the future demand for energy that will result from the more economical generation of power under the superpower system.

Many of the economies incident to superpower operation will be effected through the interconnection of existing plants and systems, and these economies should be increased as new power plants and interconnections are added. Certain steam plants that are under consideration and others that are under construction will be when completed as efficient as the proposed baseload steam-electric plants of the superpower system. Notable among these plants are the Hell Gate station now being constructed by the United Electric Light \& Power Co. of New York City and the Delaware station of the Philadelphia Electric Co. However, by keeping in mind the two conditions, already stated, that should govern the order of construction, it is believed that the quickest return will be obtained by following in chronologic sequence the order of procedure outlined on page 13. 


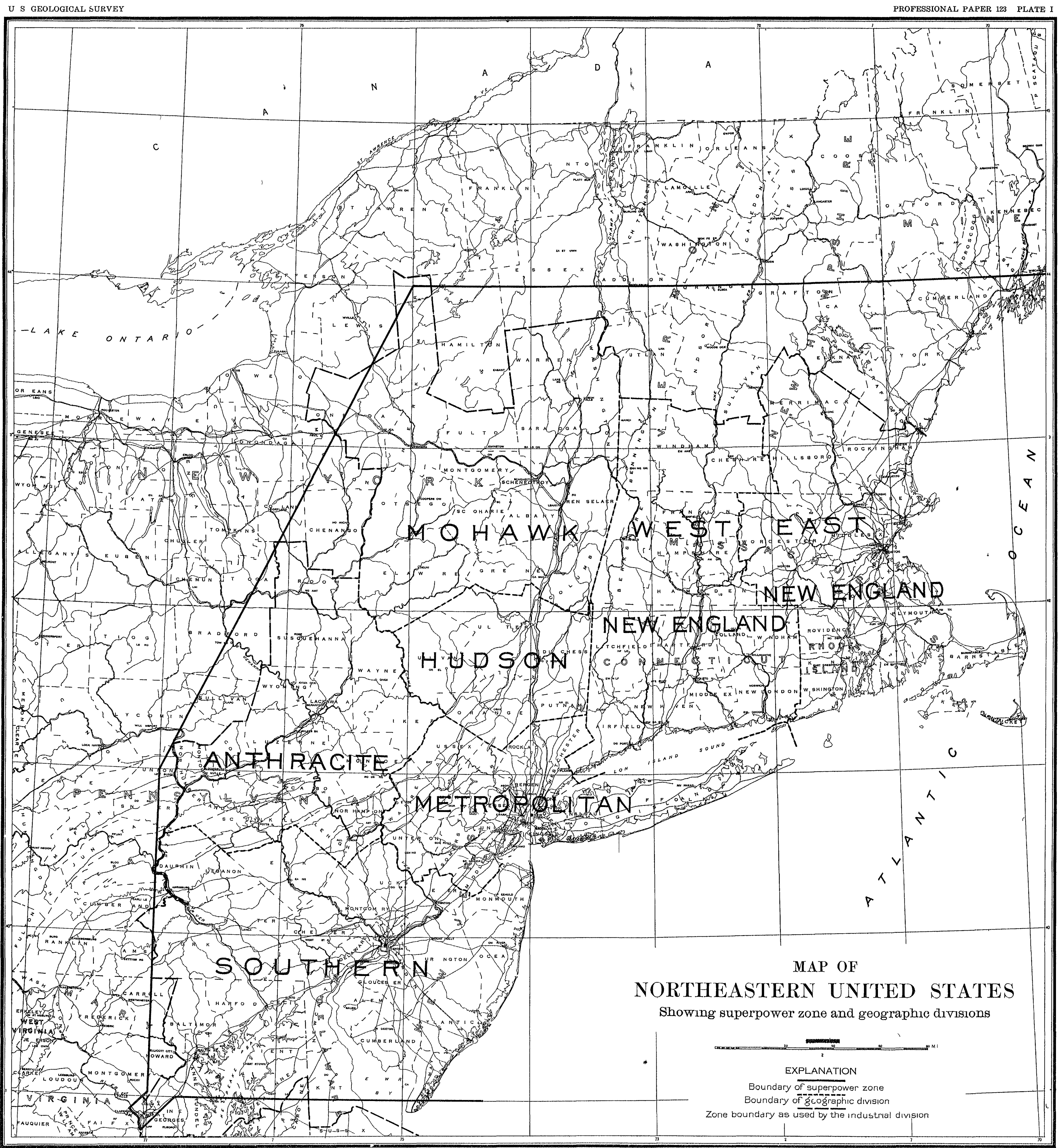


1. The construction of a steam-electric plant near Pittston, $\mathrm{Pa}$., to supply a part of its energy to the Anthracite division of the superpower zone and the remainder to the Metropolitan division, particularly New Jersey.

2. The construction of a steam-electric plant near Sunbury, Pa., to supply a part of its energy to the Anthracite division, a part to the Reading load center, and the remainder to Philadelphia.

3. The construction of hydroelectric plants on Delaware and Susquehanna rivers to supplement the steam plants indicated in paragraphs 1 and 2 .

4. The progressive development of the Hudson River projects to meet the grow th of energy requirement at the Schenectady, Utica; Poughkeepsie, and Pittsfield load centers.

5. The construction of a steam-electric plant near Boston to supply the Boston, Lowell, and Newburyport load centers.

6. The construction of a steam-electric plant near New Haven to supply the New Haven, Bridgeport, Waterbury, and Norwich load centers.

7. The partial construction of the first hydroelectric plant in the development of Potomac River as soon as the power demands of the Baltimore and Washington load centers require additional plant capacity.

Plant capacities are not stated above, as they can not be finally determined except by further and more detailed study of local conditions combined with regional demands. The load growth at all the centers, however, will make it imperative to provide new plant capacity at an early date, so that the construction of additional plants, as detailed in Appendix E, must be started promptly after the plants that will yield the greatest return have been built.

\section{THE SUPERPOWER SYSTEM.}

The territory in which the superpower survey has been made-the "superpower zone"may be described as lying between the thirty-ninth and forty-fourth parallels of latitude and extending from the coast approximately 150 miles inland, embracing parts of the States of Maine, New Hampshire, Vermont, New York, Pennsylvania, Delaware, and Maryland and all of the States of Massachusetts, Rhode Island, Connecticut and New Jersey. (See Pl. I.) Within this zone is concentrated one-fourth of the population of the United States, and within it are operated, most of them independently, 315 electric utilities, 18 railroads, and 96,000 industrial plants. The superpower zone is the finishing shop of American industry.

Unlike the Pacific coast region, where water power abounds and industry is relatively small, the superpower zon'e has relatively small hydroelectric resources and maximum industrial-power requirements. When the increases during the last 10 years are projected to 1930 , even at a lower rate, the total energy requirement of the zone in that year is found to be $31,000,000,000$ kilowatthours, of which about 21 per cent can be supplied from water power.

Fortunately some of the best coal deposits in the country lie near this great industrial territory, and a prime economic purpose should be so to conjoin the hydroelectric supply of power to the steam-electric supply as to produce a maximum of energy for a minimum investment of capital and a minimum operating expense, and at the same time to conserve the rapidly disappearing cheap fuels of the Appalachian coal fields.

The superpower system here recommended comprehends a plan of power production that includes the generation of electricity by steam at tidewater and on inland waters where a sufficient quantity of condensing water can be obtained, and also the utilization of all hydroelectric power that may be economically obtainable from rivers within the zone or within transmission distance of it. The electric power so generated will be coordinated through a system of interconnected transmission lines, the potentials of which will be on the order of 220,000 and 110,000 volts. (For the assignment of these voltages see Appendix E.)

Plates II and III show how the superpower system should appear in 1925 and 1930 . They give the locations of the new steam-electric plants, the hydroelectric plants, and the load centers for each year and show the interconnecting network of transmission systems required. Had superpower been available in 1919 the number of load centers to which its power could have 
been supplied economically would have been 20 , and this number as the maps show, will increase to 34 in 1930 .

Under the present independent operation of the electric utilities and the manufacturing industries in the superpower zone the existing power plants are numerous and small. The average capacity of the 558 electric-utility plants now in operation in the zone is 7,900 kilowatts, and that of the steam-electric plants 10,000 kilowatts, while the hydroelectric plants average only 2,800 kilowatts. Out of 96,000 industrial establishments in the superpower zone 76,000 use power, and each of these isolated plants averages about 350 horsepower. Under the superpower system, by contrast, the number of power stations required to supply the entire zone in 1930 will be only 273 , of which 218 will belong to the existing electric utilities. The capacity of the base-load steam plants will range from 60,000 to 300,000 kilowatts. In none of these plants will there be installed a turbo generator having a capacity of less than 30,000 kilowatts.

The new power stations and load centers will be, so located with reference to the existing electric-utility plants that are to be incorporated in the system as to insure the maximum aggregate economy in power generation and transmission. A prime object to be attained in the superpower plan is the maximum economic utilization of existing generation and transmission equipment. In the early stages, while the superpower system is taking form, existing electric-utility capacity will predominate. Indeed, in 1930, as much as 31 per cent of the total superpower capacity will be contained in plants belonging to the present electric-utility companies.

The superpower system would and should fail to achieve its purpose if it should seek to supplant or even to compete with the existing electric utilities. Its object is exactly the reverse. In view of the great economies already effected by the electric public utilities, the creation of the superpower system can be urged only as it shall come into being to coordinate and supplement these utilities and carry to a higher degree the service and the economies incident to their present operation.

It should not be difficult to see, therefore, that the superpower system will provide for a series of load centers, at which power may be made available at lower cost than can be attained under the present unassociated systems of power production and distribution. At these load centers, located where economy may dictate, power so made available will be coordinated with power generated at existing electric-utility plants and distributed by transmission or distribution systems to the consumers, as it is to-day.

Under the heading "Summary of conclusions" it was stated that in the operation of electric utilities the superpower system, in comparison with independent operation, would save $\$ 239,000,000$ in 1930 . The question might be asked, Could not the same result be attained by the electric utilities themselves in the course of their normal expansion? The coordinated plan of power production by the superpower system represents the highest possible commercial efficiency and must therefore yield the maximum economies. I believe that no possible expansion of the present uncoordinated electric public utilities can reach the economic results promised by the superpower system, for the physical structure of the superpower system, as outlined in the appendixes to this report, employs minimum capital and minimum labor to produce a maximum of electric energy.

In the discussion of the superpower system there has been some tendency to look upon it more as a company than as a principle, but the foregoing statements should make it clear that superpower is merely a name for the principles that should govern the expansion of the existing electric utilities. A better term than superpower would have been superutility.

The electric utilities, the railroads, and the industries within the superpower zone have freely given their data to permit a determination of the amount and location of load and demand and have supplemented them with data showing the cost of producing their power in 1919. The superpower system will be a regional system supplying power through the electric utilities, at the highest economy, to the two agencies that are most vital to American existence-industry and transportation. The highest economy in investment and operation will be gained by 


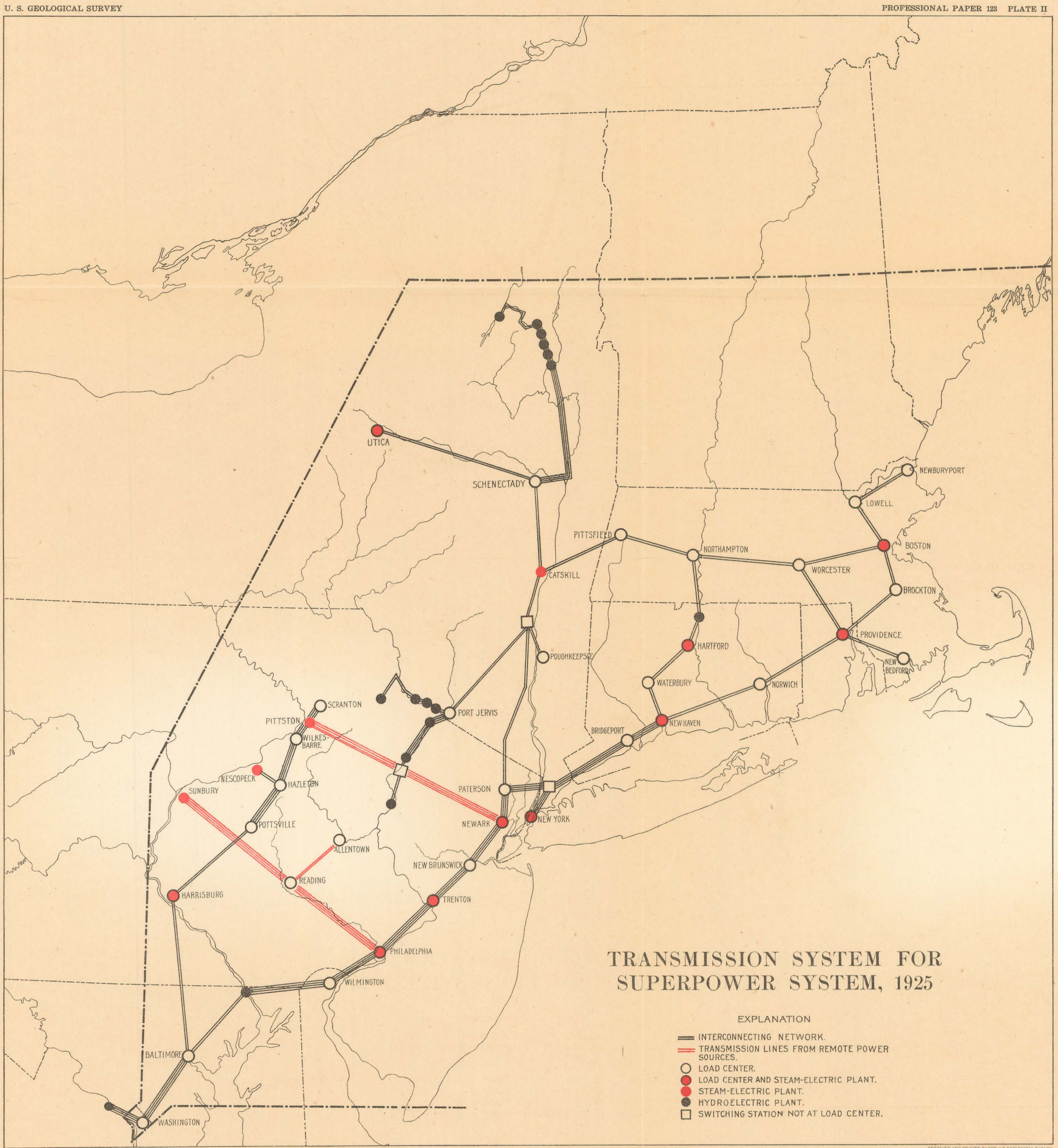




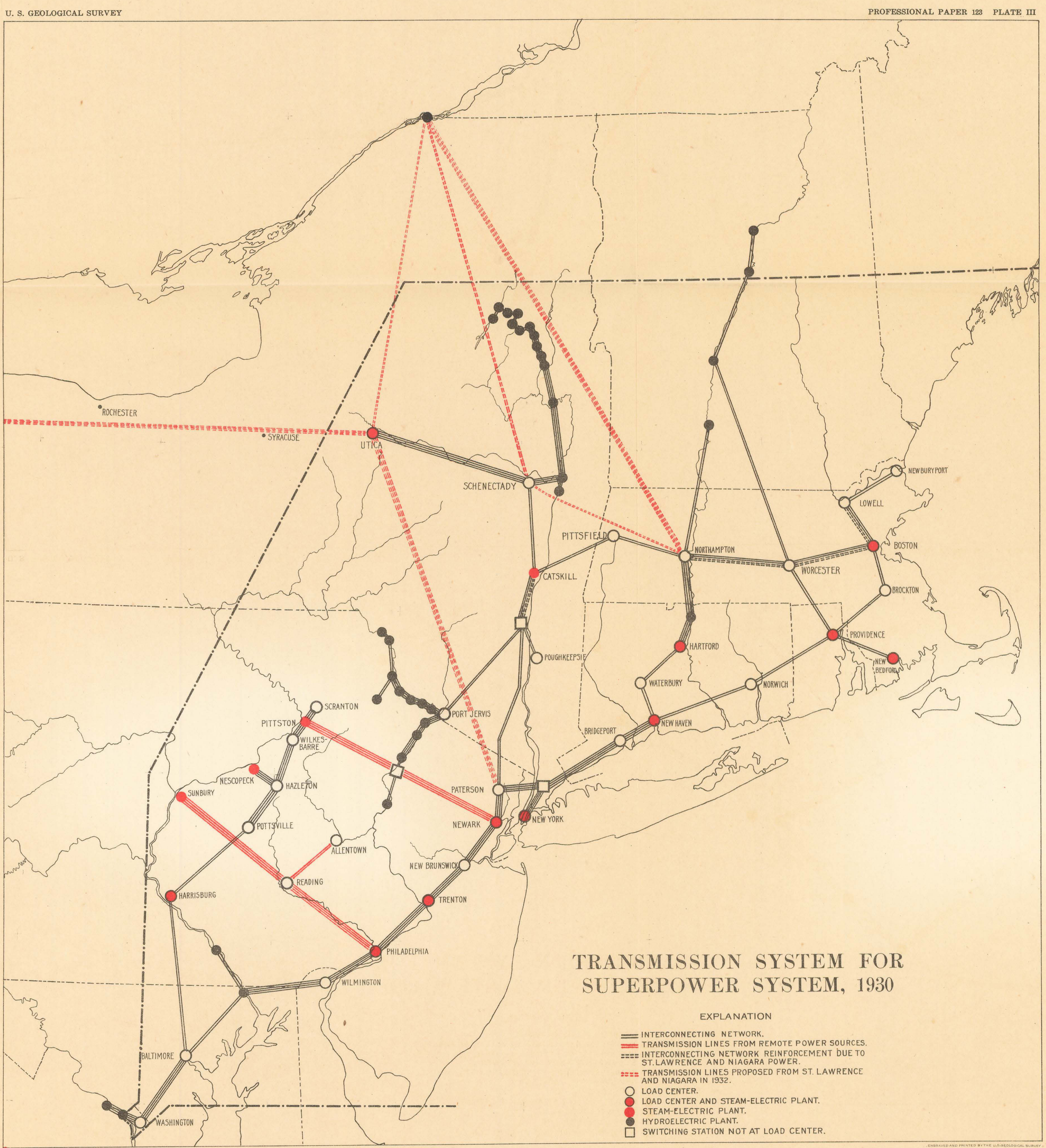


maintaining the size of the electric generating units at a maximum and thus reducing capital and operating cost to a minimum. The highest economy resulting from diversity economy will be gained through a wisely ordered interconnecting system of lines of transmission and distribution-a system which also offers the highest economy in the development of water power, for it makes possible the use of a maximum number of cubic feet of water per square mile of drainage area, thus reducing to a minimum the amount of power generated by steam.

In determining the amount and cost of the power produced within the superpower zone it was obviously necessary to select the latest year for which full construction and operating information could be obtained-the year 1919. On account of the extremely high cost of material in that year, however, this selection has introduced high fixed charges; but this is offset by the saving in high-priced coal and the consequent reduction in operating expenses resulting from the higher efficiency of the superpower system as compared with the present independently operated electric utilities.

As efficiencies have increased with the enlargement of the plants operated, the cost of producing power has been lowered. The best reflection of this decrease in cost is seen in the electric utilities themselves. Much of it has been the result of interconnection, which has permitted the use of larger machinery and a better utilization of water power. In the isolated plants and on the railroads, however, although the cost of power has been lowered, the decrease has been far less, because in both of these the power equipment is small and its operation is affected by conditions that prevent much gain in efficiency?.

It may be argued that it would be unfair to extend the costs of independent operation for 1919 to 1930 and at that year strike a difference between them and those of the superpower system. This argument can not be gainsaid, but if the figures representing the cost in 1919 of unassociated power production are not lowered by 1930 then the full savings previously indicated as possible by the superpower system can be claimed. Unquestionably the figures for 1919 will be lowered by the further consolidation of existing utilities, but unless the electric utilities act in complete cooperation and themselves adopt a plan of coordinated expansion by which the load centers of the zone can be supplied with power at minimum cost then the economies they can independently effect will never reach the maximum attainable under the superpower system, which involves the complete coordination of the existing power stations of the electric utilities and the new stations to be constructed.

DEFINITIONS.

A few of the terms used in this report are defined below:

Assigned locomotives.-Locomotives actually engaged in runs between terminals or in switching operations. Base-load plant.-A generating plant designed to carry that part of the load which is practically continuous.

Capacity factior.-The average load on a plant expressed as a percentage of the effective capacity of the plant.

Class 1 railroads. - Railroads having an annual operating revenue of $\$ 1,000,000$ or more.

Cost of power delivered.-The sum of the cost of production and transmission and the general expense.

Diversity economy.-The saving made by interconnecting generating stations whose peak loads are reached at different times and so distributing the load among stations of different unit operating costs as to deliver power at minimum cost.

Diversity factor.-The ratio of the sum of the maximum power demands of the subdivisions of any system or part of a system to the maximum demand of the whole system or of the part of the system under consideration, measured at the point of supply. (Standards of the American Institute of Electrical Engineers, section 3464.)

Effective capacity. - The rated capacity of a plant as limited by boilers, prime movers, or generators.

Fixed charges.-The cost of money, depreciation, obsolescence, taxes, and insurance.

General expenses.-The administrative, legal, and fixed expenses and expense of office supplies.

Load factor (hour yearly). - The ratio of the average power to the peak power expressed as a percentage of the peak power.

Operating cost.-The cost of fuel, operating labor, maintenance, (including depreciation and obsolescence) and supplies.

Peak-load plant. $\rightarrow$ A generating plant designed to carry the peak loads.

Production cost.-The sum of the operating cost and fixed charges for a power plant.

Reproduction cost.-The cost in midyear of 1919 of an up-to-date plant of the same capacity. 
Total ton-miles.-The weight of the train in tons, including the locomotive and tender, multiplied by the distance run in miles.

Trailing ton-miles.--The total weight of the train in tons, exclusive of the locomotive and tender, multiplied by the distance run in miles.

Transmission system cost.- The sum of the operating cost and fixed charges for a transmission system, including substations.

The problem set for the engineering staff, briefly stated, was that of determining the total amount and the location of the power load that would be required for municipal, private, industrial, and railroad purposes at a date sufficiently in advance to permit the construction of a system of the highest economy to supply it. The date chosen was 1930, and the allocation of the load and the power-generating facilities for the six geographic divisions of the superpower zone is shown in Appendix E.

In the earlier stages of the investigation, therefore, the entire attention of the engineering staff was concentrated upon the work of determining the amount and the location of the load. This work was done through the cooperation of the electric utilities, the railroads, and the industries within the zone. The engineering staff then undertook to determine the amount and the location of generating and transmission capacity to supply the demand thus ascertained.

The appendixes, which are here only briefly summarized, are largely, if not entirely, the work of their authors, to whom reference is made under "Organization," in Appendix A. I believe I can fairly say that in the endeavor to solve the problem set for us the engineering staff followed a route in which my principal engineering associates, Messrs. Butler, Flood, Hutchinson, and Imlay, were in full accord with me. To them and to their assistants may be ascribed the full credit for the collection of the information required for the report and a very large share of the credit for working it up. For the details that served as the groundwork for the conclusions reached I would suggest a careful study of the appendixes.

Appendix B. Electric utilities in independent operation in the superpower zone in 1919.

In the New York, Baltimore, and Washington load centers the predominating frequency is 25 cycles; in the remainder of the zone it is 60 cycles.

The electric-utility load will grow from approximately 10,000,000,000 kilowatt hours in 1919 to $26,000,000,000$ kilowatt hours in 1930 . The figure for 1930 has been predicated upon an annual rate of growth of 9 per cent, a safe figure, for the annual rate of growth during the last 10 years has been 11 per cent.

Figure 1 shows the distribution of electric-utility load between Boston and Washington by load centers for 1919 and indicates the tremendous concentration of power in the vicinity of New York City. The data given by the electric utilities concerning load growth are shown graphically in figure 21, which indicates the decentralization of power that will have taken place by 1930 .

It is apparent that the locations for future electric-power plants must lie outside the densely populated districts. The high-voltage circuits of the superpower system in general will form ring busses around the larger cities of the zone, on the outskirts of which will be located substations with transformers having their primaries connected to the superpower circuits and their secondaries connected to the existing distribution lines of the electric utilities.

The peak loads for the Anthracite and Mohawk-Hudson divisions occur in the morning. The peaks for the other divisions occur in the afternoon. The annual peak for the zone as a whole occurs about 5 in the afternoon, usually in December.

Out of 558 electric-utility plants in the superpower zone there are but 36 whose capacity equals or exceeds the average capacity of the plants for the superpower system in 1930. Out of the 1,074 generating units of 500 kilowatts or more operating within the zone in 1919, only about 20 had a capacity greater than 30,000 kilowatts.

It is of interest to note that a plant delivering power with a load factor of 40 per cent turns out 76 per cent of its energy (kilowatt-hours) before its capacity (kilowatts) has 
been taxed 40 per cent, the remaining 60 per cent of its capacity being required for the remaining 24 per cent of energy; thus showing the small amount of energy involved in peak operation. This statement brings out the very important point that the superpower system employs the generating capacity of the existing electric utilities for application to peak loads, the new and larger superpower stations contributing their low-cost energy for base load.

The relative cost of power production by large and small units is shown. A comparison of the production cost for plants greater than 100,000 kilowatts with that of those less than . 1,000 kilowatts shows a ratio of 3 to 1 for cost of fuel and 4 to 1 for cost of maintenance and supplies in favor of the larger plants. With these marked economies in mind, it is clear that base load should be supplied from superpower plants employing units of not less than 30,000 kilowatts each.

Table 3 brings out the performance of 400 steam-electric plants and 158 . hydroelectric plants operating within the superpower zone in 1919. The fuel rate for the average steampower plant is 2.73 pounds per kilowatt-hour, with a heat requirement of 35,800 British thermal units per kilowatt-hour. These figures contrast strikingly with the fuel rate of 1.41 pounds per kilowatt-hour and the heat requirement of 18,300 British thermal units per kilowatt-hour that can be obtained from the base-load steam-electric plants of the superpower system operating at the same annual capacity factor.

Under independent operation in 1919 the generating capacity required was 46 per cent greater than the annual peak load, and the resulting annual capacity factor was 26 per cent; under the superpower system in 1930, through joint reserve, the generating capacity required will be only 9 per cent greater than the annual peak, and the annual capacity factor will be 45 per cent.

The reproduction cost for steam and hydroelectric plants under independent operation as of 1919 is $\$ 156$ per kilowatt of capacity; the corresponding cost under superpower operation is $\$ 125$ per kilowatt.

The average unit production cost for the electric utilities in 1919 was 1.93 cents per kilowatthour; the cost of the electric power produced by steam was 2.12 cents, and that of the hydroelectric power was 0.94 cent. In the steam-electric base-load plants for the superpower system the production cost, based upon the same capacity factor that is applied to electric independent operation, will be 0.99 cent per kilowatt hour, as compared with 2.12 cents.

Appendix C. Proposed electrification of heavy-traction railroads in the superpower zone.

Density of traffic is the controlling factor in railroad electrification. Within the superpower zone there is a large railroad mileage upon which the traffic is sufficiently dense to require careful consideration of the savings to be effected by electrifica tion-in fuel, in maintenance of equipment, and through economies incident to the reduction in train-miles.

The zone contains some 36,000 miles of main line, yards, and sidings, of which 19,000 miles could be profitably electrified. The total capital expenditure necessary to electrify this mileage is $\$ 570,000,000$, and the result of the analysis promises an annual saving of $\$ 81,000,000$, or 14.2 per cent on the investment.

The response by the railroads to requests for data relating to their operations in 1919 has been so generous and the compilation of these data in this appendix, with the conclusions deduced from them, is so complete that instead of attempting to summarize the appendix I will only refer to the more general aspects of the problem.

In the earlier days of railroad electrification, as, for example, on the New York Central, the New Haven, and the Pennsylvania, we were all groping and feeling our way. That was 20 years ago, and in this age of rapid progress 20 years is a long time in which to make up our minds regarding the fundamental principles of electrification. Even the dyed-in-the-wool steam-locomotive man has become interested in the electric locomotive, because he has found that the steam locomotive can not perform its work satisfactorily in the environment that belongs to the electric locomotive. The reverse is also true-there are railroad tracks on which $63361^{\circ}-21-2$ 
electric locomotives have no place." To find where electric train propulsion should be used does not, however, completely solve the problem. Money must be obtained to put electric locomotives where they belong.

When the electrified portions of the New York Central, the New Haven, and the Pennsylrania were first operated the railroad companies paid out their own dollars for their motive-power equipment and for the power stations to run it. The whole expenditure was - therefore borne by the railroads. About that time Mr. Samuel Insull, with far-seeing perspective, declared that the power required for electrified railroads should come from the large electric-utility plants. I am glad to admit that $I$ was wrong when with others $I$ disagreed with him. I am more glad, however, to say that I stayed wrong only long enough to make up my mind to be a party to a contract for 40,000,000 kilowatt-hours per annum from the United Electric Light \& Power Co. to supply the west end of the electrified stretch of the New Haven road. Since that date it has been my belief that the production of electric energy should be confined to those in the power business and that the railroads should purchase electric energy and confine themselves to the transportation business. The railroads will thus be assured of adequate, reliable, and cheaper power and will be relieved of the cost of building their own power stations.

A further step of fundamental importance that would lighten still more the burden of investment cost, which at this time the railroads are so peculiarly unfitted to carry, would be to standardize as far as possible the motive-power equipment required for the three classes of railroad service-passenger, freight, and switching. Such standardization would simplify electrification and therefore reduce the cost of maintaining equipment, as well as lessen the investment cost. Motive-power equipment so standardized as to be operative on 19,000 miles of track would offer a foundation for an equipment trust bond that would be most attractive to bankers and would relieve the railroads of a heavy capital requirement. In short, the railroads, not being called upon to build motive-power equipment or power stations, would have to pay only the electrification cost incident to their contact and distribution lines, and the charge against their capital account would be only 20 to 25 per cent of the amount required 20 years ago, when they were paying 100 per cent of the cost of electrification.

I hold no brief in this report with regard to systems. It has been well said that either the direct-current or the alternating-current system is better than steam. After these 20 years of heavy-railroad electrification one can not close his eyes to the advantages or disadvantages of either system. Though I was instrumental in selecting and installing the single-phase (alternating current) system on the New York, New Haven \& Hartford Railroad, I am conscious of two elements that may militate against this system-(1) the low power factor, which calls for unproductive capacity in power-plant and transmission equipment, and (2) the undeniable fact that this system induces serious electromagnetic effects upon adjacent telegraph and telephone facilities. In the high-voltage direct-current system electromagnetic induction is practically eliminated, but that system has not yet offered a practical multiple-control unit equipment such as is necessary to suburban operation. On the other hand, the multiple-unit equipment of the high-voltage single-phase system has given the highest satisfaction on the railroads that use it. But these are mere details. The best high-voltage direct-current multiple-unit equipment must be worked out if the railroads in this zone are to be so operated. If power is obtained from substations of electric-utility companies the investment cost will be practically the same for either of the two systems.

This explanation should make it clear that neither system is here favored as against the other, notwithstanding the fact that in Appendix C the 3,000-volt direct-current system has been employed in making the estimates of construction cost. This has been dono only in order that a complete system of construction figures could be worked out; from the superpower stations to the driving wheels of the motive power.

Although the zone is large enough to permit the use of both systems, I would emphasize the recommendation that the great electric manufacturing companies of this country draw 
together rather than apart and that they unite in a common specification for electric motive power to replace steam, for the final result would be tremendously improved by this action.

In addition to the argument that the railroad companies should buy power from the electric utilities because the utilities are in the business of producing power, there is the very excellent argument that the railroad load will not only swell the output of the utilities and therefore permit the installation of larger and more economical generating units but will produce the inherently high load factor common to railroad operation and thus tend to promote the maximum use of the generating capacity installed.

In contrast with the indicated return of 33 per cent to the electric utilities and the industries through the operation of the superpower system the average return to the railroads on the investment necessary to electrify 19,000 miles will be only 14.2 per cent. Of course the percentage of return will vary from division to division, and figure 15 (p. 77) shows that this variation will be from 11 to 19 per cent. Naturally, therefore, the selection of railroad properties to be electrified, aside from requirements for pure increase in capacity, will be governed by the percentage of return to be expected. The greater savings attainable by the utilities and the industries should not overshadow the urgent requirement of railroad electrification. As measured to-day a money return of 14.2 per cent is good, and I think it can be fairly said that we must now begin to live into the new form of train propulsion that is offered by electricity, for thus will be created a means of railroad expansion to support the coming American industrial expansion, which our resources and the world requirements can not possibly fail to induce within the near future. No one can deny that the system in which we must live should carry with it prime principles of economy, which will include these features of commercial efficiency. Any saving in the consumption of coal by the railroads means the transfer of cars from wasteful to productive transportation.

The normal amount demanded annually for extensions and betterments for the railroads within the superpower zone is approximately $\$ 150,000,000$, an amount which even in the face of present construction prices would suffice in three or four years to cover the cost of electrifying all the mileage mentioned. Should we continue to tinker with an old and inefficient machine when it is impossible to escape the installation of the modern and efficient one?

The higher price of coal and labor of the future compared with pre-war prices, which has dislocated the economic balance between railroad grades and the tractive power of locomotives; the lack of sufficient motive power that has been plainly demonstrated at critical periods in recent years; the steady increase in the tractive capacity of individual locomotives noted during the last 20 years; and the present hauling of trains weighing two to three times as much as those of the recent past are plain indications that in the near future large sums of money. must be expended for motive power.

The well-known characteristics of electric locomotives, whose capacity and speed are not. limited by rail and bridge strength and tunnel clearance, make electrification the true system into which we must promptly grow or pay the price for delay. This aspect is one entirely apart from that of the returns to be expected on the proposed capital investment shown in this report.

Appendix D. Industry in the superpower zone.

The maximum economical use of purchased power in the superpower zone in 1919 would have produced a saving in coal amounting to 13,502,100 tons. To determine this saving it was necessary to acertain the coal-burning rates of the industries that developed their own power as against the rates that would have been required to supply them power from central stations.

Out of 96,000 individual establishments in the zone 76,000 used power. The industries analyzed included manufacturing establishments, laundries, mines and quarries, and Government manufacturing institutions. In Table 48 the industries are listed under 17 main groups, which are so subdivided as to form 53 classes. 
The fundamental information required for the determination of the mechanical powersupply equipment and fuel used by all the industries necessarily had to be procured from the Bureau of the Census, if for no other reason because time would not have permitted its independent compilation. This information is presented in the tables of the appendix variously-by character of power supply, by industrial subgroups, by county, and by size of plant. The presentation of the data in this form appears not only to be essential to this analysis but should be of great interest and value to all engineers who are interested in industrial power and heat.

The analysis showed that in 1919 the equivalent of $9,311,440,000$ kilowatt-hours was developed by prime movers operated by the industries themselves and that $3,338,800,000$ kilowatthours was purchased. It further shows that it would have been economical to shut down $4,008,200$ horsepower of prime movers and purchase energy to the amount of $5,623,800,000$ kilowatt-hours, which would have made a total of $8,962,600,000$ kilowatt-hours purchased in 1919. The saving in coal thus effected would have been 13,502,100 tons-71 per cent of the coal used by the industries for producing power, or 25 per cent of all the coal used by the industries. In making the industrial power analysis care has been taken not to invade the field of what might be termed by-product power-that is, power produced by the industries from coal that would have been burned anyway for heat and in industrial processes. The saving determined is that made on coal burned for power and chargeable to the supply of power. It has been difficult to separate one class of coal burning from the other, yet after consultation with many authorities a separation has been made..

In general it has been found that industrial establishments which require 500 horsepower or less can economically purchase energy. Only those that need more than 500 horsepower and that have special requirements for heat can generate their own power economically, and even these should have central-station connections to take up irregularities of load. The efficiency of power production by isolated industrial plants is precluded from any considerable improvement by their necessarily small average capacity.

A careful study of the power requirement for industrial establishments in the superpower zone has been made and has shown that by 1930 an annual saving of $\$ 190,000,000$ can be made to the industries themselves above the fixed charges against an investment of $\$ 185,000,000$ for the motor equipment necessary to utilize the power.

Such a result will not of course be effected by any mysterious magical act of a superpower system. Indeed, many of the electric utilities have already been in a position to offer large savings to the industrial plants within reach of their distribution circuits.

In this study of the economical generation and distribution of power throughout the superpower zone full allowance has been made for the capital required to place regional plants in action, with their generating and transmission equipment connected with the distribution systems of the existing electric utilities, so as to reach every industrial worker in the zone. It is therefore hoped that this presentation of the saving that can be made may prove worthy of consideration by the executive officials of the industrial establishments in the zone.

Appendix E. Performance and cost of the superpower system.

Appendix $\mathrm{E}$ summarizes the report. It is built up of the appendixes that precede and follow it. It gives the investment cost and the cost of power delivered to the load centers for 1919,1925 , and 1930.

The cost of power at the busses of the electric utilities includes a return of 10 per cent on the money invested in the generating and transmission system. It is thought that during this present period of high interest a yield of not less than 10 per cent would be required to attract the necessary capital to this form of investment.

Figure 1 shows the distribution of load in the superpower zone in 1919. A comparison of this diagram with figures 20 and 21 brings out the degree of decentralization that is possible through the agency of a superpower system. The 20 load centers of 1919 are increased to 34 by 1930 , and the superpower transmission system can not economically be tapped for a load of less than 20,000 kilowatts. 
The frequency selected for the superpower system is 60 cycles. At the New York, Baltimore, and Washington load centers the principal frequency is 25 cycles, but generator sales in the ratio of 9 to $6 \frac{1}{2}$ in favor of 60-cycle apparatus during the last 5 years and generated output in the ratio of 4.75 to 2.2 during the last 10 years unquestionably establish the trend and determine the choice for the superpower system.

The regional diversity existing in the superpower zone is assumed to be of more theoretical than practical importance, except the diversity existing between the Anthracite, Metropolitan, and Southern divisions, which will become very marked with the growth of the Anthracite division load by 1925 and 1930 .

Capacity to provide for load growth has been determined largely from the trend of the load factor. (See pp. 154-156.) The load factor for the electric utilities within the zone increased from 34 per cent in 1910 to 39 per cent in 1919. In some of the geographic divisions, such as the Metropolitan, the increase in load factor has been very slight; in others it has been large-for example, in the Southern division the load factor has increased from 33 to 43 per cent, largely owing to additions of industrial load.

In 1919 only 15 per cent of the total output of the electric utilities was hydroeleetric power. By 1930 this proportion will have been increased to 21 per cent. In 192550 per cent of the total generating capacity for superpower operation will be contained in plants owned by the present electric utilities, and they will produce about 26 per cent of the energy. By 1930 the corresponding percentage of generating capacity will have dropped to 39 per cent, and these plants will furnish only 18 per cent of the total output. They will be used principally to carry peak load.

In 1919 the average size of the electric-utility plants within the zone was 7,900 kilowatts; by 1930 this size will be increased to 29,900 kilowatts. An even more marked contrast is that between the average size of new steam-electric plants to be installed, which is 218,000 kilowatts, and the average size of the steam-electric utility plants existing in 1919, which is 10,000 kilowatts.

Of far-reaching importance, in my opinion, will be the maximum use of diversity economy made possible by the interconnecting circuits of the superpower system. By diversity economy I mean the ability to select capacity that will produce power at minimum cost.

The unit investment cost in new power plants for the superpower system is $\$ 118.25$ per kilowatt of effective capacity; that for all plants is $\$ 125$ per kilowatt. The unit reproduction cost of the electric utilities in 1919 was $\$ 156$ per kilowatt of effective capacity. This reduction in cost for the superpower system is due to the greatly increased size of the plants. The contrast is even more striking in the unit investment cost per kilowatt of demand, which is $\$ 196$ per kilowatt for independent operation and only $\$ 1.36$ per kilowatt for the superpower system.

In 1930 the transmission system of the superpower system will represent 9.3 per cent of the total investment cost.

The new money required for the superpower system up to 1925 is $\$ 453,143,000$ and up to $1930 \$ 693,218,000$, thus making it necessary to raise $\$ 90,600,000$ annually for the first five years and $\$ 48,000,000$ annually for the following five years. The early installation of a transmission network calls for the higher rate for the first five years. This rate, however, is justified by the annual saving resulting from interconnection.

If the demand of 1930 were provided for by the independent systems as constructed to-day the total sum required would be $\$ 856,000,000$, or $\$ 85,600,000$ a year. Accordingly the construction of the superpower system will involve a saving in investment cost of $\$ 163,000,000$ during the next 10 years; in other.words, the increase of capacity to meet growing demands can be financed by the superpower plan for $\$ 16,300,000$ annually less than by the normal expansion of the existing electric utilities. On page 169 a full comparison is made between independent operation and superpower operation for the years 1919, 1925, and 1930. The net annual saving by 1930 above fixed charges and capital is approximately $\$ 239,000,000$.

Of great interest is the economic relation established between the joint use of steam and water power. It is shown that steam and water power can be so combined as to yield annually 
$\$ 69,550,000$ on an increased investment of only $\$ 44,838,000$. Here is exemplified one of the prime advantages of superpower production, costs being reduced by means of the interconnecting system which permits the highest economy in steam-produced power together with the maximum use of water power.

The load growth in the Eastern New England, Western New England, and MohawkHudson divisions should be sufficient to absorb the total axailable output of the St. Lawrence project by 1932; and the growth in the Metropolitan division should be sufficient to absorb 300,000 kilowatts at a load factor of 80 per cent from Niagara in the same year. Power could doubtless be purchased from these hydroelectric plants at not over $\$ 20$ per horsepower-year delivered at: their bus bars, and accordingly this figure is used in determining the effect of this arrangement on the cost of power to the divisions of the superpower zone that would be so supplied.

The total annual cost for power delivered in 1932 to. the load centers of the Eastern New England, Western New England, and Mohawk-Hudson divisions, if St. Lawrence power is used, will be $\$ 130,273,000$; if the excess energy required in 1932 over that of 1930 were furnished by new steam-electric plants the cost would be about $\$ 141,601,000$. The development of St. Lawrence River would therefore save $\$ 11,328,000$ a year to these geographic divisions; moreover, the total investment required to utilize purchased St. Lawrence power would be $\$ 24,826,000$ less than that required to construct new steam-electric plants to supply this excess energy. In the three divisions mentioned, which lie farthest from the coal fields, the cost of power generated by steam plants is inherently high, and therefore the St. Lawrence development will be of very 'great benefit to them.

The total cost to the Metropolitan division for the power it will require in 1932, if Niagara power is used, will be $\$ 107,651,000$. If the growth in energy required between 1930 and 1932 were supplied from new steam-electric plants in the Metropolitan division, the total cost in 1932 would be $\$ 110,899,000$, showing an annual saving of $\$ 3,248,000$ in favor of Niagara power. Were the power purchased from the Niagara power interests, the total investment for 1932 would be $\$ 5,080,000$ less than that required to generate an equal amount by steam.

The use. of the St. Lawrence power as suggested above would save 2,234,000 tons of coal annually, and the use of Niagara power in the Metropolitan division as suggested would save $1,204,000$ tons of coal annually.

The new power-plant capacity required in the superpower zone would be 3,098,000 kilowatts in 1925 and 4,980,000 kilowatts in 1930.

In Table 76 is shown the cost of power delivered from the new power plants and transmission system of the superpower system for 1930. The lowest rate is that for the Southern division, 6.8 mills per kilowatt-hour; the highest is that for Western New England, 11.4 mills. The average for the whole superpower zone is 8.4 mills. This, however, is the combined rate for power generated in new, large, and highly efficient hydroelectric and steam plants. The true comparison in production costs between the superpower system as of 1930 and independent operation for 1919 is 9.3 mills per kilowatt-hour as against 19.3 mills per kilowatt-hour.

Finally, the appendix shows that in 1930 the cost of the power produced by the superpower system, inclusive of fixed charges, as delivered on the busses of the electric utilities, would be 10.6 mills per kilowatt-hour, whereas the cost under independent operation as of 1919, exclusive of fixed charges, would be practically the same. This, in my opinion, is the fundamental reason why the expansion of electric utilities should follow the superpower plan.

Appendix F. Steam-electric plants for the superpower system.

Appendix F shows the capacity of the existing plants of the electric utilities to be retained in the superpower system and their location by geographic divisions. The total capacity retained is $2,677,000$ kilowatts, which represents 79 per cent of the effective capacity of the steam-electric public utilities in the superpower zone in 1919. The reproduction cost of these plants is $\$ 329,219,000$. 
This appendix presents curves showing the average performance of existing steam plants and of the plants in the superpower system. The character and the design of the base-load steam plants are discussed. The performance of the retained steam plants shows that these should average about 2.15 pounds of coal per kilowatt-hour, as against 2.73 pounds per kilowatthour for all electric-utility steam plants operating in the zone in 1919, when both groups are operating at the same annual capacity factor.

The average size of the steam plants retained is 44,600 kilowatts, and the reproduction cost as of 1919 is $\$ 124$ per kilowatt, as against $\$ 109.50$ for new steam plants as of 1930 . After consultation with many representatives of manufacturers in all parts of the country and with designing and operating engineers, the following operating characteristics for base-load steam plants were determined:

Steam pressure at turbine throttle, 300 pounds per square inch.

Superheat at turbine throttle, $230^{\circ} \mathrm{F}$.

Final temperature at turbine throttle, $652^{\circ} \mathrm{F}$.

Absolute pressure at turbine exhaust nozzle, 1 inch of mercury.

Of special interest is Table 80, showing summarized estimates of cost for three sizes of baseload steam plants. These estimates were made after consultation with many of the best authorities in power-station design and are considered conservative.

The base-load steam plants for the system will be composed of units of 30,000 kilowatts or multiples thereof, and the largest plant proposed is one of 360,000 kilowatts. These plants will be built in units, and some of them will require the full 10 years for their expansion to complete size. Plate VIII shows the performance for these plants and takes into account such reasonable advances in the art of power production as may be made in 10 years. By 1930 the new steamelectric plants should operate at a capacity factor of about 62 per cent with a fuel rate of 1.43 pounds of coal per kilowatt-hour.

Table 80 shows that the unit investment cost of a base-load steam-electric plant varies but little with size after 120,000 kilowatts has been reached, being only 6.5 per cent less for a $360,000-$ kilowatt station than for a 120,000-kilowatt station. On the other hand, the unit cost of a 30,000 -kilowatt plant is 23 per cent more than that of a 120,000 -kilowatt plant. .

The proposed new steam-electric plants have been so located as to obtain the fullest advantage of low freight rates, easy coal-delivery routes, and ample condensing water. Fourteen new steam-electric plants, aggregating 2,520,000 kilowatts, will be required by 1925, and four additional plants, or eighteen in all, aggregating 3,930,000 kilowatts, by 1930 . The total for 1925 is equivalent to 63 per cent of all the present steam-electric generating capacity in service for the utilities, and that for 1930 to 98 per cent.

In the Anthracite division base-load steam-elẹctric plants, using buckwheat No. 3 coal, can be operated most advantageously because of the combined use of their power for the Metropolitan and Southern divisions. The diversity between these divisions and the Anthracite division will permit operation at a capacity factor of 75 per cent, and under these conditions electric energy can be produced in 1930, inclusive of fixed charges, at 5.7 mills per kilowatt-hour. This figure is sufficiently low to permit the additional fixed charges on transmission for the part of the power that is sent to the tidewater region.

There are three steam-electric power-station sites in the Anthracite region-one near Pittston, one near the mouth of Nescopeck Creek, and one near Sunbury, all in Pennsylvania and all on Susquehanna River-at which sufficient condensing water is available to permit the development of 300,000 kilowatts each.

\section{Appendix G. Hydroelectric plants for the superpower system.}

The construction of a hydroelectric plant is economically justified if it produces its power at a cost less than that of a steam-electric plant of the same capacity. With maximum development of water power, however, the hydroelectric energy available within the superpower zone will amount to less than 21 per cent of the total electric power required in 1930. 
Of especial importance in determining the location and capacity of the new water-power plants for the zone is the economy attained by the development of rivers beyond their primary power. The dam and headworks of a hydroelectric plant. are the principal items of its cost. Additional generating units can be installed at half the cost of providing the same steamelectric capacity, and the construction of storage reservoirs will increase the capacity of the plant above the primary power of the river for effective use under peak loads.

The principal rivers which can contribute water power to the superpower zone are the Potomac, Susquehanna, Delaware, Hudson, and Connecticut. It is proposed to utilize power - from these rivers in 1930 to the following extent:

\begin{tabular}{|c|c|c|c|c|}
\hline River. & $\begin{array}{c}\text { Capacity } \\
\text { (kilowatts). }\end{array}$ & $\begin{array}{c}\text { Output } \\
\text { (millions of } \\
\text { kilowatt- } \\
\text {. hours). }\end{array}$ & Investment. & $\begin{array}{l}\text { Production } \\
\text { cost (mills } \\
\text { per kilo- } \\
\text { watt-hour). }\end{array}$ \\
\hline 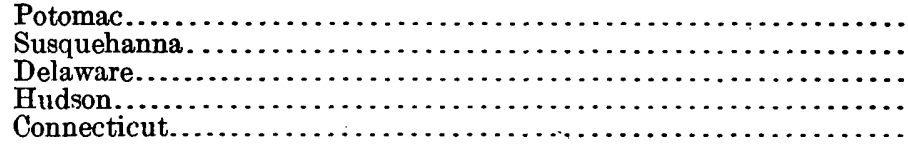 & $\begin{array}{l}200,000 \\
185,000 \\
350,000 \\
150,000 \\
165,000\end{array}$ & $\begin{array}{r}950 \\
1,230 \\
1,250 \\
900 \\
760\end{array}$ & $\begin{array}{r}\$ 22,000,000 \\
28,000,000 \\
51,500,000 \\
38,350,000 \\
29,000.000\end{array}$ & $\begin{array}{l}3.36 \\
\text { 3. } 22 \\
5.95 \\
5.84 \\
5.45\end{array}$ \\
\hline
\end{tabular}

It is proposed to develop these rivers above their primary power capacity for peak-load operation.

The water powers of Niagara and St. Lawrence rivers are within transmission distance of the superpower zone, but on account of the time required for construction on the St. Lawrence and of the treaty restrictions concerning the use of the water at Niagara Falls the power from these sources has not been considered available in the zone prior to 1930 .

Under present construction and operating costs power purchased at Niagara or on St. Lawrence River at $\$ 20$ a horsepower, ready for transmission at those points at potentials of not less than 220,000 volts, can be placed at Utica and Schenectady, N. Y., and at Northampton, Mass., for 4.6 mills per kilowatt-hour, and at Paterson, N. J., for 5.7 mills. These figures assume purchases of not less than 300,000 kilowatts delivered at a load factor of not less than 80 per cent.

The reproduction cost of the 451,500 kilowatts of existing hydroelectric capacity within the zone is $\$ 87,127,000$. The new hydroelectric capacity which should be installed by 1930 will bring the total capacity up to 1,501,500 kilowatts, of which the old plants will represent 30 per cent. In 1930 the total hydroelectric investment will be $\$ 245,977,000$, of which the old plants will represent 35 per cent.

\section{Appendix H. The superpower transmission system.}

So far as the existing electric utilities are concerned the superpower system begins and ends at their power-station busses, and so far as the new superpower plants are concerned it begins at these plants and ends on the busses of the existing electric utilities.

In presentations of the superpower plan I have said, "The primaries of to-day will be the secondaries of to-morrow." The existing transmission systems of the electric-utility companies, which comprise about 1,200 miles operated at 33,000 volts or higher, will become distribution rather than transmission systems, and they will of necessity require expansion to distribute the additional power delivered to them from the superpower system. The transmission features of the superpower system will therefore have to do only with the transmission of power from the new plants to load centers and to the busses of the existing electric-utility plants.

In 1930 the superpower transmission system should consist of 970 circuit miles of 220,000volt lines and 4,696 circuit miles of 110,000-volt interconnecting lines. To these lines will be connected 5,600,000 kilovolt-amperes of transformer capacity, not including the transformer capacity in the base-load steam-electric plants. The construction of the transmission systems for the St. Lawrence and Niagara devęlopments will add 3,140 circuit miles of 220,000-volt lines 
and 1,824,000 kilovolt-amperes of transformers. Thus potentials of not less than 220,000 volts will be selected to transmit power from plants that are at considerable distances from the general interconnected superpower plants, and within the zone a potential of not less than 110,000 volts will be employed for interconnection between power and load centers. Plates II and III illustrate the proposed transmission arrangements.

In our study of the transmission problem within and without the superpower zone we have been most fortunate in obtaining advice and counsel from most of the high-tension experts of this country. Throughout this study it has been assumed as a necessary condition that the factor of reliability of transmission service for the superpower system must be the same as that of the busses of the power stations themselves. The transmission system has therefore been considered merely as a high-tension extension of those busses.

Appendix I. Reliability of service.

The inherent features of the superpower system themselves constitute adequate provision for reserves throughout its structure.

Appendix J. The relation of coal and coal-delivery routes to the superpower system.

The elements of greatest importance in insuring a continuous supply of power are coal and the routes by which coal is delivered to the superpower stations. Table 97 shows the distribution and use of coal in the superpower zone in 1919.

Plate $\mathrm{X}$ shows the available coal-mining districts and the principal rail routes to the proposed base-load steam-electric plants for 1930. This map relates especially to bituminous coal, for the plants that burn anthracite will be built in the anthracite region.

Throughout the study the cost of bituminous coal at the mines has been taken at $\$ 2.90$ per short ton-the weighted average cost for 1919 to the industries that used bituminous coal. Doubtless labor costs will be reduced, but this reduction will be offset by the necessity of developing deeper mines and thinner seams and of extending underground haulage. The freight rates for 1919 were used in the calculations made for that year, but in the calculations for 1925 and 1930 the freight rates in force January 1, 1921, have been used.

For buckwheat coal used at stations in the anthracite region $\$ 1.75$ per long ton has been used as the mine price for all periods, with $\$ 1$ per long ton as the gathering charge.

The cost of coal delivered to the several load centers is shown in Table 98. Naturally these costs have played an important part in determining the location of steam-electric power stations.

Six months' storage capacity for each plant is recommended and would yield obvious advantages. It would absolutely prevent interruption of service due to lack of fuel; it would permit the purchase of coal at the lowest price; and it would help to stabilize the mining and transportation industries by making the demand for coal more uniform.

The question whether the superpower system should own coal mines, coal cars, coal-delivery routes, either or all, has been considered, and it has been concluded that the superpower system should confine its activities to the production of power and the storage of coal.

Appendix K. Use of process fuels and pulverized coal for base-load steam-electric plants.

Under present conditions, in general, coal must be used in raw form to produce cheap power. Coal is treated by certain processes for two purposes-to place its energy in more desirable form and to recover valuable by-products. If power is produced by the use of either coke or gas from process-fuel plants the value of the remaining products, when credited to the cost of such fuels, is not sufficient to reduce their cost below that of raw coal. As certain by-products are essential in time of war regardless of cost, however, it has been deemed desirable in selecting a site for a superpower station to provide space for a processing plant and to adopt a method of boiler-room construction that will permit the use of process fuel if and when its use is found desirable.

Appendix $K$ compares the results of the use at base-load steam-electric plants of process fuels prepared by four methods. Table 99 shows that the cost of fuel prepared by three of the 
four processes is higher than that of raw coal. Where gas is the process fuel made at by-product coke ovens it is cheaper than raw coal, but the large quantity of coke produced and the difficulty of disposing of it make this process generally impracticable. In certain situations, however, as the appendix points out, if the gas can be sold at a sufficiently high price processing of fuel may be economical.

The greatest promise regarding process fuel lies in the direction of devising plants that will convert raw fuel entirely into gas for consumption under the boilers at steam-electric stations and thus eliminate the enormous concentration of coke. Such a process plant used in combination with a steam-electric plant may produce fuel at a cost materially lower than that of raw coal, but the experimental work done is not yet sufficient to permit a stronger statement than that the progress made is exceedingly encouraging.

\section{Appendix L. Basic costs.}

Appendix L, which considers cost of money, depreciation and obsolescence, and taxes, and insurance, is so brief that it is in itself a summary. The term "general expense," used in the estimates of cost of power production, includes salaries and expenses of administrative officers, engineers, and legal counsel, salaries of clerks, and expenses covering claims, stationery, printing, etc. Amortization, taxes, and insurance have been included under "fixed charges" rather than in this item.

Figure 61 shows the relation of "general expense" to annual gross revenue. This curve shows the small rate of percentage increase in charge for general expense for revenue above $\$ 3,000,000$ and the marked increase for revenue less than $\$ 3,000,000$. 


\section{APPENDIX A. ORGANIZATION.}

By W. S. MurraY.

In planning this investigation and effecting its organization it was clear that the power market to be served by the proposed superpower system would be divided between the electric utilities, the railroads, and the isolated industrial establishments. Accordingly, Mr. Lorin E. Imlay, Dr. Cary T. Hutchinson, and Mr. Henry W. Butler were recommended and appointed, respectively, as division engineers in charge of the departments of power and transmission, of railroads, and of industries.

Associated with the division engineers as assistants, with duties so shifted as to maintain the highest engineering load factor in the work, were Messrs. Harold Goodwin, jr., Malcolm MacLaren, Norman C. McPherson, E. M. Newlin, B. J. Peterson, T. B. Rutherford, Arthur R. Wellwood, and Lyle A. Whitsit. I desire to make special mention of the able services rendered by these men.

Mr. N. C. Grover, chief hydraulic engineer of the United States Geological Survey, and Mr. O. P. Hood, chief mechanical engineer of the United States Bureau of Mines, were detailed for advisory service on the engineering staff. Mr. Grover, in addition to serving in his capacity as hydraulic engineer, rendered much assistance in administrative work, and Mr. Hood especially studied the problems pertaining to the use of process fuels.

That the work in all departments might be completely coordinated a principal assistant, charged with the assembling of all data and the preliminary preparation of the text of the report, was imperatively needed, and for this responsible duty Mr. Henry Flood, jr., was appointed, with the title of engineer-secretary. The duty of the engineer-secretary included the checking and coordination of the information collected for the several appendixes; and the speed of its collection or compilation for any particular appendix was increased or slackened, as occasion might require, to make it fit in with the rest, so that the report as a whole could be completed on time.

An advisory board was selected, consisting of the following members:

Lester P. Breckenridge (chairman), professor of mechanical engineering, Yale University, New Haven, Conn.; representing fuel engineering.

-Magnus W. Alexander, managing director, National Industrial Conference Board, Boston, Mass.; representing National Industriai Conference Board.

Edward G. Buckland; vice president New York, New Haven \& Hartford Railroad Co., New Haven, Conn.; representing New England railroads.

Charles L. Edgar, president Edison Electric Illuminating Co. of Boston, Boston, Mass.; representing National Electric Light Association.

Abraham T. Hardin, vice president New York Central Railroad Co., New. York City; representing New York railroads.

Herbert Hoover, now Secretary of Commerce, Washington, D. C.; when appointed, president American Institute of Mining and Metallurgical Engineers; representing the mining industry.

William Kelly, Colonel, United States Army, Washington, D. C.; representing the War Department.

Elisha Lee, vice president Pennsylvania Railroad Co., Philadelphia, Pa.; representing railroads south of New York.

Arthur D. Little, president of Arthur D. Little, Inc., Cambridge, Mass.; representing electro-chemical and by-products industries.

James H. McGraw, president McGraw-Hill Co., Inc., New York City; representing the technical press.

John H. Pardee, president J. G. White Management Corporation, New York City; representing American Electric Railway Association.

Henry C. Perkins, mining engineer, Washington, D. C.; representing the mining industry.

Matthew S. Sloan, president Brooklyn Edison Co., Brooklyn, N. Y.; representing National Electric Light Association. 
During the year eight meetings of the advisory board were held, and for the counsel and advice offered by its members I now express my most sincere appreciation.

Prof. L. P. Breckinridge, chairman of the advisory board, who has been constant in attendance at the meetings of the board and at many of the meetings of the engineering staff, has been encouragement personified. and with his circumspection and his ability as a leader in the solution of the fuel problem has been of invaluable assistance.

I believe I can say without contradiction that the engineering staff is a unit in the findings of this report, and I can find no words to express fitly the tribute $I$ owe these men for their loyalty and their able assistance.

The engineering staff, for all the members of which I speak, are especially grateful to the experts mentioned in the following list. To them apparently came the sense of responsibility of contributing their experience to the fullest where it was required. They made it apparent to me that I could call on them exhaustively, for they realized the national importance of this problem. Many, therefore, have been the consultations held with them, and their advice is reflected in the pages of this report.

W. K. Archbold, Archbold-Brady Co., Syracuse, N. Y.

A. H. Armstrong, General Electric Co., Schenectady, N. Y.

W. S. Barstow, W. S. Barstow Management Association, New York City.

H. B. Bradford, Edge Moor Iron Co., New York City.

George Foran, Worthington Pump \& Machinery Corporation, New York City.

F. C. Hanker, Westinghouse Electric \& Manufacturing Co., East Pittsburgh, Pa.

F. L. Hunt, Turners Falls Power Co., Greenfield, Mass.

John B. Leeper, American Bridge Co., Pittsburgh, Pa.

P. M. Líncoln, Lincoln Electric Co., Cleveland, Ohio.

William Nesbit, Westinghouse Electric \& Manufacturing Co., New York City.

William Barclay Parsons, consulting engineer, New York City.

Hugh Pattison, Westinghouse Electric \& Manufacturing Co., New York City.

Ernest W. Pragst, General Electric Co., Schenectady, N. Y.

David B. Rushmore, General Electric Co., Schenectady, N. Y.

F. H. Shepard, Westinghouse Electric \& Manufacturing Co., New York City.

John A. Stevens, consulting engineer, Boston, Mass.

Percy H. Thomas, consulting engineer, New York City.

Theodore Varney, Aluminum Company of America, Pittsburgh, Pa.

Hosea Webster, Babcock \& Wilcox Co., New York City.

Sidney Withington, New York, New Haven \& Hartford Railroad Co., New Haven, Conn.

A host of others, engineers and business men, contributed most valuable and pertinent information to this work, and I wish to make here the most grateful recognition of their services. The names of these coworkers follow, classified as to the nature of the information furnished:

Power and transmission.

Ralph W. Atkinson, assistant chief engineer, Standard Underground Cable Co., Perth Amboy, N. J.

A. O. Austin, Ohio Insulator Co., Barberton, Ohio.

H. A. Barre, Southern California Edison Co., Los Angeles, Calif.

F. G. Baum, consulting engineer, San Francisco, Calif.

H. M. Beugler, operating manager, Central Hudson Gas \& Electric Co., Poughkeepsie, N. Y.

E. H. Beugler, vice president, Foundation Co., New York City,

Francis Blossom, Sanderson \& Porter, New York City.

H. V. Bozell, Electric Railway Journal, New York City.

W. B. Brackenridge, senior vice president, Southern California Edison Co., Los Angeles, Calif.

H. W. Buck, Viele, Blackwell \& Buck, New̧ York City.

Charles I. Burkholder, general manager, Southern Power Co., Charlotte, N. C.

N. A. Carle, chief engineer, Puislic Service Electric Co., Newark, N. J.

Charles W. E. Clark, chief mechanical engineer, Dwight P. Robinson Co., New York City.

C. S. Cork, general manager, Duquesne Light Co., Pittsburgh, Pa.

Hugh L. Cooper, president, Hugh L. Cooper \& Co., New York City.

M. J. Daley, care of Fred T. Ley \& Co. (Inc.), Springfield, Mass.

C. W. DeForest, chief engineer, Union Gas \& Electric Co., Cincinnati, Ohio.

G. C. Derry, B. F. Sturtevant Co., Boston, Mass.

H. H. Dewey, power and mining-engineering department, General Electric Co., Schenectady, N. Y. 
P. M. Downing, Pacific Gas \& Electric Co., San Francisco, Calif.

McKee Duncan, consulting engineer, Duncan, Young \& Co., New York City.

E. D. Edmonston, general superintendent, Consolidated Gas \& Electric Light Co., Baltimore, Md.

W. C. L. Eglin, chief engineer, Philadelphia Electric Co., Philadelphia, Pa.

Boyd Ehle, consulting engineer, Sanderson \& Porter, New York City.

L. L. Elden, Edison Electric Illuminating Co. of Boston, Boston, Mass.

John B. Fisken, engineer, Washington Water \& Power Co., Spokane, Wash.

J. B. Foote, chief engineer, Consumers Power Co., Jackson, Mich.

F. S. Freeman, superintendent of power, Boston Elevated Railway Co., Boston, Mass.

E. U. Gibbs, chief engineer, S. Morgan Smith Co., York, Pa.

E. M. Gilbert, chief engineer, W. S. Barstow Management Association, Reading, Pa.

C. E. Groesbeck, vice president, Electric Bond \& Share Co., New York City.

John L. Harper, vice president and chief engineer, Niagara Falls Power Co., Niagara Falls, N. Y.

R. S. Hopkins, assistant manager, sales department, Standard Underground Cable Co., New York City.

Dugald C. Jackson, Jackson \& Moreland, Boston, Mass.

J. Alan Johnson, electrical engineer, Niagara Falls Power Co., Niagara Falls, N. Y.

J. P. Jollyman, Pacific Gas \& Electric Co., San Francisco, Calif.

Peter Junkersfeld, Stone \& Webster (Inc.), Boston, Mass.

Col. Charles Keller, Board of Engineers for Rivers and Harbors, Washington, D. C.

John H. Lawrence, engineering manager, Thomas E. Murray (Inc.), New York City.

H. P. Liversidge, assistant chief engineer, Philadelphia Electric Co., Philadelphia, Pa.

James Lyman, Sargent \& Lundy, Chicago, Ill.

A. M. Lynn, president, West Penn Power Co., Pittsburgh, Pa.

E. H. McHenry, Ardmore, Pa.

S. O. Moore, geveral manager, New England Power Co., Worcester, Mass.

P. J. Morrissey, vice president, Pennsylvania Public Service Corporation, Johnstown, Pa.

William S. Munroe, Sargent \& Lundy, Chicago, Ill.

George A. Orrok, consulting engineer, New York City.

Farley Osgood, vice president and general manager, Public Service Electric Co., Newark, N. J.

John Overn; manager hydraulic division, William Cramp \& Sons Ship \& Engineering Co., Philadelphia, Pa

J. W. Parker, assistant to vice president, Detroit Edison Co., Detroit, Mich.

F. W. Peck, consulting engineer, General Electric Co., Pittsfield, Mass.

Charles Penrose, assistant general manager, Day \& Zimmerman, Philadelphia, Pa.

N. L. Pollard, electrical engineer, Public Service Electric Co., Newark, N. J.

N. G. Reinicker, superintendent, Pennsylvania Power \& Light Co., Allentown, Pa.

J. W. Rickey, hydraulic engineer, Aluminum Company of America, Pittsburgh, Pa.

Charles A. Ruffner, president, Adirondack Power Co., Amsterdam, N. Y.

Frank C. Sargent, vice president, Charles H. Tenney \& Co., Boston, Mass.

E. F. Scattergood, electrical engineer, Bureau of Power \& Light, Los Angeles, Calif.

H. H. Schoolfield, chief engineer, Pacific Light \& Power Co., Portland, Oreg.

R. F. Schuchardt, electrical engineer, Commonwealth Edison Co., Chicago, Ill.

Prof. Charles F. Scott, Yale University, New Haven, Conn.

C. A. Sears, manager, Mississippi River Power Co., Keokuk, Iowa.

Paulding T. Sellers, general superintendent, Buffalo General Electric Co., Buffalo, N. Y.

Carroll H. Shaw; New York Edison Co., New York City.

Emory J. Shute, assistant superintendent, Penn Central Light \& Power Co., Altoona, Pa.

S. D. Sprong, electrical engineer, Brooklyn Edison Co., Brooklyn, N. Y.

L. B. Stillwell, consulting engineer, New York City.

V. M. F. Tallman, power engineer, Charles H. Tenney \& Co., Boston, Mass.

Philip Torchio, chief electrical engineer, New York Edison Co., New York City.

Maj. M. C. Tyler, Corps of Engineers, United States Army, Washington, D. C.

J. A. Walls, vice president and chief engineer, Pennsylvania Water \& Power Co., Baltimore, Md.

A. E. Welles, mechanical engineer, J. G. White Engineering Corporation, New York City.

J. F. Wessel, vice president, United Gas \& Electric Engineering Corporation, New York City.

W. M. White, chief engineer, Allis-Chalmers Manufacturing Co., Milwaukee, Wis.

Clifton W. Wilder, New York Edison Co., New York City.

Col. W. P. Wooten, United States Lake Survey, Detroit, Mich.

\section{Industries.}

Dan Adams, Lockwood, Green \& Co., Boston, Mass.

Joseph Brobston, vice president, Dexter Portland Cement Co., Nazareth, Pa.

J. F. Daly, chief clerk, Division of Manufactures, Bureau of the Census, Washington, D. C.

F. F. Dickerman, engineer, Philadelphia, Pa. 
Crosby Field, engineering manager, National Aniline \& Chemical Co., New York City.

B. P. Foster, electrical engineer, E. I. DuPont de Nemours \& Co., Wilmington, Del.

John J. Gillespie, United Shoe Machinery Co., Boston, Mass.

Eugene G. Grace, president; Bethlehem Steel Co., Bethlehem, Pa.

E. F. Hartley, chief statistician for manufactures, Bureau of the Census, Washington, D. C.

J. A. Hedgcock, Management Engineering \& Development Co., Dayton, Ohio.

H. A. Hornor, consulting engineer, Buckingham Valley, Bucks County, Pa.

W. F. James, Westinghouse Electric \& Manufacturing Co., Philadelphia, Pa.

W. MacDonald, Swift \& Co., Chicago, Ill.

D. M. Meyers, consulting engineer, New York City.

Edward L. Moreland, Jackson \& Moreland, Boston, Mass.

Rollin Norris, United Gas Improvement Co., Philadelphia, Pa.

George H. Perkins, consulting engineer, Boston, Mass.

W. J. Serrill, United Gas Improvement Co., Philadelphia, Pa.

H. S. Taylor, Management Engineering \& Development Co., Dayton, Ohio.

W. S. Timmins, consulting engineer, New York City.

J. M. Wadsworth, general superintendent, Empire Refineries (Inc.) Tulsa, Okla.

H. M. Warren, electrical engineer, Delaware, Lackawanna \& Western Railroad Co., Scranton, Pa.

R. H. Thite, engineer of construction, American Locomotive Co., Schenectady, N. Y.

William Wilcox, Whitlock Coil Pipe Co., Boston, Mass.

R. K. Wright, electrical engineer, Baldwin Locomotive Works, Philadelphia, Pa.

\section{Coal and by-products.}

W. H. Blauvelt, Semet-Solvay Co., Syracuse, N. Y.

F. P. Coffin, research laboratory, General Electric Co., Schenectady, N. Y.

A. C. Fieldner, Bureau of Mines, Washington, D. C.

William P. Frey, fuel engineer, Lehigh Coal \& Navigation Co., Lansford, Pa.

E. W. Hess, civil engineer, Clearfield, Pa.

A. H. Horton, United States Geological Survey, Washington, D. C.

Rudolph Kudlich, Bureau of Mines, Washington, D. C.

C. E. Lesher, editor of Coal Age, New York City.

H. M. Matthews, coal-traffic manager, Baltimore \& Ohio Railroad Co., Baltimore, Md.

R. J. Montgomery, vice president, Philadelphia \& Reading Coal \& Iron Co., Philadelphia, Pa.

E. W. Parker, Anthracite Bureau of Information, Philadelphia, Pa.

Henry M. Payne, consulting engineer, New York City.

F. B. Pryor, Consolidated Coal Co., Fäirmont, W. Va.

George S. Rice, chief mining engineer, Bureau of Mines, Washington, D. C.

W. J. Richards, president, Philadelphia \& Reading Coal \& Iron Co., Philad'elphia, Pa.

J. S. Sillyman, mining engineer, Altoona, Pa.

G. N. Snider, coal-traffic manager, New York Central Railroad Co., New York City.

F. T. Snyder, Gas Producer Products (Inc.), New York City.

W. W. Taylor, acting vice president, International Coal Product Corporation, New York City.

Samuel A. Taylor, consulting engineer, Pittsburgh, Pa:

F. G. Tryon, United States Geological Survey, Washington, D. C.

Heavy traction.

Prof. W. J. Cunningham, School of Transportation, Harvard University, Cambridge, Mass. J. H. Davis, electrical engineer, Baltimore \& Ohio Railroad Co., Baltimore, Md.

F. B. Freeman, chief engineer, Boston \& Albany Railroad Co., Boston, Mass.

A. W. Gibbs, chief 'mechanical engineer, Pennsylvania System, Philadelphia, Pa. George Gibbs, consulting engineer, New York:

Edwin B. Katte, director electric traction, New York Central Railroad Co., New York City.

M. W. Manz, development engineer, Ohio Brass Co., Barberton, Ohio.

C. H. Quinn, electrical engineer, Norfolk \& Western Railway Co., Roanoke, Va.

J. T. Wallis, chief of motive power, Pennsylvania System, Altoona, Pa.

\section{Law and finance.}

H. M. Addinsell, Harris Forbes \& Co., New York.

A. E. Barrows, president, Narragansett Lighting Co., Providence, R. I.

T. R. Beal, president, Central Hudson Gas \& Electric Co., Poughkeepsie, N. Y.

A. W. Burchard, vice president, General Electric Co., New York.

Frederick Darlington, Westinghouse Electric \& Manufacturing Co., New York. 
F. M. Feiker, Assistant to the Secretary of Commerce, Washington, D. C.

H. I. Harriman, president, New England Power Co., Boston, Mass.

John Price Jackson, Ardmore, Pa.

John W. Lieb, vice president, New York Edison Co., New York.

Joseph B. McCall, president, Philadelphia Electric Co., Philadelphia, Pa.

Thomas M. McCarter, president, Public Service Electric Co., Newark, N. J.

D. E. Manson, vice president, Charles H. Tenney \& Co., Boston, Mass.

S. Z. Mitchell, president, Electric Bond \& Share Co., New York.

Thomas E. Murray, president, Thomas E. Murray (Inc.), New York.

E. W. Rice, president, General Electric Co., New York.

James Sheldon, Lee Higginson \& Co., New York.

Guy E. Tripp, chairman board of directors, Westinghouse Electric \& Manufacturing Co., New York.

Herbert Wagner, president, Consolidated Gas, Electric Light \& Power Co., Baltimore, Md.

O. D. Young, vice president, General Flectric Co., New York.

An appropriation of $\$ 250,000$ was requested to cover the investigation and report. Congress appropriated $\$ 125,000$, with the proviso that additional funds could be subscribed by the parties in interest. The electric utilities, industries, and railroads rendered so much valuable engineering assistance that the additional amount required to complete the investigation and report was only $\$ 26,000$. This amount was subscribed by the electric public utilities and manufacturers within the zone, and its welcome receipt is now gratefully acknowledged. The sum of $\$ 25,000$ of the Federal appropriation was expended "for a survey of power production and distribution in the United States" in accordance with the terms of the appropriating act.

In concluding this investigation I wish to say that when I was asked by the Secretary of the Interior to accept the chairmanship of the superpower survey I did so with the predominating thought that a large responsibility would be attached to the authorship of the report to be prepared, and that in this great work no one man should assume that responsibility. Nothing can so surely bring success to an enterprise of this kind as its prosecution under the concordant action of a large number of minds. The estimate of the saving to be effected by the superpower system in 1930 is based upon the cost of power production in $191 \hat{9}$, and we have no doubt that it can bo made. We also agree that much of this saving can be made through the natural expansion of the electric public utilities, but if these utilities, which are the only instrumentalities througn which maximum economy can be attained, will cooperate 100 per cent to the end that a coordinated expansion through interconnecting systems of transmission and distribution circuits shall be made, then the shortest route to a maximum national conservation of money, labor, and material will have been mapped out. To show that such a project is feasible and would be profitable was the task that confronted my organization on July 1, 1920. 


\section{APPENDIX B.}

\section{ELECTRIC UTILITIES IN INDEPENDENT OPERATION IN THE SUPERPOWER ZONE IN 1919.}

By L. E. ImLAY, T. B. RUTherford, and others of the engineering staff.

\section{DEMAND AND OUTPUT.}

Table 1 shows the distribution of load, the demand, and the requirements of energy for electric utilities in the superpower zone in 1919 and the frequencies in use.

TABLE 1.-Distribution of load, by geographic divisions and load centers, for electric utilities in the superpower zone in 1919.

\begin{tabular}{|c|c|c|c|c|c|c|c|c|}
\hline \multirow{2}{*}{$\begin{array}{l}\text { Geographic division and load } \\
\text { center. }\end{array}$} & \multicolumn{4}{|c|}{ Maximum demand (thousands of kilowatts). } & \multicolumn{4}{|c|}{ Energy output (millions of kilowatt-hours). } \\
\hline & 25 cycles. & 60 cycles. & $\begin{array}{l}\text { Other fre- } \\
\text { quencies. }\end{array}$ & Total. & 25 cycles. & 60 cycles. & $\begin{array}{l}\text { Other fre- } \\
\text { quencies. }\end{array}$ & Total. \\
\hline \multirow[t]{2}{*}{ 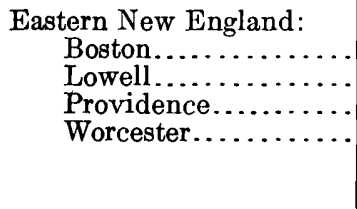 } & $\begin{array}{r}68.06 \\
4.56 \\
25.80 \\
11.00\end{array}$ & $\begin{array}{r}122.14 \\
62.18 \\
128.95 \\
86.81\end{array}$ & $\begin{array}{r}52.96 \\
1.82 \\
6.02 \\
2.52\end{array}$ & $\begin{array}{r}243.16 \\
68.56 \\
160.77 \\
100.33\end{array}$ & $\begin{array}{r}240.18 \\
13.85 \\
65.87 \\
30.60\end{array}$ & $\begin{array}{l}380.72 \\
176.05 \\
370.27 \\
314.24\end{array}$ & $\begin{array}{r}151.77 \\
7.11 \\
14.66 \\
7.09\end{array}$ & $\begin{array}{l}772.67 \\
197.01 \\
450.80 \\
351.93\end{array}$ \\
\hline & 109.42 & 400.08 & 63.32 & 572.82 & 350.50 & $1,241.28$ & 180.63 & $1,772.41$ \\
\hline \multirow[t]{2}{*}{ 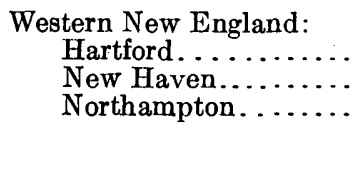 } & $\begin{array}{r}6.60 \\
33.68 \\
4.60\end{array}$ & $\begin{array}{l}50.47 \\
90.47 \\
94.04\end{array}$ & $\begin{array}{r}3.98 \\
21.06 \\
9.23\end{array}$ & $\begin{array}{r}61.05 \\
145.21 \\
107.87\end{array}$ & $\begin{array}{r}26.02 \\
133.00 \\
14.14\end{array}$ & $\begin{array}{l}133.66 \\
248.30 \\
293.64\end{array}$ & $\begin{array}{r}7.87 \\
54.77 \\
10.59\end{array}$ & $\begin{array}{l}167.55 \\
436.07 \\
318.37\end{array}$ \\
\hline & 44. 88 & 234.98 & 34.27 & 314.13 & 173. 16 & 675.60 & 73.23 & 921.99 \\
\hline \multirow{2}{*}{$\begin{array}{l}\text { Mohawk: } \\
\text { Utica................... } \\
\text { Schenectady } . \ldots \ldots \ldots\end{array}$} & $\begin{array}{r}1.57 \\
13.10\end{array}$ & $\begin{array}{r}25.36 \\
8.50\end{array}$ & $\begin{array}{r}.14 \\
87.20\end{array}$ & $\begin{array}{r}27.07 \\
108.80\end{array}$ & $\begin{array}{r}5.86 \\
30.92\end{array}$ & $\begin{array}{l}78.02 \\
28.02\end{array}$ & $\begin{array}{r}.37 \\
294.97\end{array}$ & $\begin{array}{r}84.25 \\
353.91\end{array}$ \\
\hline & 14.67 & 33.86 & 87.34 & 135.87 & 36.78 & 106. 04 & 295.34 & 438. 16 \\
\hline \multirow[t]{2}{*}{ 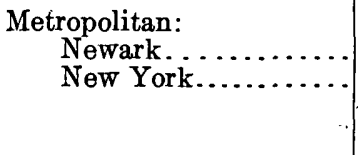 } & $\begin{array}{r}27.00 \\
809.00\end{array}$ & $\begin{array}{l}154.18 \\
148.79\end{array}$ & $\begin{array}{l}12.14 \\
13.89\end{array}$ & $\begin{array}{l}193.32 \\
971.68\end{array}$ & $\begin{array}{r}121.27 \\
2,648.99\end{array}$ & $\begin{array}{l}594.26 \\
477.34\end{array}$ & $\begin{array}{r}15.64 \\
9.17\end{array}$ & $\begin{array}{r}731.17 \\
3,135.50\end{array}$ \\
\hline & 836.00 & 302.97 & 26.03 & $1,165.00$ & $2,770.26$ & $1,071.60$ & 24.81 & $3,866.67$ \\
\hline \multirow[t]{2}{*}{$\begin{array}{l}\text { Hudson: } \\
\quad \text { Poughkeepsie........ }\end{array}$} & 0 & 20.05 & 1.45 & 21.50 & 0 & 59.33 & 1.15 & 60.48 \\
\hline & 0 & 20.05 & 1.45 & 21.50 & 0 & 59.33 & 1.15 & 60.48 \\
\hline \multirow[t]{2}{*}{ 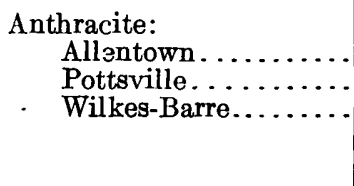 } & $\begin{array}{l}35.28 \\
0 \\
14.77\end{array}$ & $\begin{array}{l}35.40 \\
13.60 \\
79.48\end{array}$ & $\begin{array}{l}1.14 \\
1.10 \\
4.31\end{array}$ & $\begin{array}{l}71.82 \\
14.70 \\
98.56\end{array}$ & $\begin{array}{l}180.70 \\
0 \\
43.99\end{array}$ & $\begin{array}{r}148.53 \\
38.90 \\
309.16\end{array}$ & $\begin{array}{r}2.47 \\
3.30 \\
16.01\end{array}$ & $\begin{array}{r}331.70 \\
42.20 \\
369.16\end{array}$ \\
\hline & 50.05 & 128.48 & 6.55 & 185.08 & 224.69 & 496.59 & 21.78 & 743.06 \\
\hline \multirow[t]{2}{*}{ 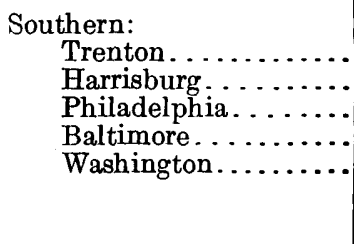 } & $\begin{array}{r}2.35 \\
.88 \\
107.70 \\
111.57 \\
66.50\end{array}$ & $\begin{array}{r}10.03 \\
69.72 \\
241.88 \\
2.54 \\
0\end{array}$ & $\begin{array}{r}3.70 \\
6.09 \\
19.25 \\
17.88 \\
\quad .60\end{array}$ & $\begin{array}{r}16.08 \\
76.69 \\
368.83 \\
131.99 \\
67.10\end{array}$ & $\begin{array}{r}7.64 \\
3.87 \\
365.31 \\
669.52 \\
231.71\end{array}$ & $\begin{array}{r}26.60 \\
234.91 \\
848.32 \\
\quad 7.37 \\
0\end{array}$ & $\begin{array}{r}10.30 \\
20.67 \\
66.11 \\
3.53 \\
2.50\end{array}$ & $\begin{array}{r}44.54 \\
259.45 \\
1,279.74 \\
680.42 \\
234.21\end{array}$ \\
\hline & 289.00 & 324.17 & 47.52 & 660.69 & $1,278.05$ & $1,117.20$ & 103.11 & $2,498.36$ \\
\hline Superpower zone... & $1,344.02$ & $1,444.59$ & 266.48 & $3,055.09$ & $4,833.44$ & $4,767.64$ & 700.05 & $10,301.13$ \\
\hline
\end{tabular}




\section{DISTRIBUTION OF. POWER.}

Figure 1 shows the electric-utility load at all the load centers in the superpower zone in 1919. A study of this load chart in combination with the analysis of load growth (p. 34) brings out the striking fact that the power required in 1930, the greater part of which will be applied to industrial uses, will be $2 \frac{1}{2}$ times that required to-day.

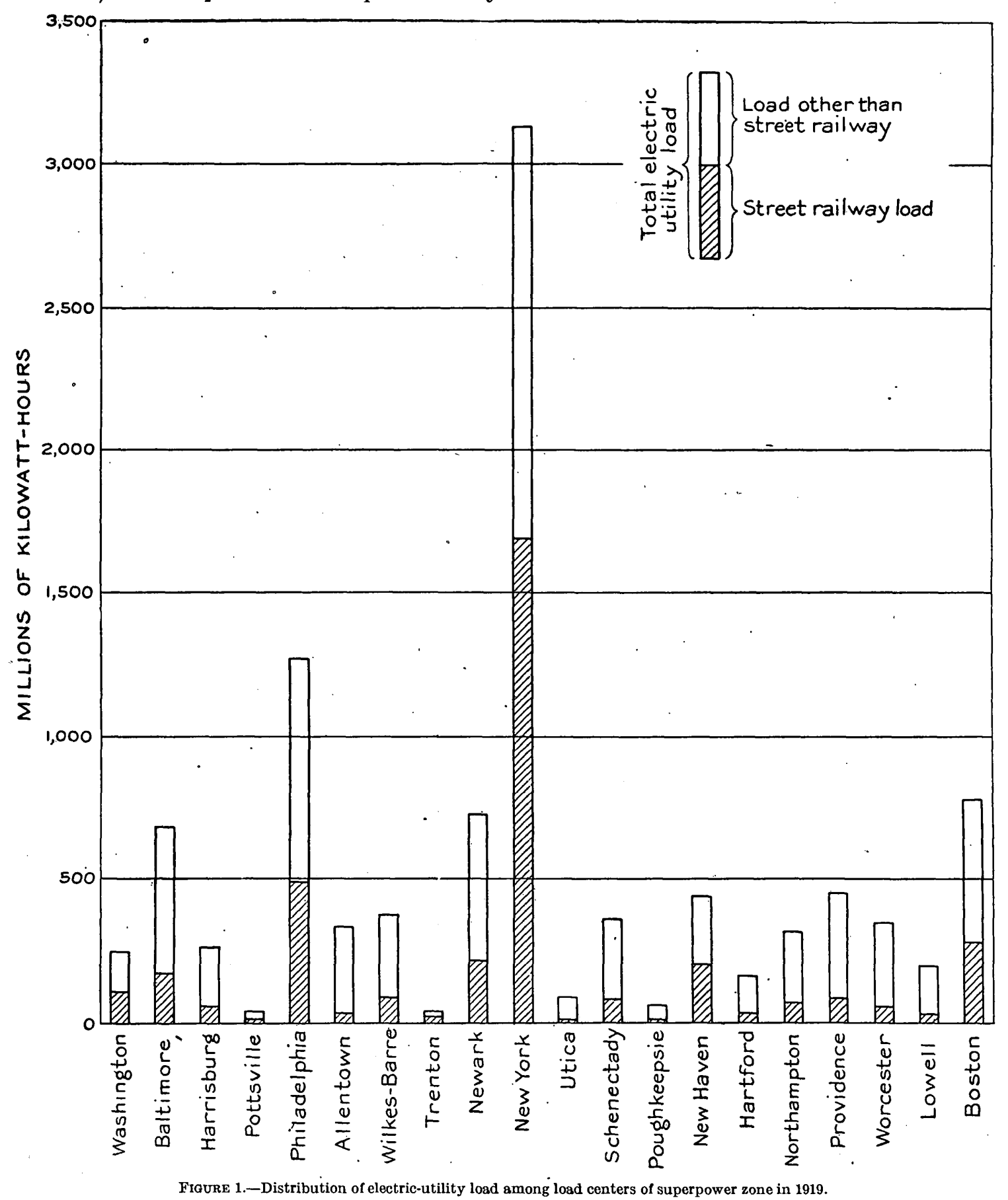

More than 50 per cent of the power generated at the present New York load center is used by the electric railways, whose slower rate of growth of load as compared with that in power for domestic and industrial uses will have the effect of decentralizing the total load on the superpower system by 1930. This effect is shown in Appendix E. The superpower system will become a means to this end.

$$
63361^{\circ}-21-3
$$


PAST AND ESTIMATED FUTURE GROWTH OF LOAD.

Plate IV shows the growth of the electric-utility industry by geographic divisions and for the entire superpower zone during the 10 years ending with 1919 and the estimated growth by 1925 and 1930. The record of the past growth includes the energy used for lighting, industrial power; electric street railways, and the electrified heavy-traction railroads. The estimate of the future growth does not include demands that may arise from the electrified heavy-traction systems.

The future rate of load growth is estimated at 8.6 per cent, compounded annually. This estimate is based upon the projection of past load growths taken in combination with opinions expressed by the operators of the electric-utility properties. The average ànnual growth during the last 10 years was 9 per cent.

\section{LOADS CARRIED.}

Figures 2-8, which are plotted from data furnished by the electric public-utility companies in the superpower zone, show the typical week-day, Saturday, and Sunday loads and also the demand for the day of peak load in 1919.

Plate V shows the relation of energy generated in kilowatt-hours to the demand in kilowatts for the several geographic divisions of the superpower zone in 1919. They show that only about 14 per cent of the energy generated in the zone is produced by the last 50 per cent of the demand. This indicates that the peak load should be carried by the less efficient steam-electric plants and by, overdeveloped hydroelectric plants, because when the dam and headworks of a hydroelectric plant are once. installed the cost of the generating apparatus for the plant is only half that of the total cost of a steam-electric plant. 
U.' S. GEOLOGICAL SURVEY
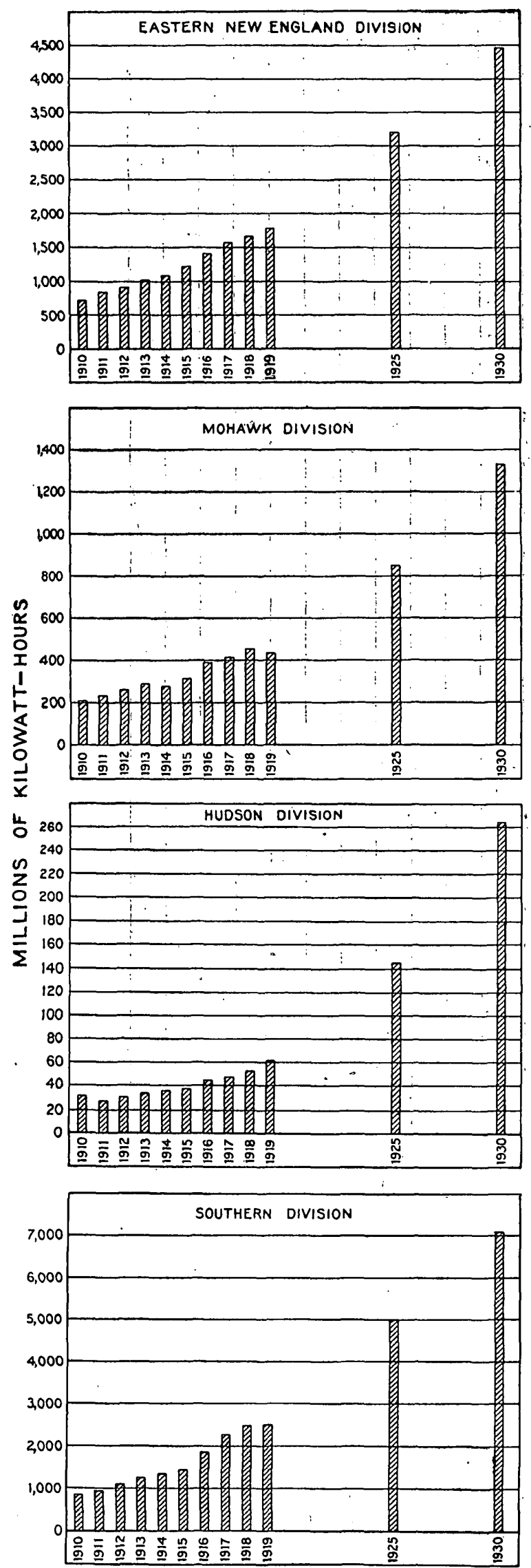

PROFESSIONAI PAPER 123 , PIATE IV.
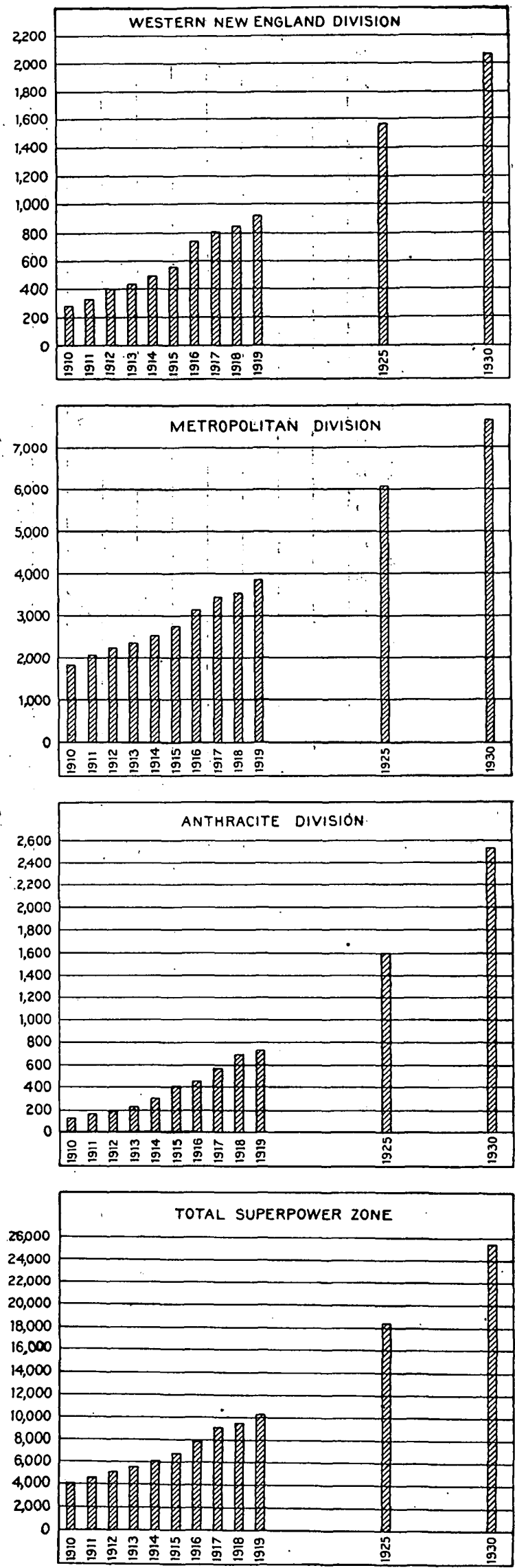

PAST AND ESTIMATED FUTURE GROWTH OF LOAD OF ELECTRIC PUBLIC UTILITIES IN SUPERPOWER ZONE, 1910-1930. 

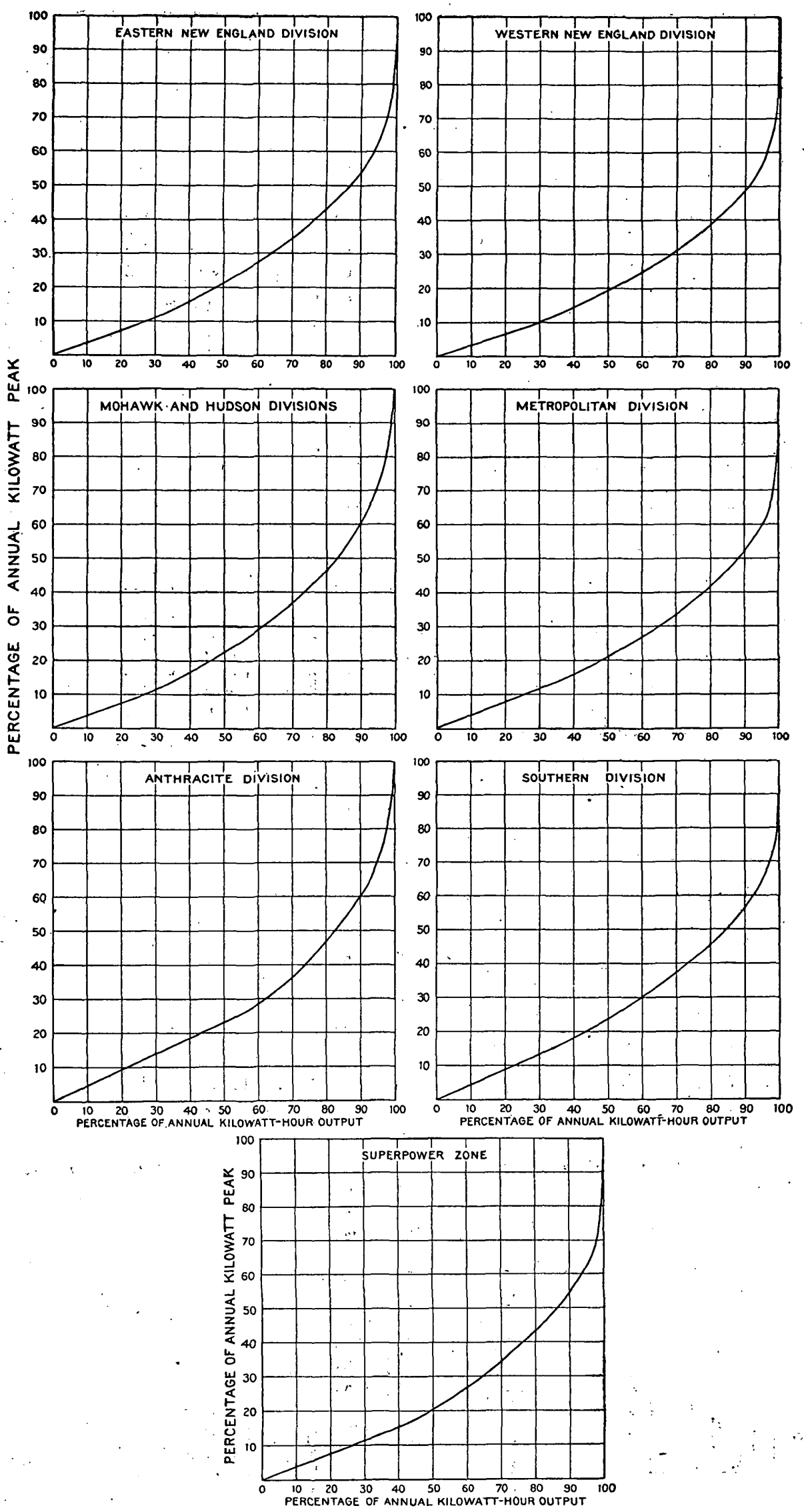

DISTRIBUTION OF LOAD FOR ELECTRIC PUBLIC UTILITIES IN SUPERPOWER ZONE IN 1919. 


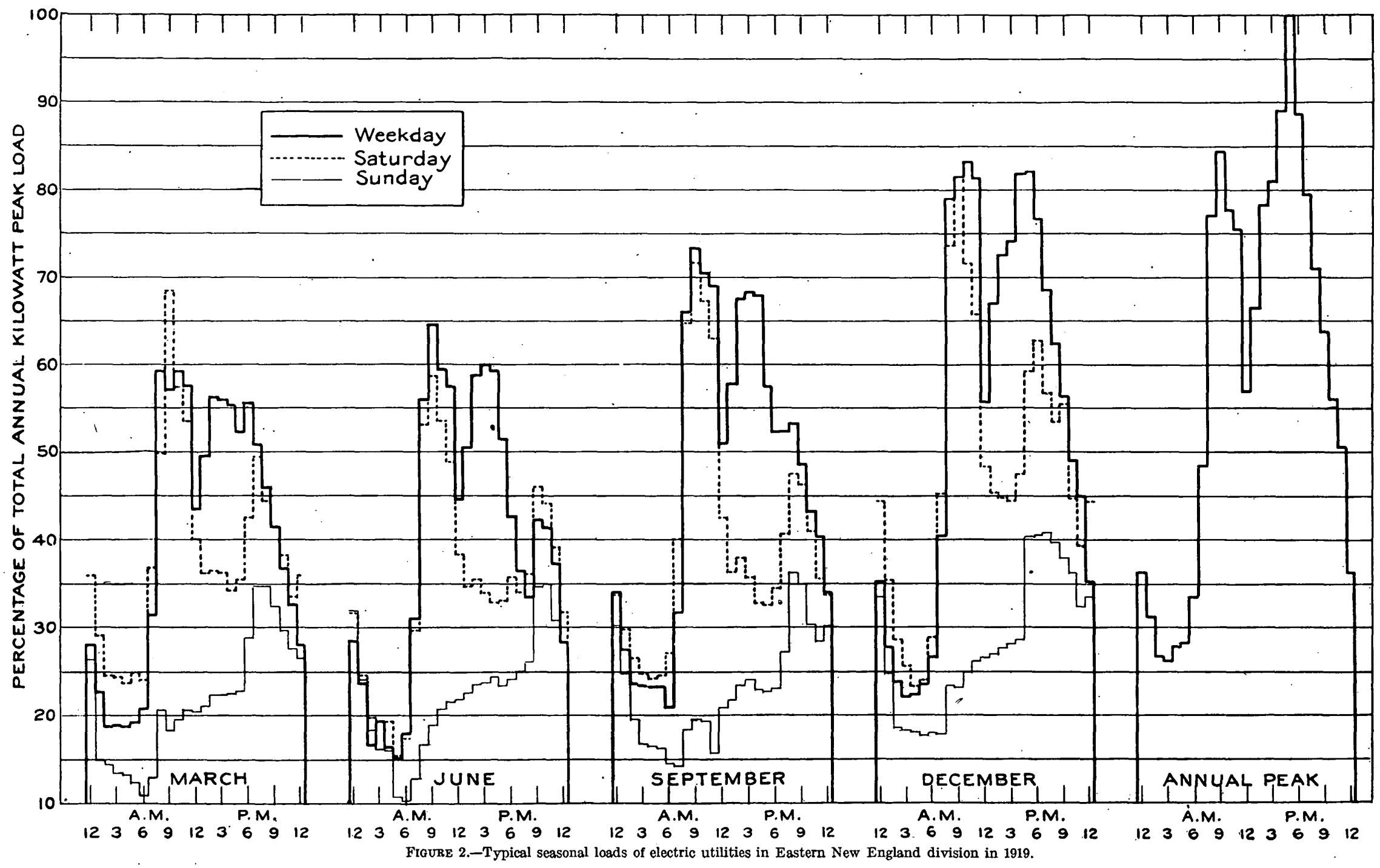

$\stackrel{\infty}{\sigma}$ 


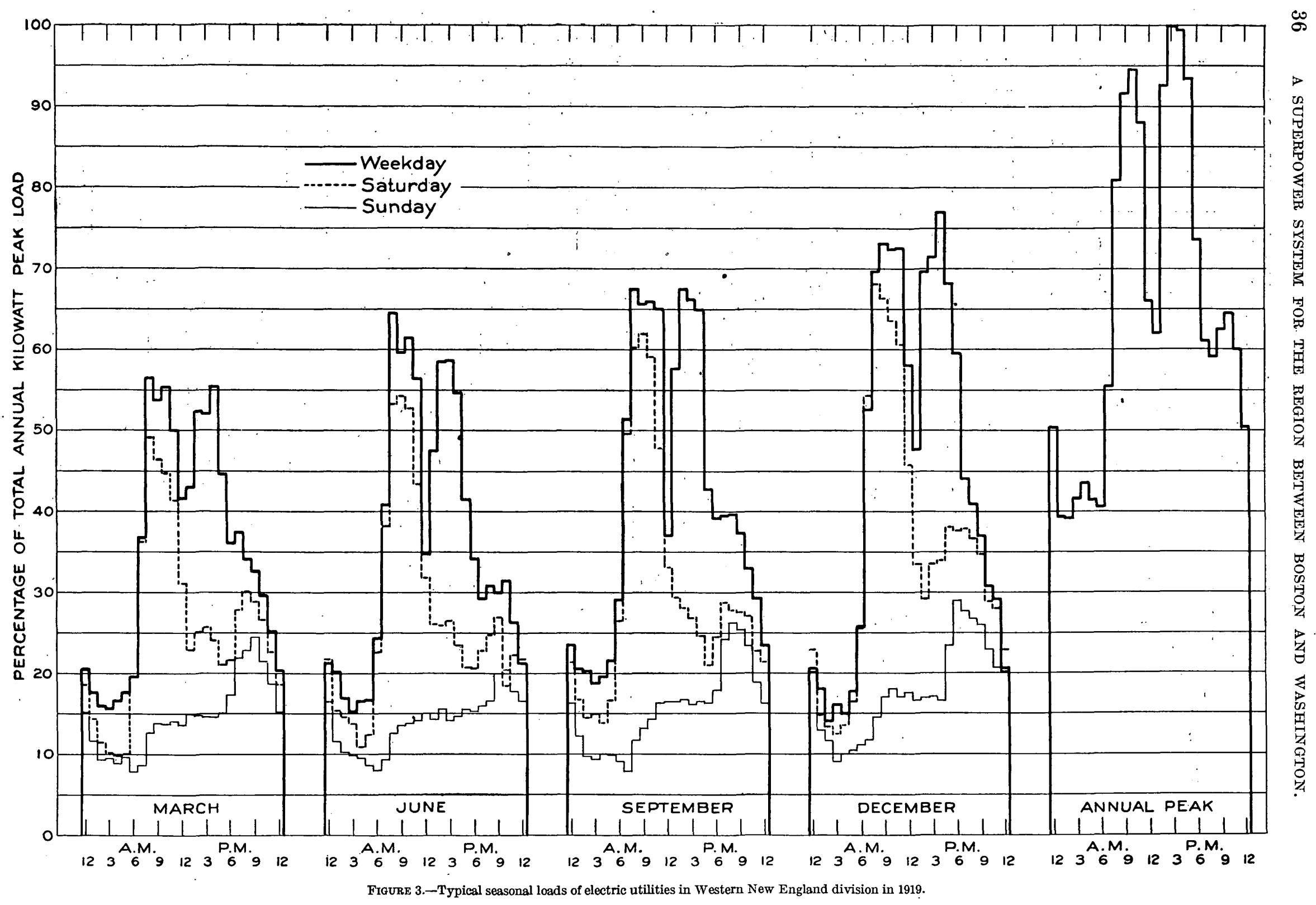




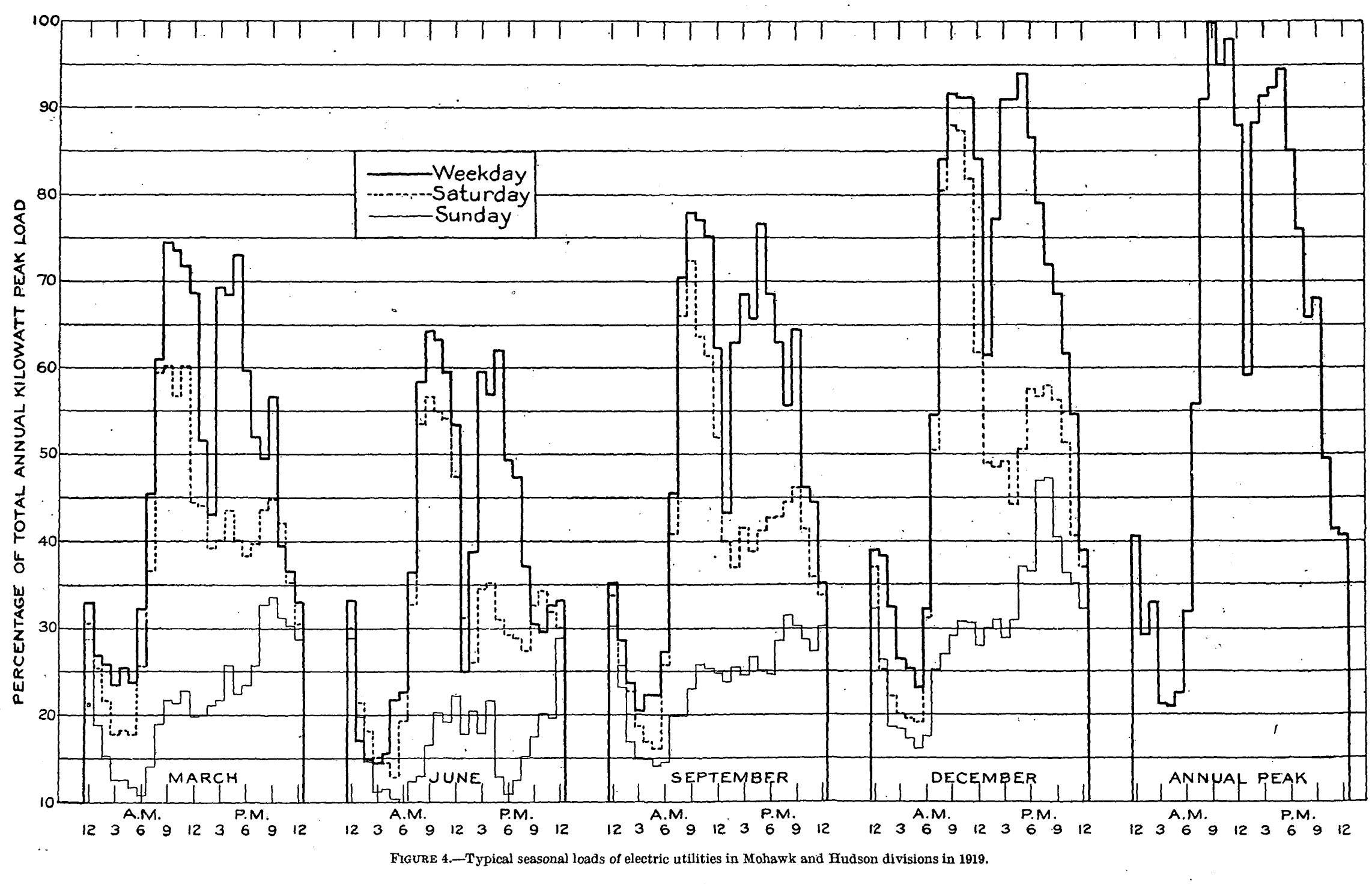




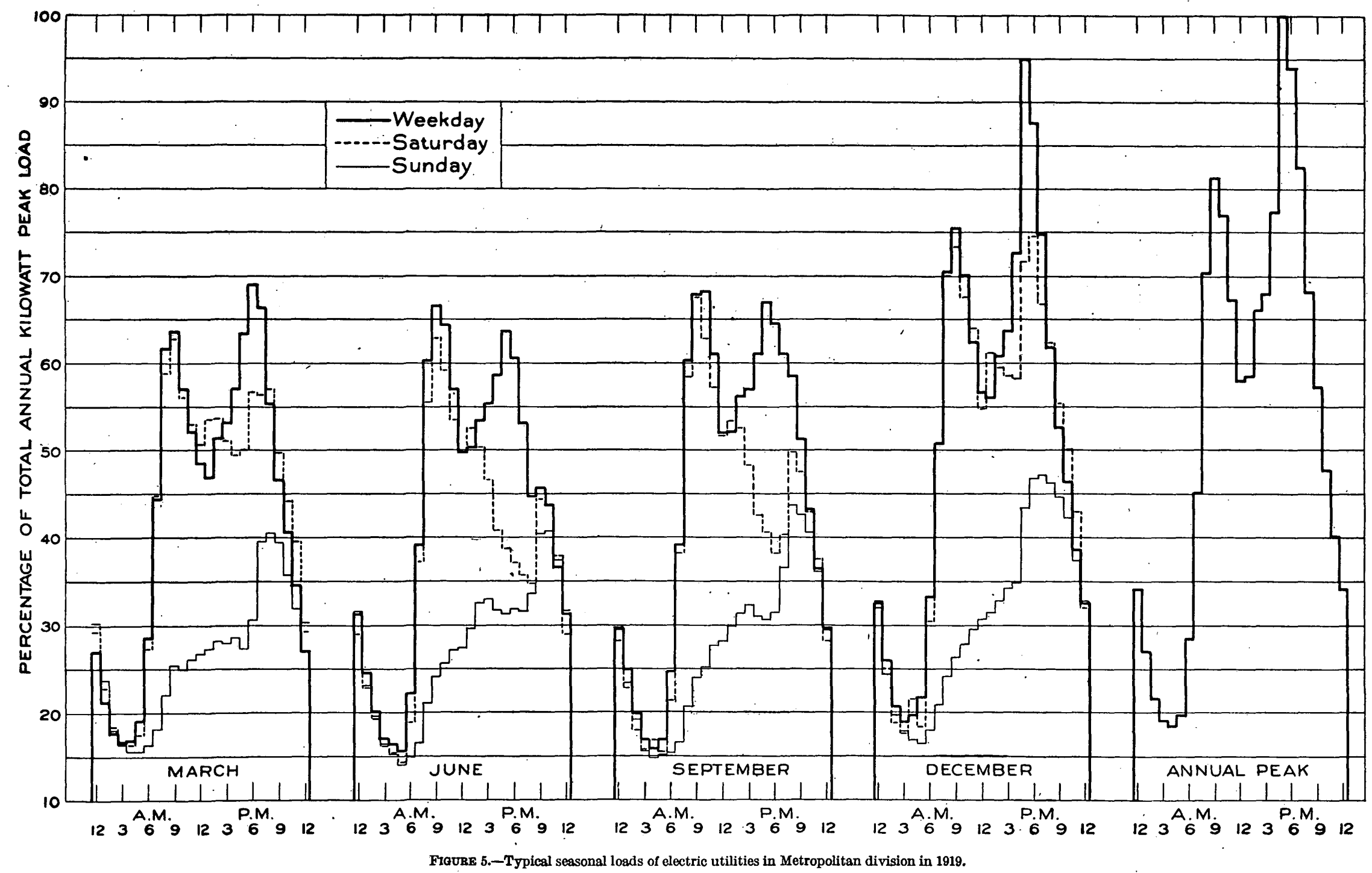




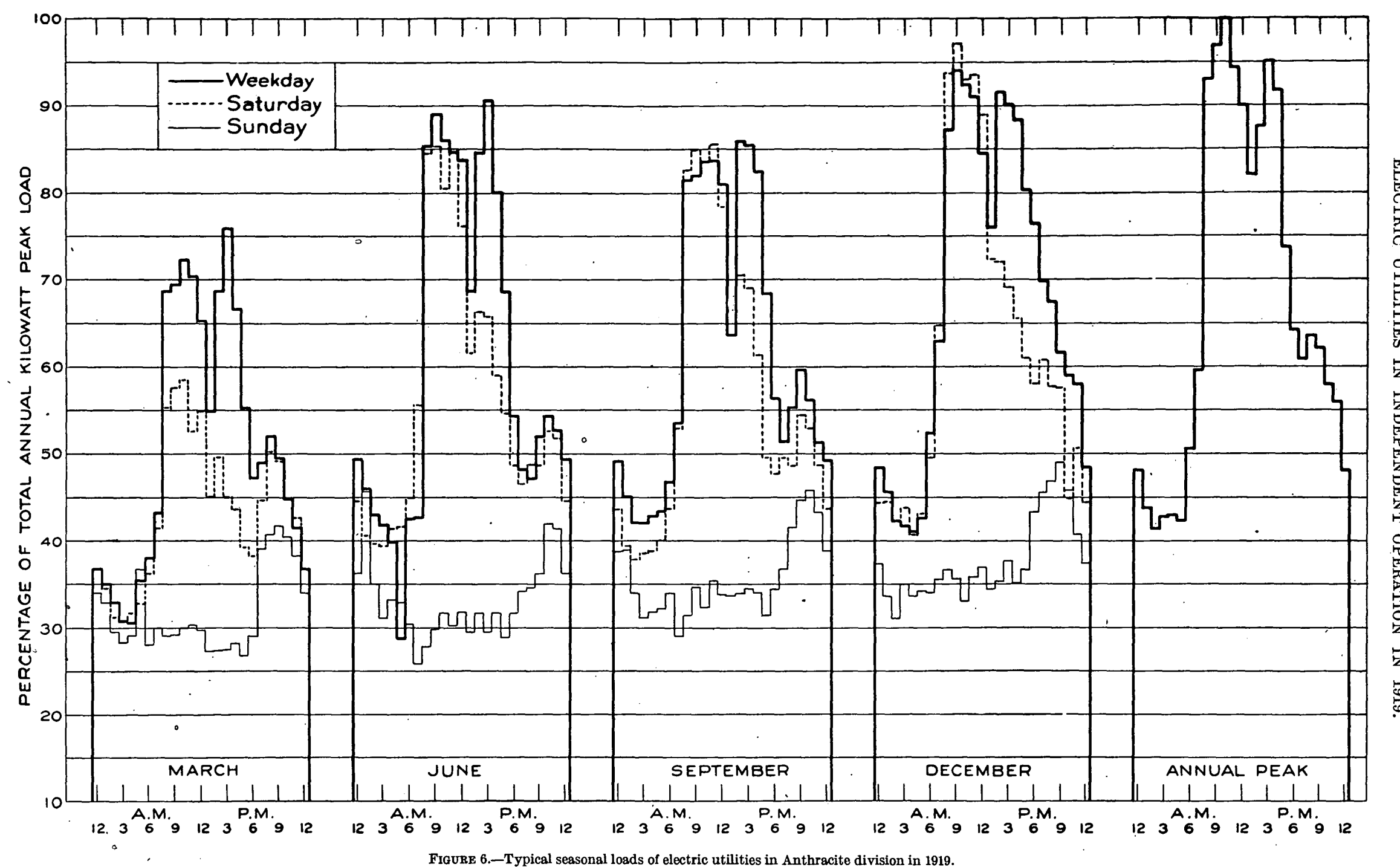





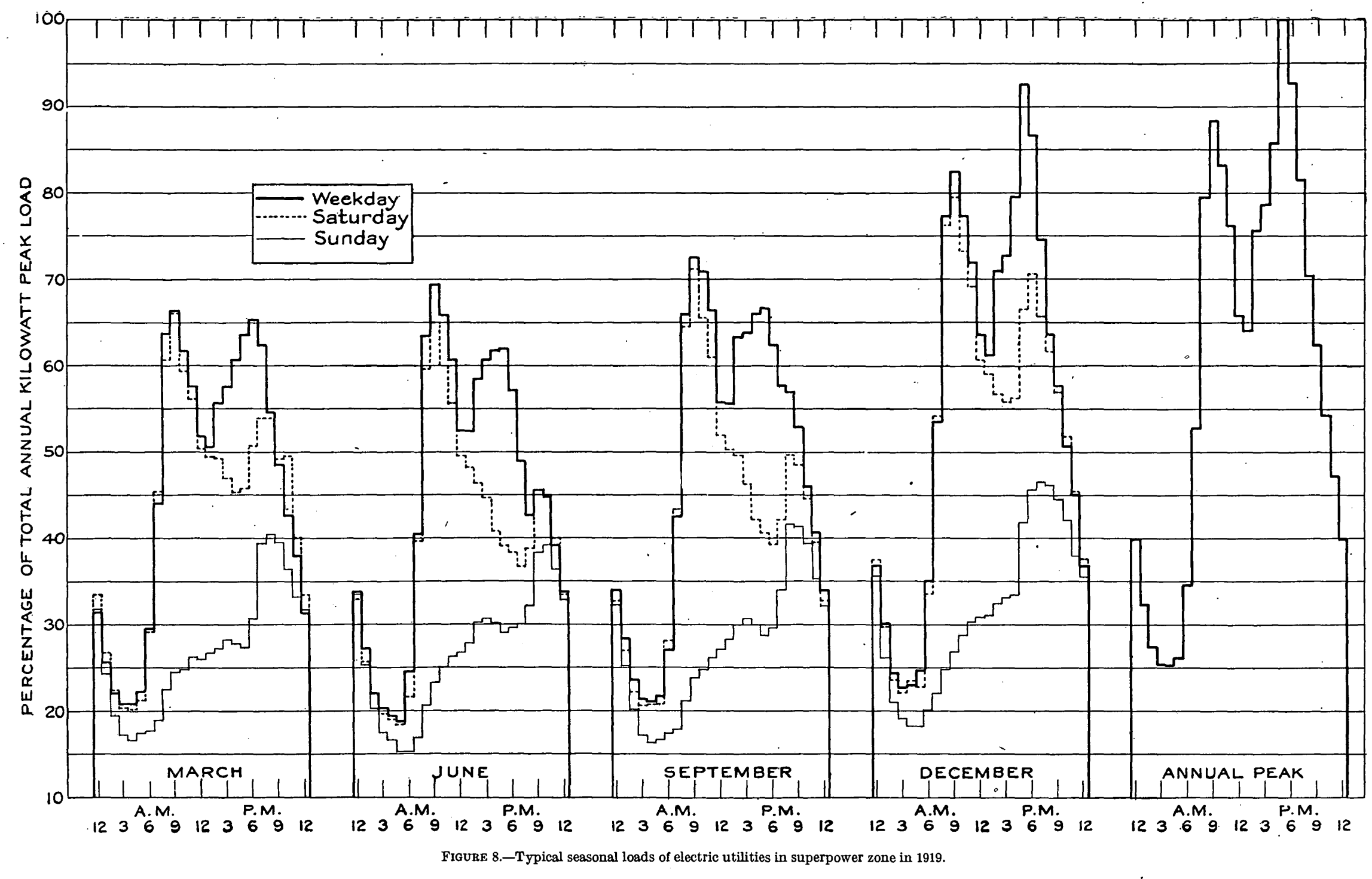


CAPACITY AND NUMBER OF POWER PLANTS.

Table 2 shows the capacity of power plants in the superpower zone, classified into steamelectric and hydroelectric and as to frequency.

TABLE 2.-Capacity of steam-electric and hydroelectric power plants of electric utilities in the superpower zone in 1919.

\begin{tabular}{|c|c|c|c|c|c|c|c|c|c|}
\hline \multirow{2}{*}{$\begin{array}{l}\text { Geographic division and losd } \\
\text { center. }\end{array}$} & \multicolumn{4}{|c|}{ Steam-electric capacity (thousands of kilowatts). } & \multicolumn{4}{|c|}{$\begin{array}{l}\text { Hydroelectric capacity (thousands of } \\
\text { kilowatts). }\end{array}$} & \multirow{2}{*}{$\begin{array}{l}\text { Total } \\
\text { capacity } \\
\text { (thou- } \\
\text { sands of } \\
\text { kilo- } \\
\text { watts). }\end{array}$} \\
\hline & 25 cycles. & 60 cycles. & $\begin{array}{l}\text { Other fre- } \\
\text { quencies. }\end{array}$ & Total. & 25 cycles. & 60 cycles. & $\begin{array}{l}\text { Other fre- } \\
\text { quencies. }\end{array}$ & Total. & \\
\hline \multirow[t]{2}{*}{ 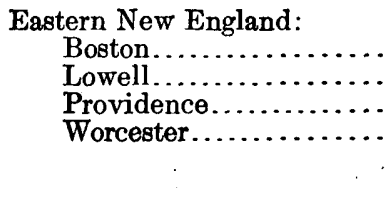 } & $\begin{array}{r}131.80 \\
5.50 \\
42.35 \\
10.00\end{array}$ & $\begin{array}{r}184.78 \\
72.00 \\
196.84 \\
76.83\end{array}$ & $\begin{array}{r}76.63 \\
3.17 \\
13.55 \\
2.25\end{array}$ & $\begin{array}{r}393.21 \\
80.67 \\
252.74 \\
89.08\end{array}$ & $\begin{array}{l}0 . \\
0 \\
0 \\
8.60\end{array}$ & $\begin{array}{r}5.70 \\
17.88 \\
1.75 \\
61.58\end{array}$ & $\begin{array}{l}0 \\
0.08 \\
0 \\
0.41\end{array}$ & $\begin{array}{r}5.70 \\
17.96 \\
1.75 \\
70.59\end{array}$ & $\begin{array}{r}398.91 \\
98.63 \\
254.49 \\
159.67\end{array}$ \\
\hline & 189.65 & 530.45 & 95.60 & 815.70 & 8.60 & 86.91 & 0.49 & 96.00 & 911.70 \\
\hline \multirow[t]{2}{*}{ 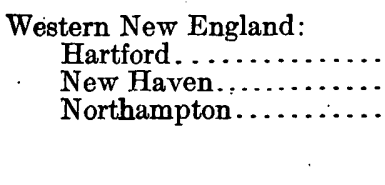 } & $\begin{array}{r}6.70 \\
51.95 \\
13.00\end{array}$ & $\begin{array}{r}43.48 \\
131.17 \\
88.39\end{array}$ & $\begin{array}{r}4.65 \\
22.99 \\
7.12\end{array}$ & $\begin{array}{r}54.83 \\
206.11 \\
108.51\end{array}$ & $0^{0} .60$ & $\begin{array}{l}13.35 \\
29.93 \\
65.69\end{array}$ & $\begin{array}{l}0 \\
.57 \\
1.39\end{array}$ & $\begin{array}{l}13.35 \\
31.10 \\
67.08\end{array}$ & $\begin{array}{r}68.18 \\
237.21 \\
175.59\end{array}$ \\
\hline & 71.65 & 263. 04 & 34.76 & 369.45 & .60 & 108.97 & 1.96 & 111.53 & 480.98 \\
\hline \multirow[t]{2}{*}{$\begin{array}{l}\text { Mohawk: } \\
\quad \text { Utica...................... } \\
\text { Schenectady ......... }\end{array}$} & $\begin{array}{l}1.75 \\
7.00\end{array}$ & $\begin{array}{r}16.54 \\
1.88\end{array}$ & $\stackrel{0}{31.10}$ & $\begin{array}{l}18.29 \\
39.98\end{array}$ & $\begin{array}{l}2.54 \\
7.29\end{array}$ & $\begin{array}{l}22.20 \\
10.02\end{array}$ & $\begin{array}{r}.12 \\
73.98\end{array}$ & $\begin{array}{l}24.86 \\
91.29\end{array}$ & $\begin{array}{r}43.15 \\
131.27\end{array}$ \\
\hline & 8.75 & 18.42 & 31.10 & 58.27 & 9.83 & 32.22 & 74. 10 & 116.15 & 174.42 \\
\hline \multirow[t]{2}{*}{$\begin{array}{l}\text { Metropolitan: } \\
\quad \text { Newark. } . \ldots \ldots \ldots \ldots \ldots \\
\quad \text { New York.............. }\end{array}$} & $\begin{array}{r}38.35 \\
1,110.60\end{array}$ & $\begin{array}{l}204.71 \\
242.73\end{array}$ & $\begin{array}{l}16.90 \\
16.53\end{array}$ & $\begin{array}{r}259.96 \\
1,369.86\end{array}$ & $\begin{array}{l}\mathbf{0} \\
\mathbf{0}\end{array}$ & $\begin{array}{r}8.13 \\
.55\end{array}$ & $0^{.03}$ & $\begin{array}{r}8.16 \\
.55\end{array}$ & $\begin{array}{r}268.12 \\
1,370.41\end{array}$ \\
\hline & $1,148.95$ & 447.44 & 33.43 & $1,629.82$ & 0 & 8. 68 & .03 & 8.71 & $1,638.53$ \\
\hline \multirow[t]{2}{*}{$\begin{array}{l}\text { Hudson: } \\
\quad \text { Poughkeepsie ............ }\end{array}$} & 0 & 25.82 & 1.01 & 26.83 & $\mathbf{0}$ & 8.69 & 0 & 8.69 & 35.52 \\
\hline & 0 & 25.82 & 1.01 & 26.83 & 0 & 8. 69 & 0 & 8.69 & 35.52 \\
\hline \multirow[t]{2}{*}{ 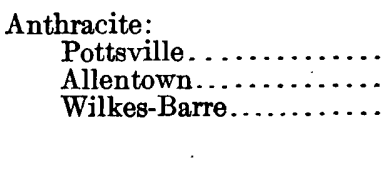 } & $\begin{array}{l}0 \\
37.20 \\
19.45\end{array}$ & $\begin{array}{l}14.19 \\
42.25 \\
91.25\end{array}$ & $\begin{array}{l}2.31 \\
1.55 \\
9.61\end{array}$ & $\begin{array}{r}16.50 \\
81.00 \\
120.31\end{array}$ & $\begin{array}{l}\mathbf{0} \\
\mathbf{0} \\
\mathbf{0}\end{array}$ & $\begin{array}{r}.14 \\
2.51 \\
2.43\end{array}$ & $\begin{array}{l}0 \\
.0 \\
0\end{array}$ & $\begin{array}{l}.14 \\
2.51 \\
2.43\end{array}$ & $\begin{array}{r}16.64 \\
83.51 \\
122.74\end{array}$ \\
\hline & 56.65 & 147.69 & 13.47 & 217.81 & 0 & 5.08 & $\mathbf{0}$ & 5.08 & 222.89 \\
\hline \multirow[t]{2}{*}{ 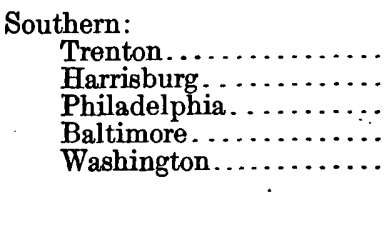 } & $\begin{array}{r}2.10 \\
0 \\
151.80 \\
191.00 \\
98.00\end{array}$ & $\begin{array}{r}15.14 \\
68.50 \\
295.74 \\
\quad 4.93 \\
\quad 0\end{array}$ & $\begin{array}{r}5.83 \\
7.17 \\
34.00 \\
6.60 \\
1.57\end{array}$ & $\begin{array}{r}23.07 \\
75.67 \\
481.54 \\
202.53 \\
99.57\end{array}$ & $\begin{array}{r}.75 \\
.88 \\
2.70 \\
84.10 \\
0\end{array}$ & $\begin{array}{r}0 \\
15.82 \\
.65 \\
.41 \\
0\end{array}$ & $\begin{array}{l}0 \\
0 \\
0 \\
0 \\
0\end{array}$ & $\begin{array}{r}.75 \\
16.70 \\
3.38 \\
84.51 \\
0\end{array}$ & $\begin{array}{r}23.82 \\
92.37 \\
484.92 \\
287.04 \\
99.57\end{array}$ \\
\hline & -442.90 & 384.31 & 55.17 & 882.38 & 88.43 & 16.88 & .03 & 105.34 & 987.72 \\
\hline Superpower zone.... & $1,918.55$ & $1,817.17$ & 264.54 & $4,000.26$ & 107.46 & 267.43 & 76.61 & 451.50 & $4,451.76$ \\
\hline
\end{tabular}


Figure 9 shows the number of power plants of different generator capacities among 280 of the larger electric-utility plants in the superpower zone in 1919. The average size of plant for all the utilities was 7,900 kilowatts, and there were 104 plants of this or greater capacity.

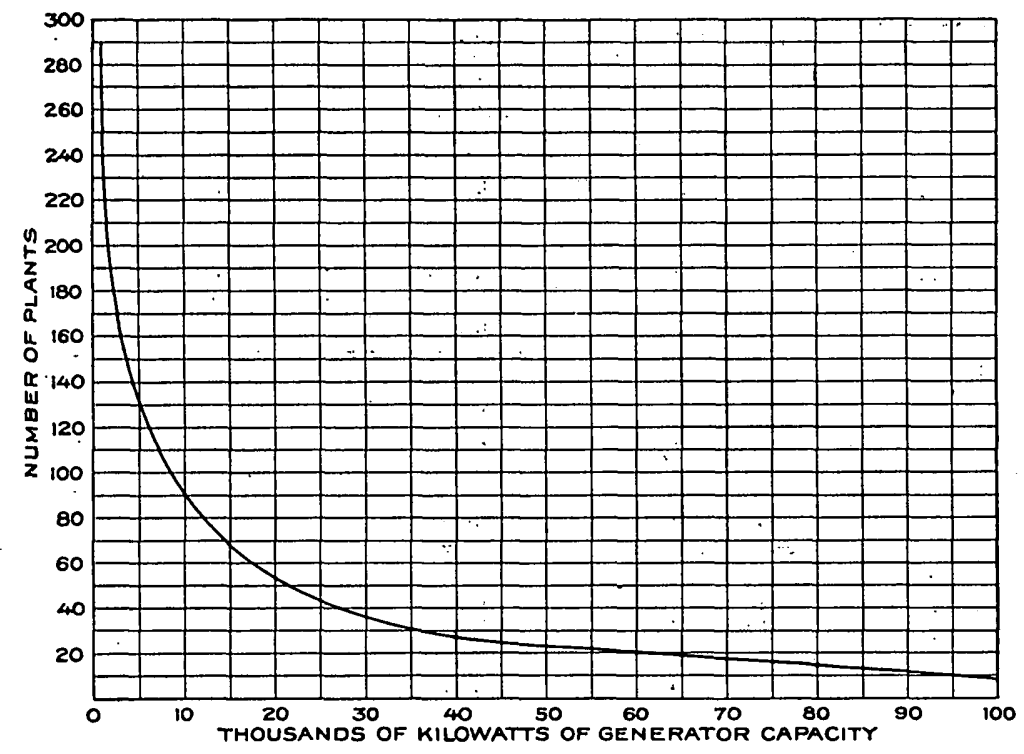

FraURe 9.-Number of generating plants of different capacities owned by 280 of the electric-utility companies in the superpower zone in 1919.

Figure 10 shows the number of generating units of different sizes among 1,074 units of 500 kilowatts or more in the superpower zone in 1919. The average size of unit for all the utilities was 2,700 kilovolt-amperes, and the number of units of this size or greater capacity was 420 . The capacity of the units to be installed in future superpower plants will be more than three times that of the plant of average size now in the zone.

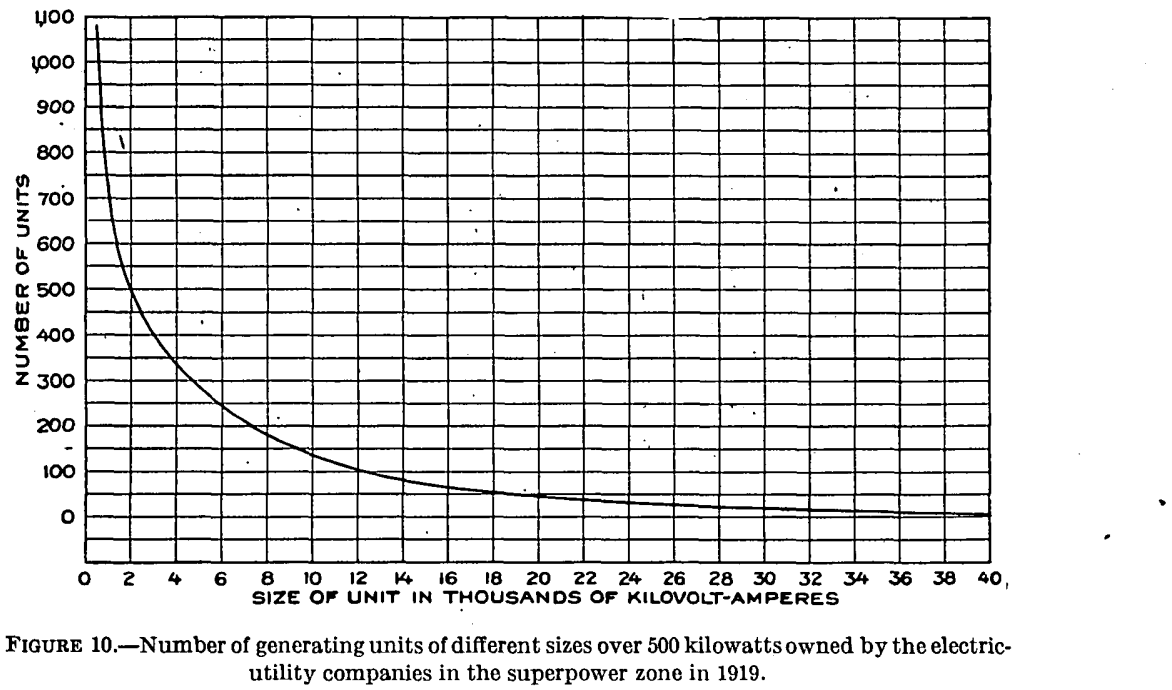

\section{PERFORMANCE.}

Table 3 shows the performance of 400 steam-electric and 158 hydroelectric power plants in the superpower zone in 1919. The effective capacity of steam-electric plants, though not of hydroelectric plants, is usually less than their generator capacity, being generally limited by boiler capacity. 
TABLE 3.-Character and performance of electric-utility plants in the superpower zone in 1919.

\begin{tabular}{|c|c|c|c|c|c|c|c|c|c|}
\hline \multirow{2}{*}{ Geographic division and load center. } & \multicolumn{3}{|c|}{$\begin{array}{l}\text { Existing generating } \\
\text { plants. }\end{array}$} & \multicolumn{3}{|c|}{$\begin{array}{l}\text { Generator capacity (thousands of } \\
\text { kilowatts). }\end{array}$} & \multicolumn{3}{|c|}{$\begin{array}{l}\text { Effective capacity (thousands of } \\
\text { kilowatts). }\end{array}$} \\
\hline & $\begin{array}{l}\text { Steam- } \\
\text { elec- } \\
\text { tric. }\end{array}$ & $\begin{array}{l}\text { Hydro- } \\
\text { elec- } \\
\text { tric. }\end{array}$ & Total. & $\begin{array}{l}\text { Steam- } \\
\text { electric } \\
\text { plants. }\end{array}$ & $\begin{array}{l}\text { Hýdro- } \\
\text { electric } \\
\text { plants. }\end{array}$ & Total. & $\begin{array}{l}\text { Steam- } \\
\text { electric } \\
\text { plants. }\end{array}$ & $\begin{array}{l}\text { Hydro- } \\
\text { electric } \\
\text { plants. }\end{array}$ & Total. \\
\hline \multirow[t]{2}{*}{ 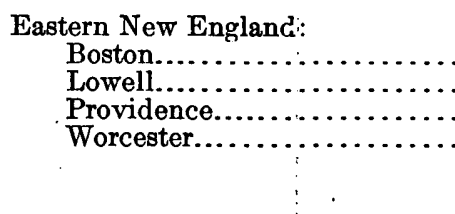 } & $\begin{array}{r}34 \\
25 \\
19 \\
8\end{array}$ & $\begin{array}{r}1 \\
15 \\
1 \\
10\end{array}$ & $\begin{array}{l}35 \\
40 \\
20 \\
18\end{array}$ & $\begin{array}{r}393.21 \\
80.67 \\
252.74 \\
89.08\end{array}$ & $\begin{array}{r}5.70 \\
17.96 \\
1.75 \\
70.59\end{array}$ & $\begin{array}{r}398.91 \\
98.63 \\
254.49 \\
159.67\end{array}$ & $\begin{array}{r}321.95 \\
75.23 \\
190.63 \\
64.38\end{array}$ & $\begin{array}{r}5.70 \\
17.96 \\
1.75 \\
70.59\end{array}$ & $\begin{array}{r}327.65 \\
93.19 \\
192.38 \\
134.97\end{array}$ \\
\hline & 86 & 27 & 113 & 815.70 & 96.00 & 911.70 & 652.19 & 96.00 & 748. 19 \\
\hline \multirow[t]{2}{*}{ 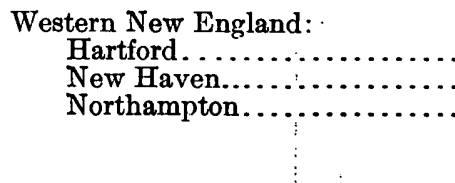 } & $\begin{array}{l}12 \\
24 \\
16\end{array}$ & $\begin{array}{r}6 \\
10 \\
22\end{array}$ & $\begin{array}{l}18 \\
34 \\
38\end{array}$ & $\begin{array}{l}54.83 \\
206.11 \\
108.51\end{array}$ & $\begin{array}{l}\text { 13. } 35 \\
31.10 \\
67.08\end{array}$ & $\begin{array}{r}68.18 \\
237.21 \\
175.59\end{array}$ & $\begin{array}{r}53.56 . \\
174.63 \\
91.05\end{array}$ & $\begin{array}{l}\text { 13. } 35 \\
31.10 \\
67.08\end{array}$ & $\begin{array}{r}66.91 \\
205.73 \\
158.13\end{array}$ \\
\hline & 52 & 38 & 90 & 369.45 & 111.53 & 480.98 & 319.24 & 111. 53 & 430. 77 \\
\hline \multirow[t]{2}{*}{ 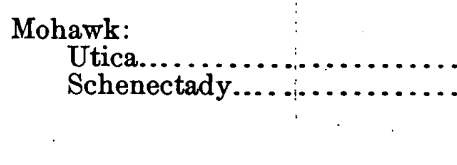 } & $\begin{array}{l}16 \\
14\end{array}$ & $\begin{array}{l}18 \\
27\end{array}$ & $\begin{array}{l}34 \\
41\end{array}$ & $\begin{array}{l}18.29 \\
39.98\end{array}$ & $\begin{array}{l}24.86 \\
91.29\end{array}$ & $\begin{array}{r}43.15 \\
131.27\end{array}$ & $\begin{array}{l}17.79 \\
38.10\end{array}$ & $\begin{array}{l}24.86 \\
91.29\end{array}$ & $\begin{array}{r}42.65 \\
129.39\end{array}$ \\
\hline & 30 & 45 & 75 & 58.27 & 116.15 & 174.42 & 55.89 & 116.15 & 172.04 \\
\hline \multirow[t]{2}{*}{$\begin{array}{l}\text { Metropolitan: } \\
\quad \text { Newark. } \\
\quad \text { New York................................. }\end{array}$} & $\begin{array}{l}25 \\
53\end{array}$ & $\begin{array}{l}8 \\
2\end{array}$ & $\begin{array}{l}33 \\
55\end{array}$ & $\begin{array}{r}259.96 \\
1,369.86\end{array}$ & $\begin{array}{r}8.16 \\
.55\end{array}$ & $\begin{array}{r}268.12 \\
1,370.41\end{array}$ & $\begin{array}{r}223.71 \\
1,119.05\end{array}$ & $\begin{array}{r}8.16 \\
.55\end{array}$ & $\begin{array}{r}231.87 \\
1,11.9 .60\end{array}$ \\
\hline & 78 & 10 & 88 & $1,629.82$ & 8. 71 & $1,638.53$ & $1,342.76$ & 8. 71 & $1,351.47$ \\
\hline \multirow[t]{2}{*}{$\begin{array}{l}\text { Hudson: } \\
\quad \text { Poughkeepsie. .............. }\end{array}$} & 13 & 13 & 26 & 26.83 & 8.69 & 35.52 & 23. 11 & 8. 69 & 31.80 \\
\hline & 13 & 13 & 26 & 26.83 & 8. 69 & 35.52 & 23.11 . & . 8.69 & 331.80 \\
\hline \multirow[t]{2}{*}{ 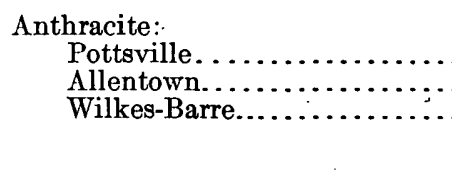 } & $\begin{array}{r}11 \\
6 \\
23\end{array}$ & $\begin{array}{l}0 \\
6 \\
4\end{array}$ & $\begin{array}{l}11 \\
12 \\
27\end{array}$ & $\begin{array}{r}16.50 \\
81.00 \\
120.31\end{array}$ & $\begin{array}{l}.14 \\
2.51 \\
2.43\end{array}$ & $\begin{array}{r}16.64 \\
83.51 \\
122.74\end{array}$ & $\begin{array}{r}13.20 \\
75.50 \\
107.40\end{array}$ & $\begin{array}{l}.14 \\
2.51 \\
2.43\end{array}$ & $\begin{array}{r}13.34 \\
78.01 \\
109.83\end{array}$ \\
\hline & 40 & 10 & 50 & 217.81 & 5.08 & 222.89 & 196.10 & 5. 08 & 201. 18 \\
\hline \multirow[t]{3}{*}{ 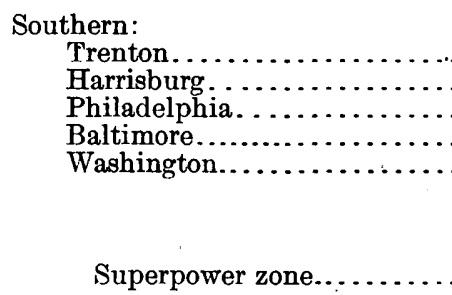 } & $\begin{array}{r}16 \\
17 \\
51 \\
14 \\
3\end{array}$ & $\begin{array}{l}1 \\
6 \\
4 \\
4 \\
0\end{array}$ & $\begin{array}{r}17 \\
23 \\
55 \\
18 \\
3\end{array}$ & $\begin{array}{r}23.07 \\
75.67 \\
481.54 \\
202.53 \\
99.57\end{array}$ & $\begin{array}{r}.75 \\
16.70 \\
3.38 \\
84.51 \\
0\end{array}$ & $\begin{array}{r}23.82 \\
92.37 \\
484.92 \\
287.04 \\
99.57\end{array}$ & $\begin{array}{r}18.05 \\
65.20 \\
422.86 \\
185.30 \\
99.57\end{array}$ & $\begin{array}{r}.75 \\
16.70 \\
3.38 \\
84.51 \\
.00\end{array}$ & $\begin{array}{r}18.80 \\
81.90 \\
426.24 \\
269.81 \\
99.57\end{array}$ \\
\hline & 101 & 15 & 116 & 882.38 & 105.34 & 987.72 & 790.98 & 105.34 & 896. 32 \\
\hline & 400 & 158 & 558 & $4,000.26$ & 451.70 & $4,451.76$ & $3,380.27$ & 451.50 & $3,831.77$ \\
\hline
\end{tabular}


ELECTRIC UTILITIES IN INDEPENDENT OPERATION IN 1919.

TABLE 3.-Character and performance of electric-utility plants in the superpower zone in 1919-Continued.

\begin{tabular}{|c|c|c|c|c|c|c|c|c|c|c|}
\hline \multirow[b]{2}{*}{$\begin{array}{l}\text { Geographic division and } \\
\text { load center. }\end{array}$} & \multicolumn{2}{|c|}{$\begin{array}{l}\text { Generator reserve in } \\
\text { steam-electric } \\
\text { plants. }\end{array}$} & \multicolumn{2}{|c|}{$\begin{array}{l}\text { Effective reserve } \\
\text { in steam-elec- } \\
\text { tric plants. }\end{array}$} & \multicolumn{3}{|c|}{$\begin{array}{l}\text { Generated output (millions of kilowatt- } \\
\text { hours). }\end{array}$} & \multicolumn{3}{|c|}{$\begin{array}{l}\text { Annual effective capa- } \\
\text { city factor (per cent). }\end{array}$} \\
\hline & $\begin{array}{c}\text { Total } \\
\text { (thousands } \\
\text { of kilo- } \\
\text { watts). }\end{array}$ & $\begin{array}{c}\text { Per } \\
\text { cent. }\end{array}$ & $\begin{array}{c}\text { Total } \\
\text { (thou- } \\
\text { sands of } \\
\text { kilo- } \\
\text { watts). }\end{array}$ & $\underset{\text { cent. }}{\text { Per }}$ & $\begin{array}{l}\text { Steam- } \\
\text { electric } \\
\text { plants. }\end{array}$ & $\begin{array}{l}\text { Hydro- } \\
\text { electric } \\
\text { plants. }\end{array}$ & Total. & $\begin{array}{l}\text { Steam- } \\
\text { electric } \\
\text { plants. }\end{array}$ & $\begin{array}{l}\text { Hydro- } \\
\text { elec- } \\
\text { tric } \\
\text { plants. }\end{array}$ & Total. \\
\hline 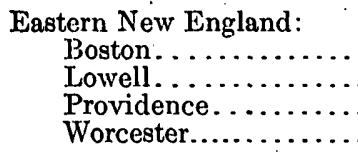 & $\begin{array}{r}136.41 \\
30.06 \\
91.90 \\
30.35\end{array}$ & $\begin{array}{l}53.1 \\
59.2 \\
57.2 \\
51.7\end{array}$ & $\begin{array}{r}65.15 \\
24.62 \\
29.79 \\
5.65\end{array}$ & $\begin{array}{r}25.4 \\
48.7 \\
18.5 \\
9.6\end{array}$ & $\begin{array}{l}\text { 759. } 16- \\
\text { 143. } 81 \\
445.79 \\
131.11\end{array}$ & $\begin{array}{r}13.52 \\
53.20 \\
5.00 \\
220.82\end{array}$ & $\begin{array}{l}772.68 \\
197.01 \\
450.79 \\
351.93\end{array}$ & $\begin{array}{l}26.9 \\
21.8 \\
26.7 \\
23.3\end{array}$ & $\begin{array}{l}27.1 \\
33.8 \\
32.6 \\
35.7\end{array}$ & $\begin{array}{l}26.9 \\
24.1 \\
26.7 \\
29.8\end{array}$ \\
\hline Worcester.............. & 288.72 & 54.8 & 125.21 & 23.8 & $1,479.87$ & 292.54 & $1,772.41$ & 25.9 & 34.8 & 27.1 \\
\hline \multirow[t]{2}{*}{ 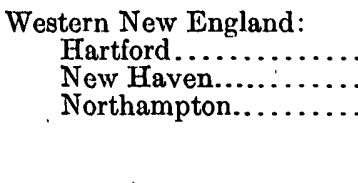 } & $\begin{array}{r}6.74 \\
70.80 \\
40.78\end{array}$ & $\begin{array}{l}14.0 \\
52.3 \\
60.2\end{array}$ & $\begin{array}{r}5.48 \\
39.32 . \\
23.32\end{array}$ & $\begin{array}{l}11.4 \\
29.0 \\
34.4\end{array}$ & $\begin{array}{l}115.22 \\
379.58 \\
123.74\end{array}$ & $\begin{array}{r}52.33 \\
56.49 \\
194.63\end{array}$ & $\begin{array}{l}\text { 167. } 55 \\
\text { 436. } 07 \\
318.37\end{array}$ & $\begin{array}{l}24.5 \\
24.8 \\
15.5\end{array}$ & $\begin{array}{l}44.7 \\
20.7 \\
33.1\end{array}$ & $\begin{array}{l}28.6 \\
24.2 \\
23.0\end{array}$ \\
\hline & 118. 32 & 47.2 & 68.12 & 27.2 & 618.54 & 303.45 & 921.99 & 22.1 & 31.1 & 24.5 \\
\hline \multirow[t]{2}{*}{ 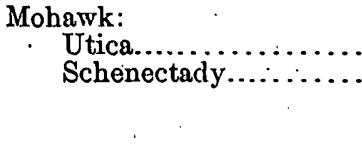 } & $\begin{array}{r}2.18 \\
18.83\end{array}$ & $\begin{array}{l}13.5 \\
89.1\end{array}$ & $\begin{array}{r}1.68 \\
16.95\end{array}$ & $\begin{array}{l}10.4 \\
80.2\end{array}$ & $\begin{array}{l}17.42 \\
30.33\end{array}$ & $\begin{array}{r}66.83 \\
323.58\end{array}$ & $\begin{array}{r}84.25 \\
353.91\end{array}$ & $\begin{array}{rl}11.2 & 9 \\
9.1\end{array}$ & $\begin{array}{l}30.6 \\
40.5\end{array}$ & $\begin{array}{l}22.6 \\
31.1\end{array}$ \\
\hline & 21.01 & 56.5 & 18.63 & 50.0 & 47.75 & 390.41 & 438.16 & 9.7 & 38.3 & 29.1 \\
\hline \multirow[t]{2}{*}{$\begin{array}{l}\text { Metropolitan: } \\
\text { Newark. } \\
\text { New York } . \ldots \ldots \ldots \ldots \ldots\end{array}$} & $\begin{array}{l}152.02 \\
353.06\end{array}$ & $\begin{array}{l}73.3 \\
34.8\end{array}$ & $\begin{array}{r}15.77 \\
102.25\end{array}$ & $\begin{array}{r}7.5^{\circ} \\
10.0\end{array}$ & $\begin{array}{r}707.82 \\
3,134.15\end{array}$ & $\begin{array}{r}23.35 \\
1.35\end{array}$ & $\begin{array}{r}731.17 \\
3,135.50\end{array}$ & $\begin{array}{l}36.2 \\
32.1\end{array}$ & $\begin{array}{l}32.6 \\
28.0\end{array}$ & $\begin{array}{l}36.0 \\
32.1\end{array}$ \\
\hline & 405.08 & 33.1 & 118. 02 & 9.6 & $3,841.97$ & 24.70 & $3,866.67$ & 32.6 & 32.3 & 32.6 \\
\hline \multirow[t]{2}{*}{$\begin{array}{l}\text { Hudson: } \\
\quad \text { Poughkeepsie.. }\end{array}$} & 10. 28 & 62.0 & 6.56 & 39.7 & 37.68 & 22.80 & 60.48 & 18. 6 & 30.0 & 21.6 \\
\hline & 10.28 & 62.0 & 6. 56 & 39.7 & 37.68 & 22.80 & 60.48 & 18. 6 & 30.0 & 21.6 \\
\hline \multirow[t]{2}{*}{ 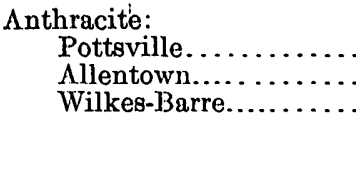 } & $\begin{array}{r}1.80 \\
1.63 \\
18.40\end{array}$ & $\begin{array}{r}12.2 \\
2.0 \\
18.0\end{array}$ & $\begin{array}{l}\cdots 0 . \\
\quad 0 . \\
5.49\end{array}$ & $\begin{array}{l}0 \\
0 . \\
5.4\end{array}$ & $\begin{array}{r}42.17 \\
317.98 \\
365.69\end{array}$ & $\begin{array}{r}.03 \\
13.72 \\
3.47\end{array}$ & $\begin{array}{r}42.20 \\
331.70 \\
369.16\end{array}$ & $\begin{array}{l}36.4 \\
48.0 \\
38.8\end{array}$ & $\begin{array}{l}24.4 \\
62.4 \\
16.3\end{array}$ & $\begin{array}{l}36.1 \\
48.5 \\
38.4\end{array}$ \\
\hline & 21.83 & 11.1 & 5.49 & 2.8 & 725.84 & 17. 22 & 743. 06 & 42.2 & 38.6 & 42.2 \\
\hline \multirow[t]{2}{*}{ 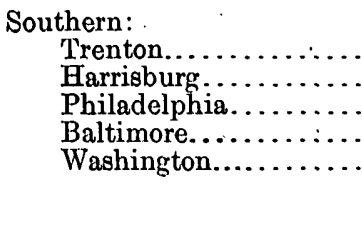 } & $\begin{array}{r}7.74 \\
16.33 \\
81.48 \\
106.50 \\
33.19\end{array}$ & $\begin{array}{r}50.5 \\
27.6 \\
20.4 \\
111.0 \\
50.0\end{array}$ & $\begin{array}{r}2.62 \\
5.86 \\
22: 8 \\
89.27 \\
33.19\end{array}$ & $\begin{array}{r}17.1 \\
9.9 \\
5.7 \\
93.0 \\
50.0\end{array}$ & $\begin{array}{r}41.87 \\
175.65 \\
1,259.10 \\
175.46 \\
234.21\end{array}$ & $\begin{array}{r}2.67 \\
83.80 \\
20.64 \\
504.96 \\
.00\end{array}$ & $\begin{array}{r}44.54 \\
259.45 \\
1,279.74 \\
680.42 \\
234.21\end{array}$ & $\begin{array}{l}26.4 \\
30.7 \\
34.0 \\
10.8 \\
26.9\end{array}$ & $\begin{array}{r}40.6 \\
57.3 \\
69.7 \\
68.2 \\
.0\end{array}$ & $\begin{array}{l}27.1 \\
36.1 \\
34.2 \\
28.8 \\
26.9\end{array}$ \\
\hline & 245.24 & 38.5 & 153.84 & 24.2 & $1,886.29$ & 612.07 & $2,498.36$ & 27.2 & 66.2 & 31.7 \\
\hline Superpower zone.... & $1,110.49$ & 38.4 & 490.50 & 17.0 & $8,637.94$ & $1,663.19$ & $10,301.13$ & 29.1 & 42.2 & 30.7 \\
\hline
\end{tabular}


A study of 196 steam-electric plants that use bituminous coal was made to ascertain their performance. These plants were selected from the 400 plants in the superpower zone because full and consistent data were available from each plant. Table 4 is a summary of the results of this study. The fuel consumption varies from 6.23 pounds per kilowatt-hour for the small plants to 2.14 pounds per kilowatt-hour for plants having a capacity of more than 100,000 kilowatts. Perhaps even more striking is the variation in the cost of maintenance, labor, and supplies, for this cost amounts to $\$ 23.10$ per kilowatt-year of effective capacity for small plants but only to $\$ 5.46$ for plants of more than 100,000 kilowatts.

The complete result of this study is given in figures 11 and 12, showing the performance and the operating cost, except the cost of fuel, which varies with size of plant, size of unit, and annual capacity factor.

TABLE 4.-Performance and operating cost of 196 selected electric plants using bituminous coal in the superpower zone in 1919 , by size of plant.

\begin{tabular}{|c|c|c|c|c|c|c|c|c|c|}
\hline & $\begin{array}{c}\text { Under } \\
1,000 \\
\text { kilowatts. }\end{array}$ & $\begin{array}{c}1,000 \text { to } \\
2,500 \\
\text { kilowatts. }\end{array}$ & $\begin{array}{c}2,500 \text { to } \\
5,000 \\
\text { kilowatts. }\end{array}$ & $\begin{array}{c}5,000 \text { to } \\
10,000 \\
\text { kilowatts. }\end{array}$ & $\begin{array}{c}10,000 \text { to } \\
25,000 \\
\text { kilowatts }\end{array}$ & $\begin{array}{c}25,000 \text { to } \\
50,000 \\
\text { kilowatts. }\end{array}$ & $\begin{array}{r}50,000 \text { to } \\
100,000 \\
\text { kilowatts }\end{array}$ & $\begin{array}{c}\text { Over } \\
100,000 \\
\text { kilowatts. }\end{array}$ & All plants. \\
\hline Number of plants......... & 33 & 36 & 32 & 29 & 31 & 14 & 13 & 8 & 196 \\
\hline otal generator capacity, & 23,485 & 62,061 & 121,575 & 230,500 & 507,675 & 476,100 & 905,400 & $1,318,600$ & $3,645,396$ \\
\hline otal generator reserve over & 21,530 & 54,308 & 106,200 & 202,875 & 449,597 & 393,600 & 721,000 & $1,048,450$ & $3,000,560$ \\
\hline $\begin{array}{c}\text { peak............. per cent. } \\
\text { Total effective reserve over peak, }\end{array}$ & 30.8 & 32.0 & 36.1 & 42.0 & 34.2 & 53.8 & 37.7 & 60.5 & 46.5 \\
\hline Average size of plant effective & 19.8 & 13.2 & 19.0 & 25.0 & 18.8 & 27.1 & 9.7 & 27.5 & 20.6 \\
\hline $\begin{array}{l}\text { capacity............. kilowatts.. } \\
\text { Average size of unit.............. } \\
\text { Load factor..............per cent. } \\
\text { Effective capacity factor, }\end{array}$ & $\begin{array}{r}650 \\
273 \\
21.3\end{array}$ & $\begin{array}{r}1,510 \\
540 \\
24.5\end{array}$ & $\begin{array}{r}3,320 \\
905 \\
27.3\end{array}$ & $\begin{array}{r}7,000 \\
1,580 \\
24.7\end{array}$ & $\begin{array}{r}14,500 \\
3,000 \\
28.5\end{array}$ & $\begin{array}{r}28,000 \\
6,420 \\
32.4\end{array}$ & $\begin{array}{r}55,500 \\
12,600 \\
38.8\end{array}$ & $\begin{array}{r}131,000 \\
15,800 \\
37.3\end{array}$ & $\begin{array}{r}15,300 \\
4,140 \\
34.2\end{array}$ \\
\hline Fuel per kilowatt-year of effec- & 17.7 & 21.4 & 23. 0 & 19.7 & 24.2 & 25.4 & 35.5 & 29.4 & 28.4 \\
\hline $\begin{array}{l}\text { tive capacity ........ short tons. } \\
\text { Coal per kilowatt-hour...pounds.. }\end{array}$ & $\begin{array}{l}4.85 \\
6.23\end{array}$ & $\begin{array}{l}\text { 3. } 96 \\
4.22\end{array}$ & $\begin{array}{l}\text { 3. } 64 \\
3.60\end{array}$ & $\begin{array}{l}\text { 3. } 30 \\
\text { 3. } 80\end{array}$ & $\begin{array}{l}\text { 3. } 21 \\
\text { 3. } 05\end{array}$ & $\begin{array}{l}2.80 \\
2.50\end{array}$ & $\begin{array}{l}\text { 3. } 42 \\
2.20\end{array}$ & $\begin{array}{l}2.76 \\
2.14\end{array}$ & $\begin{array}{l}\text { 3. } 10 \\
2.48\end{array}$ \\
\hline $\begin{array}{l}\text { Cost of maintenance, labor, and } \\
\text { supplies per kilowatt-year of } \\
\text { effective capacity............. }\end{array}$ & $\$ 23.10$ & $\$ 18.10$ & $\$ 14.56$ & $\$ 12.21$ & $\$ 10.15$ & $\$ 6.82$ & $\$ 7.80$ & $\$ 5.46$ & $\$ 9.23$ \\
\hline
\end{tabular}

\section{FUEL REQUIREMENTS.}

Table 5 (p. 48) shows the quantities and cost of the coal used by electric utilities in the superpower zone in 1919 and the results in heat units. The total cost of this coal, delivered, was $\$ 63,227,812$. The cost per short ton ranged from $\$ 2.79$ at the Wilkes-Barre load center to $\$ 8.75$ at the Lowell load center. The average cost for the zone was $\$ 5.35$. The quantity of coal consumed ranged from 2.27 pounds per kilowatt-hour at the Providence load center to 6.23 pounds at the Utica load center. The Utica load center is, however, supplied largely by hydroelectric power; its steam-electric plants are small and are used principally as a reserve. The average quantity of coal consumed per kilowatt-hour in the superpower zone was 2.73 pounds, and the average heat utilization per kilowatt-hour was 35,800 British thermal units. 

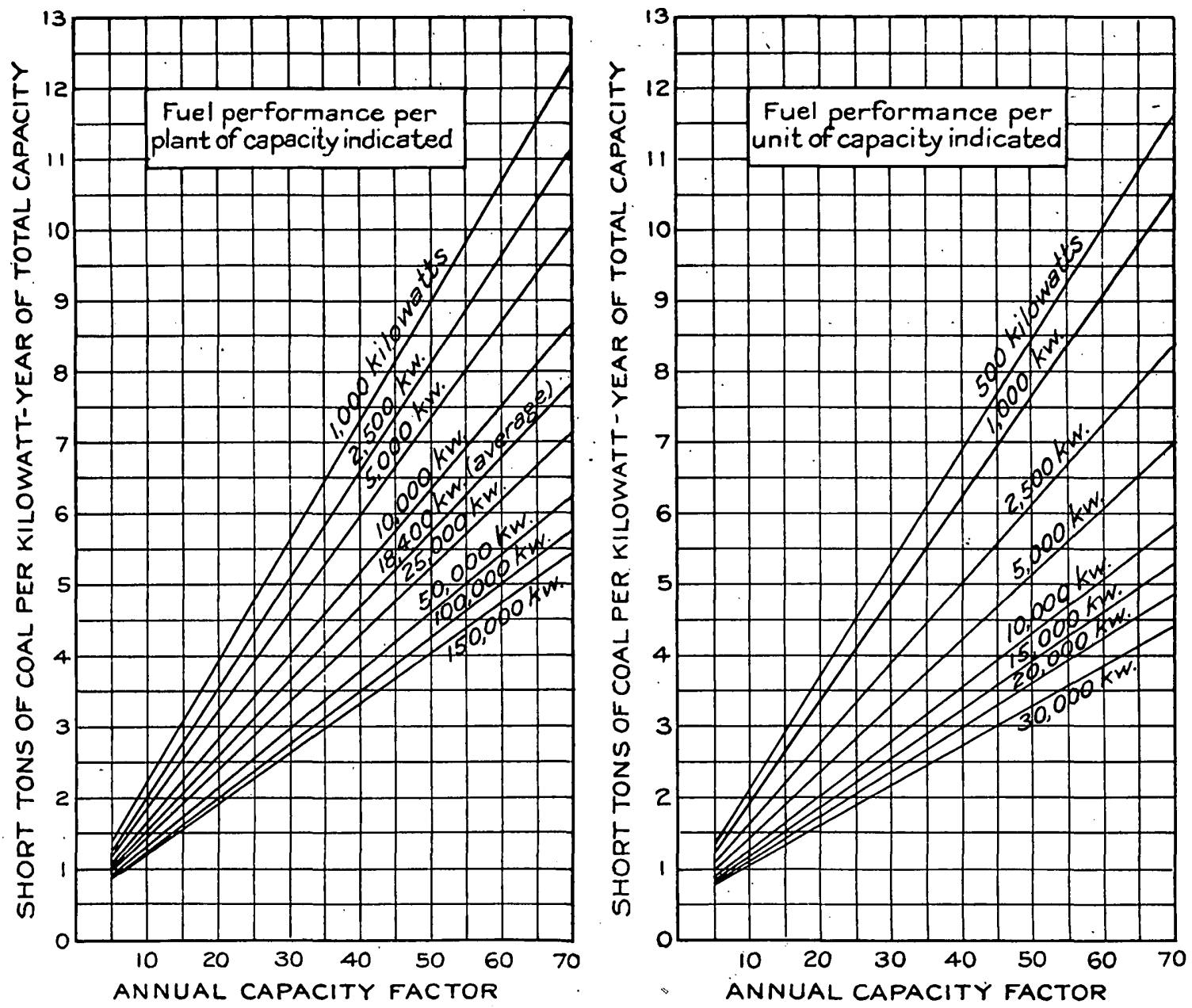

Figure 11.-Fuel performance in 1919 per plant and per unit of 196 electric-utility plants in the superpower zone that used bituminous coal.
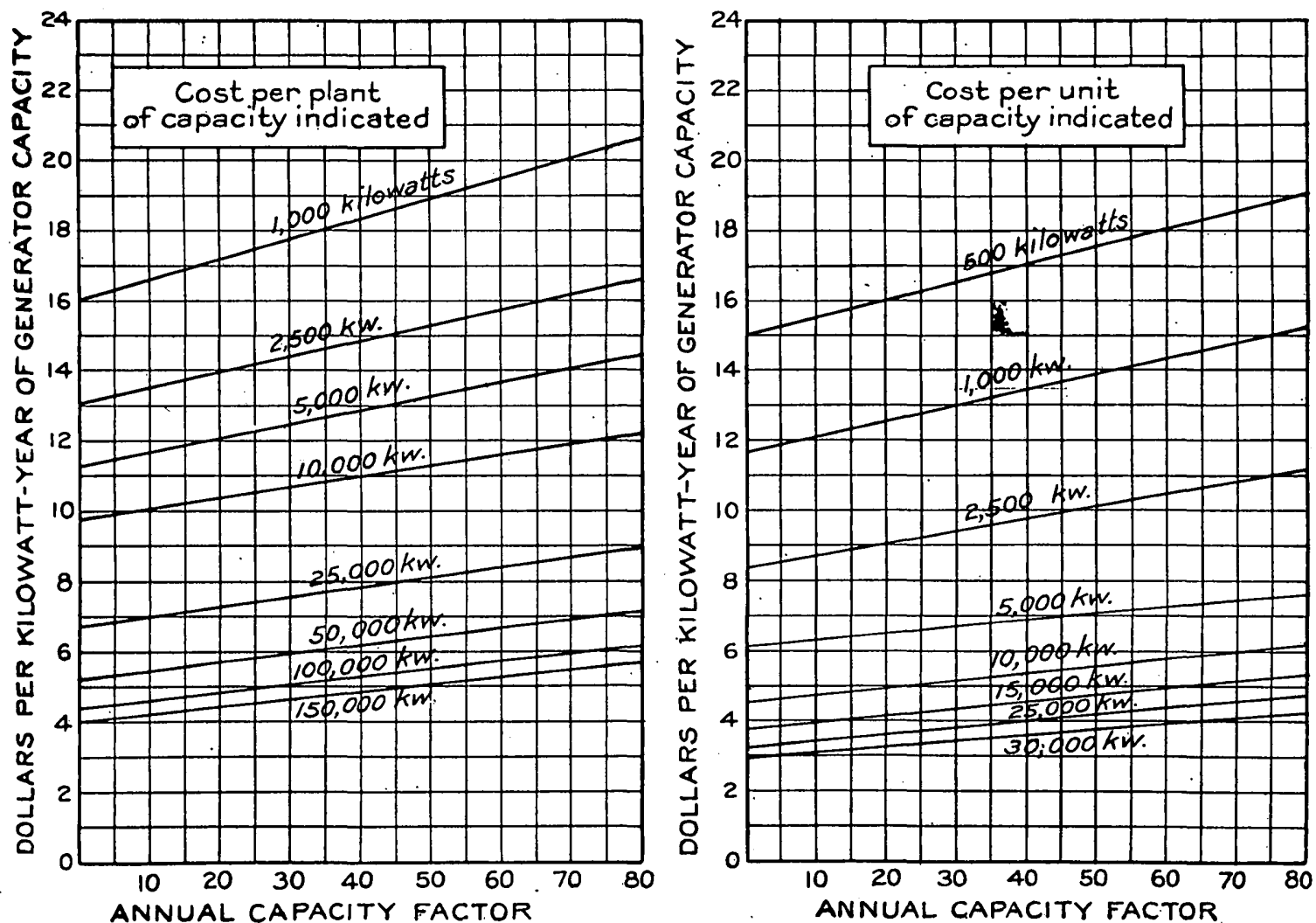

Frgure 12.-All operating costs in 1919, except that of fuel, per plant and per unit for 196 electric-utility plants in the superpower zone that used $63361^{\circ}-21-4$ 
TABLE 5.-Fuel requirements and performance of electric utilities in the superpower zone in 1919.

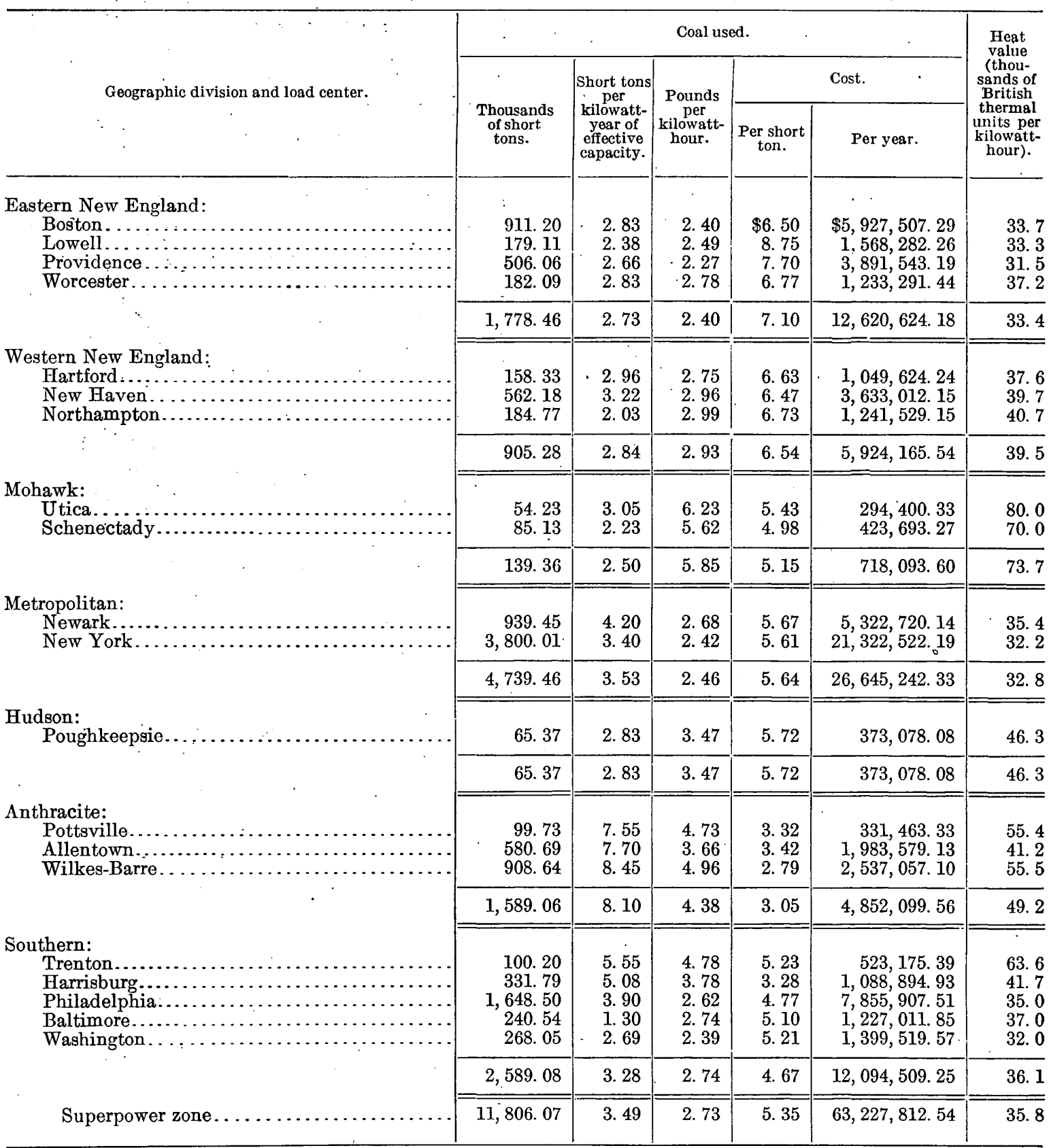

PRODUCTION COST.

Table 6 shows the production cost of the electric utilities in the superpower zone in 1919. The operating expense of the steam-electric plants was $\$ 91,195,000$, of which 69 per cent was for coal and 31 per cent for maintenance, labor, and supplies. The total annual production cost of the steam plants was $\$ 183,441,333$, of which the fixed charges were 44.5 per cent, the operating expense 49.7 per cent, and the general expense 5.8 per cent. The total annual production cost of the hydroelectric plants was $\$ 15,661,382$, of which the fixed charges were 81 per cent, the operating expense 11.1 per cent, and the general expense 7.9 per cent. The average production cost by steam was $\$ 0.0212$ per kilowatt-hour, and the average production cost by water was $\$ 0.0094$ per kilowatt-hour. 
TABLE 6.-Annual production cost of electric utilities in the superpower zone, 1919.

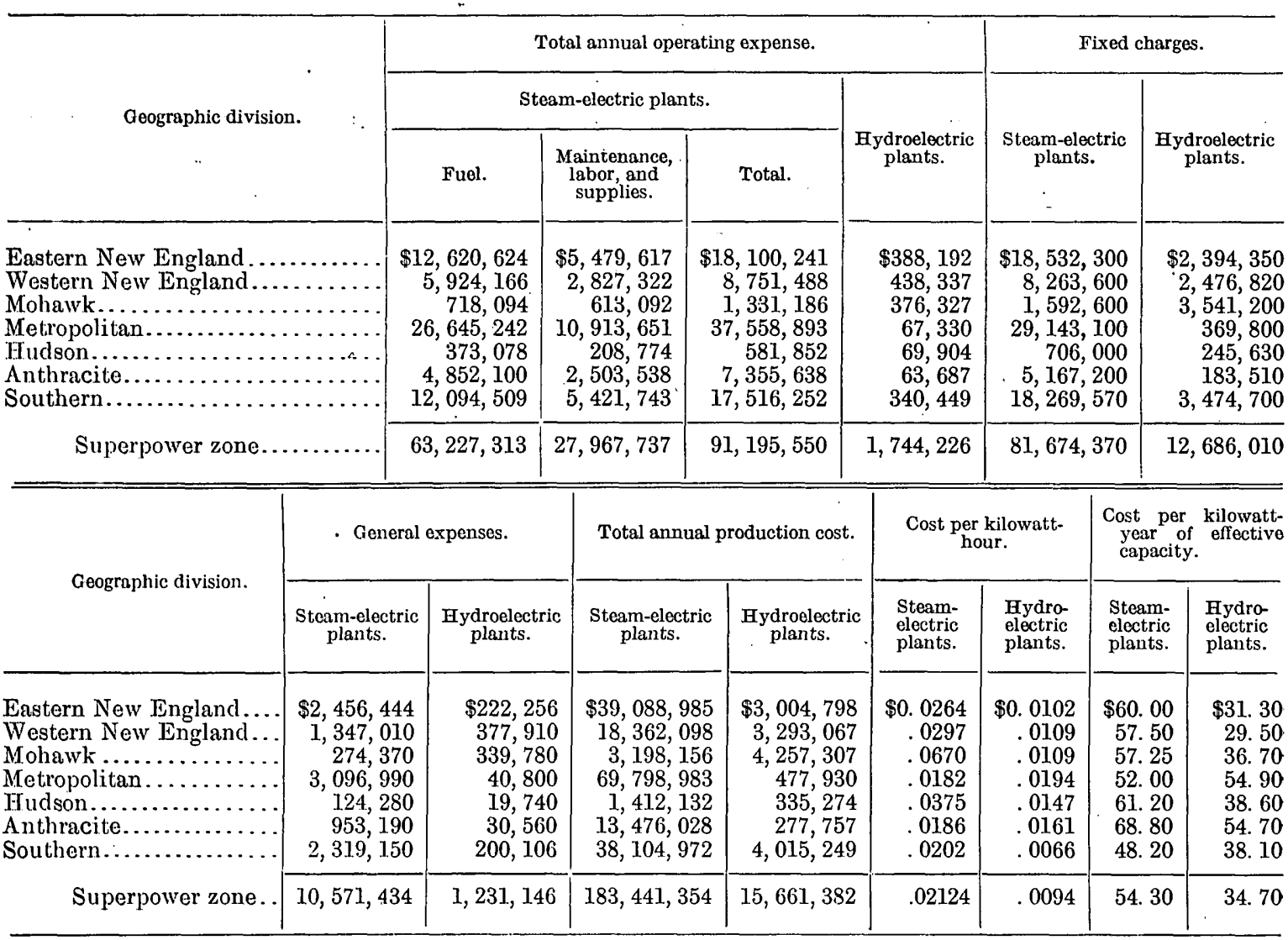

\section{REPRODUCTION COST.}

Table 7 shows the cost of reproducing the electric-utility plants in the superpower zone as equipped in 1919 . The total cost is $\$ 598,277,000$, of which approximately 85.5 per cent is that of reproducing the steam-electric plants. The method used in arriving at these costs is stated in Appendixes $\mathrm{F}$ and $\mathrm{G}$.

TABLE 7.-Reproduction cost for electric public-utility power plants as of 1919.

\begin{tabular}{|c|c|c|c|c|c|}
\hline \multirow[b]{2}{*}{ Geographic division. } & \multirow[b]{2}{*}{$\begin{array}{l}\text { Steam-electric } \\
\text { plants. }\end{array}$} & \multirow[b]{2}{*}{$\begin{array}{l}\text { Hydroelectric } \\
\text { plants. }\end{array}$} & \multirow[b]{2}{*}{$\begin{array}{c}\text { Total plants in } \\
\text { superpower zone. }\end{array}$} & \multicolumn{2}{|c|}{ Percentage. } \\
\hline & & & & $\begin{array}{l}\text { Steam- } \\
\text { electric } \\
\text { plants. }\end{array}$ & $\begin{array}{l}\text { Hydro- } \\
\text { electric } \\
\text { plants. }\end{array}$ \\
\hline 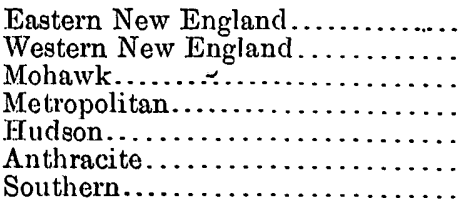 & $\begin{array}{r}\$ 115,949,000 \\
52,165,000 \\
9,957,000 \\
181,899,000 \\
4,407,000 \\
32,296,000 \\
114,477,000\end{array}$ & $\begin{array}{r}\$ 16,501,000 \\
16,713,000 \\
24,442,000 \\
2,550,000 \\
1,693,000 \\
1,265,000 \\
23,963,000\end{array}$ & $\begin{array}{r}\$ 132,450,000 \\
68,878,000 \\
34,399,000 \\
184,449,000 \\
6,100,000 \\
33,561,000 \\
138,440,000\end{array}$ & $\begin{array}{l}87.5 \\
75.8 \\
28.9 \\
98.6 \\
72.2 \\
96.2 \\
82.7\end{array}$ & $\begin{array}{r}12.5 \\
24.2 \\
71.1 \\
1.4 \\
27.8 \\
3.8 \\
17.3\end{array}$ \\
\hline Superpower zone..... & $511,150,000$ & $87,127,000$ & $598,277,000$ & 85.5 & 14.5 \\
\hline
\end{tabular}




\title{
APPENDIX C. PROPOSED ELECTRIFICATION OF HEAVY-TRACTION RAILROADS IN THE SUPER- POWER ZONE.
}

\author{
By CarY 'T. Herchinson, N. C. McPherson, and others of engineering staff.
}

\section{ADVANTAGES OF UNIFIED OPERATION.}

Many of the railroad lines in the superpower zone have been built piecemeal to serve the interests of different communities as need arose, and consequently there has been considerable duplication of trackage and an unbalanced development. Consolidation subsequently improved the conditions, and the trackage now under steam operation in the zone is in general fully loaded.

Better results would be obtained, even under steam operation, by treating these systems as a unit. A substantial increase in traffic could be handled by better routing; by setting aside certain tracks for exclusive service where lines are parallel, as between Washington and Philadelphia or New York and Scranton; by eliminating competitive branch lines; and by abandoning branch lines that are unprofitable though not competitive. These improvements and many others have been discussed within the last few years, but no action has been taken.

Even after all possible improvements of this kind had been made, however, the railroad system would still be an inferior machine, with compromises in all its parts. The character and the cost of the service would not be essentially altered.

Unified operation by electricity, on the other hand, would give much better conditions than any that could possibly be attained under unified operation by steam. There would be a new motive power, in which all units or parts designed for similar service would be identical and interchangeable. There would be pooling of all power, with great reduction of reserves. Repair shops would be consolidated, and maintenance would become a standardized manufacturing job. Track capacity would be greatly increased, and certain tracks would be allocated to freight or passenger service exclusirely. All freight trains would be run on schedule; the average speed would be more nearly the same and would be increased at least to the 12.5 miles an hour needed to avoid the present punitive overtime payments. Engine-house facilities would be much simplified by consolidation.

A specific illustration will show how wide the field is for possible savings under unified control. In 1919 one of the large railroads in the superpower zone spent about $\$ 20,000,000$ for locomotive maintenance, and another spent about $\$ 40,000,000$, the costs per locomotive-mile amounting, respectively, to 21 cents and 38 cents. Prorated to a weight of 100 tons on drivers, these costs become 24 cents and 46 cents, a difference of 90 per cent. The difference in average service is not sufficient to account for this difference in cost, which could not persist under unified control.

These improvements in operation can be made more readily under electric service than under steam, for a change in the power system would bring fresh minds into the service and would consequently liberate the mental operations of the average railroad man from their conventional routine. Under electric operation, for instance, the entire traffic between Philadelphia and Washington could readily be carried over the rails of the Pennsylvania system, those of the Baltimore \& Ohio being left for future grow th. Similarly, electric operation in the vicinity of Boston and New York would leave a margin of track capacity so great that no money need be spent for many years for further extensions of track. This release of trackage is one of the very notable advantages that would follow unified electric operation of the railroads in this territory. The great expense of any large increase in trackage should of itself force electrification; the total cost 20 years hence will be less if electrification is begun now than the cost of the added track 
and terminal facilities necessary under steam operation to provide for the inevitable 100 per cent increase in traffic within that time.

The reserves of men and of machinery required for joint operation will be much less than the aggregate of the separate reserves required for individual operation. The great waste involved in the maintenance of separate reserves of motive.power is exhibited by the operating statistics of the roads, quoted elsewhere, which show that the average freight locomotive in this territory is in productive service only 3,250 hours out of the 8,760 hours in a year, and the average passenger locomotive only 2,630 hours. With joint electric operation and consequent unification of types of motive power there would be a striking improvement. The steam locomotive runs 8 hours a day; the electric locomotive 20 hours.

The fundamental reason for coordinated control of railroad operations is precisely the same as that for regional control of the generation of electric energy. The greatest economy can be attained only by intelligent unified direction of the movements of all parts of the system for the best irterests of the whole.

\section{SPECIFIC ADVANTAGES OF ELECTRIFICATION.}

In addition to the general economic advantages that would be gained by joint operation of the rail systems within the superpower zone by either steam or electricity, there are other advantages inherent in operation by electricity. These may be classified as advantages of electric traction in operation and advantages of the electric locomotive as a machine.

\section{ADVANTAGES IN OPERATION.}

Some of the advantages of electric operation are the conservation of national resources, both of coal and labor; an increase in the capacity of main and yard tracks; an improvement of the physical condition of terminals and an increase in the value of the property, as shown by the New York Central and Pennsylvania terminals in New York City; benefits both to the traveling public and to residents along the route through the elimination of noise and smoke, the possibility of providing multiple-level terminals and freight warehouses; and economy in operation through the use of fuel and machinery for generating energy by a few skillful operators in economical stations as contrasted with a large number of technically ignorant operators with small, uneconomical machines.

The electric locomotive is equipped with meters that afford complete knowledge and control of operating conditions and that are also a valuable guide in handling the train, particularly in starting a long, heavy train. With electric traction the economy of the entire sequence of operation is not dependent upon one man, as it is with steam. Operation is therefore no longer a matter of individual human judgment, skill, or fidelity. It is this unfortunate human element that nullifies the theoretical advantages of the "full-jeweled movement" steam locomotive. The effectiveness of the devices for increasing efficiency and capacity, such as brick arches,. superheaters, stokers, siphons, automatic fire doors, and power reverses; necessarily depends on the intelligence and faithfulness of the average engineer, and in consequence the average results are low. The inherent wastefulness of the steam locomotive is proved by its own advocates in their claim that " 40 per cent of its coal can be saved by the careful use of these auxiliary devices." Then why be skeptical of a saving of 60 per cent by a modern power station, which has all these devices in greater completeness and, in addition, has brains to use them?

The speed of different classes of trains will be more nearly uniform. Much heavier trains can be handled, and at the same time light freight trains can be moved at the speed of local passenger trains. It has been proved that for the heaviest freight service, such as mountaingrade work, the electric locomotive is superior to the steam locomotive, but its superiority in handling light freight at high speed is not so generally understood.

As the electric locomotive is simple and as all locomotives of a given class are identical and no more skill is required to operate them than is demanded of an ordinary chauffeur, all locomotives will be pooled, so that the total number required will be materially reduced. 
A considerable saving in time and hence an increase in capacity will be made by lengthening the operating divisions, which will be from 200 to 400 miles long instead of 100 miles. An electric passenger locomotive will run in the morning from New York to Boston and will return in the afternoon or at night, making a total run of 450 miles a day. A similar round trip will be made between New York and Washington, or New York and Syracuse. The electric locomotive can be kept at work on the road for 20 hours a day, and if operated at an average speed of 25 miles an hour can run 500 miles a day. . This mileage, however, is double that of the electric passenger engines now used on the New Haven line and is higher than would be obtained as an average, but there is every reason to believe that with unified operation an average between 250 and 500 miles can be made.

The flexibility of the electric locomotive is much greater than that of the steam locomotive. Its capacity is determined by heating and therefore by the average work it has to do, and not by the maximum grade, which is.taken care of by the overload capacity of the engine. With electric traction the maximum grade for the profiles within the superpower zone is practically eliminated as the determining factor in locomotive equipment.

The availability of the electric locomotive for service is at least twice as great as that of the steam locomotive. After a trip it can be thoroughly inspected in less than an hour, whereas the thorough inspection of a heavy steam locomotive consumes four to ten hours. It requires no water, fuel stations, ashpits, or turntables. The repair-shop capacity required is less than a third of that needed for steam locomotives. The expense of track maintenance is reduced, and the ballast is cleaner. The engine-house expense is reduced nearly to a negligible amount. In the electric locomotive energy can be regenerated where the profile permits it, thus saving some energy and much wear of brake shoes, bettering the handling of trains, and consequently saving expense in freight-car maintenance.

As a result of these and other advantages the electric locomotive should, under favorable conditions, handle twice as many ton-miles as the steam locomotive per locomotive-year; on the Norfolk \& Western it actually handles three times as many ton-miles. This gain is not possible under all conditions, but it is possible where the traffic is great and the tracks, yards, and terminals are congested, as they are in the superpower zone.

Electric traction, then, gives increased capacity of main track, yard track, and locomotives with reduced cost of operation and maintenance per ton-mile and per passenger-mile.

\section{ADVANTAGES OF THE ELECTRIC LOCOMOTIVE AS A MACHINE.}

The electric locomotive is a better machine than the steam locomotive for the following among other reasons: It has no boilers or firebox; it has a shorter rigid wheel base; it carries no tender; it has a greater ratio of weight on drivers to total engine weight; it has less weight per driving axle, and a greater proportion of its weight is spring borne; it his uniform torque - and therefore a higher coefficient of adhesion; it can be built for any: power desired by increasing the number of driving axles and is therefore free from limitations of length; its maximum torque is available at much higher speed; the steam locomotive can work to an adhesion of 20 per cent up to only 10 or 12 miles an hour, whereas the electric locomotive can work to this adhesion up to 20 to 25 miles an hour; its efficiency over a range of load from 50 to 100 per cent varies only a few per cent and is constant throughout its life, whereas the efficiency of the steam locomotive varies over a wide range with age and use--a modern superheated steam locomotive requires 50 per cent more steam per horsepower-hour at full load than at half load; and finally, a steam locomotive must burn coal in descending a grade on which an electric locomotive will regenerate energy. To sum up, the electric locomotive is much the better transportation tool.

\section{CLASSES OF ELECTRIC LOCOMOTIVES.}

The great variety' in types and weights of steam locomotives for freight, passenger, and switcher service is largely the result of growth, of change in fashion, and of whims of individual operating officers. There is no sound reason for such variety. The United States Railroad Administration formulated certain standard designs of steam locomotives, reducing the number 
of types to about ten, including the Mallet or articulated locomotive.' With electric equipment this number can be reduced still further, certainly to as few as six types and possibly to three, as may be seen from an examination of the weight on drivers of the steam locomotives now in use. Those in freight service carry between 77 and 120 tons on drivers. Of those in passenger service, 80 per cent carry between 64 and 80 tons on drivers; but a few very small locomotives, probably 5 per cent of the total, are performing no material service. Of the switchers, 90 per cent carry from 65 to 85 tons on drivers, and a few carry more.

The entire freight service in the superpower zone can be handled by electric freight locomotives having two articulated 2-axle trucks, each carrying two motors geared to the axle, the mounting being essentially the same as that in a number of locomotives now in use and similar to the usual street-car mounting. There would be two classes of locomotives of this type - $\mathrm{a}$ light one carrying 80 tons on drivers and having a continuous drawbar pull of 22,000 pounds at 25 miles an hour, and a heavy one carrying 110 tons on drivers and having a continuous drawbar pull of 30,000 pounds at the same speed. These units can be combined in any reasonable number; the total load on drivers can be made equal to $80,110,160,190,220$ tons or as much more as may be desired, being limited only by the strength of the draft rigging. A train can of course be double-headed, and a total tractive pull up to the maximum now in use can be obtained, with at least double the present speed.

For passenger service a similar arrangement would be used-that is, two articulated 2-axle trucks, with one motor geared to each axle. The motors may be practically the same as those in the freight locomotives, the only difference being a change in gear ratio. The passenger locomotive, however, would have leading and trailing trucks, with either two or four wheels, and the total weight would be redistributed. This passenger locomotive would be of two weights, the light one having 60 tons on drivers, and the heavy one 90 tons. These also may be combined, like the freight locomotives.

For the switchers one size will be adequate, with 70 to 75 tons on drivers, of the same type as the freight locomotive. Substantially the same frame and running gear can be used, with motors of less capacity.

All three types of locomotives will have the usual overload capacity, and all will be able to operate in starting and accelerating at 25 to 30 per cent adhesion.

These suggested sizes and types of locomotives can of course be varied greatly without sacrificing the advantage of unified electric operation, but identity of types for the same service throughout the superpower zone is essential.

\section{SCOPE OF RAILROAD INVESTIGATION.}

The general purpose of this investigation is to estimate the saving that would be effected by unified electric operation of the class 1 railroads within the superpower zone and to compare this estimated saving with the investment needed to effect it.

For this purpose the traffic conditions and the kind and quantity of service assumed are those of 1919, with the substitution of the electric for the steam locomotive. Of course, to insure the greatest gain from electric traction the entire transportation scheme must be revamped and fitted to the use of the new agent. An analysis based on such a change, however, would involve a detailed study of each road, and indeed of each division, which is not now possible.

The estimated saving in the cost of operation includes a reduction in certain items of steam-railroad cost that will be effected by the change of motive power. These items, named approximately in the order of their cost, are locomotive maintenance (including engine-house service), coal and water, and wages of crew. These items make up about 90 per cent of the expense affected by the change in the method of operation. In addition to the saving on these principal items there will be some saving - an amount hard to estimate-in the maintenance of curved track and freight cars, as a result of better train handling, and in certain minor items. The reduction in all these expenses will be offset by the cost of the electric energy required to do the work done by steam, the cost of the operation and maintenance of substations and of 
the electric overhead distribution system and track circuits, and the cost of maintenance of the electric locomotives.

The cost of electric energy, as the phrase is used here, means its total cost delivered to the railroad company's substation. The railroad company will have no investment in plant for generating or transmitting energy. Its investment begins with substations segregated for railroad use, owned by the railroad company individually or jointly with other companies.

This comparison of costs of investment and operation need take no account of the system of electric traction to be used except in so far as the use of different systems might entail different costs of operation or construction. The only two systems that are applicable to general traction within the superpower zone are the 3,000-volt direct-current system and the 11,000-volt (or higher) alternating-current system, both with overhead distribution circuits and rail return. Both of these systems are in successful use, and both can no doubt be designed and constructed to give satisfactory service in the zone.

The alternating-current system generally involves a lower investment cost than the directcurrent system, as at low frequencies of supply substations with rotating machinery are replaced by transformers erected along the right of way; but this saving will not be effected under the super power system, for the frequency adopted for generation and transmission-60 cyclesrequires substations with rotating machinery for the alternating-current as well as for the direct-current system, and the capital costs of the two are nearly equal.

The operation and maintenance of substations is ordinarily an additional burden in the direct-current system, but under the superpower system this would be offset by the addition of the frequency-changing equipment.

In order, then, to avoid some uncertain elements in the estimates of the cost of the alternating-current system it has been decided to base all estimates, both of operation and of construction, on the ${ }^{\circ} 3,000$-volt direct-current overhead system. Substantially the same results in money could, however, be obtained with the alternating-current system, certain gains being offset by certain losses.

\section{PROCEDURE FOLLOWED BY RAILWAY DIVISION.}

The procedure of the railway division of the superpower survey in its study of the proposed electrification of the heavy-traction lines within the superpower zone comprised the collection of the physical data, the analysis of the data, and the formulation of conclusions.

\section{DATA COLLECTED.}

It was evident at the outset that it would not be adequate to study the roads as units but that a study should be made of the operating divisions of the railroads. A study of a railroad system as a whole, even if it lay entirely within the zone, would yield only average results, which might make a poor showing, whereas some of the divisions treated separately might make a good showing. It was therefore decided to ask each of the class 1 railroads within the superpower zone, of which a list is given below, to answer the questions on Form A, asking for certain fundamental data as to roadbed, equipment, and traffic. This information, like all other information sought,. was to cover the year 1919.

Class 1 railroads within the superpower zone.

Boston \& Maine.

Boston \& Albany.

New York, New Haven \& Hartford.

New York Central.

Delaware \& Hudson.

Ulster \& Delaware.

New York, Ontario \& Western.

Lehigh \& New England.

Lehigh \& Hudson River.
Erie.

Delaware, Lackawanna \& Western.

Lehigh Valley.

Central of New Jersey.

Long Island.

Pennsylvania.

Philadelphia \& Reading.

Western Maryland.

Baltimore \& Ohio. 
Form A.

\section{Data Sheet for Steam-Operated Divisions.}

BOUNDARY OF ZONE.

The zone included in the superpower survey is bounded as follows: Beginning where the $39^{\circ}$ parallel crosses Delaware Bay, thence west to Washington, looping around Washington to include the city; thence north along the $77^{\circ}$ meridian to its intersection with the $41^{\circ}$ parallel; thence northeasterly to the intersection of the $43^{\circ}$ parallel ${ }^{1}$ and the $75^{\circ}$ meridian; thence east to the vicinity of Portsmouth, N. H., looping around that city; and thence to the Atlantic seacoast, running outside of Long Island and New Jersey to the starting point on the $39^{\circ}$ parallel:

The information requested herein refers to those parts of your system included within the above boundaries which are steam operated wholly or in part. (Data covering electric operations are outlined on "Data sheet for electricoperated divisions.")

ROADBED.

1. Outline map, showing all lines within the zone, indicating division points, number of main tracks, sidings, etc.; also indicate nearest division point outside of zone boundaries. Maps giving track profiles.

2. Diagram of principal yards, showing track layout.

3. Summation of mileage of track-e. g., first, second, and other main tracks; sidings, etc., for each division.

EQUIPMENT.

4. Number and classification of locomotives assigned to each division for freight, passenger, and switching service, giving for each class total weight with tender full and tender empty, and weight on drivers.

TRAFFIC.

Give separately for each division for each month of 1919 , and total for the year:

5. Passenger service, train-miles, total locomotive-miles, and car-miles.

6. Freight service, train-miles and total locomotive-miles.

7. Gross ton-miles moved (including engine and tender), separately for freight and passenger.

8. Switching service, ton-miles, engine-miles, engine-hours, or in such other form as is at hand.

9. Amount of coal used for each class of service separately, if possible, and totals; kind of coal burned.

10. Average annual maintenance per locomotive-mile, separately for each class, if possible.

On January 15, 1921, all replies were in hand. A preliminary analysis was made of each set of replies when received; correspondence with the designated officer of each railroad helped to clear up points that were obscure and supplemented the information furnished; and all available data covering roadbed, equipment, and traffic were complete before the middle of February.

In addition to Form A a second sheet (Form B) was sent to the roads that were in part electrically equipped - the Baltimore \& Ohio, the Pennsylvania, the Long Island, the New York Central, and the New York, New Haven \& Hartford. The questions on this form are more general and were intended principally to elicit an accurate description of the physical property and equipment, together with sufficient statistics of traffic and of electric supply to permit their discriminating use in the allocation of energy required for the proposed unified operation of the steam roads. This information was all in hand at about the same time as the data from the steam roads.

Form B.

Data Sheet for Electric-Operated Divisions.

BOUNDARY OF ZONE.

The zone included in the superpower survey is bounded as follows: Beginning where the $39^{\circ}$ parallel crosses Delaware Bay, thence west to Washington, looping around Washington to include the city; thence north along the $77^{\circ}$ meridian to its intersection with the $41^{\circ}$ parallel; thence northeasterly to the intersection of the $43^{\circ}$ parallel and the $75^{\circ}$ meridian; thence east to the vicinity of Portsmouth, N. H., looping around that city; and thence to the Atlantic seacoast, running outside of Long Island and New Jersey to the starting point on the $39^{\circ}$ parallel.

The information requested herein refers to those parts of your system included within the above boundaries which are electrically operated wholly or in part. (Data covering all steam operations are outlined on "Data sheet for steamoperated divisions.")

1 The northern boundary of the zone as finally studied is the 44th parallel. 
DESCRIPTION OF PHYSICAL PROPERTY.

1. A map showing the electric divisions, indicating tracks electrified and location of power house and substations, and track profiles.

2. A description of the system of generation, transmission, transformation, distribution, and utilization of the electric supply, including general equipment of power stations, substations, etc. Diagrams giving feeder, trolley (or third rail), and bonding layouts, and any printed descriptions or references thereto.

3. General description with drawings of locomotives in use, with total weight and weight on drivers.

4. Characteristic performance curves of locomotives-speed, torque, and heating.

TRAFFIC STATISTICS MONTHLY FOR 1919 AND TOTALS.

5. Train-miles (excluding multiple-unit cars) for freight and passenger, or for both.

6. Electric locomotive-miles for freight and passenger, or for both.

7. Multiple-unit car mileage and train mileage.

8. Statement of switching service in electric locomotive-miles, locomotive-hours, or in'such form as is at hand.

9. Total gross ton-miles moved.

ELECTRIC SUPPLY.

10. Kilowatt-hours used-power-house output or substation input or output, preferably the latter. State point of measurement and whether record is available at either of the other points, even if for shorter periods.

11. Average daily, monthly, and annual load factors, stating how divisor is determined-that is, whether hourly peak or other.

12. Monthly peak, kilowatts.

13. Cost of electric supply in detail, if generated; or price, if purchased.

14. Cost of handling traffic per train-mile and per ton-mile.

15. Maintenance cost of locomotives per locomotive-mile and annual totals.

16. Cost of construction and equipment, subdivided into energy supply, transmission system, substations, distribution, and locomotives, with date of purchase.

17. Total cost of operation and maintenance of electric system under standard Interstate Commerce Commission classification.

Tables $8,9,10$, and 11 set forth these fundamental data of the roadbed, equipment, and traffic of each of the steam roads within the zone, and Table 12 summarizes them for the entire zone. The Central New England is included with the New Haven road in all tables.

TABLE 8.-Steam-operated tracks owned by class 1 railroads within superpower zone, 1919, in miles.

\begin{tabular}{|c|c|c|c|c|c|c|}
\hline \multirow{2}{*}{, System. } & \multicolumn{4}{|c|}{ Main track. } & \multirow{2}{*}{$\begin{array}{l}\text { Yards and } \\
\text { sidings. }\end{array}$} & \multirow{2}{*}{ Total. } \\
\hline & First. & Second. & other. & Total. & & \\
\hline 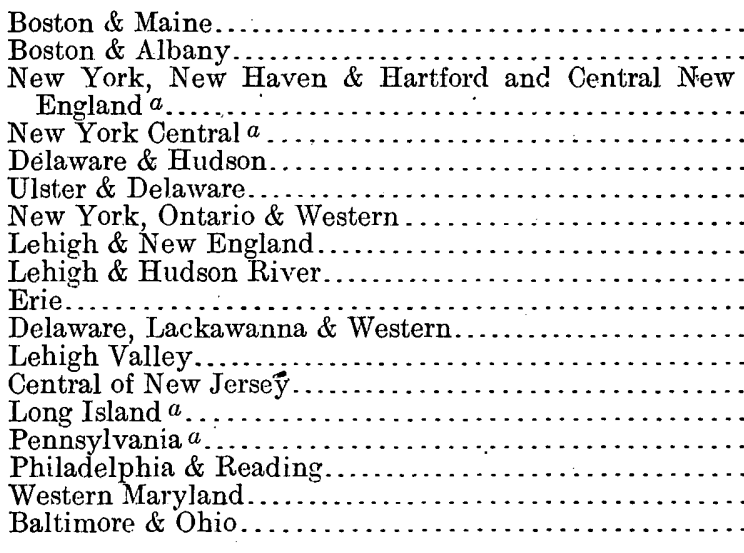 & $\begin{array}{r}1,872 \\
393 \\
\\
2,212 \\
790 \\
377 \\
129 \\
180 \\
238 \\
75 \\
715 \\
590 \\
673 \\
638 \\
312 \\
2,176 \\
1 ., 581 \\
95 \\
350\end{array}$ & \begin{tabular}{r}
819 \\
594 \\
233 \\
\hdashline 134 \\
4 \\
$\dddot{1564}$ \\
364 \\
357 \\
312 \\
252 \\
102 \\
944 \\
627 \\
20 \\
227
\end{tabular} & $\begin{array}{r}10 \\
110 \\
66 \\
414 \\
56 \\
\ldots \ldots \ldots . . \\
\cdots \cdots . . . \\
6 . .6 \\
122 \\
129 \\
80 \\
7 \\
515 \\
157\end{array}$ & $\begin{array}{r}3,097 \\
1,798 \\
666 \\
129 \\
334 \\
242 \\
75 \\
1,146 \\
1,069 \\
1,114 \\
970 \\
421 \\
3,635 \\
2,365 \\
115 \\
620\end{array}$ & $\begin{array}{r}1,124 \\
419 \\
1,558 \\
952 \\
337 \\
34 \\
118 \\
114 \\
57 \\
725 \\
705 \\
774 \\
822 \\
281 \\
2,473 \\
1,375 \\
58 \\
307\end{array}$ & $\begin{array}{r}4,655 \\
2,750 \\
1,003 \\
163 \\
452 \\
356 \\
132 \\
1,871 \\
1,774 \\
1,888 \\
1,792 \\
702 \\
6,108 \\
3,740 \\
173 \\
927\end{array}$ \\
\hline & 13,396 & 5,849 & 1,776 & $21,02]$. & 12,233 & 33,254 \\
\hline
\end{tabular}

$a$ Electrified track omitted. 
TABLE 9.-Steam locomotives in service on class 1 railroads within superpower zone, 1919.

\begin{tabular}{|c|c|c|c|c|}
\hline System. & Freight. & Passenger. & Switching. & Total. \\
\hline 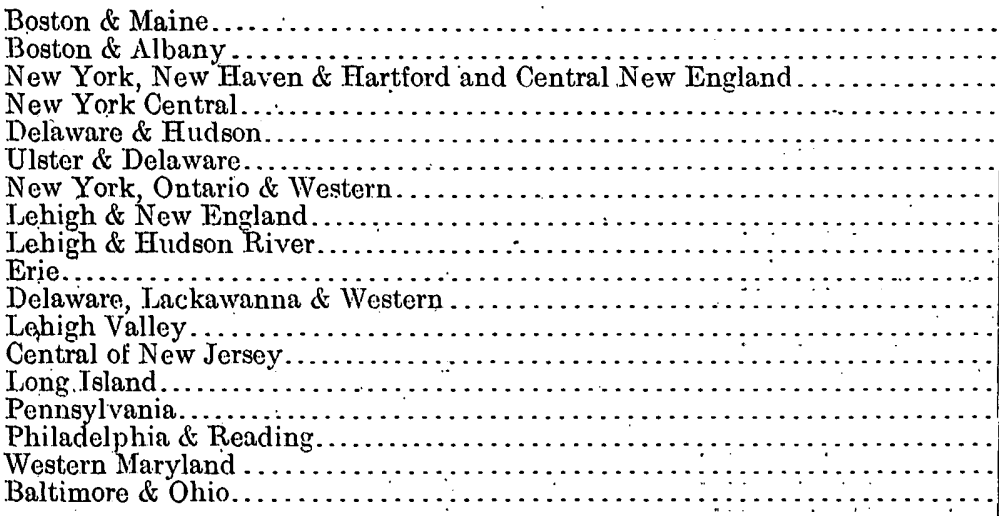 & $\begin{array}{r}465 \\
147 \\
416 \\
244 \\
262 \\
17 \\
77 \\
35 \\
40 \\
260 \\
312 \\
280 \\
253 \\
43 \\
674 \\
474 \\
46 \\
106\end{array}$ & $\begin{array}{r}305 \\
143 \\
407 \\
191 \\
34 \\
8 \\
8 \quad 39 \\
2 \\
5 \\
176 \\
128 \\
85 \\
155 \\
67 \\
593 \\
242 \\
26 \\
63\end{array}$ & $\begin{array}{r}203 \\
61 \\
344 \\
212 \\
18 \\
3 \\
8 \\
24 \\
3 \\
132 \\
130 \\
254 \\
177 \\
36 \\
568 \\
366 \\
21 \\
141\end{array}$ & $\begin{array}{r}973 \\
351 \\
1,167 \\
647 \\
314 \\
28 \\
124 \\
61 \\
48 \\
568 \\
570 \\
619 \\
585 \\
146 \\
1,835 \\
1,082 \\
93 \\
310\end{array}$ \\
\hline Per c:ent. & $\begin{array}{r}4,151 \\
43.6\end{array}$ & $\begin{array}{r}2,669 \\
28.0\end{array}$ & 2,701 & $\begin{array}{r}9,521 \\
100\end{array}$ \\
\hline
\end{tabular}

TABLE 10.-Steam traffic movement on class 1 railroads within superpover zone, 1919.

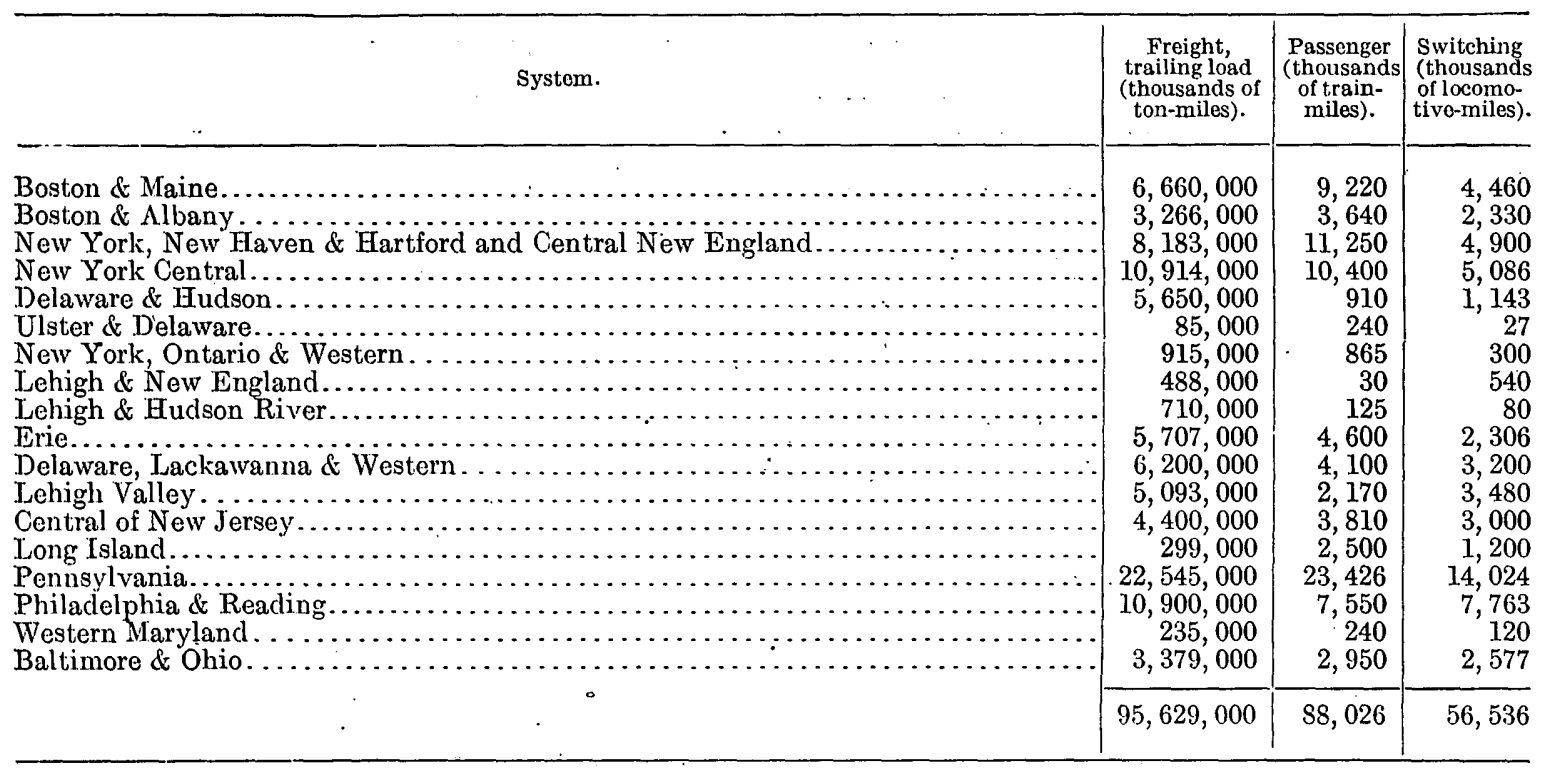


TABLE 11.-Coal used by steam locomotives of class 1 railroads within the superpower zone, 1919; in short tons.

\begin{tabular}{|c|c|c|c|c|}
\hline System. & Freight. & Passenger. & Switcher. & Total. \\
\hline 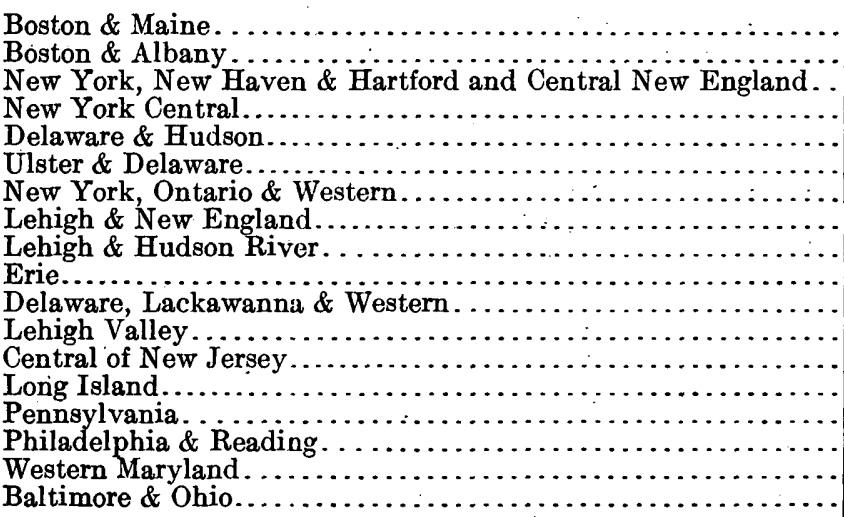 & $\begin{array}{r}642,500 \\
397,000 \\
800,000 \\
724,000 \\
622,000 \\
18,700 \\
108,300 \\
63,100 \\
58,000 \\
575,500 \\
900,000 \\
676,000 \\
505,700 \\
84,200 \\
1,731,200 \\
1,505,100 \\
48,000 \\
312,500\end{array}$ & $\begin{array}{r}485,000 \\
246,000 \\
705,000 \\
609,500 \\
62,000 \\
14,000 \\
35,000 \\
2,800 \\
7,600 \\
356,900 \\
300,000 \\
187,000 \\
260,400 \\
141,200 \\
1,413,000 \\
495,100 \\
16,700 \\
187,800\end{array}$ & $\begin{array}{r}193,500 \\
83,000 \\
279,000 \\
272,500 \\
81,000 \\
1,300 \\
16,000 \\
27,500 \\
5,300 \\
161,000 \\
200,000 \\
240,000 \\
195,400 \\
48,100 \\
750,800 \\
404,500 \\
9,600 \\
140,000\end{array}$ & $\begin{array}{r}1,321,000 \\
726,000 \\
1,784,000 \\
1,606,000 \\
765,000 \\
34,000 \\
159,300 \\
93,400 \\
70,900 \\
1,093,400 \\
1,400,000 \\
1,103,000 \\
961,500 \\
273,500 \\
3,895,000 \\
2,404,700 \\
74,300 \\
640,300\end{array}$ \\
\hline Per cent. . & $\begin{array}{r}9,771,800 \\
53.1\end{array}$ & $\begin{array}{r}5,525,000 \\
30.0\end{array}$ & $\begin{array}{r}3,108,500 \\
16.9\end{array}$ & $\begin{array}{r}18,405,300 \\
100.0\end{array}$ \\
\hline
\end{tabular}

TABLE 12.-Summary of principal data for class 1 railroads within the superpower zone for 1919.

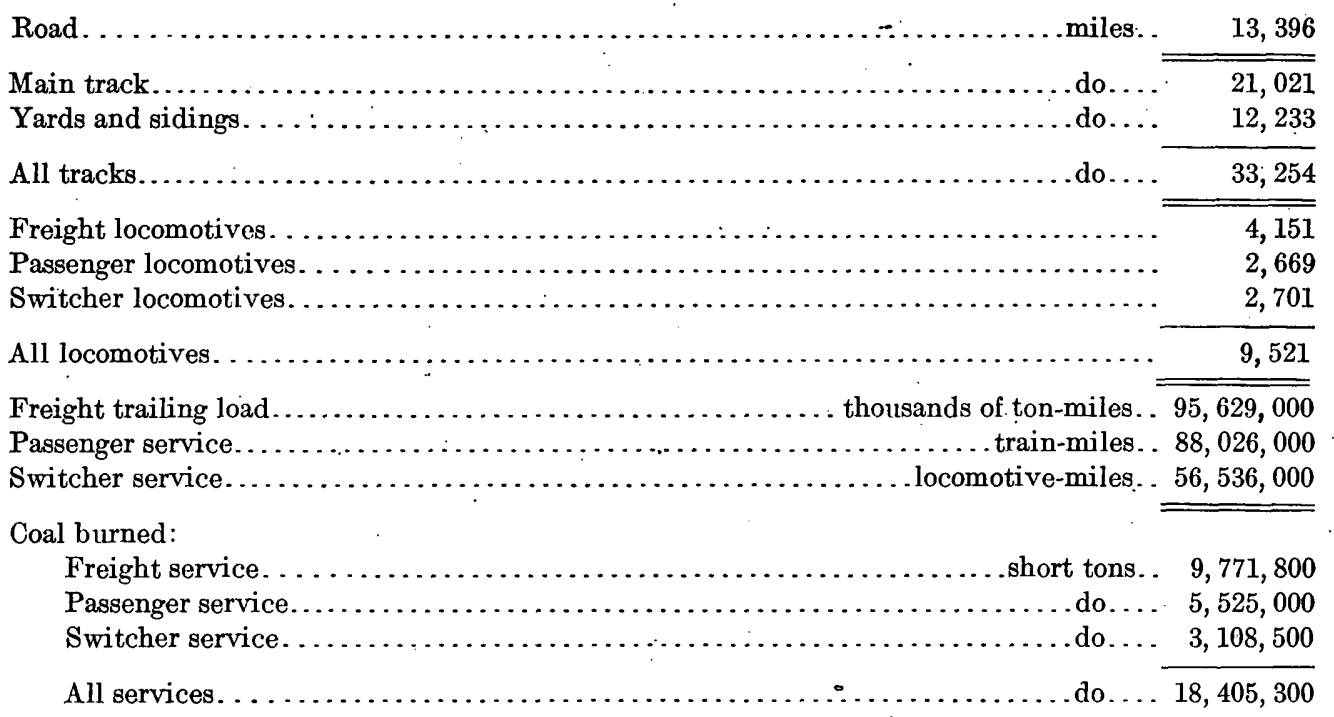

In addition to the data from the railroads two large electric companies, the General Electric and the Westinghouse, were asked to prepare estimates of cost of substation equipment, of electric locomotives, of catenary construction, and of other electric facilities-all as of the year 1919. Similar data were also asked of the Ohio Brass Co. and one or two other companies. All made prompt and full response. After a provisional analysis of certain of these data the opinions of engineers of electric railways were sought, and their criticisms were considered in making up final estimates of cost of construction and of operation.

The locomotive-mile and the ton-mile were selected as bases for the electric comparisons, principally for the reason that locomotive maintenance is always reported "per locomotivemile," both for steam and electric locomotives. The statistics of electric service for energy used can easily be put into any units. Form $\mathrm{C}$ was standardized, and the replies from the operating roads were all tabulated in this form, as shown on the following page. 
Form C.

Comparison of steam and electric operation, $M . \&$ \&. system, R. division.

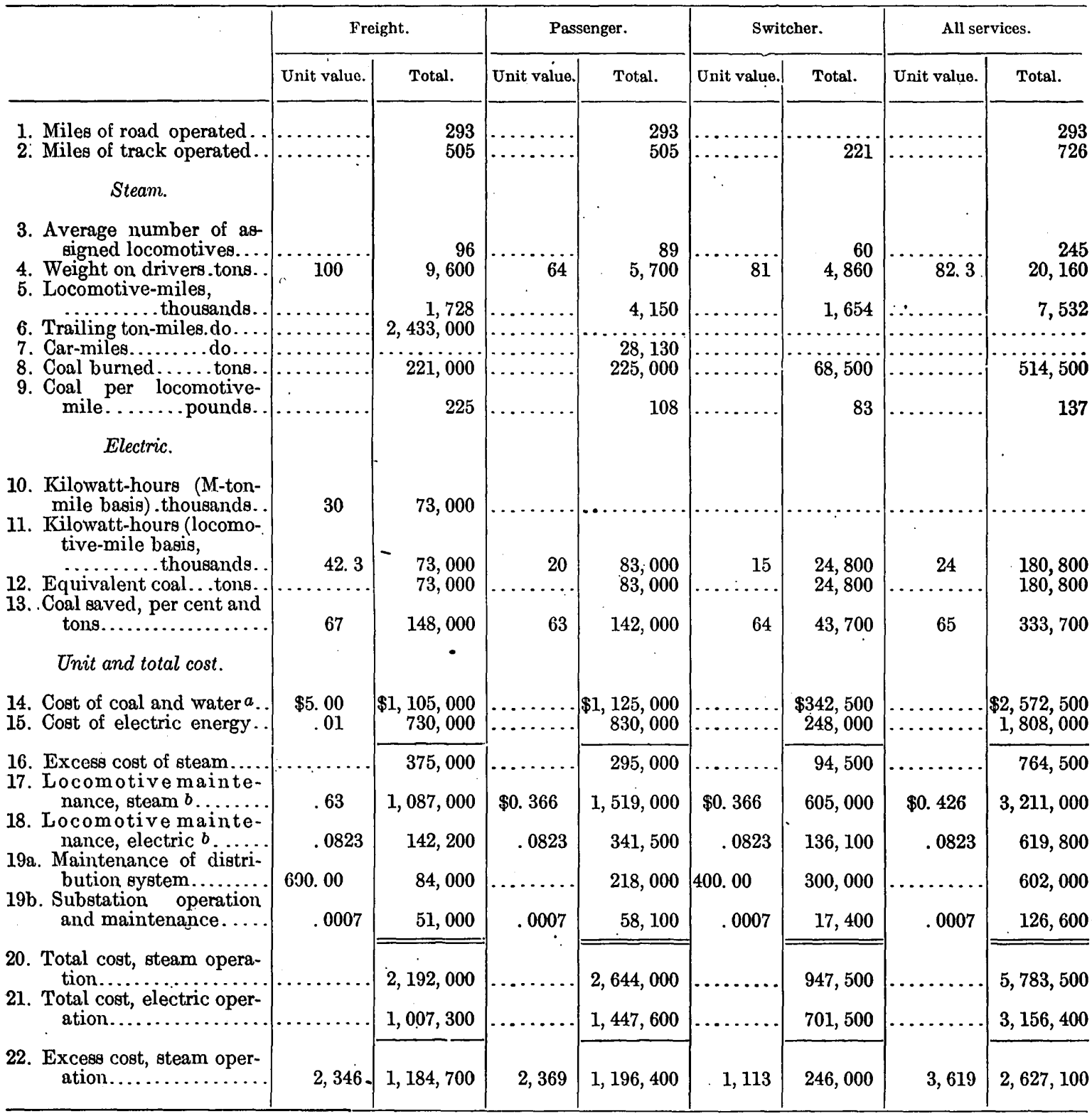

a Includes cost of fuel and water stations.

b Includes engine-house expense.

\section{ANALYSIS OF DATA.}

The first nine items of Form $\mathrm{C}$ are taken from the replies of the railroads to the questions of Form A. Items 10 and 11 cover the kilowatt-hours used.

The view here taken is that the steam locomotive is a machine doing useful work, which in freight service is represented by the gross weight of cars and contents multiplied by the distance moved - that is, the "trailing ton-miles." In this service variations in speed are of little consequence. . The total tonnage movement is here referred to as "total ton-miles" or as "trailing ton-miles plus locomotive ton-miles."

The same procedure is followed in estimating the electric requirements-the electric locomotive is regarded as a machine substituted for the steam locomotive to do the same 
work. This procedure, however, does not lead to a direct statement of the saving in tonnage movement due to the smaller total weight of the electric locomotive as compared with that of the steam locomotive and tender. This difference, including for freight service the weight of the loaded tender and the part of the weight of the steam locomotive that is not on drivers, can be estimated separately; it is approximately 8 to 13 per cent of the trailing ton-miles. This difference is considerable, but it is not of so great consequence as is sometimes assumed.

In passenger service the work done is that of moving the loaded cars over a certain distance at a certain speed, and in this service the speed-the time consumed-is important.

\section{ENERGY REQUIRED FOR ELECTRIC TRACTION.}

The electric energy required for the railroads is determined from the records of lines already electrified, with proper allowance for variations in the conditions of operation, and from calculations based on the profile and the alinement of the roads considered and the efficiency of their locomotive and distribution systems.

The most extensive data available for lines already electrified are those of the New Haven road, which has installed wattmeters on its locomotives, keeps records of their individual performance, and classifies these records for the several kinds of service performed. This company also keeps daily records of the energy generated at its Coscob station and of that which it buys from the United Electric Light \& Power Co. and the New York Central Railroad Co. Tables have been prepared by the New Haven company showing the energy used in slow-freight, local-freight, fast-freight, passenger, and multiple-unit service.

Table 13 is a summary of the average operating results of the New Haven system for 1919, showing the input to the locomotive in kilowatt-hours per locomotive-mile, train-mile, trailing ton-mile, total ton-mile (including locomotive), and car-mile for fast, slow, local, and all freight service; for express, local, and all passenger service; and for multiple-unit service. These figures can be used with confidence for railroads operating under conditions similar to those of the New Haven, which do not differ materially from those of a number of the other roads in the superpower zone, particularly along the coast. In fixing the units of energy for the different operating divisions much weight is given to the results of the New Haven service, modified as required by the profile and alinement under examination.

TABLE 13.-Electric energy used by New Haven locomotives in 1919, in kilowatt-hours of locomotive input.

\begin{tabular}{|c|c|c|c|c|c|}
\hline & \multirow{2}{*}{$\begin{array}{c}\text { Per locomotive- } \\
\text { mile. }\end{array}$} & \multirow{2}{*}{ Per train-mile. } & \multicolumn{2}{|c|}{ Per 1,000 ton-miles. } & \multirow{2}{*}{ Per car-mile. } \\
\hline & & & Trailing. & Train. & \\
\hline 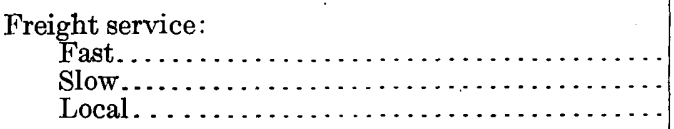 & $\begin{array}{l}26.0 \\
34.0 \\
36.1\end{array}$ & $\begin{array}{l}27.0 \\
42.7 \\
36.5\end{array}$ & $\begin{array}{l}24.5 \\
24.9 \\
42.5\end{array}$ & $\begin{array}{l}22.2 \\
23.1 \\
38.2\end{array}$ & $\begin{array}{r}0.88 \\
.93 \\
1.52\end{array}$ \\
\hline A verage........ & 33.6 & 40.0 & 26. 6 & $24 ., 5$ & .98 \\
\hline $\begin{array}{l}\text { Passenger service: } \\
\text { Express. . . . . . . . . . . . } \\
\text { Local. . }\end{array}$ & $\begin{array}{l}13.7 \\
17.5\end{array}$ & $\begin{array}{l}\text { 24. } 6 \\
26.1\end{array}$ & $\begin{array}{l}44.3 \\
76.5\end{array}$ & $\begin{array}{l}32.6 \\
51.4\end{array}$ & $\begin{array}{l}\text { 2. } 96 \\
\text { 3. } 93\end{array}$ \\
\hline A verage.... & 14.7 & 25.1 & 51.4 & 37.0 & 3. 21 \\
\hline $\begin{array}{l}\text { Multiple-unit service } \ldots \ldots \ldots \ldots \ldots \ldots \\
\text { Yard switching } . . . \ldots \ldots \ldots \ldots \ldots\end{array}$ & … 12.4 & 17.4 & 62.2 & 62.2 & $\begin{array}{l}4.2 \\
\ldots . .\end{array}$ \\
\hline
\end{tabular}

Other records of electric energy for locomotive-drawn trains, both freight and passenger, are given in Table 14. The figures for the New Haven system in this table are referred to the substation output, an efficiency of 90 per cent being used for the distribution system. Those for the Chicago, Milwaukee \& St. Paul are given on the authority of the electrical engineer of that road for the energy delivered to the substation, multiplied by 83 per cent as average 
substation efficiency; those for the New York Central Railroad were presented by the chief engineer of electric traction at the joint meeting of the American Institute of Electrical Engineers and the American Association of Mechanical Engineers October 22, 1920; those for the Pennsylvania Terminal are given in reports made to the superpower survey. All are reduced in Table 14 to the same point of reference-the substation output.

TABLE 14.-Electric energy used for locomotive-drawn freight and passenger trains, in kilowatt-hours of substation output.

\begin{tabular}{|c|c|c|c|c|}
\hline & $\begin{array}{l}\text { New } \\
\text { Haven. } a\end{array}$ & $\begin{array}{c}\text { Chicago, } \\
\text { Milwaukee } \\
\text { \& St. Paul.b }\end{array}$ & $\begin{array}{l}\text { New York } \\
\text { Central. }\end{array}$ & $\begin{array}{c}\text { Pennsyl- } \\
\text { vania } \\
\text { Terminal. }\end{array}$ \\
\hline 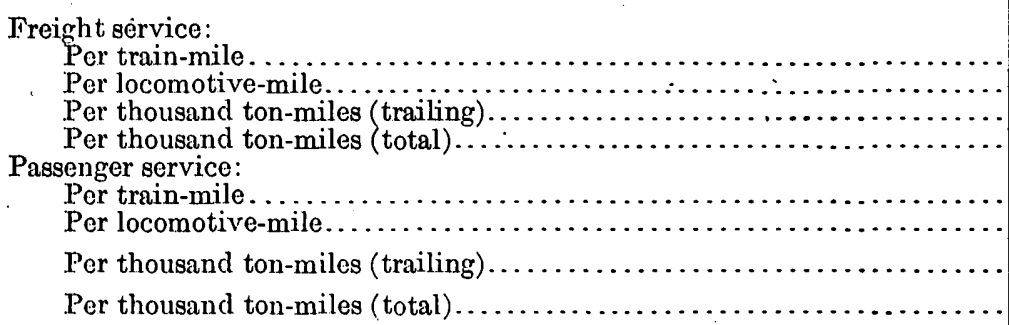 & $\begin{array}{l}44 \\
37 \\
29 \\
27 \\
\\
28 \\
16 \\
57\end{array}$ & $\begin{array}{r} \\
\\
\ldots \ldots \ldots \ldots \\
\cdots \ldots \ldots \\
33 \\
\\
29 \\
\\
\\
\ldots \ldots \ldots \ldots\end{array}$ & 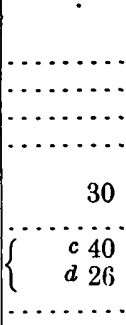 & 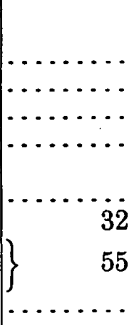 \\
\hline
\end{tabular}

a Energy at locomotive 1.17 .

$\checkmark$ Substation input 0.83 .

d Minimum.

The second method of determining electric energy required consists in calculating, from profile and alinement, the work due to normal train resistance and adding to this the net work done against gravity, plus the work due to curvature, plus the work due to acceleration. For example, on the profile shown in figure 1.3 , for. eastbound movement it is assumed that no power is required to descend the 0.6 per cent grade, but no credit is taken

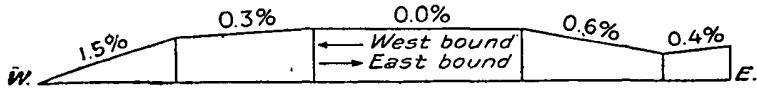

Fiaure 13.-Typical railroad profle.

for use of the kinetic energy accumulated at the bottom of this grade in ascending the next grade; for westbound movement it is assumed that no power is required on the 0.3 per cent grade for freight service, but that the difference between 0.3 and 0.5 per cent is used for passenger service. The lifting work is taken as the sum of the separate lifts; the work against curvature is the sum of the products of degrees of curvature taken from the alinement charts, multiplied by length of curve, and the unit resistance is taken at 0.8 pound per ton per degree. In freight service an acceleration from rest to 25 miles an hour and another from 10 to 25 miles an hour is assumed for each 10 miles. The sum of these elements gives the total work required at the rail to move a ton over the division considered. This process is carried through for movement in both directions, and the average of the two results is taken for the work required. This average divided by the efficiency from rail to substation input gives the watt-hours per ton-mile measured at the substation. For divisions on which the traffic is greatly unbalanced separate estimates were made for the eastbound and westbound moveinents.

Calculations made for a number of the operating divisions within the zone that differ most widely in grade and alinement show that the added resistance in freight service due to grade, curvature, and acceleration ranges from 0.5 to 10 pounds per ton. The maximum figure is that for the Jefferson division of the Erie, which includes a straight climb over a divide in both directions.

\section{SWITCHER SERVICE.}

The data of coal burned or energy required in switcher service are meager, consisting mainly of the results of a few tests recently made by the General Electric Co., of tests made by the Chicago Smoke Abatement Commission, and of tests made on the New Haven road. These tests show conclusively that the waste of coal in switcher service is great and that the actual work don $\theta$ by a switcher locomotive is small. 
The tests in Chicago were made at a number of busy yards, in heavy service, chosen as typical of the conditions there. The average results are as follows:

Work done per locomotive-hour:

Trailing................................................ton-miles. . 1,000

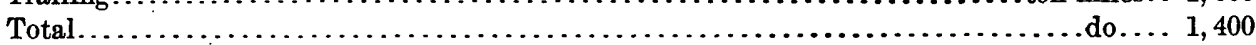

Coal used per locomotive-hour..................................... pounds.. 824

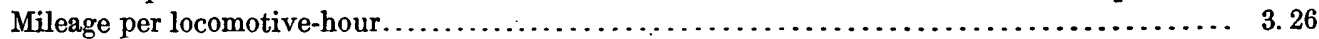

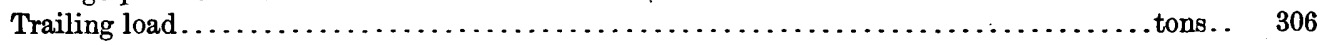

Coal per trailing ton-mile......................................... 0.824

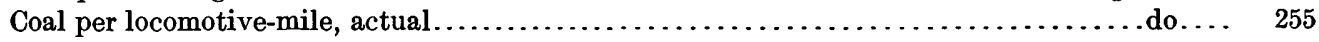

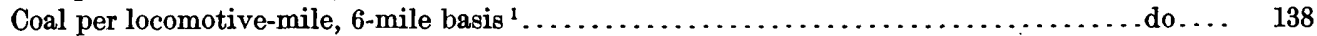

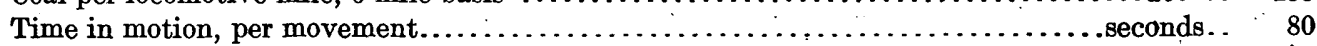

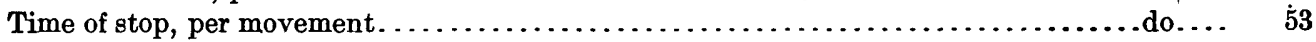

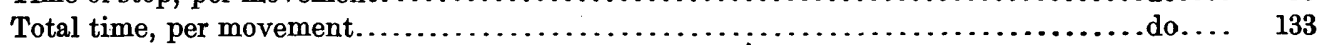

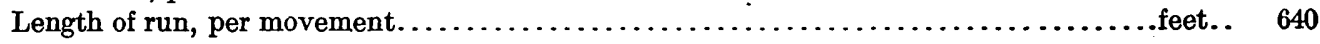

From these data the following deductions are made:

Average speed when moving...................................miles per hour.. $\quad 5.45$

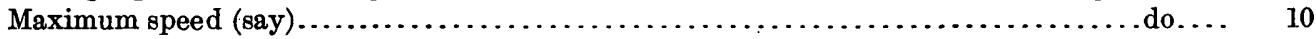

Energy required at rail for acceleration per movement................. $\left\{\begin{array}{l}\text { watt-hours per ton..... } \\ \text { watt-hours per ton-mile }\end{array}\right.$

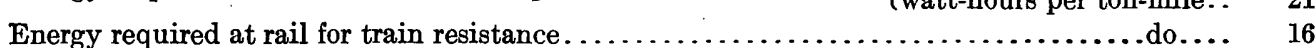

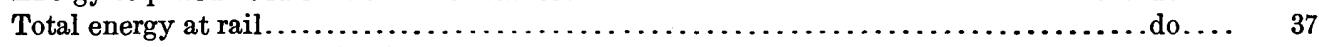

Total energy per locomotive-hour.................................. $\quad 52$

Coal burned per kilowatt-hour of work at rail . . . . . . . . . . . . 16

Efficiency assumed, rail to substation................................ per cent.. $\quad 63$

Energy required for substation input, per locomotive-hour..............kilowatt-hours.. $\quad 83$

The tests made at Erie by the General. Electric Co. with a storage-battery locomotive weighing 43 tons on drivers gave an average of 50 watt-hours per ton-mile of total train weight (including locomotive); the range from the six days' tests was from 47.8 to 55.7 watt-hours. Similar tests with a steam switcher weighing 40 tons on drivers gave 1.47 pounds of coal per total ton-mile. That is, in similar service the coal equivalent of 1 kilowatt-hour input to motors was 29 pounds, and that of 1 kilowatt-hour at rails was 34 pounds. The corresponding figure for road service, given below, is 7.5 pounds. Switcher service involves a great waste of coal due to large stand-by losses.

This 50 watt-hours per ton-mile is measured on the locomotive; referred to substation input it becomes 65 watt-hours per total ton-mile and 87 watt-hours per trailing ton-mile where 25 per cent of the total train weight is in the locomotive. This is practically the same as the 83 watt-hours per trailing ton-mile (83 kilowatt-hours per locomotive-hour) deduced above from the Chicago tests.

The above figures are all in general accord with such data as have been published; some results, however, have indicated much lower figures-as low as 30 to 50 kilowatt-hours at the substation per locomotive-hour.

COAI SAVED.

The quantity of coal burned in a steam locomotive equivalent in work done to 1 kilowatthour delivered to an electric locomotive is estimated by the electrical engineer of the Baltimore \& Ohio Railroad at 7.5 pounds and by the electrical engineer of the Chïcago, Milwaukee \& St. Paul Railway at 8.4 pounds. A committee of the American Electrical Railway Association has published data for a modern Mallet locomotive, with superheater, which makes the equivalent coal per kilowatt-hour with stand-by losses 7.5 pounds. The same authority elsewhere gives 6.5 pounds as the equivalent of 1 kilowatt-hour at the power station, equal to 8.1 pounds per kilowatt-hour at the locomotive. Other electrical authorities give materially larger figuressome as much as 12 pounds. The weight of expert opinion is, then, that not less than 7.5 pounds of coal is required to do the work of 1 kilowatt-hour at the locomotive.

The approximate uniformity shown on the operating sheets (Form C) in the percentages of coal saved in the three services on the several roads by electric operation tends to confirm the validity of the figures taken for kilowatt-hours used (items 10 and 11, Form C); on the

A standard method of expressing switching units is at 6 miles per locomotive-hour. 
assumption that all the roads in the territory are fairly well operated there should be approximately the same percentage of saving of coal on each road in freight, passenger, and switcher service, respectively." The performance of individual steam locomotives of course differs materially, but that of groups only slightly. The operating sheets show that the coal saved in freight service is from 50 to 70 per cent. For passenger service the saving is from 65 to 75 per cent, in general somewhat higher than for freight service, as would be expected, inasmuch as the freight locomotives are more closely proportioned to their work than passenger locomotives. Similarly the saving in switcher service is from 70 to 85 per cent, and this also is consistent, inasmuch as the switchers operate under the worst conditions.

\section{EFFICIENCY.}

The power and the losses in the several parts of the direct-current system from substation input to rail for average load are taken as-

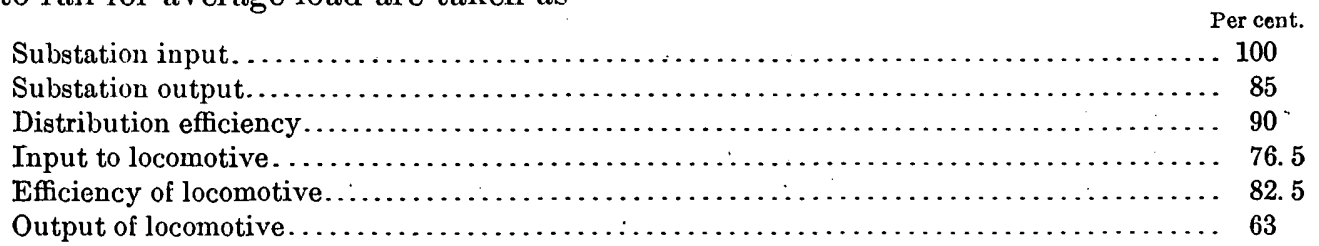

Under these conditions a freight train with a resistance of 6 pounds per ton would require 19 watt-hours per ton-mile, and a passenger train at 10 pounds per ton would require 32 watt-hours per ton-mile.

\section{EQUIVALENT COAL.}

Item 12 on Form C, "equivalent coal," is uniformly taken at 2 pounds per kilowatt-hour for energy delivered at the substation. All losses of energy in transmission and conversion from the power station to the substation are included in this figure. If 1.5 pounds per kilowatt-hour is the average for coal used in superpower stations, then the assumption of 2 pounds per kilowatt-hour at the substation means an efficiency of only 75 per cent from substation input to power house. 'This is low-80 to 85 per cent is more nearly correct. The "equivalent". coal is given only to show the percentage of coal that would be saved under electric operation; it does not enter into the comparative costs.

\section{COST OF COAL.}

Item 14 covers the total estimated cost of coal at the railroad's fuel stations, including freight on home lines, plus the estimated cost of operating and maintaining the fuel and water stations, prorated per ton to the total coal used.

Only one or two of the replies from the railroads included freight on home lines. In this analysis the cost of delivering coal to points in the superpower zone has been determined from a base mine cost of $\$ 2.90$ a ton for 1919. The cost of the coal delivered as thus determined is substantially the same as the cost reported by the railroad companies, after allowance for freight on home lines. In order to make the costs justly comparable throughout a unit price was adopted for railroad coal for each section; the cost per ton as thus fixed for the several sections of the zone is $\$ 5, \$ 5.50$, and $\$ 6$ for the south, central, and north sections, respectively. These costs include the prorated cost of fuel and water stations. The uniform base mine price used affords a truer comparison of steam and electric operation than the variable figures of the railroad companies.

\section{COST OF ELECTRIC ENERGY.}

It is assumed that the railroads will purchase energy delivered at high pressure at substations on or near the railroad right of way, at the flat rate of 1 cent per kilowatt-hour. This price includes the total cost of generating and transforming electric energy and transmitting it to the railroad substations, with profit to the supplier.

No estimate is made of the maximum power required for the service, except in so far as it is involved in the determination of the substation capacity and the feeder capacity, for as $63361^{\circ}-21-5$ 
the cost of energy is figured at a flat rate per kilowatt-hour the maxima to be provided do not enter into this item.

Similarly, no definite ratio has been assigned to the eastbound and -westbound traffic; in general this ratio is similar for most of the roads in the zone. Where the profiles indicate that greater work is required in one direction than in the other this difference has been taken into consideration in the allocation of energy. All estimated figures here given are assumed averages and would of course have to be modified for each division by detailed study.

The load factor of the several divisions will be between 40 and 60 per cent, and 50 to 53 per cent may be taken as the average for unified operation.

\section{MAINTENANCE OF STEAM LOCOMOTIVES.}

Item 17 of Form $\mathrm{C}$ is the cost of steam-locomotive maintenance as reported by the railroads, plus engine-house expense, prorated to the locomotive-mile. This item is the one affected most by electrification. The saving in maintenance by the electric locomotive is from two to five times the saving in coal; and this difference accounts for 50 to 100 per cent of the net saving made by electric traction.

Table 15 gives the cost of steam-locomotive maintenance for the principal systems in the superpower zone for 1919; the amounts included are Interstate Commerce Commission accounts No. 308, locomotive repairs, and Nos. 388 and 400, engine-house expenses for yard and train locomotives. These costs are reduced to the cost per locomotive-mile by taking as divisor the total mileage. From this result and the average weight of locomotive on drivers the sum of the cost of repairs and engine-house expense is prorated to the cost per locomotive-mile for 100 tons on drivers.

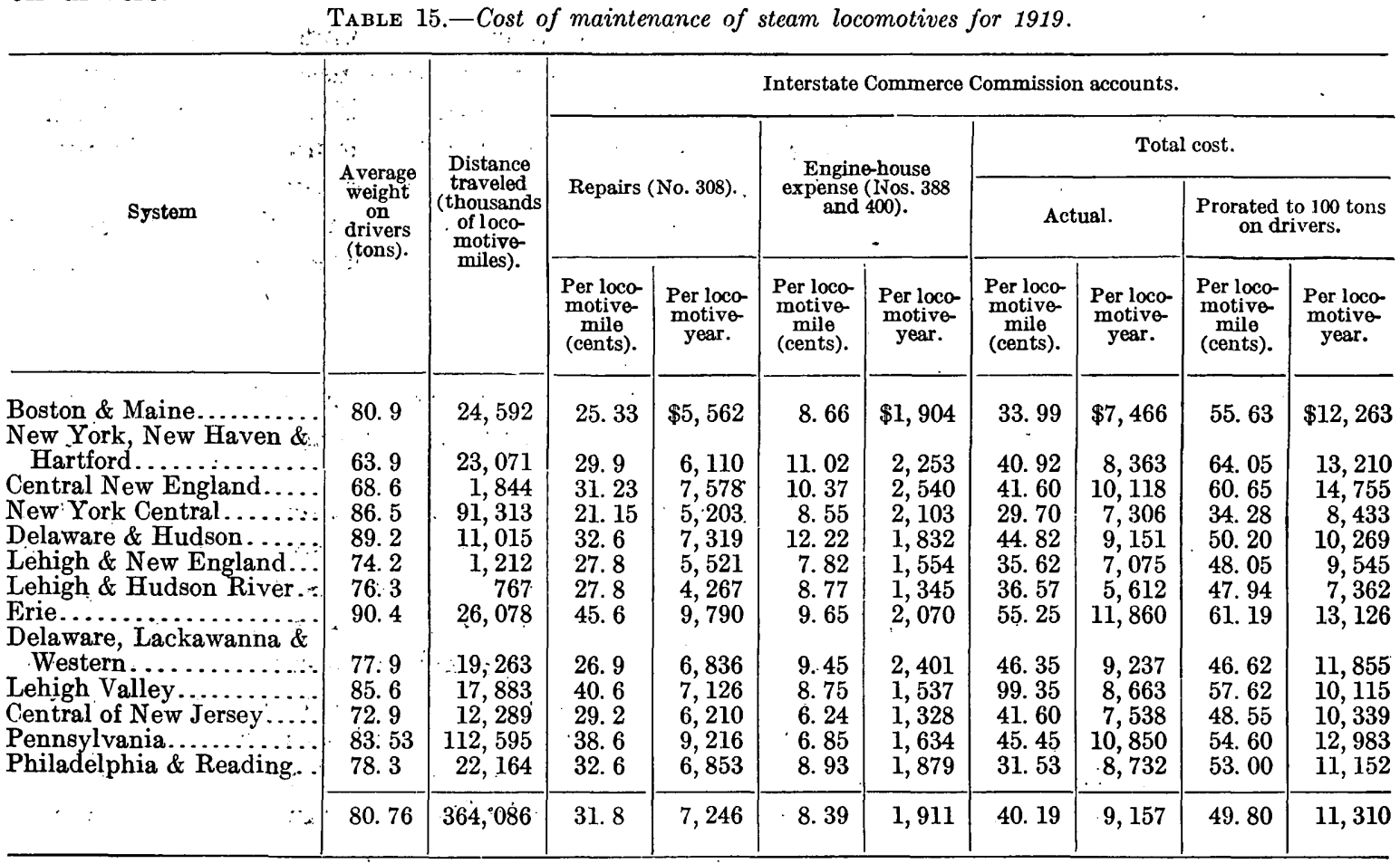

Table 16 gives similar data for the New York Central, Pennsylvania, Reading, New Haven, and Erie systems for 1911 to 1919. The weighted average is given for the years 1911 to 1915 , inclusive, "a period during which there was practically no variation in these unit costs.

It is difficult to.find a satisfactory explanation of the great variations in these figures among the different systems; the division of total cost between repairs and engine-house expense differs somewhat, certain roads throwing more of the work on the engine house; but the sum of the two items is still widely divergent. There is no difference in the kind of service to which the locomotives are put that will account for these marked variations. 
ELECTRIFICATION OF HEAVY-TRACTION RAILROADS.

TABLE 16.-Cost of maintenance of steam locomotives for 1911-1919.

\begin{tabular}{|c|c|c|c|c|c|c|c|c|c|c|}
\hline \multirow{4}{*}{ System. } & \multirow{4}{*}{$\begin{array}{c}\text { Average } \\
\text { weight } \\
\text { ont } \\
\text { drivers } \\
\text { (tons). }\end{array}$} & \multirow{4}{*}{$\begin{array}{l}\text { Distance } \\
\text { traveled } \\
\text { (thou- } \\
\text { sands of } \\
\text { locomo- } \\
\text { tive- } \\
\text { miles). }\end{array}$} & \multicolumn{8}{|c|}{ Interstate Commerce Commission accounts. } \\
\hline & & & \multirow{2}{*}{\multicolumn{2}{|c|}{ Repairs (No. 308). }} & \multirow{2}{*}{\multicolumn{2}{|c|}{$\begin{array}{l}\text { Engine-house } \\
\text { expense (Nos. } 388 \\
\text { and } 400) .\end{array}$}} & \multicolumn{4}{|c|}{ Total cost. } \\
\hline & & & & & & & \multicolumn{2}{|c|}{ Actual. } & \multicolumn{2}{|c|}{$\begin{array}{l}\text { Prorated to } 100 \text { tons } \\
\text { on drivers. }\end{array}$} \\
\hline & & & $\begin{array}{l}\text { Per loco- } \\
\text { motive- } \\
\text { mile } \\
\text { (cents). }\end{array}$ & $\begin{array}{c}\text { Per loco- } \\
\text { motive- } \\
\text { year. }\end{array}$ & $\begin{array}{c}\text { Per loco- } \\
\text { motive- } \\
\text { mile } \\
\text { (cents) }\end{array}$ & $\begin{array}{l}\text { Per loco- } \\
\text { motive- } \\
\text { year. }\end{array}$ & $\begin{array}{l}\text { Per loco- } \\
\text { motive- } \\
\text { mile } \\
\text { (cents). }\end{array}$ & $\begin{array}{c}\text { Per loco- } \\
\text { motive- } \\
\text { year. }\end{array}$ & $\begin{array}{l}\text { Per loco- } \\
\text { motive- } \\
\text { mile } \\
\text { (cents). }\end{array}$ & $\begin{array}{c}\text { Per loco- } \\
\text { motive- } \\
\text { year. }\end{array}$ \\
\hline \multirow{6}{*}{$\begin{array}{r}\text { New York Central: } \\
1911-1915 \ldots \ldots \ldots \ldots \ldots \\
1916 \ldots \ldots \ldots \ldots \\
1917 \ldots \ldots \ldots \ldots \\
1918 \ldots \ldots \ldots \ldots \ldots \\
1919 \ldots \ldots \ldots \ldots \ldots\end{array}$} & & & & & & & & & & \\
\hline & 75. 36 & 66,356 & 9.04 & $\$ 2,460$ & 3. 1 & $\$ 849$ & 12.14 & $\$ 3,309$ & 16. 11 & $\$ 4,391$ \\
\hline & 82.2 & 108,626 & 7.6 & & 3. 06 & 972 & 10.66 & 3,393 & 6 & 4,126 \\
\hline & 8 & 106,4 & 10. & & 4. & $1 ; 24$ & & & & 5 , \\
\hline & 85.6 & 100,576 & 17.5 & 4,6 & 7.3 & 1,9 & & 6,6 & & 7,752 \\
\hline & 86.5 & 91,313 & 21.15 & 5,19 & 8.54 & 2,100 & 29.69 & 7,29 & 34. 32 & 8,434 \\
\hline \multicolumn{2}{|l|}{ Pennsylvania: } & & & & & & & & & \\
\hline & 75.85 & 94,142 & & 3,22 & 2.8 & 710 & & 3,931 & 20. 44 & 5,183 \\
\hline & & 105,5 & & & & & & & & \\
\hline 19 & 87 & 108,6 & & & 3. & 89 & & 5,5 & & 6,300 \\
\hline & 90. & 122,9 & 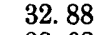 & & 3. & 1,7 & & 10,7 & 40.46 & 11,885 \\
\hline $1919 \ldots \ldots \ldots$ & 91.0 & 112,595 & 38.62 & 9,175 & 6.8 & 1,627 & 45.42 & 10,802 & 49.91 & 11,870 \\
\hline \multicolumn{11}{|l|}{ Philadelphia \& Reading: } \\
\hline $1911-1915 \ldots \ldots \ldots$ & 62.92 & 24,631 & 11.69 & & 3. 04 & 750 & 14.73 & & 23.41 & 5,779 \\
\hline $1916 \ldots \ldots$ & $70.8-8-3-1-30$ & 27,4 & 12. & & & 88 & & & & \\
\hline & 73. & & 17. & 4, & 4.. & 1,15 & & & & 8,400 \\
\hline & 75. & 27,0 & 28. & 7,4 & 7.5 & 1,975 & 35 & 9,39 & 47. 31 & 12,464 \\
\hline $1919, \ldots \ldots \ldots \ldots \ldots$ & 78.3 & 22,164 & 32.6 & 6,853 & 8.93 & 1,879 & 41.53 & 8,732 & 53. 04 & 11,152 \\
\hline \multicolumn{11}{|l|}{$\begin{array}{l}\text { New York, New Haven \& } \\
\text { Hartford: }\end{array}$} \\
\hline & & 27,027 & & & & & & & & \\
\hline $1911-1910$ & 55.6 & 27,495 & $\begin{array}{l}9.6 \\
9.98\end{array}$ & 2, & $\begin{array}{l}3.00 \\
3.61\end{array}$ & $\begin{array}{l}681 \\
822\end{array}$ & $\begin{array}{l}12.60 \\
13.59\end{array}$ & $\begin{array}{l}2,853 \\
3,094\end{array}$ & & $\begin{array}{l}5,620 \\
5,565\end{array}$ \\
\hline & 57.5 & 26,0 & 14.0 & & 4.7 & 1,078 & & & & 7,370 \\
\hline & 61.4 & 24,784 & 30.85 & 6,400 & 8.99 & 1,861 & 39.84 & 8,261 & 64.88 & 13,454 \\
\hline 1919 & 63.9 & 23,071 & 29.9 & 6,110 & 11.04 & 2,253 & 40.94 & 8,363 & 64.07 & 13,088 \\
\hline \multicolumn{11}{|l|}{ Erie: } \\
\hline - 1911-1915. & 74. 1 & 28,7 & 11.21 & & 3.45 & 749 & 14. & 3,1 & 19. 78 & 4,290 \\
\hline & & & & & & & & & & \\
\hline & 87.6 & 29,9 & 24. & 5, & 6. 11 & 1,360 & 30. & 6,7 & 34. 60 & 7, 717 \\
\hline & & & & & 11.75 & 2,582 & & 12,532 & & 13,924 \\
\hline & 90.2 & 26,078 & 45.6 & 9,790 & 9.65 & 2,070 & 55.25 & 11,860 & 61.25 & 3,1481 \\
\hline
\end{tabular}

MAINTENANCE OF EIECTRIC LOCOMOTIVES.

Item 18 of Form C, cost of maintenance of direct-current locomotives, is taken uniformly at 10 cents per locomotive-mile per 100 tons on drivers. Actual costs are shown in Table 17 for all direct-current railroads in the United States for 1.919, and in Table 18 for all grouped, with the weighted average, for 1913-1919. The base cost, as stated above, is applied for each road to the same average weight on drivers as that of the steam locomotives of the road.

TABLE-17.-Cost of maintenance of direct-current electric locomotives, 1919.

\begin{tabular}{|c|c|c|c|c|c|c|c|c|}
\hline \multirow{3}{*}{ System. } & \multirow{3}{*}{$\begin{array}{l}\text { Number of } \\
\text { locomo- } \\
\text { tives. }\end{array}$} & \multirow{3}{*}{$\begin{array}{c}\text { Average } \\
\text { weight on } \\
\text { drivers } \\
\text { (tons). }\end{array}$} & \multirow{3}{*}{$\begin{array}{c}\text { Distance } \\
\text { traveled } \\
\text { (locomotive- } \\
\text { miles). }\end{array}$} & \multicolumn{5}{|c|}{ Cost. } \\
\hline & & & & \multicolumn{3}{|c|}{ Acturl. } & \multicolumn{2}{|c|}{$\begin{array}{l}\text { Prorated to } 100 \text { tons } \\
\text { on drivers. }\end{array}$} \\
\hline & & & & Total. & \begin{tabular}{|c|} 
Per \\
locomotive- \\
mile \\
(cents).
\end{tabular} & $\begin{array}{c}\text { Per } \\
\text { locomotive- } \\
\text { year. }\end{array}$ & $\begin{array}{c}\text { Per } \\
\text { locomotive- } \\
\text { mile } \\
\text { (cents). }\end{array}$ & $\begin{array}{l}\text { Per } \\
\text { locomotive- } \\
\text { year. }\end{array}$ \\
\hline \multirow[t]{2}{*}{$\begin{array}{l}\text { Baltimore \& Ohio............ } \\
\text { Butte, Anaconda \& Pacific..... } \\
\text { Chicago, Milwaukee \& St. Paul } \\
\text { Michigan Central .............. } \\
\text { New York Central............. } \\
\text { Pennsyl vania Terminal....... }\end{array}$} & $\begin{array}{r}8 \\
28 \\
46 \\
10 \\
73 \\
31\end{array}$ & $\begin{array}{r}88 \\
81 \\
225 \\
108 \\
92 \\
103\end{array}$ & $\begin{array}{r}214,400 \\
565,600 \\
2,181,200 \\
245,500 \\
1,940,900 \\
1,348,000\end{array}$ & $\begin{array}{r}\$ 24,600 \\
36,700 \\
340,200 \\
34,600 \\
124,400 \\
225,300\end{array}$ & $\begin{array}{r}11.47 \\
6.49 \\
15.59 \\
14.10 \\
6.41 \\
16.71\end{array}$ & $\begin{array}{r}\$ 3,076 \\
1 ; 312 \\
7,394 \\
3,462 \\
1,704 \\
7,266\end{array}$ & $\begin{array}{r}13.02 \\
8.01 \\
6.93 \\
13.05 \\
7.00 \\
16.30\end{array}$ & $\begin{array}{r}\$ 3,491 \\
1,619 \\
3,286 \\
3,205 \\
1,862 \\
7,088\end{array}$ \\
\hline & 196 & 124 & $6,495,600$ & 785,800 & 12.10 & 4,009 & 9.77 & 3,238 \\
\hline
\end{tabular}


TABLE 18.-Cost of maintenance of direct-current electric locomotives, 191.3-1919.

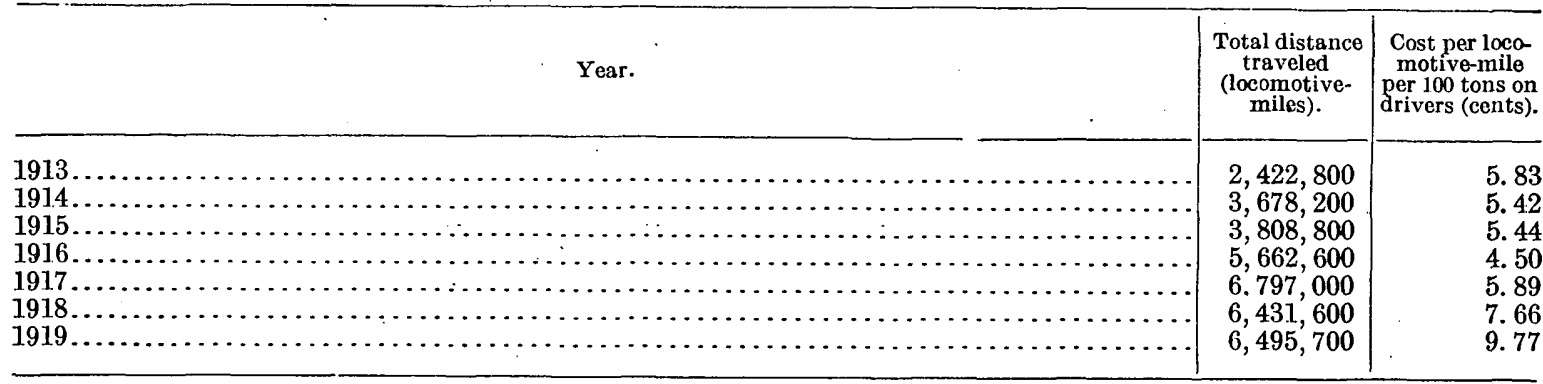

DISTRIBUTION SYSTEM.

Item 19, Form C, maintenance of the electric distribution system, is taken at $\$ 600$ per mile for main track and $\$ 400$ per mile for yard track. These figures are based on the operating costs of certain electric roads and on a consideration of the usual maintenance costs of works of similar construction. Although $\$ 600$ per mile of main track may seem low, it is probably not low if applied to a widespread system under unified control of both inspection and maintenance.

\section{MAINTENANCE OF SUBSTATIONS.}

Item 19b, Form C, cost of operation and maintenance of substations, is based on $\$ 1.50$ per kilowatt per year of capacity, giving 0.7 mill per kilowatt-hour for a capacity factor of 25 per cent. This is adequate for stations of the size required in a unified system for the entire zone.

\section{SAVING IN WAGES OF TRAIN CREWS.}

Item 22 gives the excess cost for steam service as compared with electric service without allowance for saving in crew wages. Few data are available to show the amount of such saving, but those that are available indicate that it will be considerable. In the Butte, Anaconda \& Pacific freight service there has been a decrease in crew time of 29 per cent per ton-mile and a simultaneous increase in tonnage moved of 35 per cent, together equivalent to a decrease of 47 per cent in crew wages. On the Chicago, Milwaukee \& St. Paul there has been an average decrease of 25 per cent in crew time and an increase of 30 per cent in tonnage moved, together equivalent to a decrease of 42 per cent in crew wages. On the Norfolk \& Western two electric locomotives pull the same train as three Mallets at double the speed, making an output per locomotive-hour three times as great and a consequent saving in crew wages of 67 per cent. The reason for this reduction in crew wages per ton-mile is clear: if a steam locomotive pulls a train 100 miles in 10 hours and an electric locomotive pulls it 100 miles in 8 hours, the use of the electric locomotive will save 33 per cent in crew wages (as 2 hours of the 10 would be paid for at double-time rates); and if the train pulled by the electric locomotive is 25 per cent heavier, the saving in wages will be 46 per cent. Such a saving is easily made.

- It is not yet possible to determine exactly the manner in which traffic within the superpower zone will be handled, but it is conservatively assumed that there will be an increase in tonmiles per electric locomotive-hour of 33 per cent and a consequent reduction in crew wages per ton-mile of 25 per cent.

Table 19 shows for 1919 the crew wages in freight service per thousand ton-miles for the principal systems in the zone, the tonnage moved, and the saving due to an increase of 33 per cent in output; this saving averages 10 cents per thousand ton-miles. Applied at this rate the saving on the entire freight traffic of the zone in 1919 would have been $\$ 9,560,000$.

For passenger service no data are at hand; a general consideration of the subject does not indicate a material saving in crew wages, and therefore none is assumed.

In switcher service the advantages of the electric locomotive in its quicker acceleration and quicker initial start are far-reaching. Tests made by the General Electric Co. at Erie show a movement per hour for the electric switcher of 1,000 trailing ton-miles as against 250 for a steam switcher of the same weight on drivers. The experience at the Oak Point yard of the 
New Haven road proves that the relative output per locomotive-hour is more than 2 to 1 . In view of these facts and of the characteristics of the machines, it is estimated that the electric switcher will do 50 per cent more work per hour than the steam switcher, and that consequently the wage account for the same total service will be reduced by 33 per cent.

Table 19 shows that the average wages per switcher-mile in the superpower zone are $\$ 0.60$. The saving will then be $\$ 0.20$ per mile, and the total saving in wages for the entire switcher traffic in the zone in 1919 (56,536,000 miles) would have been $\$ 11,310,000$; this is greater than the saving in freight service.

TABLE 19.-Analysis of crew wages for freight and switcher service, 1919.

\begin{tabular}{|c|c|c|c|c|c|c|}
\hline \multirow[b]{2}{*}{. $\quad$ System. } & \multicolumn{3}{|c|}{ Freight service. } & \multicolumn{3}{|c|}{ Switcher serv:ce. } \\
\hline & $\begin{array}{l}\text { Wages per } \\
\text { thousand } \\
\text { ton-miles. }\end{array}$ & $\begin{array}{c}\text { Train } \\
\text { movement } \\
\text { (millions } \\
\text { of } \\
\text { ton-miles). }\end{array}$ & $\begin{array}{c}\text { Saving in } \\
\text { wages under } \\
\text { electric } \\
\text { operation } \\
\text { (25 per cent). }\end{array}$ & $\begin{array}{l}\text { Wages per } \\
\text { switcher- } \\
\text { mile. }\end{array}$ & $\mid$\begin{tabular}{c|} 
Train \\
movement \\
(th.ousands \\
of switcher- \\
miles).
\end{tabular} & $\begin{array}{c}\text { Saving in } \\
\text { wages under } \\
\text { electrjc } \\
\text { operation } \\
\text { (33 per cent). }\end{array}$ \\
\hline 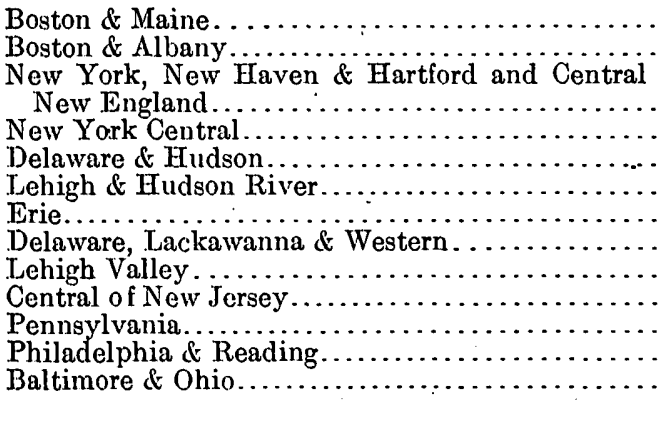 & $\begin{array}{r}\$ 0.40 \\
.42 \\
.55 \\
.27 \\
.35\end{array}$ & $\begin{array}{r}5,707 \\
6,200 \\
5,093 \\
4,400 \\
22,545 \\
10,900 \\
3,380 \\
92,838\end{array}$ & $\begin{array}{r}415,000 \\
481,000 \\
635,000 \\
550,000 \\
2,140,000 \\
1,330,000 \\
355,000 \\
9,272,000\end{array}$ & $\begin{array}{r}.58 \\
.57 \\
.57 \\
.61 \\
.68\end{array}$ & $\begin{array}{r}4,900 \\
5,086 \\
1,143 \\
\ldots \ldots \ldots \\
\ldots \ldots \\
3,200 \\
3,480 \\
3,000 \\
14,024 \\
7,763 \\
\ldots \ldots \ldots \\
42,596\end{array}$ & $\begin{array}{r}\$ 980,000 \\
760,000 \\
265,000 \\
\ldots \ldots \\
620,000 \\
660,000 \\
570,000 \\
2,850,000 \\
1,760,000 \\
\ldots \ldots \ldots \\
8,465,000\end{array}$ \\
\hline & & 92,838 & $9,272,000$ & & 42,596 & $8,465,000$ \\
\hline
\end{tabular}

Average wage saving per thousand ton-miles, 10 cents; per switcher-mile, 20 cents.

CONSTRUCTION COSTS.

Form C.

Form D gives the cost of electric equipment necessary to make the savings shown on

Form D.

Cost of catenary system and electric equipment, $M . \& N$. system, R. division.

\begin{tabular}{|c|c|c|}
\hline & Miles. & Cost. \\
\hline 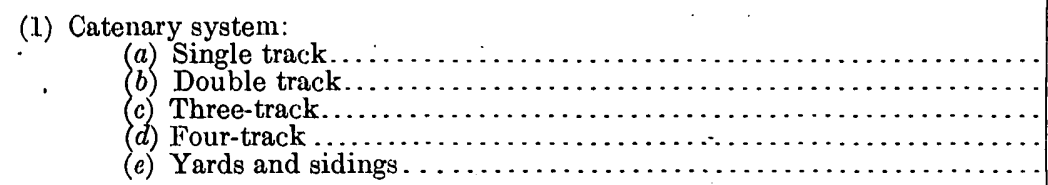 & $\begin{array}{r}175 \\
68 \\
9 \\
42 \\
221\end{array}$ & $\begin{array}{r}\$ 2,013,000 \\
1,700,000 \\
291,000 \\
1,625,000 \\
?, 658,000\end{array}$ \\
\hline 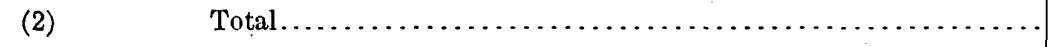 & $\ldots \ldots \ldots$ & $\ldots \ldots \ldots \ldots \$ 7,287,000$ \\
\hline (3) Substations. . . . $\ldots \ldots \ldots \ldots \ldots \ldots \ldots \ldots \ldots \ldots \ldots \ldots$ & $\begin{array}{l}\text { Capacity. } \\
82,100\end{array}$ & $4,926,000$ \\
\hline 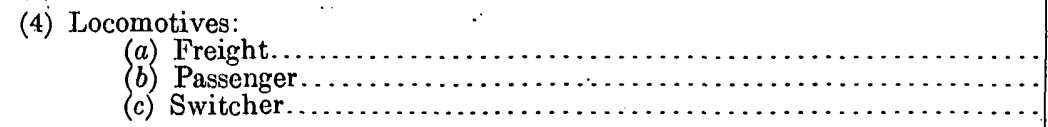 & $\begin{array}{r}\text { Number. } \\
43 \\
55 \\
41 \\
4\end{array}$ & $\begin{array}{l}3,440,000 \\
4,576,000 \\
2,657,000\end{array}$ \\
\hline 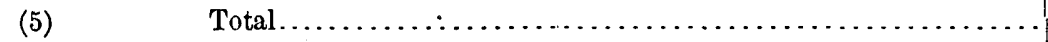 & 139 & $\cdots \ldots \ldots \ldots 10,673,000$ \\
\hline $\begin{array}{r}\text { Sum of specified items } \ldots \ldots \ldots \ldots \\
(7) \\
(8) \text { Allowance for unspecified items, } 10 \text { per cent of }(6) \ldots \ldots \ldots \ldots \ldots \ldots\end{array}$ & & 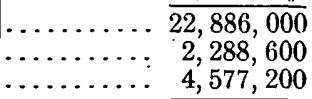 \\
\hline 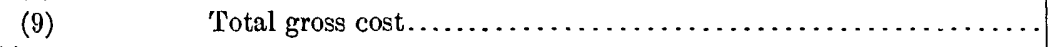 & & $\ldots \ldots \ldots \ldots \overline{29,751,800}$ \\
\hline (10) Credit for released steam locomotives $\ldots \ldots \ldots \ldots \ldots \ldots \ldots \ldots \ldots \ldots$ & $\begin{array}{r}\text { Total tonnage. } \\
\quad 30,300\end{array}$ & $\ldots{ }^{a} 6,060,000$ \\
\hline 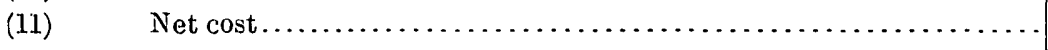 & & $\ldots \ldots \ldots \ldots 2,23,691,800$ \\
\hline
\end{tabular}

a Present value. 


\section{COST OF CATENARY SYSTEM.}

The estimates of cost of the overhead structure assume the use of cross-catenary construction, with guyed tubular steel poles, main and secondary steel-strand messengers, two 4/0 copper contact wires, concrete foundations for all. poles, and high-strength steel strand. Rails to be single-bonded with 300,000 circular mil bond; a 4/0 copper ground wire to be carried on the pole top. Poles all to carry tops and two cross arms, each with two pins.

The estimates of cost for this structure, based on prices in 1919, are derived from detailed estimates submitted by the General Electric Co., the Westinghouse Electric \& Manufacturing Co., and the Ohio Brass Co. These estimates were for single, two, three, and four track line; for tangent, $2^{\circ}, 4^{\circ}, 6^{\circ}$, and $8^{\circ}$ curvature; for yard track; and for branch lines. The estimates of the Ohio Brass Co. in particular give the quantities and prices of all items in complete detail.

These estimates have been carefully analyzed and checked up by comparison with the estimates of the Chicago Smoke Abatement Commission's report; they have also been submitted for criticism to engineers particularly versed in work of this class.

The estimates show good general agreement. Those of the Westinghouse Co. were slightly lower than those of the General Electric Co.; those of the Ohio Brass Co. were the highest. The costs given in the Chicago report, extended to the prices in 1919, are about the same as those of the General Electric Co.

The final costs determined for the 3,000-volt system are given in Table 20, which includes all costs of labor and material for the circuit outside of the substation for an average assumed alinement. The cost of the feeders is shown separately, the figures being taken from Table 24 below. Table 21 gives unit prices and quantities.

TABLE 20.-Estimated cost of cross-catenary construction, with guyed steel poles, for 3,000-volt direct-current system. Per mile of road.

\begin{tabular}{|c|c|c|c|c|}
\hline \multirow[b]{2}{*}{ Number of tracks. } & \multirow{2}{*}{$\begin{array}{c}\text { Size of feeder } \\
\text { (circular mils) }\end{array}$} & \multicolumn{3}{|c|}{ Cost. } \\
\hline & & $\begin{array}{l}\text { Catenary } \\
\text { structure. }\end{array}$ & Feeder. & Total. \\
\hline 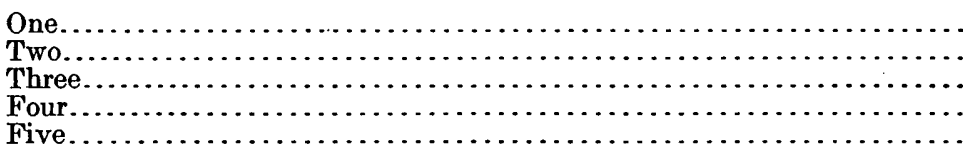 & $\begin{array}{r}500,000 \\
1,000,000 \\
1,250,000 \\
1,500,000 \\
1,500,000\end{array}$ & $\begin{array}{l}\$ 9,300 \\
20,900 \\
27,000 \\
32,500 \\
38,000\end{array}$ & $\begin{array}{r}\$ 2,200 \\
4,100 \\
5,300 \\
6,200 \\
6,200\end{array}$ & $\begin{array}{r}\$ 11,500 \\
25,000 \\
32,300 \\
38,700 \\
44,200\end{array}$ \\
\hline
\end{tabular}

Per track mile.

\begin{tabular}{|c|c|c|}
\hline Yard tracks. & $\$ 7,500$ & $\$ 7,500$ \\
\hline
\end{tabular}

TABLE 21.-Quantities and unit prices for double-track s,000-volt direct-current cross-catenary tangent, 300-foot spain.

\begin{tabular}{|c|c|c|c|}
\hline \multirow{2}{*}{ Item. } & \multirow{2}{*}{ Unit prices. } & \multicolumn{2}{|l|}{ Per mile of line. } \\
\hline & & Quantity. & Cost. \\
\hline Steel poles, guys, etc........... & 7 cents per pound...... & 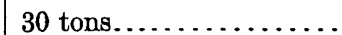 & $\$ 4,200$ \\
\hline 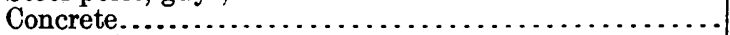 & $\$ 20$ per yard............ & 130 yards. ........ & 2,600 \\
\hline Excavation & $\$ 2$ per yard. .............. & 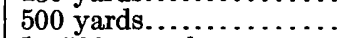 & 1,000 \\
\hline Contact wires.$\ldots \ldots \ldots \ldots \ldots \ldots \ldots \ldots \ldots \ldots \ldots$ & 23 cents per pound.... & 13,500 pounds.......... & 3,110 \\
\hline Cross span, complete............... & $\$ 71$ per span............ & 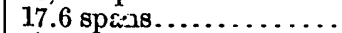 & 1,250 \\
\hline Messenger span, complete........ & $\$ 55$ per span.......... & 35.2 spans. . . . . . . . & 1,940 \\
\hline Work train, crew expenses. . . . . . & $\ldots \ldots \ldots \ldots \ldots \ldots \ldots$ & $\ldots \ldots \ldots \ldots \ldots . . . . .6$ & 600 \\
\hline Labor for erection (except bond)....... & $\ldots \ldots \ldots \ldots . . .$. & $\ldots \ldots \ldots . .$. & 2,400 \\
\hline Bonds, labor and materiall......... & & $\ldots . . .$. & 1, 400 \\
\hline Steel strand, $\frac{6}{8}-i n c h . . . . . . . . . .$. & 8 cents per foot......... & $\ldots \ldots \ldots . .$. & $\ldots \ldots \ldots$ \\
\hline Steel strand, $\frac{3}{8}-i n c h . . . \ldots \ldots \ldots$. & 3 cents per foot. . . . . . & $\ldots \ldots \ldots$ & $\ldots \ldots \ldots$ \\
\hline Labor: & se 00 nordar. & & \\
\hline 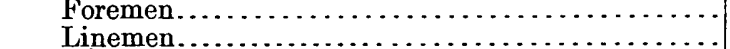 & $\begin{array}{l}\$ 8.00 \text { per day } \ldots \ldots \ldots \ldots \\
\$ 6.00 \text { per day............ }\end{array}$ & $\cdots \ldots \ldots$ & \\
\hline 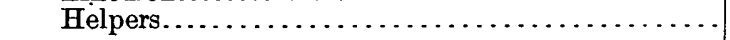 & $\$ 4.50$ per day.......... & $\ldots \ldots \ldots \ldots . . .6$ & \\
\hline
\end{tabular}


The figures given in these tables are probably high, for when construction of this magnitude is undertaken all materials will be furnished at wholesale prices and the work will be systematized as a large-scale job. Moreover, there is no doubt that a simpler design can be made, which will save weight and cost through the use of higher-grade materials for certain parts of the structure.

\section{COST OF SUBSTATIONS.}

It being impracticable to lay out load curves for the several operating divisions, the substation capacity necessary (see item 3, Form D) has been based on an analysis of existing installations. The "capacity factor"--that is, the ratio of average annual output to total equipment capacity in present railroad substations-is used as the basis for determining the capacity of the proposed railroad substations within the zone.

Table 22, compiled from data of nearly all the electrified heavy-traction roads, shows that for a total use of $486,000,000$ kilowatt-hours per year on eight roads there is a total substation capacity of 248,500 kilowatts, giving a ratio of average load to rated capacity of 22 per cent. For all the roads except the Long Island this ratio is singularly uniform, being within the limits of 21 to 26 per cent.

TABLE 22.-Average energy output of heavy-traction substations per kilowatt of capacity.

\begin{tabular}{|c|c|c|c|}
\hline System. & $\begin{array}{l}\text { Output } \\
\text { (millions } \\
\text { of } \\
\text { kilowatt- } \\
\text { hours). }\end{array}$ & $\begin{array}{c}\text { Total } \\
\text { sub- } \\
\text { station } \\
\text { capacity } \\
\text { (kilowatts) }\end{array}$ & $\begin{array}{l}\text { Kilowatt- } \\
\text { hours per } \\
\text { kilowatt } \\
\text { of } \\
\text { capacity. }\end{array}$ \\
\hline 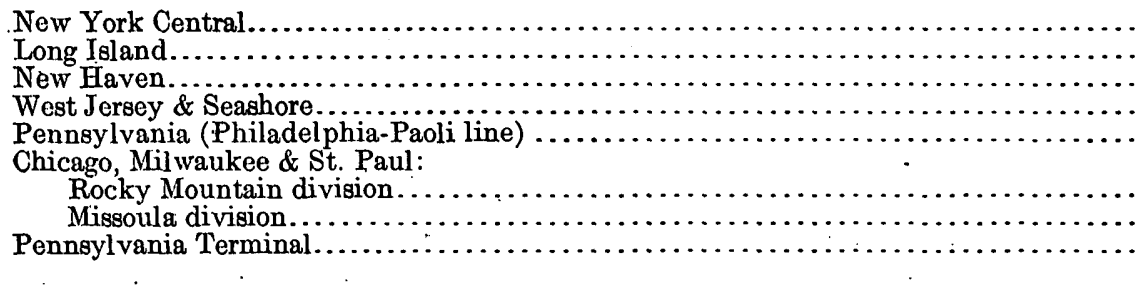 & $\begin{array}{l}97 \\
76 \\
85 \\
24 \\
24\end{array}$ & $\begin{array}{r}45,000 \\
56,000 \\
40,000 \\
12,000 \\
12,000 \\
\\
29,000 \\
30,500 \\
24,000 \\
248,500\end{array}$ & $\begin{array}{l}2,150 \\
1,360 \\
2,130 \\
2,000 \\
2,000\end{array}$ \\
\hline
\end{tabular}

Plant capacity factor, 22 per cent.

Some of these roads have a lower traffic density than those of the superpower zone, particularly than those in the vicinity of the large cities, where yard service is heavy. To make some allowance for this condition a ratio of 25 per cent is taken as applying to the entire zone. The total substation capacity for any division is then obtained by dividing the estimated kilowatt-hours required for the service by 2,200 . Peak loads will be taken care of by the overload capacity of 50 per cent for two hours and 200 per cent for five minutes.

The load factor of the individual substations will range from 15 to 60 per cent; nevertheless, owing to the variation of traffic throughout the year and the diversity between the various substation loads, the capacity should be based on a factor of 25 per cent.

A consideration of the power required for maximum trains and feeder capacity for the 3,000 -volt direct-current system indicates an average spacing of substations of about 20 miles. This distance will vary for the different divisions, but this factor does not influence the estimates of cost for the substation, as they are based on a unit price.

The items that make up the unit price used in the estimate are given in Table 23. This price is based on large substations, having from three to ten motor-generator sets of 2,500 kilowatts or greater. The figures are derived from estimates submitted by the General Electric Co. and the Westinghouse Co.

TABLE 23.-Estimated cost per kilowatt of 3,000-volt direct-current substation.

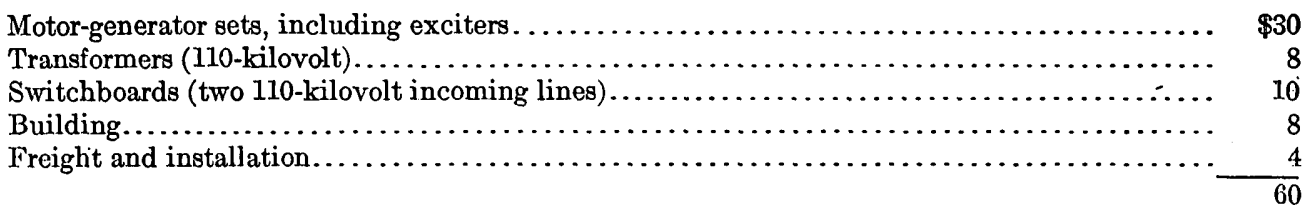




\section{COST OF 3,000-VOLT DIRECT-CURRENT FEEDERS.}

The size of the direct-current feeders is based on a maximum pressure drop of 20 per cent, equal to 600 volts, for a train requiring 4,800 kilowatts halfway between substations, drawing 1,000 amperes from each substation. The following assumptions are made: Running rails, 100 pounds, with 300,000 circular mil bonds; resistance per mile of track, $0.03 \mathrm{ohm}$; two 4/0 copper trolley wires.

These data give the basis for the following table, which shows the feeder capacity required under average conditions and the cost per mile for the feeders erected.

TABLE 24.-Capacity and cost of feeders.

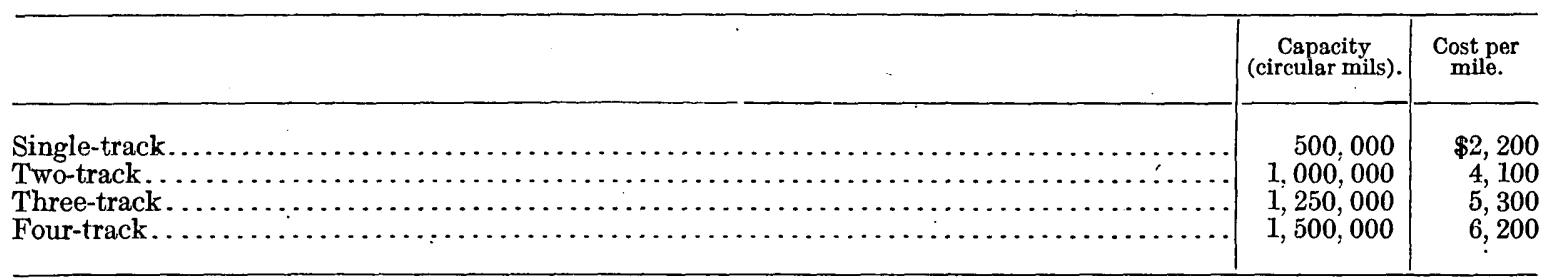

COST OF ELECTRIC LOCOMOTIVES.

Item 4, Form $\mathrm{D}$, gives the number and cost of electric locomotives required. The number called for is based on an annual mileage of 40,000 for freight, 75,000 for passenger, and 40,000 for switcher locomotives. The cost of the electric locomotives is based on estimates made by the General Electric Co. and the Westinghouse Co. for freight, passenger, and switcher service in 1919. These estimates are stated in cost per pound for the three classes; they are substantially the same for both companies for locomotives of the same kind. The unit costs used are 40 cents per pound of total weight for freight locomotives and switchers and 45 cents for passenger locomotives, equivalent to $\$ 800$ per ton on drivers for freight locomotives and switchers and $\$ 1,300$ per ton on drivers for passenger locomotives. The total weight on drivers of the electric locomotives is the product of their number by the average weight on drivers of the steam locomotives on the division.

\section{NUMBER OF ELECTRIC LOCOMOTIVES REQUIRED.}

The electric service covered by the estimates is the power equivalent of the present steam service in the zone. The year 1919 is taken for comparison, as it is the latest complete calendar year before the beginning of this investigation. The number of electric locomotives required for the service should in the final analysis be determined by a study of train movements on each division. This study was impracticable in the present investigation, and therefore a shorter method had to be used. The plan followed was to determine the average number of miles per year. per electric locomotive required for freight, passenger, and switcher service. This average mileage was determined by comparing the mileage records of the electric locomotives in certain operating electric systems in the United States with the mileage records of the steam locomotives in the zone. To show why the electric locomotive gives the greater mileage, a distribution of locomotive-hours for electric service was deduced from that of the present steam service by modifying it to accord with the proved fact of the greater availability of the electric locomotive. This procedure fixed the same number of miles per year in each class of service for the entire zone; conditions of unified operation are thus implied. This leads to some irregularities in the proportional number of steam and electric locomotives on certain of the smaller roads, but the figures are intended as averages, not to apply exactly to each operating divisiou. These smaller roads will represent less than 10 per cent of the traffic.

The assignment of the same locomotive mileage to the single-track roads with low traffic density as to the divisions having denser traffic is not strictly correct; the great variation in annual mileage of the steam locomotives of these divisions reflects the differences in traffic conditions. In order to make some allowance for the light-traffic divisions the minimum number of electric locomotives for each division is fixed at 50 per cent of the corresponding number of steam locomotives, even if the number based on mileage is less than 50 per cent. - 
MILEAGE.

Table 25 gives the steam mileage for 1919 of the freight and passenger service on the principal systems. Table 26 gives the available statistics on annual mileage of electric locomotives; the average for freight service is approximately 40,000 miles. The only extensive system that keeps records separately for passenger service is the New Haven, with a mileage of 73,000 ; this mileage can be increased with complete electric operation. The New York Central and the Pennsylvania Tunnel \& Terminal are operating a short-haul service which gives no opportunity to make great mileage.

TABLE 25.-Average steam-locomotive mileage of principal systems in superpower zone, 1919.

[Based on total number of locomotives owned.]

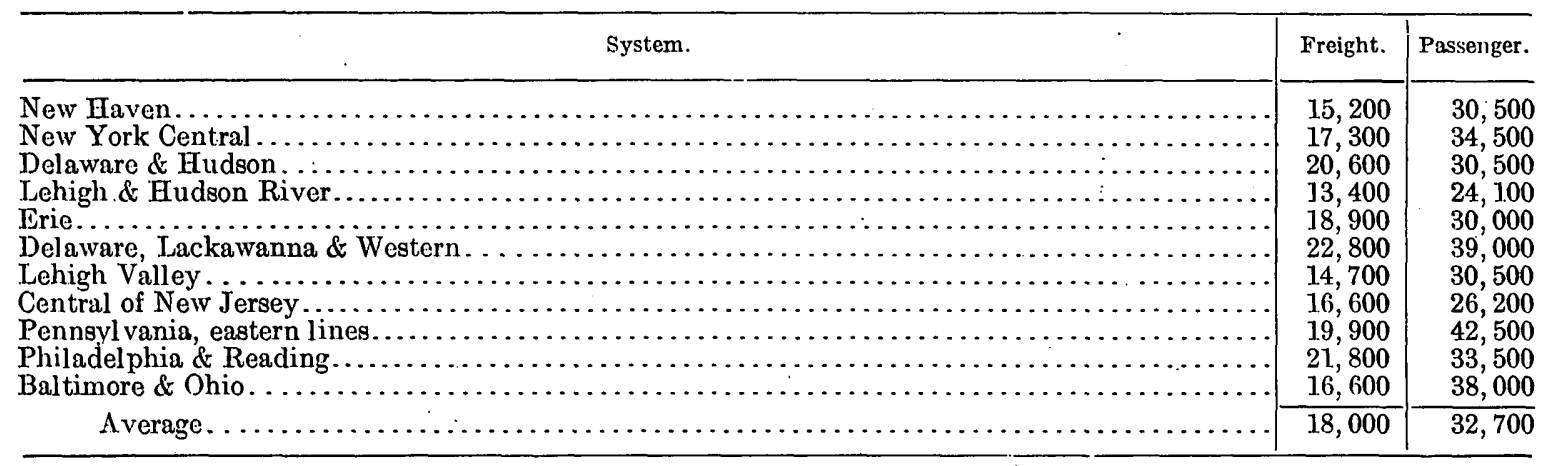

TABLE 26.-Average annual mileage of electric locomotives.

[Based on total number of locomotives owned.]

\begin{tabular}{|c|c|c|c|}
\hline System. & Freight. & Passenger. & All. \\
\hline 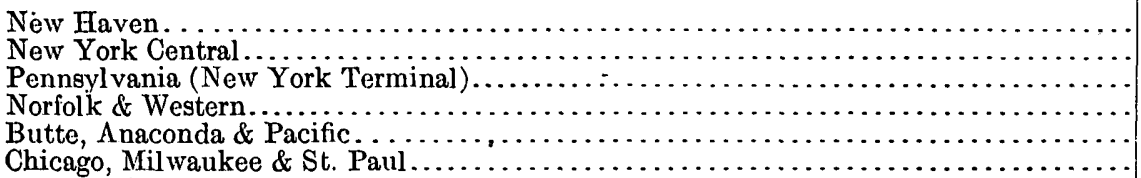 & $\begin{array}{l}33,500 \\
\cdots \ldots \ldots \\
\cdots \\
49,000 \\
43,500 \\
\cdots \cdots\end{array}$ & $\begin{array}{r}73,000 \\
34,500 \\
39,300 \\
\cdots \\
\cdots \\
\cdots \\
\cdots\end{array}$ & $\begin{array}{l}55,000 \\
34,500 \\
39,300 \\
49,000 \\
43,500 \\
49,000\end{array}$ \\
\hline
\end{tabular}

LOCOMOTIVE-HOURS.

Records of the distribution of locomotive-hours for a number of the roads within the superpower zone are available, particularly those of the Pennsylvania, of which eight operating divisions are included within the zone; they reflect the entire range of service, from the heaviest traffic on the New York division to the light traffic of the West Jersey \& Seashore and Sunbury divisions. The Pennsylvania is taken as an example of the best average operating results.

The statistics of the operations of the Pennsylvania system for 1919 within the superpower zone are given in Table 27, which sets forth the proportion of the time of all serviceable locomotives and of all assigned locomotives, in accordance with the schedule of time specified by the United States Railroad Administration in its "Operating statistics sheets." Item 1 of the table includes items 1 and 2 of the operating statistics sheets and represents the total time that locomotives are in "hands of crew," including time between termini, time waiting at termini, and time to and from engine house. From 90 to 95 per cent of this is productive time-that is, time between termini. Item 2a represents time required for cleaning fires, washing boilers, ash-pit work, inspection, running repairs, etc. Item $2 \mathrm{~b}$ represents time spent in waiting at engine house for call to service after maintenance forces have delivered locomotive to transportation forces. All this is wasted time. Item 3 gives the total time in the engine house, the sum of $2 \mathrm{a}$ and $2 \mathrm{~b}$. Item 4 ("stored hours") represents surplus equipment for which there is no call. Item 5 shows the total serviceable hours taken both as 100 per cent and as a percentage of tatal assigned locomotive hours. The differences between 100 per cent and 71 , 69 , and 80 per cent give for the three services respectively the proportion of total time in the shops under general repairs or awaiting such repairs. 
TABlE 27.-Average distribution of locomotive-hours in 1919 on all divisions of the Pennsylvania system within the superpower zone, in per cent.

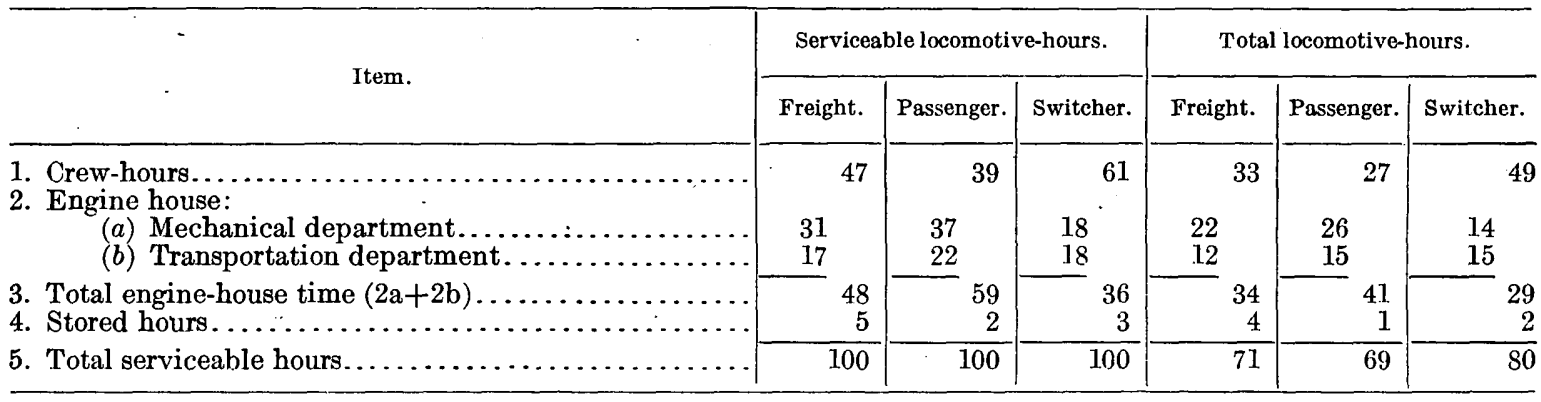

The average utilization of the locomotives in the zone as a whole is not as good as on the Pennsylvania. Table 28 gives the ratio of "crew-hours" to total serviceable hours (item 1 of Table 27) for eight of the systems within the zone, with the total number of assigned locomotives. For the weighted average of all these systems the ratio of crew-hours to total serviceable hours is 37,30 , and 50 per cent for freight, passenger, and switcher locomotives, respectively, as compared with 47,39, and 61 per cent for the Pennsylvania.

TABLE 28.-Average distribution of locomotive-hours of representative railroads within the superpower zone, 1919.

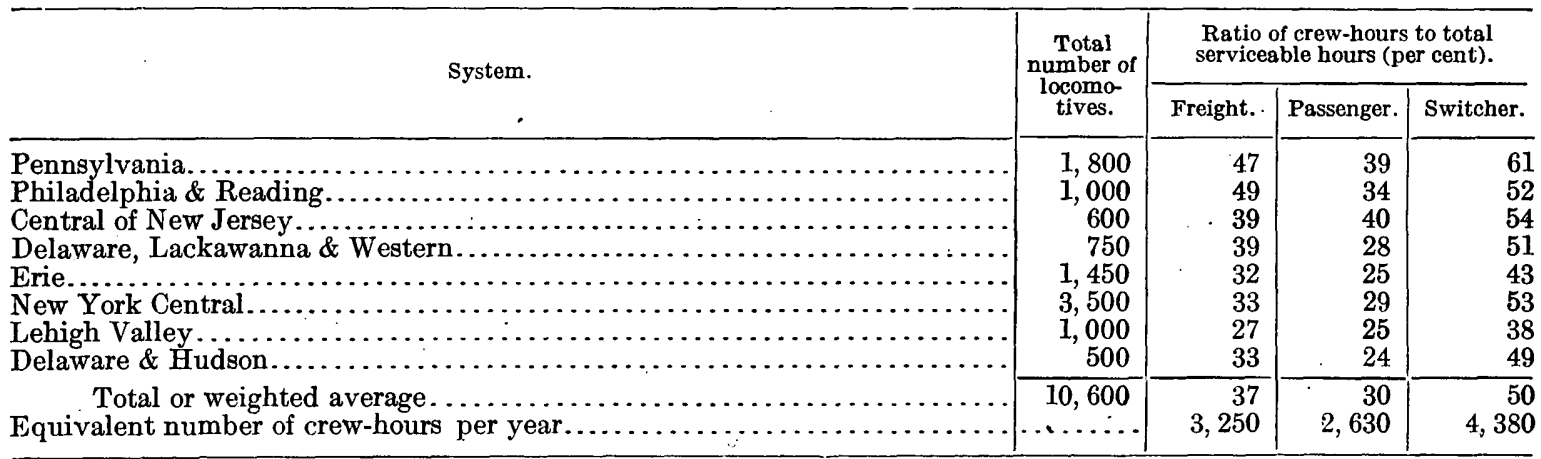

A direct comparison of time is afforded by the New Haven system. Table 29 sets forth the figures for both steam and electric operation on that system for five months of 1919 .

TABLE 29.- Ratio of crew-hours to total serviceable hours under steam and electric operation of the New Haven system, 1919.

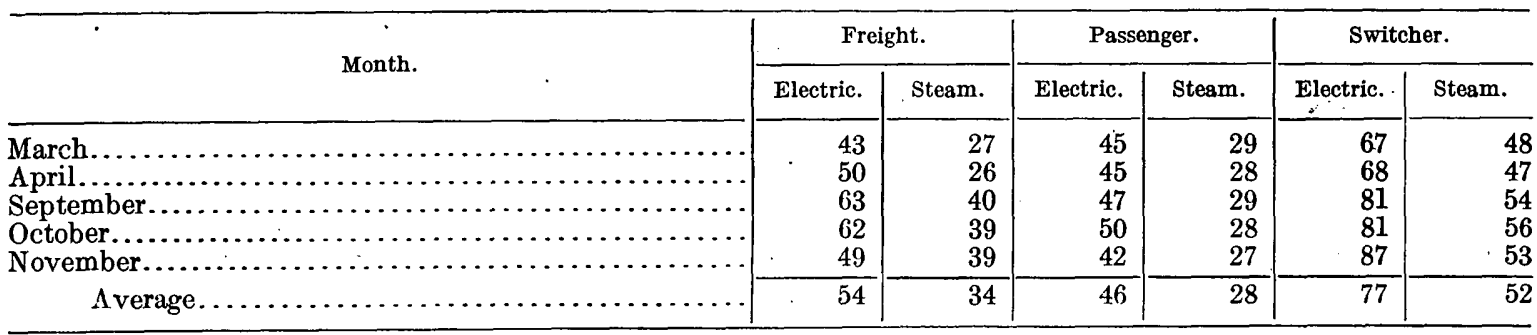

Ratio of number of serviceable electric locomotives required to do the same work:

Freight, $34 \div 54=63$ per cent.

Passenger, $28 \div 46=61$ per cent.

Switcher, $52 \div 77=68$ per cent.

What can be done with motive power in proportion to the service required is shown in Table 30, which gives the distribution of serviceable locomotive-hours on the Norfolk \& Western. Here the locomotives are in road service 74 per cent of the total time and the crew-hours are 76 per cent. This is to be compared with 33 per cent as the average for freight service on the Pennsylvania and 28 per cent for all the roads in the zone-that is, one electric locomotive in the Norfolk \& Western freight service does as much work as is done in the rest of the zone by 2.65 steam locomotives. 
TABLE 30.-Distribution of electric locomotive-hours in freight service on Norfolk \& Western Railway, in per cent.

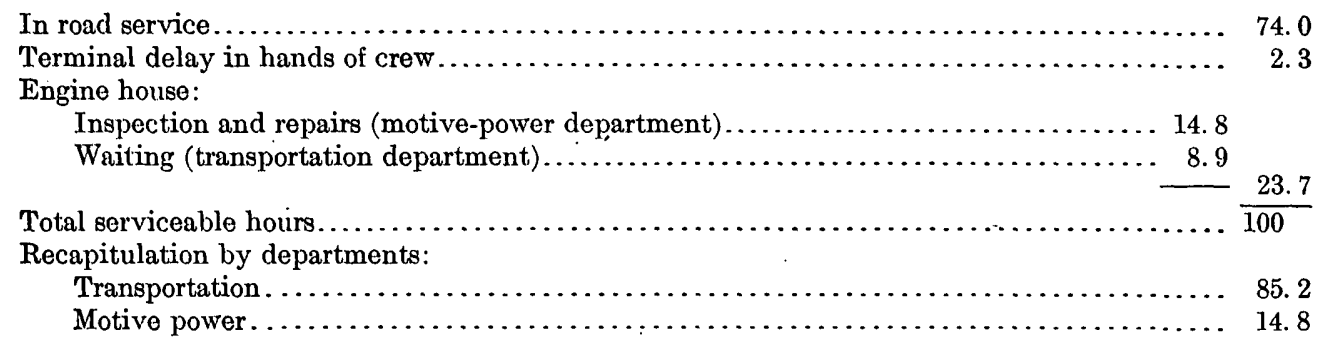

From Table 27 the figures in Table 31 are deduced, showing the estimated average distribution of locomotive-hours of electric locomotives. In this table the crew-hours for freight service are taken at 77 per cent of the corresponding figure for steam service of the Pennsylvania. This assumes that on the average an electric locomotive will yield 30 per cent more trailing ton-miles per crew-hour than the average steam locomotive-an assumption based on data of operation of several electric roads. This result is attained partly by higher speed.and heavier trains, or both; in minor part by the elimination of the loaded tender and nondriver weight of the steam locomotives; and largely by standardization of locomotive types and pooling of locomotives.

In passenger service the electric crew-hour is taken as 11 per cent more productive than the steam; this result will be attained in great measure by the widespread use of multiple-unit cars for the short runs in the extensive suburban service of the zone and by better-sustained average speed for other passenger trains. The average speed of passenger trains on the Pennsylvania system is only 17.5 miles per crew-hour; a uniform increase of 11 per cent would mean an average of less than 20 miles per hour, a speed that is now exceeded by a number of steam divisions. For switcher service the electric crew-hour is taken at 1.50 times as productive as the steam. The service on the New Haven line and the General Electric Co.'s tests at Erie and Schenectady give higher ratios.

Item 2a, Table 31, showing time in engine house for repairs, etc., is taken at about onethird of the steam time. For item 2b, time awaiting call, the ratio to crew-hours is taken at approximately the same as in steam service. This estimate is moderate or perhaps low, for with half as many locomotives in service the waits must necessarily be shorter, and moreover the use of classes of uniform locomotives will save much of this delay. The ratio of serviceable to total electric locomotive-hours is pretty well established at about 90 per cent. With these assumptions, all of which tend to minimize the savings of unified electric operation, the Pennsylvania system could be operated electrically in 61,66 , and 54 per cent of the serviceable hours, or $48.5,51$, and 48 per cent of the total hours now required for the steam operation of the freight, passenger, and switcher services, respectively.

TABLE 31.-Estimated distribution of electric locomotive-hours, in percentages of time required for steam operation of the Pennsylvania system.

\begin{tabular}{|c|c|c|c|c|c|c|}
\hline \multirow{2}{*}{ Item. } & \multicolumn{2}{|c|}{ Freight. } & \multicolumn{2}{|c|}{ Passenger. } & \multicolumn{2}{|c|}{ Switcher. } \\
\hline & Steam. & Electric. & Steam. & Electric. & Steam. & Electric. \\
\hline 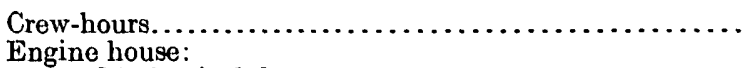 & & 36 & 39 & 35 & 61 & 41 \\
\hline 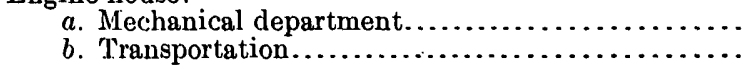 & $\begin{array}{l}31 \\
17\end{array}$ & $\begin{array}{l}10^{\prime} \\
13\end{array}$ & $\begin{array}{l}37 \\
22\end{array}$ & $\begin{array}{l}12 \\
18\end{array}$ & $\begin{array}{l}18 \\
18\end{array}$ & $\begin{array}{r}6 \\
12\end{array}$ \\
\hline 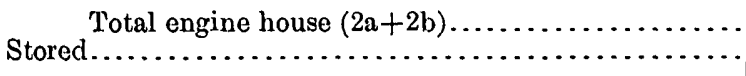 & $\begin{array}{r}48 \\
5\end{array}$ & $\begin{array}{r}23 \\
2\end{array}$ & $\begin{array}{r}59 \\
2\end{array}$ & $\begin{array}{r}30 \\
1\end{array}$ & $\begin{array}{r}36 \\
3\end{array}$ & $\begin{array}{r}18 \\
1\end{array}$ \\
\hline 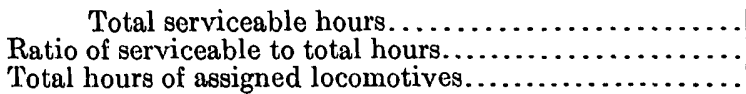 & $\begin{array}{r}100 \\
71 \\
141\end{array}$ & $\begin{array}{l}61 \\
90 \\
68\end{array}$ & $\begin{array}{r}100 \\
69 \\
144\end{array}$ & $\begin{array}{l}66 \\
90 \\
74\end{array}$ & $\begin{array}{r}100 \\
80 \\
125\end{array}$ & $\begin{array}{l}60 \\
90 \\
67\end{array}$ \\
\hline
\end{tabular}

Relative number of electric locomotives required:

Freight, $68 \div-141=48.5$ per cent.

Passenger, $74 \div 144=51.0$ per cent.

Switcher, $67 \div 125=53.5$ per cent. 
Table 32, taken from Table 31, sums up the estimated schedule for electric operation. The crew-hours amount to 59,53, and 76 per cent of the serviceable hours. These figures are low, in the opinion of several electric operating men, who claim that crew-hours should be taken at 70 per cent of total hours, equivalent to 78 per cent of serviceable hours.

TABLE 32.-Distribution of electric locomotive hours.

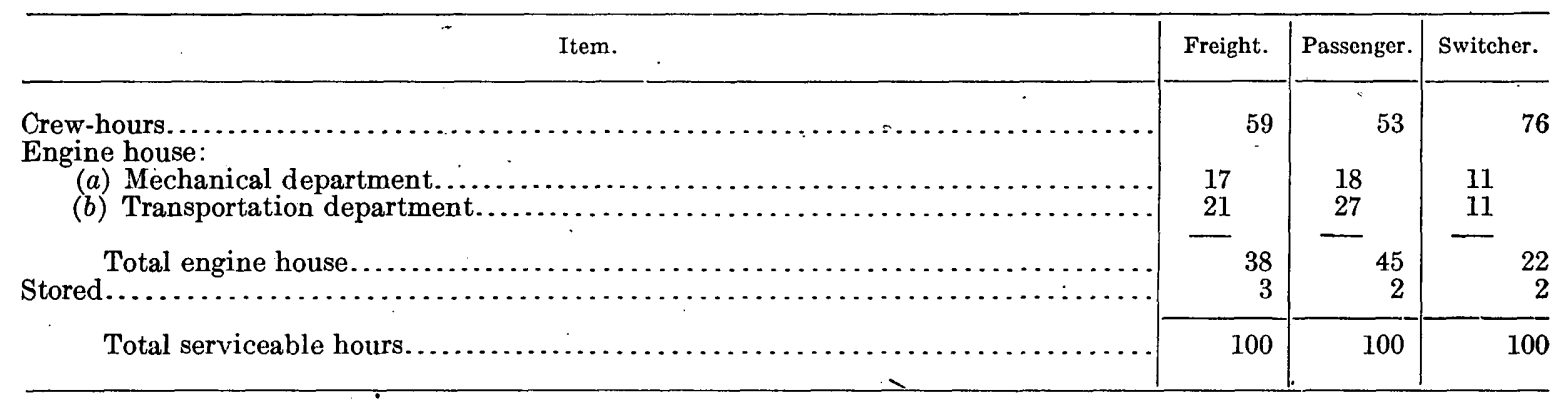

From a direct comparison of the mileage of Tables 25 and 26 and the above analysis of locomotive-hours the annual mileage of electric locomotives is taken at 40,000 for freight locomotives, 75,000 for passenger locomotives, and 40,000 for switchers.

TOTAL COST.

Item 5 of Form D, the sum of items 2, 3, and 4, gives the total estimated cost of the specified items and accounts for 90 to 95 per cent of the total cost of the work. Table 33, giving the itemized costs of the Chicago terminal electrification, shows that the other items amount to less than 8 per cent. These unspecified items are principally changes in signal system, provision against electrolysis, and certain minor items. Item 7 of Form $\mathrm{D}$ is an allowance of 10 per cent for these unspecified costs.

TABLE 33.-Cost of items of construction and equipment involved in the electrification of Chicago terminals, exclusive of power station and transmission system.

\begin{tabular}{|c|c|c|c|c|}
\hline \multirow{2}{*}{ Item. } & \multicolumn{2}{|c|}{2,400 -volt direct-current. } & \multicolumn{2}{|c|}{$\begin{array}{l}\text { 11,000-volt alternating-cur- } \\
\text { rent. }\end{array}$} \\
\hline & Total. & Per cent. & Total. & Per cent. \\
\hline Substations........ & $\$ 5,660,000$ & 4.0 & $\$ 2,025,000$ & 1.5 \\
\hline Switching stations....... & $1,522,000$ & 1. 1. & 573,000 & \\
\hline Overhead contact system. & $33,895,000$ & 23.8 & $28,142,000$ & 20.3 \\
\hline Bridge warnings........... & $1,072,000$ & & $1,072,000$ & \\
\hline Return circuit........................ & $6,070,000$ & 4.3 & $4,446,000$ & 3.2 \\
\hline Prevention of inductive effects and electrolysis. . & 27000 & …… & 997,000 & … \\
\hline 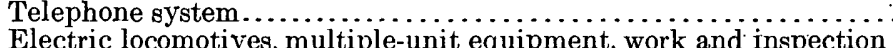 & 272,000 & & 272,000 & \\
\hline 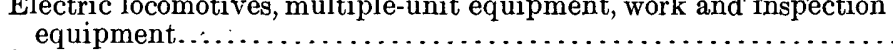 & $84,004,000$ & 59.0 & $91,704,000$ & 66.0 \\
\hline 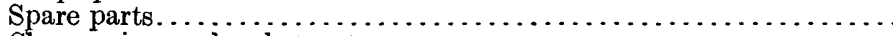 & 503,000 & & 485,000 & …… \\
\hline Changes in overhead structures. & 834,000 & & 834,000 & \\
\hline \multirow[t]{2}{*}{ Changes in signal system........... } & $\begin{array}{l}2,028,000 \\
6,694,000\end{array}$ & & $\begin{array}{l}2,028,000 \\
6,111,000\end{array}$ & \\
\hline & $142,554,000$ & 100.0 & $138,689,000$ & 100.0 \\
\hline \multirow{4}{*}{ 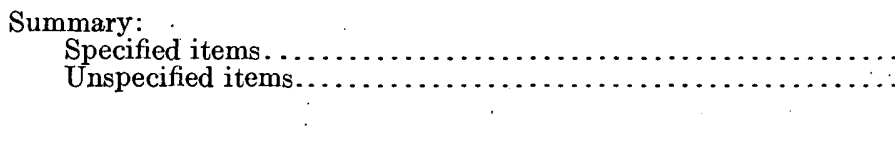 } & & & & \\
\hline & & 92.2 & & 91.4 \\
\hline & & 7.8 & & 8.6 \\
\hline & & 100.0 & & 100.0 \\
\hline
\end{tabular}


ENGINEERING, CONTINGENCIES, AND INTEREST.

Item 8 of Form D covers overhead allowance of 20 per cent for engineering, contingencies, and interest. This construction will be essentially work of duplication; the units will be identical both for substation equipment and for locomotives. The estimate assumes not special production but quantity production, which will reduce the percentage required for engineering and for contingencies. Similarly, the allowance for interest should not be as great as for construction work undertaken by a single company, as the work would be done on the general credit of the combined railroad systems; money will be obtained as needed, and the construction period, during which interest must be carried, will be minimized; in fact, much of the cost represents equipment, payments for which can fairly be assumed to be made toward the end of the period of construction.

\section{RELEASED LOCOMOTIVES.}

Item 9 of Form D gives the total gross cost of electrification, which is reduced by the credit for released steam locomotives, given by item 10. This credit is based on the assumption that all steam locomotives released within the superpower zone can be used. Electrification will be progressive, and it is a reasonable assumption that locomotives as released from one division will be transferred either to another division or to another road. The amount of the credit is determined by assuming that the average condition of the locomotives is 50 per cent new, probably an underestimate in view of the fact that much of the equipment has been bought within the last ten years. The value of a new locomotive in 1919 is taken at 18 cents per pound of total weight, and the salvage value at 2 cents per pound. These figures are based on the elaborate estimates of the equipment committee of the President's Conference Committee of Steam Railroad Companies, whose reports embody the fullest examination yet made of the value and cost of steam locomotives and of their reproduction cost. From these assumptions is obtained a net value of 10 cents per pound of total weight as the amount to be credited. The average ratio of total weight to weight on drivers is found to be 1.5 for freight, passenger, and switcher locomotives, in the proportions that now prevail in the zone; this fixes the value per pound on drivers of the released steam locomotives at 15 cents.

Deduction of item 10 gives the net cost of electrification; the percentage that the saving from electric operation bears to this total cost determines whether any division is susceptible of economical electritication.

\section{CONCIUSIONS.}

The study described above has been made for all the class 1 railroad systems within the superpower zone except the Ulster \& Delaware, the New York, Ontario \& Western, and the Western Maryland. - The first two were omitted, after a preliminary examination, because their traffic was too light to warrant electrification. The Western Maryland was omitted because only a small part of its trackage is within the zone; the preliminary examination, however, indicates that the Western Maryland traffic would justify electrification. There remained, then, 13 railroad systems ${ }^{1}$ in the zone that were studied in accordance with Forms $\mathrm{C}$ and $\mathrm{D}$ (pp. 59,67). In this study it was not possible to adhere strictly to the limits of every operating division reported by the railroads, and some divisions were therefore consolidated into routes. The number of divisions or routes ranged from one on the Boston \& Maine to nine on the Pennsylvania and aggregated 40 for the 13 roads.

The results of the study are given in figures 14 and 15, which show for each of the 40 divisions the annual saving, in percentage of the net cost of electrification, plotted against the energy required, in kilowatt-hours per year, together with the accumulated average percentage of saving for the divisions as grouped. Figure 14 shows the saving exclusive of the saving in crew wages, and the divisions are arranged in the order of percentages. With these results as the criterion of economical electrification the "selected divisions" are assumed to be all that show a saving

\footnotetext{
1 The Boston \& Albany was included with the New York Central, and the Long Island with the Pennsylvania.
} 
of 9 per cent or more. The group of divisions thus selected shows an average saving of 11.4 per cent. It includes 30 of the 40 divisions examined, comprised in 11 of the 13 systems shown * in Plate VI. Figure 15 shows the saving including the wage saving for the 40 divisions arranged in the same order as in figure 14. For the "selected divisions" these savings range from 10.6 to 19 . per cent and average 14.2 per cent. The total energy required annually for these 30 divisions will be 4,400 million kilowatt-hours, and the maximum demand approximately 850,000 kilowatts.

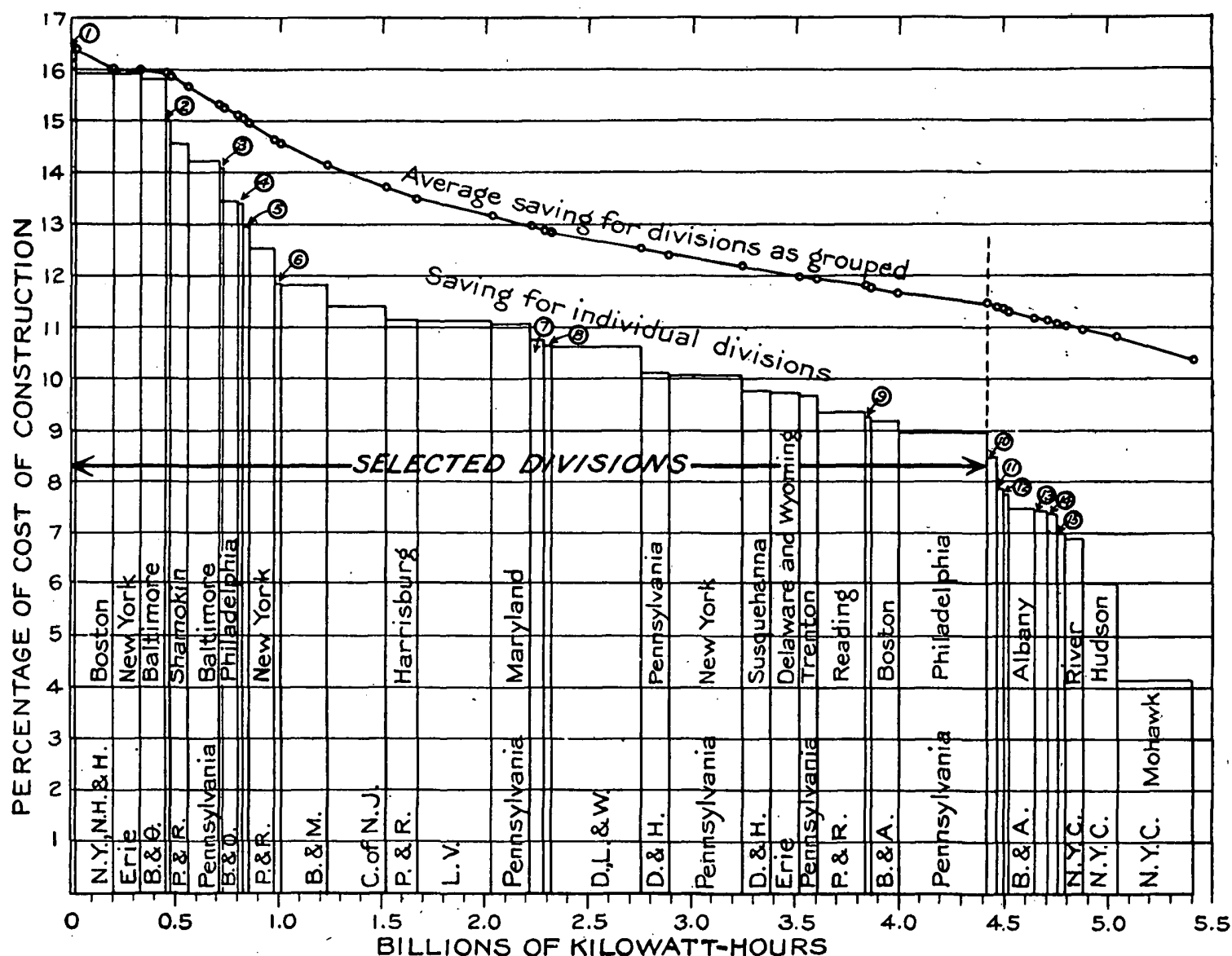

FIGURE 14.-Saving effected by electrification of heavy-traction railroads, in percentage of construction cost, not including saving in wages. Each column represents a railroad division or route, 1, New York and New Jersey division, Erie; 2, Northern division, Erie; 3, Greenwood Lake division, Erie; 4, Jefferson division, Erie; 5, Schuylkill division, Pennsylvania; 6, Springfield division, N. Y., N. H. \& H.; 7, Maybrook division, N. Y., N. H. \& H.: 8, Philadelphia division, P. \& R.; 9, New York, Susquehanna, and Western division, Erie; 10, Cumberland Valley division, Pennsylviania; 11, Atlantic City division, P. \& R.; 12, Wilmington and Columbia division, P. \& R.; 13, Sunbury division, Pennsylvania; 14, New Jersey and Seashore division, Pennsylvania; 15, Lehigh \& Hudson River R. R. Other divisions are indicated on the diagram.

The low percentage of saving shown by the divisions not included in the selected group, except those of the New York Central, is due to light traffic. On the New. York Central the train cost of transportation, the cost of maintaining steam locomotives, and the cost of coal per mile are lower than on any other system, owing in part to the fact that this is a water-level road with a large amount of through traffic; these are favorable conditions for economical steam operation and therefore afford less opportunity for saving by electrification."

The importance of the 30 selected divisions as compared with all the divisions of class 1 railroads within the zone is shown in Table 34 . 


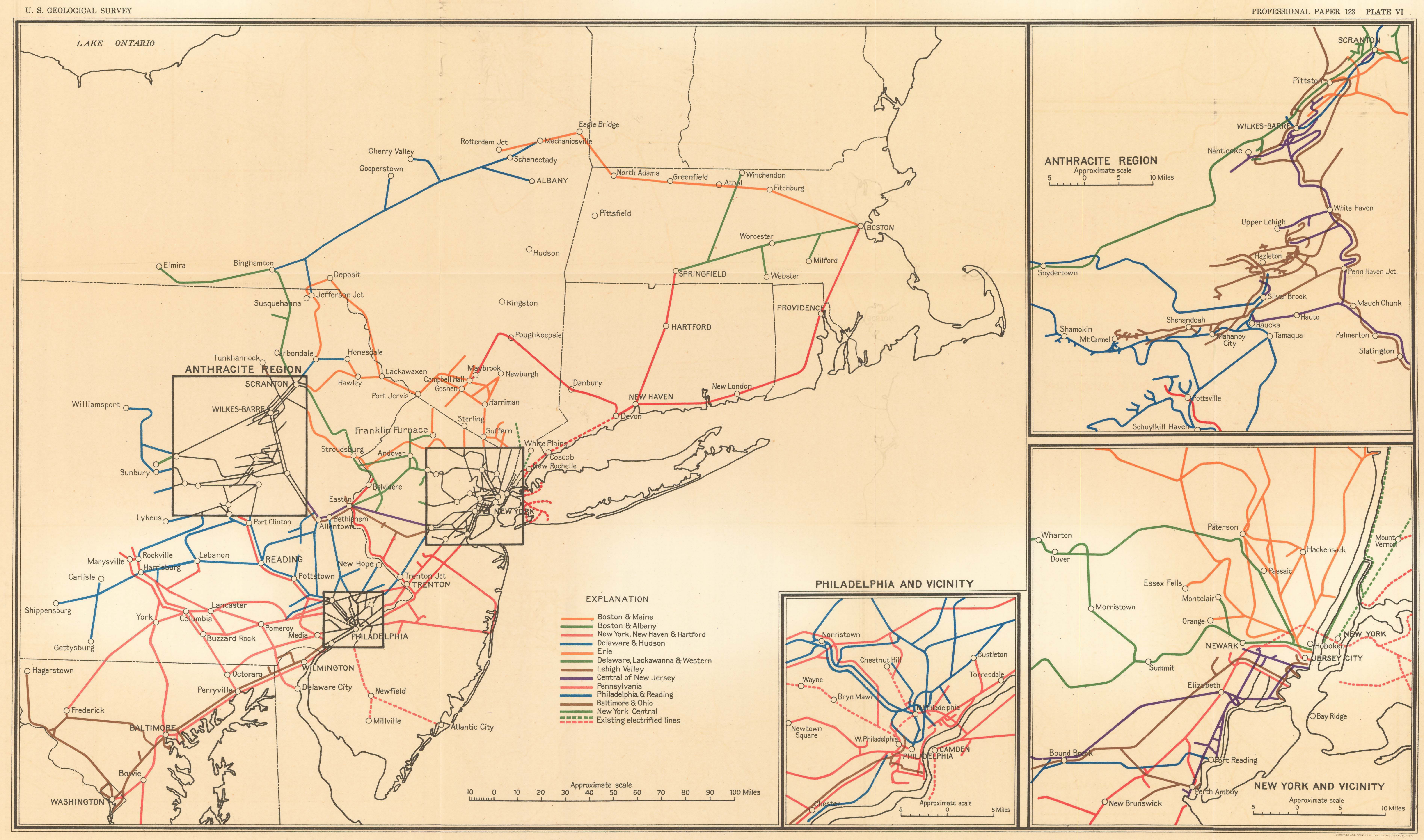

MAP SHOWING RAILROADS OF CLASS 1 WITHIN THE SUPERPOWER ZONE TO BE ELECTRIFIED 
TABLE 34.-Data for all divisions and selected divisions of class 1 railroads in the superpower zone.

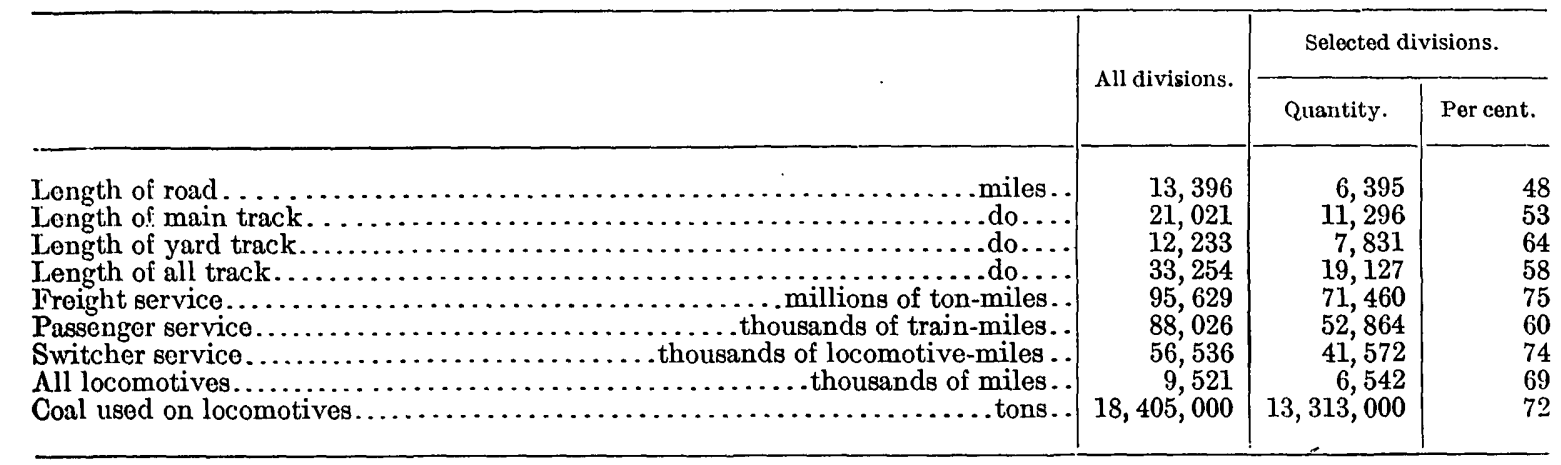

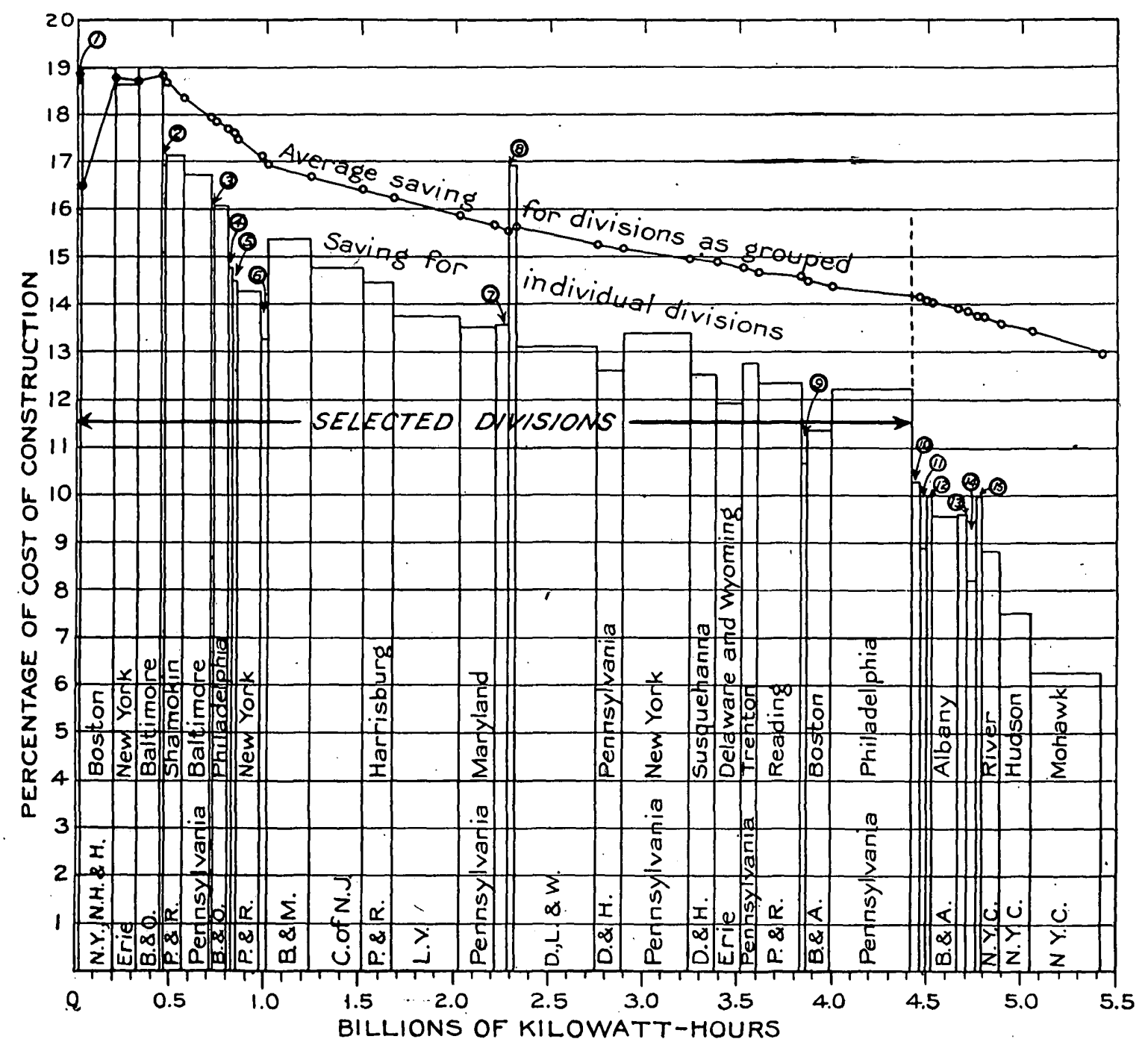

Froure 15.-Saving effected by electriflcation of heavy-traction railroads, in percentage of construction cost, including saving in wages. Each column represents a railroad division or route. For explanation of numbers see figure 14.

Table 35 summarizes for the 11 systems that include the 30 selected divisions the net estimated cost of construction and electric equipment and the net savings from operation; both mcluding and. excluding saving in wages. The net cost of electrification of all the selected divisions is $\$ 570,000,000$, and the annual net saving in operation, including the saving in wages, is $\$ 81,000,000$, equal to an average of 14.2 per cent for the entire group, ranging from 10.6 per 
cent for the New York, Susquehanna, and Western division of the Erie to 19 per cent for the New Haven-Boston route of the New Haven.

TABLE 35.-Summary of electric operation on selected divisions.

\begin{tabular}{|c|c|c|c|c|c|}
\hline \multirow{3}{*}{ System and division. } & \multirow{3}{*}{$\begin{array}{l}\text { Net cost of } \\
\text { construction. }\end{array}$} & \multicolumn{4}{|c|}{ Net reduction in annual cost of operation. } \\
\hline & & \multicolumn{2}{|c|}{ Including crew wages. } & \multicolumn{2}{|c|}{ Excluding crew wages. } \\
\hline & & Amount. & $\begin{array}{l}\text { Percentage } \\
\text { of cost of } \\
\text { construc- } \\
\text { tion. }\end{array}$ & Amount. & $\begin{array}{l}\text { Percentage } \\
\text { of cost of } \\
\text { construc- } \\
\text { tion. }\end{array}$ \\
\hline Boston \& Maine ......... & $\$ 28,862,500$ & $\$ 4,431,200$ & 15.35 & $\$ 3,411,200$ & 11.82 \\
\hline $\begin{array}{l}\text { Boston \& Albany: } \\
\text { Boston.............. }\end{array}$ & & $2,071,200$ & & $1,672,700$ & 9.17 \\
\hline 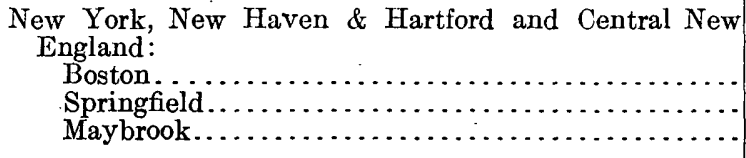 & $\begin{array}{r}20,300,500 \\
5,279,300 \\
10,812,100\end{array}$ & $\begin{array}{r}3,852,500 \\
700,000 \\
1,465,200\end{array}$ & $\begin{array}{l}18.98 \\
13.26 \\
13.55\end{array}$ & $\begin{array}{r}3,235,000 \\
627,000 \\
1,165,200\end{array}$ & $\begin{array}{l}15.93 \\
11.88 \\
10.78\end{array}$ \\
\hline & $36,391,900$ & $6,017,700$ & 16.54 & $5,027,200$ & 13.81 \\
\hline $\begin{array}{l}\text { Delaware \& Hudson: } \\
\quad \text { Susquehanna................. } \\
\text { Pennsylvania................ }\end{array}$ & $\begin{array}{l}17,885,700 \\
12,719,900\end{array}$ & $\begin{array}{l}2,223,300 \\
1,600,500\end{array}$ & $\begin{array}{l}12.43 \\
12.58\end{array}$ & $\begin{array}{l}1,742,700 \\
1,287,500\end{array}$ & $\begin{array}{r}9.75 \\
10.10\end{array}$ \\
\hline & $30,605,600$ & $3,823,800$ & 12.49 & $3,030,200$ & 9.90 \\
\hline 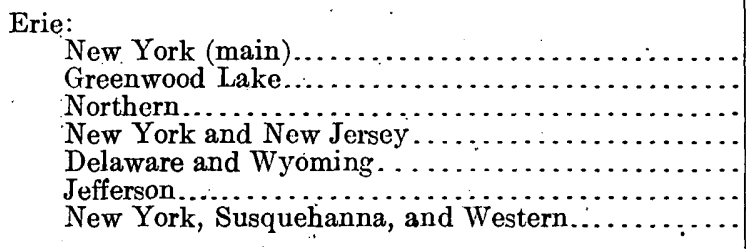 & $\begin{array}{r}19,597,100 \\
3,268,600 \\
1,891,000 \\
1,856,400 \\
16,295,700 \\
2,987,900 \\
7,372,300\end{array}$ & $\begin{array}{r}3,655,600 \\
466,060 \\
285,000 \\
304,675 \\
1,926,200 \\
441,300 \\
784,900\end{array}$ & $\begin{array}{l}18.65 \\
14.26 \\
15.07 \\
16.42 \\
11.82 \\
14.77 \\
10.65\end{array}$ & $\begin{array}{r}3,119,100 \\
459,800 \\
284,000 \\
303,800 \\
1,582,500 \\
400,400 \\
682,200\end{array}$ & $\begin{array}{r}15.92 \\
14.07 \\
15.02 \\
16.37 \\
9.72 \\
13.40 \\
9.25\end{array}$ \\
\hline & $53,269,000$ & $7,863,735$ & 14.76 & $6,831,800$ & 12.82 \\
\hline 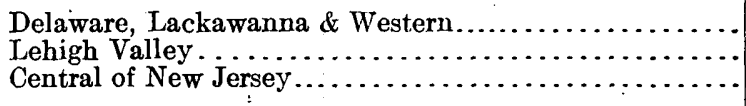 & $\begin{array}{l}50,780,700 \\
45,884,800 \\
31,997,800\end{array}$ & $\begin{array}{l}6,654,500 \\
6,310,700 \\
4,711,300\end{array}$ & $\begin{array}{l}13.10 \\
13.75 \\
14.72\end{array}$ & $\begin{array}{l}5,394,500 \\
5,105,200 \\
3,651,300\end{array}$ & $\begin{array}{l}10.62 \\
11.13 \\
11.41\end{array}$ \\
\hline 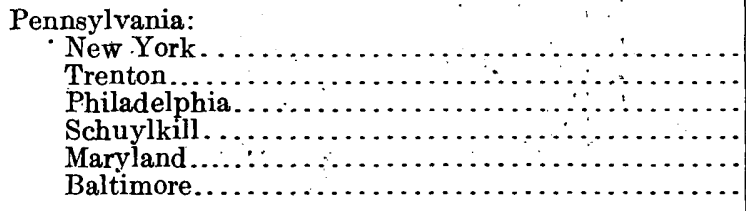 & $\begin{array}{r}46,494,100 \\
14,734,300 \\
45,597,800 \\
6,097,500 \\
23,691,800 \\
23,673,900\end{array}$ & $\begin{array}{r}6,207,300 \\
1,780,300 \\
5,562,400 \\
883,400 \\
3,201,200 \\
3,953,300\end{array}$ & $\begin{array}{l}13.35 \\
12.08 \\
12.20 \\
14.49 \\
13.51 \\
16.70\end{array}$ & $\begin{array}{r}4,677,700 \\
1,425,300 \\
4,074,000 \\
790,300 \\
2,627,100 \\
3,364,900\end{array}$ & $\begin{array}{r}10.06 \\
9.67 \\
8.93 \\
12.96 \\
11.09 \\
14.21\end{array}$ \\
\hline & $160,289,400$ & $21,587,900$ & 13.47 & $16,959,300$ & 10.58 \\
\hline 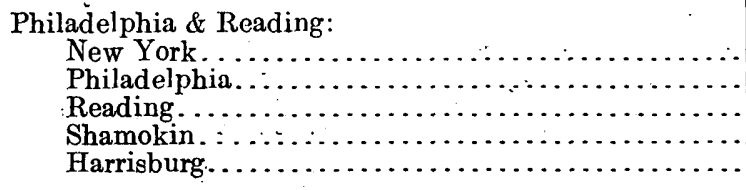 & $\begin{array}{r}16,913,100 \\
7,682,000 \\
29,540,200 \\
15,981,900 \\
15,151,500\end{array}$ & $\begin{array}{l}2,407,500 \\
1,299,800 \\
3,640,100 \\
2,734,700 \\
2,194,400\end{array}$ & $\begin{array}{l}14.23 \\
16.92 \\
12.32 \\
17.11 \\
14.48\end{array}$ & $\begin{array}{r}2,118,800 \\
814.800 \\
2,756,100 \\
2,322,700 \\
1,690,400\end{array}$ & $\begin{array}{r}12.53 \\
10.61 \\
9.33 \\
14.53 \\
11.16\end{array}$ \\
\hline & $85,268,700$ & $12,276,500$ & 14.40 & $9,702,800$ & 11.38 \\
\hline 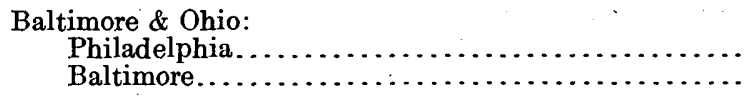 & $\begin{array}{r}18,821,100 \\
9,675,800\end{array}$ & $\begin{array}{l}3,579,000 \\
1,553,400\end{array}$ & $\begin{array}{l}19.01 \\
16.05\end{array}$ & $\begin{array}{l}2,979,700 \\
1,299,400\end{array}$ & $\begin{array}{l}13.43 \\
15.83\end{array}$ \\
\hline & $28,496,900$ & $5,132,400$ & 18.01 & $4,279,100$ & 15.02 \\
\hline Grand total................ & $570,085,000$ & $.80,880,935$ & 14.19 & $65,065,300$ & $11 ! 41$ \\
\hline
\end{tabular}


The data of roadbed, equipment, and operation, both for steam 'and for electricity, of the selected divisions are summarized in Tables 36 to 42 .

TABLE 36.-Track mileage of selected divisions.

\begin{tabular}{|c|c|c|c|c|}
\hline System. & Road. & Main. & Yard. & Total. \\
\hline 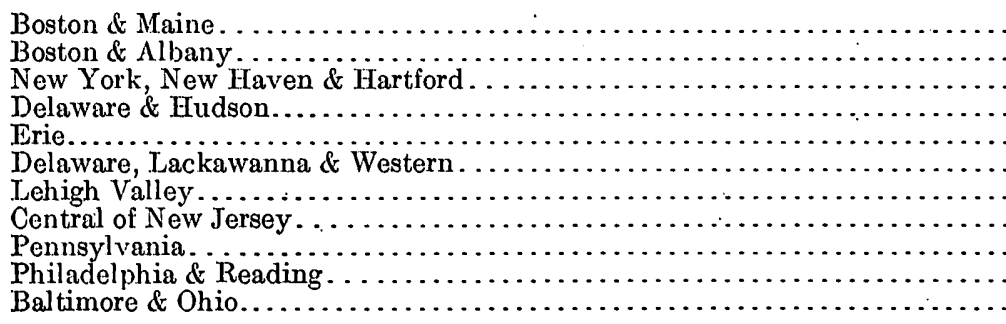 & $\begin{array}{r}278 \\
201 \\
329 \\
377 \\
715 \\
551 \\
544 \\
315 \\
1,503 \\
1,231 \\
351\end{array}$ & $\begin{array}{r}504 \\
368 \\
720 \\
666 \\
1,146 \\
1,030 \\
985 \\
597 \\
2,733 \\
1,927 \\
620\end{array}$ & $\begin{array}{r}295 \\
228 \\
495 \\
337^{\circ} \\
725 \\
682 \\
751 \\
658 \\
2,107 \\
1,246 \\
307\end{array}$ & $\begin{array}{r}799 \\
596 \\
1,215 \\
1,003 \\
1,871 \\
1,712 \\
1,736 \\
1,255 \\
4,840 \\
3,173 \\
927\end{array}$ \\
\hline & 6,395 & 11,296 & 7,831 & 19,127 \\
\hline
\end{tabular}

TABLE 37.-Data of steam operation on selected divisions.

\begin{tabular}{|c|c|c|c|c|c|c|c|c|}
\hline \multirow{3}{*}{ System. } & \multicolumn{3}{|c|}{ Total. } & \multicolumn{5}{|c|}{ Per mile of road. } \\
\hline & \multirow{2}{*}{$\begin{array}{l}\text { Loco: } \\
\text { motives. }\end{array}$} & \multirow{2}{*}{$\begin{array}{l}\text { Traffic } \\
\text { (thousands } \\
\text { of loco- } \\
\text { motive- } \\
\text { miles). }\end{array}$} & \multirow{2}{*}{$\begin{array}{c}\text { Coal } \\
\text { (thousands } \\
\text { of tons) }\end{array}$} & \multirow{2}{*}{$\begin{array}{l}\text { Loco- } \\
\text { motives. }\end{array}$} & \multicolumn{4}{|c|}{ Traffic (locomotive-miles). } \\
\hline & & & & & Freight. & Passenger. & Sum. & Total. $a$ \\
\hline 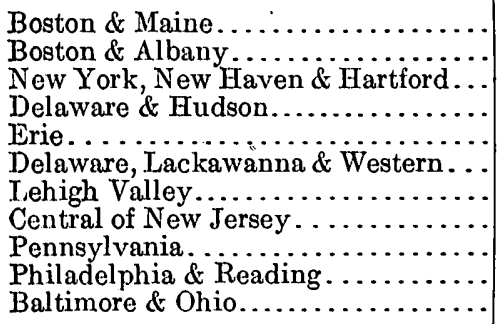 & $\begin{array}{r}363 \\
192 \\
456 \\
314 \\
568 \\
570 \\
619 \\
535 \\
1,655 \\
960 \\
310\end{array}$ & $\begin{array}{r}9,250 \\
5,550 \\
11,295 \\
6,940 \\
11,346 \\
13,900 \\
10,550 \\
10,000 \\
48,039 \\
22,353 \\
8,122\end{array}$ & $\begin{array}{r}630 \\
365 \\
825 \\
765 \\
1,093 \\
1,400 \\
1,103 \\
860 \\
3,433 \\
2,200 \\
640\end{array}$ & $\begin{array}{r}1.31 \\
.95 \\
1.39 \\
.83 \\
.79 \\
1.03 \\
1.14 \\
1.70 \\
1.10 \\
.78 \\
.88\end{array}$ & $\begin{array}{r}16,730 \\
7,110 \\
12,770 \\
12,900 \\
6,140 \\
11,250 \\
8,470 \\
12,700 \\
8,360 \\
7,380 \\
7,170\end{array}$ & $\begin{array}{r}5,750 \\
13,830 \\
13,900 \\
2,470 \\
6,510 \\
8,170 \\
4,520 \\
9,520 \\
14,750 \\
4,270 \\
8,620\end{array}$ & $\begin{array}{l}22,480 \\
20,945 \\
26,680 \\
15,380 \\
12,650 \\
19,420 \\
13,000 \\
22,220 \\
23,110 \\
12,460 \\
15,800\end{array}$ & $\begin{array}{l}33,270 \\
27,610 \\
34,340 \\
18,410 \\
15,870 \\
25,230 \\
19,390 \\
31,750 \\
31,960 \\
18,160 \\
23,140\end{array}$ \\
\hline $\begin{array}{r}\text { Baltimore \& Ohio................ } \\
\text { Total or weigh ted average..... }\end{array}$ & 6,542 & $1.56,345$ & 13,313 & 1.023 & 9,150 & 8,590 & 17,740 & 24,450 \\
\hline \multirow[b]{2}{*}{ System. } & & \multicolumn{2}{|c|}{ Per mile of road. } & \multicolumn{3}{|c|}{ Per mile of all track. } & \multirow[b]{2}{*}{$\begin{array}{c}\text { Road loco- } \\
\text { motive- } \\
\text { miles per } \\
\text { mile of } \\
\text { main track. }\end{array}$} & \multirow{2}{*}{$\begin{array}{l}\text { Switcher } \\
\text { loco- } \\
\text { motive- } \\
\text { miles per } \\
\text { mile of } \\
\text { yard track. }\end{array}$} \\
\hline & & $\begin{array}{c}\text { Coal } \\
\text { (tons) }\end{array}$ & $\begin{array}{c}\text { Gross } \\
\text { freight } \\
\text { traffic } \\
\text { (thousands } \\
\text { of ton- } \\
\text { miles). }\end{array}$ & $\begin{array}{c}\text { Loco- } \\
\text { motives. }\end{array}$ & $\begin{array}{l}\text { Total } \\
\text { traffic } \\
\text { (loco- } \\
\text { motive- } \\
\text { miles). } a\end{array}$ & $\begin{array}{c}\text { Coal } \\
\text { (tons) }\end{array}$ & & \\
\hline \multicolumn{2}{|c|}{ 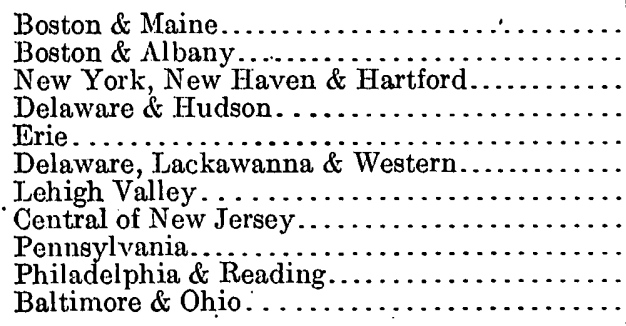 } & $\begin{array}{l}2,266 \\
1,816 \\
2,507 \\
2,030 \\
1,530 \\
2,540 \\
2,030 \\
2,730 \\
2,284 \\
1,790 \\
1,820\end{array}$ & $\begin{array}{r}15,100 \\
6,490 \\
14,800 \\
15,000 \\
8,000 \\
11,300 \\
9,400 \\
14,600 \\
13,090 \\
9,500 \\
9,600\end{array}$ & $\begin{array}{r}0.455 \\
.322 \\
.375 \\
.313 \\
.303 \\
.332 \\
.356 \\
.426 \\
.342 \\
.302 \\
.334\end{array}$ & $\begin{array}{r}11,580 \\
9,310 \\
9,300 \\
6,920 \\
6,060 \\
8,120 \\
6,080 \\
7,970 \\
9,920 \\
7,050 \\
8,760\end{array}$ & $\begin{array}{l}789 \\
612 \\
679 \\
762 \\
584 \\
818 \\
635 \\
685 \\
709 \\
693 \\
691 .\end{array}$ & $\begin{array}{r}12,400 \\
11,430 \\
12,190 \\
8,710 \\
7,890 \\
10,400 \\
7,180 \\
11,720 \\
10,430 \\
7,960 \\
8,940\end{array}$ & $\begin{array}{r}10,170 \\
5,880 \\
5,090 \\
3,390 \\
3,180 \\
4,690 \\
4,630 \\
4,560 \\
6,310 \\
5,630 \\
8,390\end{array}$ \\
\hline \multicolumn{2}{|c|}{ Total or weighted average............. } & 2,082 & 11,320 & .342 & 8,170 & 696 & 10,040 & 5,480 \\
\hline
\end{tabular}

a Includes switcher locomotive-miles. $63361^{\circ}-21-6$. 
TABLE 38.-Data of electric operation on selected divisions.

\begin{tabular}{|c|c|c|c|c|c|c|c|c|c|}
\hline \multirow{3}{*}{ System. } & \multicolumn{3}{|c|}{ Total. } & \multicolumn{3}{|c|}{ Per mile of road. } & \multicolumn{3}{|c|}{ Per mile of all track. } \\
\hline & \multirow[b]{2}{*}{$\begin{array}{l}\text { Number } \\
\text { of loco- } \\
\text { motives. }\end{array}$} & \multicolumn{2}{|c|}{ Substations. } & \multirow[b]{2}{*}{$\begin{array}{l}\text { Number } \\
\text { of loco- } \\
\text { motives. }\end{array}$} & \multicolumn{2}{|c|}{ Substations. } & \multirow[b]{2}{*}{$\begin{array}{l}\text { Number } \\
\text { of loco- } \\
\text { motives. }\end{array}$} & \multicolumn{2}{|c|}{ Substations. } \\
\hline & & $\begin{array}{c}\text { Capacity } \\
\text { (thousands } \\
\text { of } \\
\text { kilowatts). }\end{array}$ & $\begin{array}{c}\text { Energy } \\
\text { required } \\
\text { annually } \\
\text { (millions } \\
\text { of } \\
\text { kilowatt- } \\
\text { hours). }\end{array}$ & & $\begin{array}{c}\text { Capacity } \\
\text { (kilowatts). }\end{array}$ & $\begin{array}{c}\text { Energy } \\
\text { required } \\
\text { annually } \\
\text { (thousands } \\
\text { of } \\
\text { kilowatt- } \\
\text { hours). }\end{array}$ & & $\underset{\text { (kilowatts) }}{\text { Capacity }}$ & $\begin{array}{c}\text { Energy } \\
\text { required } \\
\text { annually } \\
\text { (thousands } \\
\text { of } \\
\text { kilowatt- } \\
\text { hours). }\end{array}$ \\
\hline Boston \& Maine.......... & 212 & 102 & 224 & 0.763 & 367 & 806 & 0.265 & 128 & 280 \\
\hline Boston \& Albany ............ & 107 & 59 & 129 & .532 & 294 & 642 & .180 & 99 & 216 \\
\hline New York, New Haven \& & & & & & & & & & \\
\hline 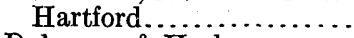 & 233 & 120 & 297 & .708 & 366 & 903 & .192 & 99 & 245 \\
\hline Delaware \& Hudson..... . & 163 & 125 & 276 & .432 & 333 & 731 & .163 & 125 & 275 \\
\hline 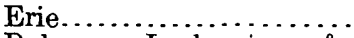 & 313 & 156 & 340 & .438 & 218 & 475 & .167 & 83 & 182 \\
\hline Delaware, Lackawánna \& & & & & & & & & & \\
\hline 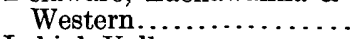 & 295 & 197 & 433 & .535 & 358 & 785 & 172 & 115 & 253 \\
\hline Lehigh Valley............ & 236 & 168 & 367 & .434 & 307 & 674 & .136 & 96 & 211 \\
\hline Central of New Jersey. . & 215 & 130 & 289 & .683 & 414 & 917 & .171 & 104 & 230 \\
\hline Pennsylvania............ & 959 & 561 & 1,232 & .638 & 373 & 820 & .198 & 116 & 255 \\
\hline Philadelphia \& Reading... & 488 & 289 & 635 & .396 & 235 & 516 & .153 & 91 & 200 \\
\hline Baltimore \& Ohio......... & 172 & 91 & 201 & .490 & 260 & 571 & .186 & 99 & 216 \\
\hline $\begin{array}{l}\text { Total or weighted } \\
\text { average......... }\end{array}$ & 3,393 & 1,998 & 4,423 & .531 & 312 & 692 & .177 & 104.4 & 231 \\
\hline
\end{tabular}

TABLE 39.-Coal saved by electric operation on selected divisions.

\begin{tabular}{|c|c|c|c|c|c|c|c|c|}
\hline \multirow{2}{*}{ System. } & \multicolumn{4}{|c|}{ Quantity (thousands of tons). } & \multicolumn{4}{|c|}{ Percentage of steam locomotive coal. } \\
\hline & Freight. & Passenger. & Switcher. & All. & Freight. & Passenger. & Switcher. & All. \\
\hline Boston \& Maine.......... & 253 & 48 & 105 & 406 & 63.3 & 60.0 & 70.0 & 64.4 \\
\hline Boston \& Albany . . . . . . . . . . . . . . . & 93 & 105 & 38 & 236 & 60.8 & 65.5 & 73.7 & 64.7 \\
\hline New York, New Haven \& Hartford.. & 247 & 176 & 105 & 528 & 61.3 & 62.8 & 73.6 & 64.0 \\
\hline Delaware \& Hudson . . . . . . . . . . . . . & 382 & 43 & 64 & 489 & 61.4 & 70.0 & 78.9 & 64.0 \\
\hline 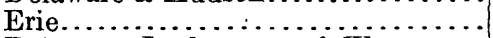 & 363 & 258 & 133 & 754 & 62.9 & 72.4 & 82.7 & 63.9 \\
\hline Delaware, Lackawanna \& Western. . : & 590 & 225 & 152 & 967 & 65.6 & 75.0 & 76.0 & 69.1 \\
\hline Lehigh Valley ................... & 422 & 126 & 188 & 736 & 62.4 & 67.5 & 78.3 & 66.7 \\
\hline Central of New Jersey & 276 & 140 & 155 & 571 & 60.0 & 70.0 & 77.5 & 66.4 \\
\hline Pennsylvania............... & . 887 & 804 & 509 & 2,200 & 60.0 & 64.5 & 71.8 & 64.1 \\
\hline Philadelphia \& Reading. & 1,035 & 264 & 265 & 1,564 & 71.6 & 67.9 & 72.7 & 71.1 \\
\hline Baltimore \& Ohio........ & 211 & 128 & 101 & 440 & 67.6 & 67.8 & 72.4 & 68.7 \\
\hline Total or weighted average... & 4,758 & 2,317 & 1,815 & 8,890 & 64.1 & 67.2 & 74.4 & 66.8 \\
\hline Percentage...$\ldots \ldots \ldots \ldots \ldots \ldots$ & 54 & 26 & 20 & 100 & .. & $\ldots \ldots \ldots$ & & $\ldots \ldots \ldots$ \\
\hline
\end{tabular}

TABLE 40.-Energy required for electric operation on selected divisions, in thousands of kilowatt-hours.

\begin{tabular}{|c|c|c|c|c|}
\hline System. & Freight. & Passenger. & Switcher. & All. \\
\hline 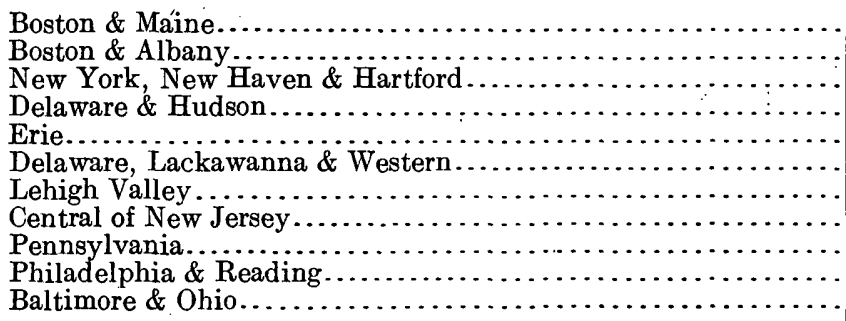 & $\begin{array}{r}147,000 \\
60,000 \\
155,500 \\
240,000 \\
213,400 \\
310,000 \\
254,000 \\
184,000 \\
590,200 \\
410,900 \\
101,400\end{array}$ & $\begin{array}{r}32,000 \\
55,600 \\
103,800 \\
18,600 \\
98,600 \\
75,000 \\
60,600 \\
60,000 \\
443,200 \\
125,100 \\
60,500\end{array}$ & $\begin{array}{r}45,000 \\
13,400 \\
37,800 \\
17,100 \\
27,800 \\
48,000 \\
52,200 \\
45,000 \\
199,600 \\
99,300 \\
38,700\end{array}$ & $\begin{array}{r}224,000 \\
129,000 \\
297,100 \\
275,700 \\
339,800 \\
433,000 \\
366,800 \\
289,000 \\
1,233,000 \\
635,300 \\
200,600\end{array}$ \\
\hline Percentage.. & $\begin{array}{r}2,666,400 \\
60.30\end{array}$ & $\begin{array}{r}1,133,000 \\
25.60\end{array}$ & $\begin{array}{r}623,900 \\
14.10\end{array}$ & $\begin{array}{r}4,423,300 \\
100.00\end{array}$ \\
\hline
\end{tabular}


TABdE 41.-Cost of electric track facilities and equipment of selected divisions, in thousands of dollars.

\begin{tabular}{|c|c|c|c|c|c|c|}
\hline & & Mileage. & & Specifie & ed items. & \\
\hline $\begin{array}{c}\text { System. } \\
.\end{array}$ & Road. & All track. & $\begin{array}{c}\text { Track } \\
\text { distribution } \\
\text { system. }\end{array}$ & $\begin{array}{c}\text { Sub- } \\
\text { stations. }\end{array}$ & $\begin{array}{c}\text { Loco- } \\
\text { motives } \\
\text {. }\end{array}$ & Sum. \\
\hline 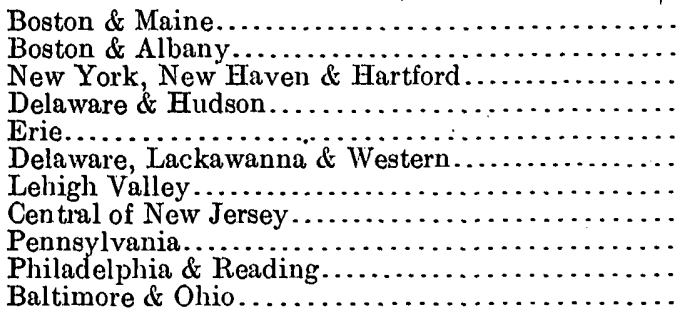 & $\begin{array}{r}27 \\
20 \\
32 \\
37 \\
71 \\
55 \\
54 \\
31 \\
1,50 \\
1,23 \\
35\end{array}$ & $\begin{array}{r}799 \\
596 \\
1,215 \\
1,003 \\
1,871 \\
1,712 \\
1,736 \\
1,255 \\
4,840 \\
3,173 \\
927\end{array}$ & $\begin{array}{r}8,397 \\
5,917 \\
12,352 \\
10,451 \\
19,032 \\
17,131 \\
17,002 \\
11,834 \\
46,555 \\
31,870 \\
9,695\end{array}$ & $\begin{array}{r}6,120 \\
3,540 \\
7,218 \\
7,524 \\
9,360 \\
11,820 \\
10,020 \\
7,824 \\
33,612 \\
17,340 \\
5,484\end{array}$ & $\begin{array}{r}14,20 \\
7,97 \\
16,23 \\
12,73 \\
23,338 \\
20,38 \\
20,07 \\
14,048 \\
75,871 \\
34,48 \\
12,63\end{array}$ & $\begin{array}{r}28,725 \\
17,429 \\
35,803 \\
30,712 \\
51,730 \\
49,339 \\
47,096 \\
33,706 \\
156,038 \\
83,699 \\
27,813\end{array}$ \\
\hline Percentage.. & 6,39 & \begin{tabular}{l|r}
5 & 19,127 \\
$\ldots$ & $\ldots \ldots$
\end{tabular} & $\begin{array}{r}190,236 \\
26.0\end{array}$ & $\begin{array}{r}119,862 \\
16.4\end{array}$ & $\begin{array}{r}251,992 \\
34 .\end{array}$ & $\begin{array}{r}562,090 \\
. \quad 76.9\end{array}$ \\
\hline System. & $\begin{array}{l}\text { Unspecified } \\
\text { items } \\
\text { (10 per cent). }\end{array}$ & $\begin{array}{c}\text { Overhead } \\
\text { (20 per cent). }\end{array}$ & $\begin{array}{c}\text { Total gros } \\
\text { cost. }\end{array}$ & $\begin{array}{l}\text { Cred } \\
\text { release } \\
\text { locom }\end{array}$ & $\begin{array}{l}\text { lit for } \\
\text { d steam } \\
\text { notives. }\end{array}$ & Net cost. \\
\hline 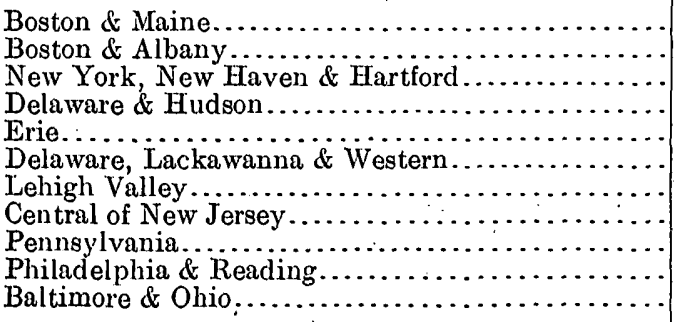 & $\begin{array}{r}2,872 \\
1,743 \\
3,580 \\
3,071 \\
5,173 \\
4,934 \\
4,710 \\
3,371 \\
15,604 \\
8,370 \\
2,781\end{array}$ & $\begin{array}{r}5,745 \\
3,486 \\
7,161 \\
6,142 \\
10,346 \\
9,868 \\
9,419 \\
6,741 \\
31,208 \\
16,740 \\
5,563\end{array}$ & $\begin{array}{r}37,3 \\
22,6 \\
46,5 \\
39,9 \\
67,2 \\
64,1 \\
61,2 \\
43,8 \\
202,8 \\
108,8 \\
36,1\end{array}$ & & $\begin{array}{r}8,480 \\
4,420 \\
10,152 \\
9,320 \\
13,980 \\
3,360 \\
5,340 \\
1,820 \\
12,560 \\
23,540 \\
7,660\end{array}$ & $\begin{array}{r}28,862 \\
18,238 \\
36,392 \\
30,605 \\
53,269 \\
50,781 \\
45,885 \\
31,998 \\
160,290 \\
85,269 \\
28,497\end{array}$ \\
\hline Percentage.. & $\begin{array}{r}56,209 \\
7.7\end{array}$ & $\begin{array}{r}112,419 \\
15.4\end{array}$ & $\begin{array}{r}730,7 \\
100 .\end{array}$ & & $\begin{array}{r}r, 632 \\
22.0\end{array}$ & $\begin{array}{r}570,086 \\
78.0\end{array}$ \\
\hline
\end{tabular}

TABLe 42.-Comparative cost of steam and electric operation on selected divisions, in thousands of dollars.

\begin{tabular}{|c|c|c|c|c|c|c|c|c|c|}
\hline \multirow[b]{2}{*}{ System. } & \multirow{2}{*}{$\begin{array}{c}\text { Net cost } \\
\text { of electric } \\
\text { construc- } \\
\text { tion and } \\
\text { equip- } \\
\text { ment. }\end{array}$} & \multicolumn{2}{|c|}{$\begin{array}{l}\text { Cost of steam } \\
\text { operation. }\end{array}$} & \multicolumn{3}{|c|}{ Cost of electric operation. } & \multicolumn{3}{|c|}{ Saving by elẹctric operation. } \\
\hline & & Coal. & $\begin{array}{l}\text { Locomo- } \\
\text { tive } \\
\text { mainte- } \\
\text { nance. }\end{array}$ & Energy. & $\begin{array}{c}\text { Locomo- } \\
\text { tive } \\
\text { mainite- } \\
\text { nance. }\end{array}$ & $\begin{array}{l}\text { Distri- } \\
\text { bution } \\
\text { and sub- } \\
\text { stations. }\end{array}$ & $\begin{array}{l}\text { Wage } \\
\text { saving. }\end{array}$ & Total. & $\begin{array}{l}\text { Ratio, to } \\
\text { cost of } \\
\text { construc- } \\
\text { tion (per } \\
\text { cent). }\end{array}$ \\
\hline 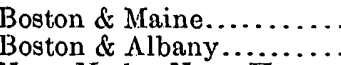 & $\begin{array}{l}28,862 \\
18,238\end{array}$ & $\begin{array}{l}3,780 \\
2,190\end{array}$ & $\begin{array}{l}3,170 \\
1,601\end{array}$ & $\begin{array}{l}2,240 \\
1,290\end{array}$ & $\begin{array}{l}721 \\
426\end{array}$ & $\begin{array}{l}578 \\
402\end{array}$ & $\begin{array}{r}1,020 \\
399\end{array}$ & $\begin{array}{l}4,431 \\
2,072\end{array}$ & $\begin{array}{l}15.4 \\
11.4\end{array}$ \\
\hline New York, New Haven & & & & & & & & & \\
\hline \& Flartford. . . . . . . & 36,392 & $\begin{array}{l}4,949 \\
4\end{array}$ & $\begin{array}{l}4,737 \\
2,984\end{array}$ & 2,971 & 849 & $\begin{array}{l}838 \\
727\end{array}$ & 991 & 6,019 & 16.5 \\
\hline Delaware \& Hudson. & 30,605 & 4,208 & 6,904 & 2,701 & 076 & 216 & 790 & 3,826 & 12. \\
\hline $\begin{array}{l}\text { Frie.......................... } \\
\text { Delaware, Lackawa }\end{array}$ & 53,269 & 5,407 & 0,913 & 3,398 & 936 & 1,216 & 1,032 & 7,862 & 14.8 \\
\hline Western $\ldots \ldots \ldots \ldots \ldots$ & 50,781 & 7,000 & $5 ; 004$ & 4,330 & 1,086 & 1,194 & 1,260 & 6,654 & 13. 1 \\
\hline Lehigh Valley......... & 45,885 & 5,514 & 5,170 & 3,668 & $\begin{array}{r}869 \\
725\end{array}$ & 1,041 & 1,205 & 6,311 & 13.8 \\
\hline Central of New Jersey. & 31,998 & 4,300 & 3,800 & 2,890 & 735 & 824 & 1,060 & 4,711 & 14.7 \\
\hline Pennsylvania......... & 160,290 & 17,162 & 19,797 & 12,330 & 4,125 & 3,547 & 4,628 & 21,585 & 13. 5 \\
\hline Philadelphia \& Reading... & $\$ 5,269$ & 10,998 & 8,976 & 6,353 & 1,819 & 2,099 & 2,574 & 12,277 & 14. 4 \\
\hline \multirow[t]{2}{*}{ Baltimore \& Ohio........... } & 28,497 & 3,202 & 4,386 & 2,006 & 667 & 635 & 853 & 5,133 & 18.0 \\
\hline & 570,086 & 68,770 & 66,538 & 44,233 & 12,910 & 13,101 & 15,817 & 80,881 & 14. 2 \\
\hline
\end{tabular}

Table 43 gives the comparative data for' steam and electric operation, in accordance with Form C, for all the selected divisions within the zone, aggregated into one operating system. This table summarizes briefly the entire results of the investigation; it does not include wage saving. 
TABL: 43.-Comparison of steam àd electric operation for all selected divisions (combined).

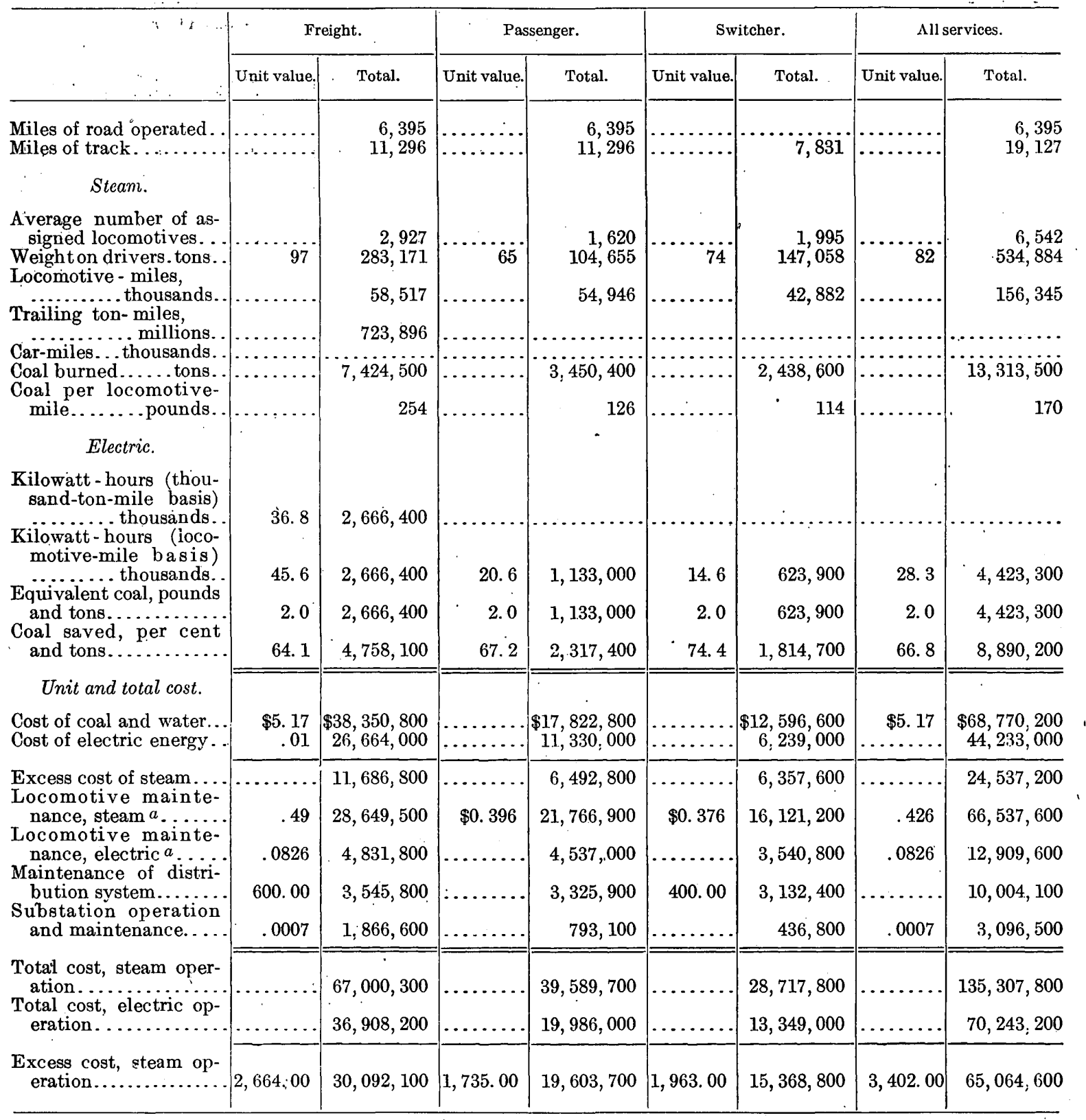

$a$ Includes engine-house expense.

Figure 16 shows the growth of traffic, both freight and passenger, of track, and of tractive power for the class 1 railroads in the superpower zone from 1900 to 1919 . The annual rate of growth has been 5.3 per cent in passenger-miles, 4.5 per cent in ton-miles, 0.75 per cent in all track, and 6.6 per cent in tractive power of locomotives.

The amount of money required for electrification is indicated in Table 42 as $\$ 570,000,000$. This figure is based on costs prevailing in 1919, but at present costs (June, 1921) it would be reduced by 18 per cent, to approximately $\$ 467,000,000$, and before this construction can be undertaken there will be further material reductions. Probably five years from now the entire work outlined could be done for not more than $\$ 400,000,000$. This is comparatively a moderate sum. Good railroad authorities have stated repeatedly that more than $\$ 1,000,000,000$ a year is needed by the railroads of the United States for extensions and betterments. The part of. this total to be allocated to the superpower zone, as determined by the number of locomotives; 
would be $\$ 150,000,000$. The amount required for normal extensions and betterments for three years would therefore be sufficient to electrify the 30 selected divisions of the railroads in this territory, with an annual saving of more than 14 per cent. The most valuable feature of the change, however, is not the amount saved but the great increase in maximum capacity of existing trackage and the general advantages of electric operation.

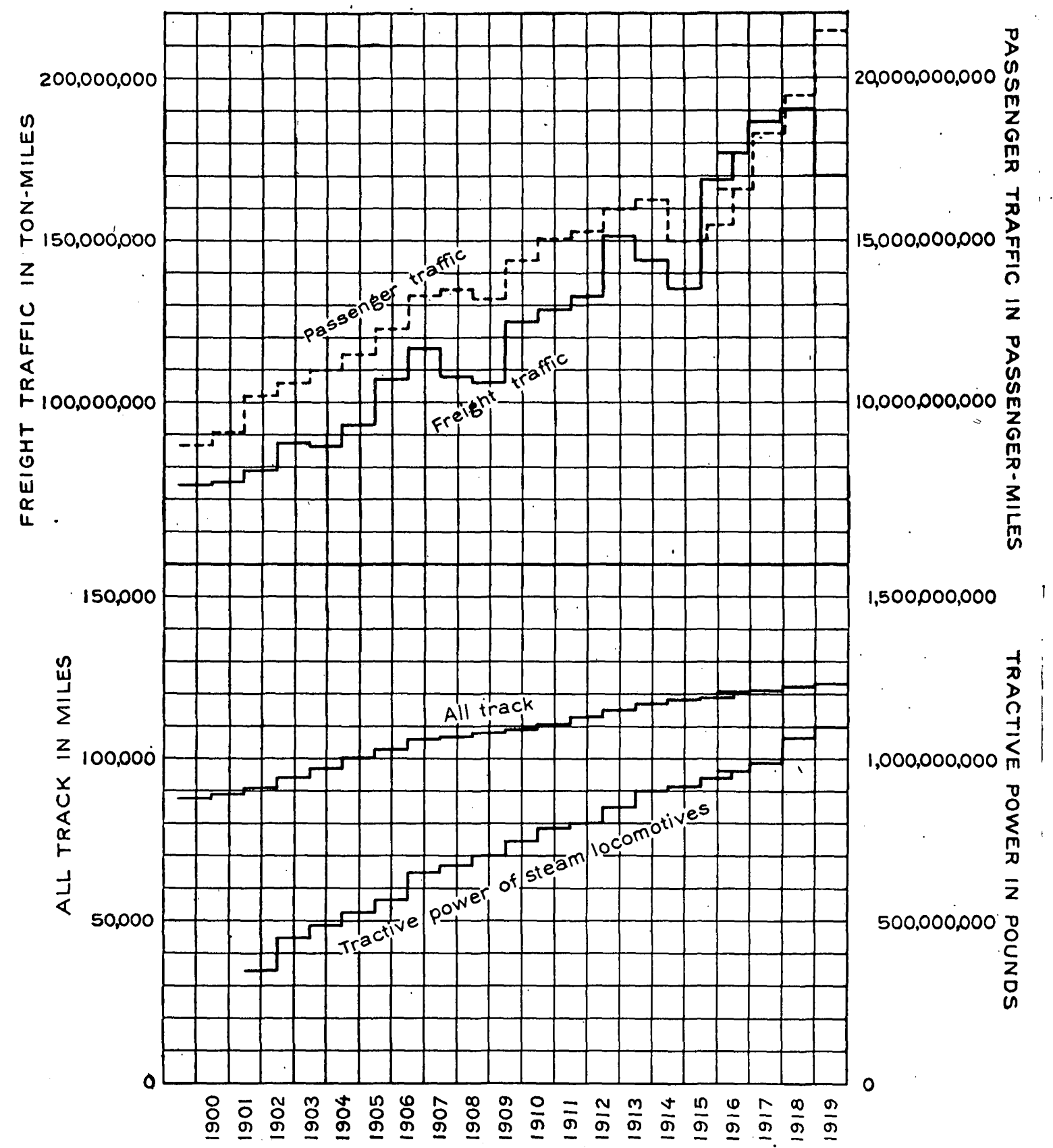

Figure 16.-Growth of steam railroads in the superpower zone in 1900-1919. Annual rate of growth compounded, 1900-1918: Passenger-miles, 5.3 per cent; ton-miles, 4.5 per cent; all track, 0.75 per cent; tractive power, 6.6 per cent.

These figures indicate that with a return of normal financial conditions all these lines should be electrified before further great expenditures have been incurred to increase in a minor degree the capacity of the existing tracks and yards. Steam operation can not satisfactorily meet the conditions of the crowded terminal herein described as the superpower zone; electric operation can easily do it. 



\section{APPENDIX D. INDUSTRY IN THE SUPERPOWER ZONE.}

By H. W. Butler, H. Goodwin, JR., and others of the engineering staff.

CONCLUSIONS.

A survey of the industrial establishments in the superpower zone in 1919 shows that the maximum economical use of purchased power in that year would have saved 13,502,100 tons of coal. This estimate assumes a consumption equivalent to 2 pounds of coal per kilowatthour at the motor leads in the industrial establishments. In order to save this coal, however, the industries would have had to purchase $5,623,800,000$ kilowatt-hours more than they did.

The energy developed by prime movers in the industries was equivalent to $9,311,440,000$ kilowatt-hours. The energy purchased from central electric stations to supply electric motors in the industries was $3,338,800,000$ kilowatt-hours.

\section{INDUSTRIES CONSIDERED.}

"Industries" as used in this report means privately owned manufacturing establishments, laundries, mines and quarries, and Government institutions. The establishments considered include only those whose annual product has a value greater than $\$ 500$. Table 48 gives the statistics for 53 industries, which have been arranged in 17 major groups adopted by the Bureau of the Census, to permit convenient comparison of the information here given with other information gathered by the Census Bureau regarding these industries.

\section{FUNDAMENTAL INFORMATION RECEIVED FROM BUREÄU OF THE CENSUS.}

\section{THE TABIES IN GENERAL.}

The only source of general figures showing power and fuel used proved to be the Bureau of the Census. The census of manufactures covering the calendar year 1919 was in process of compilation, and the Census Bureau arranged to cooperate with the superpower survey by supplying advance information in special tabular form for analysis. The titles of the tables follow:

Table 44.-Mechanical power-supply equipment and fuel used by all industries, by size of plant.

Table 45.-Mechanical power-supply equipment and fuel used by all industries, by character of power supply.

Table 46.-Mechanical power-supply equipment and fuel used by all industries, by industry subgroups and character of power supply. $\quad \cdot \quad \cdot$.

Table 47.-Mechanical powerr-supply equipment and fuel used by all industries, by counties and size of plant.

Table 48.-Summary and analysis of industrial power and fuel, by industry groups. (The summary consists of Census data; the analysis was made by the superpower survey.) :

The column headings are practically the same.in all tables. They follow the Census standard headings except as noted.

"Power-supply equipment" is used instead of the old Census term "primary power."

"Prime movers", is used instead of "owned" power.

"Operated by purchased energy" is used instead of "rented" power.

"Aggregate horsepower" of "power-supply equipment" (column 6) is the sum of the "total horsepower" of "prime movers" (column. 7) and the "total horsepower" "operated by purchased energy" (column 16).

"Total horsepower" of "prime movers" (column 7) is the sum of columns 9, 11, 13, and 15. Prime movers are included whether they are directly connected to machinery, such as pumps, air compressors, or electrical generators, or used to drive shafting. Boiler-room and engine-room auxiliaries are not included. 
"Internal-combustion engines" (columns 12 and 13) include gas, gasoline, and oil engines, whether run on special fuel or waste gases.

"Water wheels" (columns 14 and 15) include hydraulic turbines and an insignificant number of small water motors run from city water mains.

"Electric motors" "operated by purchased energy" (columns 17 and 18) consist chiefly of motors operated from the circuits of central stations but include also some that are operated by energy purchased from isolated plants.

"Other horsepower" "operated by purchased energy" (column 19) is chiefly power received through belting or shafting from the power plant of some other industrial establishment.

"Total number" of "electric motors" (column 20) is the sum of those "operated by purchased energy" (column 17) and those "run by current generated in establishment" (column 22). Similarly "Total horsepower" (column 21) is the sum of columns 18 and 23. A comparison of column 21 with column 6 gives an idea of the application of electricity in any industry.

"Fuel used" is expressed in "long tons" (2,240 pounds) for anthracite and "short tons". $(2,000$ pounds) for bituminous coal and coke. Column 26 ("Total equivalent bituminous coal") is derived from columns 24 and 25 and is presented to permit a comparison of items that show various proportions of anthracite and bituminous coal. A careful investigation of the quality of coal used by the industries showed that one long ton of anthracite was equivalent, on the average, to about nine-tenths of a short ton of bituminous coal in producing power. The "total equivalent bituminous coal" is therefore determined by multiplying the "anthracite" tons by 0.9 and adding the result to the "bituminous" tons. As comparatively little coke is used for producing power in the superpower zone, this item is not included in the "total equivalent bituminous coal." .

Statistics on the use of oil and manufactured gas in the industries are also compiled by the Bureau of the Census, but the data for 1919 were not ready in time for use. The amount of oil used for producing power is very small in comparison with the amount of coal used, and as the oil reserves are scant it must remain small.

\section{IIMITATIONS OF STATISTICS.}

It is difficult to show the present complicated conditions in industry, with its interrelated power and fuel supply; in a few uniform tables. The totals given are undoubtedly very accurate, but as the divisions become finer and finer they must be used with increasing care and knowledge of the rules used in compilation. For instance: (a) Many plants, particularly the larger ones, that are normally operated by water power have complete steam plants in reserve for their operation during periods of low water. Both forms of power are reported, and in a small group either may apparently show a disproportionately large amount of power. (b) Some plants have discontinued regular operation of direct prime movers and purchase power from a central station but must also report the old prime movers held in reserve. This again leads to a duplication. (c). Other plants are electrically driven throughout and purchase power part of the time and generate it another part. At some times the centrál station connection is only "reserve," and at other times the prime movers are only "reserve," so that to avoid duplication and to make the total as nearly correct as possible, it is necessary to report the motors as "run by current generated in establishment reporting." If the prime movers are used only occasionally, the report obviously does not give the central station any credit for what it supplies. (d) Still other plants abandoned the use of prime movers near the end of 1919 and purchased all energy. Thus the statistics show that the motors were operated by purchased energy on December 31, 1919, but that the fuel used during the year was almost enough to operate a steam plant instead of the small amount that might be needed with purchased power. This condition happened to be particularly true of ice plants, many of which changed to central-station service in 1919. 


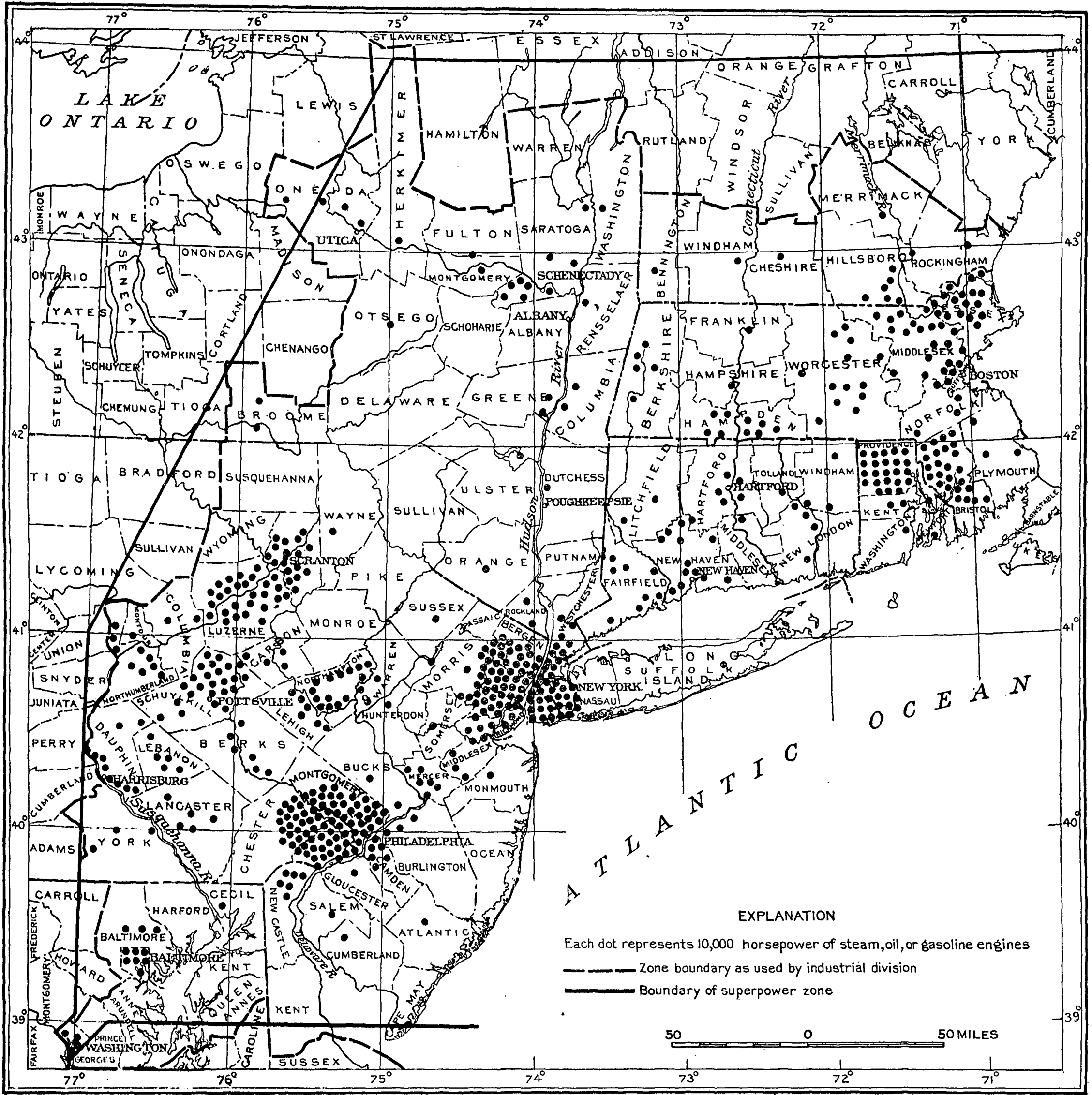

63361-21. ('To face page 86.)

ISOLATED INDUSTRIAL PLANTS IN SUPERPOWER ZONE. 
THE TABLES IN DETAIL.

Table 44 shows the total mechanical power-supply equipment and fuel used by all industries in the zone, by size of plant. First is shown the fuel used by establishments reporting "no power." On the following lines are given the power and fuel used by establishments reporting an aggregate of 1 to 200 horsepower, 201 to 500 horsepower, and 501 horsepower or more. The average size is interesting. The figures for the larger plants indicate that 2,732 establishments use $6,689,751$ horsepower-that is, 3.6 per cent of the establishments reporting power are larger than 500 horsepower and use 73.8 per cent of the grand total horsepower.

Table 45 shows the total mechanical power-supply equipment and fuel, by character of power supply, with each group subdivided by size of plant. This subdivision is made particularly for analysis. Therefore two clear-cut groups have been selected-establishments reporting "steam power only" and establishments reporting "purchased electric power only." The ratio of fuel used to power is in these establishments obviously simple, and the amount of coal used per horsepower has a definite significance. All combinations of steam power with purchased power and all other forms of power exhibit more complicated relations and have been thrown together under the heading "All other power." The relations in this group may usually be analyzed by means, of the factors derived from the previous groups by making proper allow" ance for the considerations noted above under "Limitations of statistics."

Table 46 presents data for each industrial subgroup similar to those presented for all industries in Table 45. The totals of each group in Table 46 are carried forward to Table 48. Remarks in regard to Table 45 apply to Table 46 with additional force. This table shows clearly for each group of industries the character of power supply and the fuel used, from which can be determined the relation of fuel used to character of power supply.

Table 47 gives the mechanical power-supply equipment reported in each county, by size of plant, as explained for Table 44. This table is of interest as showing the distribution of plants of various sizes and the extent to which electric power is purchased in different counties.

Plate VII shows the distribution by counties of isolated-plant power, each dot representing 10,000 horsepower of steam, oil, or gasoline engines. 
TABLE 44.-Mechanical power-supply equipment and Data from census of

\begin{tabular}{|c|c|c|c|c|c|c|c|c|c|c|c|c|c|c|}
\hline \multirow{4}{*}{ 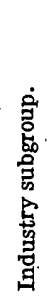 } & \multirow{4}{*}{ 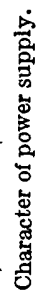 } & \multirow{4}{*}{$\begin{array}{c}\begin{array}{c}\text { Size of } \\
\text { plant } \\
\text { (horsepower) }\end{array}\end{array}$} & \multicolumn{2}{|c|}{ Establishments. } & \multicolumn{10}{|c|}{ Power-supply equipment. } \\
\hline & & & \multirow{3}{*}{$\underset{\text { ber. }}{\text { Num- }}$} & \multirow{3}{*}{$\begin{array}{l}\text { Aver- } \\
\text { age size } \\
\text { (horse- } \\
\text { power). }\end{array}$} & \multirow{3}{*}{$\begin{array}{c}\text { Aggregate } \\
\text { horse- } \\
\text { power. } \\
\\
:\end{array}$} & $\therefore$ & . & . & $\operatorname{Pr}$ & ime movers & & & & \\
\hline & & & & & & \multirow{2}{*}{$\begin{array}{l}\text { Total } \\
\text { horse- } \\
\text { power. }\end{array}$} & \multicolumn{2}{|c|}{ Steam engines. } & \multicolumn{2}{|c|}{ Steam turbines. } & \multicolumn{2}{|c|}{$\begin{array}{l}\text { Internal-combus- } \\
\text { tion engines. }\end{array}$} & \multicolumn{2}{|c|}{ Water wheels. } \\
\hline & & & & & & & $\begin{array}{l}\text { Num- } \\
\text { ber. }\end{array}$ & $\begin{array}{l}\text { Horse- } \\
\text { power. }\end{array}$ & $\begin{array}{l}\text { Num- } \\
\text { ber. }\end{array}$ & $\begin{array}{l}\text { Horse- } \\
\text { power. }\end{array}$ & $\underset{\text { ber. }}{\text { Num. }}$ & $\begin{array}{l}\text { Horse- } \\
\text { power. }\end{array}$ & Num- & $\begin{array}{l}\text { Horse- } \\
\text { power. }\end{array}$ \\
\hline $\mathbf{1}$ & 2 & 3 & 4 & 5 & 6 & 7 & 8 & $\mathbf{9}$ & 10 & 11 & 12 & 13 & 14 & 15 \\
\hline \multirow{4}{*}{ 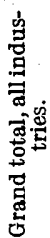 } & \multirow{4}{*}{\multicolumn{2}{|c|}{$\begin{array}{l}\text { No power.......... } \\
\text { All power: } \\
1-200 \ldots \ldots \ldots \\
201-500 \ldots \ldots \ldots \\
501 \text { and above.... } \\
\text { Total power... } \\
\text { Grand total.... }\end{array}$}} & 19,757 & & & & & & & & & & & \\
\hline & & & $\begin{array}{r}70,654 \\
2,841 \\
2,732\end{array}$ & $\begin{array}{r}21 \\
315 \\
2,450\end{array}$ & $\begin{array}{r}1,485,664 \\
894,056 \\
6,689,751\end{array}$ & $\begin{array}{r}692,047 \\
569,154 \\
4,985,801\end{array}$ & $\begin{array}{r}11,022 \\
4,618 \\
17,739\end{array}$ & $\begin{array}{r}535,505 \\
488,880 \\
3,231,483\end{array}$ & $\begin{array}{r}276 \\
174 \\
1,665\end{array}$ & $\begin{array}{r}10,135 \\
19,514 \\
1,141,412\end{array}$ & $\begin{array}{r}5,511 \\
294 \\
441\end{array}$ & $\begin{array}{r}73,408 \\
11,662 \\
193,970\end{array}$ & $\begin{array}{r}2,333 \\
627 \\
1,748\end{array}$ & $\begin{array}{r}72,999 \\
49,098 \\
418,936\end{array}$ \\
\hline & & & $.76,227$ & 119 & $9,069,471$ & $6,247,002$ & 33,379 & $4,255,868$ & 2,115 & $1,171,061$ & 6,246 & 279,040 & 4,708 & 541,033 \\
\hline & & & 95,984 & ….... & $9,069,471$ & $6,247,002$ & 33,379 & $4,255,868$ & 2,115 & $1,171,061$ & 6,246 & 279,040 . & 4,708 & 541,033 \\
\hline
\end{tabular}

TABLE 45.-Mechanical power-supply equipment and

[Data from census of

\begin{tabular}{|c|c|c|c|c|c|c|c|c|c|c|c|c|c|c|}
\hline \multirow{4}{*}{ 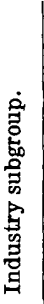 } & \multirow{4}{*}{ 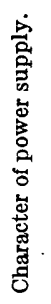 } & \multirow{4}{*}{$\begin{array}{l}\text { Size of plant } \\
\text { (horsepower). }\end{array}$} & \multicolumn{2}{|c|}{ Establishments. } & \multicolumn{10}{|c|}{ Power-supply equipment. } \\
\hline & & & \multirow{3}{*}{$\begin{array}{c}\text { Num- } \\
\text { ber. }\end{array}$} & \multirow{3}{*}{$\begin{array}{l}\text { A } \\
\text { Ager- } \\
\text { age size } \\
\text { (horse- } \\
\text { power). }\end{array}$} & \multirow{3}{*}{$\begin{array}{c}\text { Aggregate } \\
\text { horse- } \\
\text { power. }\end{array}$} & \multicolumn{9}{|c|}{ Prime movers. } \\
\hline & & & & & & \multirow{2}{*}{$\begin{array}{l}\text { Total } \\
\text { horse- } \\
\text { power. }\end{array}$} & \multicolumn{2}{|c|}{ Steam engines. } & \multicolumn{2}{|c|}{ Steam turbines. } & \multicolumn{2}{|c|}{$\begin{array}{l}\text { Internal-combus- } \\
\text { tion engines. }\end{array}$} & \multicolumn{2}{|c|}{ Water wheels. } \\
\hline & & & & & & & $\begin{array}{c}\text { Num- } \\
\text { ber. }\end{array}$ & $\begin{array}{l}\text { Horse- } \\
\text { power. }\end{array}$ & $\begin{array}{l}\text { Num- } \\
\text { ber. }\end{array}$ & $\begin{array}{l}\text { Horse- } \\
\text { power. }\end{array}$ & $\begin{array}{l}\text { Num- } \\
\text { ber. }\end{array}$ & $\begin{array}{l}\text { Horse- } \\
\text { power. }\end{array}$ & $\begin{array}{l}\text { Num. } \\
\text { ber. }\end{array}$ & $\begin{array}{l}\text { Horse- } \\
\text { power. }\end{array}$ \\
\hline $\mathbf{1}$ & 2 & 3 & 4 & 5 & 6 & $\boldsymbol{\gamma}$ & 8 & 9 & 10 & i1 & 12 & 13 & 14 & 15 \\
\hline \multirow{12}{*}{ 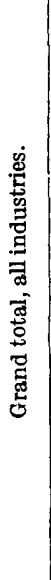 } & \multirow{4}{*}{\multicolumn{2}{|c|}{$\begin{array}{r}\text { No power............ } \\
\text { Steam power only: } \\
1-200 \ldots \ldots \ldots \ldots \\
201-500 \ldots \ldots \ldots \ldots \\
501 \text { and above.... }\end{array}$}} & 19,757 & & & - & $\ldots$ & & & & & & & \\
\hline & & & 6,446 & $\begin{array}{r}61 \\
322\end{array}$ & $\begin{array}{l}395,029 \\
305,909\end{array}$ & $\begin{array}{l}395,029 \\
305,909\end{array}$ & $\begin{array}{l}7,886 \\
2,380\end{array}$ & $\begin{array}{l}388,054 \\
291,745\end{array}$ & $\begin{array}{l}174 \\
118\end{array}$ & $\begin{array}{r}6,975 \\
14,164\end{array}$ & & & & \\
\hline & & & 912 & 2,210 & $2,017,858$ & $2,017,858$ & 7,357 & $1,437,942$ & 790 & 579,916 & ....... & & & \\
\hline & & & 8,307 & 327 & $2,718,796$ & $2,718,796$ & 17,623 & $2,117,741$ & 1,082 & 601,055 & ......... & ..... & $\cdots$ & \\
\hline & \multirow{3}{*}{\multicolumn{2}{|c|}{$\begin{array}{l}\text { Purchased electric } \\
\text { power only: } \\
1-200 \ldots \ldots \ldots \ldots \\
201-500 \ldots \ldots \ldots \ldots \\
501 \text { and above.... }\end{array}$}} & 53,968 & 13 & & & & & & & & & & \\
\hline & & & $\begin{array}{l}081 \\
367\end{array}$ & 1,620 & $\begin{array}{l}200,011 \\
596,240\end{array}$ & & & & & & & & $\cdots$ & \\
\hline & & & 55,016 & 27 & $1,483,307$ & .......... & ....... & ........... & ...... & ........... & ....... & ......... & $\cdots$ & \\
\hline & \multirow{3}{*}{\multicolumn{2}{|c|}{$\begin{array}{l}\text { All other power: } \\
1-200 \ldots \ldots \ldots \ldots \\
201-500 \ldots \ldots \ldots \\
501 \text { and above... }\end{array}$}} & 10,240 & & 410,179 & 297,018 & 3,136 & 147,451 & 102 & & 5,511 & & 2,333 & 7,999 \\
\hline & & & $\begin{array}{l}1,211 \\
1,453\end{array}$ & $\begin{array}{r}314 \\
2,800\end{array}$ & $\begin{array}{r}381,536 \\
4,075,653\end{array}$ & $\begin{array}{r}263,245 \\
2,967,943\end{array}$ & $\begin{array}{r}2,238 \\
10,382\end{array}$ & $\begin{array}{r}197,135 \\
1,793,541\end{array}$ & $\begin{array}{r}56 \\
875\end{array}$ & $\begin{array}{r}5,350 \\
561,496\end{array}$ & · $\begin{array}{r}294 \\
441\end{array}$ & $\begin{array}{r}11,662 \\
193,970\end{array}$ & $\begin{array}{r}627 \\
1,748\end{array}$ & $\begin{array}{r}49,098 \\
418,936\end{array}$ \\
\hline & & & 12,904 & 377 & $4,867,368$ & $3,528,206$ & 15,756 & $2,138,127$ & 1,033 & 570,006 & 6,246 & 279,040 & 4,708 & 541,033 \\
\hline & & Total power... & 76,227 & 119 & $9,069,471$ & $6,247,002$ & 33,379 & $4,255,868$ & 2,115 & $1,171,061$ & 6,246 & 279,040 & 4,708 & 541,033 \\
\hline & & Grand total... & 95,984 & & $9,069,471$ & $6,247,002$ & 33,379 & $4,255,868$ & 2,115 & $1,171,061$ & 6,246 & 279,040 & 4,708 & 541,033 \\
\hline
\end{tabular}


fuel used by all industries, by size of plant.

manufactures, 1919.]

\begin{tabular}{|c|c|c|c|c|c|c|c|c|c|c|c|}
\hline \multirow{2}{*}{\multicolumn{4}{|c|}{$\frac{\text { Power-supply equipmont-Continued. }}{\text { Operated by purchased energy. }}$}} & \multicolumn{4}{|c|}{ Electric motors. } & \multicolumn{4}{|c|}{ Fuel used. } \\
\hline & & & & \multirow{2}{*}{\multicolumn{2}{|c|}{ Total. }} & \multirow{2}{*}{\multicolumn{2}{|c|}{$\begin{array}{l}\text { Run by current gen- } \\
\text { erated in establish- } \\
\text { ment. }\end{array}$}} & \multicolumn{3}{|c|}{ Coal. } & \multirow{3}{*}{$\begin{array}{l}\text { Coke } \\
\text { (short } \\
\text { tons). }\end{array}$} \\
\hline \multirow{2}{*}{$\begin{array}{c}\text { Total } \\
\text { horsepower. }\end{array}$} & \multicolumn{2}{|c|}{ Electric motors. } & \multirow{2}{*}{$\begin{array}{l}\text { Other } \\
\text { (horse- } \\
\text { power). }\end{array}$} & & & & & \multirow{2}{*}{$\begin{array}{l}\text { Anthracite } \\
\text { (long tons). }\end{array}$} & \multirow{2}{*}{$\begin{array}{l}\text { Bitumu- } \\
\text { nous (short } \\
\text { tons). }\end{array}$} & \multirow{2}{*}{$\begin{array}{c}\text { Total } \\
\text { equivalent } \\
\text { bitumi- } \\
\text { nous (short } \\
\text { tons). }\end{array}$} & \\
\hline & Number. & $\begin{array}{l}\text { Horso- } \\
\text { power. }\end{array}$ & & Number. & $\begin{array}{l}\text { Horse- } \\
\text { power. }\end{array}$ & Number. & $\begin{array}{l}\text { Horse- } \\
\text { power. }\end{array}$ & & & & \\
\hline \multirow[t]{2}{*}{$\cdot 16$} & 17 & 18 & 19 & 20 & 21 & 22 & 23 & 24 & 25 & 26 & 27 \\
\hline & & & & & & & & 234,010 & 381,727 & 591,884 & 25,860 \\
\hline $\begin{array}{r}793,617 \\
324,902 \\
1,703,950 \\
\end{array}$ & $\begin{array}{r}208,962 \\
35,593 \\
117,406\end{array}$ & $\begin{array}{r}763,163 \\
321,592 \\
1,685,960\end{array}$ & $\begin{array}{r}30,454 \\
3,310 \\
17,990\end{array}$ & $\begin{array}{r}221,738 \\
58,228 \\
280,941 \\
\end{array}$ & $\begin{array}{r}837,261 \\
481,523 \\
4,017,843 \\
\end{array}$ & $\begin{array}{r}12,776 \\
22,635 \\
163,535 \\
\end{array}$ & $\begin{array}{r}74,098 \\
159,931 \\
2,331,883 \\
\end{array}$ & $\begin{array}{r}2,528,361 \\
1,265,149 \\
16,882,346\end{array}$ & $\begin{array}{r}3,887,872 \\
3,899,249 \\
26,498,476\end{array}$ & $\begin{array}{r}6,158,375 \\
5,037,683 \\
41,675,571 \\
\end{array}$ & $\begin{array}{r}566,778 \\
308,288 \\
4,760,102\end{array}$ \\
\hline $2,822,409$ & 361,961 & $2,770,715$ & 51,754 & 560,907 & $5,336,627$ & 198,946 & $2,565,912$ & $20,675,855$ & $34,287,597$ & $52,871,629$ & $5,635,168$ \\
\hline $2,822,469$ & 361,961 & $2,770,715$ & 51,754 & 560,907 & $5,336,627$ & 198,946 & $2,565,912$ & $20,909,865$ & $34,669,324$ & $53,463,513$ & $5,661,028$ \\
\hline
\end{tabular}

fuel used by all indistries, by character of power supply.

manufacturos, 1919.]

\begin{tabular}{|c|c|c|c|c|c|c|c|c|c|c|c|}
\hline \multirow{2}{*}{\multicolumn{4}{|c|}{$\frac{\text { Power-supply equipment-Continued. }}{\text { Operated by purchased energy. }}$}} & \multicolumn{4}{|c|}{ Electric motors. } & \multicolumn{4}{|c|}{ Fuel used. } \\
\hline & & & & \multirow{2}{*}{\multicolumn{2}{|c|}{ Total. }} & \multirow{2}{*}{\multicolumn{2}{|c|}{$\begin{array}{l}\text { Run by current gen- } \\
\text { erated in establish- } \\
\text { ment. }\end{array}$}} & \multicolumn{3}{|c|}{ Coal. } & \multirow{3}{*}{$\begin{array}{l}\text { Coke } \\
\text { (short } \\
\text { tons). }\end{array}$} \\
\hline \multirow{2}{*}{$\begin{array}{c}\text { Total } \\
\text { horsopowor. }\end{array}$} & \multicolumn{2}{|c|}{ Eloctric motors. } & \multirow{2}{*}{$\begin{array}{l}\text { Other } \\
\text { (horse- } \\
\text { power). }\end{array}$} & & & & & \multirow{2}{*}{$\begin{array}{l}\text { Anthracite } \\
\text { (long tons). }\end{array}$} & \multirow{2}{*}{$\begin{array}{c}\text { Bituminous } \\
\text { (short } \\
\text { tons). }\end{array}$} & \multirow{2}{*}{$\begin{array}{c}\text { Total } \\
\text { equivalent } \\
\text { bitimi- } \\
\text { nous (short } \\
\text { tons). }\end{array}$} & \\
\hline & Number. & $\begin{array}{l}\text { Horse- } \\
\text { power. }\end{array}$ & & Number. & $\begin{array}{l}\text { Horse- } \\
\text { power. }\end{array}$ & Number. & $\begin{array}{l}\text { Horse- } \\
\text { power. }\end{array}$ & & & & \\
\hline \multirow[t]{2}{*}{16} & 17 & 18 & 19 & 20 & 21 & 22 & 23 & 24 & 25 & 26 & 27 \\
\hline & & & & & & & & 234,010 & 381,727 & 591, 884 & 25,860 \\
\hline & & & & $\begin{array}{r}8,633 \\
17,179 \\
88,382\end{array}$ & $\begin{array}{r}52,326 \\
115,860 \\
1,143,666\end{array}$ & $\begin{array}{r}8,633 \\
17,179 \\
88,382\end{array}$ & $\begin{array}{r}52,326 \\
115,860 \\
1,143,666\end{array}$ & $\begin{array}{r}855,337 \\
657,603 \\
7,070,078\end{array}$ & $\begin{array}{r}1,886,507 \\
1,889,242 \\
12,139,926\end{array}$ & \begin{tabular}{|r|}
$2,655,485$ \\
$2,480,059$ \\
$18,500,448$ \\
\end{tabular} & $\begin{array}{r}149,745 \\
131,501 \\
2,286,003\end{array}$ \\
\hline & ……... & & & 114,194 & $1,311,852$ & 114,194 & $1,311,852$ & $8,583,018$ & $15,915,675$ & $23,635,992$ & $2,567,249$ \\
\hline $\begin{array}{l}680,456 \\
206,611 \\
596,240\end{array}$ & $\begin{array}{r}196,275 \\
23,709 \\
38,790\end{array}$ & $\begin{array}{l}680,456 \\
206,611 \\
596,240\end{array}$ & & $\begin{array}{r}196,275 \\
23,709 \\
38,790\end{array}$ & $\begin{array}{l}680,456 \\
206,611 \\
596,240\end{array}$ & & & $\begin{array}{r}1,091,594 \\
123,109 \\
197,520\end{array}$ & $\begin{array}{r}965,127 \\
57.5,813 \\
2,542,126\end{array}$ & $\begin{array}{r}1,943,805 \\
685,748 \\
2,719,861\end{array}$ & $\begin{array}{r}338,435 \\
44,734 \\
100,182\end{array}$ \\
\hline $1,483,307$ & 258,774 & $1,483,307$ & $\cdots$ & 258,774 & $1,483,307$ & & & $1,412,223$ & $4,083,066$ & $5,349,414$ & 483,351 \\
\hline $\begin{array}{r}113,161 \\
118,291 \\
1,107,710 \\
\end{array}$ & $\begin{array}{l}12,687 \\
11,884 \\
78,616 \\
\end{array}$ & $\begin{array}{r}82,707 \\
114,981 \\
1,089,720 \\
\end{array}$ & $\begin{array}{r}30,454 \\
3,310 \\
17,990 \\
\end{array}$ & $\begin{array}{r}16,830 \\
17,340 \\
153,769\end{array}$ & $\begin{array}{r}104,479 \\
159,052 \\
2,277,937 \\
\end{array}$ & $\begin{array}{r}4,143 \\
5,456 \\
75,153 \\
\end{array}$ & $\begin{array}{r}21,772 \\
44,071 \\
1,188,217 \\
\end{array}$ & $\begin{array}{r}581,430 \\
484,437 \\
9,614,748 \\
\end{array}$ & $\begin{array}{r}1,036,238 \\
1,436,194 \\
11,816,424 \\
\end{array}$ & $\begin{array}{r}1,559,085 \\
1,871,876 \\
20,455,262 \\
\end{array}$ & $\begin{array}{r}78,598 \\
132,053 \\
2,373,917 \\
\end{array}$ \\
\hline $1,339,162$ & 103,187 & $1,287,408$ & 51,754 & 187,939 & $2,541,468$ & 84,752 & $1,254,060$ & $10,680,615$ & $14,288,856$ & $23,886,223$ & $2,584,568$ \\
\hline $2,822,460$ & 361,961 & $2,770,715$ & 51,754 & 560,907 & $5,336,627$ & 198,946 & $2,565,912$ & $20,675,855$ & $34,287,597$ & $52,871,629$ & $5,635,168$ \\
\hline $2,822,469$ & 361,961 & $2,770,715$ & 51,754 & 560,907 & $5,336,627$ & 198,946 & $2,565,912$ & $20,909,865$ & $34,669,324$ & $53,463,513$ & $5,661,028$ \\
\hline
\end{tabular}


A SUPERPOWER SYSTEM FOR THE REGION BETWEEN BOSTON AND WASHINGTON.

TABLE 46.--Mechanical power-supply.equipment and fuel

[Data from census of

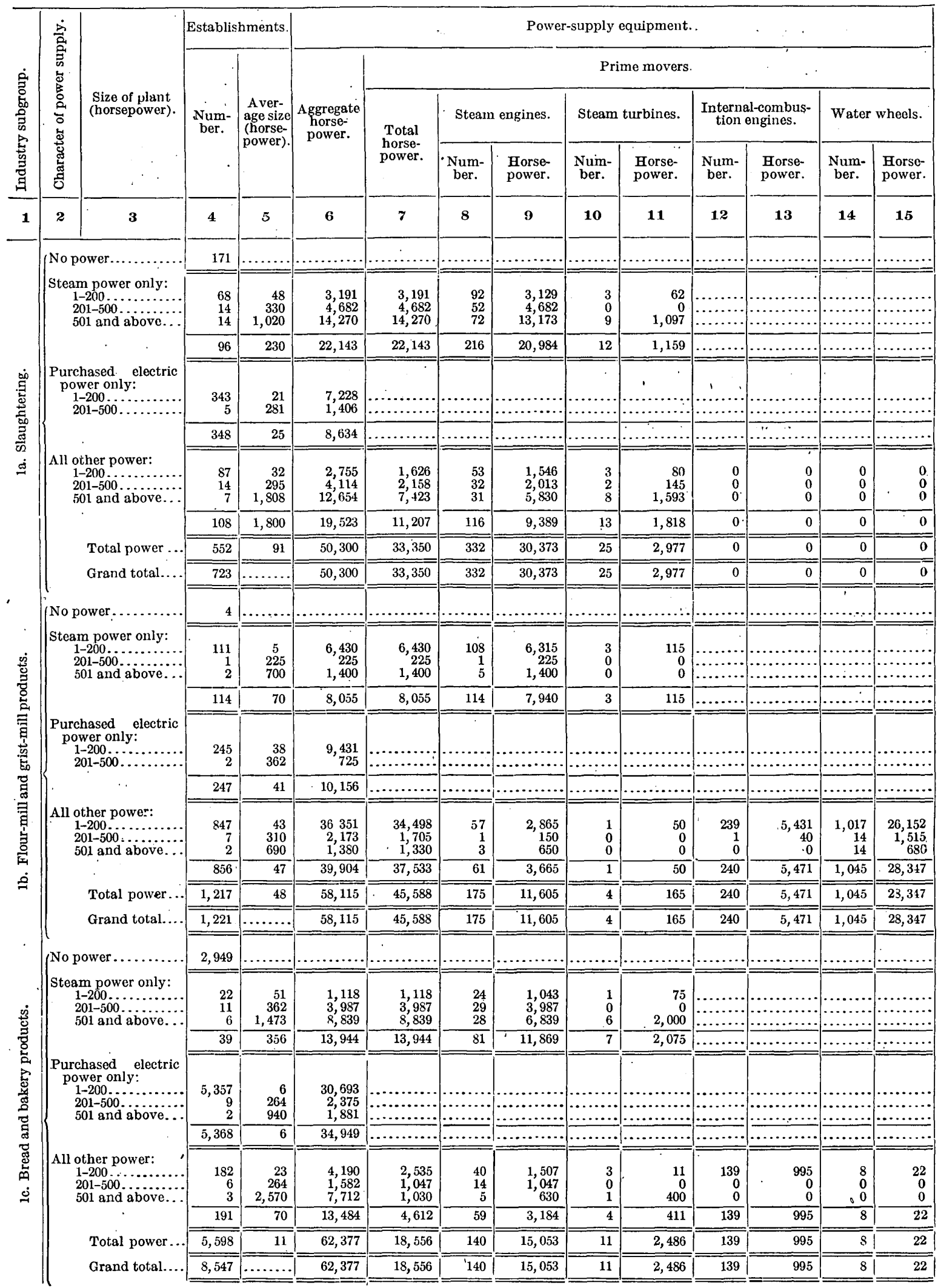


used by industry subgroups, by character of power supply.

manufuctures, 1919.]

\begin{tabular}{|c|c|c|c|c|c|c|c|c|c|c|c|}
\hline \multirow{2}{*}{\multicolumn{4}{|c|}{$\frac{\text { Power-supply oquipment-Continued. }}{\text { Operated by purchased energy. }}$}} & \multicolumn{4}{|c|}{ Electric motors. } & \multicolumn{4}{|c|}{ Fuel used. } \\
\hline & & & & \multirow{2}{*}{\multicolumn{2}{|c|}{ Total. }} & \multirow{2}{*}{\multicolumn{2}{|c|}{$\begin{array}{l}\text { Run by current gen- } \\
\text { erated in establish- } \\
\text { ment. }\end{array}$}} & \multicolumn{3}{|c|}{ Coal. } & \multirow{3}{*}{$\begin{array}{l}\text { Coke } \\
\text { (short } \\
\text { tons). }\end{array}$} \\
\hline \multirow{2}{*}{$\begin{array}{c}\text { Total } \\
\text { horsepowor. }\end{array}$} & \multicolumn{2}{|c|}{ Electric motors. } & \multirow{2}{*}{$\begin{array}{l}\text { Other } \\
\text { (horse- } \\
\text { power). }\end{array}$} & & & & & \multirow{2}{*}{$\begin{array}{l}\text { Anthracite } \\
\text { (long tons). }\end{array}$} & \multirow{2}{*}{$\begin{array}{l}\text { Bitumi- } \\
\text { nouss (short } \\
\text { tons). }\end{array}$} & \multirow{2}{*}{$\begin{array}{l}\text { Total } \\
\text { equivalent } \\
\text { bitumi- } \\
\text { nous (short } \\
\text { tons). }\end{array}$} & \\
\hline & Number. & $\begin{array}{l}\text { Horso- } \\
\text { power. }\end{array}$ & & Number. & $\begin{array}{l}\text { Horse- } \\
\text { power. }\end{array}$ & Number. & $\begin{array}{l}\text { Horse- } \\
\text { power. }\end{array}$ & & & & \\
\hline 16 & 17 & 18 & 19 & 20 & 21 & 22 & 23 & 24 & 25 & 26 & 27 \\
\hline & & & & & & & & 467 & 548 & 978 & $\therefore 0$ \\
\hline & & & & $\begin{array}{r}81 \\
202 \\
574\end{array}$ & $\begin{array}{r}703 \\
2,284 \\
6,608\end{array}$ & $\begin{array}{r}81 \\
202 \\
574\end{array}$ & $\begin{array}{r}703 \\
2,284 \\
6,608\end{array}$ & $\begin{array}{l}14,496 \\
15,131 \\
81,593\end{array}$ & $\begin{array}{l}16,339 \\
38,365 \\
97,844\end{array}$ & $\begin{array}{r}29,389 \\
51,965 \\
171 ; 344\end{array}$ & $\begin{array}{r}47 \\
0 \\
7,358\end{array}$ \\
\hline$\ldots \ldots$ & $\ldots$ & & & 857 & 9,595 & 857 & 9,595 & 111,220 & 152,548 & 252,698 & 7,405 \\
\hline $\begin{array}{l}7,228 \\
1,406\end{array}$ & $\begin{array}{r}865 \\
90\end{array}$ & $\begin{array}{l}7,228 \\
1,406\end{array}$ & & $\begin{array}{r}865 \\
96\end{array}$ & $\begin{array}{l}7,228 \\
1,406\end{array}$ & & $\mid \ldots \ldots \ldots \ldots \ldots$ & $\begin{array}{r}4,372 \\
96\end{array}$ & $\begin{array}{l}7,380 \\
2,398\end{array}$ & $\begin{array}{r}11,310 \\
2,4 S 5\end{array}$ & $\begin{array}{r}126 \\
0\end{array}$ \\
\hline 8,634 & $96 \mathrm{~L}$ & 8,634 & & 961 & 8,634 & ... & & 4,468 & $9,778^{\circ}$ & 13,795 & 126 \\
\hline $\begin{array}{l}1,129 \\
1,956 \\
5,231\end{array}$ & $\begin{array}{r}93 \\
187 \\
447\end{array}$ & $\begin{array}{r}987 \\
1,956 \\
5,231\end{array}$ & $\begin{array}{r}142 \\
0 \\
0\end{array}$ & $\begin{array}{r}98 \\
227 \\
561\end{array}$ & $\begin{array}{l}1,001 \\
2,303 \\
6,517\end{array}$ & $\begin{array}{r}5 \\
40 \\
114\end{array}$ & $\begin{array}{r}14 \\
347 \\
1,286\end{array}$ & $\begin{array}{r}5,333 \\
14,049 \\
89,131\end{array}$ & $\begin{array}{l}12,375 \\
14,656 \\
26,949\end{array}$ & $\begin{array}{r}17,175 \\
27,256 \\
\cdot \quad 106,949\end{array}$ & $\begin{array}{r}106 \\
\cdots \cdots \\
\cdots \cdots\end{array}$ \\
\hline 8,316 & 727 & 8,174 & 142 & 886 & 9,821 & 159 & 1,647 & 108,513 & 53,980 & 151,380 & 103 \\
\hline 16,950 & 1,688 & 16,808 & 142 & 2,704 & 28,050 & 1,016 & 11,242 & 224,201 & 216,306 & 417,873 & 7,637 \\
\hline 16,950 & 1,688 & 16,808 & 142 & 2,704 & 28,050 & 1,016 & 11,242 & 224,668 & 216,854 & 418,851 & 7,637 \\
\hline & … & $\ldots \ldots \ldots \ldots$ & & $\cdots$ & $\ldots \ldots$ & & $\cdots$ & 0 & 0 & 0 & 0 \\
\hline & & & & $\begin{array}{r}2 \\
0 \\
13\end{array}$ & $\begin{array}{r}11 \\
0 \\
128\end{array}$ & $\begin{array}{r}2 \\
0 \\
13\end{array}$ & $\begin{array}{r}11 \\
0 \\
128\end{array}$ & $\begin{array}{r}8,896 \\
\quad 0 \\
7,500\end{array}$ & $\begin{array}{r}10,155 \\
1,050 \\
4,080\end{array}$ & $\begin{array}{r}18,145 \\
1,050 \\
10,830\end{array}$ & $\begin{array}{l}0 \\
0 \\
0\end{array}$ \\
\hline n......... & $\ldots \ldots \cdots$ & …......... & & 15 & 139 & 15 & 139 & 16,396 & 15,285 & 30,025 & 0 \\
\hline $\begin{array}{r}9,431 \\
725\end{array}$ & $\begin{array}{r}710 \\
31\end{array}$ & $\begin{array}{r}9,431 \\
725\end{array}$ & & $\begin{array}{r}710 \\
31\end{array}$ & $\begin{array}{r}9,431 \\
725\end{array}$ & & & $\begin{array}{r}670 \\
0\end{array}$ & $\begin{array}{r}602 \\
0\end{array}$ & $\begin{array}{r}1,205 \\
0\end{array}$ & $\begin{array}{l}4 \\
0\end{array}$ \\
\hline 10,156 & 741 & 10,156 & . & 741 & 10,156 & .... & ....... & 670 & 602 & 1,205 & 4 \\
\hline $\begin{array}{r}1,853 \\
468 \\
50\end{array}$ & $\begin{array}{r}107 \\
40 \\
1\end{array}$ & $\begin{array}{r}1,775 \\
468 \\
50\end{array}$ & $\begin{array}{r}78 \\
0 \\
0\end{array}$ & $\begin{array}{r}123 \\
79 \\
1 \\
\end{array}$ & $\begin{array}{r}1,996 \\
968 \\
50 \\
\end{array}$ & $\begin{array}{r}16 \\
39 \\
0\end{array}$ & $\begin{array}{r}221 \\
500 \\
0\end{array}$ & $\begin{array}{r}7,988 \\
49 \\
0\end{array}$ & $\begin{array}{r}3,993 \\
870 \\
362\end{array}$ & $\begin{array}{r}11,173 \\
.914 \\
363\end{array}$ & $\begin{array}{r}80 \\
\text { ? }\end{array}$ \\
\hline 2,371 & 148 & 2,293 & 78 & 203 & 3,014 & 55 & $\overline{721}$ & 8,037 & 5,225 & 12,450 & 8:) \\
\hline 12,527 & 889 & 12,449 & 78 & 959 & 13,309 & 70 & 860 & 25,103 & 21,112 & 43,680 & 81 \\
\hline 12,527 & 889 & 12,449 & 78 & 959 & 13,309 & 70 & 860 & 25,103 & 21,112 & 43,680 & 81 \\
\hline & & & & $\cdots$ & & & $\ldots$. & 90,662 & 8,137 & 89,637 . & 16.511 \\
\hline ....... & & & a........ & $\begin{array}{r}50 \\
353 \\
1,035 \\
\end{array}$ & $\begin{array}{r}355 \\
2,560 \\
5,812\end{array}$ & $\begin{array}{r}50 \\
353 \\
1,035\end{array}$ & $\begin{array}{r}355 \\
2,560 \\
5,812\end{array}$ & $\begin{array}{r}2,335 \\
18,634 \\
43,280\end{array}$ & $\begin{array}{l}13,040 \\
14,540 \\
13,268\end{array}$ & $\begin{array}{l}\mathrm{i} 5,140 \\
31,340 \\
52,268\end{array}$ & $\begin{array}{r}0 \\
3,775 \\
9 j 8\end{array}$ \\
\hline$\ldots \ldots \ldots \ldots$ & $\ldots \ldots \ldots$ & $\ldots \ldots \ldots \ldots$ & $\ldots \ldots \ldots$ & 1,438 & 8,727 & 1,438 & 8,727 & 64,249 & 40,848 & 98,748 & $\overline{4,743}$ \\
\hline $\begin{array}{r}30,693 \\
2,375 \\
1,881 \\
\end{array}$ & $\begin{array}{r}10,296 \\
425 \\
317 \\
\end{array}$ & $\begin{array}{r}30,693 \\
2,375 \\
1,881 \\
\end{array}$ & & $\begin{array}{r}10,296 \\
425 \\
317\end{array}$ & $\begin{array}{r}30,693 \\
2,375 \\
1,881\end{array}$ & & & $\begin{array}{r}261,464 \\
8,086 \\
5,715\end{array}$ & $\begin{array}{r}38,469 \\
2,077 \\
473\end{array}$ & $\begin{array}{r}273,469 \\
9,337 \\
5,623\end{array}$ & $\begin{array}{r}50,984 \\
1,168 \\
0\end{array}$ \\
\hline 34,949 & 11,038 & 34,949 & $\ldots$ & 11,038 & 34,949 & $\overline{\cdots \cdots}$ & $\ldots \ldots \ldots$ & 275,265 & $41 ; 019$ & 288,429 & 52,152 \\
\hline $\begin{array}{r}1,655 \\
535 \\
6,682\end{array}$ & $\begin{array}{r}340 \\
74 \\
277\end{array}$ & $\begin{array}{r}1,638 \\
535 \\
6,682\end{array}$ & $\begin{array}{r}17 \\
0 \\
0\end{array}$ & $\begin{array}{l}457 \\
124 \\
414\end{array}$ & $\begin{array}{r}2,113 \\
844 \\
7,329\end{array}$ & $\begin{array}{r}111 \\
50 \\
137\end{array}$ & $\begin{array}{l}475 \\
309 \\
647\end{array}$ & $\begin{array}{l}17,028 \\
12,082 \\
13,565\end{array}$ & $\begin{array}{r}10,580 \\
5,205 \\
8,320\end{array}$ & $\begin{array}{l}25,880 \\
16,105 \\
20,520\end{array}$ & $\begin{array}{r}1,699 \\
0 \\
1,858\end{array}$ \\
\hline 8,872 & 697 & $8,8 \overline{55}$ & $\overline{17}$ & $\overline{995}$ & 10,286 & $\overline{298}$ & 1,431 & 42,675 & 24,105 & 62,505 & 3,557 \\
\hline 43,821 & 11,735 & 43,804 & 17 & 13,471 & 53,962 & 1,736 & 10,158 & 382,189 & 105,972 & $449 ; 682$ & 60,452 \\
\hline 43,821 & 11,735 & 43,804 & 17 & 13,471 & 53,962 & 1,736 & 10,158 & 472,851 & 114,109 & 539,319 & 76,963 \\
\hline
\end{tabular}


TABLE 46.-Mechanical power-supply equipment and fuel used

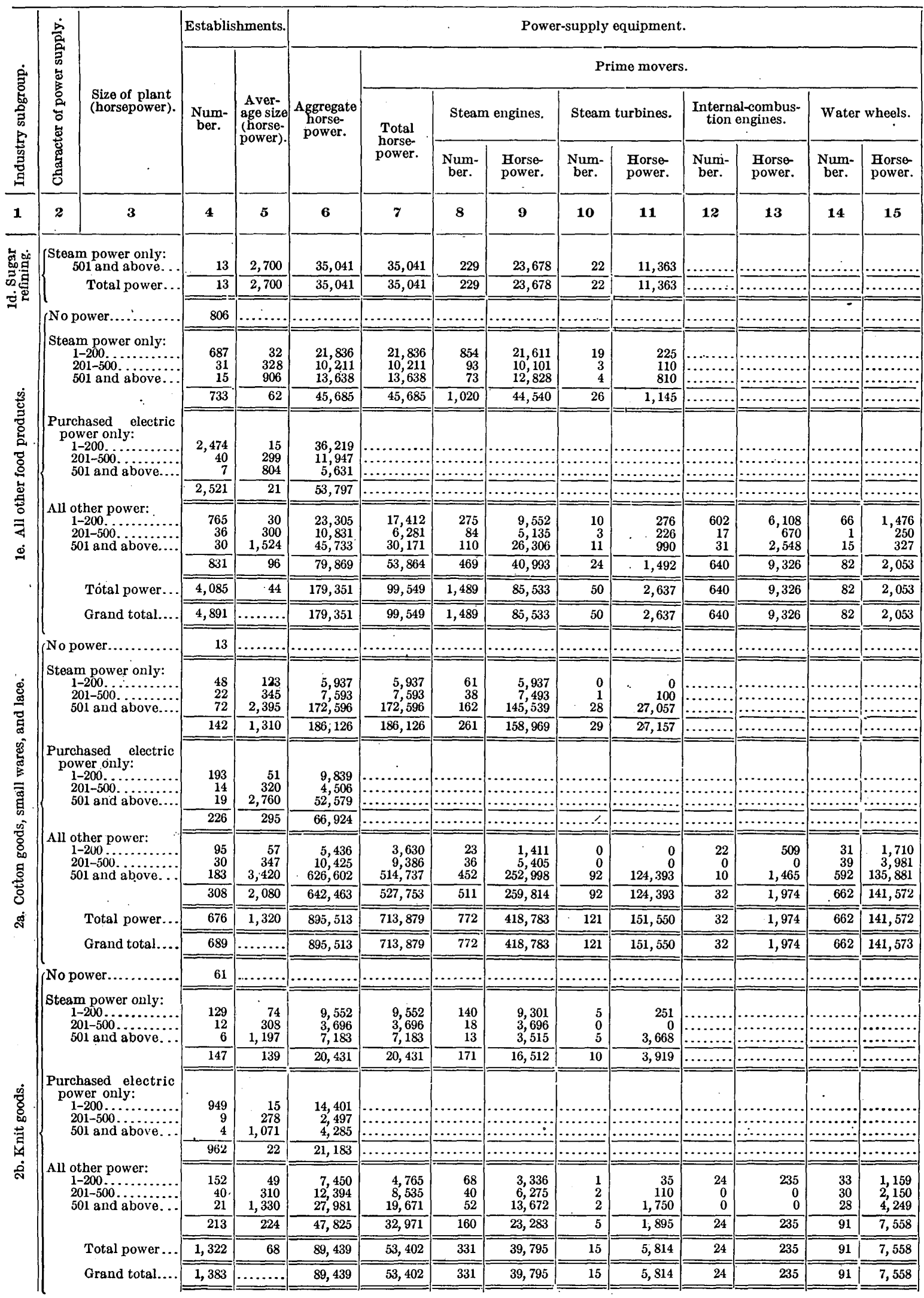


by industry subgroups, by character of poiwer supply-Continued.

\begin{tabular}{|c|c|c|c|c|c|c|c|c|c|c|c|}
\hline \multirow{2}{*}{\multicolumn{4}{|c|}{$\frac{\text { Power-supply equipment-Continued. }^{\cdots}}{\text { Operated by purchased energy. }}$}} & \multicolumn{4}{|c|}{ Electric motors. } & \multicolumn{4}{|c|}{ Fuel used. } \\
\hline & & & & \multirow{2}{*}{\multicolumn{2}{|c|}{ Total. }} & \multirow{2}{*}{\multicolumn{2}{|c|}{$\begin{array}{l}\text { Run by current gen- } \\
\text { erated in establish- } \\
\text { ment. }\end{array}$}} & \multicolumn{3}{|c|}{ Coal. } & \multirow{3}{*}{$\begin{array}{l}\text { Coke } \\
\text { (short } \\
\text { tons). }\end{array}$} \\
\hline \multirow{2}{*}{$\begin{array}{c}\text { Total } \\
\text { horsopower. }\end{array}$} & \multicolumn{2}{|c|}{ Electric motors. } & \multirow{2}{*}{$\begin{array}{l}\text { Other } \\
\text { (horse- } \\
\text { power). }\end{array}$} & & & & & \multirow{2}{*}{$\begin{array}{l}\text { Anthracite } \\
\text { (long tons) }\end{array}$} & \multirow{2}{*}{$\begin{array}{c}\text { Bitumi- } \\
\text { nous (short } \\
\text { tons). }\end{array}$} & \multirow{2}{*}{$\begin{array}{c}\text { Total } \\
\text { equivalent } \\
\text { bitumi- } \\
\text { nous (short } \\
\text { tons). }\end{array}$} & \\
\hline & Number. & $\begin{array}{l}\text { Horso- } \\
\text { power. }\end{array}$ & & Number. & $\begin{array}{l}\text { Horse- } \\
\text { power. }\end{array}$ & Number. & $\begin{array}{l}\text { Horse- } \\
\text { power. }\end{array}$ & & & & \\
\hline 16 & 17 & 18 & 19 & 20 & 21 & 22 & 23 & 24 & 25 & 26 & 27 \\
\hline & & & & 2,582 & 37,090 & 2,582 & 37,090 & 406,248 & 865,118 & $1,231,118$ & 180 \\
\hline$\ldots \ldots \ldots$ & $\ldots \ldots \ldots$ & $\overline{\ldots \ldots \ldots \ldots}$ & $\ldots \ldots \ldots$ & 2,582 & 37,090 & 2,582 & 37,090 & 406,248 & 865,118 & $1,231,118$ & 780 \\
\hline & $\cdots$ & ............. & .......... & $\ldots \ldots$ & .......... & $\ldots \ldots \ldots$ & .......... & 4,330 & 12,777 & 16,674 & 431 \\
\hline & & T.ma & $\cdots$ & $\begin{array}{r}493 \\
562 \\
\end{array}$ & $\begin{array}{r}2,558 \\
3,371\end{array}$ & $\begin{array}{r}493 \\
-\quad 562 \\
154\end{array}$ & $\begin{array}{r}2,558 \\
3,371 \\
\end{array}$ & $\begin{array}{l}40,226 \\
14,988\end{array}$ & $\begin{array}{r}104,951 \\
42,175 \\
22,864\end{array}$ & $\begin{array}{r}141,158 \\
55,675 \\
83\end{array}$ & $\begin{array}{l}281 \\
991\end{array}$ \\
\hline$\overline{\ldots \ldots \ldots}$ & 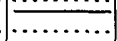 & ……......... & …....... & $\frac{1,076}{2,602}$ & 17,822 & 2,602 & $\frac{11,893}{17,822}$ & $\frac{67,331}{122,545}$ & $\frac{22,804}{169,990}$ & $\frac{83,461}{280,294}$ & $\frac{x v 0}{1,692}$ \\
\hline $\begin{array}{r}3,6219 \\
11,947 \\
5,631\end{array}$ & $\begin{array}{l}7,910 \\
1,420 \\
708\end{array}$ & $\begin{array}{r}36,219 \\
11,947 \\
5,631\end{array}$ & ...... & $\begin{array}{l}7,910 \\
1,420 \\
708\end{array}$ & $\begin{array}{r}36,219 \\
11,947 \\
5,631\end{array}$ & . & & $\begin{array}{r}43,464 \\
9,553 \\
1,914\end{array}$ & $\begin{array}{r}50,252 \\
19,746 \\
4,957\end{array}$ & $\begin{array}{r}89,365 \\
28,345 \\
6,679\end{array}$ & $\begin{array}{r}1,739 \\
1,457 \\
0\end{array}$ \\
\hline 53,797 & 10,038 & 53,797 & $\ldots \ldots \ldots$ & 10,038 & 53,797 & $\overline{\ldots \ldots \ldots \ldots \ldots}$ & $\ldots \ldots \ldots$ & 54,931 & 74,955 & 124,389 & $\overline{3,196}$ \\
\hline $\begin{array}{r}5,893 \\
4,550 \\
15,562 \\
\end{array}$ & $\begin{array}{r}1,138 \\
515 \\
1,812\end{array}$ & $\begin{array}{r}5,387 \\
4,190 \\
15,562\end{array}$ & $\begin{array}{r}506 \\
360 \\
0\end{array}$ & $\begin{array}{l}1,228 \\
802 \\
3,457\end{array}$ & $\begin{array}{r}6,014 \\
5,482 \\
31,487\end{array}$ & $\begin{array}{r}90 \\
287 \\
1,645\end{array}$ & $\begin{array}{r}627 \\
1,292 \\
15,925\end{array}$ & $\begin{array}{r}23,631 \\
12,957 \\
168,572\end{array}$ & $\begin{array}{r}61,596 \\
41,334 \\
124,850\end{array}$ & $\begin{array}{r}82,854 \\
53,000 \\
276,563\end{array}$ & $\begin{array}{r}115 \\
16 \\
64\end{array}$ \\
\hline 26,005 & 3,465 & 25,139 & $\overline{866}$ & 5,487 & 42,983 & 2,022 & 17,844 & 205,150 & 227,780 & 412,417 & 195 \\
\hline 79,802 & 13,503 & 78,936 & 866 & 18,127 & 114,602 & 4,624 & 35,666 & 382,626 & 472,725 & 817,100 & 5,083 \\
\hline \multirow{4}{*}{79,802} & 13,503 & 78,936 & 866 & 18,127 & 114,602 & 4,624 & 35,666 & 386,956 & 485,502 & 833,774 & 5,514 \\
\hline & & & & & & & & 0 & $.1,648$ & 1,648 & 0 \\
\hline & & $\ldots \ldots \ldots \ldots \ldots$ & & $\begin{array}{r}133 \\
181 \\
3,347 \\
\end{array}$ & $\begin{array}{r}787 \\
1,749 \\
46,366\end{array}$ & $\begin{array}{r}133 \\
181 \\
3,347\end{array}$ & $\begin{array}{r}787 \\
1,749 \\
46,366\end{array}$ & $\begin{array}{r}14,355 \\
7,732 \\
99,563\end{array}$ & $\begin{array}{r}23,777 \\
28,036 \\
410,178\end{array}$ & $\begin{array}{r}36,877 \\
34,996 \\
499,678\end{array}$ & $\begin{array}{r}350 \\
0 \\
13,982\end{array}$ \\
\hline & $\ldots \ldots \ldots \ldots$ & …......... & $\begin{array}{ll}\ldots \ldots \ldots \\
\ldots \ldots \ldots \ldots\end{array}$ & 3,661 & 48,902 & 3,661 & 48,902 & 121,650 & 461,991 & 571,351 & 14,332 \\
\hline $\begin{array}{r}0,839 \\
4,506 \\
52,579 \\
\end{array}$ & $\begin{array}{r}2,227 \\
865 \\
3,629 \\
\end{array}$ & $\begin{array}{r}9,839 \\
4,506 \\
52,579\end{array}$ & & $\begin{array}{r}2,227 \\
865 \\
3,629 \\
\end{array}$ & $\begin{array}{r}9,839 \\
4,506 \\
52,579 \\
\end{array}$ & & & $\begin{array}{r}3,901 \\
\cdot 1,794 \\
4,891 .\end{array}$ & $\begin{array}{r}12,108 \\
7,163 \\
14,501\end{array}$ & $\begin{array}{r}15,608 \\
8,783 \\
18,901\end{array}$ & $\begin{array}{r}399 \\
0 \\
0\end{array}$ \\
\hline 66,924 & 6,721 & 66,924 & & 6,721 & 66,924 & ....... & …..... & 10,586 & 33,772 & 43,292 & 399 \\
\hline $\begin{array}{r}1,806 \\
1,039 \\
111,865\end{array}$ & $\begin{array}{r}75 \\
67 \\
10,250\end{array}$ & $\begin{array}{r}723 \\
1,039 \\
111,470\end{array}$ & $\begin{array}{r}1,083 \\
.0 \\
395\end{array}$ & $\begin{array}{r}99 \\
236 \\
20,259\end{array}$ & $\begin{array}{r}8988 \\
2,256 \\
267,788\end{array}$ & $\begin{array}{r}24 \\
169 \\
10,009\end{array}$ & $\begin{array}{r}175 \\
1,217 \\
156,318\end{array}$ & $\begin{array}{r}2,178 \\
7,305 \\
166,061\end{array}$ & $\begin{array}{r}14,601 \\
33,930 \\
1,137,722\end{array}$ & $\begin{array}{r}16,551 \\
40,501 \\
1,278,722\end{array}$ & $\begin{array}{r}1 \\
0 \\
1,694\end{array}$ \\
\hline 114,710 & 10,392 & 113,232 & 1,478 & 20,594 & 270,942 & $\because \quad 10,202$ & 157,710 & 175,544 & $1,186,253$ & $1,335,774$ & 1,695 \\
\hline 181,034 & 17,113 & 180,156 & 1,478 & 30,976 & 386,768 & 13,863 & $\overline{206,612}$ & 307,780 & $1,682,016$ & $1,950,417$ & 16,426 \\
\hline 181,634 & 17,113 & 180,156 & 1,478 & 30,976 & 386,768 & 13,863 & 206,612 & 307,780 & $1,683,664$ & $1,952,065$ & 16,426 \\
\hline & & & & & & & & 193 & 201 & 374 & 0 \\
\hline$\cdots$ & ……, & 1 & {$[\ldots \ldots, \ldots$} & $\begin{array}{l}642 \\
555 \\
814\end{array}$ & $\begin{array}{l}2,937 \\
1,576 \\
4,747\end{array}$ & $\begin{array}{l}642 \\
555 \\
814\end{array}$ & $\begin{array}{l}2,937 \\
1,576 \\
4,747\end{array}$ & $\begin{array}{l}22,773 \\
10,1133 \\
17,694\end{array}$ & $\begin{array}{l}42,714 \\
10,446 \\
20,390\end{array}$ & $\begin{array}{l}63,114 \\
19,546 \\
36,290\end{array}$ & $\begin{array}{r}43 \\
0 \\
74\end{array}$ \\
\hline …... & …....... & 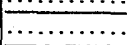 & $\mid \cdots \ldots \ldots$ & 2,011 & 9,260 & 2,011 & 9,260 & 50,630 & 73,550 & 118,950 & 117 \\
\hline $\begin{array}{r}14,401 \\
2,497 \\
4,285\end{array}$ & $\begin{array}{r}3,885 \\
526 \\
338\end{array}$ & $\begin{array}{r}14,401 \\
2,4997 \\
4,285\end{array}$ & & $\begin{array}{r}3,885 \\
526 \\
338\end{array}$ & $\begin{array}{r}14,401 \\
2,497 \\
4,285\end{array}$ & & & $\begin{array}{r}16,698 \\
900 \\
0\end{array}$ & $\begin{array}{r}40,666 \\
2,892 \\
7,696\end{array}$ & $\begin{array}{r}55,666 \\
3,702 \\
7,696\end{array}$ & $\begin{array}{r}41 \\
0 \\
0\end{array}$ \\
\hline 21,183 & 4,749 & 21,183 & $\therefore \ldots \ldots \ldots$ & 4,749 & 21,183 & $\cdots$ & ........ & 17,598 & 51,254 & 67,064 & $\overline{41}$ \\
\hline $\begin{array}{l}2,685 \\
3,859 \\
8,310\end{array}$ & $\begin{array}{l}337 \\
274 \\
820\end{array}$ & $\begin{array}{l}1,422 \\
3,084 \\
8,310\end{array}$ & $\begin{array}{r}1,263 \\
775 \\
0\end{array}$ & $\begin{array}{r}496 \\
413 \\
1,094\end{array}$ & $\begin{array}{r}2,346 \\
4,665 \\
11,544\end{array}$ & $\begin{array}{l}159 \\
139 \\
274\end{array}$ & $\begin{array}{r}924 \\
1,581 \\
3,234\end{array}$ & $\begin{array}{l}6,024 \\
9,034 \\
5,522\end{array}$ & $\begin{array}{l}19,743 \\
44,448 \\
83,973\end{array}$ & $\begin{array}{l}25,143 \\
52,548 \\
88,933\end{array}$ & $\begin{array}{l}0 \\
0 \\
0\end{array}$ \\
\hline 14,854 & 1,431 & 12,816 & $\overline{2,038}$ & 2,003 & 18,555 & 572 & 5,739 & 20,580 & 166,624 & 166,624 & $\overline{0}$ \\
\hline 36,037 & 6,180 & 33,999 & 2,038 & 8,763 & 48,998 & 2,583 & 14,999 & 88,808 & 272,968 & 352,636 & 158 \\
\hline 36,037 & 6,180 & 33,999 & 2,038 & 8,763 & 48,998 & $\overrightarrow{2,583}$ & 14,999 & 89,001 & 273,169 & 353,012 & $\overline{158}$ \\
\hline
\end{tabular}


TABLE 46.-Mechanical power-supply'equipment and fuel used

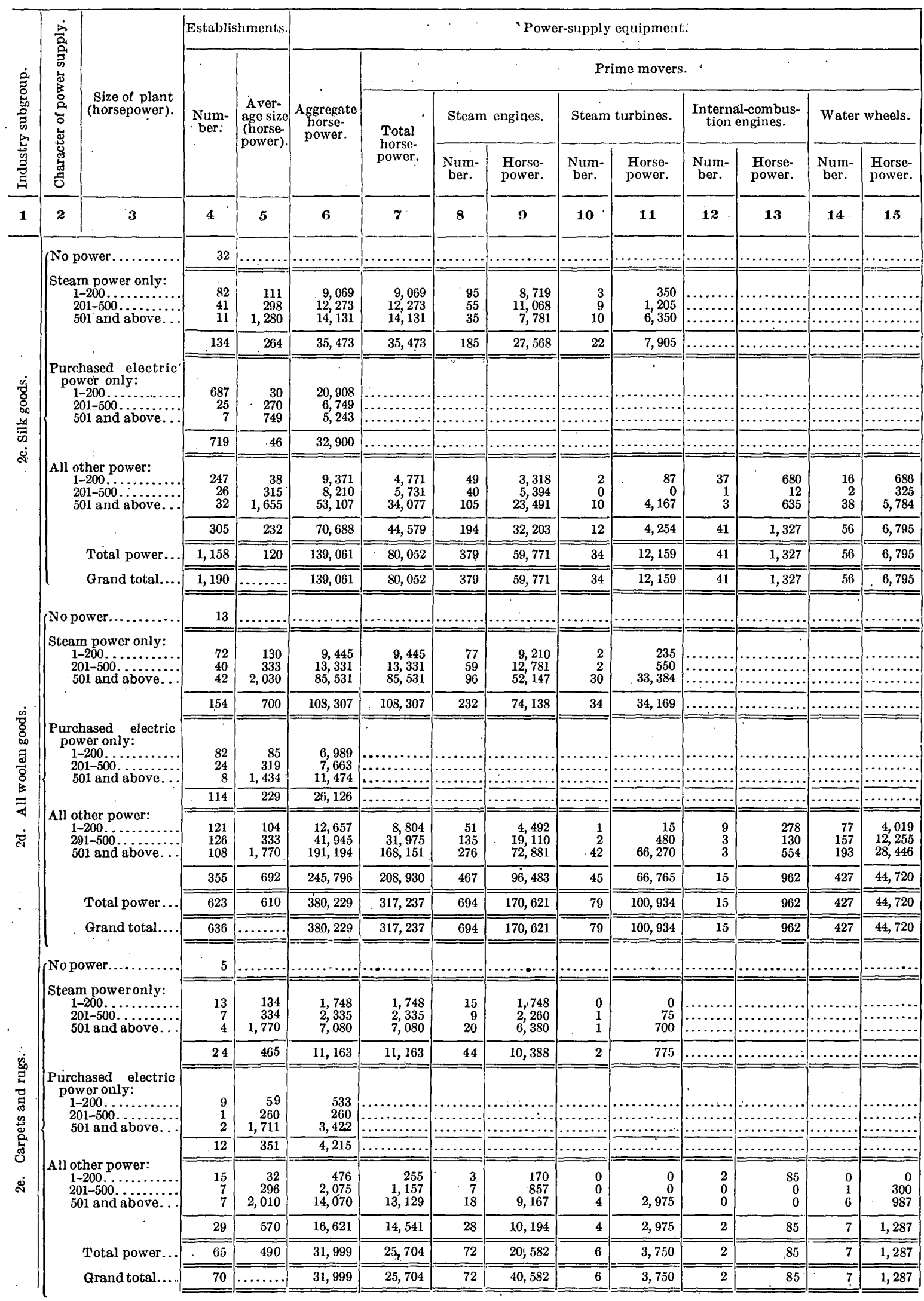


by industry subgroups, by character of power supply-Continued.

\begin{tabular}{|c|c|c|c|c|c|c|c|c|c|c|c|}
\hline \multirow{2}{*}{\multicolumn{4}{|c|}{$\frac{\text { Power-supply oquipment-Continued. }}{\text { Operated by purchased energy. }}$}} & \multicolumn{4}{|c|}{ Electric motors. } & \multicolumn{4}{|c|}{ Fuel used. } \\
\hline & & & & \multirow{2}{*}{\multicolumn{2}{|c|}{ Total. }} & \multirow{2}{*}{\multicolumn{2}{|c|}{$\begin{array}{l}\text { Run by current gen- } \\
\text { erated in establish- } \\
\text { ment. }\end{array}$}} & \multirow{3}{*}{$\begin{array}{l}\text { Anthracite } \\
\text { (long tons): }\end{array}$} & \multicolumn{2}{|l|}{ Coal. } & \multirow{3}{*}{$\begin{array}{l}\text { Coke } \\
\text { (short } \\
\text { tons). }\end{array}$} \\
\hline \multirow{2}{*}{$\begin{array}{c}\text { Total } \\
\text { horsepower. } \\
.\end{array}$} & \multicolumn{2}{|c|}{ Electric motors. } & \multirow{2}{*}{$\begin{array}{l}\text { Other } \\
\text { (horse- } \\
\text { power). }\end{array}$} & & & & & & & & \\
\hline & Number. & $\begin{array}{l}\text { Horso- } \\
\text { power. }\end{array}$ & & Number. & $\begin{array}{l}\text { Horse- } \\
\text { power. }\end{array}$ & Number. & $\begin{array}{l}\text { Horse- } \\
\text { power. }\end{array}$ & & tons). & $\begin{array}{c}\text { nous (short } \\
\text { tons). }\end{array}$ & \\
\hline 16 & 17 & 18 & 19 & 20 & 21 & 22 & 23 & 24 & 25 & 26 & 27 \\
\hline \multirow[t]{3}{*}{ …........ } & ........... & $\ldots \ldots \ldots \ldots$ & …......... & …... & … & & & $=$ & & & \\
\hline & & & & $\begin{array}{r}473 \\
1,741 \\
4,880\end{array}$ & $\begin{array}{r}1,803 \\
3,199 \\
10,263\end{array}$ & $\begin{array}{r}473 \\
1,741 \\
4,880\end{array}$ & $\begin{array}{r}1,803 \\
3,199 \\
. \quad 10,263\end{array}$ & $\begin{array}{l}32,182 \\
46,048 \\
27,226\end{array}$ & $\begin{array}{l}21,020 \\
13,799 \\
17,244\end{array}$ & $\begin{array}{l}49,820 \\
55,099 \\
41,644\end{array}$ & $\begin{array}{r}260 \\
0 \\
0\end{array}$ \\
\hline & & & ....... & 7,094 & 15,265 & 7,094 & 15,265 & 105,456 & 52,063 & 146,563 & 260 \\
\hline $\begin{array}{r}20,908 \\
6,749 \\
5,243\end{array}$ & $\begin{array}{l}7,348 \\
2,169 \\
1,214\end{array}$ & $\begin{array}{r}20,908 \\
6,749 \\
5,243\end{array}$ & & $\begin{array}{l}7,348 \\
2,169 \\
1,214\end{array}$ & $\begin{array}{r}20,909 \\
6,749 \\
5,243\end{array}$ & & ....... & $\begin{array}{r}23,446 \\
7,212 \\
2,708\end{array}$ & $\begin{array}{l}7,672 \\
2,434 \\
5,584\end{array}$ & $\begin{array}{r}28,672 \\
8,934 \\
8,014\end{array}$ & $\begin{array}{r}27 \\
0 \\
0\end{array}$ \\
\hline 32,900 & 10,731 & 32,900 & …........ & 10,731 & 32,900 & ......... & …......... & 33,366 & 15,690 & 45,620 & 27 \\
\hline $\begin{array}{r}4,600 \\
2,479 \\
10,030\end{array}$ & $\begin{array}{r}383 \\
569 \\
5,311\end{array}$ & $\begin{array}{r}1,615 \\
2,479 \\
19,030\end{array}$ & $\begin{array}{r}2,985 \\
0 \\
0\end{array}$ & $\begin{array}{r}557 \\
812 \\
6,437\end{array}$ & $\begin{array}{r}2,130 \\
3,008 \\
28,912\end{array}$ & $\begin{array}{r}174 \\
243 \\
1,126\end{array}$ & $\begin{array}{r}515 \\
.529 \\
9,882\end{array}$ & $\begin{array}{l}15,008 \\
22,074 \\
82,636\end{array}$ & $\begin{array}{r}8,847 \\
12,570 \\
99,148\end{array}$ & $\begin{array}{r}22,347 \\
32,370 \\
173,648\end{array}$ & $\begin{array}{r}96 \\
0 \\
0\end{array}$ \\
\hline 26,109 & 0,263 & 23,124 & 2,985 & 7,806 & 34,050 & 1,543 & 10,926 & 119,718 & 120,565 & 120,565 & 228.365 \\
\hline 59,009 & 16,994 & 56,024 & 2,985 & 25,631 & 82,215 & 8,637 & 26,191 & 258,540 & 188,318 & 420,548 & 383 \\
\hline 59,009 & 16,994 & 56,024 & 2,985 & 25,631 & 82,215 & 8,637 & $\overline{26,191}$ & 258,569 & 188,958 & 421,214 & 383 \\
\hline \multirow[t]{3}{*}{$\ldots \ldots \ldots \ldots$} & & & & & …...... & ….... & & . 10 & 1,060 & 1,069 & 0 \\
\hline & & & & $\begin{array}{r}94 \\
439 \\
2,589\end{array}$ & $\begin{array}{r}521 \\
2,435 \\
51,771 \\
\end{array}$ & $\begin{array}{r}94 \\
439 \\
2,589\end{array}$ & $\begin{array}{r}521 \\
2,435 \\
51,771\end{array}$ & $\begin{array}{r}7,930 \\
21,367 \\
64,154\end{array}$ & $\begin{array}{r}60,097 \\
69,, 234 \\
268,567\end{array}$ & $\begin{array}{r}67,247 \\
88,434 \\
326,267\end{array}$ & $\begin{array}{r}45 \\
0 \\
0\end{array}$ \\
\hline & ............ & …............ & $\ldots \ldots \ldots$ & 3,122 & 54,727 & 3,122 & 54,727 & 93,154 & 397,898 & 481,948 & $\overline{45}$ \\
\hline $\begin{array}{r}6,989 \\
7,663 \\
11,474 \\
\end{array}$ & $\begin{array}{l}912 \\
588 \\
899 \\
\end{array}$ & $\begin{array}{r}0,989 \\
7,663 \\
11,474 \\
\end{array}$ & ….......... & $\begin{array}{l}912 \\
588 \\
899 \\
\end{array}$ & $\begin{array}{r}6,989 \\
7,663 \\
11,474 \\
\end{array}$ & & & $\begin{array}{r}1,689 \\
1,768 \\
550 \\
\end{array}$ & $\begin{array}{l}14,250 \\
14,171 \\
23,851\end{array}$ & $\begin{array}{l}15,770 \\
15,761 \\
24,301\end{array}$ & $\begin{array}{r}2 \\
877 \\
0\end{array}$ \\
\hline 26,126 & 2,309 & 26,126 & $\ldots \ldots \ldots$ & 2,399 & 26,126 & …..... & …... & 4,007 & 52,272 & 55,832 & .879 \\
\hline $\begin{array}{r}3,853 \\
9,970 \\
23,043\end{array}$ & $\begin{array}{r}219 \\
968 \\
2,150\end{array}$ & $\begin{array}{r}2,290 \\
9,420 \\
23,043\end{array}$ & $\begin{array}{r}1,563 \\
550 \\
0\end{array}$ & $\begin{array}{r}382 \\
1,433 \\
8,140\end{array}$ & $\begin{array}{r}2,834 \\
14,212 \\
93,264\end{array}$ & $\begin{array}{r}163 \\
465 \\
5,990\end{array}$ & $\begin{array}{r}544 \\
4,792 \\
70,221\end{array}$ & $\begin{array}{r}2,054 \\
12,327 \\
69,663\end{array}$ & $\begin{array}{r}37,083 \\
168,116 \\
553,688\end{array}$ & $\begin{array}{r}38,933 \\
179,216 \\
616,488\end{array}$ & $\begin{array}{r}550 \\
434 \\
86\end{array}$ \\
\hline 36,866 & 3,337 & 34,753 & 2,113 & 9,955 & 110,310 & 6,618 & 75,557 & 84,044 & 758,887 & 834,637 & 1,070 \\
\hline 62,992 & 5,736 & 60,879 & 2,113 & 15,476 & 191,163 & 9,740 & 130,284 & 181,502 & $1,209,057$ & $1,372,417$ & $\overline{1,994}$ \\
\hline \multirow[t]{2}{*}{62,092} & 5,736 & 60,879 & 2,113 & 15,476 & 191,163 & 9,740 & 130,284 & 181,512 & $1,210,117$ & $1,373,480$ & 1,994 \\
\hline & & & …........ & & ................ & $\begin{array}{c}1 \\
\ldots \ldots \ldots \ldots \\
\end{array}$ & & 178 & 7,054 & 7,212 & 0 \\
\hline & & & & $\begin{array}{r}37 \\
103 \\
388\end{array}$ & $\begin{array}{r}426 \\
524 \\
3,494\end{array}$ & $\begin{array}{r}37 \\
103 \\
388\end{array}$ & $\begin{array}{r}426 \\
524 \\
3,494\end{array}$ & $\begin{array}{r}1,759 \\
5,712 \\
19,610\end{array}$ & $\begin{array}{r}11,312 \\
7,096 \\
23,841\end{array}$ & $\begin{array}{l}12,892 \\
12,244 \\
41,441\end{array}$ & $\begin{array}{l}0 \\
0 \\
0\end{array}$ \\
\hline ........ & .... & & & 528 & 4,444 & 528 & 4,444 & 27,081 & 42,249 & 66,579 & 0 \\
\hline $\begin{array}{r}533 \\
260 \\
3,422\end{array}$ & $\begin{array}{r}68 \\
97 \\
212\end{array}$ & $\begin{array}{r}533 \\
260 \\
3,422\end{array}$ & 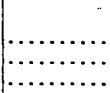 & $\begin{array}{r}68 \\
97 \\
212\end{array}$ & $\begin{array}{r}533 \\
260 \\
3,422\end{array}$ & & ……... & $\begin{array}{r}119 \\
0 \\
0\end{array}$ & $\begin{array}{r}5,424 \\
497 \\
35,804\end{array}$ & $\begin{array}{r}5,531 \\
497 \\
35,804\end{array}$ & $\begin{array}{l}0 \\
0 \\
0\end{array}$ \\
\hline$\overline{4,215}$ & 377 & 4,215 & $\overline{\ldots \ldots \ldots \ldots}$ & 377 & 4,215 & $\ldots \ldots \ldots \ldots$ & $\overline{\cdots \cdots \ldots \ldots \ldots}$ & $\overline{119}$ & 41,725 & 41,832 & $\overline{0}$ \\
\hline $\begin{array}{l}221 \\
918 \\
941\end{array}$ & $\begin{array}{r}22 \\
218 \\
30\end{array}$ & $\begin{array}{l}221 \\
918 \\
941\end{array}$ & $\begin{array}{l}0 \\
0 \\
0\end{array}$ & $\begin{array}{r}22 \\
223 \\
1,266\end{array}$ & $\begin{array}{r}221 \\
993 \\
8,958\end{array}$ & $\begin{array}{r}0 \\
5 \\
1,236\end{array}$ & $\begin{array}{r}0 \\
75 \\
8,017\end{array}$ & $\begin{array}{l}1,343 \\
1,140 \\
6,462\end{array}$ & $\begin{array}{r}1,364 \\
9,828 \\
123,232\end{array}$ & $\begin{array}{r}2,574 \\
10,858 \\
129,032\end{array}$ & $\begin{array}{r}0 \\
303 \\
0\end{array}$ \\
\hline 2,080 & 270 & 2,080 & 0 & 1,511 & 10,172 & 1,241 & 8,092 & 8,945 & 134,424 & 142,464 & 300 \\
\hline 6,295 & 647 & 6,295 & 0 & 2,416 & 18,831 & 1,769 & 12,536 & 36,145 & 218,398 & 250,875 & 330 \\
\hline 6,295 & 647 & 6,295 & $\overline{0}$ & 2,416 & 18,831 & 1,769 & 12,536 & 36,323 & 225,452 & 258,087 & 300 \\
\hline
\end{tabular}


TABLE 46.-Mechanical power-supply equipment and fuel used

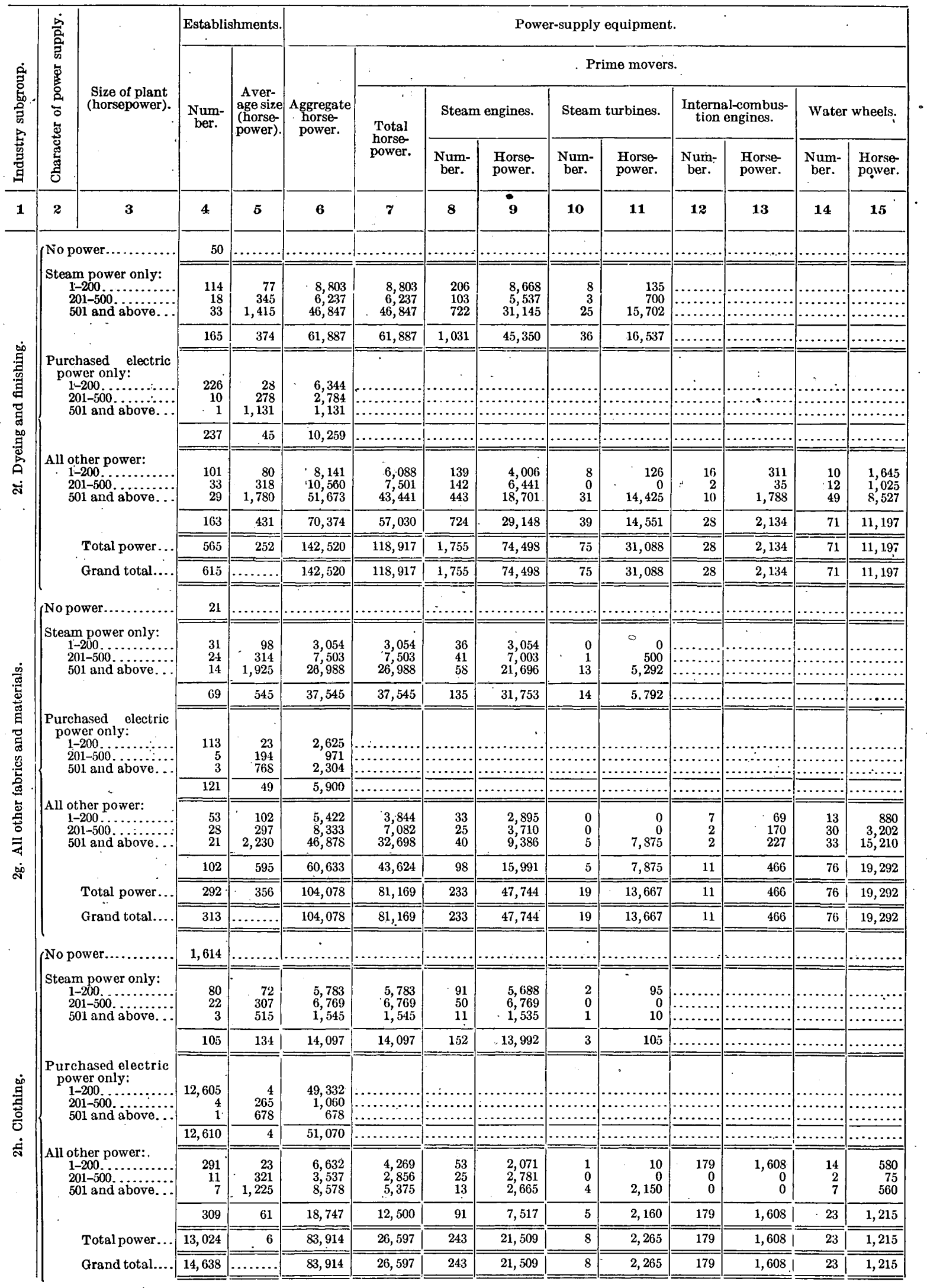


by industry subgroups, by character of power supply-Continued.

\begin{tabular}{|c|c|c|c|c|c|c|c|c|c|c|c|}
\hline \multirow{2}{*}{\multicolumn{4}{|c|}{$\frac{\text { Power-supply equipment-Continued. }}{\text {. Operated by purchased energy. }}$}} & \multicolumn{4}{|c|}{ Electric motors. } & \multicolumn{4}{|c|}{.. Fuel used. } \\
\hline & & & & \multirow{2}{*}{\multicolumn{2}{|c|}{ Total. }} & \multirow{2}{*}{\multicolumn{2}{|c|}{$\begin{array}{l}\text { Run by current gen- } \\
\text { erated in establish- } \\
\text { ment. }\end{array}$}} & \multicolumn{3}{|c|}{ Coal. } & \multirow{3}{*}{$\begin{array}{l}\text { Coke } \\
\text { (short } \\
\text { tons). }\end{array}$} \\
\hline \multirow{2}{*}{$\begin{array}{c}\text { Total } \\
\text { horsepower. }\end{array}$} & \multicolumn{2}{|c|}{ Electric motors. } & \multirow{2}{*}{$\begin{array}{l}\text { Other } \\
\text { (horse- } \\
\text { power). }\end{array}$} & & & & & \multirow{2}{*}{$\begin{array}{c}\text { Anthracite } \\
\text { (long tons) }\end{array}$} & \multirow{2}{*}{$\begin{array}{l}\text { Bitumi- } \\
\text { nous (short } \\
\text { tons). }\end{array}$} & \multirow{2}{*}{$\begin{array}{c}\text { Total } \\
\text { equivalent } \\
\text { bitumi- } \\
\text { nous (short } \\
\text { tons) }\end{array}$} & \\
\hline & Number. & $\begin{array}{l}\text { Horse- } \\
\text { power. }\end{array}$ & & Number. & $\begin{array}{l}\text { Horse- } \\
\text { power. }\end{array}$ & Number. & $\begin{array}{l}\text { Horse- } \\
\text { power. }\end{array}$ & & & & \\
\hline \multirow[t]{2}{*}{16} & 17 & 18 & 19 & 20 & 21 & 22 & 23 & 24 & 25 & 26 & 27 \\
\hline & & & & & & & & 653 & 6,546 & 7,088 & 0 \\
\hline & an........... & $\cdots$ & & $\begin{array}{r}233 \\
480 \\
2,931\end{array}$ & $\begin{array}{r}1,541 \\
2,596 \\
29,107\end{array}$ & $\begin{array}{r}233 \\
480 \\
2,931 \\
\end{array}$ & $\begin{array}{r}1,541 \\
2,596 \\
29,107\end{array}$ & $\begin{array}{r}37,950 \\
16,035 \\
218,474\end{array}$ & $\begin{array}{r}83,395 \\
53,452 \\
344,156\end{array}$ & $\begin{array}{r}117,395 \\
67,852 \\
540,156\end{array}$ & $\begin{array}{r}0 \\
0 \\
703\end{array}$ \\
\hline ......... & $\ldots \ldots \ldots$ & ........... & & 3,644 & 33,244 & 3,644 & 33,244 & 272,459 & 481,003 & 725,403 & 703 \\
\hline $\begin{array}{l}0,344 \\
2,784 \\
1,131\end{array}$ & $\begin{array}{r}1,524 \\
355 \\
62\end{array}$ & $\begin{array}{l}6,344 \\
2,784 \\
1,131 \\
\end{array}$ & & $\begin{array}{r}1,524 \\
355 \\
62 \\
\end{array}$ & $\begin{array}{l}6,344 \\
2,784 \\
1,131 \\
\end{array}$ & $\begin{array}{l}\cdots \ldots . . . \\
\cdots \ldots . . . . \\
\cdots \cdots . . . \\
\end{array}$ & & $\begin{array}{r}21,165 \\
3,188 \\
30\end{array}$ & $\begin{array}{r}41,451 \\
21,546 \\
8,980 \\
\end{array}$ & $\begin{array}{r}60,351 \\
24,406 \\
9,007 \\
\end{array}$ & $\begin{array}{r}226 \\
0 \\
0\end{array}$ \\
\hline 10,259 & 1,941 & 10,259 & .... & 1,941 & 10,259 & ......... & …........ & 24,383 & . 71,977 & 93,764 & 226 \\
\hline $\begin{array}{l}2,053 \\
3,059 \\
8,232\end{array}$ & $\begin{array}{l}298 \\
338 \\
792 \\
\end{array}$ & $\begin{array}{l}1,695 \\
2,839 \\
8,232\end{array}$ & $\begin{array}{l}358 \\
220\end{array}$ & $\begin{array}{r}351 \\
451 \\
2,297\end{array}$ & $\begin{array}{r}2,515 \\
3,817 \\
29,819\end{array}$ & $\begin{array}{r}53 \\
113 \\
1,505\end{array}$ & $\begin{array}{r}820 \\
978 \\
21,587\end{array}$ & $\begin{array}{l}21,300 \\
43,171 \\
67,535\end{array}$ & $\begin{array}{r}56,367 \\
58,249 \\
276,931\end{array}$ & $\begin{array}{r}75,467 \\
97,049 \\
337,531 \\
\end{array}$ & $\begin{array}{r}0 \\
91 \\
195 \\
\end{array}$ \\
\hline 13,344 & 1,428 & 12,766 & 578 & 3,099 & 36,151 & 1,671 & $23 ; 385$ & 132,006 & 391,547 & 510,047 & 286 \\
\hline 23,603 & 3,369 & 23,025 & 578 & 8,684 & 79,654 & 5,315 & 56,629 & 428,848 & 944,527 & $1,329,214$ & 1,215 \\
\hline 23,603 & 3,369 & 23,025 & 578 & 8,684 & 79,654 & 5,315 & 56,629 & 429,501 & 951,073 & $1,336,302$ & 1,215 \\
\hline & $\ldots \ldots \ldots \ldots$ & & & & & & & 1,078 & 0 & 970 & 6 \\
\hline & & & & $\begin{array}{r}8 \\
317 \\
1,100 \\
\end{array}$ & $\begin{array}{r}216 \\
1,957 \\
9,398 \\
\end{array}$ & $\begin{array}{r}8 \\
317 \\
1,100 \\
\end{array}$ & $\begin{array}{r}216 \\
1,957 \\
9,398 \\
\end{array}$ & $\begin{array}{r}6,003 \\
18,747 \\
58,195 \\
\end{array}$ & $\begin{array}{r}15,133 \\
29,347 \\
19,538 \\
\end{array}$ & $\begin{array}{l}20,535 \\
46,219 \\
71,918 \\
\end{array}$ & $\begin{array}{r}7 \\
0 \\
17,408 \\
\end{array}$ \\
\hline 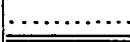 & $\ldots \ldots \ldots$ & $\ldots \ldots \ldots \ldots$ & & 1,425 & 11,571 & 1,425 & 11,571 & 82,945 & 64,018 & 138,672 & 17,415 \\
\hline $\begin{array}{r}2,625 \\
971 \\
2,304 \\
\end{array}$ & $\begin{array}{l}410 \\
116 \\
104 \\
\end{array}$ & $\begin{array}{r}2,625 \\
971 \\
2,304 \\
\end{array}$ & $\begin{array}{l}\cdots \cdot . \\
\cdots \cdots \cdot \\
\cdots \cdots \cdot \\
\end{array}$ & $\begin{array}{l}410 \\
116 \\
104 \\
\end{array}$ & $\begin{array}{r}2,625 \\
971 \\
2,304 \\
\end{array}$ & 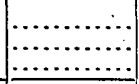 & 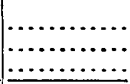 & $\begin{array}{r}1,613 \\
0 \\
0 \\
\end{array}$ & $\begin{array}{r}8,958 \\
\quad 2,487 \\
\quad 6,224 \\
\end{array}$ & $\begin{array}{r}10,409 \\
2,487 \\
6,224 \\
\end{array}$ & $\begin{array}{r}844 \\
0 \\
0 \\
\end{array}$ \\
\hline 5,900 & 630 & 5,900 & .... & 630 & 5,900 & $\ldots \ldots \ldots \ldots$ & $\ldots \ldots \ldots \ldots$ & 1,613 & 17,669 & 19,120 & 844 \\
\hline $\begin{array}{r}1,578 \\
1,251 \\
14,180 \\
\end{array}$ & $\begin{array}{r}181 \\
99 \\
559\end{array}$ & $\begin{array}{r}1,315 \\
1,251 \\
14,180 \\
\end{array}$ & $\begin{array}{r}263 \\
0 \\
0\end{array}$ & $\begin{array}{r}234 \\
136 \\
1,028 \\
\end{array}$ & $\begin{array}{r}1,463 \\
1,704 \\
29,045 \\
\end{array}$ & $\begin{array}{r}53 \\
37 \\
469 \\
\end{array}$ & $\begin{array}{r}148 \\
453 \\
14,865 \\
\end{array}$ & $\begin{array}{r}9,084 \\
2,695 \\
31,761 \\
\end{array}$ & $\begin{array}{l}21,795 \\
20,950 \\
48,918 \\
\end{array}$ & $\begin{array}{l}29,967 \\
23,330 \\
77,484 \\
\end{array}$ & $\begin{array}{r}237 \\
0 \\
0\end{array}$ \\
\hline 17,009 & 839 & 16,746 & 263 & 1,398 & 32,212 & 559 & 15,466 & 43,540 & 91,663 & 130,781 & 237 \\
\hline 22,009 & 1,469 & 22,646 & 263 & 3,453 & 49,683 & 1,984 & 27,037 & 128,098 & 173,350 & 288,573 & 18,496 \\
\hline 22,009 & 1,469 & 22,646 & 263 & 3,453 & 49,683 & 1,984 & 27,037 & 129,176 & 173,350 & 289,543 & 18,502 \\
\hline$\cdots$ & $\begin{array}{ll}\cdots \ldots \ldots \ldots \\
\end{array}$ & $\ldots \ldots \ldots \ldots$ & & ........ & & & & 2,282 & 415 & 2,465 & 15 \\
\hline & & & & $\begin{array}{r}482 \\
1,534 \\
294\end{array}$ & $\begin{array}{r}2,023 \\
2,662 \\
868\end{array}$ & $\begin{array}{r}482 \\
1,534 \\
294\end{array}$ & $\begin{array}{r}2,023 \\
2,662 \\
868\end{array}$ & $\begin{array}{r}17,978 \\
12,463 \\
572\end{array}$ & $\begin{array}{r}21,368 \\
20,437 \\
4,670\end{array}$ & $\begin{array}{r}37,568 \\
31,537 \\
5,185\end{array}$ & $\begin{array}{l}0 \\
0 \\
0\end{array}$ \\
\hline & 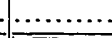 & $\quad \ldots \ldots \ldots \ldots$ & .............. & 2,310 & 5,553 & 2,310 & 5,553 & 31,013 & 46,475 & 74,290 . & $\mathbf{0}$ \\
\hline $\begin{array}{r}49,332 \\
1,060 \\
678 \\
\end{array}$ & $\begin{array}{r}39,645 \\
60 \\
49 \\
\end{array}$ & $\begin{array}{r}49,332 \\
1,060 \\
678 \\
\end{array}$ & $\begin{array}{l}\cdots \\
\cdots \\
\cdots\end{array}$ & $\begin{array}{r}39,645 \\
60 \\
49 \\
\end{array}$ & $\begin{array}{r}49,332 \\
1,060 \\
678 \\
\end{array}$ & & $\cdots$ & $\begin{array}{r}232,269 \\
511 \\
0\end{array}$ & $\begin{array}{r}20,474 \\
592 \\
0\end{array}$ & $\begin{array}{r}228,474 \\
1,052 \\
0 \\
\end{array}$ & $\begin{array}{r}8,964 \\
0 \\
0\end{array}$ \\
\hline 51,070 & 39,754 & 51,070 & $\begin{array}{c}\ldots \ldots \ldots \ldots \\
\end{array}$ & 39,754 & 51,070 & $\cdots \ldots \ldots \ldots \ldots$ & $\ldots \ldots \ldots \ldots$ & 232,780 & 21,066 & 229,526 & 8,964 \\
\hline $\begin{array}{r}2,363 \\
681 \\
3,203\end{array}$ & $\begin{array}{l}506 \\
189 \\
655\end{array}$ & $\begin{array}{r}1,602 \\
\dot{6} 681 \\
3,203\end{array}$ & $\begin{array}{r}761 \\
0 \\
0\end{array}$ & $\begin{array}{r}668 \\
426 \\
1,231\end{array}$ & $\begin{array}{l}2,133 \\
1,620 \\
6,328\end{array}$ & $\begin{array}{l}162 \\
237 \\
576 \\
\end{array}$ & $\begin{array}{r}531 \\
939 \\
3,125\end{array}$ & $\begin{array}{l}6,559 \\
3,505 \\
3,080\end{array}$ & $\begin{array}{l}11,449 \\
15,858 \\
34,883\end{array}$ & $\begin{array}{l}17,349 \\
19,008 \\
37,663\end{array}$ & $\begin{array}{r}369 \\
0 \\
0\end{array}$ \\
\hline 0,247 & 1,350 & 5,486 & 761 & 2,325 & 10,081 & 975 & 4,595 & 13,144 & 62,190 & 74,020 & 369 \\
\hline 57,317 & 41,104 & 56,556 & 761 & 44,389 & 66,704 & 3,285 & 10,148 & 276,937 & 129,731 & 377,836 & 9,333 \\
\hline 57,317 & 41,104 & 56,556 & 761 & 44,389 & 66,704 & 3,285 & 10,148 & 279,219 & 130,146 & 380,301 & 9,348 \\
\hline
\end{tabular}


TABLE 46.-Mechanical power-supply equipment and fuel used

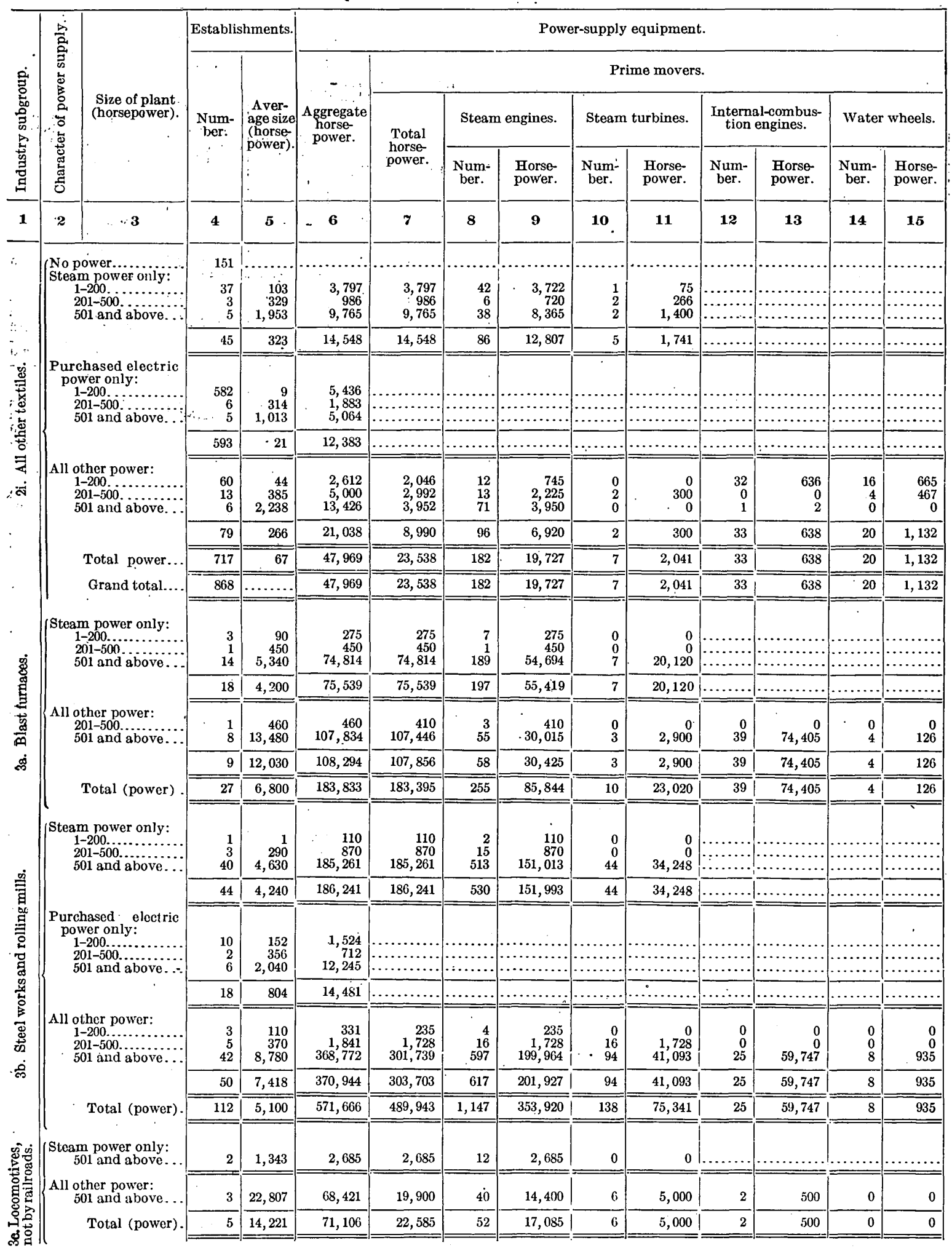


by industry subgroups, by character of power supply-Continued.

\begin{tabular}{|c|c|c|c|c|c|c|c|c|c|c|c|}
\hline \multirow{2}{*}{\multicolumn{4}{|c|}{$\begin{array}{c}\text { Power-supply equipment-Continued. } \\
\text { Operated by purchased energy. }\end{array}$}} & \multicolumn{4}{|c|}{ Electric motors. } & \multicolumn{4}{|c|}{ Fuel used. } \\
\hline & & & & \multirow{2}{*}{\multicolumn{2}{|c|}{ Total. }} & \multirow{2}{*}{\multicolumn{2}{|c|}{$\begin{array}{l}\text { Run by current gen- } \\
\text { erated in.establish- } \\
\text { ment. }\end{array}$}} & \multicolumn{3}{|c|}{ Coal. } & \multirow{3}{*}{$\begin{array}{l}\text { Coke } \\
\text { (short } \\
\text { tons). }\end{array}$} \\
\hline \multirow{2}{*}{$\begin{array}{c}\text { Total } \\
\text { horsepower. }\end{array}$} & \multicolumn{2}{|c|}{ Electric motors. } & \multirow{2}{*}{$\begin{array}{l}\text { Other } \\
\text { (horse- } \\
\text { power). }\end{array}$} & & & & & \multirow{2}{*}{$\begin{array}{l}\text { Anthracite } \\
\text { (long tons). }\end{array}$} & \multirow{2}{*}{$\begin{array}{l}\text { Bitumi- } \\
\text { nous (short } \\
\text { tons). }\end{array}$} & \multirow{2}{*}{$\begin{array}{c}\text { Total } \\
\text { equivalent } \\
\text { bitumi- } \\
\text { nous (short } \\
\text { tons). }\end{array}$} & \\
\hline & Number. & $\begin{array}{l}\text { Horse- } \\
\text { power. }\end{array}$ & & Number. & $\begin{array}{l}\text { Horse- } \\
\text { power. }\end{array}$ & Number. & $\begin{array}{l}\text { Horse- } \\
\text { power. }\end{array}$ & & & & \\
\hline \multirow[t]{4}{*}{10} & 17 & 18 & 19 & 20 & 21 & 22 & 23 & 24 & 25 & 26 & 27 \\
\hline & & & & & & & & 309 & 60 & 338 & 4 \\
\hline & & & & $\begin{array}{r}96 \\
205 \\
776\end{array}$ & $\begin{array}{r}725 \\
1,145 \\
7,102\end{array}$ & $\begin{array}{r}96 \\
205 \\
, 776\end{array}$ & $\begin{array}{r}725 \\
1,145 \\
7,102\end{array}$ & $\begin{array}{r}6,511 \\
1,522 \\
14,919\end{array}$ & $\begin{array}{l}16,236 \\
23,770 \\
79,822\end{array}$ & $\begin{array}{l}22,096 \\
25,140 \\
93,222\end{array}$ & $\begin{array}{l}1,148 \\
1,468 \\
1,072\end{array}$ \\
\hline & $\ldots$ & …..... & …....... & 1,077 & 8,972 & 1,077 & 8,972 & 22,952 & 119,828 & 140,458 & 3,678 \\
\hline $\begin{array}{l}5,430 \\
1,883 \\
5,064\end{array}$ & $\begin{array}{r}2,064 \\
154 \\
396\end{array}$ & $\begin{array}{l}5,436 \\
1,883 \\
5,064\end{array}$ & . ...... & $\begin{array}{r}2,064 \\
154 \\
396\end{array}$ & $\begin{array}{l}5,436 \\
1,883 \\
5,064\end{array}$ & & ......... & $\begin{array}{r}3,395 \\
344 \\
579\end{array}$ & $\begin{array}{r}11,702 \\
8,495 \\
17,991\end{array}$ & $\begin{array}{r}14,762 \\
8,805 \\
18,521\end{array}$ & $\begin{array}{r}165 \\
50 \\
52\end{array}$ \\
\hline 12,383 & 2,614 & 12,383 & …....... & 2,614 & 12,383 & ...... & ......... & 4,318 & 38,188 & 42,083 & 267 \\
\hline $\begin{array}{r}566 \\
2,008 \\
9,474\end{array}$ & $\begin{array}{l}186 \\
170 \\
594\end{array}$ & $\begin{array}{r}399 \\
2,008 \\
9,474\end{array}$ & $\begin{array}{r}167 \\
0 . \\
0\end{array}$ & $\begin{array}{l}186 \\
195 \\
597\end{array}$ & $\begin{array}{r}399 \\
2,167 \\
9,481\end{array}$ & $\begin{array}{r}0 \\
25 \\
3\end{array}$ & $\begin{array}{r}0 \\
159 \\
7\end{array}$ & $\begin{array}{r}1,175 \\
8 \\
23,582\end{array}$ & $\begin{array}{r}2,309 \\
27,838 \\
45,505\end{array}$ & $\begin{array}{r}3,369 \\
27,845 \\
66,705\end{array}$ & $\begin{array}{r}0 \\
53 \\
0\end{array}$ \\
\hline 12,048 & 950 & 11,881 & 167 & 978 & 12,047 & 28 & 166 & 24,765 & 75,652 & 97,919 & 53 \\
\hline 24,431 & 3,564 & 24,264 & 167 & 4,669 & 33,402 & 1,105 & 9,138 & 52,035 & 233,668 & 280,465 & 3,998 \\
\hline 24,431 & 3,564 & 24,264 & 167 & 4,669 & 33,402 & 1,105 & 9,138 & 52,344 & 233,728 & 280,803 & 4,002 \\
\hline$\cdots \cdots$ & & & & $\begin{array}{r}2 \\
0 \\
407 \\
\end{array}$ & $\begin{array}{r}100 \\
0 \\
16,513\end{array}$ & $\begin{array}{r}2 \\
0 \\
407\end{array}$ & $\begin{array}{r}100 \\
0 \\
16,513\end{array}$ & $\begin{array}{r}0 \\
0 \\
27,330\end{array}$ & $\begin{array}{r}744 \\
1,500 \\
209,196\end{array}$ & $\begin{array}{r}744 \\
1,500 \\
233,696\end{array}$ & $\begin{array}{r}54,977 \\
75,000 \\
1,366,358\end{array}$ \\
\hline ……........ & …........ & ……...... & …...... & 409 & 16,613 & 409 & 16,613 & 27,330 & 211,440 & 235,940 & $1,496,335$ \\
\hline $\begin{array}{r}50 \\
388 \\
\end{array}$ & $\cdot \begin{array}{r}1 \\
8\end{array}$ & $\begin{array}{r}50 \\
388\end{array}$ & $\begin{array}{l}0 \\
0\end{array}$ & $\begin{array}{r}1 \\
306\end{array}$ & $\begin{array}{r}50 \\
65,055\end{array}$ & $\begin{array}{r}0 \\
298\end{array}$ & $\begin{array}{r}0 \\
64,667\end{array}$ & $\begin{array}{r}0 \\
13,186\end{array}$ & $\begin{array}{r}1,400 \\
60,614\end{array}$ & $\begin{array}{r}1,400 \\
72,414\end{array}$ & $\begin{array}{r}70,000 \\
1,604,486\end{array}$ \\
\hline 438 & 9 & 438 & 0 & 307 & 65,105 & 298 & 64,667 & 13,186 & 62,014 & 73,814 & $1,674,486$ \\
\hline 438 & 0 & 438 & 0 & 716 & 81,718 & 707 & 81,280 & 40,516 & 273,454 & 309,754 & $3,170,821$ \\
\hline ….. & & … & & $\begin{array}{r}1 \\
101 \\
4,203 \\
\end{array}$ & $\begin{array}{r}15 \\
1,480 \\
83,349 \\
\end{array}$ & $\begin{array}{r}1 \\
101 \\
4,203 \\
\end{array}$ & $\begin{array}{r}15 \\
1,480 \\
83,349\end{array}$ & $\begin{array}{r}0 \\
148 \\
101,584\end{array}$ & $\begin{array}{r}556 \\
23,540 \\
1,434,581\end{array}$ & $\begin{array}{r}556 \\
23,674 \\
1,526,007\end{array}$ & $\begin{array}{r}30 \\
3,497 \\
19,507\end{array}$ \\
\hline ........ & & ....... & ........... & 4,305 & 84,844 & 4,305 & 84,844 & 101,732 & $1,458,677$ & $1,550,237$ & 23,004 \\
\hline $\begin{array}{r}1,524 \\
712 \\
12,245\end{array}$ & $\begin{array}{r}79 \\
62 \\
327\end{array}$ & $\begin{array}{r}1,524 \\
722 \\
12,245\end{array}$ & & $\begin{array}{r}79 \\
62 \\
327\end{array}$ & $\begin{array}{r}1,524 \\
712 \\
12,245\end{array}$ & & & $\begin{array}{r}141 \\
81 \\
852\end{array}$ & $\begin{array}{r}1,417 \\
73 \\
19,302\end{array}$ & $\begin{array}{r}1,543 \\
20,157\end{array}$ & $\begin{array}{r}276 \\
0 \\
2,174\end{array}$ \\
\hline 14,481 & 468 & 14,481 & ............ & 468 & 14,481 & .......... & …........... & 1,174 & 20,792 & 21,846 & 2,450 \\
\hline $\begin{array}{r}96 \\
113 \\
67,033\end{array}$ & $\cdot \begin{array}{r}13 \\
11 \\
5,583\end{array} \mid$ & $\begin{array}{r}96 \\
113 \\
66,783\end{array}$ & $\begin{array}{r}0 \\
0 \\
250\end{array}$ & $\begin{array}{r}13 \\
55 \\
18,236\end{array}$ & $\begin{array}{r}96 \\
357 \\
412,418\end{array}$ & $\begin{array}{r}0 \\
44 \\
12,853\end{array}$ & $\begin{array}{r}0 \\
244 \\
345,635\end{array}$ & $\begin{array}{r}0 \\
150 \\
418,215\end{array}$ & $\begin{array}{r}2,400 \\
19,920 \\
2,047,270\end{array}$ & $\begin{array}{r}2,400 \\
20,065 \\
2,423,668\end{array}$ & $\begin{array}{r}2,000 \\
926 \\
60,313\end{array}$ \\
\hline 67,242 & 5,607 & 66,992 & 250 & 18,304 & 412,871 & 12,697 & 345,635 & 418,365 & $2,069,590$ & $2,446,123$ & 63,244 \\
\hline 81,723 & 6,075 & 81,473 & 250 & 23,077 & 512,196 & 17,002 & 430,723 & 521,271 & $3,549,059$ & $4,018,206$ & 88,698 \\
\hline & & & & 264 & 11,531 & 264 & 11,531 & 23,178 & 6,994 & 27,794 & 1,602 \\
\hline 48,521 & 2,396 & 48,521 & 0 & $\cdot 3,660$ & 73,835 & 1,264 & 25,314 & 9,620 & 209,735 & 218,385 & 18,778 \\
\hline 48,521 & 2,396 & 48,521 & 0 & 3,924 & 85,366 & 1,528 & 36,845 & 32,798 & 216,628 & 246,179 & 20,380 \\
\hline
\end{tabular}


TABLE 46.-Mechanical power-sipply equipment and fuel used

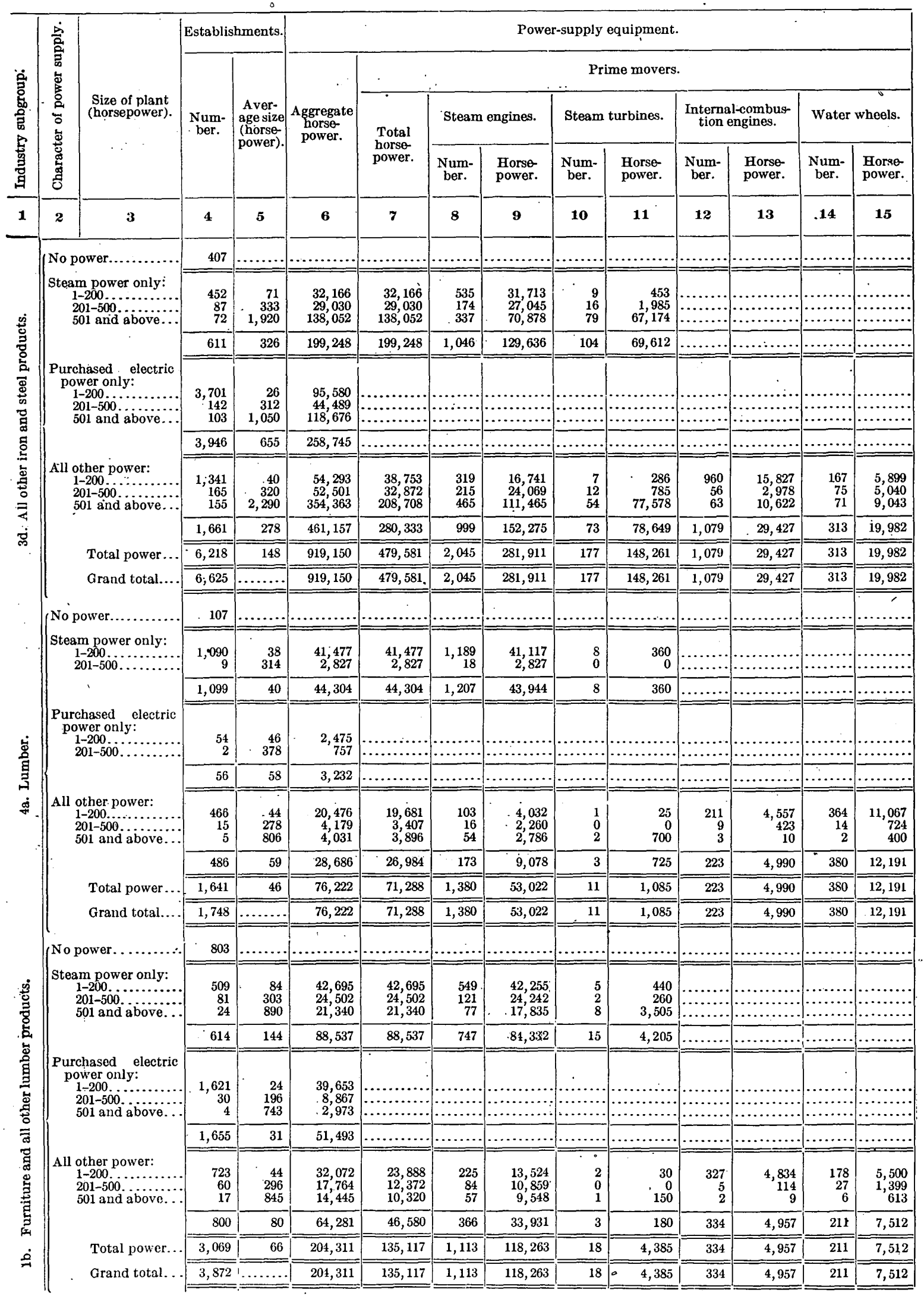


by industry subgroups, by character of power supply-Continued.

\begin{tabular}{|c|c|c|c|c|c|c|c|c|c|c|c|}
\hline \multirow{2}{*}{\multicolumn{4}{|c|}{$\frac{\text { Power-supply equipment-Continued. }}{\text { Operated by purchased energy. }}$}} & \multicolumn{4}{|c|}{ Electric motors. } & \multicolumn{4}{|c|}{ Fuel used. } \\
\hline & & & & \multirow{2}{*}{\multicolumn{2}{|c|}{ Total. }} & \multirow{2}{*}{\multicolumn{2}{|c|}{$\begin{array}{l}\text { Run by current gen- } \\
\text { erated in establish- } \\
\text { ment. }\end{array}$}} & \multicolumn{3}{|c|}{ Coal. } & \multirow{3}{*}{$\begin{array}{l}\text { Coke } \\
\text { (short } \\
\text { tons). }\end{array}$} \\
\hline \multirow{2}{*}{$\begin{array}{c}\text { Total } \\
\text { horsepower. }\end{array}$} & \multicolumn{2}{|c|}{ Electric motors. } & \multirow{2}{*}{$\begin{array}{l}\text { Other } \\
\text { (horse- } \\
\text { power). }\end{array}$} & & & & & \multirow{2}{*}{$\begin{array}{l}\text { Anthracite } \\
\text { (long tons) }\end{array}$} & \multirow{2}{*}{$\begin{array}{l}\text { Bitumi- : } \\
\text { nous (short } \\
\text { tons). }\end{array}$} & \multirow{2}{*}{$\begin{array}{c}\text { Total } \\
\text { equivalent } \\
\text { bitumi- } \\
\text { nous (short } \\
\text { tons). }\end{array}$} & \\
\hline & Number. & $\begin{array}{l}\text { Horse- } \\
\text { power. }\end{array}$ & & Number. & $\begin{array}{l}\text { Horse- } \\
\text { power. }\end{array}$ & Number. & $\begin{array}{l}\text { Horse- } \\
\text { power. }\end{array}$ & & & & \\
\hline \multirow[t]{2}{*}{16} & 17 & 18 & 19 & 20 & 21 & 22 & $\mathbf{2 3}$ & 24 & 25 & 26 & 27 \\
\hline & & & n........ & ........ & & & ............. & 4,230 & 3,304 & 7,114 & 1,077 \\
\hline & $\begin{array}{lll} \\
\cdots & \ldots\end{array}$ & (n..... & $\begin{array}{l}\cdots \ldots \cdots \cdots \\
\cdots \cdots \cdots \cdots \\
\cdots \cdots \cdots \\
\end{array}$ & $\begin{array}{l}1,213 \\
1,900 \\
9,491\end{array}$ & $\begin{array}{r}8,713 \\
19,738 \\
133,800\end{array}$ & $\begin{array}{r}1,213 \\
1,900 \\
9,491\end{array}$ & $\begin{array}{r}8,713 \\
19,738 \\
133,800\end{array}$ & $\begin{array}{r}69,628 \\
40,664 \\
243,808\end{array}$ & $\begin{array}{l}153,924 \\
105,987 \\
598,265\end{array}$ & $\begin{array}{r}216,564 \\
141,987 \\
817,865\end{array}$ & $\begin{array}{r}48,561 \\
24,465 \\
113,638 \\
\end{array}$ \\
\hline .......... & …....... & . & $\ldots \ldots \ldots$ & 12,604 & 162,251 & 12,604 & 162,251 & 354,100 & 858,176 & $1,176,416$ & 186,664 \\
\hline $\begin{array}{r}95,580 \\
44,489 \\
118,676\end{array}$ & $\begin{array}{r}13,971 \\
4,158 \\
10,144\end{array}$ & $\begin{array}{r}95,580 \\
44,489 \\
118,676\end{array}$ & $\mid \begin{array}{l}\cdots \\
\cdots \cdots \cdots \\
\cdots \cdots \cdots\end{array}$ & $\begin{array}{r}13,971 \\
4,158 \\
10,144\end{array}$ & $\begin{array}{r}95,580 \\
44,489 \\
118,676\end{array}$ & 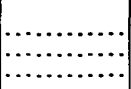 & 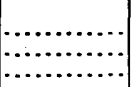 & $\begin{array}{l}66,177 \\
24,835 \\
32,453\end{array}$ & $\begin{array}{r}102,742 \\
58,478 \\
147,478\end{array}$ & $\begin{array}{r}162,242 \\
80,778 \\
176,578\end{array}$ & $\begin{array}{r}109,625 \\
31,114 \\
63,708\end{array}$ \\
\hline 258,745 & 28,273 & 258,745 & ....... & 28,273 & 258,745 & & 1 & 123,465 & 308,698 & 419,598 & 204,447 \\
\hline $\begin{array}{r}15,540 \\
19,629 \\
145,655\end{array}$ & $\begin{array}{l}1,654 \\
1,726 \\
9,093\end{array}$ & $\begin{array}{r}13,033 \\
19,454 \\
145,455\end{array}$ & $\begin{array}{r}2,507 \\
175 \\
200\end{array}$ & $\begin{array}{r}2,331 \\
2,686 \\
14,068\end{array}$ & $\begin{array}{r}17,617 \\
30,564 \\
206,497\end{array}$ & $\begin{array}{r}677 \\
960 \\
4,975 \\
\end{array}$ & $\begin{array}{r}4,584 \\
11,110 \\
61,042\end{array}$ & $\begin{array}{r}43,195 \\
40,088 \\
152,280\end{array}$ & $\begin{array}{l}101,056 \\
137,558 \\
931,306\end{array}$ & $\begin{array}{r}140,056 \\
173,558 \\
1,068,000\end{array}$ & $\begin{array}{l}38,735 \\
39,182 \\
95,199\end{array}$ \\
\hline 180,824 & 12,473 & 177,942 & 2,882 & 19,085 & 254,678 & 6,612 & 76,736 & 235,563 & $1,169,920$ & $1,381,614$ & 173,116 \\
\hline 439,569 & 40,746 & 436,687 & 2,882 & 59,962 & 675,674 & 19,216 & 238,987 & 713,128 & $2,336,794$ & $2,977,628$ & 564,227 \\
\hline 439,569 & 40,746 & 436,687 & 2,882 & 59,962 & 675,674 & 19,216 & 238,987 & 717,358 & $2,340,098$ & $2,984,744$ & 565,304 \\
\hline & & $\ldots \ldots$ & & $\cdots$ & $\underline{\underline{\cdots}}$ & $\cdots$ & $\cdots \cdots$ & 0 & 1,105 & 1,105 & 0 \\
\hline & & & & .10 & $\begin{array}{r}65 \\
415 \\
\end{array}$ & $\begin{array}{l}10 \\
20\end{array}$ & $\begin{array}{r}65 \\
415\end{array}$ & $\begin{array}{r}1,012 \\
. \quad 0\end{array}$ & $\begin{array}{l}2,183 \\
1,897\end{array}$ & $\begin{array}{l}3,090 \\
1,897\end{array}$ & $\begin{array}{l}20 \\
89\end{array}$ \\
\hline ….... & ........ & ......... & $\ldots .$. & 30 & 480 & 30 & 480 & 1,012 & 4,080 & 4,987 & 109 \\
\hline $\begin{array}{r}2,475 \\
757\end{array}$ & $\begin{array}{r}116 \\
64\end{array}$ & $\begin{array}{r}2,475 \\
757\end{array}$ & …….... & $\begin{array}{r}116 \\
64\end{array}$ & $\begin{array}{r}2,475 \\
757\end{array}$ & & & $\begin{array}{r}11 \\
0\end{array}$ & $\begin{array}{r}100 \\
0\end{array}$ & $\begin{array}{r}110 \\
0\end{array}$ & $\begin{array}{l}\mathbf{0} \\
\mathbf{0}\end{array}$ \\
\hline 3,232 & 180 & 3,232 & ...... & 180 & 3,232 & …. & $\ldots \ldots \ldots \ldots$ & 11 & 100 & 110 & 0 \\
\hline $\begin{array}{r}795 \\
772 \\
135\end{array}$ & $\begin{array}{l}3 y \\
99 \\
13\end{array}$ & $\begin{array}{l}730 \\
772 \\
135\end{array}$ & $\begin{array}{r}65 \\
0 \\
0\end{array}$ & $\begin{array}{r}45 \\
135 \\
146\end{array}$ & $\begin{array}{r}750 \\
1,052 \\
2,341\end{array}$ & $\begin{array}{r}6 \\
36 \\
133\end{array}$ & $\begin{array}{r}20 \\
280 \\
2,206\end{array}$ & $\begin{array}{r}109 \\
0 \\
. \quad 25\end{array}$ & $\begin{array}{r}184 \\
1,705 \\
12,054\end{array}$ & $\begin{array}{r}292 \\
1,705 \\
12,076\end{array}$ & $\begin{array}{r}0 \\
0 \\
166\end{array}$ \\
\hline 1,702 & 151 & 1,637 & 65 & 326 & 4,143 & 175 & 2,506 & 134 & 13,943 & 14,073 & 166 \\
\hline 4,934 & 331 & 4,869 & 65 & 536 & 7,855 & 205 & 2,986 & 1,157 & 18,123 & 19,170 & 275 \\
\hline 4,934 & 331 & 4,869 & 65 & 536 & 7,855 & 205 & 2,986 & $1, \overline{157}$ & 19,228 & 20,275 & 275 \\
\hline ....... & $\cdots \cdots$ & .......... & & $\ldots \ldots$ & $\cdots \cdot$ & & & 3,096 & 1,405 & 4,195 & 1 \\
\hline & & & & $\begin{array}{r}409 \\
1,100 \\
888\end{array}$ & $\begin{array}{l}3,186 \\
9,068 \\
9,661\end{array}$ & $\begin{array}{r}409 \\
1,100 \\
888\end{array}$ & $\begin{array}{r}3,186 \\
9,068 \\
-9,661\end{array}$ & $\begin{array}{r}35,521 \\
6,057 \\
4,665\end{array}$ & $\begin{array}{l}75,896 \\
87,439 \\
44,477\end{array}$ & $\begin{array}{r}107,864 \\
92,894 \\
48,675\end{array}$ & $\begin{array}{r}864 \\
. \quad 1,220 \\
. \quad 1,242\end{array}$ \\
\hline .......... & $\ldots \ldots \ldots$ & $\ldots \ldots \ldots \ldots$ & $\ldots \ldots \ldots$ & 2,397 & 21,915 & 2,397 & 21,915 & $46 ; 243$ & 207,812 & 249,433 & 3,326 \\
\hline $\begin{array}{r}39,653 \\
8,807 \\
2,973\end{array}$ & $\begin{array}{r}6,406 \\
961 \\
320\end{array}$ & $\begin{array}{r}39,653 \\
8,867 \\
2,973\end{array}$ & & $\begin{array}{r}6,406 \\
961 \\
320\end{array}$ & $\begin{array}{r}39,653 \\
8,867 \\
2,973\end{array}$ & & $\cdots$ & $\begin{array}{r}13,779 \\
897 \\
870\end{array}$ & $\begin{array}{r}13,524 \\
1,629 \\
2,294\end{array}$ & $\begin{array}{r}25,926 \\
2,437 \\
3,077\end{array}$ & $\begin{array}{r}1,636 \\
3,099 \\
0\end{array}$ \\
\hline 51,493 & 7,687 & 51,493 & $\therefore \ldots$ & 7,687 & 51,493 & n............. & 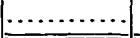 & 15,546 & 17,447 & 31,440 & 4,735 \\
\hline $\begin{array}{l}8,184 \\
5,392 \\
4,125\end{array}$ & $\begin{array}{l}864 \\
504 \\
318\end{array}$ & $\begin{array}{l}5,114 \\
5,142 \\
4,125\end{array}$ & $\begin{array}{r}3,070 \\
250 \\
0\end{array}$ & $\begin{array}{r}1,098 \\
823 \\
722\end{array}$ & $\begin{array}{l}6,608 \\
7,910 \\
7,937\end{array}$ & $\begin{array}{l}234 \\
319 \\
404\end{array}$ & $\begin{array}{l}1,494 \\
2,768 \\
3,812\end{array}$ & $\begin{array}{l}9,962 \\
3,262 \\
7,215\end{array}$ & $\begin{array}{l}31,947 \\
25,239 \\
41,888\end{array}$ & $\begin{array}{l}40,947 \\
28,174 \\
48,379\end{array}$ & $\begin{array}{r}1,141 \\
1,678 \\
0\end{array}$ \\
\hline 17,701 & 1,680 & 14,381 & 3,320 & 2,643 & 22,455 & 957 & 8,074 & 20,439 & 99,074 & 117,500 & 2,819 \\
\hline 69,194 & 9,373 & 65,874 & 3,320 & 12,727 & 95,863 & 3,354 & 29,989 & $82 ; 228$ & 324,333 & 398,373 & 10,880 \\
\hline 69,194 & 9,373 & 65,874 & 3,320 & 17,727 & 95,863 & 3,354 & $29, \overline{989}$ & 85,324 & 325,738 & 402,568 & 10,881 \\
\hline
\end{tabular}


TABLE 46.-Mechanical power-supply equipment and fuel used

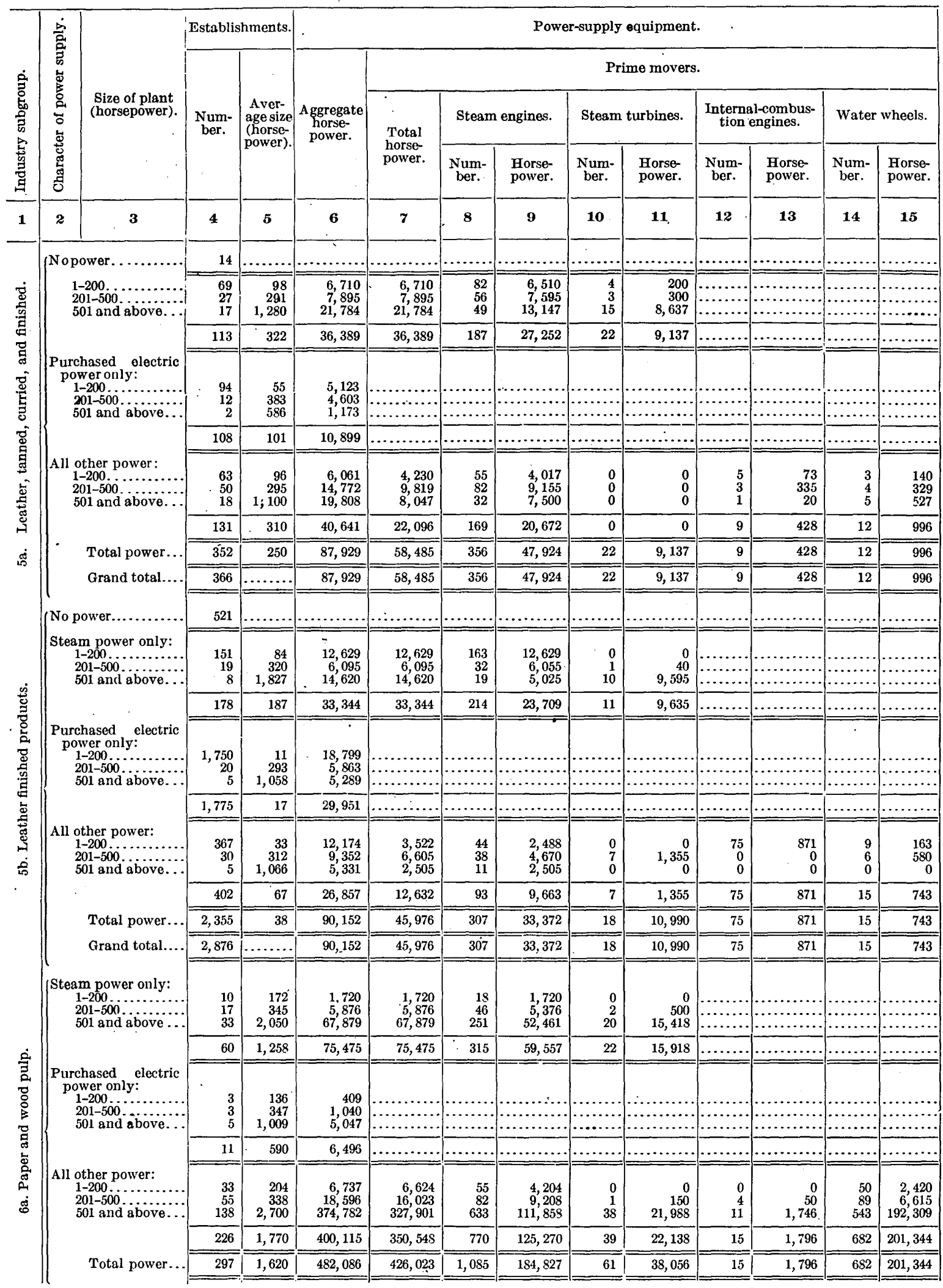


by industry subgroups, by character of power supply-Continued.

\begin{tabular}{|c|c|c|c|c|c|c|c|c|c|c|c|}
\hline \multirow{2}{*}{\multicolumn{4}{|c|}{$\frac{\text { Power-supply equipment-Continuod. }}{\text { Operated by purchased energy. }}$}} & \multicolumn{4}{|c|}{ Electric motors. } & \multicolumn{4}{|c|}{ Fuel used. } \\
\hline & & & & \multirow{2}{*}{\multicolumn{2}{|c|}{ Total. }} & \multirow{2}{*}{\multicolumn{2}{|c|}{$\begin{array}{l}\text { Run by current gen- } \\
\text { erated in establish- } \\
\text { ment. }\end{array}$}} & \multirow{3}{*}{$\begin{array}{l}\text { Anthracite } \\
\text { (long tons). }\end{array}$} & \multicolumn{2}{|l|}{ Coal. } & \multirow{3}{*}{$\begin{array}{l}\text { Coke } \\
\text { (short } \\
\text { tons). }\end{array}$} \\
\hline \multirow{2}{*}{$\begin{array}{c}\text { Total } \\
\text { horsepower. }\end{array}$} & \multicolumn{2}{|c|}{ Electric motors. } & \multirow{2}{*}{$\begin{array}{l}\text { Other } \\
\text { (horse- } \\
\text { power). }\end{array}$} & & & & & & & Total & \\
\hline & Number. & $\begin{array}{l}\text { Horse- } \\
\text { power. }\end{array}$ & & Number. & $\begin{array}{l}\text { Horse- } \\
\text { power. }\end{array}$ & Number. & $\begin{array}{l}\text { Horse- } \\
\text { power. }\end{array}$ & & Loils). & $\begin{array}{c}\text { nous (short } \\
\text { tons). }\end{array}$ & \\
\hline \multirow[t]{2}{*}{10} & 17 & 18 & 19 & 20 & 21 & 22 & 23 & $\cdot 24$ & 25 & 26 & 27 \\
\hline & & & & & & & & 925 & 762 & 1,594 & 94 \\
\hline & $\mid \begin{array}{l}\cdots \\
\cdots \cdots \cdots \cdots \\
\cdots \cdots \cdots \\
\end{array}$ & 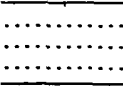 & & $\begin{array}{r}60 \\
96 \\
1,698 \\
\end{array}$ & $\begin{array}{r}713 \\
937 \\
23,541 \\
\end{array}$ & $\begin{array}{r}60 \\
96 \\
1,698\end{array}$ & $\begin{array}{r}713 \\
937 \\
23,541 \\
\end{array}$ & $\begin{array}{r}3,916 \\
9,871 \\
26,609 \\
\end{array}$ & $\begin{array}{r}30,564 \\
62,323 \\
170,468 \\
\end{array}$ & $\begin{array}{r}34,092 \\
71,323 \\
194,417 \\
\end{array}$ & $\begin{array}{r}0 \\
0 \\
58 \\
\end{array}$ \\
\hline$\ldots \ldots \ldots$ & $\ldots \ldots \ldots \ldots$ & $\ldots \ldots \ldots \ldots$ & $\ldots \ldots \ldots$ & 1,854 & 25,191 & 1,854 & 25,191 & 40,396 & 263,355 & 299,832 & 58 \\
\hline $\begin{array}{l}5,123 \\
4,603 \\
1,173\end{array}$ & $\begin{array}{r}603 \\
337 \\
32\end{array}$ & $\begin{array}{l}5,123 \\
4,603 \\
1,173 \\
\end{array}$ & & $\begin{array}{r}603 \\
337 \\
32 \\
\end{array}$ & $\begin{array}{l}5,123 \\
4,603 \\
1,173\end{array}$ & …..... & & $\begin{array}{r}2,586 \\
497 \\
0\end{array}$ & $\begin{array}{r}20,505 \\
21,270 \\
1,802 \\
\end{array}$ & $\begin{array}{r}22,835 \\
21,720 \\
1,802\end{array}$ & $\begin{array}{r}2,000 \\
200 \\
0\end{array}$ \\
\hline 10,899 & 972 & 10,899 & $\ldots \ldots \ldots$ & 972 & 10,899 & $\ldots \ldots \ldots \ldots$ & $\ldots \ldots \ldots \ldots$ & 3,083 & 43,577 & 46,357 & 2,200 \\
\hline $\begin{array}{r}1,831 \\
4,953 \\
11,761 \\
\end{array}$ & $\begin{array}{l}130 \\
354 \\
545\end{array}$ & $\begin{array}{r}1,468 \\
4,953 \\
11,761\end{array}$ & $\begin{array}{r}363 \\
0 \\
0\end{array}$ & $\begin{array}{l}175 \\
483 \\
810\end{array}$ & $\begin{array}{r}2,006 \\
6,656 \\
14,344 \\
\end{array}$ & $\begin{array}{r}45 \\
129 \\
265\end{array}$ & $\begin{array}{r}538 \\
1,703 \\
2,583 \\
\end{array}$ & $\begin{array}{r}4,243 \\
14,558 \\
14,943 \\
\end{array}$ & $\begin{array}{r}22 ; 795 \\
53,215 \\
.47,673 \\
\end{array}$ & $\begin{array}{l}26,611 \\
66,319 \\
61,119\end{array}$ & $\begin{array}{r}60 \\
8\end{array}$ \\
\hline 18,545 & 1,029 & 18,182 & 363 & 1,468 & 23,006 & 439 & 4,824 & 33,744 & 123,683 & 154,049 & 68 \\
\hline 29,444 & 2,001 & 29,081 & 363 & 4,294 & 59,096 & 2,293 & 30,015 & 77,223 & 430,615 & 500,238 & 2,326 \\
\hline \multirow[t]{2}{*}{29,444} & 2,001 & 29,081 & 363 & 4,294 & 59,096 & 2,293 & 30,015 & 78,148 & 431,377 & 501,832 & 2,420 \\
\hline & & & & & .............. & & & 1,153 & 470 & 1,505 & 1 \\
\hline & & & & $\begin{array}{r}456 \\
403 \\
1,838 \\
\end{array}$ & $\begin{array}{l}2,409 \\
2,701 \\
9,948 \\
\end{array}$ & $\begin{array}{r}456 \\
403 \\
1,838 \\
\end{array}$ & $\begin{array}{l}2,409 \\
2,701 \\
9,948 \\
\end{array}$ & $\begin{array}{r}17,223 \\
8,422 \\
12,029\end{array}$ & $\begin{array}{l}44,372 \\
13,427 \\
62,528 \\
\end{array}$ & $\begin{array}{l}59,872 \\
20,987 \\
73,328 \\
\end{array}$ & $\begin{array}{r}443 \\
0 \\
0 \\
\end{array}$ \\
\hline …n....... & $\ldots \ldots \ldots \ldots$ & $\ldots \ldots \ldots \ldots$ & $\ldots \ldots \ldots \ldots$ & 2,697 & 15,058 & 2,697 & 15,058 & 37,674 & 120,327 & 154,187 & 443 \\
\hline $\begin{array}{r}18,799 \\
5,863 \\
5,289 \\
\end{array}$ & $\begin{array}{r}5,007 \\
1,215 \\
607\end{array}$ & $\begin{array}{r}18,799 \\
5,863 \\
5,289\end{array}$ & 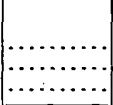 & $\begin{array}{r}5,007 \\
1,215 \\
607\end{array}$ & $\begin{array}{r}18,799 \\
5,863 \\
5,289\end{array}$ & & $\mid \begin{array}{l} \\
\cdots \\
\cdots \\
\cdots \cdots\end{array}$ & $\begin{array}{r}15,352 \\
3,852 \\
1,885\end{array}$ & $\begin{array}{r}26,721 \\
11,317 \\
7,340\end{array}$ & $\begin{array}{r}40,621 \\
14,777 \\
9,030\end{array}$ & $\begin{array}{r}207 \\
0 \\
0\end{array}$ \\
\hline 29,951 & 6,829 & 29,951 & $\ldots \ldots \ldots$ & 6,829 & 29,951 & $\ldots \ldots \ldots \ldots$ & $\ldots \ldots \ldots$ & 21,089 & 45,378 & 64,428 & 207 \\
\hline $\begin{array}{l}8,652 \\
2,747 \\
2,826\end{array}$ & $\begin{array}{l}605 \\
533 \\
308\end{array}$ & $\begin{array}{l}2,650 \\
2,747 \\
2,826\end{array}$ & $\begin{array}{r}6,002 \\
0 \\
0\end{array}$ & $\begin{array}{l}675 \\
649 \\
333 \\
\end{array}$ & $\begin{array}{l}2,946 \\
3,612 \\
3,283\end{array}$ & $\begin{array}{r}70 \\
116 \\
25\end{array}$ & $\begin{array}{l}296 \\
865 \\
457\end{array}$ & $\begin{array}{l}2,715 \\
3,680 \\
2,896\end{array}$ & $\begin{array}{r}13,143 \\
27,793 \\
8,642 \\
\end{array}$ & $\begin{array}{l}15,403 \\
31,103 \\
11,242\end{array}$ & $\begin{array}{r}195 \\
0 \\
0\end{array}$ \\
\hline 14,225 & 1,446 & 8,223 & 6,002 & 1,657 & 9,841 & 211 & 1,618 & 9,291 & 49,578 & 57,748 & 195 \\
\hline 44,176 & 8,275 & 38,174 & 6,002 & 11,183 & 54,850 & 2,908 & 16,676 & 68,054 & 215,283 & 276,363 & 845 \\
\hline 44,176 & 8,275 & 38,174 & 6,002 & 11,183 & 54,850 & 2,908 & 16,676 & 69,207 & 215,753 & 277,868 & 816 \\
\hline & & & & $\begin{array}{r}2 \\
34 \\
757\end{array}$ & $\begin{array}{r}159 \\
1,013 \\
11,392 \\
\end{array}$ & $\begin{array}{r}2 \\
34 \\
757 \\
\end{array}$ & $\begin{array}{r}159 \\
1,013 \\
11,392 \\
\end{array}$ & $\begin{array}{r}5,175 \\
8,871 \\
36,313 \\
\end{array}$ & $\begin{array}{r}4,968 \\
73,891 \\
677,183\end{array}$ & $\begin{array}{r}9,618 \\
81,851 \\
709,783\end{array}$ & $\begin{array}{r}0 \\
0 \\
1,318 \\
\end{array}$ \\
\hline$\ldots \ldots \ldots \ldots \ldots$ & $\ldots \ldots \ldots \ldots$ & $\ldots \ldots \ldots \ldots$ & …....... & 793 & 12,564 & 793 & $.12,564$ & 50,359 & 756,042 & 801,250 & 1,318 \\
\hline $\begin{array}{r}409 \\
1,040 \\
5,047\end{array}$ & $\begin{array}{r}39 \\
26 \\
102\end{array}$ & $\begin{array}{r}409 \\
1,040 \\
5,047 \\
\end{array}$ & & $\begin{array}{r}39 \\
26 \\
102\end{array}$ & $\begin{array}{r}409 \\
1,040 \\
5,047\end{array}$ & & & $\begin{array}{r}4,264 \\
652 \\
0\end{array}$ & $\begin{array}{r}2,000 \\
2,555 \\
31,788 \\
\end{array}$ & $\begin{array}{r}5,840 \\
3,140 \\
31,788\end{array}$ & $\begin{array}{l}0 \\
0 \\
0\end{array}$ \\
\hline 6,496 & 167 & 6,496 & $\ldots \ldots \ldots$ & 167 & 6,496 & ............... & & 4,916 & 36,343 & 40,768 & 0 \\
\hline $\begin{array}{r}113 \\
2,573 \\
46,881 \\
\end{array}$ & $\begin{array}{r}6 \\
124 \\
1,542\end{array}$ & $\begin{array}{r}113 \\
2,573 \\
45,371 \\
\end{array}$ & $\begin{array}{r}0 \\
0 \\
1,510\end{array}$ & $\begin{array}{r}19 \\
174 \\
3,202\end{array}$ & $\begin{array}{r}255 \\
3,366 \\
89,697\end{array}$ & $\begin{array}{r}13 \\
50 \\
1,660\end{array}$ & $\begin{array}{r}142 \\
793 \\
44,326\end{array}$ & $\begin{array}{r}11,613 \\
15,851 \\
463,652\end{array}$ & $\begin{array}{r}35,348 \\
78,855 \\
849,164\end{array}$ & $\begin{array}{r}45,848 \\
93,055 \\
1,266,164\end{array}$ & $\begin{array}{r}0 \\
522 \\
8,173\end{array}$ \\
\hline 49,567 & 1,672 & 48,057 & 1,510 & 3,395 & 93,318 & 1,723 & 45,261 & 491,116 & 963,367 & $1,405,067$ & 8,695 \\
\hline 56,063 & 1,839 & 54,553 & 1,510 & 4,355 & 112,378 & 2,516 & 57,825 & 546,391 & $1,755,752$ & $2,247,087$ & 10,013 \\
\hline
\end{tabular}


TABLE 46.-Mechanical. power-supply equipment and fuel used

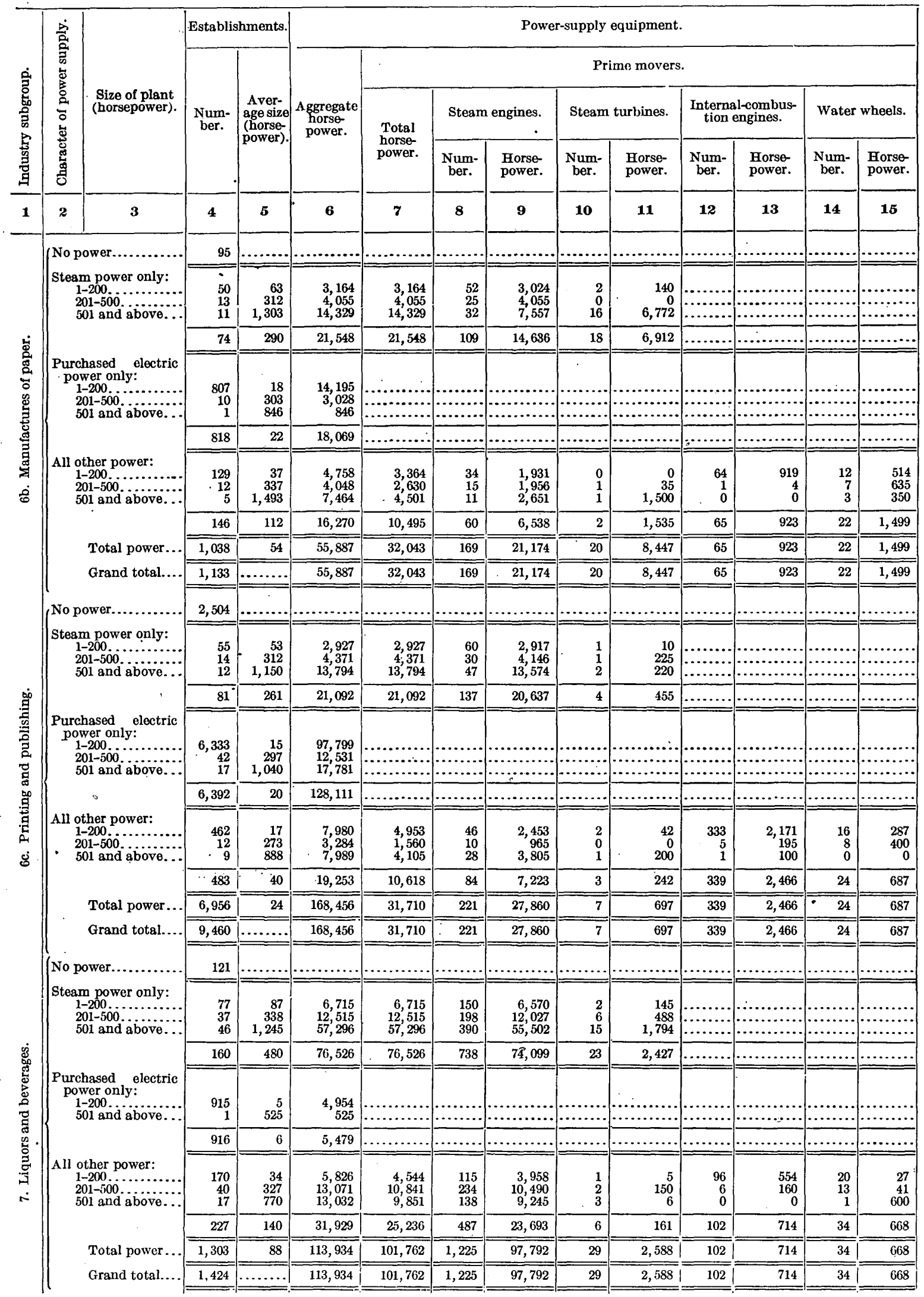


by industry subgroups, by character of power supply-Continued.

\begin{tabular}{|c|c|c|c|c|c|c|c|c|c|c|c|}
\hline \multirow{2}{*}{\multicolumn{4}{|c|}{$\frac{\text { Power-supply equipment-Continued. }}{\text { Operated by purchased energy. }}$}} & \multicolumn{4}{|c|}{ Electric motors. } & \multicolumn{4}{|c|}{ Fuel used. } \\
\hline & & & & \multirow{2}{*}{\multicolumn{2}{|c|}{ Total. }} & \multirow{2}{*}{\multicolumn{2}{|c|}{$\begin{array}{l}\text { Run by current gen- } \\
\text { erated in establish- } \\
\text { ment. }\end{array}$}} & \multicolumn{3}{|c|}{ Coal. } & \multirow{3}{*}{$\begin{array}{l}\text { Coke } \\
\text { (short } \\
\text { tons). }\end{array}$} \\
\hline \multirow{2}{*}{$\begin{array}{c}\text { Total } \\
\text { horsepower. }\end{array}$} & \multicolumn{2}{|c|}{ Eloctric motors. } & \multirow{2}{*}{$\begin{array}{l}\text { Other } \\
\text { (horse- } \\
\text { power). }\end{array}$} & & & & & \multirow{2}{*}{$\begin{array}{l}\text { Anthracite } \\
\text { (long tons). }\end{array}$} & \multirow{2}{*}{$\begin{array}{c}\text { Bitumi- } \\
\text { nous (short } \\
\text { tons). }\end{array}$} & \multirow{2}{*}{$\begin{array}{c}\text { Total } \\
\text { equivalent } \\
\text { bitumi- } \\
\text { nous (short } \\
\text { tons). }\end{array}$} & \\
\hline & Number. & $\begin{array}{l}\text { Horse- } \\
\text { power. }\end{array}$ & & Number. & $\begin{array}{c}\text { Horse- } \\
\text { power. }\end{array}$ & Number. & $\begin{array}{l}\text { Horse- } \\
\text { power. }\end{array}$ & & & & \\
\hline \multirow[t]{2}{*}{16} & 17 & 18 & 19 & 20 & 21 & 22 & 23 & 24 & 25 & 26 & 27 \\
\hline & & & & & & & & 155 & 301 & 441 & 0 \\
\hline & & $\cdots$ & & $\begin{array}{r}188 \\
800 \\
1,551\end{array}$ & $\begin{array}{r}786 \\
2,727 \\
9,338\end{array}$ & $\begin{array}{r}188 \\
800 \\
1,551\end{array}$ & $\begin{array}{r}786 \\
2,727 \\
9,338\end{array}$ & $\begin{array}{r}8,502 \\
7,896 \\
36,131\end{array}$ & $\begin{array}{l}10,895 \\
13,604 \\
47,028\end{array}$ & $\begin{array}{l}18,545 \\
20,704 \\
79,528\end{array}$ & $\begin{array}{r}200 \\
0 \\
576\end{array}$ \\
\hline ........... & $\cdots \cdots$ & $\ldots \ldots \ldots \ldots$ & $\ldots \ldots \ldots$ & 2,539 & 12,851 & 2,539 & 12,851 & 52,529 & 71,527 & 118,777 & 776 \\
\hline $\begin{array}{r}14,195 \\
3,028 \\
846 \\
\end{array}$ & $\begin{array}{r}5,028 \\
478 \\
56\end{array}$ & $\begin{array}{r}14,195 \\
3,028 \\
846 \\
\end{array}$ & 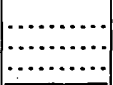 & $\begin{array}{r}5,028 \\
-\quad 478 \\
56 \\
\end{array}$ & $\begin{array}{r}14,195 \\
3,028 \\
846\end{array}$ & $\begin{array}{l}\cdots \\
\cdots \\
\cdots \\
\cdots\end{array}$ & 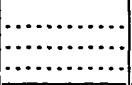 & $\begin{array}{r}10,177 \\
590 \\
0\end{array}$ & $\begin{array}{r}19,755 \\
2,837 \\
0\end{array}$ & $\begin{array}{r}28,955 \\
3,367 \\
0\end{array}$ & $\begin{array}{r}89 \\
75 \\
0\end{array}$ \\
\hline 18,069 & 5,562 & 18,069 & $\cdots$. & 5,562 & 18,069 & $\ldots$ & $\cdots$ & 10,767 & 22,592 & 32,322 & 164 \\
\hline $\begin{array}{l}1,394 \\
1,418 \\
2,963\end{array}$ & $\begin{array}{l}228 \\
326 \\
206\end{array}$ & $\begin{array}{l}1,018 \\
1,418 \\
2,963\end{array}$ & $\begin{array}{r}376 \\
0 \\
0\end{array}$ & $\begin{array}{l}461 \\
528 \\
256\end{array}$ & $\begin{array}{l}1,525 \\
2,030 \\
3,618\end{array}$ & $\begin{array}{r}233 \\
202 \\
50\end{array}$ & $\begin{array}{l}507 \\
612 \\
655\end{array}$ & $\begin{array}{l}4,403 \\
1,167 \\
2,359\end{array}$ & $\begin{array}{r}9,503 \\
7,972 \\
12,343\end{array}$ & $\begin{array}{r}13,463 \\
9,022 \\
14,463\end{array}$ & $\begin{array}{r}3 \\
370 \\
0\end{array}$ \\
\hline 5,775 & 760 & 5,399 & 376 & 1,245 & 7,173 & 485 & 1,774 & 7,929 & 29,818 & 36,948 & 373 \\
\hline 23,844 & 6,322 & 23,468 & 376 & 9,346 & 38,093 & 3,024 & 14,625 & 71,225 & 123,937 & 188,047 & 1,313 \\
\hline 23,844 & 6,322 & 23,468 & 376 & 9,346 & 38,093 & 3,024 & 14,625 & 71,380 & 124,238 & 188,488 & 1,313 \\
\hline $\begin{array}{c} \\
\ldots \ldots \ldots \ldots \\
\end{array}$ & $\ldots \ldots \ldots \ldots$ & $\ldots \ldots \ldots \ldots$ & $\cdots$ & (n....... & 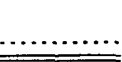 & $\begin{array}{c}\cdot \\
\cdots \cdots \\
\ldots \cdot \cdots \\
\end{array}$ & 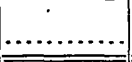 & 2,735 & 414 & 2,874 & 4 \\
\hline & & & $\begin{array}{c}\cdots \cdots \\
\cdots \cdots \ldots \ldots \\
\cdots\end{array}$ & $\begin{array}{r}136 \\
814 \\
2,318 \\
\end{array}$ & $\begin{array}{r}433 \\
3,718 \\
10,885\end{array}$ & $\begin{array}{r}136 \\
814 \\
2,318\end{array}$ & $\begin{array}{r}433 \\
3,718 \\
10,865 \\
\end{array}$ & $\begin{array}{r}9,098 \\
12,513 \\
35,672 \\
\end{array}$ & $\begin{array}{r}8,934 \\
9,887 \\
17,525 \\
\end{array}$ & $\begin{array}{l}17,114 \\
21,172 \\
50,225 \\
\end{array}$ & $\begin{array}{r}0 \\
1,500 \\
0\end{array}$ \\
\hline$\ldots \ldots \ldots \ldots$ & $\ldots \ldots \ldots$ & $\ldots \ldots \ldots \ldots$ & .............. & 3,268 & 15,016 & 3,268 & 15,016 & 57,283 & 36,346 & 88,511 & 1,500 \\
\hline $\begin{array}{l}97,799 \\
12,531 \\
17,781\end{array}$ & $\begin{array}{r}36,517 \\
3,236 \\
2,786\end{array}$ & $\begin{array}{l}97,799 \\
12,531 \\
17,781 \\
\end{array}$ & 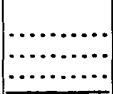 & $\begin{array}{r}36,517 \\
3,236 \\
2,786\end{array}$ & $\begin{array}{l}97,799 \\
12,531 \\
17,781\end{array}$ & 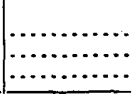 & \begin{tabular}{|c|} 
\\
$\cdots \ldots \ldots \ldots \ldots$
\end{tabular} & $\begin{array}{r}37,447 \\
4,366 \\
12,402\end{array}$ & $\begin{array}{r}14,867 \\
1,332 \\
1,554\end{array}$ & $\begin{array}{r}46,867 \\
5,257 \\
12,724 \\
\end{array}$ & $\begin{array}{r}343 \\
0 \\
0\end{array}$ \\
\hline 128,111 & 42,539 & 128,111 & ............ & 42,539 & 128,111 & ........ & $\ldots \ldots \ldots \ldots$ & 54,215 & $-17,753$ & 64,848 & 343 \\
\hline $\begin{array}{l}3,027 \\
1,724 \\
3,884\end{array}$ & $\begin{array}{r}650 \\
411 \\
1,070\end{array}$ & $\begin{array}{l}2,403 \\
1,724 \\
3,884\end{array}$ & $\begin{array}{r}624 \\
0 \\
0\end{array}$ & $\begin{array}{r}776 \\
474 \\
2,563 \\
\end{array}$ & $\begin{array}{l}2,601 \\
1,924 \\
8,165\end{array}$ & $\begin{array}{r}126 \\
63 \\
1,493 \\
\end{array}$ & $\begin{array}{r}198 \\
200 \\
4,281 \\
\end{array}$ & $\begin{array}{r}10,275 \\
6,763 \\
16,217 \\
\end{array}$ & $\begin{array}{r}6,381 \\
2,915 \\
10,617 \\
\end{array}$ & $\begin{array}{r}15,631 \\
9,005 \\
25,227\end{array}$ & $\begin{array}{l}3 \\
2 \\
0\end{array}$ \\
\hline 8,635 & 2,131 & 8,011 & 624 & 3,813 & 12,690 & 1,682 & 4,679 & 33,255 & 19,913 & 49,863 & 5 \\
\hline 136,746 & 44,670 & 136,122 & 624 & 49,620 & 155,817 & 4,950 & 19,695 & 144,753 & $74, \overline{012}$ & 203,222 & 1,848 \\
\hline 136,746 & 44,670 & 136,122 & 624 & 49,620 & 155,817 & 4,950 & 19,695 & 147,488 & 74,486 & 206,096 & 1,852 \\
\hline & & & & & & & $\ldots . . .$. & 493 & 2,610 & 3,053 & 0 \\
\hline & & & & $\begin{array}{r}254 \\
634 \\
1,769\end{array}$ & $\begin{array}{r}1,221 \\
3,318 \\
12,233\end{array}$ & $\begin{array}{r}254 \\
634 \\
1,769\end{array}$ & $\begin{array}{r}1,221 \\
3,318 \\
12,233\end{array}$ & $\begin{array}{r}44,665 \\
33,910 \\
140,003\end{array}$ & $\begin{array}{r}36,511 \\
55,811 \\
174,410\end{array}$ & $\begin{array}{r}76,711 \\
86,311 \\
300,410\end{array}$ & $\begin{array}{r}16 \\
869 \\
989\end{array}$ \\
\hline 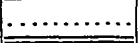 & $\ldots \ldots \ldots$ & .......... & …......... & 2,657 & 16,772 & 2,657 & 16,772 & 218,578 & 266,732 & 463,432 & 1,879 \\
\hline $\begin{array}{r}4,954 \\
525\end{array}$ & $\begin{array}{r}2,062 \\
58\end{array}$ & $\begin{array}{r}4,954 \\
525\end{array}$ & & $\begin{array}{r}2,062 \\
58\end{array}$ & $\begin{array}{r}4,954 \\
525\end{array}$ & & 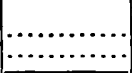 & $\begin{array}{r}10,696 \\
0 \\
\end{array}$ & $\begin{array}{r}17,519 \\
3,654 \\
\end{array}$ & $\begin{array}{r}26,869 \\
3,654 \\
\end{array}$ & $\begin{array}{r}2,267 \\
0\end{array}$ \\
\hline 5,479 & 2,120 & 5,479 & $\ldots \ldots \ldots$ & 2,120 & 5,479 & ....... & ..... & $10 ; 696$ & 21,173 & 30,523 & 2,267 \\
\hline $\begin{array}{l}1,282 \\
2,230 \\
3,181 \\
\end{array}$ & $\begin{array}{l}289 \\
368 \\
340 \\
\end{array}$ & $\begin{array}{l}1,273 \\
1,960 \\
3,181 \\
\end{array}$ & $\begin{array}{r}9 \\
270 \\
0 \\
\end{array}$ & $\begin{array}{l}297 . \\
483 \\
489\end{array}$ & $\begin{array}{l}1,302 \\
2,658 \\
4,455\end{array}$ & $\begin{array}{r}8 \\
115 \\
149 \\
\end{array}$ & $\begin{array}{r}29 \\
698 \\
1,274 \\
\end{array}$ & $\begin{array}{l}29,389 \\
45,732 \\
40,200 \\
\end{array}$ & $\begin{array}{l}27,058 \\
40,098 \\
38,388\end{array}$ & $\begin{array}{l}53,358 \\
81,298 \\
74,588\end{array}$ & $\begin{array}{r}0 \\
0 \\
999 \\
\end{array}$ \\
\hline 6,603 & 997 & 6,414 & 279 & 1,269 & 8,415 & 272 & 2,001 & 115,321 & 105,544 & 209,244 & 999 \\
\hline 12,172 & 3,117 & 11,893 & 279 & 6,046 & 30,666 & 2,929 & 18,773 & 344,595 & 393,449 & 703,199 & 5,140 \\
\hline 12,172 & 3,117 & 11,893 & 279 & 6,046 & 30,666 & 2,929 & $\therefore \quad 18,773$ & 345,088 & 396,059 & 706,252 & 5,140 \\
\hline
\end{tabular}


TABLE 46.-Mechanical power-supply equipment and fuel used

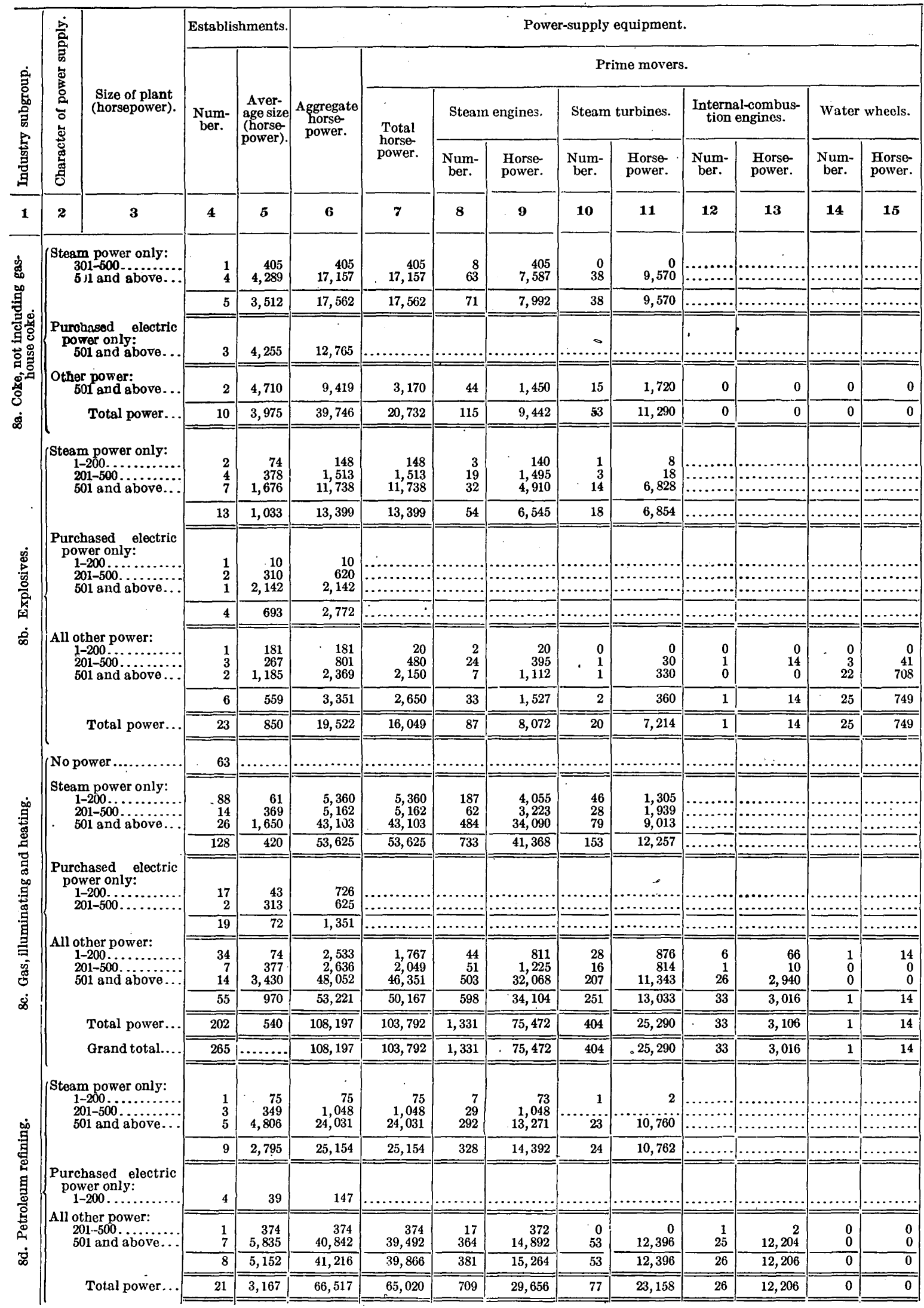


by industry subgroups, by character of power supply-Continued.

\begin{tabular}{|c|c|c|c|c|c|c|c|c|c|c|c|}
\hline Powor-su & apply equi & ment-Con & tinued. & & Electric & motors. & & & Fuel & used. & \\
\hline Oper & ated by pu & rchased ener & gy. & & & & & & . Coal. & & \\
\hline & Electri & c motors. & & & & ment. & & & & Total & Coke \\
\hline & Number. & $\begin{array}{l}\text { Horse- } \\
\text { power. }\end{array}$ & & Number. & $\begin{array}{l}\text { Horse- } \\
\text { power. }\end{array}$ & Number. & $\begin{array}{l}\text { Horse- } \\
\text { power. }\end{array}$ & & tons) & $\begin{array}{c}\text { nous (short } \\
\text { tons). }\end{array}$ & \\
\hline 10 & 17 & 18 & 19 & 20 & 21 & 22 & 23 & $\mathbf{2 4}$ & 25 & 26 & 27 \\
\hline & & & $\begin{array}{l}\cdots \ldots \\
\cdots \cdots\end{array}$ & $\begin{array}{r}62 \\
356\end{array}$ & $\begin{array}{r}1,711 \\
12,641\end{array}$ & $\begin{array}{r}62 \\
356\end{array}$ & $\begin{array}{r}1,711 \\
12,641\end{array}$ & $\begin{array}{r}0 \\
3,113\end{array}$ & $\begin{array}{r}181,066 \\
1,431,323\end{array}$ & $\begin{array}{r}181,066 \\
1,434,122\end{array}$ & $\begin{array}{r}0 \\
36,945\end{array}$ \\
\hline ....... & $\ldots \ldots \ldots$ & n.m.n. & $\ldots \ldots \ldots$ & 418 & 14,352 & 418 & 14,352 & 3,113 & $1,612,389$ & $1,615,188$ & 36,945 \\
\hline 12,705 & 316 & 12,765 & $\ldots \ldots \ldots \ldots$ & 316 & 12,765 & $\ldots$. & & 500 & $1,406,938$ & $1,407,388$ & 0 \\
\hline 6,240 & 154 & 6,249 & 0 & 213 & 7,124 & 59 & 875 & 464 & $1,000,443$ & $1,000,860$ & 0 \\
\hline 19,014 & 470 & 19,014 & 0 & 947 & 34,241 & 477 & 15,227 & 4,077 & $4,019,770$ & $4,023,436$ & 36,945 \\
\hline & & & $\begin{array}{l}\cdots . . . \\
\cdots \cdots . . \\
\cdots \cdots\end{array}$ & $\begin{array}{r}0 \\
328 \\
670\end{array}$ & $\begin{array}{r}0 \\
1,431 \\
11,068\end{array}$ & $\begin{array}{r}0 \\
328 \\
670\end{array}$ & $\begin{array}{r}0 \\
1,431 \\
11,068\end{array}$ & $\begin{array}{r}792 \\
9,543 \\
21,234\end{array}$ & $\begin{array}{r}0 \\
57,983 \\
180,102\end{array}$ & $\begin{array}{r}713 \\
66,533 \\
199,202\end{array}$ & $\begin{array}{l}0 \\
0 \\
0\end{array}$ \\
\hline ......... & ....... & $\ldots .$. & …........ & 998 & 12,499 & 998 & 12,499 & 31,569 & 238,085 & 266,448 & 0 \\
\hline $\begin{array}{r}10 \\
620 \\
2,142 \\
\end{array}$ & $\begin{array}{r}2 \\
42 \\
78\end{array}$ & $\begin{array}{r}10 \\
620 \\
2,142\end{array}$ & $\begin{array}{l}\ldots . . . \\
\cdots \cdots . . \\
\cdots \cdots .\end{array}$ & $\begin{array}{r}2 \\
42 \\
78\end{array}$ & $\begin{array}{r}10 \\
620 \\
2,142\end{array}$ & & $\begin{array}{c}\cdots \cdots \cdots \\
\cdots \cdots \cdots \cdots\end{array}$ & $\begin{array}{r}0 \\
2,135 \\
0\end{array}$ & $\begin{array}{r}10 \\
45 \\
4,700\end{array}$ & $\begin{array}{r}10 \\
1,955 \\
4,700\end{array}$ & $\begin{array}{l}0 \\
0 \\
0\end{array}$ \\
\hline 2,772 & 122 & $\overline{2,772}$ & $\ldots$. & 122 & 2,772 & $\ldots \ldots \ldots \ldots \ldots$ & ............ & 2,135 & 4,755 & 6,665 & 0 \\
\hline $\begin{array}{l}161 \\
321 \\
219\end{array}$ & $\begin{array}{r}9 \\
13 \\
11\end{array}$ & $\begin{array}{l}161 \\
321 \\
219\end{array}$ & $\begin{array}{l}0 \\
0 \\
0\end{array}$ & $\begin{array}{r}9 \\
14 \\
46\end{array}$ & $\begin{array}{l}161 \\
336 \\
807\end{array}$ & $\begin{array}{r}0 \\
1 \\
35\end{array}$ & $\begin{array}{r}0 \\
15 \\
588\end{array}$ & $\begin{array}{r}226 \\
6,119 \\
108\end{array}$ & $\begin{array}{r}0 \\
5,000 \\
3,576\end{array}$ & $\begin{array}{r}203 \\
10,500 \\
3,673\end{array}$ & $\begin{array}{l}0 \\
0 \\
0\end{array}$ \\
\hline 701 & 33 & 701 & 0 & 69 & 1,304 & 36 & 603 & 6,453 & 8,576 & 14,376 & 0 \\
\hline 3,473 & 155 & 3,473 & 0 & 1,189 & $-16,575$ & 1,034 & 13,102 & 40,157 & 251,416 & $\overline{287,489}$ & 0 \\
\hline & & & & & & & & 61,526 & 225,348 & 280,548 & 3,146 \\
\hline & & & $\begin{array}{ll}\cdots \\
\cdots \ldots \ldots \ldots \\
\cdots \ldots \ldots \ldots\end{array}$ & $\begin{array}{r}53 \\
21 \\
296 \\
\end{array}$ & $\begin{array}{r}819 \\
210 \\
4,000 \\
\end{array}$ & $\begin{array}{r}53 \\
21 \\
296 \\
\end{array}$ & $\begin{array}{r}819 \\
210 \\
4,000 \\
\end{array}$ & $\begin{array}{r}79,958 \\
68,757 \\
423,775 \\
\end{array}$ & $\begin{array}{r}109,818 \\
96,096 \\
1,045,529\end{array}$ & $\begin{array}{r}180,616 \\
157,896 \\
1,425,529\end{array}$ & $\begin{array}{r}17,611 \\
7,938 \\
228,741\end{array}$ \\
\hline$\ldots \ldots \ldots \ldots$ & $\ldots \ldots \ldots \ldots$ & $\overline{\ldots \ldots \ldots \ldots}$ & $\overline{\ldots \ldots \ldots}$ & 370 & 5,029 & $3 \overline{370}$ & 5,029 & 572,490 & $1,250,443$ & $1,764,041$ & 254,290 \\
\hline $\begin{array}{l}726 \\
625\end{array}$ & $\begin{array}{l}55 \\
31\end{array}$ & $\begin{array}{l}726 \\
625\end{array}$ & $\begin{array}{ll}\ldots \ldots \ldots \\
\cdots \ldots \ldots\end{array}$ & $\begin{array}{l}55 \\
31 \\
\end{array}$ & $\begin{array}{l}726 \\
625 \\
\end{array}$ & $\begin{array}{r}\ldots \ldots \ldots \ldots \\
\cdots \cdots \cdots \cdots\end{array}$ & a............... & $\begin{array}{r}10,798 \\
8,652\end{array}$ & $\begin{array}{r}95,521 \\
149,341\end{array}$ & $\begin{array}{l}105,121 \\
157,091\end{array}$ & $\begin{array}{r}26,125 \\
1,810\end{array}$ \\
\hline 1,351 & 86 & 1,351 & ......... & 86 & 1,351 & $\ldots \ldots \ldots \ldots \ldots$ & $\ldots \ldots \ldots \ldots$ & 19,450 & 244,862 & 262,212 & 27,935 \\
\hline $\begin{array}{r}706 \\
587 \\
1,701\end{array}$ & $\begin{array}{r}54 \\
48 \\
225\end{array}$ & $\begin{array}{r}753 \\
587 \\
1,701\end{array}$ & $\begin{array}{r}13 \\
0 \\
0\end{array}$ & $\begin{array}{r}79 \\
48 \\
420\end{array}$ & $\begin{array}{r}1,008 \\
587 \\
4,900\end{array}$ & $\begin{array}{r}25 \\
0 \\
195\end{array}$ & $\begin{array}{r}255 \\
0 \\
3,199\end{array}$ & $\begin{array}{r}46,742 \\
753 \\
528,141\end{array}$ & $\begin{array}{r}98,952 \\
170,413 \\
409,365\end{array}$ & $\begin{array}{l}140,952 \\
171,090 \\
883,365\end{array}$ & $\begin{array}{r}10,634 \\
1,427 \\
311,197\end{array}$ \\
\hline 3,054 & 327 & 3,041 & $\overline{13}$ & 547 & 6,495 & $\overline{220}$ & 3,454 & 575,636 & 678,730 & $1,195,407$ & 323,258 \\
\hline 4,405 & 413 & 4,392 & 13 & 1,003 & 12,875 & 590 & 8,483 & $1,167,576$ & $2,174,035$ & $3,221,660$ & 605,483 \\
\hline 4,405 & 413 & 4,392 & 13 & 1,003 & $12, \overline{875}$ & 590 & 8,483 & $1,229,102$ & $2,399,383$ & $3,3,502,208$ & 608,629 \\
\hline & & & & $\begin{array}{r}5 \\
104 \\
231\end{array}$ & $\begin{array}{r}21 \\
1,204 \\
4,936\end{array}$ & $\begin{array}{r}5 \\
104 \\
231\end{array}$ & $\begin{array}{r}21 \\
1,204 \\
4,936\end{array}$ & $\begin{array}{r}0 \\
11,062 \\
395,366\end{array}$ & $\begin{array}{r}0 \\
69,536 \\
122,396\end{array}$ & $\begin{array}{r}0 \\
79,492 \\
478,225\end{array}$ & $\begin{array}{r}0 \\
0 \\
44,479 \\
\end{array}$ \\
\hline$\cdots \cdots$ & …......... & .......... & $\ldots \ldots \ldots \ldots$ & 340 & 6,161 & 340 & 6,161 & 406,428 & 191,932 & 557,717 & 44,479 \\
\hline 147 & 10 & 147 & & 19 & 147 & ..... & & 0 & 0 & 0 & 0 \\
\hline $\begin{array}{r}0 \\
1,350\end{array}$ & $\begin{array}{r}0 \\
29\end{array}$ & $\begin{array}{r}0 \\
1,350\end{array}$ & $\begin{array}{l}0 \\
0\end{array}$ & $\begin{array}{r}0 \\
766\end{array}$ & $\begin{array}{r}0 \\
19,333\end{array}$ & $\begin{array}{r}0 \\
737\end{array}$ & $\begin{array}{r}0 \\
17,983\end{array}$ & $\begin{array}{r}6,000 \\
625,225\end{array}$ & $\begin{array}{r}3,000 \\
193,981\end{array}$ & $\begin{array}{r}8,400 \\
756,683\end{array}$ & $\begin{array}{r}0 \\
177,677\end{array}$ \\
\hline 1,350 & 29 & 1,350 & 0 & 766 & 19,333 & 737 & 17,983 & 631,225 & 196,981 & 765,083 & 177,677 \\
\hline 1,497 & 48 & 1,497 & 0 & 1,125 & 25,641 & 1,077 & 24,144 & $1,037,653$ & 388,913 & $1,322,800$ & 222,156 \\
\hline
\end{tabular}


'TABLE 46.-Mechanical power-supply equipment and fuel used

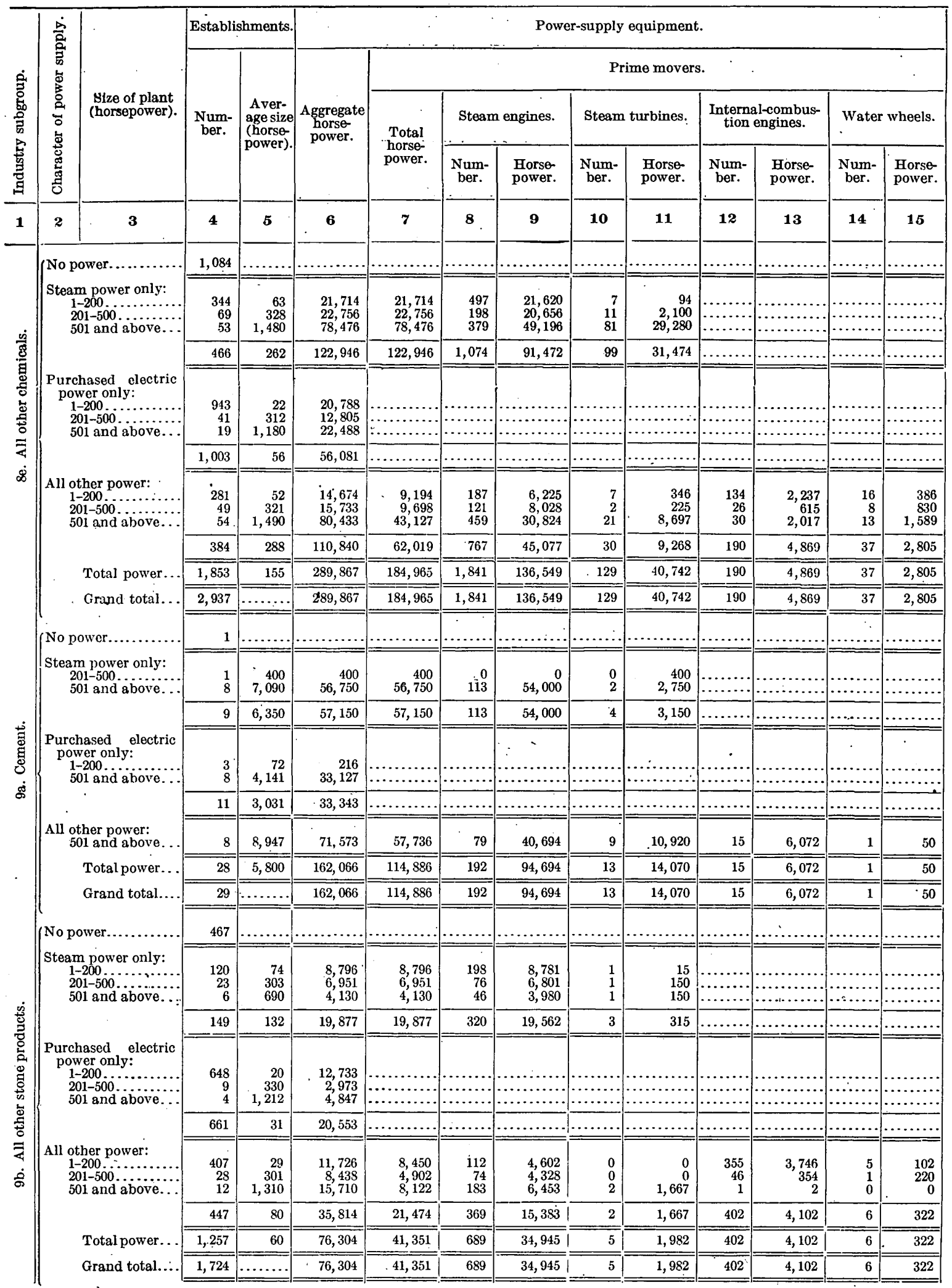


by industry sübgrouips, by character of poiver supply-Continued.

\begin{tabular}{|c|c|c|c|c|c|c|c|c|c|c|c|}
\hline \multirow{2}{*}{\multicolumn{4}{|c|}{$\begin{array}{c}\text { Power-supply equipment-Continued. } \\
\text { Operated by purchased energy. }\end{array}$}} & \multicolumn{4}{|c|}{ Electric motors. } & \multicolumn{4}{|c|}{ Fuel used. } \\
\hline & & & & \multirow{2}{*}{\multicolumn{2}{|c|}{ Total. }} & \multirow{2}{*}{\multicolumn{2}{|c|}{$\begin{array}{l}\text { Run by current gen- } \\
\text { erated in establish- } \\
\text { ment. }\end{array}$}} & \multicolumn{3}{|c|}{ Coal. } & \multirow{3}{*}{$\begin{array}{l}\text { Coke } \\
\text { (short } \\
\text { tons). }\end{array}$} \\
\hline \multirow{2}{*}{$\begin{array}{c}\text { Total } \\
\text { horsopower. }\end{array}$} & \multicolumn{2}{|c|}{ Electric motors. } & \multirow{2}{*}{$\begin{array}{l}\text { Other } \\
\text { (horse- } \\
\text { power). }\end{array}$} & & & & & \multirow{2}{*}{$\begin{array}{l}\text { Anthracite } \\
\text { (long tons). }\end{array}$} & \multirow{2}{*}{$\begin{array}{c}\text { Bitumi- } \\
\text { nous (short } \\
\text { tons). }\end{array}$} & \multirow{2}{*}{$\begin{array}{c}\text { Total } \\
\text { equivalent } \\
\text { bitumi- } \\
\text { nous (short } \\
\text { tons). }\end{array}$} & \\
\hline & Number. & $\begin{array}{l}\text { Horse- } \\
\text { power. }\end{array}$ & & Number. & $\begin{array}{l}\text { Horse- } \\
\text { power. }\end{array}$ & Number. & $\begin{array}{l}\text { Horse- } \\
\text { power. }\end{array}$ & & & & \\
\hline \multirow[t]{2}{*}{16} & 17 & 18 & 19 & 20 & 21 & 22 & 23 & 24 & 25 & 26 & 27 \\
\hline & $\because$ & …..... & & $\cdots$ & & & $\cdots$ & 17,747 & 38,978 & 54,953 & 327 \\
\hline & & & & $\begin{array}{r}466 \\
1,192 \\
5,309\end{array}$ & $\begin{array}{r}4,867 \\
12,562 \\
63,872\end{array}$ & $\begin{array}{r}466 \\
1,192 \\
5,309\end{array}$ & $\begin{array}{r}4,867 \\
12,562 \\
63,872\end{array}$ & $\begin{array}{r}88,393 \\
60,491 \\
304,617\end{array}$ & $\begin{array}{l}186,889 \\
190,625 \\
736,776\end{array}$ & $\begin{array}{r}266,443 \\
245,066 \\
1,010,933\end{array}$ & $\begin{array}{r}6,072 \\
5,364 \\
10,509\end{array}$ \\
\hline & $\cdots$ & ...... & …....... & 6,967 & 81,301 & 6,967 & 81,301 & 453,501 & $1,114,290$ & $1,522,442$ & 21,945 \\
\hline $\begin{array}{l}20,788 \\
12,805 \\
22,488\end{array}$ & $\begin{array}{l}3,459 \\
1,083 \\
1,172\end{array}$ & $\begin{array}{l}20,788 \\
12,805 \\
22,488\end{array}$ & 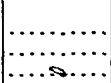 & $\begin{array}{l}3,459 \\
1,083 \\
1,172\end{array}$ & $\begin{array}{l}20,788 \\
12,805 \\
22,488\end{array}$ & & ........ & $\begin{array}{r}123,834 \\
9,016 \\
14,180\end{array}$ & $\begin{array}{l}87,017 \\
47,344 \\
86,066\end{array}$ & $\begin{array}{r}198,468 \\
55,458 \\
98,828\end{array}$ & $\begin{array}{l}3,597 \\
1,648 \\
180\end{array}$ \\
\hline 56,081 & 5,714 & 56,081 & $\ldots$ & 5,714 & 56,081 & ........ & 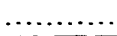 & 147,030 & 220,427 & 352,754 & 5,425 \\
\hline $\begin{array}{r}5,480 \\
6,035 \\
37,300\end{array}$ & $\begin{array}{r}779 \\
580 \\
2,455\end{array}$ & $\begin{array}{r}4,869 \\
6,035 \\
37,306\end{array}$ & $\begin{array}{r}611 \\
0 \\
0\end{array}$ & $\begin{array}{r}914 \\
841 \\
3,510\end{array}$ & $\begin{array}{r}5,636 \\
8,577 \\
49,691\end{array}$ & $\begin{array}{r}135 \\
261 \\
1,055\end{array}$ & $\begin{array}{r}767 \\
2,542 \\
12,385\end{array}$ & $\begin{array}{r}53,270 \\
71,528 \\
250,121\end{array}$ & $\begin{array}{r}69,402 \\
67,974 \\
445,742\end{array}$ & $\begin{array}{l}117,345 \\
132,351 \\
670,850\end{array}$ & $\begin{array}{l}2,595 \\
3,593 \\
5,955\end{array}$ \\
\hline 48,821 & 3,814 & 48,210 & 611 & 5,265 & 63,904 & 1,451 & 15,694 & 374,919 & 583,118 & 920,546 & 12,143 \\
\hline 104,902 & 9,528 & 104,291 & 611 & 17,946 & 201,286 & 8,418 & 96,995 & 975,450 & $1,917,835$ & $2,795,742$ & 39,513 \\
\hline 104,902 & 0,528 & 104,291 & 611 & 17,946 & 201,286 & 8,418 & 96,995 & 993,197 & $1,956,813$ & $2,850,695$ & 39,840 \\
\hline & & & & & & & & 42 & 128 & 165 & 0 \\
\hline & & & & $\begin{array}{r}25 \\
836\end{array}$ & $\begin{array}{r}500 \\
26,271\end{array}$ & $\begin{array}{r}25 \\
836\end{array}$ & $\begin{array}{r}500 \\
26,271\end{array}$ & $\begin{array}{r}0 \\
214,422\end{array}$ & $\begin{array}{r}7,436 \\
810,711\end{array}$ & $\begin{array}{r}7,436 \\
1,003,711\end{array}$ & $\begin{array}{l}0 \\
0\end{array}$ \\
\hline .......... & ....... & ......... & & 861 & 26,771 & 861 & 26,771 & 214,422 & 818,147 & $1,011,147$ & 00 \\
\hline $\begin{array}{r}216 \\
. \quad 33,127 \\
\end{array}$ & $\begin{array}{r}16 \\
610\end{array}$ & $\begin{array}{r}216 \\
33,127\end{array}$ & $\ldots .$. & $\begin{array}{r}16 \\
610\end{array}$ & $\begin{array}{r}216 \\
33,127\end{array}$ & & & $\begin{array}{r}0 \\
7,370\end{array}$ & $\begin{array}{r}0 \\
285,379\end{array}$ & $\begin{array}{r}0 \\
292,009\end{array}$ & $\begin{array}{r}120 \\
1,466\end{array}$ \\
\hline 33,343 & 626 & 33,343 & & 626 & 33,343 & ..... & ….... & 7,370 & 285,379 & 292,009 & 1,586 \\
\hline 13,837 & 211 & 13,837 & 0 & 499 & 28,128 & 288 & 14,291 & 50,407 & 750,867 & 796,167 & . \\
\hline 47,180 & 837 & 47,180 & 0 & 1,986 & 88,242 & 1,149 & 41,062 & 272,199 & $1,854,393$ & $2,099,323$ & 1,586 \\
\hline 47,180 & 837 & 47,180 & 0 & 1,986 & 88,242 & 1,149 & 41,062 & 272,241 & $1,854,521$ & $2,099,488$ & 1,586 \\
\hline & & ....... & & & & & & 7,510 & 17,361 & 24,111 & 2,065 \\
\hline & & & & $\begin{array}{r}36 \\
146 \\
48\end{array}$ & $\begin{array}{r}500 \\
1,845 \\
1,653\end{array}$ & $\begin{array}{r}36 \\
146 \\
48\end{array}$ & $\begin{array}{r}500 \\
1,845 \\
1,653\end{array}$ & $\begin{array}{r}16,758 \\
18,648 \\
7,865\end{array}$ & $\begin{array}{l}27,468 \\
21,277 \\
22,885\end{array}$ & $\begin{array}{l}42,468 \\
37,977 \\
29,935\end{array}$ & $\begin{array}{r}3,861 \\
0 \\
30,900\end{array}$ \\
\hline …..... & $\therefore \ldots$ & ......... & & 230 & 3,998 & 230 & 3,998 & 43,271 & 71,630 & 110,380 & 34,761 \\
\hline $\begin{array}{r}12,733 \\
2,973 \\
4,847\end{array}$ & $\begin{array}{r}1,157 \\
209 \\
190\end{array}$ & $\begin{array}{r}12,733 \\
2,973 \\
4,847\end{array}$ & ........... & $\begin{array}{r}1,157 \\
209 \\
190\end{array}$ & $\begin{array}{r}12,733 \\
2,973 \\
4,847\end{array}$ & & & $\begin{array}{l}5,388 \\
1,400 \\
215\end{array}$ & $\begin{array}{l}13,311 \\
25,100 \\
21,599\end{array}$ & $\begin{array}{l}18,141 \\
26,300 \\
21,792\end{array}$ & $\begin{array}{r}3,921 \\
0 \\
0\end{array}$ \\
\hline 20,553 & 1,556 & 20,553 & …....... & 1,556 & 20,553 & $\ldots \ldots$ & $\ldots$ & 7,003 & 60,010 & 66,293 & 3,921 \\
\hline $\begin{array}{l}3,276 \\
3,536 \\
7,588\end{array}$ & $\begin{array}{l}219 \\
172 \\
369\end{array}$ & $\begin{array}{l}2,937 \\
3,536 \\
7,588\end{array}$ & $\begin{array}{r}339 \\
0 \\
0\end{array}$ & $\begin{array}{l}249 \\
203 \\
429\end{array}$ & $\begin{array}{l}.2,357 \\
3,984 \\
8,938\end{array}$ & $\begin{array}{l}30 \\
31 \\
60\end{array}$ & $\begin{array}{r}320 \\
448 \\
1,350\end{array}$ & $\begin{array}{r}13,133 \\
3,511 \\
21,758\end{array}$ & $\begin{array}{l}33,830 \\
35,937 \\
65,141\end{array}$ & $\begin{array}{l}45,630 \\
39.097 \\
84,641\end{array}$ & $\begin{array}{r}3,259 \\
50 \\
9,392\end{array}$ \\
\hline 14,400 & 760 & 14,061 & 339 & 881 & 16,179 & 121 & 2,118 & 38,402 & 134,908 & 169,308 & 12,691 \\
\hline 34,053 & 2,316 & 34,014 & 339 & 2,667 & 40,730 & 351 & 6,116 & 88,676 & 266,548 & 346,041 & 51,373 \\
\hline 34,953 & 2,316 & 34,614 & 339 & 2,667 & 40,730 & 351. & 6,116 & 96,186 & 283,909 & 370,152 & 53,438 \\
\hline
\end{tabular}


TABLE 46.-Mechanical power-supply equipment and fuel used

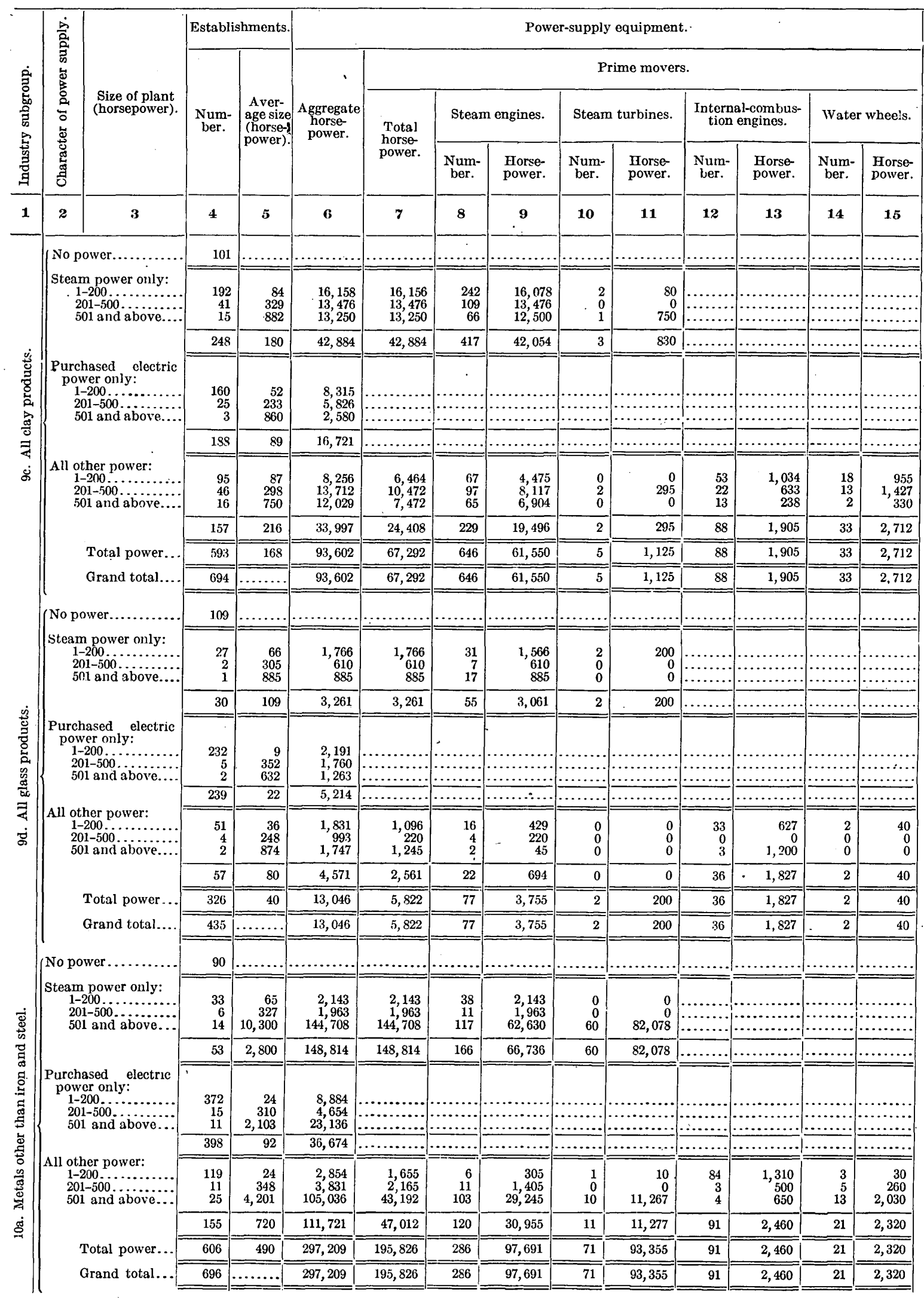


by industry subgroups, by chafacter of power supply-Continued.

\begin{tabular}{|c|c|c|c|c|c|c|c|c|c|c|c|}
\hline \multirow{2}{*}{\multicolumn{4}{|c|}{$\frac{\text { Power-supply equipment-Continued. }}{\text { Operated by purchased energy. }}$}} & \multicolumn{4}{|c|}{ Electric motors. } & \multicolumn{4}{|c|}{ Fuel used. } \\
\hline & & & & \multirow{2}{*}{\multicolumn{2}{|c|}{ Total. }} & \multirow{2}{*}{\multicolumn{2}{|c|}{$\begin{array}{l}\text { Run by current gen- } \\
\text { erated in establish- } \\
\text { ment. }\end{array}$}} & \multirow{3}{*}{$\begin{array}{l}\text { Anthracite } \\
\text { (long tons). }\end{array}$} & \multicolumn{2}{|l|}{ Coal. } & \multirow{3}{*}{$\begin{array}{l}\text { Coke } \\
\text { (short } \\
\text { tons). }\end{array}$} \\
\hline \multirow{2}{*}{$\begin{array}{c}\text { Total } \\
\text { horsepower. }\end{array}$} & \multicolumn{2}{|c|}{ Electric motors. } & \multirow{2}{*}{$\begin{array}{l}\text { Other } \\
\text { (horse- } \\
\text { power). }\end{array}$} & & & & & & & & \\
\hline & Number. & $\begin{array}{l}\text { Horse- } \\
\text { power. }\end{array}$ & & Number. & $\begin{array}{l}\text { Horse- } \\
\text { power. }\end{array}$ & Number. & $\begin{array}{l}\text { Horse- } \\
\text { power. }\end{array}$ & & & $\begin{array}{c}\text { nous (short } \\
\text { tons). }\end{array}$ & \\
\hline \multirow[t]{2}{*}{16} & 17 & 18 & 19 & 20 & 21 & 22 & 23 & 24 & 25 & 26 & 27 \\
\hline & & & & & & & & 3,879 & 12,493 & 16,003 & 144 \\
\hline & & …............ & ......... & $\begin{array}{r}60 \\
140 \\
144\end{array}$ & $\begin{array}{r}506 \\
2,167 \\
3,992\end{array}$ & $\begin{array}{r}60 \\
140 \\
144\end{array}$ & $\begin{array}{r}506 \\
2,167 \\
3,992\end{array}$ & $\begin{array}{l}40,566 \\
19,724 \\
38,424\end{array}$ & $\begin{array}{r}174,129 \\
94,358 \\
64,395\end{array}$ & $\begin{array}{r}210,652 \\
112,109 \\
98,973\end{array}$ & $\begin{array}{r}940 \\
1,049 \\
138\end{array}$ \\
\hline ……..... & $1 \ldots \ldots \ldots \ldots$ & $\ldots \ldots \ldots \ldots$ & $\ldots \ldots \ldots$ & 344 & 6,665 & 344 & 6,665 & 98,714 & 332,882 & 421,734 & 2,127 \\
\hline $\begin{array}{l}8,315 \\
5,826 \\
2,580 \\
\end{array}$ & $\begin{array}{r}537 \\
131 \\
86 \\
\end{array}$ & $\begin{array}{r}8,315 \\
5,826 \\
2,580 \\
\end{array}$ & & $\begin{array}{r}537 \\
131 \\
86 \\
\end{array}$ & $\begin{array}{l}8,315 \\
5,826 \\
2,580 \\
\end{array}$ & & & $\begin{array}{r}13,094 \\
2,818 \\
45 \\
\end{array}$ & $\begin{array}{l}57,225 \\
44,588 \\
19,228 \\
\end{array}$ & $\begin{array}{l}69,010 \\
46,408 \\
19,268\end{array}$ & $\begin{array}{l}349 \\
372 \\
340\end{array}$ \\
\hline 16,721 & 754 & 16,721 & $\ldots \ldots \ldots$ & 754 & 16,721 & ....... & ......... & 15,957 & 121,041 & 134,686 & 1,061 \\
\hline $\begin{array}{l}1,792 \\
3,240 \\
4,557\end{array}$ & $\begin{array}{l}153 \\
167 \\
198\end{array}$ & $\begin{array}{l}1,745 \\
3,240 \\
4,557\end{array}$ & $\begin{array}{r}47 \\
0 \\
0\end{array}$ & $\begin{array}{l}153 \\
204 \\
273\end{array}$ & $\begin{array}{l}1,745 \\
3,865 \\
5,049\end{array}$ & $\begin{array}{r}0 \\
37 \\
75\end{array}$ & $\begin{array}{r}0 \\
625 \\
492\end{array}$ & $\begin{array}{l}24,121 \\
11,553 \\
22,068\end{array}$ & $\begin{array}{r}46,063 \\
102,304 \\
123,455\end{array}$ & $\begin{array}{r}67,771 \\
112,699 \\
143,316\end{array}$ & $\begin{array}{r}2,171 \\
750 \\
369\end{array}$ \\
\hline 9,589 & 518 & 9,542 & 47 & 630 & 10,659 & 112 & 1,117 & 57,742 & 271,822 & 323,786 & 3,290 \\
\hline 26,310 & 1,272 & 26,263 & 47 & 1,728 & 34,045 & 456 & 7,782 & 172,413 & 725,745 & 880,206 & 6,478 \\
\hline 26,310 & 1,272 & 26,263 & 47 & 1,728 & 34,045 & 456 & 7,782 & $176,3,12$ & 738,238 & 896,209 & 6,622 \\
\hline & …........ & ….... & & … & & & & 231 & 55 & 262 & 125 \\
\hline & & & & $\begin{array}{l}39 \\
44 \\
25\end{array}$ & $\begin{array}{l}239 \\
392 \\
168\end{array}$ & $\begin{array}{l}39 \\
44 \\
25\end{array}$ & $\begin{array}{l}239 \\
392 \\
168\end{array}$ & $\begin{array}{r}5,396 \\
0 \\
239\end{array}$ & $\begin{array}{l}46,479 \\
17,111 \\
37,768\end{array}$ & $\begin{array}{l}51,329 \\
17,111 \\
37,398\end{array}$ & $\begin{array}{r}889 \\
0 \\
0\end{array}$ \\
\hline …...... & …...... & …......... & $\ldots \ldots \ldots \ldots$ & 108 & 799 & 108 & 799 & 5,635 & 101,358 & 106,423 & 889 \\
\hline $\begin{array}{l}2,191 \\
1,760\end{array}$ & $\begin{array}{l}576 \\
138\end{array}$ & $\begin{array}{l}2,191 \\
1,760\end{array}$ & …......... & $\begin{array}{l}576 \\
138\end{array}$ & $\begin{array}{l}2,191 \\
1,760\end{array}$ & & & $\begin{array}{l}2,951 \\
\ldots \ldots \ldots\end{array}$ & $\begin{array}{l}13,143 \\
36,951\end{array}$ & $\begin{array}{l}15,793 \\
36,951\end{array}$ & $\begin{array}{r}285 \\
0\end{array}$ \\
\hline 1,263 & 31 & 1,263 & ….......... & 31 & 1,263 & …....... & $\cdots \cdots$ & $40^{\circ}$ & $\begin{array}{r}4,732 \\
\end{array}$ & 4,769 & 0 \\
\hline 5,214 & 745 & 5,214 & $\ldots \ldots \ldots \ldots$ & 745 & 5,214 & $\ldots \ldots \ldots \ldots$ & ……..... & 2,991 & 54,826 & 57,513 & 285 \\
\hline $\begin{array}{l}735 \\
773 \\
502\end{array}$ & $\begin{array}{l}95 \\
43 \\
39\end{array}$ & $\begin{array}{l}639 \\
773 \\
502\end{array}$ & $\begin{array}{r}96 \\
0 \\
0\end{array}$ & $\begin{array}{r}111 \\
43 \\
130\end{array}$ & $\begin{array}{r}765 \\
773 \\
1,966\end{array}$ & $\begin{array}{r}16 \\
0 \\
91\end{array}$ & $\begin{array}{r}126 \\
\cdot \quad 1,464\end{array}$ & $\begin{array}{r}3,091 \\
297 \\
0\end{array}$ & $\begin{array}{r}26,223 \\
5,864 \\
42,847\end{array}$ & $\begin{array}{r}29,003 \\
6,131 \\
42,847\end{array}$ & $\begin{array}{r}5,092 \\
200 \\
0\end{array}$ \\
\hline 2,010 & 177 & 1,914 & 96 & 284 & 3,504 & 107 & 1,590 & 3,388 & 74,934 & 77,981 & 5,292 \\
\hline 7,224 & 922 & 7,128 & 96 & 1,137 & 9,517 & 215 & 2,389 & 12,014 & 231,118 & 241,917 & 6,466 \\
\hline 7,224 & 922 & 7,128 & 96 & 1,137 & 9,517 & 215 & 2,389 & 12,245 & 231,173 & 242,179 & 6,591 \\
\hline & & & & & & & & 2,737 & 2,892 & 5,252 & 944 \\
\hline$\cdots \cdots$ & & & …...... & $\begin{array}{r}63 \\
55 \\
3,685 \\
\end{array}$ & $\begin{array}{r}764 \\
993 \\
66,628 \\
\end{array}$ & $\begin{array}{r}63 \\
55 \\
3,685 \\
\end{array}$ & $\begin{array}{r}764 \\
993 \\
66,628\end{array}$ & $\begin{array}{r}6,157 \\
621,673 \\
621,618\end{array}$ & $\begin{array}{r}9,149 \\
10,137 \\
613,713 \\
\end{array}$ & $\begin{array}{r}14,649 \\
10,832 \\
1,173,713\end{array}$ & $\begin{array}{r}1,764 \\
2,880 \\
155,913\end{array}$ \\
\hline ............. & ........ & ............. & ............ & 3,803 & 68,385 & 3,803 & 68,385 & 628,548 & 632,999 & $1,199,194$ & 160,557 \\
\hline $\begin{array}{r}8,884 \\
4,654 \\
23,136\end{array}$ & $\begin{array}{r}1,287 \\
631 \\
1,003 \\
\end{array}$ & $\begin{array}{r}8,884 \\
4,654 \\
23,136 \\
\end{array}$ & & $\begin{array}{r}1,287 \\
631 \\
1,003\end{array}$ & $\begin{array}{r}8,884 \\
4,654 \\
23,136\end{array}$ & & & $\begin{array}{r}21,164 \\
1,848 \\
27,009\end{array}$ & $\begin{array}{r}20,008 \\
5,034 \\
12,271\end{array}$ & $\begin{array}{r}39,008 \\
6,694 \\
56,571\end{array}$ & $\begin{array}{r}117,034 \\
1,790 \\
1,253\end{array}$ \\
\hline 36,674 & 2,921 & 36,674 & $\overline{\ldots \ldots \ldots \ldots}$ & 2,921 & 36,674 & $\ldots \ldots$ & $\overline{\cdots \cdots \cdots}$ & 50,021 & 37,313 & 82,273 & 120,077 \\
\hline $\begin{array}{r}1,199 \\
1,666 \\
61,844\end{array}$ & $\begin{array}{r}81 \\
133 \\
2,412 \\
\end{array}$ & $\begin{array}{r}761 \\
1,666 \\
48,159\end{array}$ & $\begin{array}{r}438 \\
0 \\
13,685\end{array}$ & $\begin{array}{r}83 \\
165 \\
2,944 \\
\end{array}$ & $\begin{array}{r}762 \\
2,002 \\
62,640\end{array}$ & $\begin{array}{r}2 \\
32 \\
532\end{array}$ & $\begin{array}{r}1 \\
336 \\
14,481\end{array}$ & $\begin{array}{r}4,725 \\
2,036 \\
108,408\end{array}$ & $\begin{array}{r}10,115 \\
15,289 \\
281,089\end{array}$ & $\begin{array}{r}14,365 \\
17,129 \\
378,589\end{array}$ & $\begin{array}{r}5,061 \\
5,627 \\
37,129\end{array}$ \\
\hline 64,709 & 2,626 & 50,586 & 14,123 & 3,192 & 65,404 & 566 & 14,818 & 115,169 & 306,493 & 410,083 & 47,817 \\
\hline 101,383 & 5,547 & 87,260 & 14,123 & 9,916 & 170,463 & 4,369 & 83,203 & 793,738 & 976,805 & $1,691,550$ & 328,451 \\
\hline 101,383 & 5,547 & 87,260 & 14,123 & 9,916 & 170,463 & 4,369 & 83,203 & 796,475 & 979,697 & $2,696,803$ & 329,395 \\
\hline
\end{tabular}


TABLE 46.-Mechanical power-suipply equipment and fuel used

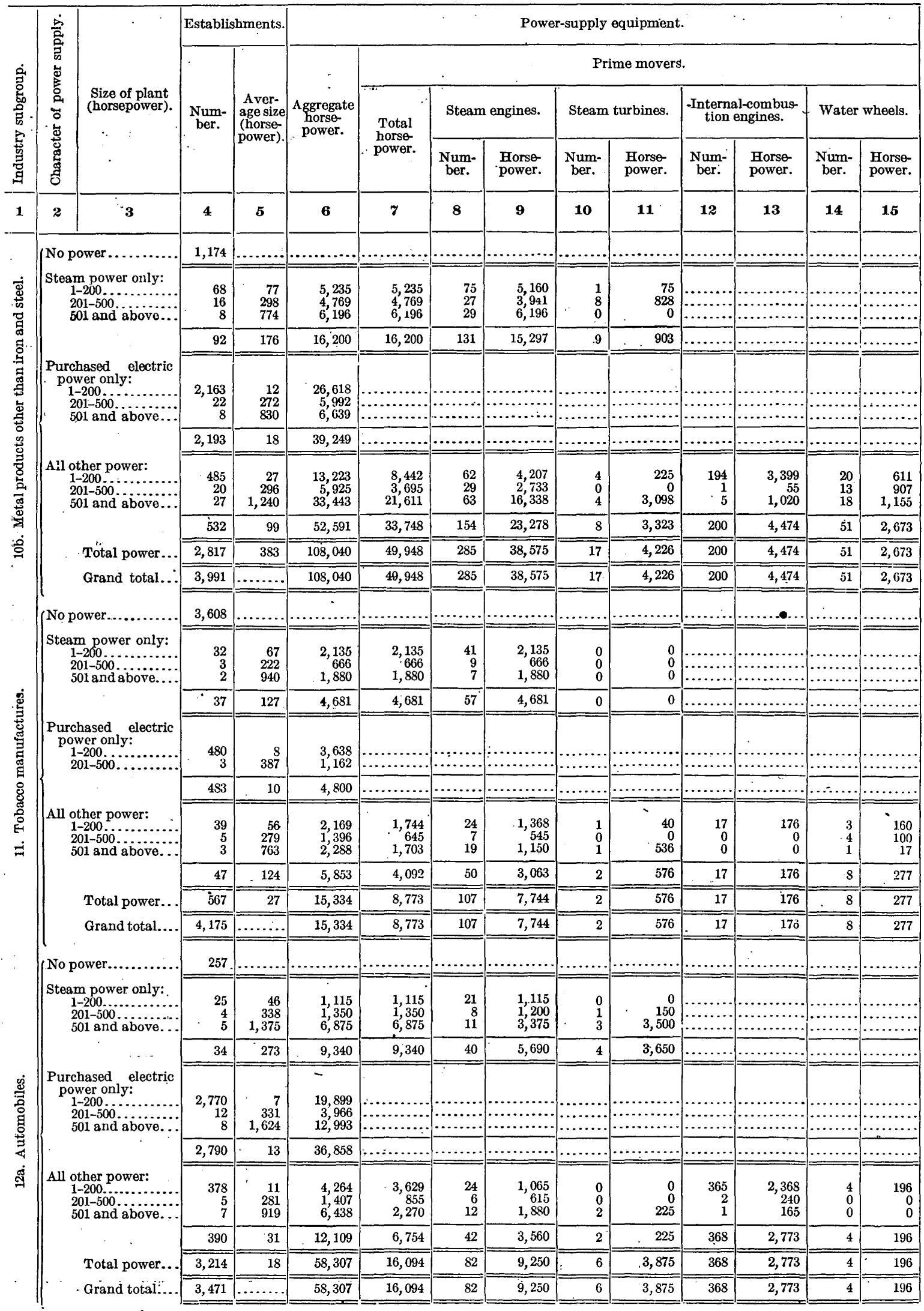


by industry subgroups, by character of power supply $\rightarrow$ Continued.

\begin{tabular}{|c|c|c|c|c|c|c|c|c|c|c|c|}
\hline \multirow{2}{*}{\multicolumn{4}{|c|}{$\frac{\text { Power-supply equipment-Continued. }}{\text { Operated by purchased energy. }}$}} & \multicolumn{4}{|c|}{ Electric motors. } & \multicolumn{4}{|c|}{ Fuel used. } \\
\hline & & & & \multirow{2}{*}{\multicolumn{2}{|c|}{ Totäl. }} & \multirow{2}{*}{\multicolumn{2}{|c|}{$\begin{array}{l}\text { Run by current gen- } \\
\text { erated in èstablish- } \\
\text { ment. }\end{array}$}} & \multicolumn{3}{|c|}{ Coal. } & \multirow{3}{*}{$\begin{array}{l}\text { Coke } \\
\text { (short } \\
\text { tons). }\end{array}$} \\
\hline \multirow{2}{*}{$\begin{array}{c}\text { Total } \\
\text { horsepower. }\end{array}$} & \multicolumn{2}{|c|}{ Electric motors. } & \multirow{2}{*}{$\begin{array}{l}\text { Other } \\
\text { (horse- } \\
\text { power). }\end{array}$} & & & & & \multirow{2}{*}{$\begin{array}{l}: \\
\text { Anthracite } \\
\text { (long tons). }\end{array}$} & \multirow{2}{*}{$\begin{array}{l}\text { Bitumi- } \\
\text { nous(short } \\
\text { tons) }\end{array}$} & \multirow{2}{*}{$\begin{array}{c}\text { Total } \\
\text { equivalent } \\
\text { bitumi- } \\
\text { nous (short } \\
\text { tons). }\end{array}$} & \\
\hline & Number. & $\begin{array}{l}\text { Horse: } \\
\text { power. }\end{array}$ & & Number. & $\begin{array}{l}\text { Horse- } \\
\text {-power. }\end{array}$ & Number. & $\begin{array}{l}\text { Horse } \\
\text { power. }\end{array}$ & & & & \\
\hline \multirow[t]{2}{*}{16} & 17 & 18 & 19 & 20 & 21 & 22 & 23 & 24 & 25 & 26 & 27 \\
\hline & $\cdots$ & $\cdots$ & & $\ldots \ldots \ldots$ & & n......... & .............. & 2,350 & 899 & $\cdot 3,014$ & 817 \\
\hline & & & $\mid \begin{array}{l}\mid \cdots \ldots \ldots \\
\cdots \ldots \ldots \\
\cdots \cdots \ldots\end{array}$ & $\begin{array}{r}317 \\
577 \\
\therefore 577\end{array}$ & $\begin{array}{r}r 2,039 \\
2,954 \\
-\quad .7,958 \\
\end{array}$ & $\begin{array}{l}317 \\
577 \\
577 .\end{array}$ & $\begin{array}{l}2,039 \\
2,954 \\
7,958\end{array}$ & $\begin{array}{r}11,370 . \\
8,956 \\
14,737\end{array}$ & $\begin{array}{l}21,267 \\
15,257 \\
29,630\end{array}$ & $\begin{array}{l}31,500 \\
23,322 \\
42,896\end{array}$ & $\begin{array}{r}2,094 \\
43 \\
734\end{array}$ \\
\hline$\cdots$ & & $\ldots \ldots$ & ....... & 1,471 & 12,951 & 1,471 & 12,951 & 35,063 & 66,154 & 97,718 & 2,871 \\
\hline $\begin{array}{r} \\
5,618 \\
5,992 \\
6,639 \\
\end{array}$ & $\begin{array}{r}7,384^{\circ} \\
617 \\
613\end{array}$ & $\begin{array}{r}26,618 \\
5,992 \\
6,639 \\
\end{array}$ & 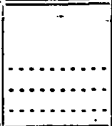 & $\begin{array}{r}-\cdots \\
7,384 \\
617 \\
613\end{array}$ & $\begin{array}{r}\quad \therefore \\
\quad 26,618 \\
5,992 \\
6,639 \\
\end{array}$ & 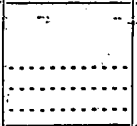 & 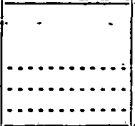 & $\begin{array}{r}13,100 \\
388 \\
1,978 \\
\end{array}$ & $\begin{array}{r}15,314 \\
6,726 \\
5,428\end{array}$ & $\begin{array}{r}27,104 \\
7,075 \\
7,210\end{array}$ & $\begin{array}{r}3,564 \\
192 \\
0\end{array}$ \\
\hline 39,249 & 8,614 & 39,249 & ....... & 8,614 & $.39,249$ & n............. & ......... & 15,466 & 27,468 & $41,38 \dot{9}$ & 3,756 \\
\hline $\begin{array}{r}4,781 \\
2,230 \\
11,832 \\
\end{array}$ & $\begin{array}{r}350 \\
\therefore \quad 291 \\
1,908 \\
\end{array}$ & $\begin{array}{r}2,567 \\
1,980 \\
11,832 \\
\end{array}$ & $\begin{array}{r}2,214 \\
250 \\
0\end{array}$ & $\begin{array}{r}900 \\
485 \\
3,307 \\
\end{array}$ & $\begin{array}{r}4,901 \\
3,543 \\
22,640\end{array}$ & $\begin{array}{r}550 \\
194 \\
1,399 \\
\end{array}$ & $\begin{array}{r}2,334 \\
1,563 \\
10,808\end{array}$ & $\begin{array}{r}5,510 \\
3,848 \\
25,149 \\
\end{array}$ & $\begin{array}{l}30,135 \\
17,727 \\
84,42.1\end{array}$ & $\begin{array}{r}35,094 \\
21,195 \\
107,156\end{array}$ & $\begin{array}{r}1,627 \\
0 \\
766\end{array}$ \\
\hline 18,843 & 2,549 & 16,379 & 2,464 & 4,692 & 31,084 & 2,143 & $14 ; 705$ & 34,507 & 132,283 & 163,445 & 2,393 \\
\hline 58,092 & 11,163 & 55,628 & 2,464 & 14,777 & 83,284 & 3,614 & 27,656 & 85,036 & 225,905 & 302,552 & 9,020 \\
\hline 58,092 & 11,163 & 55,628 & 2,464 & 14,777 & 83,284 & 3,614 & 27,656 & 87,386 & 226,804 & 305,566 & 9,837 \\
\hline & $\cdots$ & $\cdots \cdots$ & & & & $\ldots \ldots \ldots$ & $\cdots$ & 8,198 & 2,513 & 9,863 & 10 \\
\hline & & .......... & & $\begin{array}{r}107 \\
9 \\
99\end{array}$ & $\begin{array}{r}598 \\
240 \\
1,386\end{array}$ & $\begin{array}{r}107 \\
9 \\
99\end{array}$ & $\begin{array}{r}598 \\
240 \\
1,386\end{array}$ & $\begin{array}{r}5,914 \\
890 \\
46\end{array}$ & $\begin{array}{r}4,373 \\
4,652 \\
13,996\end{array}$ & $\begin{array}{r}9,693 \\
5,442 \\
14,037\end{array}$ & $\begin{array}{r}58 \\
0 \\
180\end{array}$ \\
\hline ……. & ....... & …… & ....... & 215 & 2,224 & 215 & $-2,224$ & 6,850 & 23,021 & 29,172 & 238 \\
\hline $\begin{array}{l}3,038 \\
1,162\end{array}$ & $\begin{array}{r}1,274 \\
74\end{array}$ & $\begin{array}{l}3,638 \\
1,162\end{array}$ & 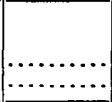 & $\begin{array}{r}1,274 \\
74\end{array}$ & $\begin{array}{l}3,638 \\
1,162 \\
\end{array}$ & (n............... & $\therefore \cdots .$. & $\begin{array}{r}11,206 \\
299\end{array}$ & $\begin{array}{r}4,878 \\
400 \\
\end{array}$ & $\begin{array}{r}14,978 \\
668\end{array}$ & $\begin{array}{r}482 \\
.0 \\
\end{array}$ \\
\hline 4,800 & 1,348 & 4,800 & ........... & 1,348 & 4,800 & 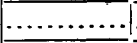 & 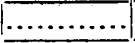 & 11,505 & 5,278 & 15,646 & 482 \\
\hline $\begin{array}{l}\because \cdot \\
425 \\
751 \\
585\end{array}$ & $\begin{array}{r}94 \\
203 \\
.40\end{array}$ & $\begin{array}{l}425 \\
751 \\
585\end{array}$ & $\begin{array}{l}0 \\
0 \\
0\end{array}$ & $\begin{array}{r}155 \\
294 \\
40\end{array}$ & $\begin{array}{l}872 \\
999 \\
585\end{array}$ & $\begin{array}{r}61 \\
31 \\
.0\end{array}$ & $\begin{array}{r}447 \\
248 \\
0\end{array}$ & $\begin{array}{r}6,073 \\
2,212 \\
4,691\end{array}$ & $\begin{array}{rr}2,927 \\
1,235 \\
5,033\end{array}$ & $\begin{array}{l}8,477 \\
3,225 \\
9,233\end{array}$ & $\begin{array}{r}0 \\
0 \\
178\end{array}$ \\
\hline 1,761 & 397 & 1,761 & 0 & 489 & 2,456 & 92 & 695 & 12,976 & 9,195 । & 20,935 & 178 \\
\hline 6,561 & 1,745 & 6,561 & 0 & 2,052 & $-9,480$ & 307. & $\therefore \quad 2,919$ & 31,331 & 37,494 & 65,753 & 898 \\
\hline$(0,561$ & 1,745 & 6,561 & $\overline{0}$ & 2,052 & 9,480 & 307 I & 2,919 & 39,529 & 40,007 & 75,616 & $\overline{908}$ \\
\hline$\cdots$ & & & & .... & & & & 1,291 & 384 & 1,549 & 0 \\
\hline & & & & $\begin{array}{r}79 \\
\cdot 16 \\
348 \\
\end{array}$ & $\begin{array}{r}489 \\
121 \\
4,590\end{array}$ & $\begin{array}{rr}. . \quad 79 \\
& 16 \\
& 348\end{array}$ & $\begin{array}{r}489 \\
121 \\
4,590\end{array}$ & $\begin{array}{l}1,561 \\
2,113 \\
3,659\end{array}$ & $\begin{array}{r}8,199 \\
3,996 \\
27,690\end{array}$ & $\begin{array}{r}9,603 \\
5,900 \\
30,983\end{array}$ & $\begin{array}{l}0 \\
0 \\
0\end{array}$ \\
\hline & & $\ldots \ldots$ & ............. & 443 & 5,200 & 443 & 5,200 & 7,333 & 39,885 & 46,486 & 0 \\
\hline $\begin{array}{r}19,899 \\
3,966 \\
12,993\end{array}$ & $\begin{array}{r}5,645 \\
449 \\
1,746\end{array}$ & $\begin{array}{r} \\
19,899 \\
3,966 \\
12,993\end{array}$ & $\begin{array}{l}\cdots . . \\
\cdots \cdots \\
\cdots\end{array}$ & $\begin{array}{r}5,645 \\
449 \\
1,746\end{array}$ & $\begin{array}{r}19,899 \\
3,966 \\
12,993\end{array}$ & $\begin{array}{l}\cdots \\
\cdots \cdots \\
\cdots \cdots \\
\cdots \cdots\end{array}$ & $\mid \begin{array}{l} \\
\cdots \\
\cdots \\
\cdots \cdots \cdots\end{array}$ & $\begin{array}{r}26,771 \\
3,418 \\
14,772\end{array}$ & $\begin{array}{r}23,937 \\
3,098 \\
. \quad 24,940\end{array}$ & $\begin{array}{r}48,030 \\
6,175 \\
38,233\end{array}$ & $\begin{array}{r}\cdot \\
488 \\
2 \\
580\end{array}$ \\
\hline 36,858 & 7,840 & 36,858 & .......... & 7,840 & 36,858 & a. & $\begin{array}{llll} & & & \\
\end{array}$ & 44,961 & 51,975 & 92,438 & 1,070 \\
\hline $\begin{array}{r}635 \\
552 \\
4,168\end{array}$ & $\begin{array}{r}162 \\
84 \\
367\end{array}$ & $\begin{array}{r}554 \\
552 \\
4,168\end{array}$ & $\begin{array}{r}81 \\
0 \\
0\end{array}$ & $\begin{array}{r}202 \\
91 \\
490\end{array}$ & $\begin{array}{r}754 \\
588 \\
5,016\end{array}$ & $\begin{array}{r}40 \\
7 \\
123\end{array}$ & $\begin{array}{r}200 \\
36 \\
848\end{array}$ & $\begin{array}{r}3,065 \\
850 \\
902\end{array}$ & $\begin{array}{r}4,761 \\
3,095 \\
18,425\end{array}$ & $\begin{array}{r}7,520 \\
3,860 \\
19,237\end{array}$ & $\begin{array}{r}91 \\
50 \\
2\end{array}$ \\
\hline 5,355 & 613 & 5,274 & 81 & 783 & 6,358 & 170 & 1,084 & $\dot{4}, 817$ & 26,281 & 30,617 & 143 \\
\hline 42,213 & 8,453 & 42,132 & 81 & 9,066 & 48,416 & 613 & 6,284 & 57,111 & 118,141 & 169,541 & 1,213 \\
\hline 42,213 & 8,453 & 42,132 & 81 & 9,066 & 48,416 & 613 & 6,284 & 58,402 & 118,525 & 171,090 & $\overline{1,213}$ \\
\hline
\end{tabular}




\section{A SUPERPOWER SYSTEM FOR THE REGION BETWEEN BOSTON AND WASHINGTON.}

TABLE 46.-Mechanical power-supply equipment and fuel used

\begin{tabular}{|c|c|c|c|c|c|c|c|c|c|c|c|c|c|}
\hline \multirow{4}{*}{ 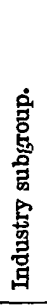 } & \multirow{4}{*}{$\begin{array}{l}\text { Size of plant } \\
\text { (horsepower). }\end{array}$} & \multicolumn{2}{|c|}{ Establishments. } & \multicolumn{10}{|c|}{ Power-supply equipment. } \\
\hline & & \multirow{3}{*}{$\underset{\text { ber. }}{\text { Num. }}$} & \multirow{3}{*}{$\begin{array}{l}\text { Aver- } \\
\text { age size } \\
\text { (horse- } \\
\text { power). }\end{array}$} & \multirow{3}{*}{$\begin{array}{c}\text { Aggregate } \\
\text { horse- } \\
\text { power. }\end{array}$} & \multicolumn{9}{|c|}{ Prime movers. } \\
\hline & & & & & \multirow{2}{*}{$\begin{array}{l}\text { Total } \\
\text { horse- } \\
\text { power. }\end{array}$} & \multicolumn{2}{|c|}{ Steam engines. } & \multicolumn{2}{|c|}{ Steam turbines. } & \multicolumn{2}{|c|}{$\begin{array}{l}\text { Internal-combus- } \\
\text { tion engines. }\end{array}$} & \multicolumn{2}{|c|}{ Water wheels. } \\
\hline & & & & & & $\underset{\text { ber. }}{\text { Num- }}$ & $\begin{array}{l}\text { Horse- } \\
\text { power. }\end{array}$ & $\underset{\text { ber. }}{\text { Num- }}$ & $\begin{array}{l}\text { Horse- } \\
\text { power. }\end{array}$ & $\begin{array}{c}\text { Num- } \\
\text { ber. }\end{array}$ & $\begin{array}{l}\text { Horse- } \\
\text { power. }\end{array}$ & $\begin{array}{l}\text { Num- } \\
\text { ber. }\end{array}$ & $\begin{array}{l}\text { Horse- } \\
\text { power. }\end{array}$ \\
\hline $\mathbf{1}$ & $\mathbf{2}$ & 4 & $\mathbf{5}$ & 6 & 7 & 8 & $\mathbf{9}$ & 10 & 11 & 12 & 13 & 14 & 15 \\
\hline \multirow{5}{*}{ 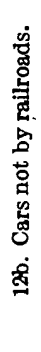 } & \multirow[t]{2}{*}{$\mid \begin{array}{r}\text { Steam power only: } \\
1-200 \ldots \ldots \ldots \ldots \ldots \\
201-500 \ldots \ldots \ldots \ldots\end{array}$} & $\begin{array}{l}2 \\
1\end{array}$ & $\begin{array}{l}110 \\
350\end{array}$ & $\begin{array}{l}220 \\
350\end{array}$ & $\begin{array}{l}\prime \\
220 \\
350\end{array}$ & $\begin{array}{l}3 \\
2\end{array}$ & $\begin{array}{r}220 \\
350\end{array}$ & $\begin{array}{l}\mathbf{0} \\
\mathbf{0}\end{array}$ & $\begin{array}{l}0 \\
0\end{array}$ & & & & \\
\hline & & 3 & 190 & 570 & 570 & 5 & 570 & 0 & $\mathbf{0}$ & ......... & $\ldots \ldots \ldots$ & $\ldots \ldots \ldots$ & .......... \\
\hline & $\begin{array}{l}\text { Purchased electric } \\
\text { power only: } \\
501 \text { and above... }\end{array}$ & 2 & 2,772 & 5,543 & & & & & & & & & \\
\hline & $\begin{array}{l}\text { All other power: } \\
501 \text { and above... }\end{array}$ & 6 & 2,752 & 16,515 & 4,828 & 14 & 4,320 & 1 & 500 & 2 & $\cdot 8$ & 0 & $\mathbf{0}$ \\
\hline & Total power... & 11 & 2,057 & 22,628 & 5,398 & 19 & 4,890 & 1 & .500 & 2 & 8 & $\mathbf{0}$ & $\mathbf{0}$ \\
\hline \multirow{9}{*}{ 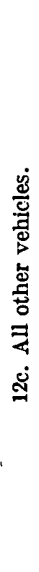 } & No power.. & 186 & $\cdots .$. & ….... & & & & & & & $\cdots$ & & …...... \\
\hline & $\begin{array}{r}\text { Steam power only: } \\
1-200 \ldots \ldots \ldots \ldots \\
201-500 \ldots \ldots \ldots \ldots\end{array}$ & $\begin{array}{r}30 \\
1\end{array}$ & $\begin{array}{r}48 \\
300\end{array}$ & $\begin{array}{r}1,431 \\
300\end{array}$ & $\begin{array}{r}1,431 \\
300\end{array}$ & $\begin{array}{r}27 \\
1\end{array}$ & $\begin{array}{r}1,375 \\
300\end{array}$ & $\begin{array}{l}2 \\
0\end{array}$ & $\begin{array}{r}56 \\
0\end{array}$ & & & & \\
\hline & \multirow{3}{*}{$\begin{array}{c}\text { Purchased el ectric } \\
\text { power only: } \\
1-200 \ldots \ldots \ldots \ldots \\
201-500 \ldots \ldots \ldots \ldots \\
501 \text { and above.... }\end{array}$} & 31 & 56 & 1,731 & 1,731 & 28 & 1,675 & 2 & 56 & ....... & +5 & ... & $\ldots \ldots \ldots$ \\
\hline & & $\begin{array}{r}450 \\
1 \\
1\end{array}$ & $\begin{array}{r}8 \\
395 \\
2,074\end{array}$ & $\begin{array}{r}3,618 \\
395 \\
2,074\end{array}$ & & & & & & & & & \\
\hline & & 452 & 13 & 6,087 & …........ & …..... & …........ & ......... & …......... & $\ldots \ldots \ldots$ & …......... & …..... & ........... \\
\hline & \multirow[t]{2}{*}{$\begin{array}{r}\text { All other power: } \\
1-200 \ldots \ldots \ldots \ldots \\
201-500 \ldots \ldots \ldots \\
501 \text { and above..... }\end{array}$} & $\begin{array}{r}148 \\
4 \\
2\end{array}$ & $\begin{array}{r}20 \\
348 \\
1,110\end{array}$ & $\begin{array}{l}3,017 \\
1,390 \\
2,220\end{array}$ & $\begin{array}{l}2,509 \\
1,290 \\
1,200\end{array}$ & $\begin{array}{r}16 \\
5 \\
4\end{array}$ & $\begin{array}{r}795 \\
775 \\
1,200\end{array}$ & $\begin{array}{l}0 \\
0 \\
0\end{array}$ & $\begin{array}{l}0 \\
0 \\
0\end{array}$ & $\begin{array}{r}128 \\
0 \\
0\end{array}$ & $\begin{array}{r}1,083 \\
0 \\
0\end{array}$ & $\begin{array}{r}18 \\
9 \\
0\end{array}$ & $\begin{array}{r}631 \\
515 \\
0\end{array}$ \\
\hline & & 154 & 43 & 6,627 & 4,999 & 25 & 2,770 & 0 & $\mathbf{0}$ & 128 & 1,083 & 27 & 1,146 \\
\hline & Total power ... & 637 & 23 & 14,445 & 6,730 & 53 & 4,445 & 2 & 56 & 128 & 1,083 & 27 & 1,146 \\
\hline & Grand total.... & 823 & $\ldots \ldots \ldots$ & 14,445 & 6,730 & 53 & 4,445 & 2 & 56 & 128 & 1,083 & 27 & 1,146 \\
\hline \multirow{9}{*}{ 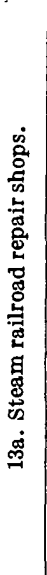 } & No power............. & 26 & ….... & & & & & & & & & & \\
\hline & $\begin{array}{l}\text { Steam power only: } \\
\quad \begin{array}{l}1-200 \\
201-50 \ldots \ldots \ldots \ldots \ldots\end{array} \\
501 \text { and above...... }\end{array}$ & $\begin{array}{l}40 \\
12 \\
25 \\
\end{array}$ & $\begin{array}{r}62 \\
293 \\
1,960 \\
\end{array}$ & $\begin{array}{r}2,496 \\
3,521 \\
49,006 \\
\end{array}$ & $\begin{array}{r}2,496 \\
3,521 \\
49,006\end{array}$ & $\begin{array}{r}56 \\
33 \\
182 \\
\end{array}$ & $\begin{array}{r}2,446 \\
3,521 \\
43,456 \\
\end{array}$ & $\begin{array}{r}1 \\
0 \\
10 \\
\end{array}$ & $\begin{array}{r}50 \\
0 \\
5,550\end{array}$ & & & & \\
\hline & \multirow{3}{*}{$\begin{array}{c}\text { Purchased electric } \\
\text { power only: } \\
1-200 \ldots \ldots \ldots \ldots \ldots \\
201-500 \ldots \ldots \ldots \ldots \\
501 \text { and above..... }\end{array}$} & 77 & 715 & 55,023 & 55,023 & 271 & 49,423 & 11 & 5,600 & ...... & …....... & …..... & ............ \\
\hline & & $\begin{array}{r}50 \\
8 \\
7\end{array}$ & $\begin{array}{r}59 \\
259 \\
1,034\end{array}$ & $\begin{array}{l}2,974 \\
2,075 \\
7,238\end{array}$ & & ..... & & & & …... & & & \\
\hline & & 65 & 189 & 12,287 & ............ & .......... & …........ & ......... & n.......... & .......... & …........ & ........ & ……... \\
\hline & \multirow[t]{2}{*}{$\begin{array}{l}\text { All other power: } \\
1-200 \ldots \ldots \ldots \ldots . . . \\
201-500 \ldots \ldots \ldots \\
501 \text { and above..... }\end{array}$} & $\begin{array}{r}27 \\
5 \\
15\end{array}$ & $\begin{array}{r}102 \\
383 \\
1,880\end{array}$ & $\begin{array}{r}2,748 \\
1,915 \\
28,371\end{array}$ & $\begin{array}{r}1,728 \\
660 \\
10,333\end{array}$ & $\begin{array}{r}26 \\
7 \\
62\end{array}$ & $\begin{array}{l}1,521 \\
960 \\
9,537\end{array}$ & $\begin{array}{l}0 \\
0 \\
3\end{array}$ & $\begin{array}{r}0 \\
0 \\
550\end{array}$ & $\begin{array}{r}16 \\
0 \\
6\end{array}$ & $\begin{array}{r}207 \\
0 \\
151\end{array}$ & $\begin{array}{l}0 \\
0 \\
2\end{array}$ & $\begin{array}{r}0 \\
0 \\
95\end{array}$ \\
\hline & & 47 & 702 & $33, \quad 034$ & 12,721 & 95 & 11,718 & 3 & $' 550$ & 22 & 358 & 2 & 95 \\
\hline & Total power.... & 189 & 530 & 100,344 & 67,744 & 366 & 61,141 & 14 & 6,150 & 22. & 358 & 2 & 95 \\
\hline & Grand total.... & 215 & (......... & 100,344 & 67,744 & 366 & 61,141 & 14 & 6,150 & 22 & 358 & 2 & 95 \\
\hline
\end{tabular}


by industry subgroups, by character of power supply-Continued.

\begin{tabular}{|c|c|c|c|c|c|c|c|c|c|c|c|}
\hline \multirow{2}{*}{\multicolumn{4}{|c|}{$\frac{\text { Power-supply equipment-Continued. }}{\text { Operated by purchased energy. }}$}} & \multicolumn{4}{|c|}{ Electric motors. } & \multicolumn{4}{|c|}{$\therefore$. . . Fuel used. } \\
\hline & & & & \multirow{2}{*}{\multicolumn{2}{|c|}{ Total. }} & \multirow{2}{*}{\multicolumn{2}{|c|}{$\begin{array}{l}\text { Run by current gen- } \\
\text { erated in establish- } \\
\text { ment. }\end{array}$}} & \multicolumn{3}{|c|}{ Coal. } & \multirow{3}{*}{ 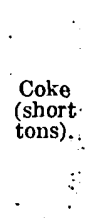 } \\
\hline \multirow{2}{*}{$\begin{array}{c}\text { Total } \\
\text { horsepower. }\end{array}$} & \multicolumn{2}{|c|}{ Electric motors. } & \multirow{2}{*}{$\begin{array}{l}\text { Other } \\
\text { (horse- } \\
\text { power). }\end{array}$} & & & & & \multirow{2}{*}{$\begin{array}{l}\text { Anthracite } \\
\text { (long tons). }\end{array}$} & \multirow{2}{*}{$\begin{array}{l}\text { Bitumi- } \\
\text { nous (short } \\
\text { tons). }\end{array}$} & \multirow{2}{*}{$\begin{array}{c}\text { Total } \\
\text { equivalent } \\
\text { bitumi- } \\
\text { nous (short } \\
\text { tons). }\end{array}$} & \\
\hline & Number. & $\begin{array}{l}\text { Horse- } \\
\text { power. }\end{array}$ & & Number. & $\begin{array}{l}\text { Horse- } \\
\text { power. }\end{array}$ & Number. & $\begin{array}{l}\text { Horse } \\
\text { power. }\end{array}$ & & & & \\
\hline \multirow[t]{3}{*}{16} & 17 & 18 & 19 & 20 & 21 & 22 & 23 & $\mathbf{2 4}$ & 25 & 26 & 27 \\
\hline & …......... & ……, & ….......... & $\begin{array}{l}50 \\
15\end{array}$ & $\begin{array}{l}200 \\
231\end{array}$ & $\begin{array}{l}50 \\
15\end{array}$ & $\begin{array}{l}200 \\
231\end{array}$ & $\begin{array}{r}384 \\
3\end{array}$ & $\begin{array}{r}700 \\
5,574\end{array}$ & $\begin{array}{l}1,044 \\
5,574\end{array}$ & $\begin{array}{r}0 \\
30\end{array}$ \\
\hline & ......... & $\ldots \ldots \ldots \ldots$ & $\ldots \ldots \ldots$ & 65 & 431 & 65 & 431 & 387 & 6,274 & 6,618 & 30 \\
\hline 5,543 & 340 & 5,543 & $\ldots \ldots \ldots$ & 340 & 5,543 & $\ldots$. & $\cdots \cdots$ & 232 & 7,838 & 8,046 & 282 \\
\hline 11,687 & 689 & 11,687 & 0 & 1,593 & 20,792 & 904 & 9,105 & 37,852 & 68,816 & 102,816 & 8,432 \\
\hline \multirow[t]{2}{*}{17,230} & 1,029 & 17,230 & $\overline{0}$ & 1,998 & 26,766 & 969 & 9,536 & 38,471 & 82,928 & 117,480 & $\overrightarrow{8,744}$ \\
\hline & & & & & & & & 304 & 1,129 & 1,403 & 11 \\
\hline & & $\cdots$ & 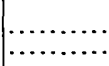 & $\begin{array}{l}7 \\
0\end{array}$ & $\begin{array}{r}148 \\
0\end{array}$ & $\begin{array}{l}7 \\
0\end{array}$ & $\begin{array}{r}148 \\
0\end{array}$ & $\begin{array}{r}2,134 \\
0\end{array}$ & $\begin{array}{r}4,328 \\
991\end{array}$ & $\begin{array}{r}6,238 \\
991\end{array}$ & $\begin{array}{r}428 \\
0\end{array}$ \\
\hline ....... & ...... & ....... & $\ldots \ldots \ldots$ & 7 & 148 & 7 & 148 & 2,134 & 5,319 & 7,229 & 428 \\
\hline $\begin{array}{r}3,618 \\
395 \\
2,074\end{array}$ & $\begin{array}{r}1,083 \\
27 \\
130\end{array}$ & $\begin{array}{r}3,618 \\
395 \\
2,074\end{array}$ & $\cdots$ & $\begin{array}{r}1,083 \\
27 \\
130\end{array}$ & $\begin{array}{r}3,618 \\
395 \\
2,074\end{array}$ & & & $\begin{array}{r}2,486 \\
5 \\
4,280\end{array}$ & $\begin{array}{l}5,531 \\
1,400 \\
2,392\end{array}$ & $\begin{array}{l}7,771 \\
1,405 \\
6,242\end{array}$ & $\begin{array}{r}41 \\
0 \\
0\end{array}$ \\
\hline 6,087 & 1,240 & 6,087 & $\ldots \ldots \ldots$ & 1,240 & 6,087 & ……… & .......... & 6,771 & 9,323 & 15,418 & 41 \\
\hline $\begin{array}{r}508 \\
100 \\
1,020 \\
\end{array}$ & $\begin{array}{r}98 \\
3 \\
69\end{array}$ & $\begin{array}{r}425 \\
100 \\
1,020 \\
\end{array}$ & $\begin{array}{r}83 \\
0 \\
0\end{array}$ & $\begin{array}{r}127 \\
4 \\
77\end{array}$ & $\begin{array}{r}627 \\
101 \\
1,280\end{array}$ & $\begin{array}{r}29 \\
1 \\
8\end{array}$ & $\begin{array}{r}202 \\
1 \\
260\end{array}$ & $\begin{array}{r}1,227 \\
0 \\
360\end{array}$ & $\begin{array}{l}4,996 \\
1,604 \\
4,461\end{array}$ & $\begin{array}{l}6,096 \\
1,604 \\
4,785\end{array}$ & $\begin{array}{r}67 \\
75 \\
0\end{array}$ \\
\hline 1,628 & 170 & 1,545 & 83 & 208 & 2,008 & 38 & 463 & 1,587 & 11,061 & 12,485 & $\overline{142}$ \\
\hline 7,715 & 1,410 & 7,632 & 83 & 1,455 & 8,243 & 45 & 611 & 10,492 & 25,703 & 35,132 & 611 \\
\hline 7,715 & 1,410 & 7,632 & 83 & 1,455 & 8,243 & 45 & 611 & 10,795 & 26,832 & 36,535 & 622 \\
\hline & & & & & & & & 737 & 4,115 & 4,778 & 0 \\
\hline & & & & $\begin{array}{r}65 \\
182 \\
3,013\end{array}$ & $\begin{array}{r}1,442 \\
3,932 \\
41,309\end{array}$ & $\begin{array}{r}65 \\
182 \\
3,013\end{array}$ & $\begin{array}{r}1,442 \\
3,932 \\
41,309\end{array}$ & $\begin{array}{r}17,838 \\
38,690 \\
245,406\end{array}$ & $\begin{array}{r}57,310 \\
43,623 \\
226,354\end{array}$ & $\begin{array}{r}73,360 \\
78,444 \\
447,220\end{array}$ & $\begin{array}{r}0 \\
0 \\
202,313\end{array}$ \\
\hline .......... & ............ & $\ldots \ldots \ldots \ldots$ & n.......... & 3,260 & 46,683 & 3,260 & 46,683 & 301,934 & 327,287 & 599,024 & 202,313 \\
\hline $\begin{array}{l}2,974 \\
2,075 \\
7,238 \\
\end{array}$ & $\begin{array}{l}240 \\
106 \\
268\end{array}$ & $\begin{array}{l}2,974 \\
2,075 \\
7,238 \\
\end{array}$ & 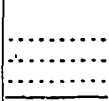 & $\begin{array}{l}240 \\
106 \\
268 \\
\end{array}$ & $\begin{array}{l}2,974 \\
2,075 \\
7,238 \\
\end{array}$ & & & $\begin{array}{r}3,240 \\
2,056 \\
14,534 \\
\end{array}$ & $\begin{array}{r}46,311 \\
5,018 \\
65,035\end{array}$ & $\begin{array}{r}49,227 \\
6,870 \\
78,116\end{array}$ & $\begin{array}{r}9 \\
0 \\
. \quad 294\end{array}$ \\
\hline 12,287 & 614 & 12,287 & ............. & 614 & 12,287 & n.......... & n............... & 19,830 & 116,364 & 134,213 & 303 \\
\hline $\begin{array}{r}1,020 \\
1,255 \\
18,038\end{array}$ & $\begin{array}{r}50 \\
51 \\
962\end{array}$ & $\begin{array}{r}670 \\
1,005 \\
18,038\end{array}$ & $\begin{array}{r}350 \\
250 \\
0\end{array}$ & $\begin{array}{r}59 \\
51 \\
1,059\end{array}$ & $\begin{array}{r}815 \\
1,005 \\
20,056\end{array}$ & $\begin{array}{r}3 \\
0 \\
\quad 97\end{array}$ & $\begin{array}{r}145 \\
0 \\
2,018\end{array}$ & $\begin{array}{r}11,986 \\
1,321 \\
85,897\end{array}$ & $\begin{array}{r}44,300 \\
4,853 \\
103,024\end{array}$ & $\begin{array}{r}55,088 \\
6,042 \\
180,332\end{array}$ & $\begin{array}{r}0 \\
253 \\
2,216\end{array}$ \\
\hline 20,313 & 1,069 & 19,713 & 600 & 1,169 & 21,876 & 100 & 2,163 & 99,204 & 152,177 & 241,462 & 2,469 \\
\hline 32,600 & 1,683 & 32,000 & 600 & 5,043 & 80,846 & 3,360 & 48,846 & 420,968 & 595,828 & 974,699 & 205,085 \\
\hline 32,600 & 1,683 & 32,000 & 600 & 5,043 & 80,846 & 3,360 & 48,846 & 421,705 & 599,943 & 979,477 & 205,085 \\
\hline
\end{tabular}


TABLE 46.-Mechanical power-supply equipment and fuel used

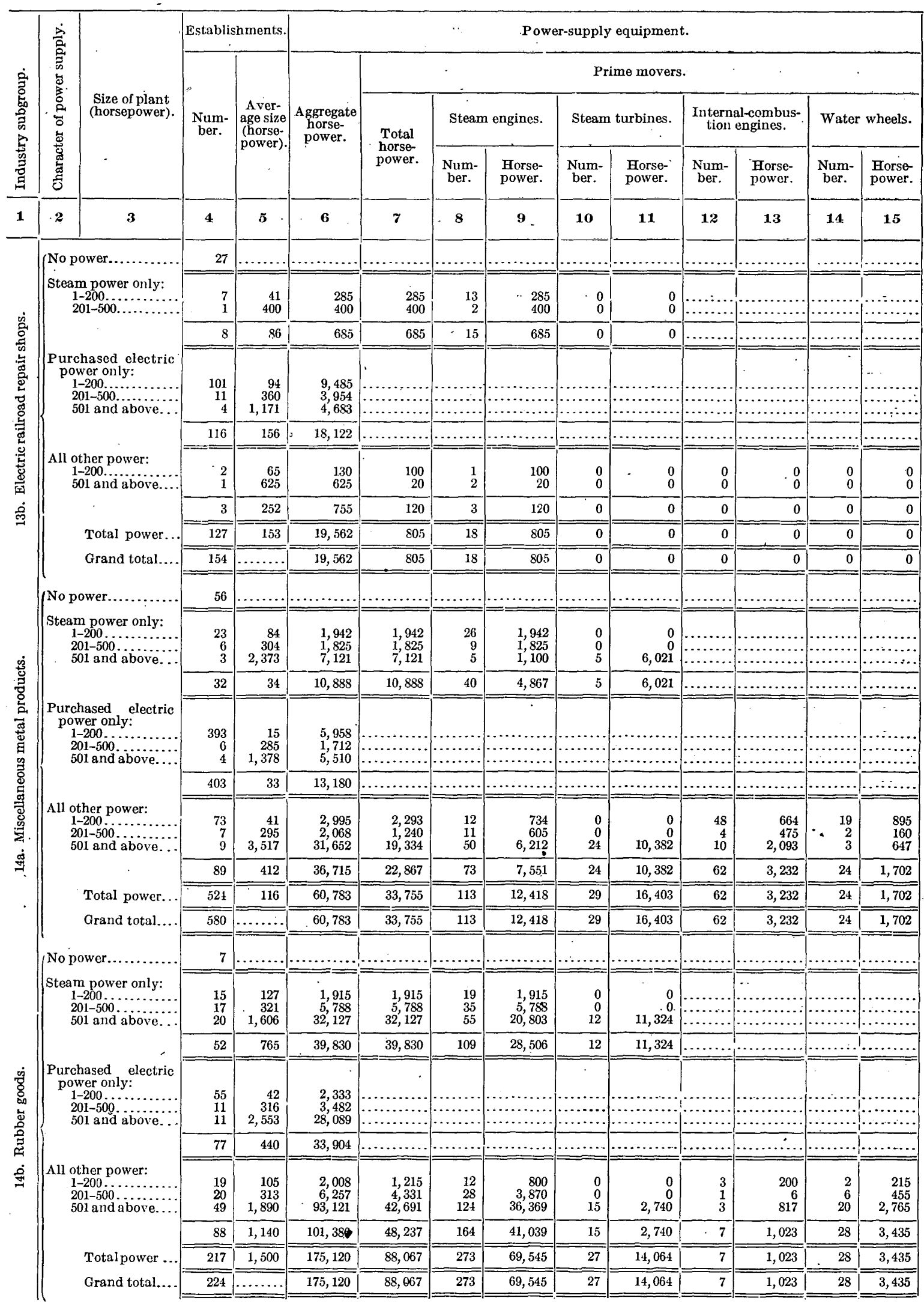


by industry subgroups, by character of power supply-Continued.

\begin{tabular}{|c|c|c|c|c|c|c|c|c|c|c|c|}
\hline \multirow{2}{*}{\multicolumn{4}{|c|}{$\frac{\text { Power-supply equipment-Continued. }}{\text { Operated by purchased energy. }}$}} & \multicolumn{4}{|c|}{ Electric motors. } & \multicolumn{4}{|c|}{ Fuel used. } \\
\hline & & & & \multirow{2}{*}{\multicolumn{2}{|c|}{ Total. }} & \multirow{2}{*}{\multicolumn{2}{|c|}{$\begin{array}{l}\text { Run by current gen- } \\
\text { erated in establish- } \\
\text { ment. }\end{array}$}} & \multirow{3}{*}{$\begin{array}{l}\text { Anthracite } \\
\text { (long tons). } \\
\text { - }\end{array}$} & \multicolumn{2}{|l|}{ Coal. } & \multirow{3}{*}{$\begin{array}{l}\text { Coke } \\
\text { (short } \\
\text { tons). }\end{array}$} \\
\hline \multirow{2}{*}{$\begin{array}{c}\text { Total } \\
\text { horsepower. }\end{array}$} & \multicolumn{2}{|c|}{ Electric motors. } & \multirow{2}{*}{$\begin{array}{l}\text { Other } \\
\text { (horsc- } \\
\text { power). }\end{array}$} & & & & & & & & \\
\hline & Number. & $\begin{array}{l}\text { Horse- } \\
\text { power. }\end{array}$ & & Number. & $\begin{array}{l}\text { Horse- } \\
\text { power. }\end{array}$ & Number. & $\begin{array}{l}\text { Horse- } \\
\text { power. }\end{array}$ & & tons). & $\left|\begin{array}{c}\text { nous (short } \\
\text { tons). }\end{array}\right|$ & \\
\hline 16 & 17 & 18 & 19 & 20 & 21 & 22 & 23 & 24 & 25 & 26 & 27 \\
\hline$\cdots \cdots \cdots$ & $\cdots$. & $\cdots \cdots$ & …....... & & …….......... & & …....... & 782 & 304 & 1,006 & 1 \\
\hline & & & & $\begin{array}{l}0 \\
0\end{array}$ & $\begin{array}{l}0 \\
0 \\
\end{array}$ & $\begin{array}{l}0 \\
0 \\
\end{array}$ & $\begin{array}{l}0 \\
0 \\
\end{array}$ & $\begin{array}{r}30 \\
0 \\
\end{array}$ & $\begin{array}{r}581 \\
4,397 \\
\end{array}$ & $\begin{array}{r}608 \\
4,397 \\
\end{array}$ & $\begin{array}{l}0 \\
0 \\
\end{array}$ \\
\hline ........... & ........... & …........ & …........ & 0 & 0 & 0 & 0 & 30 & 4,978 & 5,005 & 0 \\
\hline $\begin{array}{l}9,485 \\
3,954 \\
4,683\end{array}$ & $\begin{array}{l}584 \\
219 \\
256\end{array}$ & $\begin{array}{l}9,485 \\
3,954 \\
4,683\end{array}$ & 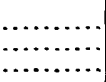 & $\begin{array}{l}584 \\
219 \\
256\end{array}$ & $\begin{array}{l}9,485 \\
3,954 \\
4,683\end{array}$ & 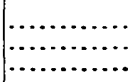 & 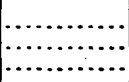 & $\begin{array}{l}6,040 \\
1,896 \\
5,393\end{array}$ & $\begin{array}{r}9,641 \\
1,564 \\
530\end{array}$ & $\begin{array}{r}15,071 \\
3,264 \\
5,380\end{array}$ & $\begin{array}{l}0 \\
0 \\
0\end{array}$ \\
\hline 18,122 & 1,059 & 18,122 & ........... & 1,059 & 18,122 & ….............. & …............. & 13,329 & 11,735 & 23,715 & 0 \\
\hline $\begin{array}{r}30 \\
-\quad 605 \\
\end{array}$ & $\begin{array}{r}1 \\
20\end{array}$ & $\begin{array}{r}5 \\
605 \\
\end{array}$ & $\begin{array}{r}25 \\
0\end{array}$ & $\begin{array}{r}1 \\
20 \\
\end{array}$ & $\begin{array}{r}5 \\
605 \\
\end{array}$ & $\begin{array}{l}0 \\
0\end{array}$ & $\begin{array}{l}0 \\
0 \\
\end{array}$ & $\begin{array}{r}20 \\
0\end{array}$ & $\begin{array}{r}0 \\
13,422 \\
\end{array}$ & $\begin{array}{r}18 \\
13,422 \\
\end{array}$ & $\begin{array}{l}0 \\
0\end{array}$ \\
\hline 635 & 21 & 610 & 25 & 21 & 610 & 0 & 0 & 20 & 13,422 & 13,440 & $\underline{0}$ \\
\hline 18,757 & 1,080 & 18,732 & 25 & 1,050 & 18,732 & 0 & 0 & 13,379 & 30,135 & 42,160 & 0 \\
\hline 18,757 & 1,080 & 18,732 & 25 & 1,080 & 18,732 & 0 & 0 & 14,161 & 30,439 & 43,166 & 1 \\
\hline & & & & & & & & 190 & 199 & 370 & $\underline{0}$ \\
\hline & & & ….......... & $\begin{array}{r}212 \\
66 . \\
378 \\
\end{array}$ & $\begin{array}{r}545 \\
364 \\
1,560 \\
\end{array}$ & $\begin{array}{r}212 \\
66 \\
378 \\
\end{array}$ & $\begin{array}{r}545 \\
364 \\
1,560 \\
\end{array}$ & $\begin{array}{r}3,019 \\
2,732 \\
3,716 \\
\end{array}$ & $\begin{array}{r}4,969 \\
1,693 \\
24,200 \\
\end{array}$ & $\begin{array}{r}7,687 \\
4,180 \\
27,548\end{array}$ & $\begin{array}{r}711 \\
0 \\
0\end{array}$ \\
\hline …........ & …....... & …....... & …....... & 656 & 2,469 & 656 & 2,469 & 9,467 & 30,062 & 39,415 & 711 \\
\hline $\begin{array}{l}5,958 \\
1,712 \\
5,510\end{array}$ & $\begin{array}{r}1,841 \\
160 \\
502\end{array}$ & $\begin{array}{l}5,958 \\
1,712 \\
5,510\end{array}$ & & $\begin{array}{r}1,841 \\
166 \\
502\end{array}$ & $\begin{array}{r}5,958 \\
1,712 \\
-5,510\end{array}$ & & & $\begin{array}{r}6,461 \\
968 \\
80\end{array}$ & $\begin{array}{l}6,835 \\
3,197 \\
9,084\end{array}$ & $\begin{array}{r}12,649 \\
4,070 \\
9,156\end{array}$ & $\begin{array}{r}133 \\
0 \\
0\end{array}$ \\
\hline 13,180 & 2,509 & 13,180 & …...... & 2,509 & 13,180 & & ….......... & 7,509 & 19,116 & 25,875 & 133 \\
\hline $\begin{array}{r}702 \\
828 \\
12,318\end{array}$ & $\begin{array}{r}102 \\
126 \\
1,039\end{array}$ & $\begin{array}{r}561 \\
828 \\
12,318\end{array}$ & $\begin{array}{r}141 \\
0 \\
0\end{array}$ & $\begin{array}{r}158 \\
127 \\
2,593\end{array}$ & $\begin{array}{r}794 \\
883 \\
26,015\end{array}$ & $\begin{array}{r}56 \\
1 \\
1,554\end{array}$ & $\begin{array}{r}233 \\
55 \\
13,697\end{array}$ & $\begin{array}{r}3,813 \\
27,090 \\
16,901\end{array}$ & $\begin{array}{r}1,461 \\
2,975 \\
102,782\end{array}$ & $\begin{array}{r}4,890 \\
27,356 \\
117,990\end{array}$ & $\begin{array}{r}548 \\
3,408 \\
4,420\end{array}$ \\
\hline 13,848 & 1,267 & 13,707 & 141 & 2,878 & 27,692 & 1,611 & 13,985 & 47,804 & 107,218 & 150,236 & 8,376 \\
\hline 27,028 & 3,776 & 26,887 & 141 & $6, \theta+3$ & 43,341 & 2,267 & 16,454 & 64,780 & 157,196 & 215,526 & 9,220 \\
\hline 27,028 & 3,776 & 26,887 & 141 & 6,043 & 43,341 & 2,267 & 16,454 & 64,970 & 157,395 & 215,896 & 9,220 \\
\hline …......... & …........ & ...... & & & & & & 115 & 1,100 & 1,203 & 0 \\
\hline & $\cdots \cdots \cdot$ & ….... & $\cdots \cdot$ & $\begin{array}{r}13 \\
112 \\
1,288\end{array}$ & $\begin{array}{r}125 \\
2,314 \\
23,582\end{array}$ & $\begin{array}{r}13 \\
112 \\
1,288\end{array}$ & $\begin{array}{r}125 \\
2,314 \\
23,582 \\
\end{array}$ & $\begin{array}{r}1,434 \\
9,737 \\
46,190\end{array}$ & $\begin{array}{r}10,745 \\
22,174 \\
151,602\end{array}$ & $\begin{array}{r}12,035 \\
30,924 \\
193,202\end{array}$ & $\begin{array}{r}0 \\
70 \\
3,099\end{array}$ \\
\hline ….... & …....... & ............ & …....... & 1,413 & 26,021 & 1,413 & 26,021 & 57,361 & 184,521 & 236,161 & 3,169 \\
\hline $\begin{array}{r}2,333 \\
3,482 \\
28,0 \leqslant 9\end{array}$ & $\begin{array}{r}178 \\
108 \\
1,412 \\
\end{array}$ & $\begin{array}{r}2,333 \\
3,482 \\
28,089\end{array}$ & & $\begin{array}{r}178 \\
108 \\
1,412 \\
\end{array}$ & $\begin{array}{r}2,333 \\
3,482 \\
28,089 \\
\end{array}$ & & & $\begin{array}{r}471 \\
809 \\
4,121 \\
\end{array}$ & $\begin{array}{r}4,544 \\
15,573 \\
58,335\end{array}$ & $\begin{array}{r}4,969 \\
16,300 \\
62,055\end{array}$ & $\begin{array}{l}0 \\
0 \\
0\end{array}$ \\
\hline 33,904 & 1,698 & 33,904 & … & 1,698 & 33,904 & …..... & ......... & 5,401 & 78,452 & 83,324 & 0 \\
\hline $\begin{array}{r}793 \\
1,926 \\
50,430\end{array}$ & $\begin{array}{r}58 \\
106 \\
2,101\end{array}$ & $\begin{array}{r}660 \\
1,926 \\
50,430\end{array}$ & $\begin{array}{r}127 \\
0 \\
0\end{array}$ & $\begin{array}{r}58 \\
124 \\
3,073 \\
\end{array}$ & $\begin{array}{r}666 \\
2,123 \\
60,944 \\
\end{array}$ & $\begin{array}{r}0 \\
18 \\
972\end{array}$ & $\begin{array}{r}0 \\
197 \\
10,514 \\
\end{array}$ & $\begin{array}{r}2,190 \\
1,857 \\
61,377\end{array}$ & $\begin{array}{r}5,309 \\
26,769 \\
289,312\end{array}$ & $\begin{array}{r}7,279 \\
28,429 \\
344,512\end{array}$ & $\begin{array}{r}0 \\
825 \\
12\end{array}$ \\
\hline 53,149 & 2,265 & 53,022 & 127 & 3,255 & 63,733 & 990 & 10,711 & 65,424 & 321,390 & 380,220 & 837 \\
\hline 87,053 & 3,963 & 86,926 & 127 & 0,366 & 123,658 & 2,403 & 36,732 & 128,186 & 584,363 & 699,705 & 4,006 \\
\hline 87,053 & 3,963 & 86,926 & 127 & 6,366 & 123,658 & $2,4 \cong 3$ & 36,732 & 128,301 & 585,463 & 700,908 & 4,006 \\
\hline
\end{tabular}




\section{A SUPERPOWER SYSTEM FOR THE REGION BETWEEN BOSTON AND WASHINGTON.}

TABLE 46.-Mechanical power-supply equipment and fuel used

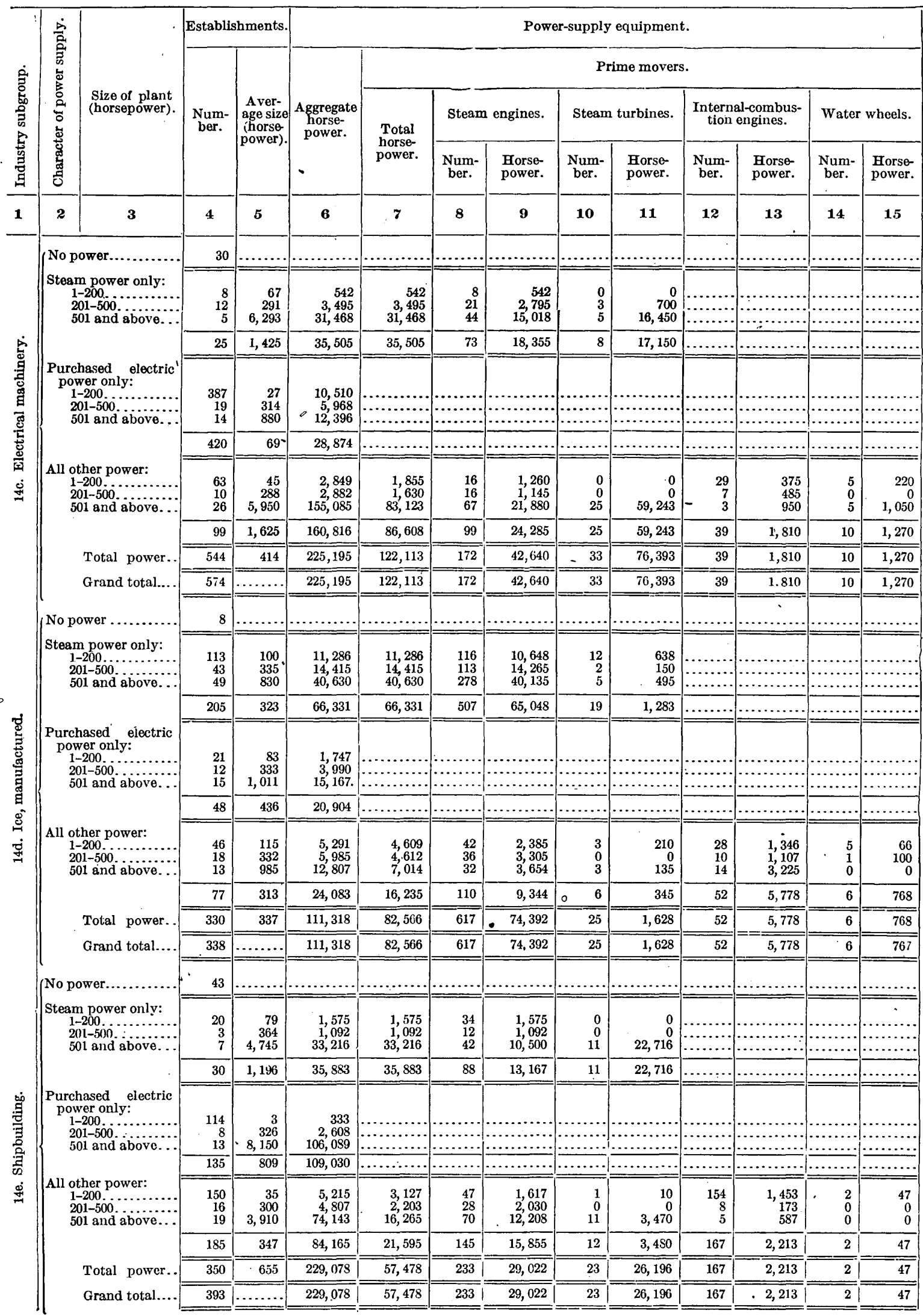


by industry suogroups, by character of power supply-Continued.

\begin{tabular}{|c|c|c|c|c|c|c|c|c|c|c|c|}
\hline \multirow{2}{*}{\multicolumn{4}{|c|}{$\frac{\text { Power-supply equipment-Continued. }}{\text { Operated by purchased energy. }}$}} & \multicolumn{4}{|c|}{ Electric motors. } & \multicolumn{4}{|c|}{ Fuel used. } \\
\hline & & & & \multirow{2}{*}{\multicolumn{2}{|c|}{ Total. }} & \multirow{2}{*}{\multicolumn{2}{|c|}{$\begin{array}{l}\text { Run by current gen- } \\
\text { erated in establish- } \\
\text { ment. }\end{array}$}} & \multirow{3}{*}{$\begin{array}{l}\text { Anthracite } \\
\text { (long tons) }\end{array}$} & \multicolumn{2}{|l|}{ Coal. } & \multirow{3}{*}{$\begin{array}{l}\text { Coke } \\
\text { (short } \\
\text { tons). }\end{array}$} \\
\hline \multirow{2}{*}{$\begin{array}{c}\text { Total } \\
\text { horsepower. }\end{array}$} & \multicolumn{2}{|c|}{ Electric motors. } & \multirow{2}{*}{$\begin{array}{l}\text { Other } \\
\text { (horse- } \\
\text { power). }\end{array}$} & & & & & & & & \\
\hline & Number. & $\begin{array}{l}\text { Horse- } \\
\text { power. }\end{array}$ & & Number. & $\begin{array}{l}\text { Horse- } \\
\text { power. }\end{array}$ & Number. & $\begin{array}{l}\text { Horse- } \\
\text { power. }\end{array}$ & & tons). & $\begin{array}{l}\text { nous (short } \\
\text { tons). }\end{array}$ & \\
\hline \multirow[t]{2}{*}{16} & 17 & 18 & 19 & 20 & 21 & 22 & 23 & 24 & 25 & 26 & 27 \\
\hline & $\cdots \cdots \cdot$ & ........ & ….... & …….... & ……и & ............. & n.......... & 20 & 254 & 272 & 8 \\
\hline & & & $\cdots \cdots$ & $\begin{array}{r}30 \\
\quad 254 \\
9,007\end{array}$ & $\begin{array}{r}242 \\
2,384 \\
42,891\end{array}$ & $\begin{array}{r}30 \\
254 \\
9,007\end{array}$ & $\begin{array}{r}242 \\
2,384 \\
42,891\end{array}$ & $\begin{array}{r}677 \\
5,908 \\
5,645\end{array}$ & $\begin{array}{r}2,508 \\
17,941 \\
45,828\end{array}$ & $\begin{array}{r}3,118 \\
23,241 \\
50,898\end{array}$ & $\begin{array}{r}10 \\
592 \\
2,414\end{array}$ \\
\hline ........ & ........ & ........ & $\ldots \ldots \ldots \ldots$ & 9,291 & 45,517 & 9,291 & 45,517 & 12,230 & 66,277 & 77,257 & 3,016 \\
\hline $\begin{array}{r}10,510 \\
5,968 \\
12,396\end{array}$ & $\begin{array}{l}3,257 \\
1,267 \\
1,329\end{array}$ & $\begin{array}{r}10,510 \\
5,968 \\
12,396\end{array}$ & $\begin{array}{l}\cdots \ldots . . \\
\cdots \cdots \cdot . \\
\cdots \cdots . .\end{array}$ & $\begin{array}{l}3,257 \\
1,267 \\
1,329\end{array}$ & $\begin{array}{l}10,510 \\
5,968 \\
12,396\end{array}$ & $\cdots \cdots$ & ……...... & $\begin{array}{l}5,963 \\
7,041 \\
5,161\end{array}$ & $\begin{array}{l}11,061 \\
17,820 \\
22,955\end{array}$ & $\begin{array}{r}6,431 \\
24,140 \\
27,605\end{array}$ & $\begin{array}{l}469 \\
687 \\
400\end{array}$ \\
\hline 28,874 & 5,853 & 28,874 & $\ldots$. & 5,853 & 28,874 & 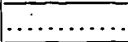 & ......... & 18,165 & 31,386 & 68,176 & 1,556 \\
\hline $\begin{array}{r}994 \\
1,252 \\
71,962\end{array}$ & $\begin{array}{r}125 \\
316 \\
12,073\end{array}$ & $\begin{array}{r}767 \\
1,252 \\
71,962\end{array}$ & $\begin{array}{r}227 \\
0 \\
0\end{array}$ & $\begin{array}{r}233 \\
389 \\
25,421\end{array}$ & $\begin{array}{r}1,239 \\
1,797 \\
163,894\end{array}$ & $\begin{array}{r}108 \\
73 \\
13,348\end{array}$ & $\begin{array}{r}472 \\
545 \\
91,932\end{array}$ & $\begin{array}{r}2,938 \\
9,743 \\
53,991\end{array}$ & $\begin{array}{r}4,170 \\
8,042 \\
364,960\end{array}$ & $\begin{array}{r}6,810 \\
16,802 \\
414,360\end{array}$ & $\begin{array}{r}2 \\
3312 \\
5,782\end{array}$ \\
\hline 74,208 & 12,514 & 73,981 & 227 & 26,043 & 166,930 & 13,529 & 92,949 & 66,672 & 377,172 & 437,972 & 6,096 \\
\hline 103,082 & 18,367 & 102,855 & 227 & 41,187 & 241,321 & 22,820 & 138,466 & 97,067 & 495,285 & 583,405 & 10.668 \\
\hline 103,082 & 18,367 & 102,855 & 227 & 41,187 & 241,321 & 22,820 & 138,466 & 97,087 & 495,539 & 583,677 & 10,676 \\
\hline & & & & & & & & 7,516 & 13,493 & 29,261 & 0 \\
\hline & & & & $\begin{array}{r}49 \\
162 \\
369\end{array}$ & $\begin{array}{r}482 \\
1,331 \\
4,576\end{array}$ & $\begin{array}{r}49 \\
162 \\
369\end{array}$ & $\begin{array}{r}482 \\
1,331 \\
4,476\end{array}$ & $\begin{array}{l}23,875 \\
25,270 \\
81,195\end{array}$ & $\begin{array}{l}120,156 \\
107,876 \\
229,719\end{array}$ & $\begin{array}{l}141,648 \\
130,619 \\
302,794\end{array}$ & $\begin{array}{r}1,000 \\
0 \\
0\end{array}$ \\
\hline$\ldots \ldots$. & .......... & ............ & ........... & 580 & 6,389 & 580 & 6,389 & 130,340 & 457,751 & 575,061 & 1,000 \\
\hline $\begin{array}{r}1,747 \\
3,990 \\
15,167\end{array}$ & $\begin{array}{r}93 \\
93 \\
302\end{array}$ & $\begin{array}{r}1,747 \\
3,990 \\
15,167\end{array}$ & n.......... & $\begin{array}{r}93 \\
\cdot \begin{array}{r}93 \\
302\end{array}\end{array}$ & $\begin{array}{r}1,747 \\
3,990 \\
15,167\end{array}$ & & & $\begin{array}{r}3,145 \\
106 \\
188\end{array}$ & $\begin{array}{r}4,367 \\
388 \\
13,352\end{array}$ & $\begin{array}{r}7,197 \\
483 \\
13,616\end{array}$ & $\begin{array}{l}0 \\
0 \\
0\end{array}$ \\
\hline 20,904 & 488 & 20,904 & ....... & 488 & 20,904 & ..... & …... & 3,439 & 18,107 & 21,196 & 0 \\
\hline $\begin{array}{r}682 \\
1,373 \\
5,793\end{array}$ & $\begin{array}{l}70 \\
70 \\
72\end{array}$ & $\begin{array}{r}682 \\
1,373 \\
3,843\end{array}$ & $\begin{array}{r}0 \\
0 \\
1,950\end{array}$ & $\begin{array}{l}101 \\
124 \\
146\end{array}$ & $\begin{array}{r}869 \\
1,935 \\
4,777\end{array}$ & $\begin{array}{l}31 \\
54 \\
74\end{array}$ & $\begin{array}{l}187 \\
562 \\
934\end{array}$ & $\begin{array}{r}2,755 \\
12,233 \\
14,430\end{array}$ & $\begin{array}{l}25,526 \\
23,386 \\
20,579\end{array}$ & $\begin{array}{l}28,005 \\
34,447 \\
33,566\end{array}$ & $\begin{array}{r}0 \\
414 \\
0\end{array}$ \\
\hline 7,848 & 212 & 5,898 & 1,950 & 371 & 7,581 & 159 & 1,683 & 29,478 & 69,491 & 96,018 & 414 \\
\hline 28,752 & $\overline{700}$ & 26,802 & 1,950 & 1,439 & 34,874 & 739 & 8,072 & 163,257 & 545,349 & 692,375 & 1,414 \\
\hline 28,752 & $\overline{700}$ & 26,802 & 1,950 & 1,439 & 34,874 & 739 & 8,072 & 170,773 & 558,842 & 712,536 & 1,414 \\
\hline & & & & & & & & 382 & 45 & . 388 & 0 \\
\hline & & & & $\begin{array}{r}7 \\
110^{7} \\
1,341\end{array}$ & $\begin{array}{r}60 \\
795 \\
32,009\end{array}$ & $\begin{array}{r}7 \\
110^{7} \\
1,341\end{array}$ & $\begin{array}{r}60 \\
795 \\
32,009\end{array}$ & $\begin{array}{l}1,083 \\
2,379 \\
1,252\end{array}$ & $\begin{array}{r}6,902 \\
5,737 \\
191,739\end{array}$ & $\begin{array}{r}7,877 \\
7,879 \\
192,864\end{array}$ & $\begin{array}{r}122 \\
0 \\
9,906\end{array}$ \\
\hline & ... & & ....... & 1,458 & 32,864 & 1,458 & 32,864 & 4,714 & 204,378 & 208,620 & 10,028 \\
\hline $\begin{array}{r}333 \\
2,608 \\
106,089\end{array}$ & $\begin{array}{r}328 \\
146 \\
4,674\end{array}$ & $\begin{array}{r}333 \\
2,608 \\
106,089\end{array}$ & & $\begin{array}{r}328 \\
146 \\
4,674\end{array}$ & $\begin{array}{r}333 \\
2,608 \\
106,089\end{array}$ & & ….... & $\begin{array}{r}1,404 \\
6,177 \\
10,203\end{array}$ & $\begin{array}{r}2,194 \\
2,473 \\
118,790\end{array}$ & $\begin{array}{r}3,454 \\
8,035 \\
127,970\end{array}$ & $\begin{array}{r}60 \\
114 \\
29.453\end{array}$ \\
\hline 109,030 & 5,148 & 109,030 & $\ldots \ldots \ldots$ & 5,148 & 109,030 & $\ldots \ldots \ldots \ldots$ & $\ldots \ldots \ldots \ldots$ & 17,784 & 123,457 & 139,459 & 29,627 \\
\hline $\begin{array}{r}2,088 \\
2,604 \\
57,878\end{array}$ & $\begin{array}{r}172 \\
151 \\
3,379\end{array}$ & $\begin{array}{r}2,073 \\
2,394 \\
57,878\end{array}$ & $\begin{array}{r}15 \\
210 \\
0\end{array}$ & $\begin{array}{r}172 \\
155 \\
3,517\end{array}$ & $\begin{array}{r}2,073 \\
2,569 \\
62,147\end{array}$ & $\begin{array}{r}0 \\
4 \\
138\end{array}$ & $\begin{array}{r}0 \\
175 \\
4,269\end{array}$ & $\begin{array}{l}1,225 \\
1,897 \\
8,220\end{array}$ & $\begin{array}{r}5,392 \\
8,517 \\
154,640\end{array}$ & $\begin{array}{r}6,494 \\
10,227 \\
162,038\end{array}$ & $\begin{array}{r}110 \\
127 \\
15,555\end{array}$ \\
\hline 62,570 & 3,702 & 62,345 & 225 & 3,844 & 66,789 & 142 & 4,444 & 11,342 & 168,549 & 178,759 & 15,792 \\
\hline 171,600 & 8,850 & 171,375 & 225 & 10,450 & 208,683 & 1,600 & 37,308 & 33,840 & 496,384 & 526,838 & 55,447 \\
\hline 171,600 & 8,850 & 171,375 & 225 & 10,450 & 208,683 & 1,600 & $\begin{array}{l}37,308 \\
\end{array}$ & 34,222 & 496,429 & 527,226 & 55,447 \\
\hline
\end{tabular}


TABLE 46.-Mechanical power-supply equipment and fuel used

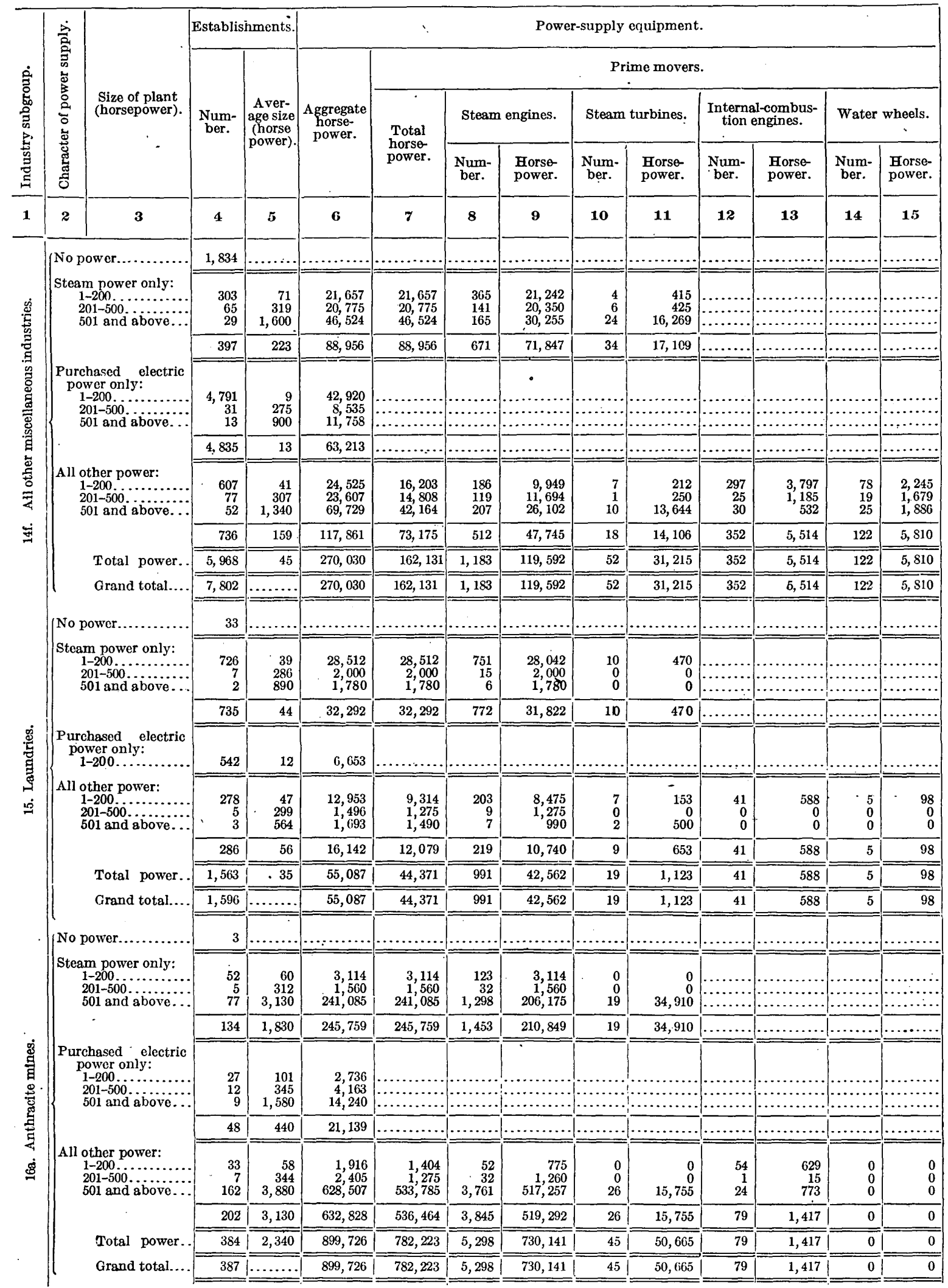


by industry subgroups, by character of power supply-Continued.

\begin{tabular}{|c|c|c|c|c|c|c|c|c|c|c|c|}
\hline \multirow{2}{*}{\multicolumn{4}{|c|}{$\frac{\text { Power-supply equipment-Continued. }}{\text { Operatod by purchased energy. }}$}} & \multicolumn{4}{|c|}{ Electric motors. } & \multicolumn{4}{|c|}{ Fuel used. } \\
\hline & & & & \multirow{2}{*}{\multicolumn{2}{|c|}{ Total. }} & \multirow{2}{*}{\multicolumn{2}{|c|}{$\begin{array}{l}\text { Run by current gen- } \\
\text { erated in establish- } \\
\text { ment. }\end{array}$}} & \multicolumn{3}{|c|}{. Coal. } & \multirow{3}{*}{$\begin{array}{l}\text { Coke } \\
\text { (short } \\
\text { tons). }\end{array}$} \\
\hline \multirow{2}{*}{$\begin{array}{c}\text { Total } \\
\text { horsopower. }\end{array}$} & \multicolumn{2}{|c|}{ Electric motors. } & \multirow{2}{*}{$\begin{array}{l}\text { Other } \\
\text { (horse- } \\
\text { power). }\end{array}$} & & & & & \multirow{2}{*}{$\begin{array}{l}\text { Anthracite } \\
\text { (long tons) }\end{array}$} & \multirow{2}{*}{$\begin{array}{c}\text { Bitumi- } \\
\text { nous (short } \\
\text { tons). }\end{array}$} & \multirow{2}{*}{$\begin{array}{c}\text { Total } \\
\text { equivalent } \\
\text { bitumi- } \\
\text { nous (short } \\
\text { tons) }\end{array}$} & \\
\hline & Number. & $\begin{array}{l}\text { Horse- } \\
\text { power. }\end{array}$ & & Number. & $\begin{array}{l}\text { Horse- } \\
\text { power. }\end{array}$ & Number. & $\begin{array}{l}\text { Horse- } \\
\text { power. }\end{array}$ & & & & \\
\hline 16 & 17 & $18{ }^{\prime}$ & 19 & 20 & 21 & $\mathbf{2 R}$ & 23 & 24 & 25 & 26 & 27 \\
\hline$\cdots \cdots$ & & $\ldots \ldots \ldots \ldots$ & & & & & & 3,559 & 9,731 & 12,931 & 118 \\
\hline & $\ldots \ldots \ldots \cdots$ & a.n. & & $\begin{array}{r}483 \\
833 \\
2,691 \\
\end{array}$ & $\begin{array}{r}2,453 \\
5,915 \\
30,449 \\
\end{array}$ & $\begin{array}{r}483 \\
833 \\
2,691 \\
\end{array}$ & $\begin{array}{r}2,453 \\
5,915 \\
30,449 \\
\end{array}$ & $\begin{array}{l}23,185 \\
29,517 \\
42,280\end{array}$ & $\begin{array}{r}79,714 \\
69,594 \\
248,693\end{array}$ & $\begin{array}{r}100,514 \\
96,194 \\
286,000\end{array}$ & $\begin{array}{r}2,867 \\
671 \\
10,242\end{array}$ \\
\hline ........ & $\ldots \ldots \ldots \ldots$ & $\ldots \ldots \ldots \ldots$ & $\ldots \ldots \ldots$ & 4,007 & 38,817 & 4,007 & 38,817 & 94,982 & 398,001 & 482,708 & 13,780 \\
\hline $\begin{array}{r}42,920 \\
8,535 \\
11,758 \\
\end{array}$ & $\begin{array}{r}17,475 \\
569 \\
977 \\
\end{array}$ & $\begin{array}{r}42,920 \\
8,535 \\
11,758 \\
\end{array}$ & $\begin{array}{l}\cdots \cdots \cdots \\
\cdots \cdots \cdots \\
\cdots \cdots \cdots\end{array}$ & $\begin{array}{r}17,475 \\
569 \\
977 \\
\end{array}$ & $\begin{array}{r}42,920 \\
8,535 \\
11,758 \\
\end{array}$ & & 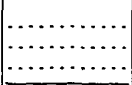 & $\begin{array}{r}27,649 \\
2,154 \\
2,120 \\
\end{array}$ & $\begin{array}{l}36,968 \\
25,075 \\
30,447\end{array}$ & $\begin{array}{l}61,768 \\
27,015 \\
32,357 \\
\end{array}$ & $\begin{array}{r}663 \\
79 \\
0\end{array}$ \\
\hline 63,213 & 19,021 & 63,213 & & 19,021 & 63,213 & & & 31,923 & 92,490 & 121,140 & 742 \\
\hline $\begin{array}{r}8,322 \\
8,799 \\
27,565 \\
\end{array}$ & $\begin{array}{r}940 \\
818 \\
1,794 \\
\end{array}$ & $\begin{array}{r}6,262 \\
8,799 \\
27,565 \\
\end{array}$ & $\begin{array}{r}2,060 \\
0 \\
0 \\
\end{array}$ & $\begin{array}{l}1,137 \\
1,486 \\
3,213 \\
\end{array}$ & $\begin{array}{r}7,529 \\
12,650 \\
43,271 \\
\end{array}$ & $\begin{array}{r}197 \\
668 \\
1,419 \\
\end{array}$ & $\begin{array}{r}1,267 \\
3,851 \\
15,706 \\
\end{array}$ & $\begin{array}{r}119,020 \\
19,239 \\
80,906 \\
\end{array}$ & $\begin{array}{r}45,504 \\
52,572 \\
150,084 \\
\end{array}$ & $\begin{array}{r}152,524 \\
69,872 \\
222,784 \\
\end{array}$ & $\begin{array}{l}1,503 \\
1,211 \\
1,919 \\
\end{array}$ \\
\hline 44,686 & 3,552 & 42,626 & 2,060 & 5,836 & 63,450 & 2,284 & 20,824 & 219,165 & 248,160 & 445,180 & 4,633 \\
\hline 107,899 & 22,573 & 105,839 & 2,060 & 28,864 & 165,480 & 6,291 & 59,641 & 346,070 & 738,651 & $1,049,028$ & 19,155 \\
\hline \multirow[t]{2}{*}{107,899} & 22,573 & 105,839 & 2,060 & 28,864 & 165,480 & 6,291 & 59,641 & 349,629 & 748,382 & $1,061,959$ & 19,273 \\
\hline & & & & & & & & 1,771 & 247 & 1,837 & 0 \\
\hline & & & & $\begin{array}{l}927 \\
131 \\
228 \\
\end{array}$ & $\begin{array}{r}3,126 \\
705 \\
1,481 \\
\end{array}$ & $\begin{array}{l}927 \\
131 \\
228\end{array}$ & $\begin{array}{r}3,126 \\
705 \\
1,481 \\
\end{array}$ & $\begin{array}{r}93,616 \\
4,355 \\
7,217 \\
\end{array}$ & $\begin{array}{r}138,193 \\
5,575 \\
2,812 \\
\end{array}$ & $\begin{array}{r}222,493 \\
9,505 \\
9,312\end{array}$ & $\begin{array}{r}3,234 \\
0 \\
0\end{array}$ \\
\hline$\ldots \ldots \ldots$ & $\cdots \cdots \cdots$ & $\ldots \ldots \ldots$ & .......... & $1,2 S 6$ & 5,312 & 1,286 & 5,312 & 105,188 & $146 ; 580$ & 241,310 & $3 ; 234$ \\
\hline 6,653 & 1,369 & 6,653 & & 1,369 & 6,653 & $\ldots$ & & 24,478 & 26,357 & 48,357 & 1,131 \\
\hline $\begin{array}{r}3,639 \\
221 \\
203\end{array}$ & $\begin{array}{r}534 \\
102 \\
22 \\
\end{array}$ & $\begin{array}{r}2,254 \\
221 \\
203\end{array}$ & $\begin{array}{r}1,385 \\
0 \\
0 \\
\end{array}$ & $\begin{array}{r}972 \\
-\quad 261 \\
243 \\
\end{array}$ & $\begin{array}{r}4,268 \\
634 \\
636 \\
\end{array}$ & $\begin{array}{l}438 \\
159 \\
221 \\
\end{array}$ & $\begin{array}{r}2,014 \\
413 \\
433 \\
\end{array}$ & $\begin{array}{r}37,820 \\
4,959 \\
4,353 \\
\end{array}$ & $\begin{array}{r}46,670 \\
10,806 \\
3,601 \\
\end{array}$ & $\begin{array}{r}80,670 \\
15,266 \\
7,521 \\
\end{array}$ & $\begin{array}{r}467 \\
39 \\
0\end{array}$ \\
\hline 4,063 & 658 & 2,678 & 1,385 & 1,476 & 5,538 & 818 & 2,860 & 47,132 & 61,077 & 103,457 & 506 \\
\hline 10,716 & 2,027 & 9,331 & 1,385 & 4,131 & 17,503 & 2,104 & 8,172 & 176,798 & 234,014 & 393,124 & 4,871 \\
\hline 10,716 & 2,027 & 9,331 & 1,385 & 4,131 & 17,503 & 2,104 & 8,172 & 178,569 & 234,261 & 394,961 & 4,871 \\
\hline$\ldots \ldots \ldots \ldots \ldots$ & $\ldots \ldots \ldots \ldots$ & & & & & & & 90 & 0 & 80 & 0 \\
\hline & & & & $\begin{array}{r}2 \\
0 \\
2,595 \\
\end{array}$ & $\begin{array}{r}.60 \\
0 \\
120,983 \\
\end{array}$ & $\begin{array}{r}2 \\
0 \\
2,595 \\
\end{array}$ & $\begin{array}{r}60 \\
0 \\
120,983 \\
\end{array}$ & $\begin{array}{r}17,995 \\
17,441 \\
2,734,426 \\
\end{array}$ & $\begin{array}{r}2,749 \\
0 \\
0 \\
\end{array}$ & $\begin{array}{r}18,900 \\
15,700 \\
2,460,000 \\
\end{array}$ & $\begin{array}{l}0 \\
0 \\
0\end{array}$ \\
\hline n.......... & …........ & $\ldots \ldots \ldots \cdots$ & $\ldots \ldots \ldots$ & 2,597 & 121,043 & 2,597 & $121,0+3$ & $2,769,862$ & 2,749 & $2,494,600$ & 1 \\
\hline $\begin{array}{r}2,736 \\
4,163 \\
14,240\end{array}$ & $\begin{array}{r}91 \\
112 \\
325 \\
\end{array}$ & $\begin{array}{r}2,736 \\
4,163 \\
14,240 \\
\end{array}$ & & $\begin{array}{r}91 \\
112 \\
325 \\
\end{array}$ & $\begin{array}{r}2,736 \\
4,163 \\
14,240 \\
\end{array}$ & & & $\begin{array}{r}3,195 \\
2,361 \\
20,085\end{array}$ & $\begin{array}{r}0 \\
20 \\
0\end{array}$ & $\begin{array}{r}2,980 \\
2,140 \\
18,100\end{array}$ & $\begin{array}{l}0 \\
0 \\
0\end{array}$ \\
\hline 21,139 & 528 & 21,139 & $\ldots \ldots \ldots$ & 528 & 21,139 & . & $\ldots \ldots \ldots \ldots$ & 25,641 & 20 & 23,220 & 0 \\
\hline $\begin{array}{r}512 \\
1,130 \\
94,722 \\
\end{array}$ & $\begin{array}{r}30 \\
42 \\
1,281 \\
\end{array}$ & $\begin{array}{r}512 \\
1,130 \\
94,722 \\
\end{array}$ & $\begin{array}{l}0 \\
0 \\
0 \\
\end{array}$ & $\begin{array}{r}30 \\
42 \\
2,449 \\
\end{array}$ & $\begin{array}{r}512 \\
1,130 \\
159,422 \\
\end{array}$ & $\begin{array}{r}0 \\
0 \\
1,168 \\
\end{array}$ & $\begin{array}{r}0 \\
0 \\
61,700 \\
\end{array}$ & $\begin{array}{r}1,198 \\
24,077 \\
5,731,766 \\
\end{array}$ & $\begin{array}{r}1,327 \\
0 \\
25,567\end{array}$ & $\begin{array}{r}2,390 \\
21,700 \\
5,180,000 \\
\end{array}$ & $\begin{array}{l}0 \\
0 \\
0\end{array}$ \\
\hline 96,364 & 1,353 & 96,364 & 0 & 2,521 & 161,064 & 1,168 & 64,700 & $5,757,041$ & 26,894 & $5,204,090$ & 0 \\
\hline 117,503 & 1,881 & 117,503 & 0 & 5,646 & 303,246 & 3,765 & 185,713 & $8,552,544$ & 29,663 & $7,721,910$ & 0 \\
\hline 117,503 & 1,881 & 117,503 & 0 & 5,646 & 303,246 & 3,765 & 185,743 & $8,552,634$ & 29,663 & $7,721,990$ & 0 \\
\hline
\end{tabular}


TABLE 46.-Mechanical power-supply equipment and fuel used

\begin{tabular}{|c|c|c|c|c|c|c|c|c|c|c|c|c|c|c|}
\hline \multirow{4}{*}{ 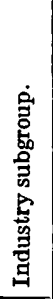 } & \multirow{4}{*}{ 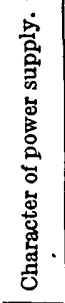 } & \multirow{4}{*}{$\begin{array}{l}\text { Size of plant } \\
\text { (horsepower.) }\end{array}$} & \multicolumn{2}{|c|}{ Establishments. } & \multicolumn{10}{|c|}{ Power-supply equipment. } \\
\hline & & & \multirow{3}{*}{$\begin{array}{c}\text { Num- } \\
\text { ber. }\end{array}$} & \multirow{3}{*}{$\begin{array}{l}\text { Aver- } \\
\text { age size } \\
\text { (horse- } \\
\text { power). }\end{array}$} & \multirow{3}{*}{$\begin{array}{l}\text { Aggregate } \\
\text { horse- } \\
\text { power. }\end{array}$} & \multicolumn{9}{|c|}{ Prime movers. } \\
\hline & & & & & & \multirow{2}{*}{$\begin{array}{l}\text { Total } \\
\text { horse- } \\
\text { power. }\end{array}$} & \multicolumn{2}{|c|}{ Steam engines. } & \multicolumn{2}{|c|}{ Steam turbines. } & \multicolumn{2}{|c|}{$\begin{array}{l}\text { Internal-combus- } \\
\text { tion engines. }\end{array}$} & \multicolumn{2}{|c|}{ Water wheels. } \\
\hline & & & & & & & $\begin{array}{l}\text { Num- } \\
\text { ber. }\end{array}$ & $\begin{array}{l}\text { Horse- } \\
\text { power. }\end{array}$ & $\begin{array}{c}\text { Num- } \\
\text { ber. }\end{array}$ & $\begin{array}{l}\text { Horse- } \\
\text { power. }\end{array}$ & $\begin{array}{c}\text { Num- } \\
\text { ber. }\end{array}$ & $\begin{array}{l}\text { Horse- } \\
\text { power. }\end{array}$ & $\underset{\text { ber. }}{\text { Num- }}$ & $\begin{array}{l}\text { Horse- } \\
\text { power. }\end{array}$ \\
\hline 1 & 2 & 3 . & 4 & $\mathbf{5}$ & 6 & 7 & 8 & $\mathbf{9}$ & 10 & 11 & $\mathbf{1 2}$ & 13 & 14 & 15 \\
\hline \multirow{10}{*}{ 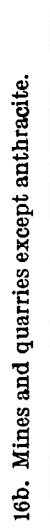 } & \multirow{4}{*}{\multicolumn{2}{|c|}{ 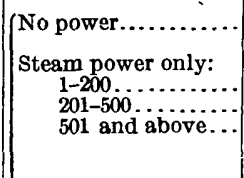 }} & 88 & & & & & & & & $\therefore$ & & & \\
\hline & & & $\begin{array}{r}213 \\
35\end{array}$ & $\begin{array}{r}71 \\
314\end{array}$ & $\begin{array}{l}15,038 \\
11,005\end{array}$ & $\begin{array}{r}15,038 \\
11,005\end{array}$ & $\begin{array}{l}356 \\
131\end{array}$ & $\begin{array}{l}14,837 \\
11,005\end{array}$ & $\begin{array}{l}6 \\
0\end{array}$ & $\begin{array}{r}201 \\
0\end{array}$ & & & & \\
\hline & & & 14 & 1,223 & 17,158 & 17,158 & 114 & 14,168 & $\mathbf{5}$ & 2,990 & & $\cdots \cdot \cdot$ & & \\
\hline & & & 262 & 165 & 43,201 & 43,201 & 601 & 40,010 & 11 & 3,191 & ...... & $\therefore \ldots \ldots$ & ...... & $\cdots$ \\
\hline & \multirow{3}{*}{\multicolumn{2}{|c|}{$\begin{array}{c}\text { Purchased electric } \\
\text { power only: } \\
1-200 \ldots \ldots \ldots \ldots \\
201-500 \ldots \ldots \ldots \\
501 \text { and above.... }\end{array}$}} & 78 & 72 & & & & & & & & & & \\
\hline & & & $\begin{array}{l}8 \\
4\end{array}$ & $\begin{array}{l}300 \\
806\end{array}$ & $\begin{array}{l}2,405 \\
3,226\end{array}$ & & & & & & & & & \\
\hline & & & 90 & 125 & 11,260 & ........ & ..... & ............ & ......... & ........ & ......... & ............ & ........ & ...... \\
\hline & \multirow{2}{*}{\multicolumn{2}{|c|}{$\mid \begin{array}{r}\text { All other power: } \\
1-200 \ldots \ldots \ldots \ldots \\
201-500 . \ldots \ldots \ldots \\
501 \text { and above... }\end{array}$}} & $\begin{array}{r}131 \\
41 \\
31\end{array}$ & $\begin{array}{r}71 \\
303 \\
1,123\end{array}$ & $\begin{array}{r}9,315 \\
12,431 \\
34,324\end{array}$ & $\begin{array}{r}5,863 \\
7,693 \\
18,293\end{array}$ & $\begin{array}{l}123 \\
117 \\
315\end{array}$ & $\begin{array}{r}4,036 \\
6,220 \\
14,020\end{array}$ & $\begin{array}{l}0 \\
0 \\
1\end{array}$ & $\begin{array}{r}0 \\
0 \\
275\end{array}$ & $\begin{array}{l}\prime \\
93 \\
20 \\
20\end{array}$ & $\begin{array}{l}1,352 \\
3,878\end{array}$ & $\begin{array}{l}7 \\
8 \\
2\end{array}$ & $\begin{array}{r}475 \\
1,096 \\
150\end{array}$ \\
\hline & & & 203 & 279 & 56,570 & 31,849 & 555 & 24,276 & 1 & 275 & 133 & 5,577 & 17 & 1,721 \\
\hline & \multirow{2}{*}{\multicolumn{2}{|c|}{$\begin{array}{l}\text { Total power. } \\
\text { Grand total.... }\end{array}$}} & 555 & 200 。 & 111,031 & 75,050 & 1,156 & 64,286 & 12 & 3,466 & 133 & 5,577 & 17 & 1,721 \\
\hline & & & 643 & ......... & 111,031 & 75,050 & 1,156 & 64,286 & 12 & 3,466 & 133 & 5,577 & 17 & 1,721 \\
\hline \multirow{6}{*}{ 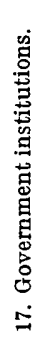 } & \multirow{2}{*}{\multicolumn{2}{|c|}{$\left(\begin{array}{r}\text { Steam power only: } \\
1-200 \ldots \ldots \ldots \ldots \\
501 \text { and above.... }\end{array}\right.$}} & $\begin{array}{l}1 \\
8\end{array}$ & $\begin{array}{r}20 \\
6,480\end{array}$ & $\begin{array}{r}20 \\
51,856\end{array}$ & $\begin{array}{r}20 \\
51,856\end{array}$ & $\begin{array}{r}1 \\
34\end{array}$ & $\begin{array}{r}20 \\
19,660\end{array}$ & $\begin{array}{r}0 \\
20\end{array}$ & $\begin{array}{r}0 \\
32,196\end{array}$ & & & & \\
\hline & & & 9 & 5,760 & 51,876 & 51,876 & 35 & 19,680 & 20 & 32,196 & ......... & …........ & :........ & .......... \\
\hline & \multicolumn{2}{|c|}{$\begin{array}{r}\text { Purchased electric } \\
\text { power only: } \\
1-200 \ldots \ldots \ldots \ldots \\
201-500 \ldots \ldots \ldots \ldots\end{array}$} & $\begin{array}{r}13 \\
1\end{array}$ & $\begin{array}{r}70 \\
225\end{array}$ & $\begin{array}{l}906 \\
225\end{array}$ & & & & & & & & & \\
\hline & & & 14 & 81 & 1,131 & n.......... & . & … & ........ & …....... & …..... & …....... & ........ & .......... \\
\hline & \multicolumn{2}{|c|}{$\begin{array}{c}\text { All other power: } \\
501 \text { and above... }\end{array}$} & 8 & 6,340 & 49,722 & 25,658 & 21 & 10,648 & 16 & 14,000 & 4 & 100 & 3 & 910 \\
\hline & & Total power.. & 31 & 3,350 & 102,729 & 77,534 & 59 & 30,328 & 36 & 46,196 & 4 & 100 & 3 & 910 \\
\hline
\end{tabular}


INDUSTRY IN THE SUPERPOWER ZONE.

by industry subgroups, by character of power supply-Continued.

\begin{tabular}{|c|c|c|c|c|c|c|c|c|c|c|c|}
\hline \multirow{2}{*}{\multicolumn{4}{|c|}{ Power-supply equipment-Continued. }} & \multicolumn{4}{|c|}{ Electric motors. } & \multicolumn{4}{|c|}{ Fuel used. } \\
\hline & & & & \multirow{2}{*}{\multicolumn{2}{|c|}{ Total. }} & \multirow{2}{*}{\multicolumn{2}{|c|}{$\begin{array}{l}\text { Run by current gen- } \\
\text { erated in establisl- } \\
\text { ment. }\end{array}$}} & \multicolumn{3}{|c|}{ Coal. } & \multirow{3}{*}{$\begin{array}{l}\text { Coke } \\
\text { (short } \\
\text { tons). }\end{array}$} \\
\hline \multirow{2}{*}{$\begin{array}{c}\text { Total } \\
\text { horsepower. }\end{array}$} & \multicolumn{2}{|c|}{ Electric motors. } & \multirow{2}{*}{$\begin{array}{l}\text { Other } \\
\text { (horse- } \\
\text { power). }\end{array}$} & & & & & \multirow{2}{*}{$\begin{array}{l}\text { Anthracite } \\
\text { (long tons) }\end{array}$} & \multirow{2}{*}{$\begin{array}{l}\text { Bitumi- } \\
\text { nous (short } \\
\text { tons). }\end{array}$} & \multirow{2}{*}{$\begin{array}{c}\text { Total } \\
\text { equivalent } \\
\text { bitumi- } \\
\text { nous (short } \\
\text { tons). }\end{array}$} & \\
\hline & Number. & $\begin{array}{l}\text { Horse- } \\
\text { power. }\end{array}$ & & Number. & $\begin{array}{l}\text { Horse- } \\
\text { power. }\end{array}$ & Number. & $\begin{array}{l}\text { Horse- } \\
\text { power. }\end{array}$ & & & & \\
\hline \multirow[t]{2}{*}{16} & 17 & 18 & 19 & 20 & 21 & 22 & $\mathbf{2 3}$ & 24 & 25 & $\mathbf{2 6}$ & 27 \\
\hline & & & & & & & & 35 & 602 & 633 & \\
\hline & & & & $\begin{array}{r}8 \\
21 \\
62\end{array}$ & $\begin{array}{r}195 \\
386 \\
4,367\end{array}$ & $\begin{array}{r}8 \\
21 \\
62\end{array}$ & $\begin{array}{r}195 \\
386 \\
4,367\end{array}$ & $\begin{array}{r}5,068 \\
3,720 \\
27,133\end{array}$ & $\begin{array}{l}60,586 \\
33,484 \\
47,752\end{array}$ & $\begin{array}{l}65,140 \\
36,830 \\
72,200\end{array}$ & $\begin{array}{r}41 \\
0 \\
12\end{array}$ \\
\hline …... & n......... & $\ldots \ldots$ & n.......... & 91 & 4,948 & 91 & 4,948 & 35,921 & 141,822 & 174,170 & 53 \\
\hline $\begin{array}{l}5,629 \\
2,405 \\
3,226\end{array}$ & $\begin{array}{r}173 \\
31 \\
70\end{array}$ & $\begin{array}{l}5,629 \\
2,405 \\
3,226\end{array}$ & …… & $\begin{array}{r}173 \\
31 \\
70\end{array}$ & $\begin{array}{l}5,629 \\
2,405 \\
3,226\end{array}$ & (n......... & …......... & $\begin{array}{r}325 \\
0 \\
64\end{array}$ & $\begin{array}{r}1,440 \\
669 \\
814\end{array}$ & $\begin{array}{r}1,730 \\
669 \\
870\end{array}$ & $\begin{array}{l}0 \\
0 \\
0\end{array}$ \\
\hline 11,260 & 274 & 11,260 & .......... & 274 & 11,260 & $\ldots \ldots \ldots \ldots \ldots$ & …........ & 389 & 2,923 & 3,269 & 0 \\
\hline $\begin{array}{r}3,452 \\
4,738 \\
16,531 \\
\end{array}$ & $\begin{array}{l}136 \\
140 \\
239\end{array}$ & $\begin{array}{r}3,452 \\
4,738 \\
16,531\end{array}$ & $\begin{array}{l}0 \\
0 \\
0\end{array}$ & $\begin{array}{l}136 \\
141 \\
292\end{array}$ & $\begin{array}{r}3,452 \\
4,753 \\
19,300\end{array}$ & $\begin{array}{c}1 \\
53\end{array}$ & 2,769 & $\begin{array}{l}2,683 \\
1,607 \\
5,198\end{array}$ & $\begin{array}{l}17,258 \\
18,310 \\
55,212\end{array}$ & $\begin{array}{l}19,670 \\
19,760 \\
59,880\end{array}$ & $\begin{array}{r}41 \\
50 \\
184\end{array}$ \\
\hline 24,721 & 515 & 24,721 & 0 & 569 & 27,505 & 54 & 2,784 & 9,488 & 90,780 & 99,310 & 275 \\
\hline 35,981 & 789 & 35,981 & 0 & 934 & 43,713 & 145 & 7,732 & 45,798 & 235,525 & 276,749 & $\overline{328}$ \\
\hline 35,981 & 789 & 35,981 & 0 & 934 & 43,713 & 145 & 7,732 & 45,833 & 236,127 & 277,382 & 328 \\
\hline & & & & $\begin{array}{r}0 \\
6,732 \\
\end{array}$ & $\begin{array}{r}0 \\
74,478 \\
\end{array}$ & $\begin{array}{r}0 \\
6,732 \\
\end{array}$ & $\begin{array}{r}0 \\
74,478\end{array}$ & • $\begin{array}{r}0 \\
12,822\end{array}$ & $\begin{array}{r}1,211 \\
200,078\end{array}$ & $\begin{array}{r}1,211 \\
211,618\end{array}$ & $\begin{array}{r}781 \\
2,025\end{array}$ \\
\hline ............ & ............ & $\ldots \ldots \ldots \ldots$ & $\ldots \ldots \ldots \ldots$ & 6,732 & 74,478 & 6,732 & 74,478 & 12,822 & 201,289 & 212,829 & 2,806 \\
\hline $\begin{array}{l}906 \\
225\end{array}$ & $\begin{array}{r}460 \\
21\end{array}$ & $\begin{array}{l}906 \\
225\end{array}$ & $\cdots \cdots$ & $\begin{array}{r}460 \\
21\end{array}$ & $\begin{array}{l}906 \\
225\end{array}$ & & & $\begin{array}{r}3,536 \\
340\end{array}$ & $\begin{array}{r}956 \\
0\end{array}$ & $\begin{array}{r}4,138 \\
306\end{array}$ & $\begin{array}{l}0 \\
0\end{array}$ \\
\hline 1,131 & 481 & 1,131 & n........ & 481 & 1,131 & .............. & ……..... & 3,876 & 956 & 4,444 & 0 \\
\hline 24,064 & 1,338 & 24,064 & 0 & 5,433 & 55,814 & 4,095 & 31,750 & 7,677 & 201,404 & $208,3: 3$ & 726 \\
\hline 25,195 & 1,819 & 25,195 & 0 & 12,646 & 131,423 & 10,827 & 106,228 & 24,375 & 403,649 & 425,586 & $\overline{3,532}$ \\
\hline
\end{tabular}


TABLE 47.-Mechanicai power-supply equipment, [Data from census of

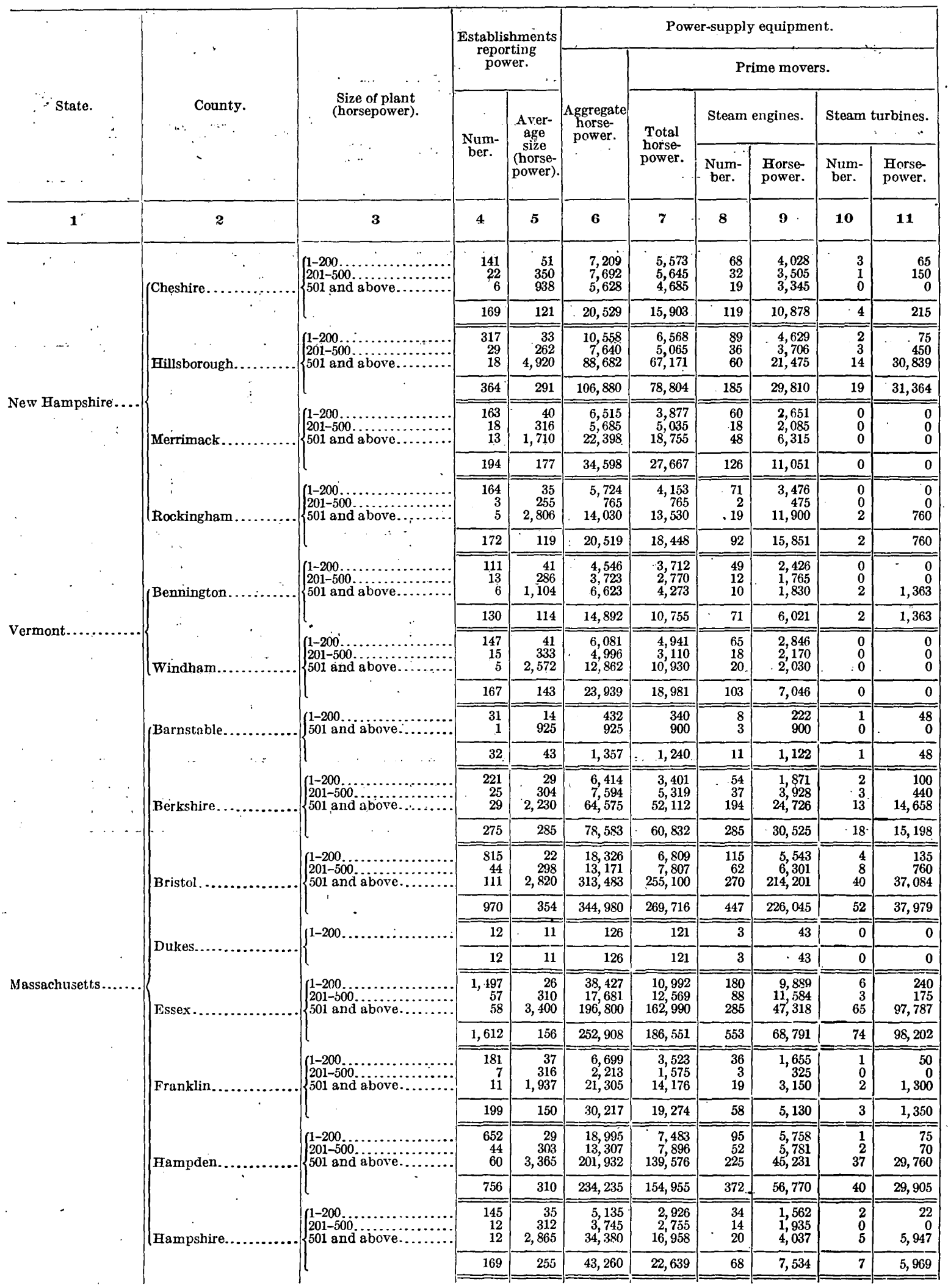


by counlies and size of plant.

manufnctures, 1919.$]$

\begin{tabular}{|c|c|c|c|c|c|c|c|c|c|c|c|c|}
\hline \multicolumn{8}{|c|}{ Power-supply equipment-Continued. } & \multicolumn{4}{|c|}{ Electric motors. } & \multirow{4}{*}{$\begin{array}{l}\text { Number } \\
\text { of estab- } \\
\text { lishments } \\
\text { reporting } \\
\text { no power. }\end{array}$} \\
\hline \multicolumn{4}{|c|}{ Primo movers-Continued. } & \multicolumn{4}{|c|}{ O perated by purchased energy. } & \multirow{2}{*}{\multicolumn{2}{|c|}{ Total. }} & \multirow{2}{*}{\multicolumn{2}{|c|}{$\begin{array}{l}\text { Run by current } \\
\text { generated in } \\
\text { establishment. }\end{array}$}} & \\
\hline $\begin{array}{c}\text { Internal } \\
\text { tion el }\end{array}$ & $\begin{array}{l}\text { combus- } \\
\text { igines. }\end{array}$ & Water & wheels. & \multirow{2}{*}{$\begin{array}{l}\text { Total } \\
\text { horse- } \\
\text { power. }\end{array}$} & \multicolumn{2}{|c|}{ Electric motors. } & \multirow{2}{*}{$\begin{array}{c}\text { Other } \\
\text { (horse- } \\
\text { power). }\end{array}$} & & & & & \\
\hline $\begin{array}{c}\text { Num- } \\
\text { ber. }\end{array}$ & $\begin{array}{l}\text { Horso- } \\
\text { power. }\end{array}$ & $\underset{\text { ber. }}{\text { Num. }}$ & $\begin{array}{l}\text { Horse- } \\
\text { power. }\end{array}$ & & Number. & $\begin{array}{l}\text { Horse- } \\
\text { power. }\end{array}$ & & Number. & $\begin{array}{l}\text { Horse- } \\
\text { power. }\end{array}$ & Number. & $\begin{array}{l}\text { Horse- } \\
\text { power. }\end{array}$ & \\
\hline 12 & 13 & 14 & 15 & 16 & 17 & 18 & 19 & 20 & 21 & 22 & 23 & 24 \\
\hline $\begin{array}{l}9 \\
0 \\
0\end{array}$ & $\begin{array}{r}133 \\
. \quad 0 \\
-\quad 0\end{array}$ & $\begin{array}{l}33 \\
26 \\
10\end{array}$ & $\begin{array}{l}1,347 \\
1,990 \\
1,340\end{array}$ & $\begin{array}{r}1,636 \\
2,047 \\
943\end{array}$ & $\begin{array}{r}236 \\
-\quad 92 \\
\quad 69\end{array}$ & $\begin{array}{r}1,636 \\
1,932 \\
943\end{array}$ & $\begin{array}{r}0 \\
115 \\
0\end{array}$ & $\begin{array}{r}237 \\
158 \\
84\end{array}$ & $\begin{array}{l}1,639 \\
2,573 \\
1,113\end{array}$ & $\begin{array}{l}.1 \\
66 \\
15\end{array}$ & $\begin{array}{r}3 \\
641 \\
170\end{array}$ & \\
\hline 9 & 133 & 69 & 4,677 & 4,626 & 397 & 4,511 & 115 & 479 & 5,325 & 82 & 814 & 17 \\
\hline $\begin{array}{r}24 \\
0 \\
0\end{array}$ & $\begin{array}{r}198 \\
0 \\
0\end{array}$ & $\begin{array}{l}44 \\
9 \\
65\end{array}$ & $\begin{array}{r}1,666 \\
909 \\
14,857\end{array}$ & $\begin{array}{r}3,990 \\
2,575 \\
21,511\end{array}$ & $\begin{array}{r}783 \\
273 \\
1,779 \\
\end{array}$ & $\begin{array}{r}3,740 \\
2,575 \\
21,511\end{array}$ & $\begin{array}{r}250 \\
0 \\
0\end{array}$ & $\begin{array}{r}799 \\
502 \\
2,879 \\
\end{array}$ & $\begin{array}{r}3,910 \\
4,249 \\
53,110\end{array}$ & $\begin{array}{r}16 \\
229 \\
1,100\end{array}$ & $\begin{array}{r}170 \\
1,674 \\
31,599\end{array}$ & ㅈ........... \\
\hline 24 & 198 & 118 & 17,432 & 28,076 & 2,835 & 27,826 & 250 & 4,180 & 61,269 & 1,345 & 33,443 & 50 \\
\hline $\begin{array}{l}8 \\
0 \\
0\end{array}$ & $\begin{array}{r}126 \\
0 \\
0\end{array}$ & $\begin{array}{l}34 \\
34 \\
46\end{array}$ & $\begin{array}{r}1,100 \\
2,950 \\
12,440\end{array}$ & $\begin{array}{l}2,638 \\
650 \\
3,643\end{array}$ & $\begin{array}{r}453 \\
32 \\
470 \\
\end{array}$ & $\begin{array}{l}2,612 \\
3,650 \\
3,643\end{array}$ & $\begin{array}{r}26 \\
0 \\
0\end{array}$ & $\begin{array}{r}467 \\
56 \\
562\end{array}$ & $\begin{array}{l}2,696 \\
1,006 \\
4,337\end{array}$ & $\begin{array}{l}14 \\
24 \\
92\end{array}$ & $\begin{array}{r}84 \\
356 \\
694\end{array}$ & \\
\hline 8 & 126 & 114 & 16,490 & 6,931 & 955 & 6,905 & 26 & 1,085 & 8,039 & 130 & 1,134 & 20 \\
\hline $\begin{array}{r}14 \\
2 \\
0\end{array}$ & $\begin{array}{r}207 \\
230 \\
0\end{array}$ & $\begin{array}{r}14 \\
2 \\
6\end{array}$ & $\begin{array}{r}470 \\
. \quad 60 \\
. \quad 870 \\
\end{array}$ & $\begin{array}{r}1,571 \\
0 \\
500\end{array}$ & $\begin{array}{r}230 \\
0 \\
111 \\
\end{array}$ & $\begin{array}{r}1,571 \\
0 \\
500\end{array}$ & $\begin{array}{l}0 \\
0 \\
0\end{array}$ & $\begin{array}{l}276 \\
15 \\
663 \\
\end{array}$ & $\begin{array}{r}1,733 \\
0 \\
6,855\end{array}$ & $\begin{array}{r}46 \\
15 \\
552\end{array}$ & $\begin{array}{r}162 \\
79 \\
6,355\end{array}$ & \\
\hline 16 & 437 & 22 & 1,400 & 2,071 & 341 & 2,071 & 0 & 954 & 8,667 & 613 & 6,596 & 24 \\
\hline $\begin{array}{r}14 \\
4 \\
0 \\
\end{array}$ & $\begin{array}{r}102 \\
50 \\
0\end{array}$ & $\begin{array}{l}38 \\
15 \\
11 \\
\end{array}$ & $\begin{array}{l}1,184 \\
1,055 \\
1,080\end{array}$ & $\begin{array}{r}834 \\
953 \\
2,350 \\
\end{array}$ & $\begin{array}{r}132 \\
64 \\
26 \\
\end{array}$ & $\begin{array}{r}834 \\
953 \\
2,350 \\
\end{array}$ & $\begin{array}{l}0 \\
0 \\
0 \\
\end{array}$ & $\begin{array}{r}132 \\
76 \\
168 \\
\end{array}$ & $\begin{array}{r}834 \\
1,271 \\
3,000 \\
\end{array}$ & $\begin{array}{r}0 \\
12 \\
142 \\
\end{array}$ & $\begin{array}{r}0 \\
318 \\
650\end{array}$ & \\
\hline 18 & 152 & 64 & 3,219 & 4,137 & 222 & 4,137 & 0 & $376^{\circ}$ & 5,105 & 154 & 968 & 14 \\
\hline $\begin{array}{r}21 \\
0 \\
0\end{array}$ & $\begin{array}{r}167 \\
0 \\
0\end{array}$ & $\begin{array}{l}55 \\
14 \\
34\end{array}$ & $\begin{array}{l}1,928 \\
8,900 \\
8,900\end{array}$ & $\begin{array}{l}1,140 \\
1,886 \\
1,932\end{array}$ & $\begin{array}{r}242 \\
205 \\
72 \\
\end{array}$ & $\begin{array}{l}1,140 \\
1,886 \\
1,932\end{array}$ & $\begin{array}{l}0 \\
0 \\
0\end{array}$ & $\begin{array}{l}244 \\
325 \\
104\end{array}$ & $\begin{array}{l}2,780 \\
2,195 \\
2,927\end{array}$ & $\begin{array}{r}2 \\
120 \\
32\end{array}$ & $\begin{array}{r}1,640 \\
309 \\
995\end{array}$ & \\
\hline 21 & 167 & 103 & 11,768 & 4,958 & 519 & $.4,958$ & 0 & 673 & 7,902 & .154 & 2,944 & 7 \\
\hline $\begin{array}{r}12 \\
0\end{array}$ & $\begin{array}{r}59 \\
0\end{array}$ & $\begin{array}{l}3 \\
0\end{array}$ & $\begin{array}{r}11 \\
0\end{array}$ & $\begin{array}{l}92 \\
25\end{array}$ & $\begin{array}{r}10 \\
1\end{array}$ & $\begin{array}{l}92 \\
25\end{array}$ & $\begin{array}{l}0 \\
0\end{array}$ & $\begin{array}{r}10 \\
153\end{array}$ & $\begin{array}{r}92 \\
2,215\end{array}$ & $\begin{array}{r}0 \\
152\end{array}$ & $\begin{array}{r}0 \\
2,190\end{array}$ & …............. \\
\hline 12 & 59 & $\overline{3}$ & 11 & 117 & 11 & 117 & 0 & 163 & 2,307 & 152 & 2,190 & 20 \\
\hline \begin{tabular}{r|}
18 \\
2 \\
0 \\
\end{tabular} & $\begin{array}{r}347 \\
110 \\
0\end{array}$ & $\begin{array}{l}25 \\
11 \\
81\end{array}$ & $\begin{array}{r}1,083 \\
841 \\
12,728\end{array}$ & $\begin{array}{r}3,013 \\
2,275 \\
12,463\end{array}$ & $\begin{array}{l}512 \\
234 \\
847 \\
\end{array}$ & $\begin{array}{r}3,001 \\
2,275 \\
12,463 \\
\end{array}$ & $\begin{array}{r}12 \\
0 \\
0\end{array}$ & $\begin{array}{r}559 \\
316 \\
5,334 \\
\end{array}$ & $\begin{array}{r}3,144 \\
3,018 \\
49,068 \\
\end{array}$ & $\begin{array}{r}47 \\
82 \\
4,487 \\
\end{array}$ & $\begin{array}{r}143 \\
743 \\
36,605 \\
\end{array}$ & \\
\hline 20 & 457 & $\overline{117}$ & 14,652 & 17,751 & 1,593 & 17,739 & 12 & 6,209 & 55,230 & 4,616 & 37,491 & 40 \\
\hline $\begin{array}{r}41 \\
5 \\
3\end{array}$ & $\begin{array}{l}484 \\
221 \\
675\end{array}$ & \begin{tabular}{r|}
18 \\
9 \\
46
\end{tabular} & $\begin{array}{r}647 \\
525 \\
3,140\end{array}$ & $\begin{array}{r}11,517 \\
5,364 \\
58,383\end{array}$ & $\begin{array}{l}, 023 \\
378 \\
3,849\end{array}$ & $\begin{array}{r}11,517 \\
5,364 \\
58,383\end{array}$ & $\begin{array}{l}0 \\
0 \\
0\end{array}$ & $\begin{array}{l}2,044 \\
487 \\
6,757\end{array}$ & $\begin{array}{r}11,832 \\
7,021 \\
106,388\end{array}$ & $\begin{array}{r}21 \\
109 \\
2,908\end{array}$ & $\begin{array}{r}315 \\
1,657 \\
48,005\end{array}$ & \\
\hline 49 & 1,380 & 73 & 4,312 & 75,264 & 6,250 & 75,264 & 0 & 9,288 & 125,241 & 3,038 & 49,977 & 120 \\
\hline 9 & 78 & 0 & 0 & 5 & 5 & 5 & 0 & 7 & 12 & 2 & 7 & \\
\hline 9 & 78 & 0 & 0 & 5 & 5 & 5 & 0 & 7 & 12 & 2 & 7 & 6 \\
\hline $\begin{array}{r}38 \\
0 \\
11\end{array}$ & $\begin{array}{r}403 \\
0 \\
870\end{array}$ & $\begin{array}{l}13 \\
16 \\
57\end{array}$ & $\begin{array}{r}460 \\
810 \\
17,015 \\
\end{array}$ & $\begin{array}{r}27,435 \\
5,112 \\
33,810\end{array}$ & $\begin{array}{l}4,412 \\
584 \\
4,523\end{array}$ & $\begin{array}{r}21,724 \\
5,112 \\
33,810 \\
\end{array}$ & $\begin{array}{r}5,711 \\
0 \\
0\end{array}$ & $\begin{array}{r}4,688 \\
881 \\
17,011 \\
\end{array}$ & $\begin{array}{r}23,386 \\
8,962 \\
151,113\end{array}$ & $\begin{array}{r}276 \\
297 \\
12,488 \\
\end{array}$ & $\begin{array}{r}1,662 \\
3,850 \\
117,303\end{array}$ & \\
\hline 49 & 1,273 & 86 & 18,285 & 66,357 & 9,519 & 60,646 & 5,711 & 22,580 & 183,461 & 13,061 & 122,815 & 210 \\
\hline $\begin{array}{r}17 \\
1 \\
0\end{array}$ & $\begin{array}{r}216 \\
125 \\
0\end{array}$ & $\begin{array}{r}45 \\
7 \\
31\end{array}$ & $\begin{array}{l}1,602 \\
1,125 \\
9,726\end{array}$ & $\begin{array}{l}3,176 \\
7,128 \\
7,129\end{array}$ & $\begin{array}{l}629 \\
61 \\
991\end{array}$ & $\begin{array}{l}3,176 \\
638 \\
7,129\end{array}$ & $\begin{array}{l}0 \\
0 \\
0\end{array}$ & $\begin{array}{r}757 \\
116 \\
1,128\end{array}$ & $\begin{array}{r}3,804 \\
1,086 \\
10,319 \\
\end{array}$ & $\begin{array}{r}128 \\
55 \\
137\end{array}$ & $\begin{array}{r}628 \\
448 \\
3,190\end{array}$ & \\
\hline 18 & 341 & 83 & 12,453 & 10,943 & 1,681 & 10,943 & 0 & 2,001 & 15,209 & 320 & 4,266 & 15 \\
\hline $\begin{array}{r}14 \\
1 \\
4 \\
\end{array}$ & $\begin{array}{r}209 \\
3 \\
52\end{array}$ & $\begin{array}{r}38 \\
27 \\
177\end{array}$ & $\begin{array}{r}1,441 \\
2,042 \\
64,533\end{array}$ & $\begin{array}{r}11,512 \\
5,411 \\
62,357\end{array}$ & $\begin{array}{l}2,347 \\
630 \\
2,849\end{array}$ & $\begin{array}{r}11,188 \\
5,411 \\
50,257\end{array}$ & $\begin{array}{r}324 \\
0 \\
12,100 \\
\end{array}$ & $\begin{array}{l}2,450 \\
1,046 \\
5,413\end{array}$ & $\begin{array}{r}12,090 \\
7,685 \\
99,418\end{array}$ & $\begin{array}{r}103 \\
416 \\
2,564\end{array}$ & $\begin{array}{r}902 \\
2,274 \\
49,161 \\
\end{array}$ & \\
\hline 19 & 264 & 242 & 68,016 & 79,280 & 5,826 & 66,856 & 12,424 & 8,909 & 119,193 & 3,083 & 52,337 & 135 \\
\hline $\begin{array}{l}6 \\
0 \\
3 \\
\end{array}$ & $\begin{array}{r}127 \\
0 \\
635\end{array}$ & $\begin{array}{l}36 \\
8 \\
36\end{array}$ & $\begin{array}{l}1,215 \\
820 \\
6,339\end{array}$ & $\begin{array}{r}2,209 \\
990 \\
17,422\end{array}$ & $\begin{array}{r}334 \\
119 \\
1,652 \\
\end{array}$ & $\begin{array}{r}2,209 \\
990 \\
17,422 \\
\end{array}$ & $\begin{array}{l}0 \\
0 \\
0\end{array}$ & $\begin{array}{r}399 \\
383 \\
1,850\end{array}$ & $\begin{array}{r}2,310 \\
1,222 \\
23,334\end{array}$ & $\begin{array}{r}65 \\
264 \\
198\end{array}$ & $\begin{array}{r}101 \\
232 \\
8,112\end{array}$ & \\
\hline 9 & 762 & 80 & 8,374 & 20,621 & 2,105 & 20,621 & 0 & 2,632 & 27,066 & 527 & 6,445 & 34 \\
\hline
\end{tabular}


TABLE 47.-Mechanical power-supply equipment,

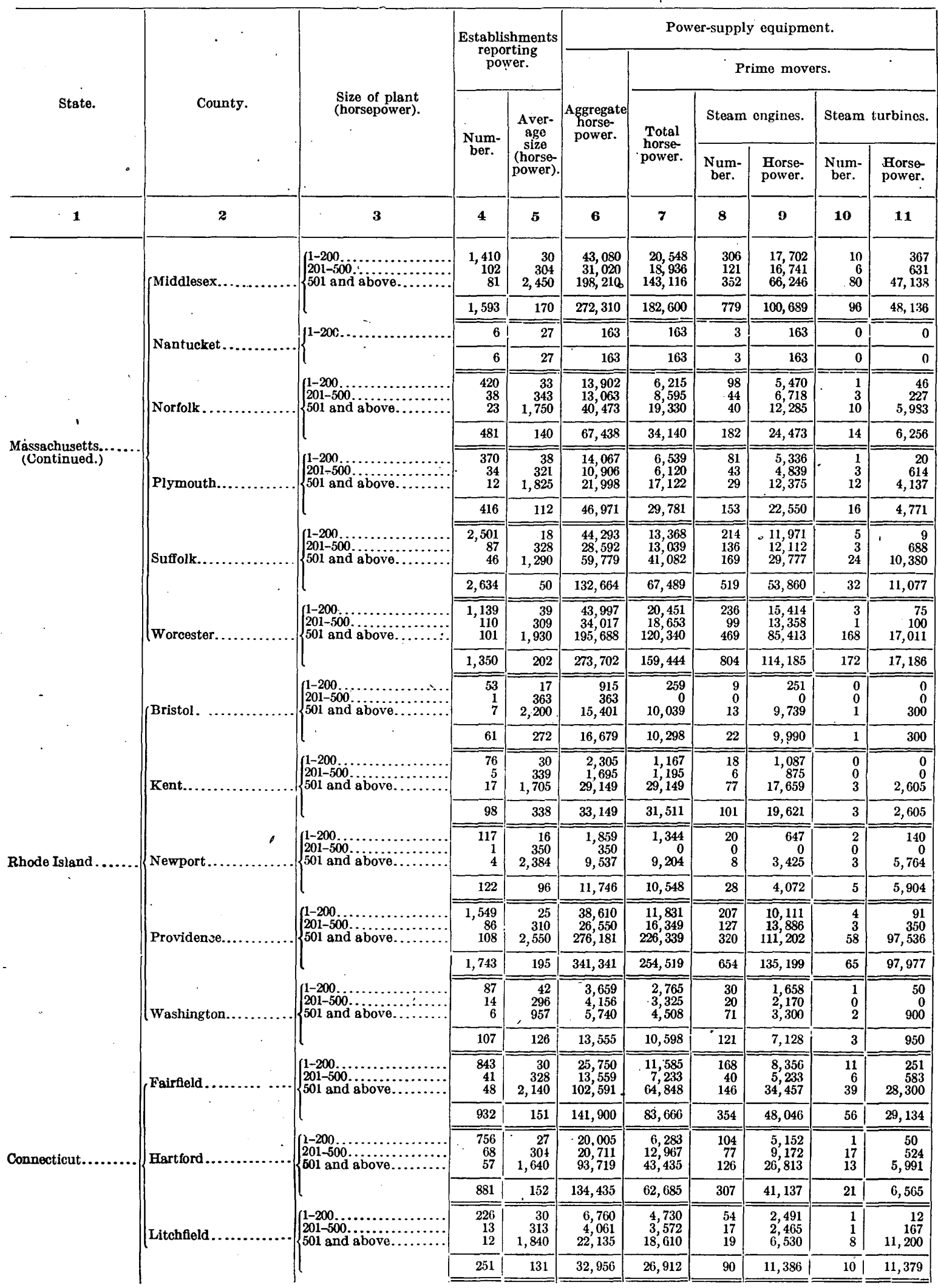


by counties and size of plant-Continued.

\begin{tabular}{|c|c|c|c|c|c|c|c|c|c|c|c|c|}
\hline \multicolumn{8}{|c|}{ Power-supply equipment-Continued. } & \multicolumn{4}{|c|}{ Electric motors. } & \multirow{4}{*}{$\begin{array}{l}\text { Number } \\
\text { of estab- } \\
\text { lishments } \\
\text { reporting } \\
\text { no power. }\end{array}$} \\
\hline \multicolumn{4}{|c|}{ Prime movers-Continued. } & \multicolumn{4}{|c|}{ Operated by purchased energy. } & \multirow{2}{*}{\multicolumn{2}{|c|}{ Total. }} & \multirow{2}{*}{\multicolumn{2}{|c|}{$\begin{array}{l}\text { Run by current } \\
\text { generated in } \\
\text { establishment. }\end{array}$}} & \\
\hline $\begin{array}{c}\text { Interne } \\
\text { tion }\end{array}$ & $\begin{array}{l}\text {-combus- } \\
\text { igines. }\end{array}$ & Water & wheels. & \multirow{2}{*}{$\begin{array}{l}\text { Total } \\
\text { horse } \\
\text { power. }\end{array}$} & \multicolumn{2}{|c|}{ Electric motors. } & \multirow{2}{*}{$\begin{array}{l}\text { Other } \\
\text { (horse- } \\
\text { power). }\end{array}$} & & & & & \\
\hline $\begin{array}{c}\text { Num- } \\
\text { ber. }\end{array}$ & $\begin{array}{l}\text { Horse- } \\
\text { power. }\end{array}$ & $\begin{array}{c}\text { Num- } \\
\text { ber. }\end{array}$ & $\begin{array}{l}\text { Horse- } \\
\text { power. }\end{array}$ & & Number. & $\begin{array}{l}\text { Horse- } \\
\text { power. }\end{array}$ & & Number. & $\begin{array}{l}\text { Horse- } \\
\text { power. }\end{array}$ & Number. & $\begin{array}{l}\text { Horse- } \\
\text { power. }\end{array}$ & \\
\hline 12 & $\mathbf{1 3}$ & 14 & 15 & 16 & 17 & 18 & 19 & 20 & 21 & $\mathbf{2 2}$ & 23 & 24 \\
\hline $\begin{array}{r}80 \\
5 \\
1\end{array}$ & $\begin{array}{r}1,413 \\
379 \\
10\end{array}$ & $\begin{array}{r}34 \\
16 \\
113\end{array}$ & $\begin{array}{r}1,067 \\
1,185 \\
29,722\end{array}$ & $\begin{array}{l}22,532 \\
12,084 \\
55,094\end{array}$ & $\begin{array}{l}4,335 \\
1,357 \\
3,809\end{array}$ & $\begin{array}{l}20,621 \\
12,084 \\
55,094\end{array}$ & $\begin{array}{r}1,911 \\
0 \\
0\end{array}$ & $\begin{array}{l}4,597 \\
1,973 \\
9,511\end{array}$ & $\begin{array}{r}22,336 \\
16,339 \\
124,198\end{array}$ & $\begin{array}{r}262 \\
616 \\
5,702\end{array}$ & $\begin{array}{r}1,715 \\
4,255 \\
69,104\end{array}$ & \\
\hline 86 & 1,802 & 163 & 31,974 & 89,710 & 9,501 & 87,799 & 1,911 & 16,081 & 162,873 & 6,580 & 75,074 & 273 \\
\hline 0 & 0 & $\overline{0}$ & 0 & 0 & 0 & 0 & 0 & $\overline{0}$ & $\overline{0}$ & 0 & $\overline{0}$ & \\
\hline 0. & $\mathbf{0}$ & 0 & 0 & 0 & 0 & 0 & 0 & 0 & 0 & 0 & $\mathbf{0}$ & 3 \\
\hline $\begin{array}{r}18 \\
4 \\
2\end{array}$ & $\begin{array}{r}231 \\
453 \\
52\end{array}$ & $\begin{array}{l}13 \\
17 \\
17\end{array}$ & $\begin{array}{r}468 \\
1,197 \\
1,010\end{array}$ & $\begin{array}{r}7,687 \\
4,468 \\
21,143\end{array}$ & $\begin{array}{l}1,393 \\
3,103 \\
2,106\end{array}$ & $\begin{array}{r}7,433 \\
4,468 \\
21,143\end{array}$ & $\begin{array}{r}254 \\
0 \\
0\end{array}$ & $\begin{array}{l}1,477 \\
2,571 \\
2,557\end{array}$ & $\begin{array}{r}7,779 \\
6,018 \\
28,309\end{array}$ & $\begin{array}{r}84 \\
308 \\
451\end{array}$ & $\begin{array}{r}346 \\
1,550 \\
7,166\end{array}$ & \\
\hline 24 & 736 & 47 & 2,675 & 33,298 & 3,862 & 33,044 & 254 & 4,705 & 42,106 & 843 & 9,062 & $\overline{58}$ \\
\hline $\begin{array}{r}19 \\
3 \\
0\end{array}$ & $\begin{array}{r}351 \\
136 \\
0\end{array}$ & $\begin{array}{r}29 \\
11 \\
8\end{array}$ & $\begin{array}{l}832 \\
531 \\
610\end{array}$ & $\begin{array}{l}7,528 \\
4,786 \\
4,876\end{array}$ & $\begin{array}{r}1,368 \\
847 . \\
506\end{array}$ & $\begin{array}{l}6,798 \\
4,786 \\
4,876\end{array}$ & $\begin{array}{r}730 \\
0 \\
0\end{array}$ & $\begin{array}{r}1,444 \\
910 \\
680\end{array}$ & $\begin{array}{l}7,427 \\
5,450 \\
8,360\end{array}$ & $\begin{array}{r}76 \\
63 \\
174\end{array}$ & $\begin{array}{r}629 \\
664 \\
3,484\end{array}$ & \\
\hline 22 & 487 & 48 & 1,973 & 17,190 & 2,721 & 16,460 & 730 & 3,034 & 21,237 & 313 & 4,777 & 53 \\
\hline $\begin{array}{r}64 \\
6 \\
5\end{array}$ & $\begin{array}{r}1,224 \\
204 \\
425\end{array}$ & $\begin{array}{r}7 \\
1 \\
17\end{array}$ & $\begin{array}{r}164 \\
35 \\
500\end{array}$ & $\begin{array}{l}\begin{array}{l}30,925 \\
15,553 \\
18,697\end{array}\end{array}$ & $\begin{array}{l}8,866 \\
.2,246 \\
1,563\end{array}$ & $\begin{array}{l}29,106 \\
15,093 \\
18,497\end{array}$ & $\begin{array}{r}1,819 \\
460 \\
200\end{array}$ & $\begin{array}{l}9,392 \\
3,259 \\
4,809\end{array}$ & $\begin{array}{l}31,271 \\
19,044 \\
43,659\end{array}$ & $\begin{array}{l}526 \\
1,013 \\
3,246\end{array}$ & $\begin{array}{r}2,165 \\
3,951 \\
25,162\end{array}$ & \\
\hline 75 & 1,853 & 25 & 699 & 65,175 & 12,675 & 62,696 & 2,479 & 17,460 & 93,974 & 4,785 & 31,278 & 698 \\
\hline $\begin{array}{r}44 \\
0 \\
2\end{array}$ & $\begin{array}{r}842 \\
0 \\
827\end{array}$ & $\begin{array}{r}103 \\
65 \\
76\end{array}$ & $\begin{array}{r}4,120 \\
5,195 \\
17,079\end{array}$ & $\begin{array}{l}3,546 \\
15,364 \\
75,348\end{array}$ & $\begin{array}{l}4,384 \\
1,823 \\
4,151\end{array}$ & $\begin{array}{l}23,091 \\
15,364 \\
75,348\end{array}$ & $\begin{array}{r}455 \\
0 \\
0\end{array}$ & $\begin{array}{l}4,694 \\
2,513 \\
6,695\end{array}$ & $\begin{array}{r}25,223 \\
10,038 \\
10 \epsilon^{\prime}, 601\end{array}$ & $\begin{array}{r}310 \\
690 \\
2,544\end{array}$ & $\begin{array}{r}2,132 \\
3,674 \\
31,253\end{array}$ & \\
\hline 40 & 1,669 & 244 & 26,404 & 114,258 & 10,358 & 113,803 & 455 & 13,902 & 150,862 & 3,544 & 37,059 & 168 \\
\hline $\begin{array}{l}2 \\
0 \\
0\end{array}$ & $\begin{array}{l}8 \\
0 \\
0\end{array}$ & $\begin{array}{l}0 \\
0 \\
0\end{array}$ & $\begin{array}{l}0 \\
0 \\
0\end{array}$ & $\begin{array}{r}656 \\
363 \\
5,362\end{array}$ & $\begin{array}{r}127 \\
256 \\
256\end{array}$ & $\begin{array}{r}654 \\
363 \\
5,362\end{array}$ & $\begin{array}{l}2 \\
0 \\
0\end{array}$ & $\begin{array}{r}127 \\
283\end{array}$ & $\begin{array}{r}654 \\
363 \\
6,229\end{array}$ & $\begin{array}{r}0 \\
0 \\
27\end{array}$ & $\begin{array}{r}0 \\
0 \\
867\end{array}$ & \\
\hline 2 & 8 . & 0 & 0 & 6,381 & 389 & 6,379 & 2 & 416 & 7,246 & 27 & 867 & 15 \\
\hline $\begin{array}{l}6 \\
2 \\
0\end{array}$ & $\begin{array}{r}55 \\
20 \\
0\end{array}$ & $\begin{array}{r}1 \\
3 \\
53\end{array}$ & $\begin{array}{r}25 \\
300 \\
8,885\end{array}$ & $\begin{array}{r}1,138 \\
500 \\
0\end{array}$ & $\begin{array}{r}329 \\
.43 \\
0\end{array}$ & $\begin{array}{r}1,103 \\
500 \\
0\end{array}$ & $\begin{array}{r}35 \\
0 \\
0\end{array}$ & $\begin{array}{l}331 \\
188 \\
382 \\
\end{array}$ & $\begin{array}{l}, 126 \\
946 \\
4,534\end{array}$ & $\begin{array}{r}2 \\
145 \\
382\end{array}$ & $\begin{array}{r}23 \\
446 \\
4,534\end{array}$ & ㄱ…....... \\
\hline 8 & 75 & 57 & 9,210 & 1,638 & 372 & 1,603 & 35 & 901 & 6,606 & 529 & 5,003 & 9 \\
\hline $\begin{array}{r}0 \\
0 \\
2\end{array}$ & 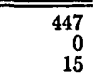 & $\begin{array}{l}3 \\
0 \\
0\end{array}$ & $\begin{array}{r}110 \\
0 \\
0\end{array}$ & $\begin{array}{l}515 \\
350 \\
333\end{array}$ & $\begin{array}{r}157 \\
45 \\
5\end{array}$ & $\begin{array}{l}515 \\
350 \\
333\end{array}$ & $\begin{array}{l}\overline{0} \\
0 \\
0\end{array}$ & $\begin{array}{r}160 \\
45 \\
683\end{array}$ & $\begin{array}{r}523 \\
350 \\
4,876\end{array}$ & \begin{tabular}{r|}
3 \\
0 \\
678
\end{tabular} & $\begin{array}{r}8 \\
0 \\
4,543\end{array}$ & \\
\hline 34 & 462 & 3 & 110 & $.1,198$ & 207 & 1,198 & 0 & 888 & 5,749 & 681 & 4,551 & 25 \\
\hline $\begin{array}{r}43 \\
1 \\
6\end{array}$ & $\begin{array}{r}652 \\
3,125\end{array}$ & $\begin{array}{r}27 \\
23 \\
103\end{array}$ & $\begin{array}{r}977 \\
2,109 \\
14,476\end{array}$ & $\begin{array}{l}26,779 \\
10,201 \\
49,842\end{array}$ & $\begin{array}{l}5,315 \\
1,211 \\
4,517\end{array}$ & $\begin{array}{l}25,458 \\
10,201 \\
49,842\end{array}$ & $\begin{array}{r}1,321 \\
0 \\
0\end{array}$ & $\begin{array}{r}5,606 \\
1,583 \\
10,670\end{array}$ & $\begin{array}{r}27,666 \\
13,404 \\
101,936\end{array}$ & $\begin{array}{r}291 \\
372 \\
6,153\end{array}$ & $\begin{array}{r}2,208 \\
3,203 \\
52,094\end{array}$ & \\
\hline 50 & 3,781 & 153 & 17,562 & 86,822 & 11,043 & 85,501 & 1,321 & 17,859 & 143,006 & 6,816 & 57,505 & 375 \\
\hline $\begin{array}{r}16 \\
2 \\
0\end{array}$ & $\begin{array}{r}104 \\
35 \\
0\end{array}$ & $\begin{array}{r}21 \\
23 \\
6\end{array}$ & $\begin{array}{r}953 \\
1,120 \\
308\end{array}$ & $\begin{array}{r}894 \\
831 \\
1,232\end{array}$ & $\begin{array}{r}214 \\
64 \\
27\end{array}$ & $\begin{array}{r}839 \\
831 \\
1,232\end{array}$ & $\begin{array}{r}55 \\
0 \\
0\end{array}$ & $\begin{array}{l}347 \\
143 \\
109\end{array}$ & $\begin{array}{l}1,079 \\
2,523 \\
2,601\end{array}$ & $\begin{array}{r}133 \\
79 \\
82\end{array}$ & $\begin{array}{r}240 \\
692 \\
1,369\end{array}$ & \\
\hline 18 & 139 & 50 & 2,381 & 2,957 & 305 & 2,902 & 55 & 599 & 5,203 & 294 & 2,301 & 15 \\
\hline $\begin{array}{r}65 \\
4 \\
8\end{array}$ & $\begin{array}{r}1,051 \\
355 \\
869\end{array}$ & $\begin{array}{r}33 \\
13 \\
13\end{array}$ & $\begin{array}{l}1,927 \\
1,062 \\
1,222\end{array}$ & $\begin{array}{r}14,165 \\
6,326 \\
37,743\end{array}$ & $\begin{array}{l}, 400 \\
2,816 \\
2,865\end{array}$ & $\begin{array}{r}14,165 \\
6,326 \\
37,743\end{array}$ & $\begin{array}{l}0 \\
0 \\
0\end{array}$ & $\begin{array}{l}2,619 \\
876 \\
6,569\end{array}$ & $\begin{array}{r}15,177 \\
9,013 \\
75,237\end{array}$ & $\begin{array}{r}219 \\
260 \\
3,704\end{array}$ & $\begin{array}{r}1,012 \\
2,687 \\
37,494\end{array}$ & \\
\hline 77 & 2,275 & 33 & 4,211 & 58,234 & 5,881 & 58,234 & 0 & 10,064 & 99,427 & 4,183 & 41,193 & 160 \\
\hline $\begin{array}{r}29 \\
12 \\
1\end{array}$ & $\begin{array}{r}265 \\
238 \\
60\end{array}$ & $\begin{array}{l}27 \\
43 \\
.68\end{array}$ & $\begin{array}{r}816 \\
3,033 \\
10,571\end{array}$ & $\begin{array}{r}13,722 \\
7,744 \\
50,284\end{array}$ & $\begin{array}{l}2,318 \\
583 \\
2,642\end{array}$ & $\begin{array}{r}13,722 \\
7,744 \\
50,284\end{array}$ & $\begin{array}{l}\overline{0} \\
0 \\
0\end{array}$ & $\begin{array}{r}, 563 \\
800 \\
3,966\end{array}$ & $\begin{array}{r}15,298 \\
9,773 \\
68,590\end{array}$ & $\begin{array}{r}245 \\
217 \\
1,324\end{array}$ & $\begin{array}{r}1,576 \\
2,029 \\
18,306\end{array}$ & \\
\hline 42 & 563 & 138 & 14,420 & 71,750 & 5,543 & 71,750 & 0 & 7,329 & 93,661 & 1,786 & 21,911 & $\overline{181}$ \\
\hline $\begin{array}{r}36 \\
0 \\
0\end{array}$ & $\begin{array}{r}545 \\
0 \\
0\end{array}$ & $\begin{array}{l}46 \\
16 \\
10\end{array}$ & $\begin{array}{r}1,682 \\
1,040 \\
880\end{array}$ & $\begin{array}{l}2,030 \\
489 \\
3,525\end{array}$ & $\begin{array}{r}288 \\
36 \\
274\end{array}$ & $\begin{array}{l}2,018 \\
489 \\
3,525\end{array}$ & $\begin{array}{r}12 \\
0 \\
0\end{array}$ & $\begin{array}{l}472 \\
115 \\
603\end{array}$ & $\begin{array}{r}2,941 \\
1,555 \\
13,478\end{array}$ & $\begin{array}{r}184 \\
729 \\
\end{array}$ & $\begin{array}{l}923 \\
1,066 \\
9,953\end{array}$ & \\
\hline 30 & 545 & 72 & 3,602 & $6, \dot{044}$ & 598 & 6,032 & 12 & 1,190 & 17,974 & 592 & 11,942 & 35 \\
\hline
\end{tabular}

$63361^{\circ}-21 \longrightarrow 9$ ' 
TABLE 47.-Mechanical power-supply equipment,

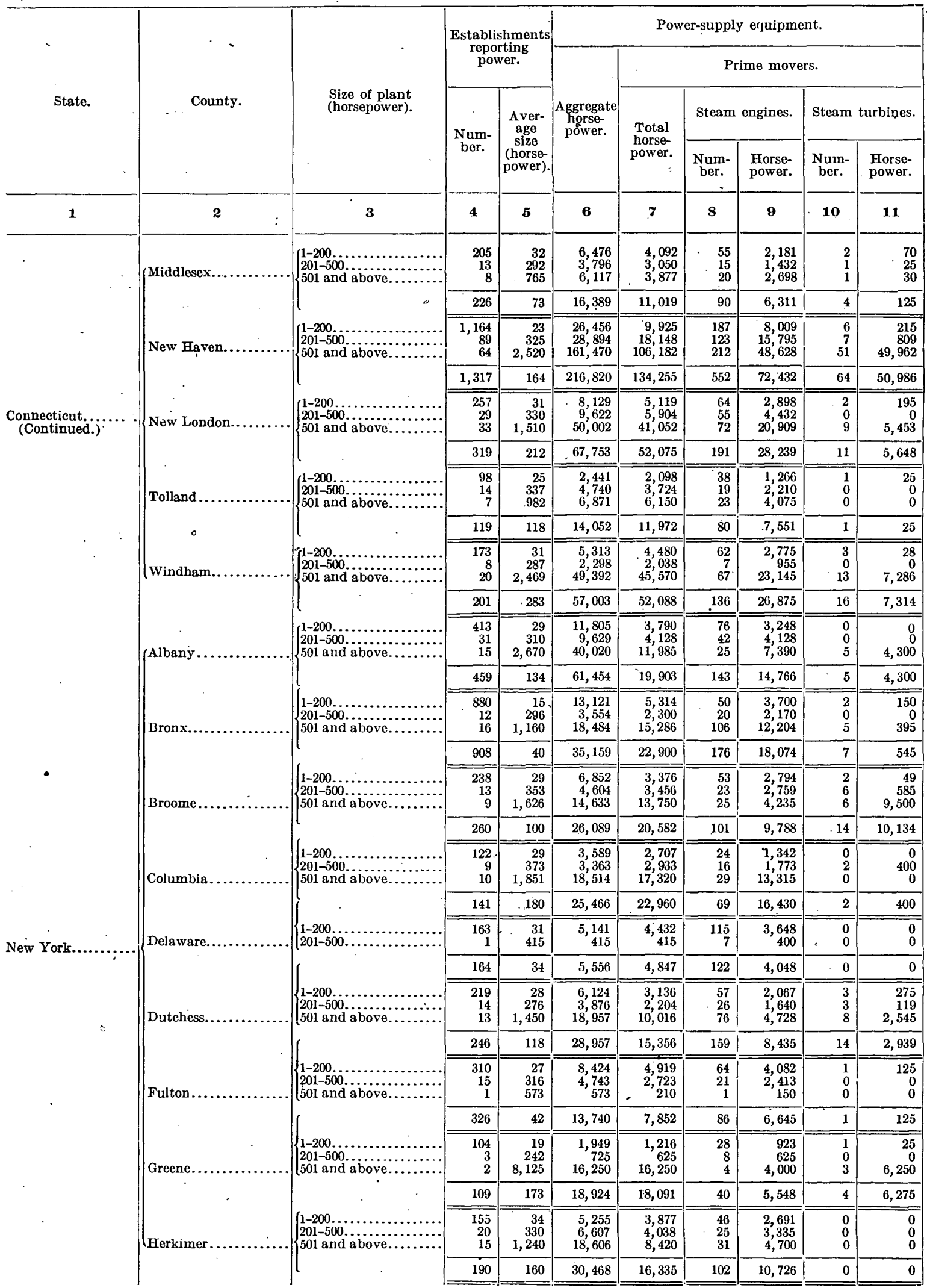


by counties and size of plant-Continued.

\begin{tabular}{|c|c|c|c|c|c|c|c|c|c|c|c|c|}
\hline & & Pow & r-supply c & quipment & -Continuc & & & & Electric & motors. & & \\
\hline$\therefore$ Prir & ne movor & - Conti & hued. & & rated by & Irchased on & rgy. & & & & & Number \\
\hline $\begin{array}{l}\text { Intorna } \\
\text { tion } 0\end{array}$ & $\begin{array}{l}\text {-combus- } \\
\text { ngines. }\end{array}$ & Water & wheels. & & Electric & motors. & & 100 & & estab & & lishments \\
\hline $\begin{array}{c}\text { Num- } \\
\text { ber. }\end{array}$ & $\begin{array}{l}\text { Horse- } \\
\text { power. }\end{array}$ & $\underset{\text { ber. }}{\text { Num- }}$ & $\begin{array}{l}\text { Horse- } \\
\text { power. }\end{array}$ & & Number. & $\begin{array}{l}\text { Horse- } \\
\text { power. }\end{array}$ & & Number. & $\begin{array}{l}\text { Horse- } \\
\text { power. }\end{array}$ & Number. & $\begin{array}{l}\text { Horse- } \\
\text { power. }\end{array}$ & \\
\hline 12. & 13 & 14 & 15 & 16 & 17 & 18 & 19 & 20 & 21 & 22 & 23 & $\cdot 24$ \\
\hline $\begin{array}{r}48 \\
7 \\
5\end{array}$ & $\begin{array}{r}678 \\
70 \\
226\end{array}$ & $\begin{array}{l}34 \\
17 \\
.16\end{array}$ & $\begin{array}{r}1,163 \\
.1,523 \\
.923\end{array}$ & $\begin{array}{l}2,384 \\
746 \\
2,240\end{array}$ & $\begin{array}{r}391 \\
60 \\
373\end{array}$ & $\begin{array}{l}2,384 \\
246 . \\
2,240\end{array}$ & $\begin{array}{l}0 \\
0 \\
0\end{array}$ & $\begin{array}{l}.434 \\
117 \\
784\end{array}$ & $\begin{array}{r}2,681 \\
1,342 \\
3,506 .\end{array}$ & $\begin{array}{r}43 \\
5 \quad \quad 57 \\
\ldots \quad 411\end{array}$ & $\begin{array}{r}297 \\
596 \\
1,266\end{array}$ & \\
\hline 60 & 974 & 07 & $\cdot 3,609$ & 5,370 & 824 & 5,370 & 0 & 1,335 & 7,529 & 511 & 2,159 & 32 \\
\hline $\begin{array}{r}74 \\
6 \\
12\end{array}$ & $\begin{array}{r}823 \\
299 \\
2,720\end{array}$ & $\begin{array}{l}32 \\
20 \\
35\end{array}$ & $\begin{array}{r}878 \\
1,245 \\
4,872\end{array}$ & $\begin{array}{l}16,531 \\
10,746 \\
55,288\end{array}$ & $\begin{array}{l}3,627 \\
1,208 \\
3,011\end{array}$ & $\begin{array}{l}16,319 \\
10,746 \\
55,288\end{array}$ & $\begin{array}{r}212 \\
0 \\
0\end{array}$ & $\begin{array}{l}3,756 \\
1,924 \\
7,348\end{array}$ & $\begin{array}{r}17,153 \\
17,516 \\
102,805\end{array}$ & $\begin{array}{r}129 \\
716 \\
4,337\end{array}$ & $\begin{array}{r}834 \\
6,770 \\
47,517\end{array}$ & \\
\hline 92 & 3,842 & 87 & 6,995 & 82,565 & 7,846 & 82,353 & 212 & 13,028 & 137,474 & 5,182 & 55,121 & 356 \\
\hline $\begin{array}{r}18 \\
5 \\
6\end{array}$ & $\begin{array}{r}163 \\
135 \\
1,645\end{array}$ & $\begin{array}{l}13 \\
15 \\
61\end{array}$ & $\begin{array}{r}1,863 \\
1,337 \\
13,045\end{array}$ & $\begin{array}{l}3,010 \\
3,718 \\
8,950\end{array}$ & $\begin{array}{l}445 \\
481 \\
859\end{array}$ & $\begin{array}{l}3,000 \\
3,718 \\
8,950\end{array}$ & $\begin{aligned} . \quad 10 \\
\because \quad 0 \\
.0\end{aligned}$ & $\begin{array}{r}577 \\
570 \\
1,646\end{array}$ & $\begin{array}{r}3,843 \\
4,262 \\
20,843\end{array}$ & $\begin{array}{r}132 \\
89 \\
787\end{array}$ & $\begin{array}{r}843 \\
544 \\
11,893\end{array}$ & \\
\hline 29 & 1,943 & 89 & 16,245 & 15,678 & 1,785 & 15,668 & 10 & 2,793 & 28,948 & 1,008 & 13,280 & 66 \\
\hline $\begin{array}{r}20 \\
0 \\
0\end{array}$ & $\begin{array}{r}196 \\
0 \\
0\end{array}$ & $\begin{array}{r}4 \\
20 \\
21\end{array}$ & $\begin{array}{r}611 \\
1,514 \\
2,075\end{array}$ & $\begin{array}{r}343 \\
1,016 \\
721\end{array}$ & $\begin{array}{r}66 \\
142 \\
68\end{array}$ & $\begin{array}{r}343 \\
1,016 \\
721\end{array}$ & $\begin{array}{l}0 \\
0 \\
0\end{array}$ & $\begin{array}{r}70 \\
206 \\
594\end{array}$ & $\begin{array}{r}369 \\
1,918 \\
4,471\end{array}$ & $\begin{array}{r}4 \\
64 \\
.526\end{array}$ & $\begin{array}{r}26 \\
3,750 \\
3,750\end{array}$ & \\
\hline 20 & 196 & 45 & 4,200 & 2,080 & 276 & 2,080 & 0 & 870 & 6,758 & 594 & 4,678 & 13 \\
\hline $\begin{array}{r}31 \\
3 \\
0\end{array}$ & $\begin{array}{r}410 \\
276 \\
0\end{array}$ & $\begin{array}{r}32 \\
9 \\
72\end{array}$ & $\begin{array}{r}1,267 \\
807 \\
15,139\end{array}$ & $\begin{array}{r}.833 \\
260 \\
3,822\end{array}$ & $\begin{array}{l}216 \\
242 \\
384\end{array}$ & $\begin{array}{r}828 \\
160 \\
3,822\end{array}$ & $\begin{array}{l}5 \\
0 \\
0\end{array}$ & $\begin{array}{l}222 \\
289 \\
805\end{array}$ & $\begin{array}{r}874 \\
876 \\
.8,907\end{array}$ & $\begin{array}{r}6 \\
47 \\
421\end{array}$ & $\begin{array}{r}46 \\
616 \\
5,085\end{array}$ & \\
\hline 34 & 686 & 113 & 17,213 & 4,915 & 842 & 4,910 & 5 & 1,316 . & 10,657 & 474 & 5,747 & 22 \\
\hline $\begin{array}{r}22 \\
0 \\
0\end{array}$ & $\begin{array}{r}164 \\
0 \\
0\end{array}$ & $\begin{array}{l}7 \\
0 \\
2\end{array}$ & $\begin{array}{r}378 \\
0 \\
295\end{array}$ & $\begin{array}{r}8,015 \\
5,501 \\
.28,035\end{array}$ & $\begin{array}{r}1,333 \\
476 \\
.915\end{array}$ & $\begin{array}{r}8,014 \\
5,501 \\
28,035\end{array}$ & $\begin{array}{l}1 \\
0 \\
0\end{array}$ & $\begin{array}{l}1,429 \\
635 \\
1,490\end{array}$ & $\begin{array}{r}8,620 \\
6,835 \\
40,788\end{array}$ & $\begin{array}{r}96 \\
159 \\
575\end{array}$ & $\begin{array}{r}606 \\
1,334 \\
12,753\end{array}$ & \\
\hline 22 & 164 & 9 & 673 & 41,551 & 2,724 & 41,550 & 1 & 3,554 & 56,243 & 830 & 14,693 & 138 \\
\hline $\begin{array}{r}105 \\
1 \\
26\end{array}$ & $\begin{array}{l}1,464 \\
35 \\
2,687\end{array}$ & $\begin{array}{l}0 \\
2 \\
0\end{array}$ & $\begin{array}{r}0 \\
95 \\
0\end{array}$ & $\begin{array}{l}7,807 \\
1,254 \\
3,198\end{array}$ & $\begin{array}{r}2,550 \\
155 \\
544\end{array}$ & $\begin{array}{l}7,717 \\
1,254 \\
3,198\end{array}$ & $\begin{array}{r}90 \\
0 \\
0\end{array}$ & $\begin{array}{r}2,675 \\
261 \\
978\end{array}$ & & $\begin{array}{l}125 \\
106 \\
434\end{array}$ & $\begin{array}{l}3,119 \\
813 \\
6,125\end{array}$ & \\
\hline 132 & 4,186 & 2 & 95 & 12,259 & 3,249 & 12,169 & 90 & 3,914 & 22,226 & 665 & 10,057 & 471 \\
\hline $\begin{array}{r}27 \\
-2 \\
1\end{array}$ & $\begin{array}{r}289 \\
7 \\
15\end{array}$ & $\begin{array}{r}10 \\
3 \\
0\end{array}$ & $\begin{array}{r}244 \\
105 \\
0\end{array}$ & $\begin{array}{r}3,476 \\
1,148 \\
883\end{array}$ & $\begin{array}{r}749 \\
53 \\
38\end{array}$ & $\begin{array}{r}3,476 \\
1,148 \\
883\end{array}$ & $\begin{array}{l}0 \\
0 \\
0\end{array}$ & $\begin{array}{r}788 \\
270 \\
2,638\end{array}$ & $\begin{array}{r}3,729 \\
2,161 \\
18,332\end{array}$ & $\begin{array}{r}39 \\
217 \\
2,600\end{array}$ & $\begin{array}{r}253 \\
1,013 \\
17,449\end{array}$ & \\
\hline 30 & 311 & 13 & 349 & 5,507 & 840 & 5,507 & 0 & 3,696 & 24,222 & 2,856 & 18,715 & 68 \\
\hline $\begin{array}{r}17 \\
1 \\
1\end{array}$ & $\begin{array}{r}109 \\
5 \\
50\end{array}$ & $\begin{array}{r}40 \\
9 \\
15\end{array}$ & $\begin{array}{l}1,256 \\
755 \\
3,955\end{array}$ & $\begin{array}{r}882 \\
430 \\
1,194\end{array}$ & $\begin{array}{r}155 \\
13 \\
85\end{array}$ & $\begin{array}{r}882 \\
430 \\
1,194\end{array}$ & $\begin{array}{l}0 \\
0 \\
0\end{array}$ & $\begin{array}{r}163 \\
39 \\
194\end{array}$ & $\begin{array}{r}995 \\
932 \\
4,364\end{array}$ & $\begin{array}{r}8 \\
26 \\
109\end{array}$ & $\begin{array}{r}113 \\
502 \\
3,170\end{array}$ & \\
\hline 19 & 164 & 64 & $.5,966$ & 2,506 & 253 & 2,506 & 0 & 396 & 6,291 & 143 & 3,785 & 40 \\
\hline $\begin{array}{r}41 \\
2\end{array}$ & $\begin{array}{r}311 \\
15\end{array}$ & $\begin{array}{r}28 \\
0\end{array}$ & $\begin{array}{r}473 \\
0\end{array}$ & $\begin{array}{r}709 \\
0\end{array}$ & $\begin{array}{r}166 \\
0\end{array}$ & $\begin{array}{r}709 \\
0\end{array}$ & $\begin{array}{l}0 \\
0\end{array}$ & $\begin{array}{r}240 \\
0\end{array}$ & $\begin{array}{r}1,140 \\
0\end{array}$ & $\begin{array}{r}74 \\
0\end{array}$ & $\begin{array}{r}431 \\
0\end{array}$ & \\
\hline 43 & 326 & 28 & 473 & 709 & 160 & 709 & 0 & 240 & 1,140 & 74 & 431 & 34 \\
\hline $\begin{array}{r}33 \\
0 \\
16\end{array}$ & $\begin{array}{r}385 \\
0 \\
195\end{array}$ & $\begin{array}{r}14 \\
2 \\
9\end{array}$ & $\begin{array}{r}409 \\
445 \\
2,548\end{array}$ & $\begin{array}{l}2,988 \\
1,672 \\
8,941\end{array}$ & $\begin{array}{l}663 \\
184 \\
336\end{array}$ & & $\begin{array}{r}52 \\
0 \\
0\end{array}$ & $\begin{array}{r}689 \\
278 \\
1,087\end{array}$ & $\begin{array}{r}3,229 \\
2,647 \\
14,392\end{array}$ & $\begin{array}{r}26 \\
94 \\
751\end{array}$ & $\begin{array}{r}293 \\
975 \\
5,451\end{array}$ & \\
\hline 49 & 580 & 25 & 3,402 & 13,601 & 1,183 & 13,549 & 52 & 2,054 & 23,268 & $8 \bar{i} 1$ & 6,719 & 61 \\
\hline $\begin{array}{l}5 \\
0 \\
0\end{array}$ & $\begin{array}{r}40 \\
0 \\
0\end{array}$ & $\begin{array}{r}25 \\
3 \\
2\end{array}$ & $\begin{array}{r}672 \\
310 \\
60\end{array}$ & $\begin{array}{r}3,505 \\
2,020 \\
363\end{array}$ & $\begin{array}{r}740 \\
129 \\
16\end{array}$ & $\begin{array}{r}3,440 \\
2,020 \\
363\end{array}$ & $\begin{array}{r}65 \\
0 \\
0\end{array}$ & $\begin{array}{r}741 \\
.196 \\
29\end{array}$ & $\begin{array}{r}3,450 \\
2,702 \\
556\end{array}$ & $\begin{array}{r}1 \\
67 \\
13\end{array}$ & $\begin{array}{r}10 \\
682 \\
193\end{array}$ & $\cdots \cdots$ \\
\hline 5 & 40 & 30 & 1,042 & 5,888 & 885 & 5,823 & 65 & 966 & 6,708 & 81 & 885 & 57 \\
\hline $\begin{array}{r}15 \\
0 \\
8\end{array}$ & $\begin{array}{r}60 \\
0 \\
6,000\end{array}$ & $\begin{array}{r}11 \\
0 \\
0\end{array}$ & $\begin{array}{r}208 \\
0 \\
0\end{array}$ & $\begin{array}{r}733 \\
100 \\
0\end{array}$ & $\begin{array}{r}104 \\
2 \\
0\end{array}$ & $\begin{array}{r}733 \\
100 \\
0\end{array}$ & $\begin{array}{l}0 \\
0 \\
0\end{array}$ & $\begin{array}{r}104 \\
177\end{array}$ & $\begin{array}{r}733 \\
400 \\
8,944\end{array}$ & $\begin{array}{r}0 \\
5 \\
177\end{array}$ & $\begin{array}{r}0 \\
300 \\
8,944\end{array}$ & \\
\hline 23 & 6,060 & 11 & 208 & 833 & 106 & 833 & 0 & 288 & 10,077 & 182 & 9,244 & 27 \\
\hline $\begin{array}{l}8 \\
7 \\
4\end{array}$ & $\begin{array}{l}73 \\
98 \\
15\end{array}$ & $\begin{array}{c}32 \\
4 \\
21\end{array}$ & $\begin{array}{l}1,113 \\
605 \\
3,705\end{array}$ & $\begin{array}{r}1,378 \\
2,569 \\
10,186\end{array}$ & $\begin{array}{l}252 \\
195 \\
578\end{array}$ & $\begin{array}{r}1,378 \\
2,569 \\
10,186\end{array}$ & $\begin{array}{l}0 \\
0 \\
0\end{array}$ & $\begin{array}{l}284 \\
359 \\
860\end{array}$ & $\begin{array}{r}1,718 \\
3,801 \\
14,176\end{array}$ & $\begin{array}{r}32 \\
164 \\
282\end{array}$ & $\begin{array}{r}340 \\
1,232 \\
3,990\end{array}$ & $\cdots$ \\
\hline 19 & 186 & 57 & 5,429 & 14,133 & 1,025 & 14,133 & 0 & 1,503 & 19,695 & 478 & 5,562 & 33 \\
\hline
\end{tabular}


TABLE 47.-Mechanical power-supply equipment,

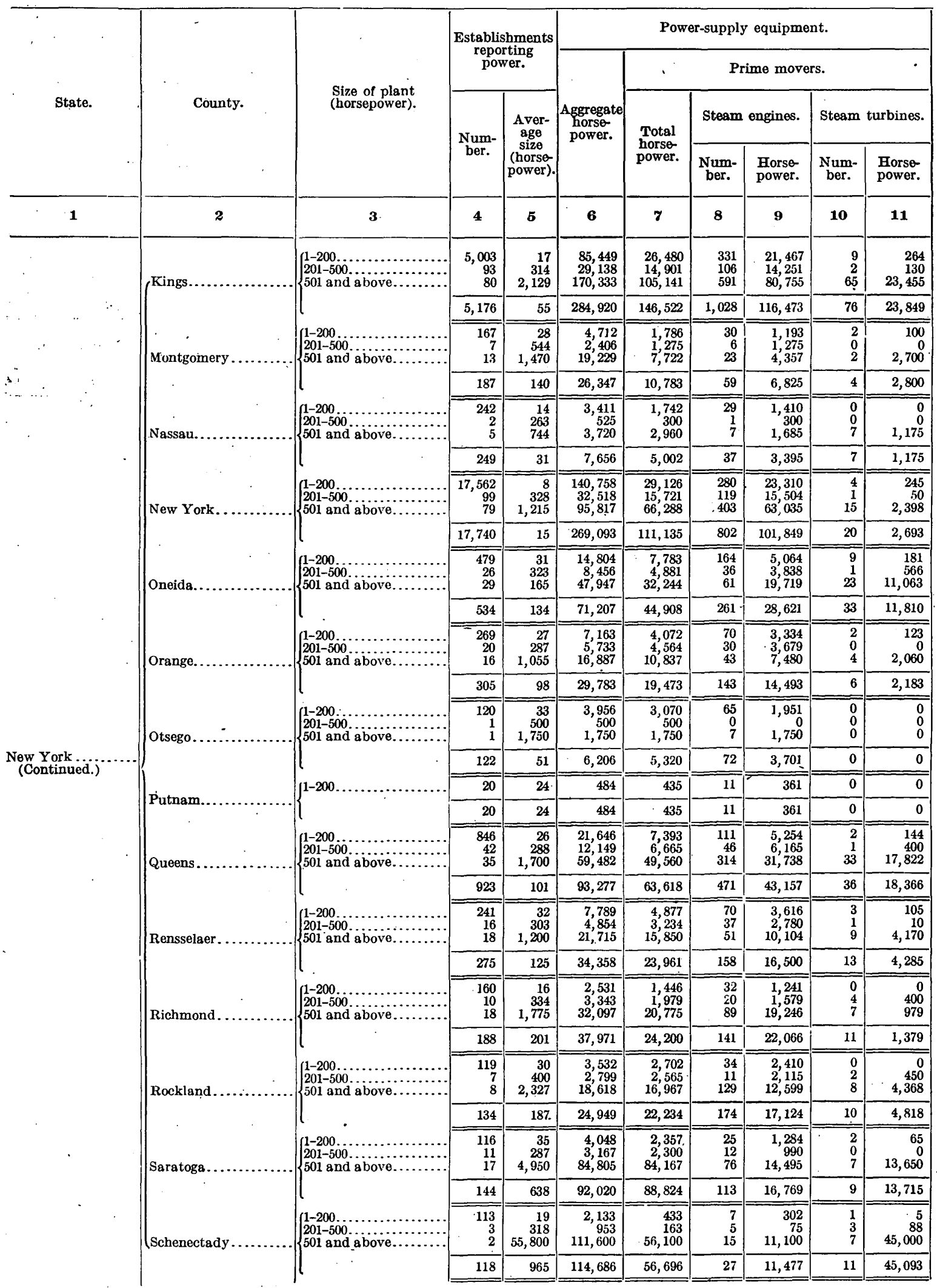


by countics and size of plant-Continued.

\begin{tabular}{|c|c|c|c|c|c|c|c|c|c|c|c|c|}
\hline \multicolumn{8}{|c|}{ Power-supply equipment-Continued. } & \multicolumn{4}{|c|}{ Electric motors. } & \multirow{4}{*}{$\begin{array}{l}\text { Number } \\
\text { of estab- } \\
\text { lishments } \\
\text { reporting } \\
\text { no power. }\end{array}$} \\
\hline \multicolumn{4}{|c|}{ Prime movers-Continued. } & \multicolumn{4}{|c|}{ Operated by purchased energy. } & \multirow{2}{*}{\multicolumn{2}{|c|}{ Total. }} & \multirow{2}{*}{\multicolumn{2}{|c|}{$\begin{array}{l}\text { Run by current } \\
\text { generated in } \\
\text { establishment. }\end{array}$}} & \\
\hline $\begin{array}{c}\text { Interna } \\
\text { tion } \\
\text { tion }\end{array}$ & $\begin{array}{l}\text {-combus- } \\
\text { ngines. }\end{array}$ & Water & wheels. & \multirow{2}{*}{$\begin{array}{l}\text { Total } \\
\text { horse- } \\
\text { power. }\end{array}$} & \multicolumn{2}{|c|}{ Electric motors. } & \multirow{2}{*}{$\begin{array}{l}\text { Other } \\
\text { (horse- } \\
\text { power). }\end{array}$} & & & & & \\
\hline $\begin{array}{c}\text { Num- } \\
\text { ber. }\end{array}$ & $\begin{array}{l}\text { Horse- } \\
\text { power. }\end{array}$ & $\begin{array}{c}\text { Num- } \\
\text { ber. }\end{array}$ & $\begin{array}{l}\text { Horse- } \\
\text { power. }\end{array}$ & & Number. & $\begin{array}{l}\text { Horse- } \\
\text { power. }\end{array}$ & & Number. & $\begin{array}{l}\text { Horse- } \\
\text { power. }\end{array}$ & Number. & $\begin{array}{l}\text { Horse- } \\
\text { power. }\end{array}$ & \\
\hline 12 & 13 & 14 & 15 & 16 & 17 & 18 & 19 & 20 & 21 & 22 & 23 & 24 \\
\hline $\begin{array}{r}329 \\
4 \\
11\end{array}$ & $\begin{array}{r}4,744 \\
520 \\
931\end{array}$ & $\begin{array}{l}1 \\
0 \\
0\end{array}$ & $\begin{array}{l}5 \\
0 \\
0\end{array}$ & $\begin{array}{l}58,969 \\
14,237 \\
65,192\end{array}$ & $\begin{array}{r}15,079 \\
1,684 \\
3,769\end{array}$ & $\begin{array}{l}57,392 \\
14,229 \\
64,942\end{array}$ & $\begin{array}{r}1,577 \\
8 \\
250\end{array}$ & $\begin{array}{r}15,567 \\
2,216 \\
8,257\end{array}$ & $\begin{array}{r}60,749 \\
19,896 \\
115,224\end{array}$ & $\begin{array}{r}488 \\
532 \\
4,488\end{array}$ & $\begin{array}{r}3,357 \\
5,667 \\
50 ; 282\end{array}$ & \\
\hline 344 & 6,105 & 1 & 5 & 138,398 & 20,532 & 136,563 & 1,835 & 26,040 & 195,869 & 5,508 & 59,306 & 1,589 \\
\hline $\begin{array}{l}0 \\
0 \\
0\end{array}$ & $\begin{array}{r}78 \\
0 \\
0\end{array}$ & $\begin{array}{l}8 \\
0 \\
5\end{array}$ & $\begin{array}{l}415 \\
0 \\
665\end{array}$ & $\begin{array}{r}2,926 \\
1,31 \\
11,507\end{array}$ & $\begin{array}{r}567 \\
30 \\
989\end{array}$ & $\begin{array}{r}2,926 \\
11,131 \\
11,507\end{array}$ & $\begin{array}{l}0 \\
0 \\
0\end{array}$ & $\begin{array}{r}569 \\
36 \\
1,383\end{array}$ & $\begin{array}{r}2,941 \\
1,199 \\
14,923\end{array}$ & $\begin{array}{r}2 \\
6 \\
394\end{array}$ & $\begin{array}{r}15 \\
68 \\
3,416\end{array}$ & $\begin{array}{l}\cdots \ldots . . \\
\cdots \cdots . . \\
\cdots \cdots\end{array}$ \\
\hline 6 & 78 & 13 & 1,080 & 15,564 & 1,586 & 15,564 & 0 & 1,988 & 19,063 & 402 & 3,499 & 34 \\
\hline $\begin{array}{r}42 \\
0 \\
1\end{array}$ & $\begin{array}{r}332 \\
0 \\
100\end{array}$ & $\begin{array}{l}0 \\
0 \\
0\end{array}$ & $\begin{array}{l}0 \\
0 \\
0\end{array}$ & $\begin{array}{r}1,669 \\
225 \\
760\end{array}$ & $\begin{array}{r}455 \\
21 \\
155\end{array}$ & $\begin{array}{r}1,669 \\
225 \\
760\end{array}$ & $\begin{array}{l}0 \\
0 \\
0\end{array}$ & $\begin{array}{l}455 \\
21 \\
480\end{array}$ & $\begin{array}{l}1,669 \\
225 \\
1,560\end{array}$ & $\begin{array}{r}0 \\
0 \\
325\end{array}$ & $\begin{array}{r}0 \\
0 \\
800\end{array}$ & \\
\hline 43 & 432 & 0 & 0 & 2,654 & 631 & 2,654 & 0 & 956 & 3,454 & 325 & 800 & 71 \\
\hline $\begin{array}{r}408 \\
8 \\
5\end{array}$ & $\begin{array}{r}5,561 \\
\quad 167 \\
855\end{array}$ & $\begin{array}{r}10 \\
0 \\
0\end{array}$ & $\begin{array}{r}10 \\
0 \\
0\end{array}$ & $\begin{array}{r}111,632 \\
16,797 \\
29,529\end{array}$ & $\begin{array}{r}66,404 \\
2,822 \\
2,974\end{array}$ & $\begin{array}{l}108,026 \\
16,432 \\
27,579\end{array}$ & $\begin{array}{l}, 606 \\
365 \\
1,950\end{array}$ & $\begin{array}{r}67,005 \\
3,236 \\
6,913\end{array}$ & $\begin{array}{r}113,855 \\
19,676 \\
53,499\end{array}$ & $\begin{array}{r}601 \\
414 \\
3,939\end{array}$ & $\begin{array}{r}5,829 \\
3,244 \\
25,920\end{array}$ & \\
\hline 421 & 6,583 & 10 & 10 & 157,958 & 72,200 & 152,037 & 5,921 & 77,154 & 187,030 & 4,954 & 34,993 & 5,279 \\
\hline $\begin{array}{r}50 \\
0 \\
3\end{array}$ & $\begin{array}{r}674 \\
0 \\
72\end{array}$ & $\begin{array}{r}56 \\
5 \\
14\end{array}$ & $\begin{array}{l}1,864 \\
477 \\
1,390\end{array}$ & $\begin{array}{r}7,021 \\
3,575 \\
15,703\end{array}$ & $\begin{array}{r}1,132 \\
409 \\
816\end{array}$ & $\begin{array}{r}7,021 \\
3,575 \\
15,703\end{array}$ & $\begin{array}{l}0 \\
0 \\
0\end{array}$ & $\begin{array}{l}1,234 \\
568 \\
1,672\end{array}$ & $\begin{array}{r}7,753 \\
5,060 \\
27,699\end{array}$ & $\begin{array}{l}102 \\
159 \\
850\end{array}$ & $\begin{array}{r}732 \\
1,485 \\
11,996\end{array}$ & $\begin{array}{l}\ldots . . . \\
\cdots \ldots . . \\
\ldots \ldots .\end{array}$ \\
\hline 53 & 746 & 75 & 3,731 & 26,299 & 2,357 & 26,299 & $\mathbf{0}$ & 3,474 & 40,512 & 1,117 & 14,213 & 170 \\
\hline $\begin{array}{r}23 \\
5 \\
0\end{array}$ & $\begin{array}{r}226 \\
265 \\
0\end{array}$ & $\begin{array}{r}9 \\
7 \\
10\end{array}$ & $\begin{array}{r}389 \\
620 \\
1,297\end{array}$ & $\begin{array}{l}3,091 \\
1,169 \\
6,050\end{array}$ & $\begin{array}{l}603 \\
436 \\
245\end{array}$ & $\begin{array}{l}3,091 \\
1,169 \\
6,050\end{array}$ & $\begin{array}{l}0 \\
0 \\
0\end{array}$ & $\begin{array}{l}708 \\
497 \\
691\end{array}$ & $\begin{array}{r}4,222 \\
1,996 \\
10,287\end{array}$ & $\begin{array}{l}105 \\
61 \\
446\end{array}$ & $\begin{array}{l}1,131 \\
4,237\end{array}$ & 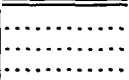 \\
\hline 28 & 491 & 26 & 2,306 & 10,310 & 1,284 & 10,310 & 0 & 1,896 & 16,505 & 612 & 6,195 & 62 \\
\hline $\begin{array}{r}22 \\
0 \\
0\end{array}$ & $\begin{array}{r}381 \\
0 \\
0\end{array}$ & $\begin{array}{r}23 \\
4 \\
0\end{array}$ & $\begin{array}{r}738 \\
500 \\
0\end{array}$ & $\begin{array}{r}886 \\
0 \\
0\end{array}$ & $\begin{array}{r}154 \\
0 \\
0\end{array}$ & $\begin{array}{r}88,6 \\
\\
0 \\
0\end{array}$ & $\begin{array}{l}0 \\
0 \\
0\end{array}$ & $\begin{array}{r}669 \\
39 \\
37\end{array}$ & $\begin{array}{r}1,277 \\
500 \\
595\end{array}$ & $\begin{array}{r}115 \\
39 \\
37\end{array}$ & $\begin{array}{l}391 \\
500 \\
595\end{array}$ & \\
\hline 22 & 381 & 27 & 1,238 & 886 & 154 & 886 & 0 & 345 & 2,372 & 191 & 1,480 & 25 \\
\hline 11 & 74 & $\overline{0}$ & $\overline{0}$ & 49 & 15 & $\overline{49}$ & 0 & 19 & 88 & 4 & 39 & \\
\hline 11 & 74 & 0 & 0 & 49 & 15 & 49 & 0 & 19 & 88 & 4 & 39 & 4 \\
\hline $\begin{array}{r}r 14 \\
0 \\
0\end{array}$ & $\begin{array}{r}1,995 \\
0 \\
0\end{array}$ & $\begin{array}{l}0 \\
1 \\
0\end{array}$ & $\begin{array}{r}0 \\
100 \\
0\end{array}$ & $\begin{array}{r}14,253 \\
5,484 \\
9,922\end{array}$ & $\begin{array}{r}, 962 \\
493 \\
726\end{array}$ & $\begin{array}{r}14,040 \\
5 ; 484 \\
9,922\end{array}$ & $\begin{array}{r}213 \\
0 \\
0 .\end{array}$ & $\begin{array}{l}3,063 \\
877 \\
2,781\end{array}$ & $\begin{array}{r}14,972 \\
8,262 \\
27,128\end{array}$ & $\begin{array}{r}101 \\
384 \\
2,055\end{array}$ & $\begin{array}{r}932 \\
2,778 \\
17,206\end{array}$ & \\
\hline 114 & 1,995 & 1 & 100 & 27,659 & 4,181 & 29,446 & 213 & 6,721 & 50,362 & 2,540 & 20,916 & 326 \\
\hline $\begin{array}{r}30 \\
0 \\
3\end{array}$ & $\begin{array}{r}376 \\
0 \\
10\end{array}$ & $\begin{array}{r}20 \\
8 \\
9\end{array}$ & $\begin{array}{r}780 \\
444 \\
1,566\end{array}$ & $\begin{array}{l}2,912 \\
1,620 \\
5,865\end{array}$ & $\begin{array}{l}471 \\
121 \\
289\end{array}$ & $\begin{array}{l}2,799 \\
1,620 \\
5,865\end{array}$ & $\begin{array}{r}113 \\
0 \\
0\end{array}$ & $\begin{array}{r}706 \\
304 \\
1,034\end{array}$ & $\begin{array}{r}3,539 \\
3,099 \\
11,152\end{array}$ & $\begin{array}{l}235 \\
183 \\
745\end{array}$ & $\begin{array}{r}740 \\
1,479 \\
5,287\end{array}$ & \\
\hline 33 & 386 & 37 & 2,790 & 10,397 & 881 & 10,284 & 113 & 2,044 & 17,790 & 1,163 & 7,506 & 82 \\
\hline $\begin{array}{r}19 \\
0 \\
3\end{array}$ & $\begin{array}{r}202 \\
550 \\
\end{array}$ & $\begin{array}{l}1 \\
0 \\
0\end{array}$ & $\begin{array}{l}3 \\
0 \\
0\end{array}$ & $\begin{array}{r}1,085 \\
1,364 \\
11,322\end{array}$ & $\begin{array}{c}273 \\
52 \\
390\end{array}$ & $\begin{array}{r}985 \\
1,364 \\
11,322\end{array}$ & $\begin{array}{r}100 \\
0 \\
0\end{array}$ & $\begin{array}{r}306 \\
115 \\
1,021\end{array}$ & $\begin{array}{r}1,229 \\
2,032 \\
18,989\end{array}$ & $\begin{array}{r}33 \\
63 \\
631\end{array}$ & $\begin{array}{r}244 \\
668 \\
7,667\end{array}$ & ……...... \\
\hline 22 & 752 & 1 & 3 & $13 ; 771$ & 715 & 13,671 & 100 & 1,442 & 22,250 & 727 & 8,579 & 68 \\
\hline $\begin{array}{l}5 \\
0 \\
0\end{array}$ & \begin{tabular}{r|}
60 \\
0 \\
0
\end{tabular} & $\begin{array}{l}0 \\
0 \\
0\end{array}$ & $\begin{array}{r}232 \\
0 \\
0\end{array}$ & $\begin{array}{r}830 \\
234 \\
1,651\end{array}$ & $\begin{array}{r}220 \\
9 \\
97\end{array}$ & $\begin{array}{r}730 \\
234 \\
1,651\end{array}$ & $\begin{array}{r}100 \\
0 \\
0\end{array}$ & $\begin{array}{r}242 \\
42 \\
257\end{array}$ & $\begin{array}{r}970 \\
444 \\
7,531\end{array}$ & $\begin{array}{r}22 \\
33 \\
160\end{array}$ & $\begin{array}{r}240 \\
210 \\
5,880\end{array}$ & \\
\hline 5 & 60 & 6 & 232 & 2,715 & 326 & 2,615 & 100 & 541 & 8,945 & 215 & $6,330^{\circ}$ & 21 \\
\hline $\begin{array}{r}13 \\
0 \\
0\end{array}$ & $\begin{array}{r}168 \\
0 \\
0\end{array}$ & $\begin{array}{l}26 \\
15 \\
70\end{array}$ & $\begin{array}{r}840 \\
1,310 \\
56,022\end{array}$ & $\begin{array}{r}1,691 \\
867 \\
638\end{array}$ & $\begin{array}{r}231 \\
56 \\
26\end{array}$ & $\begin{array}{r}1,691 \\
867 \\
638\end{array}$ & $\begin{array}{l}0 \\
0 \\
0\end{array}$ & $\begin{array}{r}231 \\
90 \\
1,519\end{array}$ & $\begin{array}{r}1,691 \\
1,167 \\
14,926\end{array}$ & $\begin{array}{r}0 \\
34 \\
1,493\end{array}$ & $\begin{array}{r}0 \\
300 \\
14,288\end{array}$ & \\
\hline 13 & 168 & 111 & 58,172 & 3,196 & 313 & 3,196 & 0 & 1,840 & 17,784 & 1,527 & 14,588 & 29 \\
\hline $\begin{array}{l}5 \\
0 \\
0\end{array}$ & $\begin{array}{r}86 \\
0 \\
0\end{array}$ & $\begin{array}{l}1 \\
0 \\
0\end{array}$ & $\begin{array}{r}0 \\
0 \\
0\end{array}$ & $\begin{array}{r}1,700 \\
790 \\
55,500\end{array}$ & $\begin{array}{r}341 \\
250 \\
7,680\end{array}$ & $\begin{array}{r}1,700 \\
790 \\
55,500\end{array}$ & $\begin{array}{l}0 \\
0 \\
0\end{array}$ & $\begin{array}{r}341 \\
250 \\
15,530\end{array}$ & $\begin{array}{r}1,700 \\
790 \\
114,500\end{array}$ & $\begin{array}{r}0 \\
0 \\
7,850\end{array}$ & $\begin{array}{r}0 \\
0 \\
59,000\end{array}$ & \\
\hline 5 & 86 & 1 & 40 & 57,990 & 8,271 & 57,990 & 0 & 16,121 & 116,990 & 7,850 & 59,000 & 41 \\
\hline
\end{tabular}


TABLE 47.-Mechanical power-supply equipment,

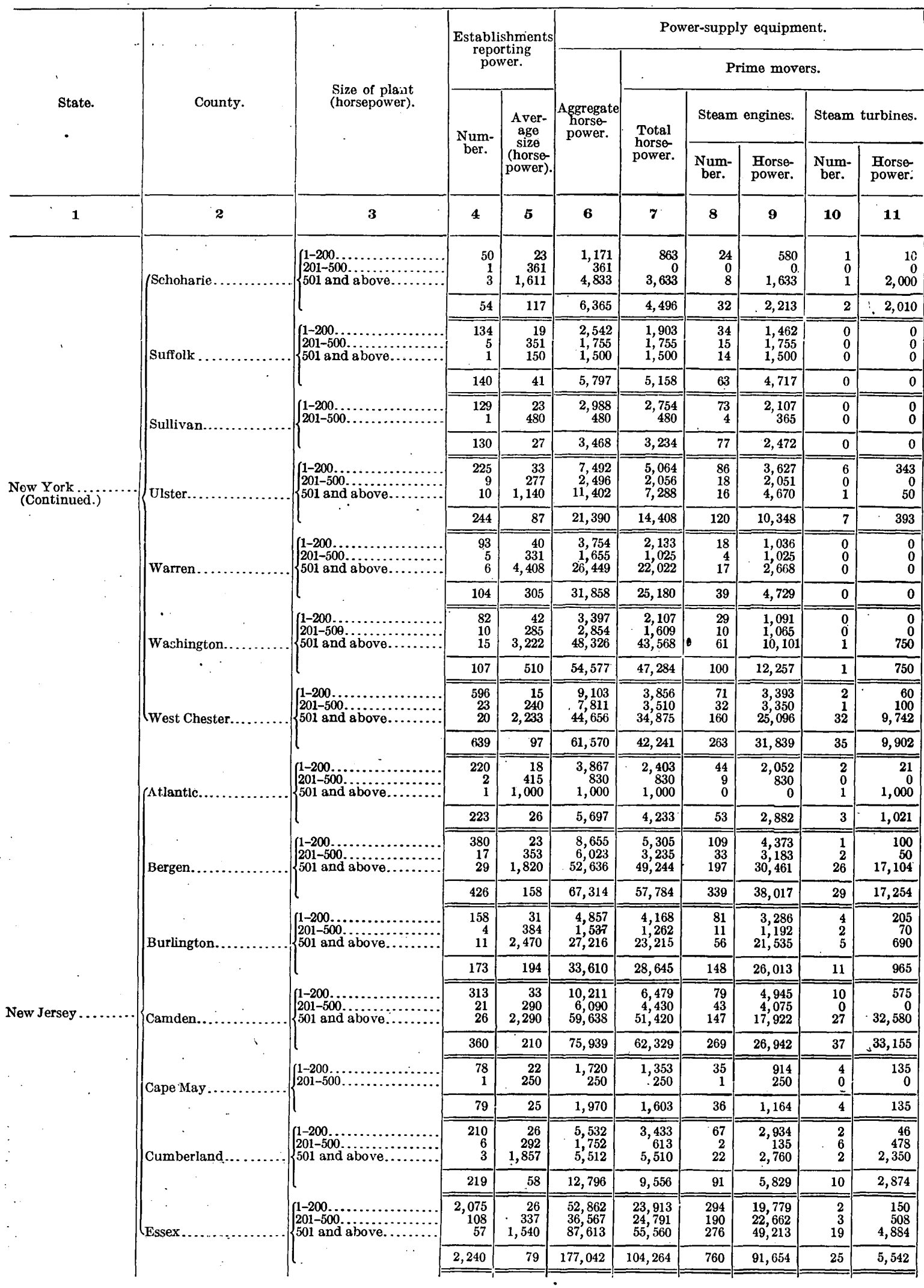


by counties and size of plant-Continued.

\begin{tabular}{|c|c|c|c|c|c|c|c|c|c|c|c|c|}
\hline \multicolumn{8}{|c|}{ Power-supply oquipment-Continued. } & \multicolumn{4}{|c|}{ Electric motors. } & \multirow{4}{*}{$\begin{array}{l}\text { Number } \\
\text { of estab- } \\
\text { lishments } \\
\text { reporting } \\
\text { no power. }\end{array}$} \\
\hline \multicolumn{4}{|c|}{ Prime movers-Continued. } & \multicolumn{4}{|c|}{ Operated by purchased energy. } & \multirow{2}{*}{\multicolumn{2}{|c|}{ Total. }} & \multirow{2}{*}{\multicolumn{2}{|c|}{$\begin{array}{l}\text { Run by current } \\
\text { generated in } \\
\text { establishment. }\end{array}$}} & \\
\hline $\begin{array}{l}\text { Interna } \\
\text { tion }\end{array}$ & $\begin{array}{l}\text { combus- } \\
\text { igines. }\end{array}$ & Water & wheels. & \multirow{2}{*}{$\begin{array}{l}\text { Total } \\
\text { horse- } \\
\text { power. }\end{array}$} & \multicolumn{2}{|c|}{ Electric motors. } & \multirow{2}{*}{$\begin{array}{c}\text { Other } \\
\text { (horse } \\
\text { power). }\end{array}$} & & & & & \\
\hline Num- & $\begin{array}{l}\text { Horse- } \\
\text { power. }\end{array}$ & $\underset{\text { ber. }}{\text { Num- }}$ & $\begin{array}{l}\text { Horse- } \\
\text { power. }\end{array}$ & & Number. & $\begin{array}{l}\text { Horse- } \\
\text { power. }\end{array}$ & & Number. & $\begin{array}{l}\text { Horse- } \\
\text { power. }\end{array}$ & Number. & $\begin{array}{l}\text { Horse- } \\
\text { power. }\end{array}$ & \\
\hline 12 & 13 & 14 & 15 & 16 & 17 & 18 & 19 & 20 & 21 & 22 & 23 & 24 \\
\hline $\begin{array}{l}7 \\
0 \\
0\end{array}$ & $\begin{array}{r}92 \\
0 \\
0\end{array}$ & $\begin{array}{r}12 \\
0 \\
0\end{array}$ & $\begin{array}{r}181 \\
0 \\
0\end{array}$ & $\begin{array}{r}308 \\
361 \\
1,200\end{array}$ & $\begin{array}{l}47 \\
60 \\
12\end{array}$ & $\begin{array}{r}308 \\
361 \\
1,200\end{array}$ & $\begin{array}{l}\mathbf{0} \\
\mathbf{0} \\
\mathbf{0}\end{array}$ & $\begin{array}{l}48 \\
60 \\
67\end{array}$ & $\begin{array}{r}312 \\
361 \\
4,137\end{array}$ & $\begin{array}{r}1 \\
\mathbf{0} \\
\mathbf{5 5}\end{array}$ & $\begin{array}{r}4 \\
0 \\
2,937\end{array}$ & 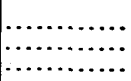 \\
\hline 7 & 92 & 12 & 181 & 1,869 & 119 & 1,869 & 0 & 175 & 4,810 & 56 & 2,941 & 16 \\
\hline $\begin{array}{r}44 \\
0 \\
0\end{array}$ & $\begin{array}{r}391 \\
0 \\
0\end{array}$ & $\begin{array}{l}2 \\
0 \\
0\end{array}$ & $\begin{array}{r}50 \\
0 \\
0\end{array}$ & $\begin{array}{r}639 \\
0 \\
0\end{array}$ & $\begin{array}{r}174 \\
0 \\
0\end{array}$ & $\begin{array}{r}639 \\
0 \\
0\end{array}$ & $\begin{array}{ll} & \mathbf{0} \\
& \mathbf{0} \\
& \mathbf{0}\end{array}$ & $\begin{array}{r}188 \\
64 \\
0\end{array}$ & $\begin{array}{r}775 \\
620 \\
0\end{array}$ & $\begin{array}{r}14 \\
64 \\
0\end{array}$ & $\begin{array}{r}136 \\
620 \\
+\quad 0\end{array}$ & 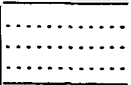 \\
\hline 44 & 391 & 2 & 50 & 639 & 174 & 639 & $\mathbf{0}$ & 252 & 1,395 & 78 & 756 & 79 \\
\hline $\begin{array}{r}28 \\
0\end{array}$ & $\begin{array}{r}325 \\
0\end{array}$ & $\begin{array}{r}16 \\
2\end{array}$ & $\begin{array}{l}322 \\
115\end{array}$ & $\begin{array}{r}234 \\
0\end{array}$ & $\begin{array}{r}46 \\
0\end{array}$ & $\begin{array}{r}234 \\
0\end{array}$ & $\begin{array}{l}\mathbf{0} \\
\mathbf{0}\end{array}$ & $\begin{array}{r}47 \\
0\end{array}$ & $\begin{array}{r}239 \\
0\end{array}$ & $\begin{array}{l}1 \\
0\end{array}$ & $\begin{array}{l}5 \\
0\end{array}$ & (n...... \\
\hline 28 & 325 & 18 & 437 & 234 & 46 & 234 & $\overline{0}$ & 47 & 239 & 1 & 5 & $\overline{22}$ \\
\hline $\begin{array}{r}14 \\
1 \\
6 \\
\end{array}$ & $\begin{array}{r}86 \\
5 \\
130 \\
\end{array}$ & $\begin{array}{r}25 \\
0 \\
15\end{array}$ & $\begin{array}{r}1,008 \\
0 \\
2,438\end{array}$ & $\begin{array}{r}2,428 \\
440 \\
4,114\end{array}$ & $\begin{array}{r}353 \\
19 \\
61\end{array}$ & $\begin{array}{r}2,413 \\
440 \\
4,114\end{array}$ & $\begin{array}{r}15 \\
0 \\
0\end{array}$ & $\begin{array}{r}401 \\
81 \\
289 \\
\end{array}$ & $\begin{array}{r}2,806 \\
797 \\
7,755\end{array}$ & $\begin{array}{r}48 \\
62 \\
228\end{array}$ & $\begin{array}{r}393 \\
357 \\
3,641 \\
\end{array}$ & $\begin{array}{l}\cdots \cdots \cdots \\
\cdots \cdots \cdots \cdots \\
\cdots \cdots \cdots\end{array}$ \\
\hline 21 & 221 & 40 & 3,446 & 6,982 & 433 & 6,967 & 15 & 771 & 11,358 & 338 & 4,391 & 54 \\
\hline $\begin{array}{r}11 \\
0 \\
1\end{array}$ & $\begin{array}{r}156 \\
0 \\
4\end{array}$ & $\begin{array}{r}24 \\
0 \\
18\end{array}$ & $\begin{array}{r}941 \\
0 \\
19,350\end{array}$ & $\begin{array}{r}1,621 \\
630 \\
4,427\end{array}$ & $\begin{array}{r}224 \\
6 \\
86\end{array}$ & $\begin{array}{r}1,621 \\
630 \\
4,427\end{array}$ & $\begin{array}{l}0 \\
0 \\
0\end{array}$ & $\begin{array}{r}224 \\
27 \\
176\end{array}$ & $\begin{array}{l}1,621 \\
1,062 \\
5,995\end{array}$ & $\begin{array}{r}0 \\
21 \\
90\end{array}$ & $\begin{array}{r}0 \\
432 \\
1,568 \\
\end{array}$ & 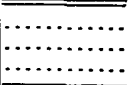 \\
\hline 12 & 160 & 42 & 20,291 & 6,678 & 316 & 6,678 & 0 & 427 & 8,678 & 111 & 2,000 & 21 \\
\hline $\begin{array}{l}6 \\
1 \\
1\end{array}$ & $\begin{array}{r}59 \\
225 \\
20\end{array}$ & $\begin{array}{r}21 \\
4 \\
77\end{array}$ & $\begin{array}{r}957 \\
319 \\
32,697\end{array}$ & $\begin{array}{l}1,290 \\
1,245 \\
4,758\end{array}$ & $\begin{array}{r}280 \\
26 \\
225\end{array}$ & $\begin{array}{l}1,290 \\
1,245 \\
4,758\end{array}$ & $\begin{array}{l}0 \\
0 \\
0\end{array}$ & $\begin{array}{r}309 \\
66 \\
593\end{array}$ & $\begin{array}{r}1,470 \\
1,574 \\
11,430\end{array}$ & $\begin{array}{r}29 \\
40 \\
368\end{array}$ & $\begin{array}{r}180 \\
329 \\
6,672 \\
\end{array}$ & 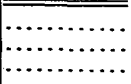 \\
\hline 8 & 304 & 102 & 33,973 & 7,293 & 531 & 7,293 & 0 & 968 & 14,474 & 437 & 7,181 & 12 \\
\hline $\begin{array}{r}32 \\
1 \\
7\end{array}$ & $\begin{array}{r}349 \\
60 \\
37\end{array}$ & $\begin{array}{l}3 \\
0 \\
0\end{array}$ & $\begin{array}{r}54 \\
0 \\
0\end{array}$ & $\begin{array}{l}5,247 \\
4,301 \\
9,781\end{array}$ & $\begin{array}{r}1,596 \\
358 \\
805\end{array}$ & $\begin{array}{l}5,193 \\
4,301 \\
9,781\end{array}$ & $\begin{array}{r}54 \\
0 \\
0\end{array}$ & $\begin{array}{l}1,652 \\
1,227 \\
2,263\end{array}$ & $\begin{array}{r}5,632 \\
5,915 \\
24,753\end{array}$ & $\begin{array}{r}56 \\
869 \\
1,458\end{array}$ & $\begin{array}{r}439 \\
1,614 \\
14,972\end{array}$ & $\left(\begin{array}{c}\cdots \\
\cdots \cdots \cdots\end{array}\right.$ \\
\hline 40 & 446 & 3 & 54 & 19,329 & 2,759 & 19,275 & 54 & 5,142 & 36,300 & 2,383 & 17,025 & 207 \\
\hline $\begin{array}{r}28 \\
0 \\
0\end{array}$ & $\begin{array}{r}330 \\
0 \\
0\end{array}$ & $\begin{array}{l}0 \\
0 \\
0\end{array}$ & $\begin{array}{l}0 \\
. \quad 0 \\
0\end{array}$ & $\begin{array}{r}1,464 \\
0 \\
0\end{array}$ & $\begin{array}{r}466 \\
0 \\
0\end{array}$ & $\begin{array}{r}1,459 \\
0 \\
0\end{array}$ & $\begin{array}{l}5 \\
0 \\
0\end{array}$ & $\begin{array}{r}544 \\
7 \\
221\end{array}$ & $\begin{array}{r}1,791 \\
54 \\
1,157\end{array}$ & $\begin{array}{r}78 \\
7 \\
221\end{array}$ & $\begin{array}{r}332 \\
54 \\
1,157\end{array}$ & 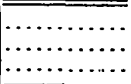 \\
\hline 28 & 330 & 0 & $\overrightarrow{0}$ & 1,464 & 466 & 1,459 & 5 & 772 & 3,002 & 306 & 1,543 & 44 \\
\hline $\begin{array}{r}63 \\
1 \\
7\end{array}$ & $\begin{array}{r}709 \\
2 \\
1,679 \\
\end{array}$ & $\begin{array}{l}4 \\
0 \\
0\end{array}$ & $\begin{array}{r}123 \\
0 \\
0\end{array}$ & $\begin{array}{l}3,350 \\
2,788 \\
3,392\end{array}$ & $\begin{array}{l}989 \\
200 \\
188\end{array}$ & $\begin{array}{l}3,350 \\
2,788 \\
3,392\end{array}$ & $\begin{array}{l}0 \\
0 \\
0\end{array}$ & $\begin{array}{r}1,254 \\
313 \\
3,477\end{array}$ & $\begin{array}{r}4,260 \\
4,316 \\
38,983\end{array}$ & $\begin{array}{r}265 \\
113 \\
3,289\end{array}$ & $\begin{array}{r}910 \\
1,528 \\
35,591 \\
\end{array}$ & 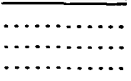 \\
\hline 71 & 2,390 & 4 & 123 & 9,530 & 1,377 & 9,530 & 0 & 5,044 & 47,559 & 3,667 & 38,029 & 84 \\
\hline $\begin{array}{r}51 \\
0 \\
2\end{array}$ & $\begin{array}{r}487 \\
0 \\
740\end{array}$ & $\begin{array}{l}7 \\
0 \\
1\end{array}$ & $\begin{array}{r}190 \\
0 \\
250\end{array}$ & $\begin{array}{r}689 \\
275 \\
4,001\end{array}$ & $\begin{array}{r}174 \\
8 \\
178\end{array}$ & $\begin{array}{r}689 \\
275 \\
4,001\end{array}$ & $\begin{array}{l}0 \\
0 \\
0\end{array}$ & $\begin{array}{r}244 \\
14 \\
929\end{array}$ & $\begin{array}{r}981 \\
443 \\
14,693\end{array}$ & $\begin{array}{r}70 \\
6 \\
751\end{array}$ & $\begin{array}{r}292 \\
168 \\
10,692\end{array}$ & 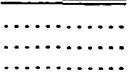 \\
\hline 53 & 1,227 & 8 & 440 & 4,965 & 360 & 4,965 & 0 & 1,187 & 16,117 & 827 & 11,152 & 31 \\
\hline $\begin{array}{r}66 \\
4 \\
8 \\
\end{array}$ & $\begin{array}{l}894 \\
255 \\
889\end{array}$ & $\begin{array}{r}10 \\
1 \\
1\end{array}$ & $\begin{array}{r}65 \\
100 \\
29\end{array}$ & $\begin{array}{l}3,732 \\
1,660 \\
8,218\end{array}$ & $\begin{array}{l}845 \\
139 \\
711\end{array}$ & $\begin{array}{l}3,683 \\
1,660 \\
7,869\end{array}$ & $\begin{array}{r}49 \\
0 \\
349\end{array}$ & $\begin{array}{r}964 \\
299 \\
3,509 \\
\end{array}$ & $\begin{array}{r}4,198 \\
3,425 \\
56,183\end{array}$ & $\begin{array}{r}119 \\
160 \\
2,798\end{array}$ & $\begin{array}{r}515 \\
1,765 \\
48,314 \\
\end{array}$ & 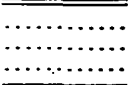 \\
\hline 78 & 2,038 & 12 & 194 & 13,610 & 1,695 & 13,212 & 398 & 4,772 & 63,806 & 3,077 & 50,594 & 80 \\
\hline $\begin{array}{r}26 \\
0\end{array}$ & $\begin{array}{r}304 \\
0\end{array}$ & $\begin{array}{l}0 \\
0\end{array}$ & $\begin{array}{l}0 \\
0\end{array}$ & $\begin{array}{r}367 \\
0\end{array}$ & $\begin{array}{r}86 \\
0\end{array}$ & $\begin{array}{r}367 \\
0\end{array}$ & $\begin{array}{l}0 \\
0\end{array}$ & $\begin{array}{r}94 \\
2\end{array}$ & $\begin{array}{r}436 \\
15\end{array}$ & $\begin{array}{l}8 \\
2\end{array}$ & $\begin{array}{l}69 \\
15\end{array}$ & $\begin{array}{l} \\
\cdots \\
\cdots \\
\cdots\end{array}$ \\
\hline 28 & 304 & 0 & 0 & 367 & 86 & 367 & 0 & 96 & 451 & 10 & 84 & 13 \\
\hline $\begin{array}{r}39 \\
0 \\
0\end{array}$ & $\begin{array}{r}305 \\
0 \\
0\end{array}$ & $\begin{array}{l}8 \\
0 \\
2\end{array}$ & $\begin{array}{r}148 \\
0 \\
400\end{array}$ & $\begin{array}{r}2,099 \\
1,139 \\
2\end{array}$ & $\begin{array}{r}486 \\
84 \\
0\end{array}$ & $\begin{array}{r}2,029 \\
1,139 \\
0\end{array}$ & $\begin{array}{r}70 \\
0 \\
2\end{array}$ & $\begin{array}{l}549 \\
253 \\
210\end{array}$ & $\begin{array}{l}2,337 \\
2,190 \\
3,959\end{array}$ & $\begin{array}{r}63 \\
169 \\
310\end{array}$ & $\begin{array}{r}308 \\
1,051 \\
3,959\end{array}$ & \\
\hline 39 & 305 & 10 & 548 & 3,240 & 570 & 3,168 & 72 & 1,112 & 8,486 & 542 & 5,318 & 38 \\
\hline $\begin{array}{r}210 \\
47 \\
14 \\
\end{array}$ & $\begin{array}{l}3,801 \\
1,505 \\
1,413\end{array}$ & $\begin{array}{l}3 \\
2 \\
1\end{array}$ & $\begin{array}{r}183 \\
116 \\
50\end{array}$ & $\begin{array}{l}28,949 \\
11,776 \\
32,053\end{array}$ & $\begin{array}{l}5,550 \\
1,665 \\
3,678\end{array}$ & $\begin{array}{l}27,407 \\
11,776 \\
32,053\end{array}$ & $\begin{array}{r}1,542 \\
0 \\
0\end{array}$ & $\begin{array}{l}6,235 \\
2,666 \\
7,362\end{array}$ & $\begin{array}{l}31,317 \\
20,102 \\
65,013\end{array}$ & $\begin{array}{r}685 \\
1,001 \\
3,684\end{array}$ & $\begin{array}{r}3,910 \\
8,326 \\
32,960 \\
\end{array}$ & 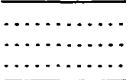 \\
\hline 271 & 6,719 & 6 & 349 & 72,778 & 10,893 & 71,236 & 1,542 & 16,263 & 116,432 & 5,370 & 45,196 & 447 \\
\hline
\end{tabular}


TABLE 47.-Mechanical power-supply equipment,

\begin{tabular}{|c|c|c|c|c|c|c|c|c|c|c|}
\hline \multirow{4}{*}{ State. } & \multirow{4}{*}{ County. } & \multirow{4}{*}{$\begin{array}{c}\text { Size of plant } \\
\text { (horsepower). }\end{array}$} & \multirow{2}{*}{\multicolumn{2}{|c|}{$\begin{array}{c}\text { Establishments } \\
\text { reporting } \\
\text { power. }\end{array}$}} & \multicolumn{6}{|c|}{ Power-supply equipment. } \\
\hline & & & & & \multirow{3}{*}{$\begin{array}{c}\text { Aggregate } \\
\text { horse- } \\
\text { power. }\end{array}$} & \multicolumn{5}{|c|}{ Prime movers. } \\
\hline & & & \multirow{2}{*}{$\underset{\text { ber. }}{\text { Num. }}$} & \multirow{2}{*}{$\begin{array}{l}\text { Aver- } \\
\text { age } \\
\text { size } \\
\text { (horse- } \\
\text { power). }\end{array}$} & & \multirow{2}{*}{$\begin{array}{l}\text { Total } \\
\text { horse- } \\
\text { power. }\end{array}$} & \multicolumn{2}{|c|}{ Steam engines. } & \multicolumn{2}{|c|}{ Steam turbines. } \\
\hline & & & & & & & $\begin{array}{c}\text { Num- } \\
\text { ber. }\end{array}$ & $\begin{array}{l}\text { Horse- } \\
\text { power. }\end{array}$ & $\begin{array}{l}\text { Num- } \\
\text { ber. }\end{array}$ & $\begin{array}{l}\text { Horse- } \\
\text { power. }\end{array}$ \\
\hline 1 & $\boldsymbol{z}$ & $\mathbf{3}$ & 4 & 5 & 6 & 7 & 8 & 9 & 10 & 11 \\
\hline & \multirow[t]{3}{*}{ (Gloucester... } & \multirow{3}{*}{ 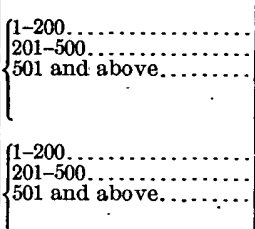 } & $\begin{array}{r}98 \\
5 \\
4\end{array}$ & $\begin{array}{r}22 \\
360 \\
1,449\end{array}$ & $\begin{array}{l}2,166 \\
1,800 \\
5,795\end{array}$ & $\begin{array}{l}1,582 \\
1,569 \\
5,195\end{array}$ & $\begin{array}{r}29 \\
14 \\
9\end{array}$ & $\begin{array}{l}1,048 \\
945 \\
1,660\end{array}$ & $\begin{array}{r}1 \\
6 \\
14\end{array}$ & $\begin{array}{r}4 \\
624 \\
2,297\end{array}$ \\
\hline & & & 107 & 91 & 9,761 & 8,346 & 52 & 3,653 & 21 & 2,925 \\
\hline & & & $\begin{array}{r}, 731 \\
81 \\
79\end{array}$ & $\begin{array}{r}19 \\
334 \\
2,200\end{array}$ & $\begin{array}{r}33,285 \\
27,35 \\
173,345\end{array}$ & $\begin{array}{r}15,774 \\
16,446 \\
119,763\end{array}$ & $\begin{array}{l}254 \\
134 \\
576\end{array}$ & $\begin{array}{l}12,713 \\
14,762 \\
78,894\end{array}$ & $\begin{array}{r}5 \\
62 \\
7\end{array}$ & $\begin{array}{r}355 \\
1,100 \\
34,118\end{array}$ \\
\hline & Hudson... & \multirow[b]{2}{*}{ 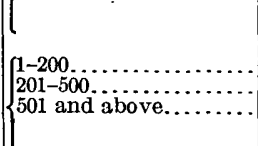 } & 1,891 & 123 & 233,765 & 151,983 & 964 & 106,369 & 74 & 35,573 \\
\hline & Eunterdon... & & $\begin{array}{r}128 \\
6 \\
6\end{array}$ & $\begin{array}{r}33 \\
309 \\
1,765\end{array}$ & $\begin{array}{r}4,285 \\
1,855 \\
10,593\end{array}$ & $\begin{array}{l}3,968 \\
1,855 \\
8,095\end{array}$ & $\begin{array}{l}46 \\
13 \\
23\end{array}$ & $\begin{array}{l}1,861 \\
1,600 \\
3,836\end{array}$ & $\begin{array}{l}3 \\
0 \\
3\end{array}$ & $\begin{array}{r}107 \\
0 \\
2,300\end{array}$ \\
\hline & \multirow[b]{2}{*}{ Mercer.. } & \multirow[b]{2}{*}{$\begin{array}{l}1-200 \ldots \ldots \ldots \ldots \ldots \ldots \ldots \\
201-500 \ldots \ldots \ldots \ldots \ldots \ldots\end{array}$} & 140 & 120 & 16,733 & 13,918 & 82 & 7,297 & 6 & 2,407 \\
\hline & & & $\begin{array}{r}348 \\
28 \\
27 \\
\end{array}$ & $\begin{array}{r}30 \\
350 \\
2,120 \\
\end{array}$ & $\begin{array}{r}10,513 \\
9,836 \\
57,277\end{array}$ & $\begin{array}{r}6,144 \\
7,946 \\
45,712\end{array}$ & $\begin{array}{r}95 \\
64 \\
132 \\
\end{array}$ & $\begin{array}{r}5,228 \\
6,788 \\
30,483 \\
\end{array}$ & \begin{tabular}{r|}
0 \\
3 \\
17 \\
\end{tabular} & $\begin{array}{r}0 \\
733 \\
13,043\end{array}$ \\
\hline & \multirow[b]{2}{*}{ Middlesex.... } & \multirow{2}{*}{$\begin{array}{l}1-200 \ldots \ldots \ldots \ldots \ldots \ldots \ldots \ldots \\
200-500, \ldots \ldots \ldots \ldots \ldots \ldots \ldots\end{array}$} & 403 & 191 & 77,626 & 59,802 & 291 & 42,499 & 20 & 13,776 \\
\hline & & & $\begin{array}{r}359 \\
30 \\
45\end{array}$ & $\begin{array}{r}26 \\
344 \\
2,600\end{array}$ & $\begin{array}{r}9,450 \\
10,332 \\
117,730\end{array}$ & $\begin{array}{r}4,932 \\
6,733 \\
101,761\end{array}$ & $\begin{array}{r}800 \\
104 \\
231\end{array}$ & $\begin{array}{r}4,015 \\
6,230 \\
69 ; 893\end{array}$ & $\begin{array}{r}3 \\
16 \\
46\end{array}$ & $\begin{array}{r}155 \\
295 \\
29,686\end{array}$ \\
\hline & \multirow{2}{*}{ Monmouth... } & \multirow{2}{*}{$\begin{array}{l}\{ \\
\left\{\begin{array}{l}1-200 \ldots \ldots \ldots \ldots \ldots \ldots \\
201-500 \ldots \ldots \ldots \ldots \ldots \ldots\end{array}\right.\end{array}$} & 434 & 316 & 137,512 & 113,426 & 415 & 80,138 & 50 & 30,066 \\
\hline \multirow[t]{3}{*}{$\therefore$} & & & $\begin{array}{r}330 \\
8 \\
4\end{array}$ & $\begin{array}{r}16 \\
339 \\
871\end{array}$ & $\begin{array}{l}5,430 \\
2,712 \\
3,484\end{array}$ & $\begin{array}{l}2,727 \\
1,856 \\
1,868\end{array}$ & $\begin{array}{l}51 \\
30 \\
15\end{array}$ & $\begin{array}{r}1,960 \\
1,655 \\
523\end{array}$ & $\begin{array}{l}1 \\
3 \\
4 \\
\end{array}$ & $\begin{array}{r}15 \\
186 \\
1,345\end{array}$ \\
\hline & & & 342 & 34 & 11,626 & 6,451 & 96 & 4,138 & 8 & 1,546 \\
\hline & Morris.. & $\left\{\begin{array}{l}1-200 \ldots \ldots \ldots \ldots \ldots \ldots \\
201-500 \ldots \ldots \ldots \ldots \ldots \ldots \\
501 \text { and above } \ldots \ldots \ldots \ldots\end{array}\right.$ & $\begin{array}{r}173 \\
12 \\
15\end{array}$ & $\begin{array}{r}24 \\
1,436 \\
1,080\end{array}$ & $\begin{aligned} 4,078 \\
17,226 \\
16,198\end{aligned}$ & $\begin{array}{l}2,885 \\
16,443 \\
11,775\end{array}$ & $\begin{array}{l}44 \\
59 \\
40\end{array}$ & $\begin{array}{r}2,160 \\
15,952 \\
9,039\end{array}$ & $\begin{array}{c}1 \\
4 \\
5\end{array}$ & $\begin{array}{r}12 \\
121 \\
1,836\end{array}$ \\
\hline New Jersey.... & - & l & 200 & 188 & 37,502 & 30,503 & 143 & 27,151 & 10 & 1,969 \\
\hline & Ocean.. & $\left\{\begin{array}{l}1-200 \ldots \ldots \\
201-500 \ldots \ldots\end{array}\right.$ & $\begin{array}{r}72 \\
2\end{array}$ & $\begin{array}{r}13 \\
352\end{array}$ & $\begin{array}{l}965 \\
705\end{array}$ & $\begin{array}{l}806 \\
705\end{array}$ & $\begin{array}{l}13 \\
12\end{array}$ & $\begin{array}{l}349 \\
600\end{array}$ & $\begin{array}{c}3 \\
1\end{array}$ & $\begin{array}{r}47 \\
105\end{array}$ \\
\hline & & & 74 & 23 & 1,670 & 1,511 & 25 & 949 & 4 & 152 \\
\hline & Passaic.. & $\left\{\begin{array}{l}1-200 \ldots \ldots \ldots \ldots \ldots \\
201-500 \ldots \ldots \ldots \ldots \\
501 \text { and above............ }\end{array}\right.$ & $\begin{array}{r}1,137 \\
65 \\
26\end{array}$ & $\begin{array}{r}23 \\
633 \\
1,620\end{array}$ & $\begin{array}{l}26,544 \\
41,200 \\
42,379\end{array}$ & $\begin{array}{l}11,443 \\
38,128 \\
24,902\end{array}$ & $\begin{array}{l}179 \\
611 \\
125\end{array}$ & $\begin{array}{l}9,626 \\
29,929 \\
19,851\end{array}$ & $\begin{array}{l}20 \\
19 \\
15\end{array}$ & $\begin{array}{r}560 \\
7,923 \\
3,890\end{array}$ \\
\hline . & & $l$ & 1,328 & 83 & 110,123 & 74,473 & 915 & 59,406 & 54 & 12,373 \\
\hline & Salem.. & 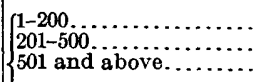 & $\begin{array}{r}86 \\
2 \\
2\end{array}$ & $\begin{array}{r}28 \\
380 \\
6,168\end{array}$ & $\begin{array}{r}2,418 \\
12,336\end{array}$ & $\begin{array}{r}1,768 \\
320 \\
12,336\end{array}$ & $\begin{array}{l}45 \\
4 \\
37\end{array}$ & $\begin{array}{l}1,209 \\
320 \\
2,361\end{array}$ & $\begin{array}{r}2 \\
0 \\
18\end{array}$ & $\begin{array}{r}32 \\
0 \\
9,975\end{array}$ \\
\hline & & l & 90 & 172 & 15,515 & 14,424 & 86 & 3,890 & 20 & 10,007 \\
\hline & Somerset.. & $\left\{\begin{array}{l}1-200 \ldots \ldots \ldots \ldots \ldots \\
201-500 \ldots \ldots \ldots \ldots \ldots \\
501 \text { and above: } \ldots \ldots . .\end{array}\right.$ & $\begin{array}{r}88 \\
7 \\
7\end{array}$ & $\begin{array}{r}70 \\
350 \\
1,564\end{array}$ & $\begin{array}{r}616 \\
2,452 \\
10,945\end{array}$ & $\begin{array}{r}1,573 \\
1,209 \\
10,940\end{array}$ & $\begin{array}{l}22 \\
10 \\
14\end{array}$ & $\begin{array}{r}971 \\
1,209 \\
3,840\end{array}$ & $\begin{array}{l} \\
0 \\
5\end{array}$ & $\begin{array}{r}0 \\
0 \\
7,100\end{array}$ \\
\hline & & & 102 & 157 & 16,013 & 13,722 & 46 & 6,020 & 5 & 7,100 \\
\hline & Sussex... & $\left\{\begin{array}{l}1-200 \ldots \ldots \ldots \ldots \ldots \\
201-500 \ldots \ldots \ldots \ldots\end{array}\right.$ & \begin{tabular}{r|}
79 \\
1 \\
3
\end{tabular} & $\begin{array}{r}31 \\
250 \\
944\end{array}$ & $\begin{array}{l}, 489 \\
250 \\
2,833\end{array}$ & $\begin{array}{l}2,312 \\
250 \\
2,833\end{array}$ & $\begin{array}{r}43 \\
1 \\
15\end{array}$ & $\begin{array}{l}1,576 \\
150 \\
2,250\end{array}$ & $\begin{array}{l}2 \\
0 \\
1\end{array}$ & $\begin{array}{r}183 \\
0 \\
450\end{array}$ \\
\hline & & ( & 83 & 67 & 5,572 & 5,395 & 59 & 3,976 & 3 & 633 \\
\hline & Union.. & $\left\{\begin{array}{l}1-200 \ldots \ldots \ldots \ldots \ldots \\
201-500 \\
501 \text { and above } \ldots \ldots \ldots \ldots\end{array}\right.$ & $\begin{array}{r}365 \\
32 \\
21\end{array}$ & $\begin{array}{r}23 \\
312 \\
2,560\end{array}$ & $\begin{array}{r}8,376 \\
10,034 \\
53,881\end{array}$ & $\begin{aligned} 4,061 \\
5,962 \\
45,898\end{aligned}$ & $\begin{array}{r}89 \\
54 \\
196\end{array}$ & $\begin{array}{r}3,018 \\
5,380 \\
19,489\end{array}$ & $\begin{array}{r}1 \\
1 \\
51\end{array}$ & $\begin{array}{r}2 \\
250 \\
21,751\end{array}$ \\
\hline & & & 418 & 173 & 72,291 & 55,921 & 339 & 27,887 & 53 & 22,003 \\
\hline & (Warren.... & $\left\{\begin{array}{l}1-200 \ldots \ldots \ldots \ldots \ldots \ldots \\
201-500 \ldots \ldots \ldots \ldots \ldots \ldots\end{array}\right.$ & $\begin{array}{r}145 \\
9 \\
14\end{array}$ & $\begin{array}{r}34 \\
308 \\
1,860\end{array}$ & $\begin{array}{r}4,853 \\
2,773 \\
26,013\end{array}$ & $\begin{array}{r}3,246 \\
1,870 \\
25,405\end{array}$ & $\begin{array}{l}49 \\
12 \\
86\end{array}$ & $\begin{array}{r}1,758 \\
1,225 \\
19,395\end{array}$ & $\begin{array}{r}2 \\
0 \\
10\end{array}$ & $\begin{array}{r}95 \\
0 \\
5,625\end{array}$ \\
\hline & & & 168 & 200 & 33,639 & 30,521 & 147 & 22,373 & 12 & 5,720 \\
\hline
\end{tabular}


by counties and size of plant-Continued.

\begin{tabular}{|c|c|c|c|c|c|c|c|c|c|c|c|c|}
\hline \multicolumn{8}{|c|}{ Power-supply equipment-Continued. } & \multicolumn{4}{|c|}{ Electric motors. } & \multirow{4}{*}{$\begin{array}{l}\text { Number } \\
\text { of estab- } \\
\text { lishments } \\
\text { reporting } \\
\text { no power. }\end{array}$} \\
\hline \multicolumn{4}{|c|}{ Prime movers-Continued. } & \multicolumn{4}{|c|}{ Operated by purchased energy. } & \multirow{2}{*}{\multicolumn{2}{|c|}{ Total. }} & \multirow{2}{*}{\multicolumn{2}{|c|}{$\begin{array}{l}\text { Run by current } \\
\text { generated in } \\
\text { establishment. }\end{array}$}} & \\
\hline $\begin{array}{l}\text { Interna } \\
\text { tion } 0\end{array}$ & $\begin{array}{l}\text {-combus- } \\
\text { ngines. }\end{array}$ & Water & wheols. & \multirow{2}{*}{$\begin{array}{l}\text { Total } \\
\text { horso- } \\
\text { power. }\end{array}$} & \multicolumn{2}{|c|}{ Electric motors. } & \multirow{2}{*}{$\begin{array}{l}\text { Other } \\
\text { (horse- } \\
\text { power). }\end{array}$} & & & & & \\
\hline $\begin{array}{c}\text { Num- } \\
\text { bor. }\end{array}$ & $\begin{array}{l}\text { Horse- } \\
\text { powor. }\end{array}$ & $\underset{\text { ber. }}{\text { Num- }}$ & $\begin{array}{l}\text { Horse- } \\
\text { power. }\end{array}$ & & Number. & $\begin{array}{l}\text { Horse- } \\
\text { power. }\end{array}$ & & Number. & $\begin{array}{l}\text { Horse- } \\
\text { power. }\end{array}$ & Number. & $\begin{array}{l}\text { Horse- } \\
\text { power. }\end{array}$ & \\
\hline 12 & 13 & 14 & 15 & 16 & 17 & 18 & 19 & 20 & 21 & 22 & 23 & $\mathbf{2 4}$ \\
\hline $\begin{array}{r}32 \\
0 \\
5\end{array}$ & $\begin{array}{r}354 \\
0 \\
1,208 \\
\end{array}$ & $\begin{array}{l}7 \\
0 \\
2\end{array}$ & $\begin{array}{r}176 \\
0 \\
30\end{array}$ & $\begin{array}{l}584 \\
231 \\
600\end{array}$ & $\begin{array}{r}104 \\
9 \\
2\end{array}$ & $\begin{array}{l}584 \\
231 \\
600\end{array}$ & $\begin{array}{l}0 \\
0 \\
0\end{array}$ & $\begin{array}{l}\mathbf{1 5 0} \\
363 \\
342\end{array}$ & $\begin{array}{r}780 \\
1,707 \\
5,322\end{array}$ & $\begin{array}{r}46 \\
354 \\
340\end{array}$ & $\begin{array}{r}196 \\
1,476 \\
4,722\end{array}$ & $\begin{array}{l}\cdots \\
\cdots \cdots \\
\cdots \cdots\end{array}$ \\
\hline 37 & 1,562 & 9 & 206 & 1,415 & 115 & 1,415 & 0 & 855 & 7,809 & 740 & 6,394 & 26 \\
\hline $\begin{array}{r}150 \\
11 \\
30 \\
\end{array}$ & $\begin{array}{r}2,571 \\
584 \\
6,751 \\
\end{array}$ & $\begin{array}{l}2 \\
0 \\
0 \\
\end{array}$ & $\begin{array}{r}135 \\
0 \\
0\end{array}$ & $\begin{array}{l}17,511 \\
10,689 \\
53,582\end{array}$ & $\begin{array}{l}5,466 \\
1,072 \\
4,430\end{array}$ & $\begin{array}{l}17,252 \\
10,689 \\
53,582\end{array}$ & $\begin{array}{r}259 \\
0 \\
0\end{array}$ & $\begin{array}{l}5,847 \\
2,285 \\
9,736\end{array}$ & $\begin{array}{r}20,062 \\
18,021 \\
114,171\end{array}$ & $\begin{array}{r}381 \\
1,213 \\
5,306\end{array}$ & $\begin{array}{r}2,810 \\
7,332 \\
60,589\end{array}$ & $\begin{array}{l}\cdots \\
\cdots \\
\cdots \cdots\end{array}$ \\
\hline 197 & 9,906 & 2 & 135 & 81,782 & 10,968 & 81,523 & 259 & 17,868 & 152,254 & 6,900 & 70,731 & 493 \\
\hline $\begin{array}{r}45 \\
0 \\
4 \\
\end{array}$ & $\begin{array}{r}638 \\
0 \\
12 \\
\end{array}$ & $\begin{array}{r}43 \\
4 \\
6 \\
\end{array}$ & $\begin{array}{l}1,362 \\
255 \\
1,947\end{array}$ & $\begin{array}{r}317 \\
0 \\
2,498 \\
\end{array}$ & $\begin{array}{r}92 \\
0 \\
110\end{array}$ & $\begin{array}{r}317 \\
0 \\
2,498\end{array}$ & $\begin{array}{l} \\
0 \\
0\end{array}$ & $\begin{array}{r}100 \\
20 \\
419 \\
\end{array}$ & $\begin{array}{r}392 \\
140 \\
6,282\end{array}$ & $\begin{array}{r}8 \\
20 \\
309\end{array}$ & $\begin{array}{r}75 \\
140 \\
3,784\end{array}$ & $\cdots$ \\
\hline 49 & 650 & 53 & 3,564 & 2,815 & 202 & 2,815 & 0 & 539 & 6,814 & 337 & 3,999 & 12 \\
\hline $\begin{array}{r}30 \\
2 \\
6 \\
\end{array}$ & $\begin{array}{r}450 \\
50 \\
2,111 \\
\end{array}$ & $\begin{array}{r}21 \\
5 \\
1 \\
\end{array}$ & $\begin{array}{r}466 \\
375 \\
75\end{array}$ & $\begin{array}{r}4,369 \\
1,890 \\
11,565\end{array}$ & $\begin{array}{l}989 \\
160 \\
810 \\
\end{array}$ & $\begin{array}{r}4,367 \\
1,620 \\
11,565\end{array}$ & $\begin{array}{r}2 \\
270 \\
0\end{array}$ & $\begin{array}{r}1,155 \\
545 \\
1,968\end{array}$ & $\begin{array}{r}5,262 \\
4,093 \\
29,067\end{array}$ & $\begin{array}{r}166 \\
385 \\
1,158\end{array}$ & $\begin{array}{r}895 \\
2,473 \\
17,502\end{array}$ & a......... \\
\hline 38 & 2,011 & 27 & 916 & 17,824 & 1,959 & 17,552 & 272 & 3,668 & 38,422 & 1,709 & 20,870 & 108 \\
\hline $\begin{array}{r}37 \\
6 \\
18 \\
\end{array}$ & $\begin{array}{r}572 \\
278 \\
2,160\end{array}$ & $\begin{array}{l}6 \\
0 \\
2\end{array}$ & $\begin{array}{r}190 \\
0 \\
22\end{array}$ & $\begin{array}{r}4,518 \\
3,599 \\
15,969\end{array}$ & $\begin{array}{r}888 \\
297 \\
1,131\end{array}$ & $\begin{array}{r}4,368 \\
3,349 \\
15,969\end{array}$ & $\begin{array}{r}150 \\
250 \\
0\end{array}$ & $\begin{array}{r}996 \\
523 \\
4,291\end{array}$ & $\begin{array}{r}5,321 \\
5,294 \\
67,247\end{array}$ & $\begin{array}{r}108 \\
226 \\
3,160\end{array}$ & $\begin{array}{r}953 \\
1,945 \\
51,278\end{array}$ & (a........ \\
\hline 61 & 3,010 & 8 & 222 & 24,086 & 2,316 & 23,686 & 400 & 5,810 & 77,862 & 3,494 & 54,176 & 72 \\
\hline $\begin{array}{r}46 \\
4 \\
0 \\
\end{array}$ & $\begin{array}{r}485 \\
15 \\
0\end{array}$ & $\begin{array}{l}8 \\
0 \\
0\end{array}$ & $\begin{array}{r}267 \\
0 \\
0\end{array}$ & $\begin{array}{r}2,703 \\
856 \\
1,616\end{array}$ & $\begin{array}{r}708 \\
77 \\
62\end{array}$ & $\begin{array}{r}2,670 \\
856 \\
1,616\end{array}$ & $\begin{array}{r}33 \\
0 \\
0\end{array}$ & $\begin{array}{r}714 \\
77 \\
72\end{array}$ & $\begin{array}{r}2,708 \\
856 \\
1,741\end{array}$ & $\begin{array}{r}6 \\
0 \\
10\end{array}$ & $\begin{array}{r}38 \\
0 \\
125\end{array}$ & 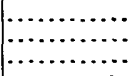 \\
\hline 50 & 500 & 8 & 267 & 5,175 & 847 & 5,142 & 33 & 863 & 5,305 & 16 & 163 & 54 \\
\hline $\begin{array}{r}17 \\
0 \\
2 \\
\end{array}$ & $\begin{array}{r}264 \\
0 \\
15 \\
\end{array}$ & $\begin{array}{r}16 \\
4 \\
5\end{array}$ & $\begin{array}{l}449 \\
370 \\
285\end{array}$ & $\begin{array}{r}1,193 \\
783 \\
5,023\end{array}$ & $\begin{array}{r}281 \\
42 \\
79\end{array}$ & $\begin{array}{r}1,193 \\
783 \\
5,023\end{array}$ & $\begin{array}{l}0 \\
0 \\
0\end{array}$ & $\begin{array}{l}385 \\
410 \\
523 \\
\end{array}$ & $\begin{array}{r}1,458 \\
4,206 \\
12,574\end{array}$ & $\begin{array}{l}104 \\
368 \\
444\end{array}$ & $\begin{array}{r}265 \\
3,423 \\
7,551\end{array}$ & 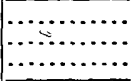 \\
\hline 19 & 279 & 25 & 1,104 & 6,999 & 402 & 6,999 & 0 & $.1,318$ & 18,238 & 916 & 11,239 & 33 \\
\hline $\begin{array}{r}33 \\
0\end{array}$ & $\begin{array}{r}299 \\
0\end{array}$ & $\begin{array}{l}4 \\
0\end{array}$ & $\begin{array}{r}111 \\
0\end{array}$ & $\begin{array}{r}159 \\
0\end{array}$ & $\begin{array}{r}68 \\
0\end{array}$ & $\begin{array}{r}159 \\
0\end{array}$ & $\begin{array}{l}0 \\
0\end{array}$ & $\begin{array}{r}68 \\
2\end{array}$ & $\begin{array}{r}159 \\
6\end{array}$ & $\begin{array}{l}0 \\
2\end{array}$ & $\begin{array}{l}0 \\
6\end{array}$ & …….... \\
\hline 33 & 299 & 4 & 111 & 159 & 68 & 159 & 0 & 70 & 165 & 2 & 6 & 10 \\
\hline $\begin{array}{r}82 \\
5 \\
4\end{array}$ & $\begin{array}{r}1,041 \\
161 \\
811\end{array}$ & $\begin{array}{r}12 \\
2 \\
4\end{array}$ & $\begin{array}{l}216 \\
115 \\
350\end{array}$ & $\begin{array}{r}15,101 \\
3,072 \\
17,477\end{array}$ & $\begin{array}{r}3,161 \\
378 \\
1,253\end{array}$ & $\begin{array}{r}12,409 \\
2,597 \\
17,477\end{array}$ & $\begin{array}{r}2,692 \\
475 \\
0\end{array}$ & $\begin{array}{l}3,454 \\
1,223 \\
3,849\end{array}$ & $\begin{array}{r}14,840 \\
6,902 \\
48,467\end{array}$ & $\begin{array}{r}293 \\
845 \\
2,596\end{array}$ & $\begin{array}{r}2,431 \\
4,305 \\
30,990\end{array}$ & {$\left[\begin{array}{c}\cdots \\
\cdots \cdots \cdots\end{array}\right.$} \\
\hline 91 & 2,013 & 18 & 681 & 35,650 & 4,792 & 32,483 & 3,167 & 8,526 & 70,209 & 3,734 & 37,726 & 209 \\
\hline $\begin{array}{r}23 \\
0 \\
0 \\
\end{array}$ & $\begin{array}{r}168 \\
0 \\
0\end{array}$ & $\begin{array}{r}13 \\
0 \\
0 \\
\end{array}$ & $\begin{array}{r}359 \\
0 \\
0\end{array}$ & $\begin{array}{r}650 \\
441 \\
0\end{array}$ & $\begin{array}{r}103 \\
29 \\
.0\end{array}$ & $\begin{array}{r}650 \\
441 \\
0 \\
\end{array}$ & $\begin{array}{l}0 . \\
0 \\
0\end{array}$ & $\begin{array}{r}108 \\
96 \\
434\end{array}$ & $\begin{array}{r}724 \\
831 \\
7,681 \\
\end{array}$ & $\begin{array}{r}5 \\
67 \\
434 \\
\end{array}$ & $\begin{array}{r}74 \\
390 \\
7,681 \\
\end{array}$ & 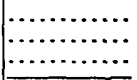 \\
\hline 23 & 168 & 13 & 359 & 1,091 & 132 & 1,091 & 0 & 638 & 9,236 & 506 & 8,145 & 19 \\
\hline $\begin{array}{r}20 \\
0 \\
0\end{array}$ & $\begin{array}{r}307 \\
0 \\
0\end{array}$ & $\begin{array}{l}9 \\
0 \\
0\end{array}$ & $\begin{array}{r}295 \\
0 \\
0\end{array}$ & $\begin{array}{r}1,043 \\
1,243 \\
5\end{array}$ & $\begin{array}{r}329 \\
79 \\
1\end{array}$ & $\begin{array}{r}1,043 \\
1,243 \\
5\end{array}$ & $\begin{array}{l}0 \\
0 \\
0\end{array}$ & $\begin{array}{l}416 \\
109 \\
476\end{array}$ & $\begin{array}{l}1,253 \\
1,536 \\
6,943\end{array}$ & $\begin{array}{r}87 \\
30 \\
475\end{array}$ & $\begin{array}{r}210 \\
293 \\
6,938\end{array}$ & 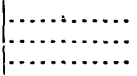 \\
\hline 20 & 307 & 9 & 295 & 2,291 & 409 & 2,291 & 0 & 1,001 & 9,732 & 592 & 7,441 & 20 \\
\hline $\begin{array}{r}27 \\
7 \\
1\end{array}$ & $\begin{array}{r}306 \\
100 \\
8\end{array}$ & $\begin{array}{l}7 \\
0 \\
2\end{array}$ & $\begin{array}{r}247 \\
0 \\
125\end{array}$ & $\begin{array}{r}177 \\
0 \\
0\end{array}$ & $\begin{array}{r}157 \\
0 \\
0\end{array}$ & $\begin{array}{r}177 \\
0 \\
0\end{array}$ & $\begin{array}{l}0 \\
0 \\
0\end{array}$ & $\begin{array}{r}195 \\
6 \\
38\end{array}$ & $\begin{array}{r}542 \\
60 \\
292\end{array}$ & $\begin{array}{r}38 \\
6 \\
38\end{array}$ & $\begin{array}{r}365 \\
60 \\
292\end{array}$ & $\mid \begin{array}{l}\cdots \ldots \ldots \ldots \\
\cdots \cdots \cdots\end{array}$ \\
\hline 35 & 414 & 9 & 372 & 177 & 157 & . 177 & 0 & 239 & 894 & 82 & 717 & 11 \\
\hline $\begin{array}{l}55 \\
23 \\
18 \\
\end{array}$ & $\begin{array}{r}1,021 \\
332 \\
4,658 \\
\end{array}$ & $\begin{array}{l}1 \\
0 \\
0\end{array}$ & $\begin{array}{r}20 \\
0 \\
0\end{array}$ & $\begin{array}{l}4,315 \\
4,072 \\
7,083\end{array}$ & $\begin{array}{l}974 \\
505 \\
\mathbf{5 4 7}\end{array}$ & $\begin{array}{l}4,315 \\
4,072 \\
7,983\end{array}$ & $\begin{array}{l}0 \\
0 \\
0 \\
\end{array}$ & $\begin{array}{l}1,073 \\
714 \\
2,677 \\
\end{array}$ & $\begin{array}{r}4,961 \\
5,846 \\
39,787 \\
\end{array}$ & $\begin{array}{r}99 \\
209 \\
2,130 \\
\end{array}$ & $\begin{array}{r}646 \\
1,774 \\
31,804 \\
\end{array}$ & 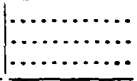 \\
\hline 96 & 6,011 & 1 & 20 & 16,370 & 2,026 & 16,370 & 0 & 4,464 & 50,594 & 2,438 & 34,224 & 69 \\
\hline $\begin{array}{r}37 \\
7 \\
2\end{array}$ & $\begin{array}{r}1,398 \\
645 \\
385\end{array}$ & $\begin{array}{l}0 \\
0 \\
0\end{array}$ & $\begin{array}{l}0 \\
0 \\
0\end{array}$ & $\begin{array}{r}1,607 \\
903 \\
608\end{array}$ & $\begin{array}{r}322 \\
43 \\
13\end{array}$ & $\begin{array}{r}1,607 \\
903 \\
608\end{array}$ & $\begin{array}{l}0 \\
0 \\
0\end{array}$ & $\begin{array}{l}531 \\
132 \\
946\end{array}$ & $\begin{array}{r}2,264 \\
2,131 \\
16,116\end{array}$ & $\begin{array}{r}209 \\
89 \\
933\end{array}$ & $\begin{array}{r}657 \\
1,228 \\
15,508\end{array}$ & 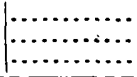 \\
\hline 46 & 2,428 & 0 & 0 & 3,118 & 378 & 3,118 & 0 & 1,609 & 20,511 & 1,231 & 17,393 & 13 \\
\hline
\end{tabular}


TABLE 47.-Mechanical power-supply equipment,

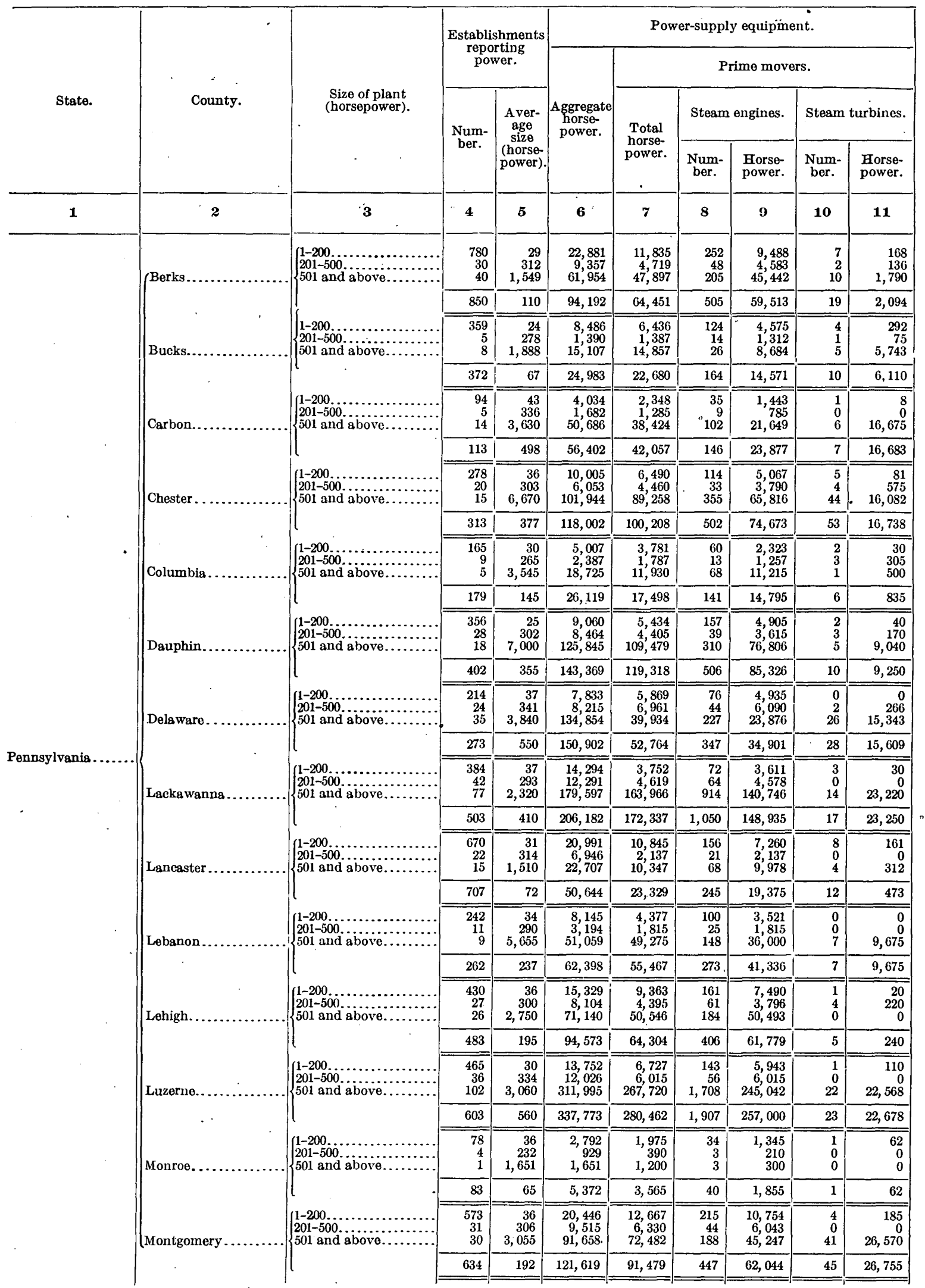


by counties and size of plant-Continued.

\begin{tabular}{|c|c|c|c|c|c|c|c|c|c|c|c|c|}
\hline \multicolumn{8}{|c|}{ Power-supply equipment-Continued. } & \multicolumn{4}{|c|}{ Electric motors. } & \multirow{4}{*}{$\begin{array}{l}\text { Number } \\
\text { of estab- } \\
\text { lishments } \\
\text { reporting } \\
\text { no power. }\end{array}$} \\
\hline \multicolumn{4}{|c|}{ Prime movers-Continued. } & \multicolumn{4}{|c|}{ Operated by purchased energy. } & \multirow{2}{*}{\multicolumn{2}{|c|}{ Total. }} & \multirow{2}{*}{\multicolumn{2}{|c|}{$\begin{array}{c}: \\
\text { Run by current } \\
\text { generated in } \\
\text { establishment. }\end{array}$}} & \\
\hline $\begin{array}{l}\text { Internal } \\
\text { tion o }\end{array}$ & $\begin{array}{l}\text {-combus- } \\
\text { igines. }\end{array}$ & Water & wheels. & \multirow{2}{*}{$\begin{array}{l}\text { Total } \\
\text { horss- } \\
\text { power. }\end{array}$} & \multicolumn{2}{|c|}{ Electric motors. } & \multirow{2}{*}{$\begin{array}{l}\text { Other } \\
\text { (horse- } \\
\text { power). }\end{array}$} & & & & & \\
\hline $\begin{array}{c}\text { Num- } \\
\text { bor. }\end{array}$ & $\begin{array}{l}\text { Horso- } \\
\text { powor. }\end{array}$ & $\begin{array}{c}\text { Num- } \\
\text { ber. }\end{array}$ & $\begin{array}{l}\text { Horse- } \\
\text { power. }\end{array}$ & & Number. & $\begin{array}{l}\text { Horse- } \\
\text { power. }\end{array}$ & & Number. & $\begin{array}{l}\text { Horse- } \\
\text { power. }\end{array}$ & Number. & $\begin{array}{l}\text { Horse- } \\
\text { power. }\end{array}$ & \\
\hline 12 & 13 & 14 & 15 & 16 & 17 & 18 & 19 & 20 & 21 & 22 & 23 & 24 \\
\hline $\begin{array}{r}73 \\
0 \\
4 \\
\end{array}$ & $\begin{array}{r}915 \\
0 \\
540\end{array}$ & $\begin{array}{r}64 \\
0 \\
2 \\
\end{array}$ & $\begin{array}{r}1,264 \\
0 \\
125 \\
\end{array}$ & $\begin{array}{r}11,046 \\
4,638 \\
14,057 \\
\end{array}$ & $\begin{array}{r}2,395 \\
821 \\
808 \\
\end{array}$ & $\begin{array}{r}11,046 \\
4,638 \\
14,057 \\
\end{array}$ & $\begin{array}{l}0 \\
0 \\
0\end{array}$ & $\begin{array}{l}2,541 \\
879 \\
2,424\end{array}$ & $\begin{array}{r}11,766 \\
5,356 \\
34,5 \pm 3\end{array}$ & $\begin{array}{r}146 \\
58 \\
1,616\end{array}$ & $\begin{array}{r}720 \\
718 \\
20,486\end{array}$ & \\
\hline 77 & 1,455 & 66 & 1,389 & 29,741 & 4,024 & 29,741 & 0 & 5, 844 & 51,665 & 1,820 & 21,924 & 216 \\
\hline $\begin{array}{r}102 \\
0 \\
2 \\
\end{array}$ & $\begin{array}{r}911 \\
0 \\
30 \\
\end{array}$ & $\begin{array}{r}23 \\
0 \\
2 \\
\end{array}$ & $\begin{array}{r}658 \\
0 \\
400 \\
\end{array}$ & $\begin{array}{r}2,050 \\
3 \\
250 \\
\end{array}$ & $\begin{array}{r}391 \\
2 \\
2 \\
\end{array}$ & $\begin{array}{r}2,023 \\
3 \\
250 \\
\end{array}$ & $\begin{array}{r}27 \\
0 \\
0 \\
\end{array}$ & $\begin{array}{r}456 \\
26 \\
540\end{array}$ & $\begin{array}{r}2,362 \\
158 \\
11,953\end{array}$ & $\begin{array}{r}65 \\
24 \\
538 \\
\end{array}$ & $\begin{array}{r}339 \\
155 \\
11,703 \\
\end{array}$ & \\
\hline 104 & 841 & 25 & 1,058 & 2,303 & 395 & 2,276 & 27 & 1,022 & 14,473 & 627 & 12,197 & 136 \\
\hline $\begin{array}{r}17 \\
0 \\
0\end{array}$ & $\begin{array}{r}432 \\
0 \\
0\end{array}$ & $\begin{array}{l}9 \\
6 \\
2 \\
\end{array}$ & $\begin{array}{l}465 \\
500 \\
100 \\
\end{array}$ & $\begin{array}{r}1,686 \\
397 \\
12,262\end{array}$ & $\begin{array}{r}164 \\
18 \\
334\end{array}$ & $\begin{array}{r}1,656 \\
397 \\
12,262\end{array}$ & $\begin{array}{r}30 \\
0 \\
0\end{array}$ & $\begin{array}{r}164 \\
18 \\
1,008\end{array}$ & $\begin{array}{r}1,656 \\
397 \\
34,338\end{array}$ & $\begin{array}{r}0 \\
0 \\
674\end{array}$ & \begin{tabular}{r|}
0 \\
0 \\
22,076
\end{tabular} & \\
\hline 17 & 432 & 17 & 1,065 & 14,345 & 516 & 14,315 & 30 & 1,190 & 36,391 & 674 & 22,076 & 19 \\
\hline $\begin{array}{r}24 \\
0 \\
8 \\
\end{array}$ & $\begin{array}{r}346 \\
0 \\
7,270 \\
\end{array}$ & $\begin{array}{r}49 \\
3 \\
3 \\
\end{array}$ & $\begin{array}{r}996 \\
95 \\
90 \\
\end{array}$ & $\begin{array}{r}3,515 \\
1,593 \\
12,686 \\
\end{array}$ & $\begin{array}{r}591 \\
52 \\
495 \\
\end{array}$ & $\begin{array}{r}3,430 \\
1,593 \\
12,686 \\
\end{array}$ & $\begin{array}{r}85 \\
0 \\
0\end{array}$ & $\begin{array}{r}630 \\
113 \\
2,119 \\
\end{array}$ & $\begin{array}{r}3,719 \\
2,360 \\
49,585 \\
\end{array}$ & $\begin{array}{r}39 \\
61 \\
1,624 \\
\end{array}$ & $\begin{array}{r}289 \\
767 \\
36,899 \\
\end{array}$ & 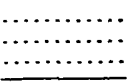 \\
\hline 32 & 7,616 & 55 & 1,181 & 17,794 & 1,138 & 17,709 & 85 & 2,862 & 55,664 & 1,724 & 37,955 & 44 \\
\hline $\begin{array}{r}37 \\
0 \\
5 \\
\end{array}$ & $\begin{array}{r}325 \\
0 \\
215 \\
\end{array}$ & $\begin{array}{r}38 \\
7 \\
0 \\
\end{array}$ & $\begin{array}{r}1,103 \\
225 \\
0\end{array}$ & $\begin{array}{l}1,226 \\
600 \\
6,795 \\
\end{array}$ & $\begin{array}{l}195 \\
146 \\
342 \\
\end{array}$ & $\begin{array}{l}1,226 \\
600 \\
6,795 \\
\end{array}$ & $\begin{array}{l}0 \\
0 \\
0 \\
\end{array}$ & $\begin{array}{r}201 \\
158 \\
1,026 \\
\end{array}$ & $\begin{array}{r}1,291 \\
885 \\
13,490 \\
\end{array}$ & $\begin{array}{r}6 \\
12 \\
684 \\
\end{array}$ & $\begin{array}{r}65 \\
285 \\
6,695\end{array}$ & \\
\hline 42 & 540 & 45 & 1,328 & 8,621 & 683 & 8,621 & 0 & 1,385 & 15,666 & 702 & 7,045 & 18 \\
\hline $\begin{array}{l}29 \\
10 \\
24\end{array}$ & $\begin{array}{r}148 \\
620 \\
23,633\end{array}$ & $\begin{array}{r}14 \\
0 \\
0\end{array}$ & $\begin{array}{r}341 \\
0 \\
0\end{array}$ & $\begin{array}{r}3,626 \\
4,059 \\
16,366\end{array}$ & $\begin{array}{r}1,021 \\
330 \\
814 \\
\end{array}$ & $\begin{array}{r}3,626 \\
4,059 \\
16,366\end{array}$ & $\begin{array}{l}0 \\
0 \\
0 \\
\end{array}$ & $\begin{array}{l}1,072 \\
3,700 \\
3,707\end{array}$ & $\begin{array}{r}3,954 \\
5,536 \\
76,640\end{array}$ & $\begin{array}{r}51 \\
460 \\
2,893\end{array}$ & $\begin{array}{r}328 \\
1,477 \\
60,274\end{array}$ & \\
\hline 63 & 24,401 & 14 & 341 & 24,051 & 2,165 & 24,051 & 0 & 5,569 & 86,130 & 3,404 & 62,079 & 62 \\
\hline $\begin{array}{r}49 \\
6 \\
5 \\
\end{array}$ & $\begin{array}{l}668 \\
425 \\
590 \\
\end{array}$ & $\begin{array}{r}9 \\
3 \\
4 \\
\end{array}$ & $\begin{array}{l}266 \\
180 \\
125 \\
\end{array}$ & $\begin{array}{r}1,964 \\
1,254 \\
94,920 \\
\end{array}$ & $\begin{array}{r}359 \\
132 \\
4,539 \\
\end{array}$ & $\begin{array}{r}1,964 \\
1,254 \\
94,920 \\
\end{array}$ & $\begin{array}{l}0 \\
0 \\
0 \\
\end{array}$ & $\begin{array}{r}402 \\
442 \\
6,387 \\
\end{array}$ & $\begin{array}{r}2,355 \\
4,916 \\
119,638 \\
\end{array}$ & $\begin{array}{r}43 \\
310 \\
1,848 \\
\end{array}$ & $\begin{array}{r}391 \\
3,662 \\
24,718 \\
\end{array}$ & \\
\hline 60 & 1,683 & 16 & 571 & 98,138 & 5,030 & 98,138 & 0 & 7,231 & 126,909 & 2,201 & 28,771 & 46 \\
\hline $\begin{array}{r}11 \\
0 \\
0 \\
\end{array}$ & $\begin{array}{r}68 \\
0 \\
0 \\
\end{array}$ & $\begin{array}{l}2 \\
3 \\
0 \\
\end{array}$ & $\begin{array}{r}43 \\
41 \\
0 \\
\end{array}$ & $\begin{array}{r}10,542 \\
7,672 \\
15,631 \\
\end{array}$ & $\begin{array}{r}1,480 \\
618 \\
557\end{array}$ & $\begin{array}{r}10,452 \\
7,672 \\
15,631 \\
\end{array}$ & $\begin{array}{r}90 \\
0 \\
0\end{array}$ & $\begin{array}{r}1,550 \\
709 \\
2,743\end{array}$ & $\begin{array}{r}10,648 \\
8,975 \\
100,923 \\
\end{array}$ & $\begin{array}{r}70 \\
91 \\
2,186 \\
\end{array}$ & $\begin{array}{r}196 \\
1,303 \\
85,292\end{array}$ & \\
\hline 11 & 68 & 5 & 84 & 33,845 & 2,655 & 33,755 & 90 & 5,002 & 120,546 & 2,347 & 86,791 & 74 \\
\hline $\begin{array}{r}73 \\
0 \\
2\end{array}$ & $\begin{array}{r}848 \\
0 \\
17\end{array}$ & $\begin{array}{r}122 \\
0 \\
2 \\
\end{array}$ & $\begin{array}{r}2,576 \\
0 \\
40 \\
\end{array}$ & $\begin{array}{r}10,146 \\
4,809 \\
12,360\end{array}$ & $\begin{array}{r}1,741 \\
449 \\
1,494 \\
\end{array}$ & $\begin{array}{r}10,126 \\
4,809 \\
12,360\end{array}$ & $\begin{array}{r}20 \\
0 \\
0 \\
\end{array}$ & $\begin{array}{r}1,967 \\
469 \\
1,595\end{array}$ & $\begin{array}{r}11,298 \\
4,849 \\
14,019\end{array}$ & $\begin{array}{r}226 \\
20 \\
101\end{array}$ & $\begin{array}{r}1,172 \\
40 \\
1,659\end{array}$ & \\
\hline 75 & 865 & 124 & 2,616 & 27,315 & 3,684 & 27,295 & 20 & 4,031 & 30,166 & 347 & 2,871 & 231 \\
\hline $\begin{array}{r}39 \\
0 \\
3 \\
\end{array}$ & $\begin{array}{r}290 \\
0 \\
3,600 \\
\end{array}$ & $\begin{array}{r}28 \\
0 \\
0 \\
\end{array}$ & $\begin{array}{r}566 \\
0 \\
0 \\
\end{array}$ & $\begin{array}{l}3,768 \\
1,379 \\
1,784 \\
\end{array}$ & $\begin{array}{r}619 \\
73 \\
61 \\
\end{array}$ & $\begin{array}{l}3,768 \\
1,379 \\
1,784 \\
\end{array}$ & $\begin{array}{l}0 \\
0 \\
0 \\
\end{array}$ & $\begin{array}{l}651 \\
139 \\
533 \\
\end{array}$ & $\begin{array}{r}4,138 \\
3,108 \\
18,553 \\
\end{array}$ & $\begin{array}{c}32 \\
660 \\
472 \\
\end{array}$ & $\begin{array}{r}370 \\
1,7729 \\
16,769 \\
\end{array}$ & \\
\hline 42 & 3,890 & 28 & 566 & 6,931 & 753 & 6,931 & 0 & 1,323 & 25,799 & 570 & 18,868 & 66 \\
\hline $\begin{array}{r}31 \\
2 \\
7\end{array}$ & $\begin{array}{r}374 \\
214 \\
27 \\
\end{array}$ & $\begin{array}{r}40 \\
1 \\
2 \\
\end{array}$ & $\begin{array}{r}1,479 \\
165 \\
26\end{array}$ & $\begin{array}{r}5,966 \\
3,709 \\
20,594\end{array}$ & $\begin{array}{r}1,540 \\
849 \\
901\end{array}$ & $\begin{array}{r}5,791 \\
3,709 \\
20,594\end{array}$ & \begin{tabular}{r|r}
175 \\
0 \\
0
\end{tabular} & $\begin{array}{r}1,600 \\
934 \\
1,067 \\
\end{array}$ & $\begin{array}{r}6,451 \\
4,288 \\
22,777 \\
\end{array}$ & $\begin{array}{r}60 \\
85 \\
166 \\
\end{array}$ & $\begin{array}{r}660 \\
579 \\
2,183 \\
\end{array}$ & \\
\hline 40 & 615 & 49 & 1,670 & 30,269 & 3,290 & 30,094 & 175 & 3,601 & 33,516 & 311 & 3,422 & 100 \\
\hline $\begin{array}{r}35 \\
0 \\
7\end{array}$ & $\begin{array}{r}311 \\
0 \\
110 \\
\end{array}$ & $\begin{array}{r}10 \\
0 \\
0\end{array}$ & $\begin{array}{r}363 \\
0 \\
0 \\
\end{array}$ & $\begin{array}{r}7,025 \\
6,011 \\
44,275 \\
\end{array}$ & $\begin{array}{r}1,469 \\
649 \\
2,949 \\
\end{array}$ & $\begin{array}{r}7,025 \\
6,011 \\
44,275 \\
\end{array}$ & $\begin{array}{l}0 \\
0 \\
0 \\
\end{array}$ & $\begin{array}{l}1,600 \\
1,274 \\
4,930 \\
\end{array}$ & $\begin{array}{r}7,766 \\
8,502 \\
124,098 \\
\end{array}$ & $\begin{array}{r}131 \\
625 \\
1,981\end{array}$ & $\begin{array}{r}741 \\
2,491 \\
79,823\end{array}$ & \\
\hline 42 & 421 & 10 & 363 & 57,311 & 5,067 & 57,311 & 0 & 7,804 & 140,366 & 2,737 & 83,055 & 85 \\
\hline $\begin{array}{r}22 \\
0 \\
0 \\
\end{array}$ & $\begin{array}{r}352 \\
0 \\
0 \\
\end{array}$ & $\begin{array}{r}11 \\
3 \\
3 \\
\end{array}$ & $\begin{array}{l}216 \\
180 \\
900 \\
\end{array}$ & $\begin{array}{r}817 \\
539 \\
451 \\
\end{array}$ & \begin{tabular}{r|}
286 \\
39 \\
13 \\
\end{tabular} & $\begin{array}{l}817 \\
539 \\
451 \\
\end{array}$ & $\begin{array}{l}0 \\
0 \\
0 \\
\end{array}$ & $\begin{array}{r}287 \\
39 \\
13 \\
\end{array}$ & $\begin{array}{l}837 \\
539 \\
451 \\
\end{array}$ & $\begin{array}{l}1 \\
0 \\
0 \\
\end{array}$ & \begin{tabular}{r|}
20 \\
0 \\
0
\end{tabular} & \\
\hline 22 & 352 & 17 & 1,296 & 1,807 & 338 & 1,807 & 0 & 339 & 1,827 & 1 & 20 & 17 \\
\hline $\begin{array}{r}74 \\
2 \\
3 \\
\end{array}$ & $\begin{array}{r}789 \\
37 \\
665 \\
\end{array}$ & $\begin{array}{r}42 \\
1 \\
0 \\
\end{array}$ & $\begin{array}{r}939 \\
250 \\
0 \\
\end{array}$ & $\begin{array}{r}7,779 \\
3,185 \\
19,176 \\
\end{array}$ & $\begin{array}{r}1,269 \\
258 \\
1,257 \\
\end{array}$ & $\begin{array}{r}7,779 \\
3,185 \\
19,176 \\
\end{array}$ & $\begin{array}{l}0 \\
0 \\
0 \\
\end{array}$ & $\begin{array}{r}1,464 \\
487 \\
3,401 \\
\end{array}$ & $\begin{array}{r}9,346 \\
5,944 \\
60,927 \\
\end{array}$ & $\begin{array}{r}195 \\
229 \\
2,144 \\
\end{array}$ & $\begin{array}{r}1,567 \\
2,759 \\
41,751 \\
\end{array}$ & $\cdots$ \\
\hline 79 & 1,491 & 43 & 1,189 & 30,140 & 2,784 & 30,140 & 0 & 5,352 & 76,217 & 2,568 & 46,077 & 120 \\
\hline
\end{tabular}


TABLE-47.-Mechanical power-supply equipment,

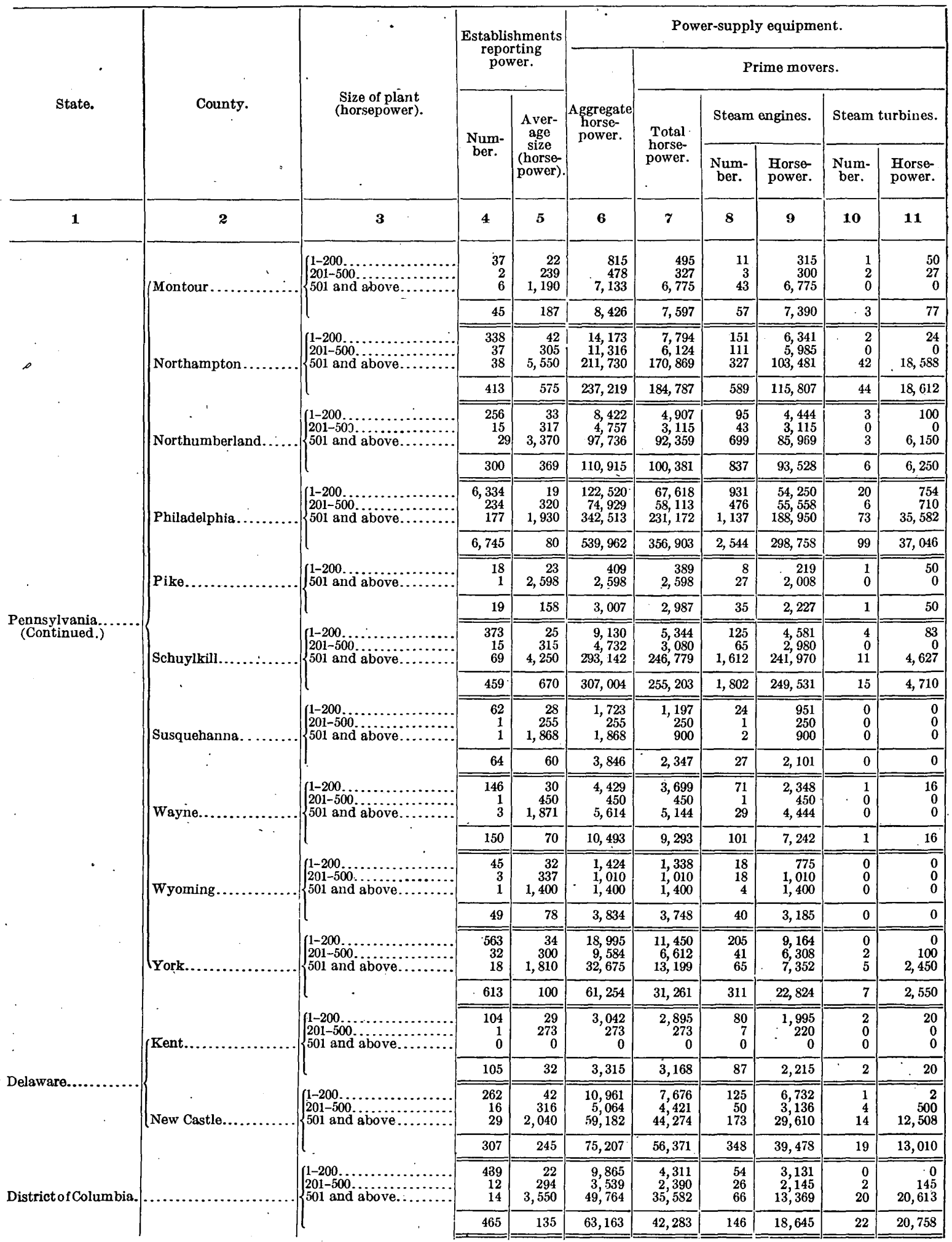


by counties and size of plant-Continued.

\begin{tabular}{|c|c|c|c|c|c|c|c|c|c|c|c|c|}
\hline \multicolumn{8}{|c|}{ Power-supply equipment-Continued. } & \multicolumn{4}{|c|}{ Electric motors. } & \multirow{4}{*}{$\begin{array}{c}\text { Number } \\
\text { of estab- } \\
\text { lishments } \\
\text { reporting } \\
\text { no power. }\end{array}$} \\
\hline \multicolumn{4}{|c|}{ Prime movers-Continued. } & \multicolumn{4}{|c|}{ Operated by purchased energy. } & \multirow{2}{*}{\multicolumn{2}{|c|}{ Total. }} & \multirow{2}{*}{\multicolumn{2}{|c|}{$\begin{array}{l}\text { Run by current } \\
\text { generated in } \\
\text { establishment. }\end{array}$}} & \\
\hline $\begin{array}{l}\text { Interna } \\
\text { tion } 0\end{array}$ & $\begin{array}{l}\text {-combus- } \\
\text { nginos. }\end{array}$ & Water & wheels. & \multirow{2}{*}{$\begin{array}{l}\text { Total } \\
\text { horse- } \\
\text { power. }\end{array}$} & \multicolumn{2}{|c|}{ Electric motors. } & \multirow{2}{*}{$\begin{array}{c}\text { Other } \\
\text { (horse- } \\
\text { power). }\end{array}$} & & & & & \\
\hline $\begin{array}{c}\text { Num- } \\
\text { ber. }\end{array}$ & $\begin{array}{l}\text { Horso- } \\
\text { power. }\end{array}$ & $\begin{array}{c}\text { Num- } \\
\text { ber. }\end{array}$ & $\begin{array}{l}\text { Horse- } \\
\text { power. }\end{array}$ & & Number. & $\begin{array}{l}\text { Horse- } \\
\text { power. }\end{array}$ & & Number. & $\begin{array}{l}\text { Horse- } \\
\text { power. }\end{array}$ & Number. & $\begin{array}{l}\text { Horse- } \\
\text { power. }\end{array}$ & \\
\hline 12 & $\mathbf{1 3}$ & 14 & 15 & 16 & 17 & 18 & 19 & $\cdot 20$ & 21 & 22 & 23 & 24 \\
\hline $\begin{array}{l}7 \\
0 \\
0\end{array}$ & $\begin{array}{r}79 \\
0 \\
0\end{array}$ & $\begin{array}{l}4 \\
0 \\
0\end{array}$ & $\begin{array}{r}51 \\
0 \\
0\end{array}$ & $\begin{array}{l}320 \\
151 \\
358\end{array}$ & $\begin{array}{l}67 \\
32 \\
18\end{array}$ & $\begin{array}{l}320 \\
151 \\
358\end{array}$ & $\begin{array}{l}0 \\
0 \\
0\end{array}$ & $\begin{array}{l}67 \\
32 \\
19\end{array}$ & $\begin{array}{l}320 \\
151 \\
363\end{array}$ & $\begin{array}{l}0 \\
0 \\
1\end{array}$ & $\begin{array}{l}0 \\
0 \\
5\end{array}$ & (…........ \\
\hline 7 & 79 & 4 & 51 & 829 & 117 & 829 & $\mathbf{0}$ & 118 & 834 & 1 & 5 & 13 \\
\hline $\begin{array}{l}21 \\
2 \\
23\end{array}$ & $\begin{array}{r}195 \\
48 \\
48,500\end{array}$ & $\begin{array}{r}41 \\
2 \\
4\end{array}$ & $\begin{array}{r}1,234 \\
135 \\
300\end{array}$ & $\begin{array}{r}6,379 \\
5,192 \\
40,361\end{array}$ & $\begin{array}{l}1,392 \\
325 \\
2,134\end{array}$ & $\begin{array}{r}6,379 \\
5,192 \\
40,861 \\
\end{array}$ & $\begin{array}{l}0 \\
0 \\
0 \\
\end{array}$ & $\begin{array}{r}1,443 \\
10,038 \\
10,038\end{array}$ & $\begin{array}{r}7,021 \\
5,437 \\
232,743\end{array}$ & $\begin{array}{r}51 \\
22 \\
7,904 \\
\end{array}$ & $\begin{array}{r}642 \\
245 \\
191,882\end{array}$ & \\
\hline 46 & 48,699 & 47 & 1,669 & 52,432 & 3,851 & 52,432 & 0 & 11,828 & 245,201 & 7,977 & 192,769 & 49 \\
\hline $\begin{array}{r}25 \\
0 \\
6\end{array}$ & $\begin{array}{r}270 \\
0 \\
240\end{array}$ & $\begin{array}{l}4 \\
0 \\
0\end{array}$ & $\begin{array}{r}93 \\
0 \\
0\end{array}$ & $\begin{array}{l}3,515 \\
1,642 \\
5,377\end{array}$ & $\begin{array}{r}560 \\
36 \\
203\end{array}$ & $\begin{array}{l}3,515 \\
1,642 \\
5,377 \\
\end{array}$ & $\begin{array}{l}0 \\
0 \\
0 \\
\end{array}$ & $\begin{array}{r}677 \\
407 \\
1,283 \\
\end{array}$ & $\begin{array}{r}3,904 \\
1,860 \\
20,889 \\
\end{array}$ & $\begin{array}{r}117 \\
371 \\
1,080 \\
\end{array}$ & $\begin{array}{r}389 \\
218 \\
15,512 \\
\end{array}$ & \\
\hline 31 & 510 & 4 & 93 & 10,534 & 799 & 10,534 & 0 & 2,367 & 26,653 & 1,568 & 16,119 & 41 \\
\hline $\begin{array}{r}807 \\
17 \\
17\end{array}$ & $\begin{array}{r}12,525 \\
1,685 \\
4,640\end{array}$ & $\begin{array}{l}9 \\
3 \\
3\end{array}$ & $\begin{array}{r}89 \\
160 \\
2,000\end{array}$ & $\begin{array}{r}54,902 \\
16,816 \\
111,341\end{array}$ & $\begin{array}{r}15,110 \\
1,925 \\
9,062\end{array}$ & $\begin{array}{r}48,915 \\
16,201 \\
111,341\end{array}$ & $\begin{array}{r}5,987 \\
615 \\
0\end{array}$ & $\begin{array}{l}17,201 \\
5,216 \\
20,213\end{array}$ & $\begin{array}{r}59,801 \\
38,649 \\
241,732\end{array}$ & $\begin{array}{r}2,091 \\
3,291 \\
11,151\end{array}$ & $\begin{array}{r}10,886 \\
22,448 \\
130,391\end{array}$ & \\
\hline 844 & 18,850 & 15 & 2,249 & 183,059 & 26,097 & 176,457 & 6,602 & 42,630 & 340,182 & 16,533 & 163,725 & 2,427 \\
\hline $\begin{array}{l}8 \\
5\end{array}$ & $\begin{array}{r}45 \\
590\end{array}$ & $\begin{array}{l}3 \\
0\end{array}$ & $\begin{array}{r}75 \\
0\end{array}$ & $\begin{array}{r}20 \\
0\end{array}$ & $\begin{array}{l}1 \\
0\end{array}$ & $\begin{array}{r}20 \\
0\end{array}$ & $\begin{array}{l}0 \\
0\end{array}$ & $\begin{array}{l}1 \\
0\end{array}$ & $\begin{array}{r}20 \\
0\end{array}$ & $\begin{array}{l}0 \\
0\end{array}$ & $\begin{array}{l}0 \\
0\end{array}$ & \\
\hline 13 & 635 & 3 & 75 & 20 & 1 & 20 & 0 & 1 & 20 & 0 & $\mathbf{0}$ & 11 \\
\hline $\begin{array}{r}41 \\
4 \\
9\end{array}$ & $\begin{array}{l}398 \\
100 \\
182\end{array}$ & $\begin{array}{r}14 \\
0 \\
0\end{array}$ & $\begin{array}{r}282 \\
0 \\
0\end{array}$ & $\begin{array}{r}3,786 \\
1,652 \\
46,363\end{array}$ & $\begin{array}{l}773 \\
110 \\
520\end{array}$ & $\begin{array}{r}3,786 \\
1,652 \\
46,363\end{array}$ & $\begin{array}{l}0 \\
0 \\
0\end{array}$ & $\begin{array}{r}811 \\
186 \\
1,008\end{array}$ & $\begin{array}{r}4,059 \\
2,366 \\
66,935\end{array}$ & $\begin{array}{r}38 \\
76 \\
488\end{array}$ & $\begin{array}{r}273 \\
714 \\
20,572\end{array}$ & \\
\hline 54 & 680 & 14 & 282 & 51,801 & 1,403 & 51,801 & 0 & 2,005 & 73,360 & 602 & 21,559 & 90 \\
\hline $\begin{array}{r}11 \\
0 \\
0\end{array}$ & $\begin{array}{r}161 \\
0 \\
0\end{array}$ & $\begin{array}{l}3 \\
0 \\
0\end{array}$ & $\begin{array}{r}85 \\
0 \\
0\end{array}$ & $\begin{array}{r}526 \\
5 \\
968\end{array}$ & $\begin{array}{r}73 \\
2 \\
46\end{array}$ & $\begin{array}{r}526 \\
5 \\
968\end{array}$ & $\begin{array}{l}0 \\
0 \\
0\end{array}$ & $\begin{array}{l}73 \\
26 \\
46\end{array}$ & $\begin{array}{l}526 \\
218 \\
968\end{array}$ & $\begin{array}{r}0 \\
24 \\
0\end{array}$ & $\begin{array}{r}0 \\
213 \\
0\end{array}$ & \\
\hline 11 & 161 & 3 & 85 & 1,499 & 121 & 1,499 & 0 & 145 & 1,712 & 24 & 213 & 17 \\
\hline \begin{tabular}{r|}
13 \\
0 \\
0
\end{tabular} & $\begin{array}{r}121 \\
0 \\
0\end{array}$ & $\begin{array}{r}33 \\
0 \\
2\end{array}$ & $\begin{array}{r}1,214 \\
0 \\
700\end{array}$ & $\begin{array}{r}730 \\
0 . \\
470\end{array}$ & $\begin{array}{r}130 \\
0 \\
81\end{array}$ & $\begin{array}{r}862 \\
0 \\
470 \\
\end{array}$ & $\begin{array}{r}48 \\
0 \\
0 \\
\end{array}$ & $\begin{array}{r}148 \\
0 \\
288\end{array}$ & $\begin{array}{r}831 \\
0 \\
2,822\end{array}$ & $\begin{array}{r}18 \\
0 \\
207\end{array}$ & $\begin{array}{r}149 \\
0 \\
2,352\end{array}$ & ……..... \\
\hline 13 & 121 & 35 & 1,914 & 1,200 & 211 & 1,152 & 48 & 436 & 3,653 & 225 & 2,501 & 21 \\
\hline $\begin{array}{r}17 \\
0 \\
0\end{array}$ & $\begin{array}{r}179 \\
0 \\
0\end{array}$ & $\begin{array}{r}11 \\
0 \\
0\end{array}$ & $\begin{array}{r}384 \\
0 \\
0\end{array}$ & $\begin{array}{r}86 \\
0 \\
0\end{array}$ & $\begin{array}{r}10 \\
0 \\
0\end{array}$ & $\begin{array}{r}46 \\
0 \\
0\end{array}$ & $\begin{array}{r}40 \\
0 \\
0\end{array}$ & $\begin{array}{r}10 \\
2 \\
44\end{array}$ & $\begin{array}{r}46 \\
30 \\
751\end{array}$ & $\begin{array}{r}0 \\
2 \\
44\end{array}$ & $\begin{array}{r}0 \\
30 \\
751\end{array}$ & 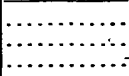 \\
\hline 17 & 179 & 11 & 384 & 86 & 10 & 46 & 40 & 56 & 827 & 46 & 781 & 5 \\
\hline $\begin{array}{r}89 \\
6 \\
2\end{array}$ & $\begin{array}{r}670 \\
204 \\
7\end{array}$ & $\begin{array}{c}83 \\
0 \\
18\end{array}$ & $\begin{array}{r}1,616 \\
3,390 \\
3,3\end{array}$ & $\begin{array}{r}7,545 \\
2,972 \\
19,776 \\
\end{array}$ & $\begin{array}{l}1,336 \\
309 \\
1,577\end{array}$ & $\begin{array}{r}7,450 \\
2,972 \\
19,476 \\
\end{array}$ & $\begin{array}{r}95 \\
0 \\
0 \\
\end{array}$ & $\begin{array}{l}1,555 \\
513 \\
1,600\end{array}$ & $\begin{array}{r}8,713 \\
4,264 \\
19,965\end{array}$ & $\begin{array}{l}219 \\
204 \\
23\end{array}$ & $\begin{array}{r}1,263 \\
1,292 \\
489\end{array}$ & $\begin{array}{l}\ldots \ldots . . \\
\cdots \cdots . . . \\
\cdots \cdots \cdots\end{array}$ \\
\hline 97 & 881 & 101 & 5,006 & 29,993 & 3,222 & 29,898 & 95 & 3,668 & 32,942 & 446 & 3,044 & 428 \\
\hline $\begin{array}{r}33 \\
4 \\
0 \\
\end{array}$ & $\begin{array}{r}504 \\
53 \\
0 \\
\end{array}$ & $\begin{array}{r}18 \\
0 \\
0 \\
\end{array}$ & $\begin{array}{r}376 \\
0 \\
0 \\
\end{array}$ & $\begin{array}{r}147 \\
0 \\
0\end{array}$ & $\begin{array}{r}59 \\
0 \\
5\end{array}$ & $\begin{array}{r}147 \\
0 \\
0\end{array}$ & $\begin{array}{l}0 \\
0 \\
0\end{array}$ & $\begin{array}{r}64 \\
0 \\
05 \\
\end{array}$ & $\begin{array}{r}197 \\
0 \\
0\end{array}$ & $\begin{array}{l}5 \\
0 \\
0\end{array}$ & $\begin{array}{r}50 \\
0 \\
0\end{array}$ & …….... \\
\hline 37 & 557 & 18 & 376 & 147 & 64 & 147 & 0 & 69 & 197 & 5 & 50 & 6 \\
\hline $\begin{array}{r}18 \\
6 \\
3\end{array}$ & $\begin{array}{r}222 \\
160 \\
15\end{array}$ & $\begin{array}{r}22 \\
6 \\
3\end{array}$ & $\begin{array}{r}720 \\
625 \\
2,141\end{array}$ & $\begin{array}{r}3,285 \\
643 \\
14,908 .\end{array}$ & $\begin{array}{r}699 \\
73 \\
760\end{array}$ & $\begin{array}{r}3,240 \\
643 \\
14,908\end{array}$ & $\begin{array}{r}45 \\
0 \\
0\end{array}$ & $\begin{array}{r}723 \\
177 \\
2,272\end{array}$ & $\begin{array}{r}3,456 \\
1,768 \\
38,522\end{array}$ & $\begin{array}{r}24 \\
104 \\
1,512\end{array}$ & $\begin{array}{r}216 \\
1,125 \\
23,614\end{array}$ & ….... \\
\hline 27 & 397 & 27 & 3,486 & 18,836 & 1,532 & 18,791 & 45 & 3,172 & 43,746 & 1,640 & 24,955 & 59 \\
\hline $\begin{array}{r}55 \\
0 \\
6\end{array}$ & $\begin{array}{r}739 \\
1,475\end{array}$ & $\begin{array}{l}3 \\
1 \\
1\end{array}$ & $\begin{array}{l}441 \\
100 \\
125\end{array}$ & $\begin{array}{r}5,554 \\
1,149 \\
14,182\end{array}$ & $\begin{array}{l}2,048 \\
121 \\
1,041 .\end{array}$ & $\begin{array}{r}5,544 \\
1,149 \\
14,182\end{array}$ & $\begin{array}{r}10 \\
0 \\
0\end{array}$ & $\begin{array}{l}2,174 \\
247 \\
7,070\end{array}$ & $\begin{array}{r}6,039 \\
2,412 \\
68,987\end{array}$ & $\begin{array}{r}126 \\
126 \\
0,029\end{array}$ & $\begin{array}{r}495 \\
1,263 \\
54,805\end{array}$ & ……... \\
\hline 61 & 2,214 & 5 & 666 & 20,885 & 3,210 & 20,875 & 10 & 9,491 & 77,438 & 6,281 & 56,563 & 170 \\
\hline
\end{tabular}


TABLE 47.-Mechanical power-supply equipment,

\begin{tabular}{|c|c|c|c|c|c|c|c|c|c|c|}
\hline \multirow{4}{*}{ State. } & \multirow{4}{*}{ County. } & \multirow{4}{*}{$\begin{array}{l}\text { Size of plant } \\
\text { (horsepower). }\end{array}$} & \multirow{2}{*}{\multicolumn{2}{|c|}{$\begin{array}{l}\text { Establishments } \\
\text { reporting } \\
\text { power. }\end{array}$}} & \multicolumn{6}{|c|}{ Power-supply equipment. } \\
\hline & & & & & \multirow{3}{*}{$\begin{array}{c}\text { Aggregate } \\
\text { horse-. } \\
\text { power. }\end{array}$} & \multicolumn{5}{|c|}{ Prime movers. } \\
\hline & & & \multirow{2}{*}{$\underset{\text { ber. }}{\text { Num- }}$} & \multirow{2}{*}{$\begin{array}{c}\text { Aver- } \\
\text { age } \\
\text { size } \\
\text { (horse- } \\
\text { power). }\end{array}$} & & \multirow{2}{*}{$\begin{array}{l}\text { Total } \\
\text { horse- } \\
\text { power. }\end{array}$} & \multicolumn{2}{|c|}{ Steam engines. } & \multicolumn{2}{|c|}{ Steam turbines. } \\
\hline & & & & & & & $\begin{array}{c}\text { Num- } \\
\text { ber. }\end{array}$ & $\begin{array}{l}\text { Horse- } \\
\text { power. }\end{array}$ & $\begin{array}{l}\text { Num- } \\
\text { ber. }\end{array}$ & $\begin{array}{l}\text { Horse- } \\
\text { power. }\end{array}$ \\
\hline 1 & 2 & 3 & 4 & $\mathbf{5}$ & 6 & .7 & 8 & $\mathbf{9}$ & 10 & 11. \\
\hline \multirow{7}{*}{ Marylan } & \multirow[t]{3}{*}{ (Anne Arundel.. } & \multirow{3}{*}{$\begin{array}{l}\left\{\begin{array}{l}1-200 \\
201-500 \ldots \ldots \ldots \ldots\end{array}\right. \\
501 \text { and above } \ldots\end{array}$} & $\begin{array}{r}44 \\
2 \\
2\end{array}$ & $\begin{array}{r}25 \\
299 \\
.983\end{array}$ & $\begin{array}{l}1,075 \\
597 \\
1,965\end{array}$ & $\begin{array}{r}685 \\
\quad \quad 250 \\
-\quad 0\end{array}$ & $\begin{array}{r}28 \\
1 \\
0\end{array}$ & $\begin{array}{r}531 \\
250 \\
0\end{array}$ & $\begin{array}{l}1 \\
0 \\
0\end{array}$ & $\begin{array}{r}10 \\
0 \\
0\end{array}$ \\
\hline & & & 48 & 76 & 3,637 & 935 & 29 & 781 & 1 & 10 \\
\hline & & & $\begin{array}{r}90 \\
6 \\
7\end{array}$ & $\begin{array}{r}25 \\
301 \\
15,300\end{array}$ & $\begin{array}{r}2,285 \\
1,808 \\
107,089\end{array}$ & $\begin{array}{r}1,646 \\
1,492 \\
83,470\end{array}$ & $\begin{array}{l}38 \\
22 \\
11\end{array}$ & $\begin{array}{r}1,146 \\
: 1,492 \\
21,470\end{array}$ & $\begin{array}{r}0 \\
0 \\
13 \\
\end{array}$ & $\begin{array}{r}0 \\
0 \\
4,495\end{array}$ \\
\hline & \multirow{2}{*}{ Baltimore City. } & \multirow[b]{2}{*}{ 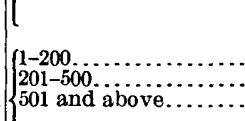 } & 103 & 1,080 & 111,182 & 87,008 & 71 & 24,108 & 13 & 4,495 \\
\hline & & & $\begin{array}{r}1,863 \\
99 \\
74\end{array}$ & $\begin{array}{r}38 \\
317 \\
1,730\end{array}$ & $\begin{array}{r}70,862 \\
31,412 \\
128,473\end{array}$ & $\begin{array}{l}18,411 \\
18,659 \\
41,591\end{array}$ & $\begin{array}{l}295 \\
161 \\
413\end{array}$ & $\begin{array}{l}16,035 \\
17,787 \\
35,342\end{array}$ & $\begin{array}{r}5 \\
7 \\
28\end{array}$ & $\begin{array}{r}315 \\
271 \\
4,153\end{array}$ \\
\hline & \multirow{2}{*}{$\begin{array}{c} \\
. \\
\text { Cecil.............. }\end{array}$} & \multirow{2}{*}{ 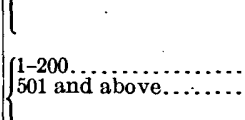 } & 2,036 & 113 & 230,747 & 78,661 & 869 & 69,164 & 40 & 4,739 \\
\hline & & & $\begin{array}{r}78 \\
6\end{array}$ & $\begin{array}{r}36 \\
884\end{array}$ & $\begin{array}{l}2,854 \\
5,308\end{array}$ & $\begin{array}{l}2,455 \\
5,308\end{array}$ & $\begin{array}{l}50 \\
76\end{array}$ & $\begin{array}{l}1,638 \\
4,880\end{array}$ & $\begin{array}{l}0 \\
0\end{array}$ & $\begin{array}{l}0 \\
0\end{array}$ \\
\hline \multirow[t]{9}{*}{ Marylaso } & \multirow{2}{*}{ Harford............ } & \multirow[b]{2}{*}{$\begin{array}{l}1-200 \ldots \ldots \ldots \ldots \ldots \\
201-500 \ldots \ldots \ldots \ldots\end{array}$} & 84 & 97 & 8,162 & 7,763 & 126 & 6,518 & 0 & 0 \\
\hline & & & $\begin{array}{r}164 \\
5 \\
1\end{array}$ & $\begin{array}{r}24 \\
282 \\
750\end{array}$ & $\begin{array}{l}3,961 \\
1,410 \\
750\end{array}$ & $\begin{array}{l}3,295 \\
1,380 \\
750\end{array}$ & $\begin{array}{r}132 \\
13 \\
0\end{array}$ & $\begin{array}{r}2,190 \\
780 \\
0\end{array}$ & $\begin{array}{l}1 \\
0 \\
1\end{array}$ & $\begin{array}{r}15 \\
0 \\
750\end{array}$ \\
\hline & & \multirow{3}{*}{$\int_{\{1-200 \ldots \ldots \ldots \ldots \ldots \ldots}^{l}}$. & 170 & 36 & 6,121 & 5,425 & 145 & 2,970 & 2 & 765 \\
\hline & & & 44 & 35 & 1,548 & 1,541 & 34 & 1,149 & 1 & 12 \\
\hline & \multirow{3}{*}{ Prince Georges.. } & & 44 & 35 & 1,548 & 1,541 & 34 & 1,149 & 1 & 12 \\
\hline & & \multirow{4}{*}{$\begin{array}{l}\left\{\begin{array}{l}1-200 \ldots \ldots \ldots \ldots \ldots \ldots \\
\{1-200 \ldots \ldots \ldots \ldots \ldots \ldots\end{array}\right. \\
\left\{\begin{array}{l} \\
\{\end{array}\right.\end{array}$} & 46 & 16 & 746 & 734 & 32 & 620 & 0 & 0 \\
\hline & & & 46 & 16 & 746 & 734 & 32 & 620 & 0 & 0 \\
\hline & \multirow{2}{*}{ Queen Annes.......... } & & 41 & 24 & 1,002 & 933 & 32 & 766 & 0 & 0 \\
\hline & & & 41 & 24 & 1,002 & 933 & 32 & 766 & 0 & 0 \\
\hline
\end{tabular}


by counties and size of plant-Continued.

\begin{tabular}{|c|c|c|c|c|c|c|c|c|c|c|c|c|}
\hline \multicolumn{8}{|c|}{ Power-supply oquipment-Continued. } & \multicolumn{4}{|c|}{ Electric motors. } & \multirow{4}{*}{$\begin{array}{l}\text { Number } \\
\text { of estab- } \\
\text { lishments } \\
\text { reporting } \\
\text { no power. }\end{array}$} \\
\hline \multicolumn{4}{|c|}{ Primo movors-Continued. } & \multicolumn{4}{|c|}{ Operated by purchased energy. } & \multirow{2}{*}{\multicolumn{2}{|c|}{ Total. }} & \multirow{2}{*}{\multicolumn{2}{|c|}{$\begin{array}{c}\text { Run by current } \\
\text { generated in } \\
\text { establishment. }\end{array}$}} & \\
\hline $\begin{array}{l}\text { Interng } \\
\text { tion }\end{array}$ & $\begin{array}{l}\text { combus- } \\
\text { igines. }\end{array}$ & Water & wheels. & \multirow{2}{*}{$\begin{array}{l}\text { ' } \\
\text { Total } \\
\text { horse- } \\
\text { power. }\end{array}$} & \multicolumn{2}{|c|}{ Electric motors. } & \multirow{2}{*}{$\begin{array}{l}\text { Other } \\
\text { (horse- } \\
\text { power). }\end{array}$} & & & & & \\
\hline$\underset{\text { ber. }}{\text { Num- }}$ & $\begin{array}{l}\text { Horse- } \\
\text { power. }\end{array}$ & $\begin{array}{c}\text { Num-' } \\
\text { ber. }\end{array}$ & $\begin{array}{l}\text { Horse- } \\
\text { power. }\end{array}$ & & Number. & $\begin{array}{l}\text { Horse- } \\
\text { power. }\end{array}$ & & Number. & $\begin{array}{l}\text { Horse- } \\
\text { power. }\end{array}$ & Number. & $\begin{array}{l}\text { Horse- } \\
\text { power. }\end{array}$ & \\
\hline 12 & 13 & 14 & 15 & 16 & 17 & 18 & 19 & 20 & 21 & $\mathbf{2 2}$ & 23 & $\mathbf{2 4}$ \\
\hline $\begin{array}{l}3 \\
0 \\
0 \\
\end{array}$ & $\begin{array}{r}144 \\
0 \\
0 \\
\end{array}$ & $\begin{array}{l}0 \\
0 \\
0\end{array}$ & $\begin{array}{l}\mathbf{0} \\
0 \\
0 \\
\end{array}$ & $\begin{array}{r}390 \\
347 \\
1,965 \\
\end{array}$ & $\begin{array}{l}80 \\
25 \\
51 \\
\end{array}$ & $\begin{array}{r}390 \\
347 \\
1,965 \\
\end{array}$ & $\begin{array}{l}0 \\
0 \\
0 \\
\end{array}$ & $\begin{array}{l}81 \\
25 \\
51 \\
\end{array}$ & $\begin{array}{r}399 \\
347 \\
1,965 \\
\end{array}$ & $\begin{array}{l}1 \\
0 \\
0 \\
\end{array}$ & $\begin{array}{l}9 \\
0 \\
0\end{array}$ & 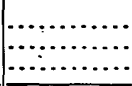 \\
\hline 3 & 144 & 0 & 0 & 2,702 & 156 & 2,702 & 0 & 157 & 2,711 & 1 & 9 & 7 \\
\hline $\begin{array}{r}15 \\
0 \\
17 \\
\end{array}$ & $\begin{array}{r}96 \\
0 \\
55,700 \\
\end{array}$ & $\begin{array}{r}20 \\
0 \\
11\end{array}$ & $\begin{array}{r}404 \\
0 \\
2,205 \\
\end{array}$ & $\begin{array}{r}639 \\
316 \\
23,219\end{array}$ & $\begin{array}{r}63 \\
101 \\
698 \\
\end{array}$ & $\begin{array}{r}635 \\
316 \\
23,219 \\
\end{array}$ & $\begin{array}{r}4 \\
-\quad 0 \\
\quad 0 \\
\end{array}$ & $\begin{array}{r}83 \\
101 \\
2,745 \\
\end{array}$ & $\begin{array}{r}792 \\
316 \\
133,314 \\
\end{array}$ & $\begin{array}{r}20 \\
0 \\
2,047 \\
\end{array}$ & $\begin{array}{r}157 \\
0 \\
110,095 \\
\end{array}$ & \\
\hline 32 & 55,796 & 31 & 2,609 & 24,174 & 862 & 24,170 & 4 & 2,929 & 134,422 & 2,067 & 110,252 & 28 \\
\hline $\begin{array}{r}138 \\
10 \\
10\end{array}$ & $\begin{array}{r}1,887 \\
601 \\
2,096\end{array}$ & $\begin{array}{l}3 \\
0 \\
0 \\
\end{array}$ & $\begin{array}{r}174 \\
0 \\
0 \\
\end{array}$ & $\begin{array}{l}52,451 \\
12,753 \\
86,882 \\
\end{array}$ & $\begin{array}{l}6,011 \\
1,059 \\
5,555\end{array}$ & $\begin{array}{l}52,342 \\
12,753 \\
86,882\end{array}$ & $\begin{array}{r}109 \\
0 \\
0\end{array}$ & $\begin{array}{l}6,511 \\
1,824 \\
6,427\end{array}$ & $\begin{array}{r}54,709 \\
17,996 \\
. \quad 97,128\end{array}$ & $\begin{array}{l}500 \\
765 \\
872 \\
\end{array}$ & $\begin{array}{r}2,367 \\
5,243 \\
10,256\end{array}$ & 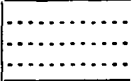 \\
\hline 104 & 4,584 & 3 & 174 & 152,086 & 12,625 & 151,977 & 109 & 14,762 & 169,843 & 2,137 & 17,866 & 796 \\
\hline 23 & $\begin{array}{l}180 \\
128\end{array}$ & $\begin{array}{r}23 \\
2 \\
\end{array}$ & $\begin{array}{l}637 \\
300\end{array}$ & $\begin{array}{r}399 \\
0\end{array}$ & $\begin{array}{r}38 \\
0\end{array}$ & $\begin{array}{r}399 \\
0\end{array}$ & $\begin{array}{l}0 \\
0\end{array}$ & $\begin{array}{l}69 \\
15 \\
\end{array}$ & $\begin{array}{l}491 \\
193\end{array}$ & $\begin{array}{l}31 \\
15\end{array}$ & $\begin{array}{r}92 \\
193\end{array}$ & 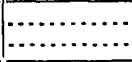 \\
\hline 30 & 308 & 25 & 937 & 399 & 38 & 399 & 0 & 84 & 684 & 46 & 285 & 12 \\
\hline $\begin{array}{r}41 \\
0 \\
0\end{array}$ & $\begin{array}{r}389 \\
0 \\
0 \\
\end{array}$ & $\begin{array}{r}24 \\
2 \\
0 \\
\end{array}$ & $\begin{array}{r}701 \\
600 \\
0 \\
\end{array}$ & $\begin{array}{r}666 \\
30 \\
0\end{array}$ & $\begin{array}{r}77 \\
2 \\
0 \\
\end{array}$ & $\begin{array}{r}666 \\
30 \\
0\end{array}$ & $\begin{array}{l}0 \\
0 \\
0\end{array}$ & $\begin{array}{r}77 \\
2 \\
12 \\
\end{array}$ & $\begin{array}{r}666 \\
30 \\
745\end{array}$ & $\begin{array}{r}0 \\
0 \\
12\end{array}$ & $\begin{array}{r}0 \\
0 \\
745 \\
\end{array}$ & $\begin{array}{l}\cdots \\
\cdots \\
\cdots \cdots \cdots\end{array}$ \\
\hline 41 & 389 & 26 & 1,301 & 696 & 79 & 696 & 0 & 91 & 1,441 & 12 & 745 & 11 \\
\hline 24 & 249 & 6 & 131 & 7 & 2 & 7 & 0 & 3 & 9 & 1 & 2 & …........ \\
\hline 24 & 249 & 6 & 131 & 7 & 2 & 7 & 0 & 3 & 9 & 1 & 2 & 1 \\
\hline 14 & 114 & 0 & 0 &.$\quad 12$ & 6 & 12 & 0 & 6 & 12 & 0 & 0 & $\ldots \ldots$ \\
\hline 14 & 114 & 0 & 0 & 12 & 6 & 12 & 0 & 6 & 12 & 0 & 0 & 23 \\
\hline 11 & 69 & 6 & 98 & 69 & 10 & 69 & 0 & 10 & 69 & 0 & 0 & $\therefore \ldots$ \\
\hline 11 & 69 & 6 & 98 & 69 & 10 & 69 & 0 & 10 & 69 & 0 & 0 & 3 \\
\hline
\end{tabular}




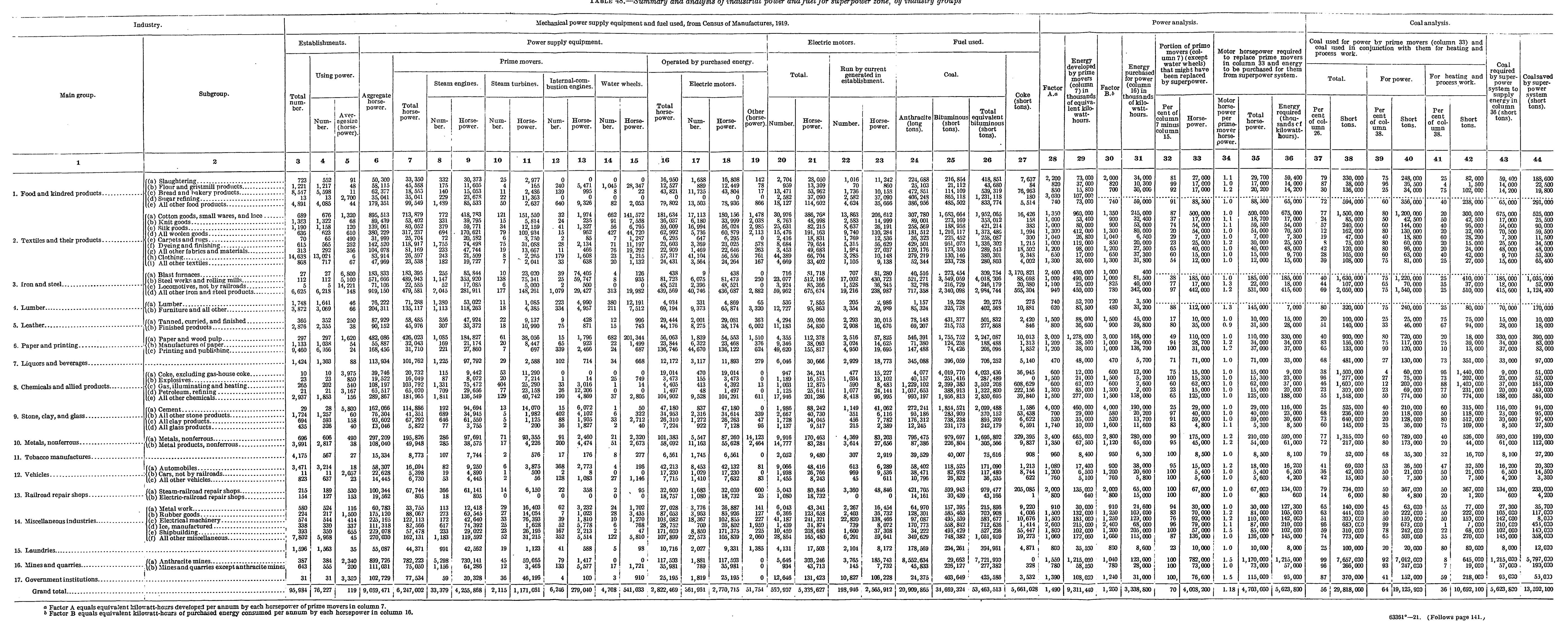




\section{ANALYSIS OF INDUSTRIES. \\ GENERAL FEATURES.}

In order to determine the quantity of coal that might be saved and the amount of power that might have been economically supplied by purchased energy, the detailed statistics of the industries shown in Table 46 were submitted to several engineers and manufacturers, who analyzed the data and gave their opinions as to the amount of energy that might have been economically purchased and the resulting saving of fuel. In the estimates made by this survey due regard has been given to the opinions thus obtained.

The results of this analysis are shown in Table 48. The headings for columns 5 to 27 in Table 48 are the same as the corresponding headings in Tables 44, 45, and 46 . Other columns are explained as follows:

Column 29 is column 7 multiplied by column 28 .

Column 31 is column 16 multiplied by column 30 .

Column 32 is the ratio, in per cent, of column 33 to the difference between column 7 and column 15.

For each size of power plant in each industry the prime mover that might have been replaced by superpower was determined. The sum of these items is shown in column 33 .

Column 34 shows the motor horsepower per prime-mover horsepower as determined by the authorities consulted.

Column 35 is column 33 multiplied by column 34 .

Column 36 is column 35 multiplied by factor B (column 30 ).

Column 37 is ratio in per cent of column 38 to column 26.

Column 43 is based on a consumption by the superpower system of 2 pounds of coal per kilowatt-hour delivered at the motor leads. Column $43=\frac{\text { column } 36 \times 1000 \times 2}{2000}$.

Column 44 equals column 40 minus column 43.

This table shows that the energy developed by prime movers in the industries in 1919 was equivalent to $9,311,440,000$ kilowatt-hours and that the energy purchased was $3,338,800,000$ kilowatt-hours, a total of 12,650,240,000 kilowatt-hours; also that it would have been economical to shut down $4,008,200$ horsepower of prime movers, exclusive of water wheels, and to purchase additional energy to the amount of 5,623,800,000 kilowatt-hours, which would have made a total of $8,962,600,000$ kilowatt-hours of purchased electrical energy.

The total coal used for power by prime movers that might have been replaced by superpower and the coal used in conjunction with them for heating and in manufacturing processes was $29,818,000$ tons, of which $19,125,900$ tons was used for power and 10,692,100 tons for heating and in manufacturing processes. If the energy developed by these prime movers had been purchased, the $19,125,900$ tons of coal burned for power would have been replaced by $5,623,800$ tons burned at the central stations (at the rate of 2 pounds of coal per kilowatt-hour as measured at the motor leads), a saving of $13,502,100$ tons. That is, 71 per cent of the coal used for power by the prime movers or 25 per cent of the total coal used by the industries might have been saved.

In estimating the fuel saved by the superpower system (Table 48) the percentages given in columns 39 and 41, "For power" and "For heating and process work," are to be construed not as percentages for the whole industry but as percentages for only that part for which purchased energy might have been supplied. These percentages were obtained from the analyses made by the authorities consulted.

Column 33 shows the power that might have been supplied economically to each industry by a superpower system. In determining this item the groups that use waste gases for fuel, that use waste-heat boilers, and that have water power were omitted. In all but a very few industries it was found to be more economical for plants of less than 200 horsepower to purchase all the energy they require, regardless of their requirements for heat. Almost the same is true $63361^{\circ}-21-10$ 


\section{A SUPERPOWER SYSTEM FOR THE REGION BETWEEN BOSTON AND WASHINGTON,}

for plants of 201 to 500 horsepower. It is only in plants that are larger than 500 horsepower and that have some special requirements for heat that the generation of power can be justified. Even in these plants the power supply and demand can not be completely balanced, and centralstation connections should be available for taking up irregularities.

\section{SECONDARY SAVINGS.}

In this analysis the only fuel saving credited to the purchase of electrical energy is the direct saving in the production of power. Experience has shown that in plants using purchased power much of the fuel formerly used for process heat can be saved through the simplification of the heating arrangements by the elimination of power production. Further, it was assumed in the analysis that much prime-mover power would be retained, owing to the use of waste-heat boilers and strict modernization of power-producing equipment. Such improvements would undoubtedly also result in an improvement in the heating arrangements similar to that found in an establishment purchasing electrical energy.

WATERWORKS.

The accompanying tables do not include the mechanical power-supply equipment or fuel used by waterworks, because these plants are usually considered in a different class from industries. A survey of the waterworks in the superpower zone shows that they used 260,000 long tons of anthracite and 260,000 short tons of bituminous coal in 1919. To replace this coal would require $340,000,000$ kilowatt-hours of energy, the generation of which would require 340,000 tons of coal, at 2 pounds of coal per kilowatt-hour at the motor leads; this indicates a saving of the equivalent of 154,000 tons of bituminous coal. The possible load due to waterworks has not been included in any figure of this analysis.

\section{COMMENTS ON SPECIAL INDUSTRIES.}

The industry using the largest amount of coal is anthracite mining, and in this industry a coal saving of more than 75 per cent could be made if the mines were supplied from an effcient central electric power system. The present large consumption may be accounted for by the use of inefficient prime movers, long steam lines, inefficient pumps, and improper boiler and furnace design for burning the coal.

Many industries could save coal by the use of waste-heat boilers. Probably the greatest. saving by this means could be made in the cement industry. It is estimated that if waste- heat boilers had been in use in all the cement plants in the superpower zone in 1919, 540,000 tons of coal would have been saved.

There are many blast furnaces in the superpower zone which are isolated from any steel plants or rolling mills, and approximately half their gases are wasted. These gases would produce sufficient heat for boilers to generate 500,000,000 kilowatt-hours a year.

In certain plants the low-pressure steam requirements greatly exceed the power requirements, and there is no reason why such plants should not generate by-product power and sell it to the electrical distributing companies.

\section{ENERGY REQUIRED BY LOAD CENTERS.}

Table 49 gives the electric energy in kilowatt-hours that might have been supplied by a superpower system in 1919 to replace the energy produced by prime movers in isolated plants. The factors for energy requirements obtained from the analysis summarized in Table 48 were applied to the detailed data for each industry in the Bureau of the Census, and the results summarized by load centers are given in Table 49. 
TABLe 49.-Electric energy, in kilowatt-hours, that might have been supplied by a superpower system in 1919 to replace the energy produced by prime movers in isolated plants.

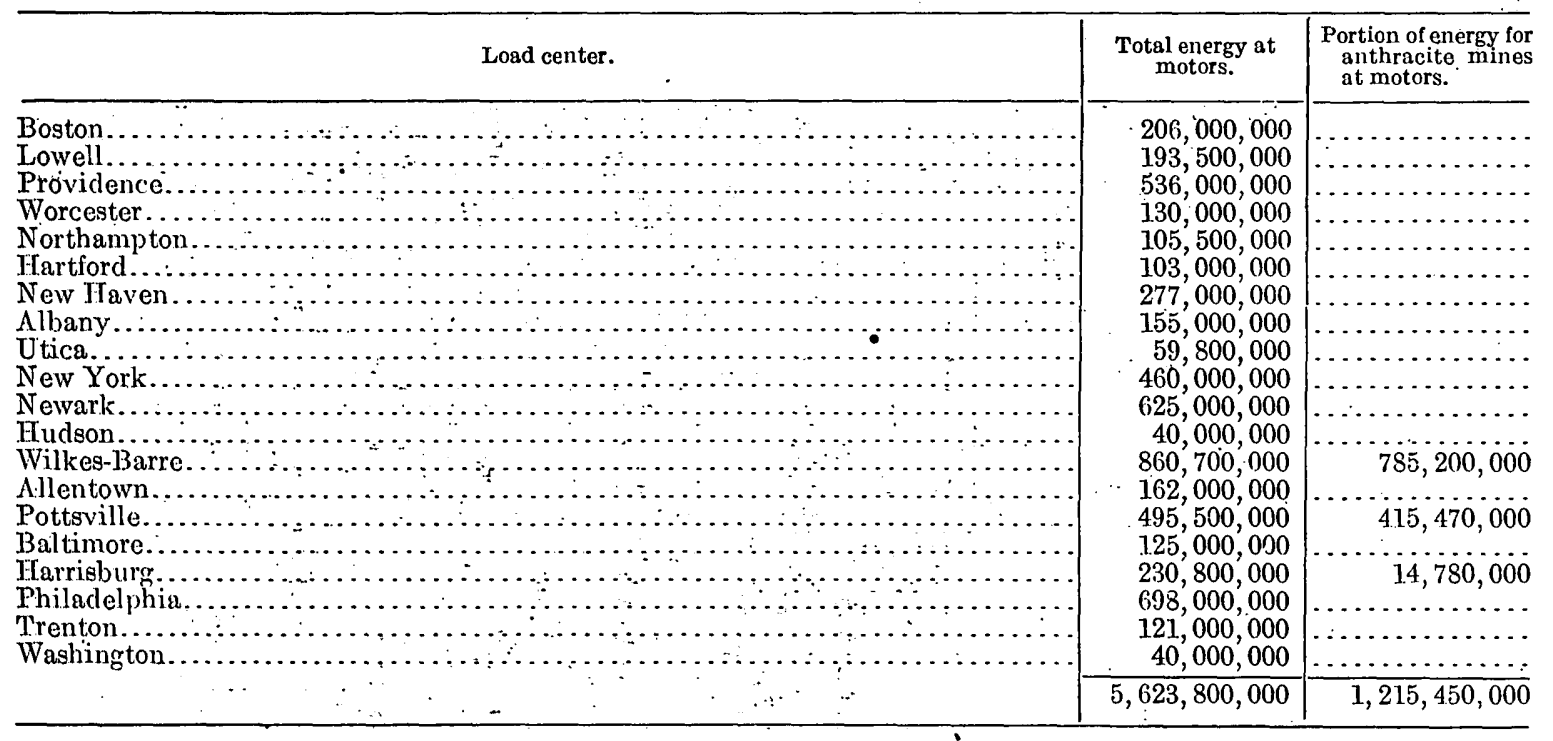

PREDICTION OF - FUTURE LOAD.

Figure 17 shows the past and predicted future industrial mechanical power-supply equipment. The past has been plotted from Census data and the future from the past and the opinion of several authorities on industrial development in the zone. It is shown in Table 48 that on the average 1.18 horsepower of motors is required to replace 1 horsepower of prime movers. The increase in recent years of motors operated by purchased energy has therefore affected the aggregate horsepower, giving the curve an increased slope. This has been considered in predicting the 1930 value, which shows an increase in the aggregate horsepower of 33 per cent from 1919. If the ratio of motors operated by purchased energy to aggregate horsepower remained as in 1919 the increase in aggregate horsepower in 1930 would be only 20 per cent.

The curve of horsepower that might have been supplied by superpower as drawn in figure 17 is based on the analysis in Table 48 for 1919. As in that year 4,008,200 horsepower of prime movers would have been replaced by $4,703,000$ borsepower of motors, it has been necessary to consider the ratios

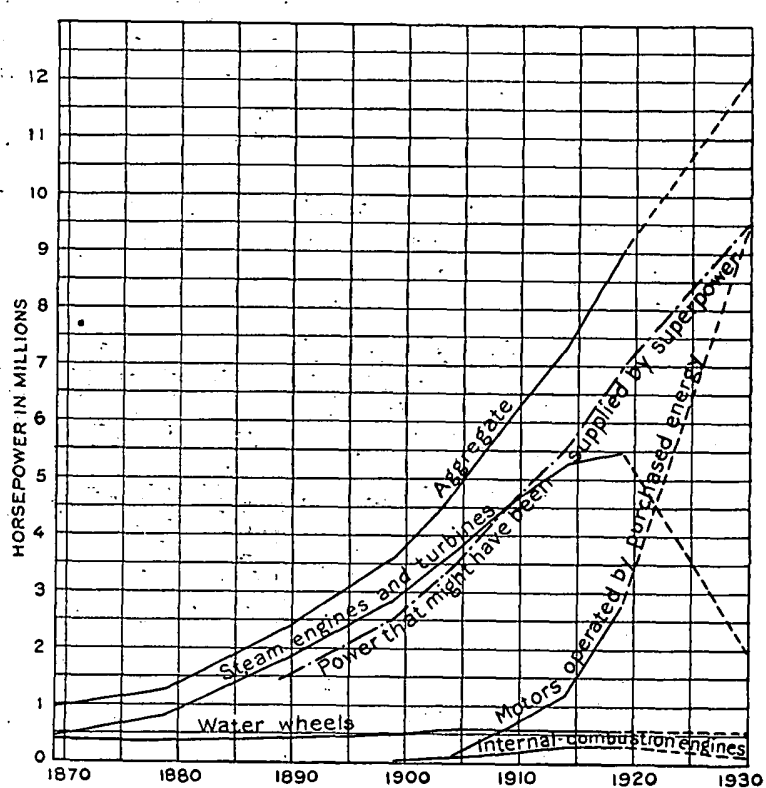

FrgURE 17.-Past and predicted future mechanical power-supply equipment used by industries in superpower zone, 1870-1930. discussed in the preceding paragraph in plotting this curve. When "saturation" is reached in 1930 these considerations are eliminated; prior to that time the form of the curve is correct, but exact values have been adjusted in consideration of the actual horsepower of motors operated by purchased energy.

\section{COST OF INDUSTRIAL POWER.}

Figures 18 and 19 show the comparative cost of power generated in isolated condensing plants of capacities up to 5,000 kilowatts, operating at four load factors, and of purchased power for the same capacities. For the same load factor the curve of the cost of purchased power 


\section{A SUPERPOWER SYSTEM FOR THE REGION BETWEEN BOSTON AND WASHINGTON.}

is considerably below the cost of generated power. As these curves represent condensing plants, all noncondensing plants, where the exhaust 'steam is not utilized in manufacturing, would realize an even greater saving by the purchase of power.

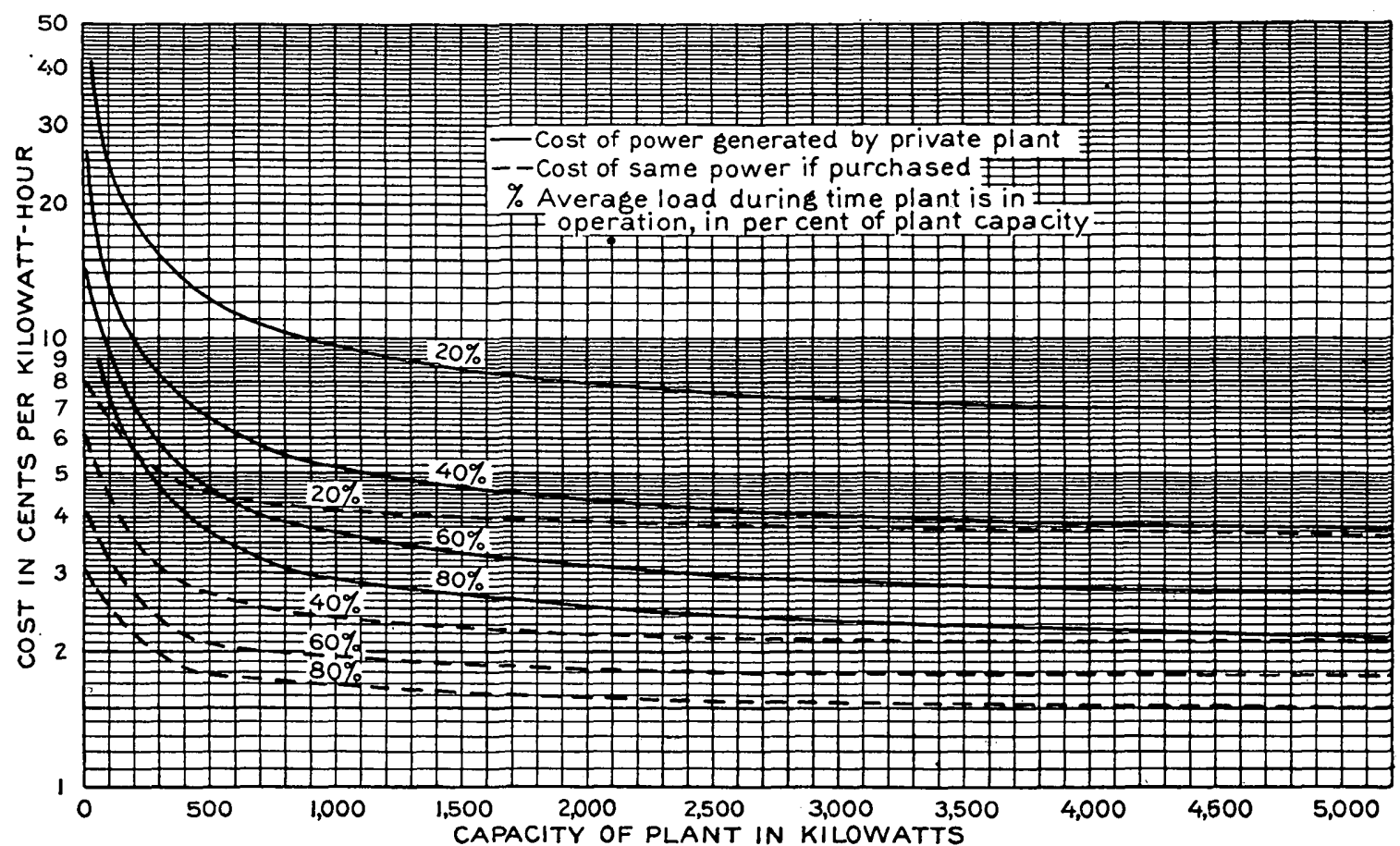

FIGURE 18.-Cost of electric power for industrial plants operating one shift daily. Based on prices and central-station rates prevailing in July, 1919. Coal figured at $\$ 5.18$ per short ton delivered. Fixed charges, 16 per cent.

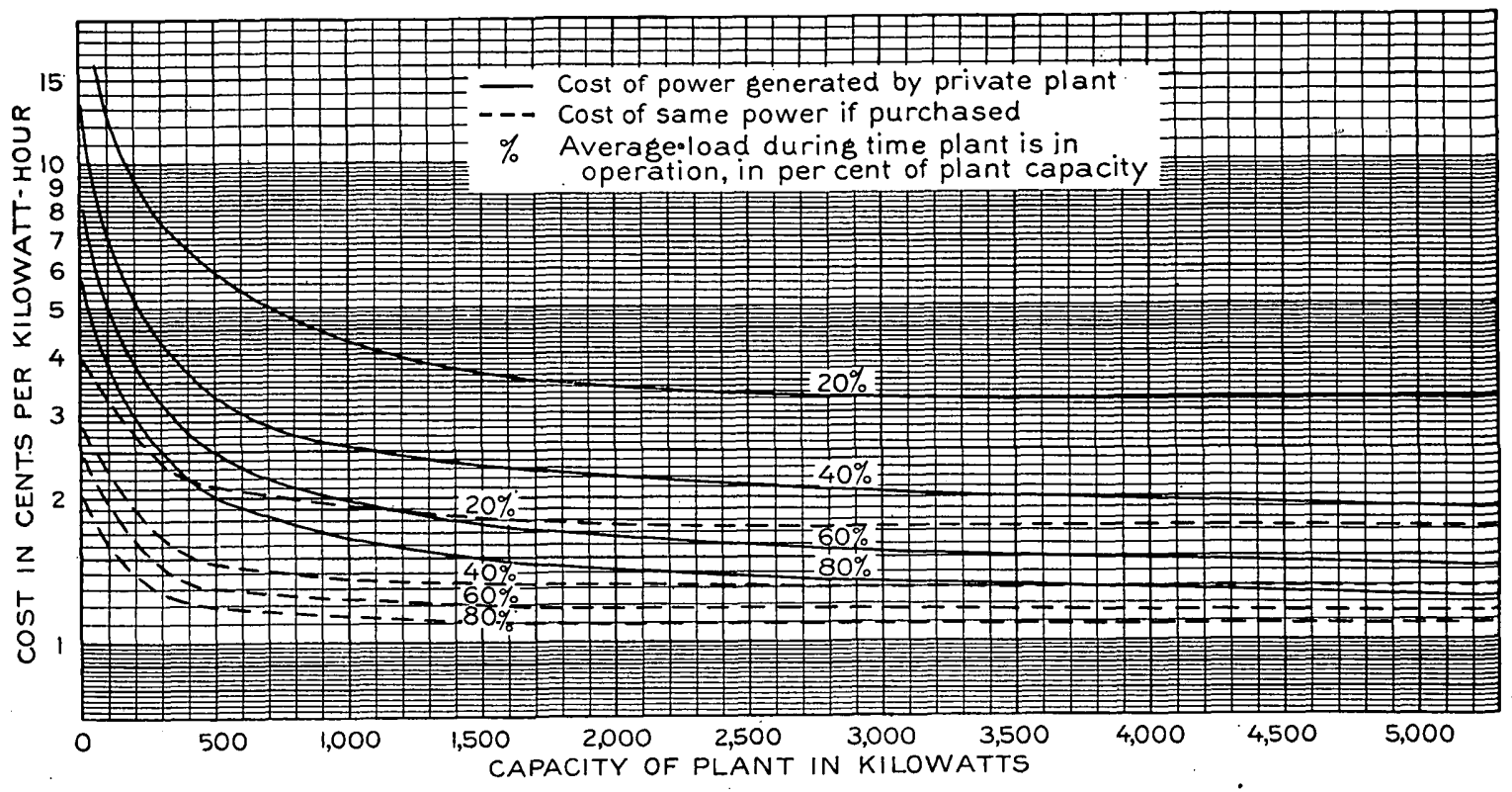

FIGURE 19.-Cost of electric power for industrial plants operating three shifts daily. Based on prices and central-station rates prevailing in July, 1919. Coal figured at $\$ 5.18$ per short ton delivered. Fixed charges, 16 per cent.

\section{ISOLATED PLANTS.}

The cost of power shown for isolated plants includes all labor, fuel, and fixed charges. Labor rates are those of 1919 . Fuel was charged at $\$ 5.18$ per short ton delivered. Fixed charges, including interest, depreciation, taxes, and insurance, were taken as 16 per cent of 
the investment cost as of 1919. The isolated plants were assumed to be designed in accordance with the best modern practice.

\section{CENTRAL STATIONS.}

The central-station rates shown on the curves are the average rates in force in 1919 for several electric utilities that used coal-produced energy exclusively and that supply approximately 400,000,000 kilowatt-hours yearly for industrial power at these rates. The rates are adjusted to coal at $\$ 5.18$ per short ton delivered. At the present time these rates are typical of the large central stations only and not of the smaller companies, which are prevented by limitations of generating capacity from soliciting large power loads. These limitations would, however, be removed by the development of a complete unified system of electric supply.

\section{SAVING IN COST OF POWER TO INDUSTRIES.}

In Table 50 are given estimates showing the saving in cost of power to the industries possible by a change from the several types of power-supply equipment actually used in 1919 to the maximum economical use of purchased electrical energy. The costs of power have been taken from figure 18, the data being applied in detail to each type and average size of plant, and the estimates therefore. show the difference between average best isolated-plant practice and central-station service. Savings are also shown for 1930 on the same basis as for 1919 . A fixed charge of 16 per cent per annum has been made against electrification, based on the cost of motors at $\$ 35$ per horsepower installed. It is to be noted that in either 1919 or 1930 , when the maximum purchase of electrical energy is considered, the aggregate horsepower is greater, owing to the ratio of motor to engine horsepower, as explained in connection with figure 17. The figures in the last two columns of the table are rounded to represent the nearest $\$ 10,000,000$.

TABLE 50.-Possible saving in annual cost of industrial power through maximum economical use of purchased electrical energy, 1919 and 1980.

1919.

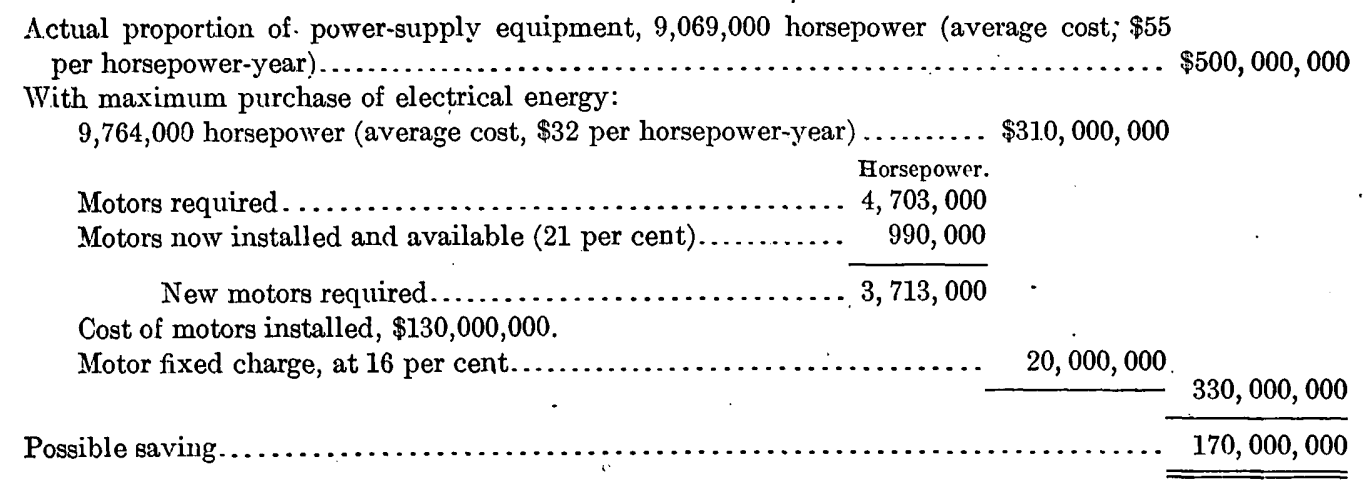

1930 .

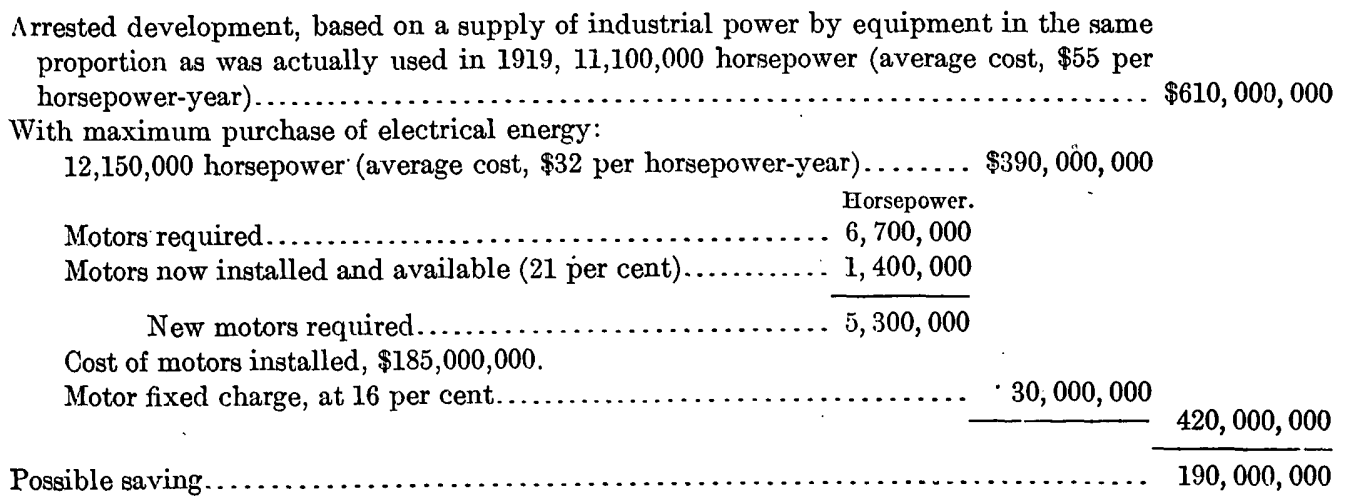




\section{APPENDIX E. PERFORMANCE AND COST OF THE SUPERPOWER SYSTEM.}

By Henry Flöod, jr.; A. R. Weliwood, and others of the engineering staff.

\section{GENERAT CONDITIONS.}

The accompanying tables and diagrams show the investment cost and the cost of power delivered by a superpower system to the load centers in 1919, in 1925, and in 1930. St. Lawrence and Niagara power will probably not be available until after 1930, but the effect of St. Lawrence power on the Eastern New England, Western. New England, and Mohawk-Hudson divisions and that of Niagara power on the Metropolitan division are shown for 1932.

The cost of delivering power from a superpower system in 1930 if all the new power plants were of the steam-electric type is mentioned in order to justify the construction of both steamelectric and hydro-electric plants as proposed.

The figures given for cost of superpower operation; including those for 1919, are of course hypothetical; the figures for independent operation in 1919, where given, represent actual cost.

\section{DEMAND AND ENERGY.}

Table 51 shows the estimated demand and energy for the superpower system in 1919, 1925, and 1930. These estimates are based on the rate of growth of the utilities, the industries, and the railroads within the zone.

The figures in the first two columns in this table show the peak demand for power and the energy used during the year 1919 that could have been economically supplied by a superpower system. The figures in the second column include, first, the energy actually supplied by electric public-utility companies as reported by them; second, the energy now generated and used by isolated plants of industries that might have obtained it more economically from a superpower system, as determined by a method stated in detail in Appendix D (p. 143); third, the energy required for the heavy-traction load, which includes that of the railroads which can be economically electrified.

The figures showing the demand in 1919 were derived from the load factor of the energy actually supplied to the load centers in that year. The industrial and railroad loads that were added naturally tended to raise the load factor, but in order to be conservative the electricutility load factor used was that for 1919.

TABLE 51.-Demand and energy requirements for superpower zone.

\begin{tabular}{l}
\hline$\ldots \ldots$ \\
Geographic division and load center.
\end{tabular}


TABLE 51.-Demand and energy requirements for superpower zone-Continued.

\begin{tabular}{|c|c|c|c|c|c|c|}
\hline \multirow{2}{*}{ Goographic division and load center. } & \multicolumn{2}{|c|}{1919} & \multicolumn{2}{|c|}{1925} & \multicolumn{2}{|c|}{1930} \\
\hline & $\begin{array}{c}\text { Demand } \\
\text { (thousands } \\
\text { of } \\
\text { kilowatts). }\end{array}$ & $\begin{array}{c}\text { Energy } \\
\text { (millions of } \\
\text { kilowatt- } \\
\text { hours). }\end{array}$ & $\begin{array}{l}\text { Demand } \\
\text { (thousands } \\
\text { of } \\
\text { kilowatts) }\end{array}$ & $\begin{array}{c}\text { Energy } \\
\text { (millions of } \\
\text { kilowatt-. } \\
\text { hours). }\end{array}$ & $\begin{array}{c}\text { Demand } \\
\text { (thousands } \\
\text { of } \\
\text { kilowatts). }\end{array}$ & $\begin{array}{l}\text { Energy } \\
\text { (millions of } \\
\text { kilowatt- } \\
\text { hours). }\end{array}$ \\
\hline 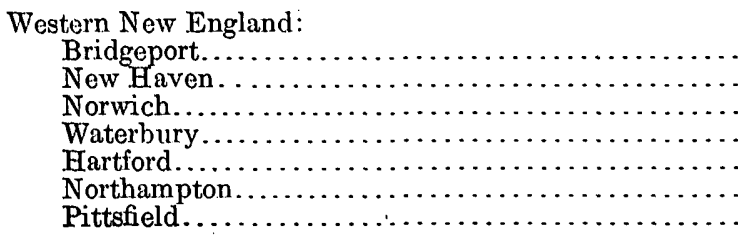 & $\mid \begin{array}{r}244.0 \\
75.9 \\
148.5\end{array}$ & $\begin{array}{r}869.8 \\
\cdots \\
270.6 \\
530.4 \\
\cdots \cdots\end{array}$ & $\begin{array}{r}115 \\
64 \\
39 \\
44 \\
80 \\
136 \\
35\end{array}$ & $\begin{array}{l}428 \\
239 \\
144 \\
165 \\
297 \\
507 \\
129\end{array}$ & $\begin{array}{r}146 \\
81 \\
49 \\
57 \\
103 \\
173 \\
43\end{array}$ & $\begin{array}{l}555 \\
308 \\
184 \\
218 \\
392 \\
657 \\
163\end{array}$ \\
\hline & .. 468.4 & $1,670.8$ & 513 & 1,909 & 652 & 2,477 \\
\hline 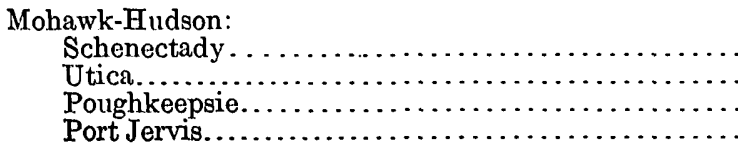 & $\begin{array}{r}201.0 \\
58.6 \\
62.1\end{array}$ & $\begin{array}{r}81.1 .9 \\
238.5 \\
262.5 \\
-\cdots\end{array}$ & $\begin{array}{r}233 \\
92 \\
56 \\
34\end{array}$ & $\begin{array}{l}973 \\
383 \\
356 \\
155\end{array}$ & $\begin{array}{r}300 \\
162 \\
83 \\
46\end{array}$ & $\begin{array}{r}1,263 \\
680 \\
374 \\
209\end{array}$ \\
\hline & 321.7 & $1,312.9$ & 415 & 1,767 & 591 & 2,526 \\
\hline $\begin{array}{l}\text { Metropolitan: } \\
\text { New York........... } \\
\text { Paterson.............. } \\
\text { Newark............. } \\
\text { New Brunswick.... }\end{array}$ & $\begin{array}{r}923.0 \\
-513.0\end{array}$ & $\mid$\begin{tabular}{l}
$3,595.5$ \\
\hdashline$\ldots \ldots .$. \\
\hdashline$\ldots \ldots$
\end{tabular} & $\begin{array}{r}1,270 \\
55 \\
360 \\
45\end{array}$ & $\begin{array}{r}5,066 \\
21.9 \\
1,438 \\
180\end{array}$ & $\begin{array}{r}1,570 \\
66 \\
461 \\
59\end{array}$ & $\begin{array}{r}6,393 \\
271 \\
1,878 \\
239\end{array}$ \\
\hline . & $1,436.0$ & $5,590.0$ & 1,730 & 6,903 & 2,156 & 8,781 \\
\hline 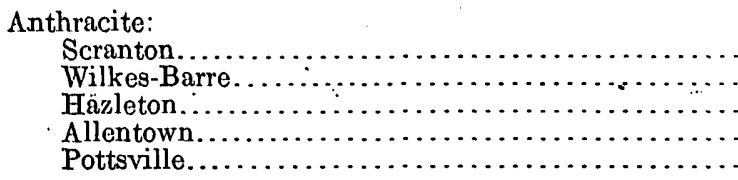 & \begin{tabular}{l}
346.2 \\
\hdashline 150.0 \\
157.2
\end{tabular} & $\begin{array}{r}1,592 . .9 \\
689.4 \\
723.0\end{array}$ & $\begin{array}{r}120 \\
145 \\
156 \\
58 \\
70\end{array}$ & $\begin{array}{l}569 \\
687 \\
737 \\
276 \\
331\end{array}$ & $\begin{array}{r}168 \\
218 \\
229 \\
78 \\
92\end{array}$ & $\begin{array}{r}771 \\
1,000 \\
1,051 \\
359 \\
425\end{array}$ \\
\hline$v^{\circ}$ & 653.4 & $3,005.3$ & 549 & 2,600 & 785 & 3,606 \\
\hline 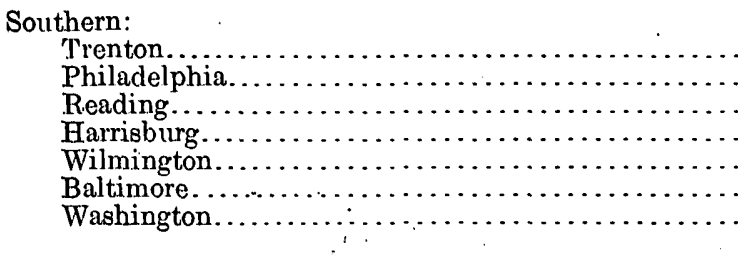 & $\begin{array}{r}223.1 \\
71.2 \\
1,131.8\end{array}$ & $\begin{array}{r}376.2 \\
2,202.7 \\
2975.7 \\
921.7 \\
9292.9 \\
4,669.2\end{array}$ & $\begin{array}{r}83 \\
706 \\
106 \\
161 \\
46 \\
291 \\
84 \\
1,477\end{array}$ & $\begin{array}{r}342 \\
2,983 \\
448 \\
681 \\
196 \\
1,229 \\
354 \\
6,233\end{array}$ & $\begin{array}{r}99 \\
1,040 \\
144 \\
219 \\
65 \\
336 \\
92 \\
1,995\end{array}$ & $\begin{array}{r}426 \\
4,459 \\
619 \\
941 \\
282 \\
1,447 \\
393 \\
8,567\end{array}$ \\
\hline Superpower zone........ & $4,854.0$ & $19,264.1$ & 5,602 & 22,870 & 7,422 & 30,712 \\
\hline
\end{tabular}

Figure 20 shows the distribution of load in the superpower zone for 1925 and 1930 and is comparable to figure 1 (p. 33), showing the distribution of the electric-utility load in 1919.

Figure 21 shows the load in 1919 and 1930 for each center compared with that of New York, which has been taken at 100 per cent. This chart shows the decentralization that should occur between those years through the agency of a superpower system. The electrification of heavy-traction railroads and of isolated industrial plants will be effective in relieving the congestion of load at the larger centers. For 1919 only 20 load centers are designated for the electric-utility load; for 1925 and 1930 the number of centers is increased to 34 . For these later years the heavy-traction railroad load is added to that of the electric utilities, thus making it desirable and economical to tap the transmission system at a larger number of points. However, from the cost of substations given in Appendix $\mathrm{H}$ it is evident that it will not be economical to tap the transmission system for a load of less than 20,000 kilowatts. 
A SUPERPOWER SYSTEM FOR THE REGION BETWEEN BOSTON AND WASHINGTON.

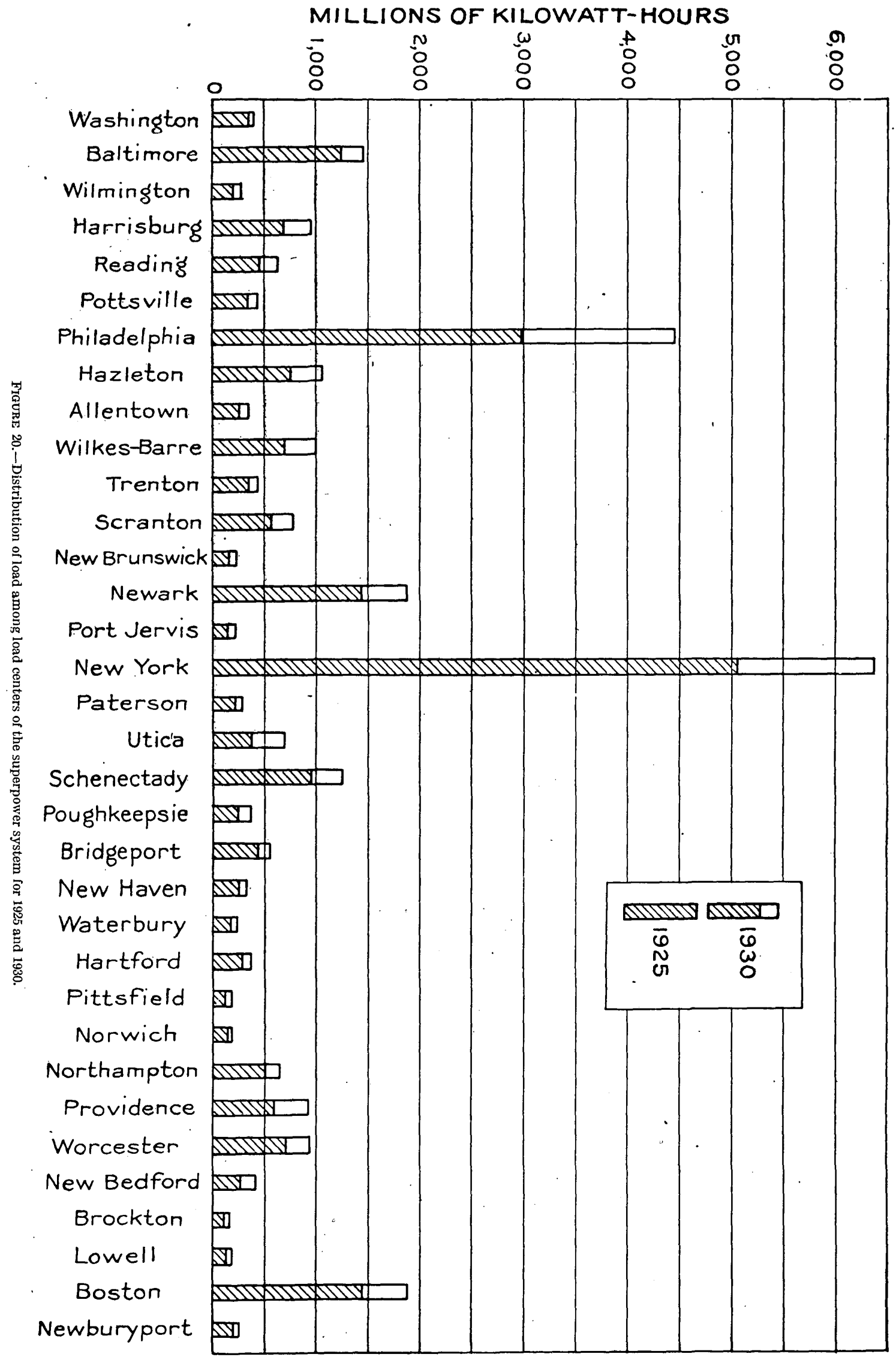




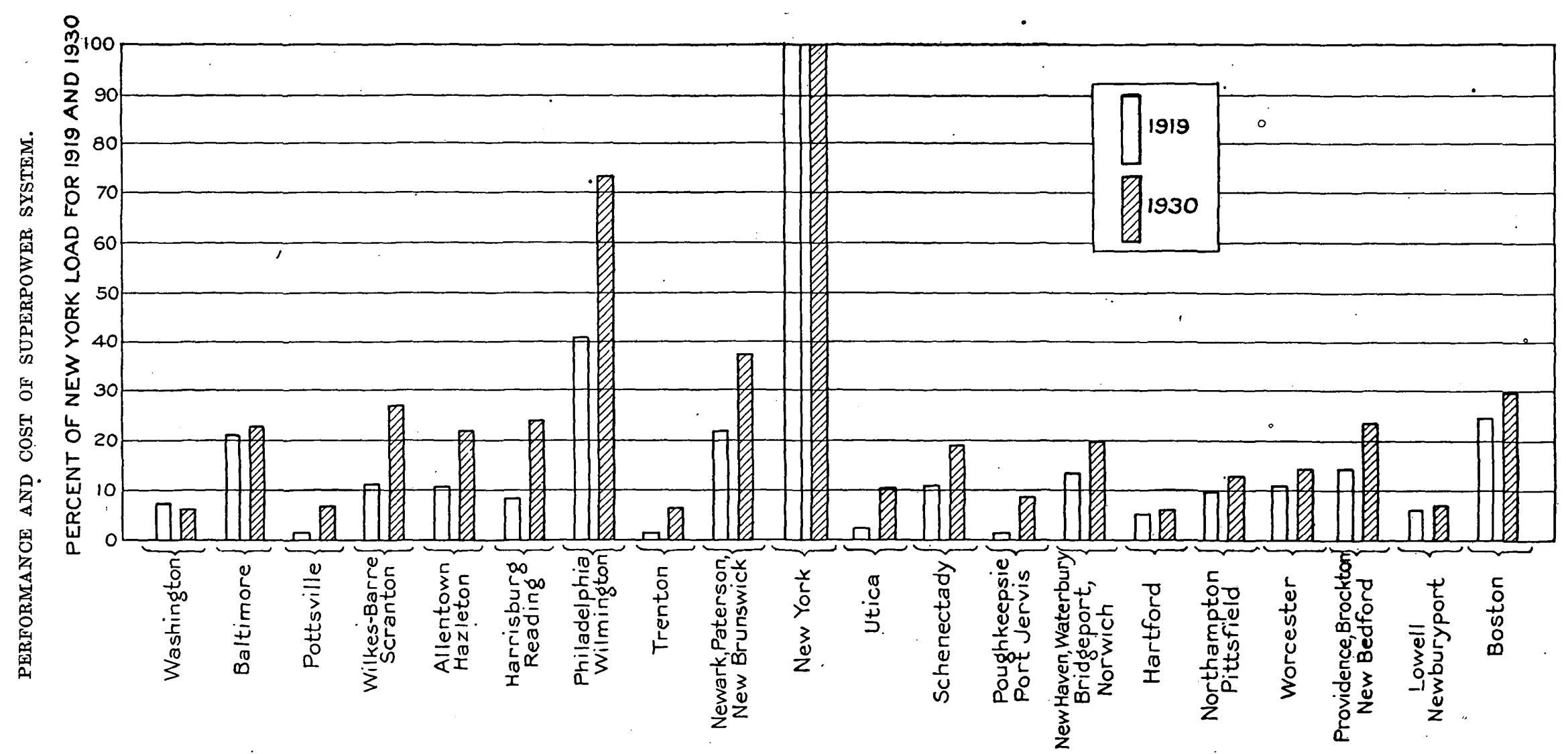

FIGURE 21.-Load at the several load centers in 1919 and 1930, in percentage of load at New York. This diagram shows decentralization of the load through the relatively large growth of heavy-traction railroad and industrial loads. The 20 load centers for 1919 have been increaser to 34 for 1930 . The first name in each group is the original load center; the others are the additional centers for 1930 . The district
represented by each group is the same for both years. 


\section{FREQUENCY.}

The adoption of a standard frequency for the entire country would afford unquestionable advantages. The two frequencies 60 and 25 cycles have become well established throughout the superpower zone. Table 52 is a summary of the energy generated at different frequencies in each geographic division during 1919.

TABLE 52.-Percentages of energy generated at different frequencies for electric public utilities in the superpower zone in 1919.

\begin{tabular}{|c|c|c|c|c|c|}
\hline \multirow{2}{*}{ Geographic division. } & \multirow{2}{*}{$\begin{array}{c}\text { Demand } \\
\text { (thousands } \\
\text { cf kilowatts). }\end{array}$} & \multirow{2}{*}{$\begin{array}{l}\text { Output } \\
\text { (millions of } \\
\text { kilowatt- } \\
\text { hours). }\end{array}$} & \multicolumn{3}{|c|}{$\begin{array}{l}\text { Percentage of output generated at } \\
\text { different-frequencies. }\end{array}$} \\
\hline & & & 25 cycles. & 60) cycles. & $\begin{array}{l}\text { Other fre- } \\
\text { quencies. }\end{array}$ \\
\hline 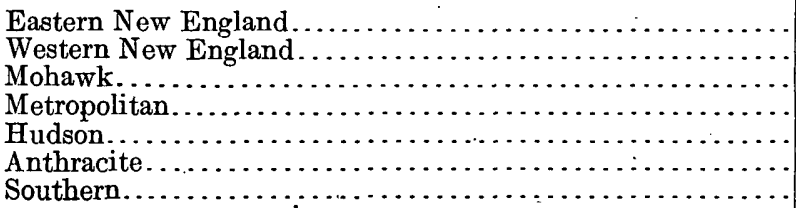 & $\begin{array}{r}572.82 \\
314.13 \\
135.87 \\
1,165.00 \\
21.50 \\
185.08 \\
660.69\end{array}$ & $\begin{array}{r}1,772.41 \\
921.99 \\
438.16 \\
3,866.67 \\
60.48 \\
743.06 \\
2,498.36\end{array}$ & $\begin{array}{r}19.8 \\
18.8 \\
8.4 \\
71.6 \\
.0 \\
30.2 \\
51.1\end{array}$ & $\begin{array}{l}70.0 \\
73.3 \\
24.2 \\
27.8 \\
98.1 \\
66.9 \\
44.8\end{array}$ & $\begin{array}{r}10.2 \\
7.9 \\
67.4 \\
.6 \\
1.9 \\
2.9 \\
4.1\end{array}$ \\
\hline . & $3,055.09$ & $10,301.13$ & 47.0 & 46.2 & 6.8 \\
\hline
\end{tabular}

Table 53 shows the percentages of energy generated at different frequencies in the five most densely populated load centers in the superpower zone-Boston, New York, Philadelphia, Baltimore, and Washington-and in the superpower zone exclusive of these five load centers.

TABLE 53.-Percentages of energy generated at different frequencies at five principal load centers in superpower zone and in the remainder of the zone.

\begin{tabular}{|c|c|c|c|c|c|}
\hline . & & Output & $\begin{array}{r}\text { Percenta } \\
\text { at di }\end{array}$ & $\begin{array}{l}\text { of out nut } \\
\text { rent frequ }\end{array}$ & $\begin{array}{l}\text { generated } \\
\text { ncies. }\end{array}$ \\
\hline & kilowatts). & hours). & $\begin{array}{c}25 \\
\text { cycles. }\end{array}$ & $\begin{array}{c}60 \\
\text { cycles. }\end{array}$ & $\begin{array}{l}\text { Other fre- } \\
\text { quencies. }\end{array}$ \\
\hline $\begin{array}{l}\text { Five principal load centers } \ldots \ldots \ldots \ldots \ldots \\
\text { Remainder of superpower zone } \ldots \ldots \ldots \ldots \ldots\end{array}$ & $\begin{array}{l}1,782.76 \\
1,272.33\end{array}$ & $\begin{array}{l}6,102.54 \\
4,198.59\end{array}$ & $\begin{array}{l}68: 2 \\
16.2\end{array}$ & $\begin{array}{l}28.0 \\
72.7\end{array}$ & $\begin{array}{r}3.8 \\
11.1\end{array}$ \\
\hline
\end{tabular}

In New York City 84.6 per cent of the energy is generated at 25 cycles, in Baltimore 98.5 per cent, and in Washington 99 per cent. In all other parts of the superpower zone the principal frequency used is 60 cycles.

Table 54 shows the percentages of total capacity at different frequencies in the several geographic divisions of the superpower zone in 1919:

TABLE 54.-Percentages of total capacity at different frequencies of steam-electric and hydroelectric plants generating electricity for use by electric public utilities in the superpower zone in 1919.

\begin{tabular}{|c|c|c|c|c|c|c|c|}
\hline \multirow{2}{*}{. } & & \multicolumn{3}{|c|}{$\begin{array}{c}\text { Capacity } \\
\text { (thousands of kilowatts). }\end{array}$} & \multicolumn{3}{|c|}{$\begin{array}{l}\text { Percentage of total capacity at } \\
\text { different frequencies. }\end{array}$} \\
\hline & & $\begin{array}{l}\text { Steam-: } \\
\text { electric. }\end{array}$ & $\begin{array}{l}\text { Hydro- } \\
\text { electric. }\end{array}$ & Total. & $\begin{array}{c}25 \\
\text { cycles. }\end{array}$ & $\begin{array}{c}60 \\
\text { cycles. }\end{array}$ & $\begin{array}{l}\text { Other fre- } \\
\text { quencies. }\end{array}$ \\
\hline \multicolumn{2}{|c|}{ 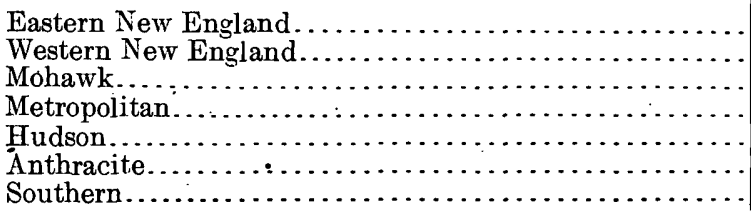 } & $\begin{array}{r}815.7 \\
369.4 \\
58.3 \\
1,629.8 \\
26.8 \\
217.8 \\
882.4\end{array}$ & $\begin{array}{r}96.0 \\
111.5 \\
116.2 \\
8.7 \\
8.7 \\
5.1 \\
105.3\end{array}$ & $\begin{array}{r}911.7 \\
481.0 \\
174.4 \\
1,638.5 \\
35.5 \\
222.9 \\
987.7\end{array}$ & $\begin{array}{l}21.8 \\
15.1 \\
10.6 \\
70.1 \\
0 \\
25.4 \\
53.7\end{array}$ & $\begin{array}{l}67.7 \\
77.3 \\
29.1 \\
27.9 \\
97.2 \\
68.5 \\
40.7\end{array}$ & $\begin{array}{r}10.5 \\
7.6 \\
60.3 \\
2.0 \\
2.8 \\
6.1 \\
5.6\end{array}$ \\
\hline$\cdot$ & - & $4,000.2$ & 451.5 & $4,451.7$ & 45.5 & 46.8 & 7.7 \\
\hline
\end{tabular}


Of the power-plant capacity in the zone 89.9 per cent is steam-electric and 10.1 per cent is hydroelectric.

. The electric street railways are by far the principal users of 25-cycle energy, because 25-cycle rotary, converters were developed before the use of 60-cycle converters became practicable.

Figure 22 shows the number of sales and the trend of sales of generating equipment in the superpower zone between 1914 and 1919 for the two frequencies mentioned. Similarly figure 23 shows the electric-utility output at the two frequencies for $1910^{\circ}$ to 1919 , inclusive. This

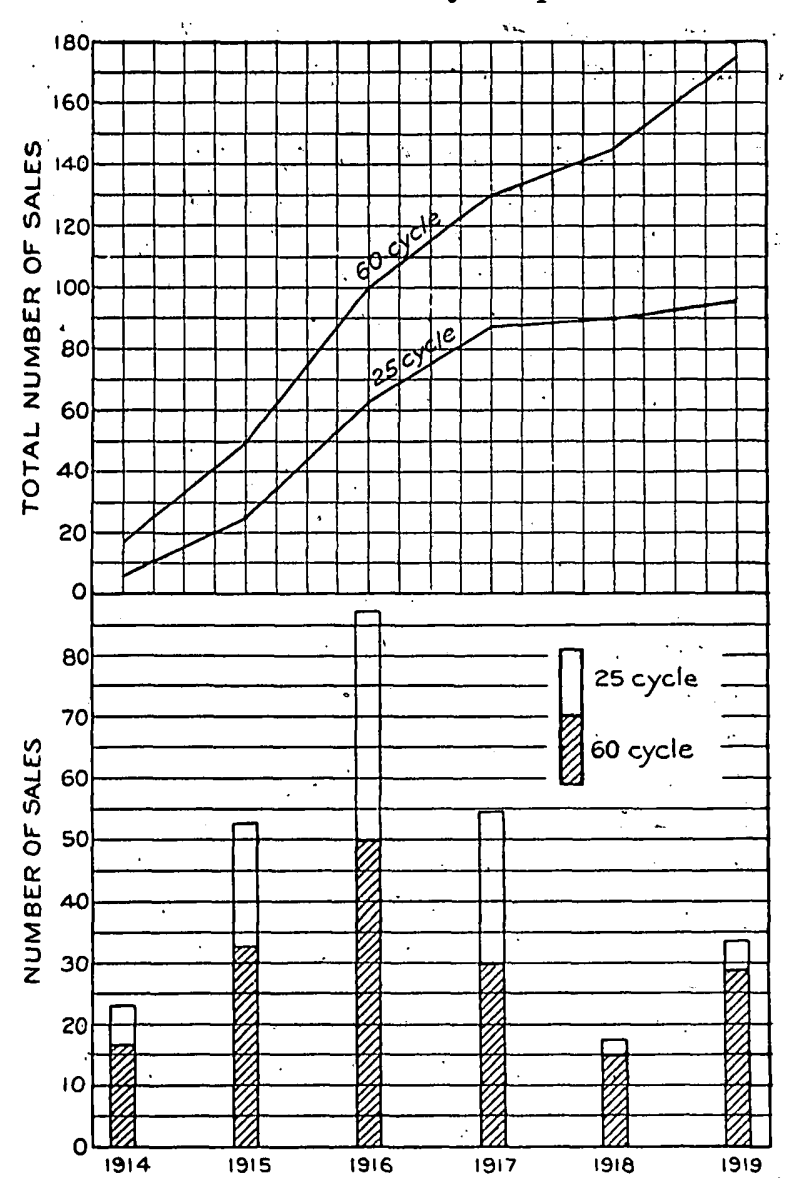

Figure 22.- Sales of 25-cycle and 60-cycle generators in the superpower zone, 1914-1919. figure indicates a decided trend toward 60 cycles, both in generator sales and in electricutility output.

The generator; motor equipment, and transformers for a 60-cycle installation cost, respectively, about 10,25 , and 35 per cent less. than those for a 25-cycle installation. A 300,000-kilowatt plant employing 60 cycles rather than 25 cycles would save in its generator equipment and in motors and transformers connected to its distribution system about $\$ 7,000,000$. Incandescent lamps furnished with 60-cycle energy are free from the flickering that is incidënt to lower frequencies. On the other hand, for a steel mill; where slow-speed motors are used, and for street railways, where the energy is converted into direct current, the

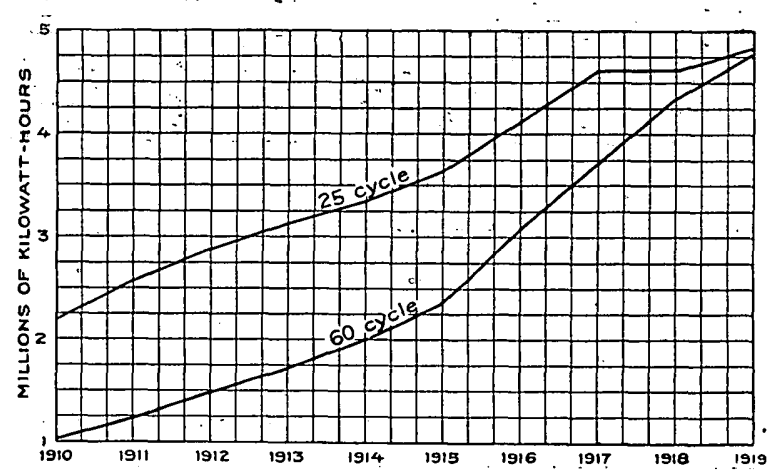
FIGURE 23.-Output of electric utilities in the superpower zone, 19101919.

lower frequency can still be used with advantage where a large investment has already been made in equipment. Although 25 cycles has been the frequency used for two of the largest railroad electrifications in the zone it is evident that the trend is toward 60 cycles and that this frequency will eventually predominate. These two frequencies will be interconnected by means of frequency changers as rapidly as economic conditions justify their use.

For long-distance transmission there is a limit beyond which 60 cycles can not be used. A 60-cycle 220,000-volt line can be operated practically to a distance of 350 miles; lower frequencies may be necessary on longer lines.

It is clear that the superpower zone will eventually have an extensive network of interconnected transmission lines, and in order that this network may be established and operated at the least expense it is necessary to fix a standard frequency. 'The evidence assembled shows that this frequency should be 60 cycles. 


\section{ESTIMATED LOAD GROWTH.}

Figure 24 shows graphically the past and estimated future load growth for the superpower zone for energy supplied to street railroads, electrified heavy-traction railroads, industries, and domestic consumers. This figure differs from Plate IV, in Appendix B, by the inclusion of the heavy-traction railroad load.

\section{EFFECT OF DIVERSITY AND LOAD FACTOR.}

Investigation was made of the diversity existing on November 25, 1919, the day of apparent maximum load for the superpower zone. Seasonal diversity, which is greater than daily diversity, was not taken into account.

There are three distinct diversities in the superpower zone-local diversity, or that which exists between the sum of the peaks of the individual electric public-utility companies as now operated and the peak that would be reached if they were interconnected at their respective

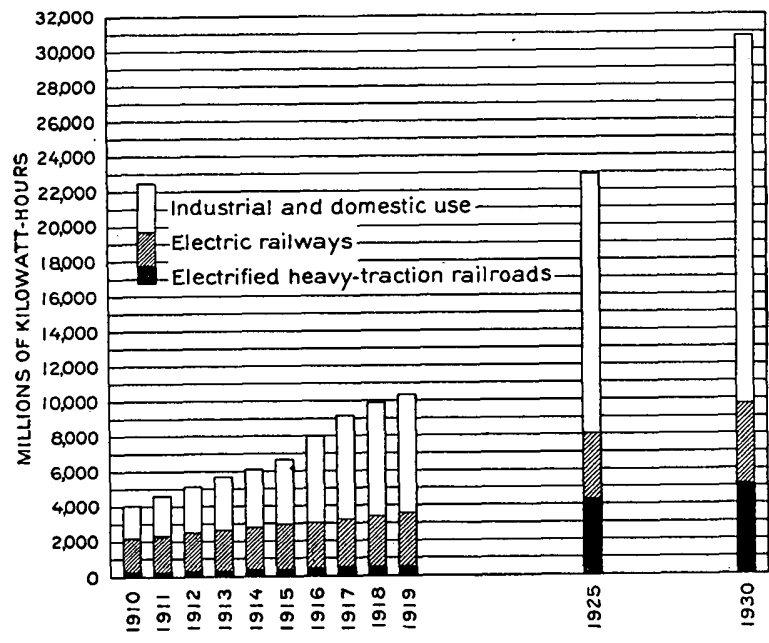

FigURE 24.-Past and estimated future growth in'load for superpower zone, 1910-1930. load centers; regional diversity, or that which exists between the sum of the peaks of the individual load centers and the peak that would be reached in the entire superpower system if these load centers were interconnected; and total diversity, or that which exists between the sum of the peaks of the individual public-utility companies as now operated and the peak that would be reached in the superpower system if there were complete interconnection throughout the superpower zone.

The local diversity ranges from zero at Baltimore and Pottsville to 14.4 per cent at the New York load center. The comparatively high local diversity shown for New York on November 25 suggested the further investigation of this load center, where exceptional conditions exist. The following table shows the diversity that existed among the four largest utility companies in New York City on seven days in 1919 and three days in 1920:

TABLE 55.-Diversity among four utility companies in New York on certain days.

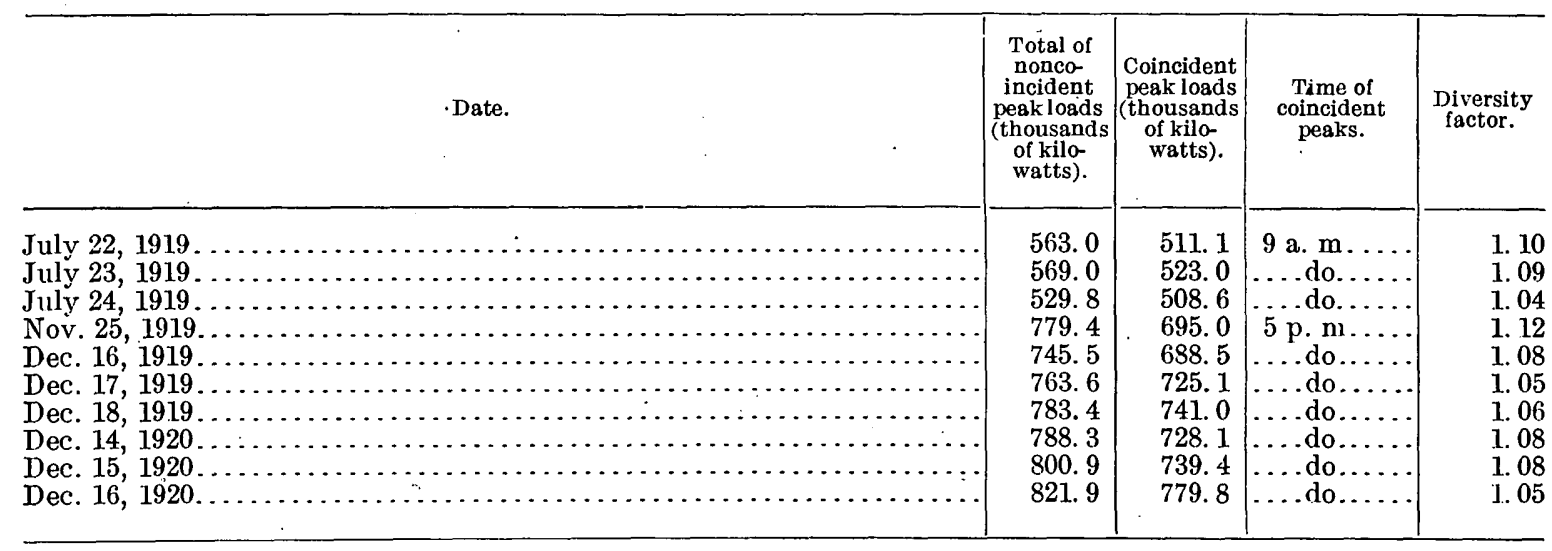


At certain load centers a large part of the local diversity has been absorbed through interconnection. Utilization of local diversity is not necessarily an attribute of the superpower system. It can be accomplished, as now, by the interconnection of the present electric-utility plants.

Regional diversity as applied to the superpower zone is in general so small as to be of theoretical rather than practical value. Partial regional diversity between the Anthracite division and the Metropolitan and Southern divisions is very marked and will become particularly evident with the growth of the Anthracite load by 1925 and 1930. In the Anthracite division the peak is controlled by the mining industry and occurs in the morning; there is a rapid falling off in load after 3 p. m. A combination of this load with the loads of the Metropolitan and Southern divisions will produce a great saving in power-plant cost over and above the cost of the transmission system necessary to effect the interconnection.

Table 56 shows the local diversity at each load center, the regional diversity between load centers, and the total diversity in 1919.

TABLE 56.-Diversity in superpower zone, 1919.

\begin{tabular}{|c|c|c|c|c|c|c|}
\hline \multirow[t]{2}{*}{ Geographic division and load center. } & $\begin{array}{l}\text { Noncoincident } \\
\text { peak loads of } \\
\text { utility com- } \\
\text { panies (thou- } \\
\text { sands of kilo- } \\
\text { watts). }\end{array}$ & $\begin{array}{c}\text { Peak at load } \\
\text { center if } \\
\text { utility plants } \\
\text { had been } \\
\text { interconnected } \\
\text { (thousands of } \\
\text { kilowatts). }\end{array}$ & $\begin{array}{l}\text { Local diver- } \\
\text { sity factor. }\end{array}$ & $\begin{array}{l}\text { Demand at } \\
\text { load centers } \\
\text { at time of } \\
\text { superpower- } \\
\text { zone peak } \\
\text { (thousands of } \\
\text { kilowatts). }\end{array}$ & $\begin{array}{l}\text { Regional } \\
\text { diversity } \\
\text { factor. }\end{array}$ & $\begin{array}{l}\text { Total } \\
\text { diversity } \\
\text { factor. }\end{array}$ \\
\hline & $\mathbf{A}$ & B & C & D & $\mathbf{E}$ & $\mathbf{F}$ \\
\hline \multicolumn{7}{|l|}{ Eastern New England: } \\
\hline Boston.$\ldots \ldots \ldots \ldots$ & $\begin{array}{r}208.48 \\
34.53\end{array}$ & $\begin{array}{r}190.64 \\
32.27\end{array}$ & $\begin{array}{l}1.09 \\
1.07\end{array}$ & $\begin{array}{r}190.64 \\
24.76\end{array}$ & & \\
\hline Providence........ & 132.10 & 121.07 & 1.09 & 121.07 & & \\
\hline Worcester ........... & 91.25 & 85.51 & 1.07 & 85.51 & & \\
\hline \multicolumn{7}{|l|}{ Western New England: } \\
\hline New Haven............ & $\begin{array}{r}105.90 \\
105.96\end{array}$ & $\begin{array}{l}49.95 \\
98.85\end{array}$ & $\begin{array}{l}1.05 \\
1.07\end{array}$ & $\begin{array}{l}49.93 \\
98.85\end{array}$ & & \\
\hline $\begin{array}{l}\text { Northampton.. } \\
\text { Mohawk: }\end{array}$ & 66.22 & 66.04 & 1.00 & 66.04 & & \\
\hline \multicolumn{7}{|l|}{$\begin{array}{l}\text { Mohawk: } \\
\text { Utica.......... }\end{array}$} \\
\hline $\begin{array}{l}\text { Utica....... } \\
\text { Albany.... }\end{array}$ & 22.83 & 22.34 & 1.02 & 19. 76 & & \\
\hline \multicolumn{7}{|l|}{ Metropolitan: } \\
\hline New York... & 863.78 & 755.25 & 1.14 & 755.25 & & \\
\hline $\begin{array}{l}\text { Newark.......... } \\
\text { Hudson: }\end{array}$ & 155.18 & 154.03 & 1.01 & 154.03 & & \\
\hline Poughkeepsie... & 11.96 & 11.50 & 1.04 & 10.37 & & $\begin{array}{l}\text { Hudson: } \\
\quad \text { Poughkeepsie... }\end{array}$ \\
\hline \multicolumn{7}{|l|}{ Anthracite: } \\
\hline Pottsville............... & 8.00 & 8. 00 & 1.00 & 6.75 & & \\
\hline Allentown............. & 96.35 & 95.26 & 1. 01 & 73.90 & & \\
\hline $\begin{array}{l}\text { Wilkes-Barre } \ldots \ldots \ldots \ldots \ldots \ldots \ldots \ldots \ldots \\
\text { Southern: }\end{array}$ & & 44.89 & - & \\
\hline $\begin{array}{l}\text { Southern: } \\
\text { Trenton } \ldots \ldots \ldots \ldots \ldots \ldots \ldots \ldots \ldots \ldots \ldots \ldots\end{array}$ & 5.15 & 4. 90 & 1.05 & 3.99 & & \\
\hline Farrisburg... & 51.84 & 51.03 & 1.02 & 51.03 & . & \\
\hline Philadelphia..... & 297.24 & 286.72 & 1. 04 & 286.72 & & \\
\hline Baltimore......... & 118. 78 & 118.78 & 1.00 & 118. 10 & & \\
\hline \multirow[t]{2}{*}{ Washington. } & 55.20 & 54.22 & 1.02 & 52.96 & & \\
\hline & $2,514.94$ & $2,337.39$ & & $2,299.75$ & 1.02 & 1.09 \\
\hline
\end{tabular}

In this report diversity has been used only as an aid to determine the capacity that would have been required for a superpower system in 1919. The estimated capacity required for 1925 and 1930 is arrived at through a study of the trend of load factor for each of the individual load centers. 
Figure 25 shows the trend of load factor in each geographic ditision of the superpower zone during the period 1910 to 1919 , inclusive. The curve for the zone as a whole is extended

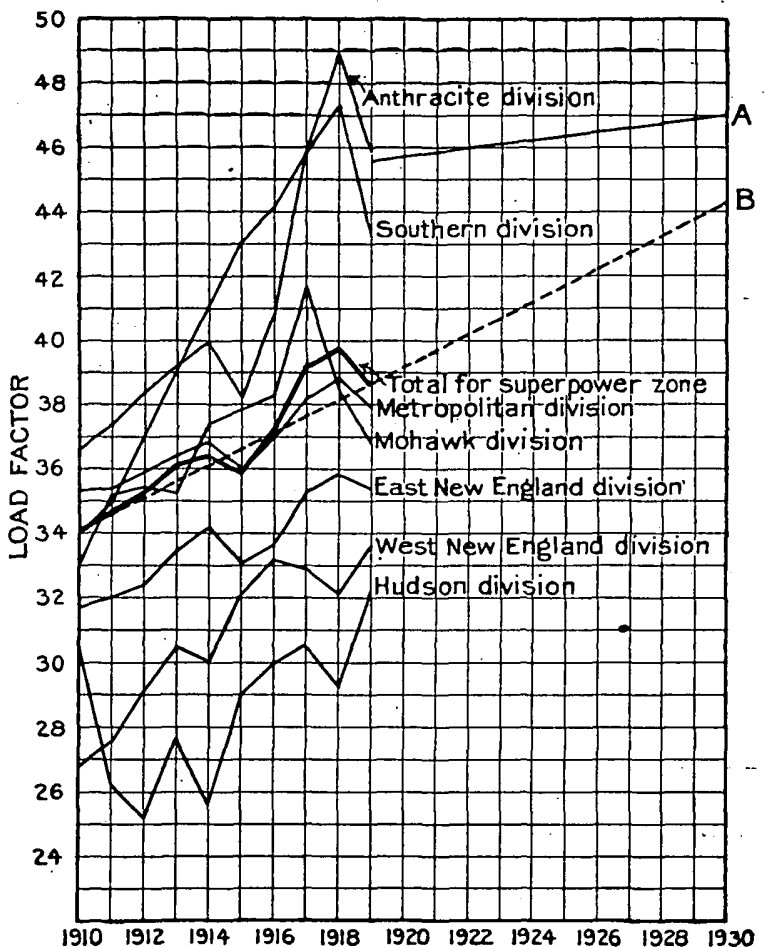

Figure 25.-Trend of load factor for superpower zone. A, Load factor inclusive of electrified heavy-traction railroads; $B$, load factor for electric utilities and street railroads. to indicate estimated load factor on utility systems in 1930 (curve B). The steady improvement in load factor shown by these curves is due to three causes-interconnection of utility plants, increase of off-peak load, and growth of industrial demand. The greatest improvement in load factor is realized where the ratio of industrial load to lighting load is high. Where the industrial load is small compared with the lighting load, as in New York City, there is little opportunity for improvement in load factor.

The effect of the war in increasing the load factor in 1917 and 1918 by introducing overtime and night work in many of the industries is very apparent. In extending the curves to indicate future improvement in load factor this abnormal increase has been discounted.

Curve $\mathrm{A}$ in this figure shows the load factor assumed for superpower operation. This curve is determined by adding the heavytraction railroad load to that of the street railroads and electric utilities, represented by curve B. With the expected growth of industrial and heavy-traction loads it would seem that the estimated load factor of 47 per cent for the entire superpower zone in 1930 is conservative.

\section{PHYSICAL DATA.}

\section{PRODUCTION FACILITIES.}

Table 60, giving the total power-plant capacity and output for the superpower system for 1919,1925 , and 1930 , shows the following division of this capacity and output between steamelectric plants and hydroelectric plants:

TABLE 57.-Capacity and output of steam-electric and hydroelectric plants, 1919, 1925, and 1980, in percentages.

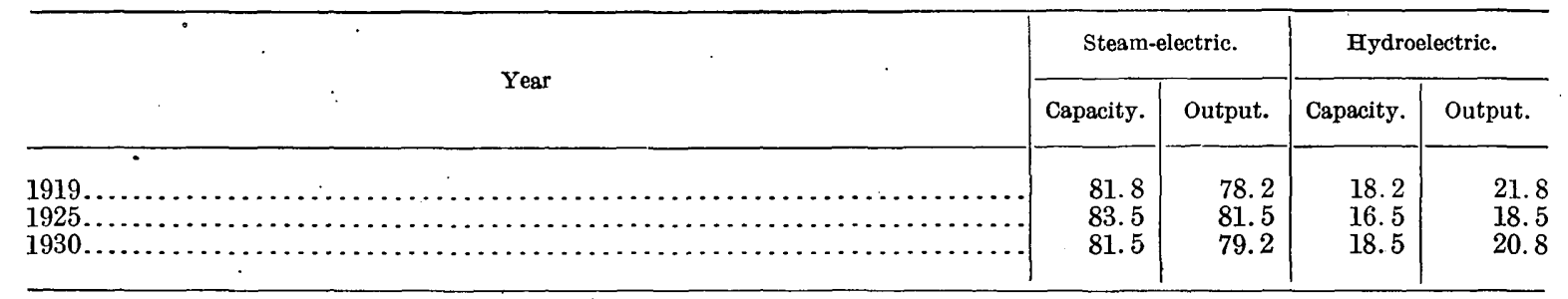

The division of capacity and output between new power plants and present power plants retained for the superpower system is as follows: 
TABLE 58.-Capacity and output of new and retained plants, in percentages.

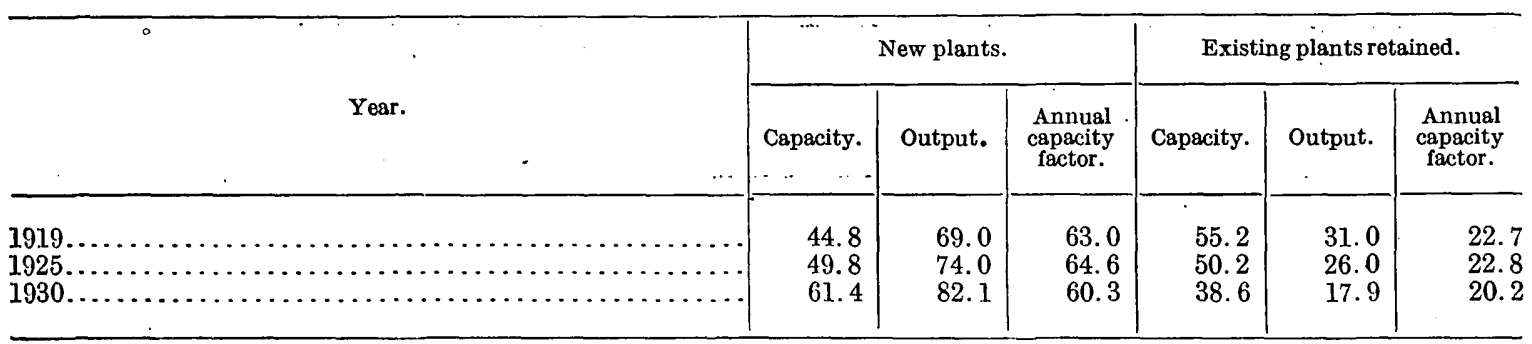

The higher efficiency under the superpower system is largely attained by operating the new power plants at high annual capacity factors and by using the older plants to carry peak load at low annual capacity factors.

TABLE 59.-Weighted average capacity of the power plants of the superpower system, in kilowatts.

\begin{tabular}{|c|c|c|}
\hline & 1925 & $' 1930$ \\
\hline 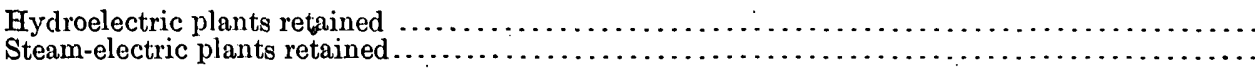 & $\begin{array}{r}2,860 \\
44,600\end{array}$ & $\begin{array}{r}2,860 \\
44,600\end{array}$ \\
\hline Weighted average of old plants retained:.. & 14,300 & 14,300 \\
\hline $\begin{array}{l}\text { New hydroelectric plants...................... } \\
\text { New steam-electric plants.............. }\end{array}$ & $\begin{array}{r}36,100 \\
180,000\end{array}$ & $\begin{array}{r}30,000 \\
218,000\end{array}$ \\
\hline Weighted average of new plants.. & 103,200 & 94,000 \\
\hline Weighted average of all plants....... & 25,100 & 29,900 \\
\hline
\end{tabular}

The average capacity of the steam-electric plants in operation in the electric utilities in 1919 was 10;000 kilowatts, and the average capacity of the steam-electric plants retained is 44,600 kilowatts, a gain made by eliminating the smaller and less efficient plants. The program of construction for new steam-electric plants shows an average capacity of plant in 1930 of more than twenty times that of the steam-electric plants serving electric public utilities in 1919 .

TABLE 60.-POPer-plant capacity for the superpower system, 1919, 1925, and 1930.

\begin{tabular}{|c|c|c|c|c|c|}
\hline Geographic division. & $\begin{array}{l}\text { Plant } \\
\text { capacity } \\
\text { (thousands } \\
\text { of kilo- } \\
\text { (watts). }\end{array}$ & $\begin{array}{l}\text { Peak } \\
\text { demand } \\
\text { (thousands } \\
\text { of kilo- } \\
\text { watts). }\end{array}$ & $\begin{array}{l}\text { Plant } \\
\text { reserve } \\
\text { (thounsands } \\
\text { of kilo- } \\
\text { watts). }\end{array}$ & $\begin{array}{l}\text { Output } \\
\text { (millions } \\
\text { of kilo- } \\
\text { watt- } \\
\text { hours). }\end{array}$ & $\begin{array}{l}\text { Capac- } \\
\text { ity } \\
\text { factor } \\
\text { (per } \\
\text { cent). }\end{array}$ \\
\hline \multirow{4}{*}{ 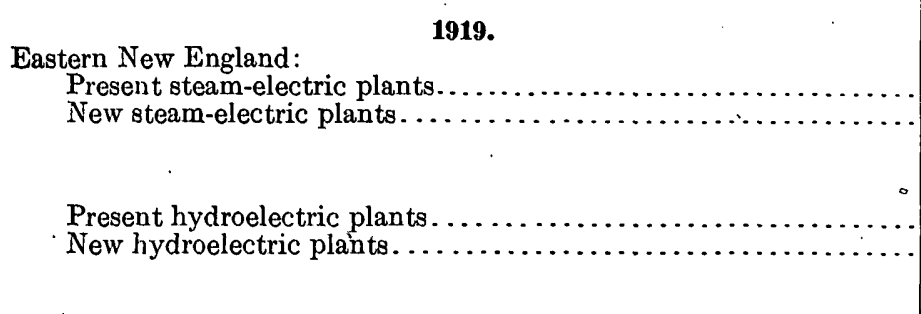 } & $\begin{array}{l}514.6 \\
360.0\end{array}$ & & & $\begin{array}{r}516.0 \\
2,366.0\end{array}$ & $\begin{array}{l}11.5 \\
75.0\end{array}$ \\
\hline & 874.6 & 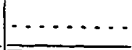 & $\ldots \ldots \ldots$ & $2,882.0$ & 37.6 \\
\hline & $\begin{array}{r}96.0 \\
-\ldots \ldots .\end{array}$ & & & $\begin{array}{r}269.0 \\
\ldots \ldots\end{array}$ & $\begin{array}{r}32.0 \\
\ldots \ldots\end{array}$ \\
\hline & 96.0 & $\ldots \ldots \ldots$ & $\ldots \ldots \ldots$ & 269.0 & 32.0 \\
\hline 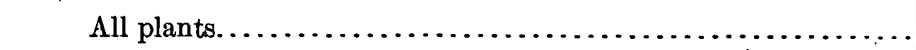 & 970.6 & 842.7 & 127.8 & $3,151.0$ & 37.0 \\
\hline \multirow[t]{2}{*}{$\begin{array}{l}\text { Western New England: } \\
\quad \text { Present steam-electric plants. } \ldots \ldots \ldots \ldots \ldots \ldots \ldots \ldots \ldots \ldots \ldots \ldots \ldots \ldots \ldots \ldots\end{array}$} & $\begin{array}{l}171.8 \\
270.0\end{array}$ & & & $\begin{array}{r}77.0 \\
1,091.0\end{array}$ & $\begin{array}{r}5.1 \\
46.0\end{array}$ \\
\hline & 441.8 & $\ldots \ldots \ldots$ & $\ldots \ldots \ldots$ & $1,168.0$ & 30.1 \\
\hline \multirow[t]{3}{*}{ 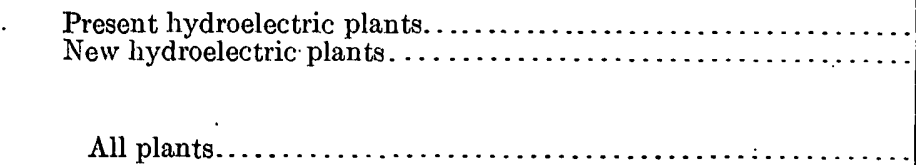 } & $\begin{array}{r}111.5 \\
50.0\end{array}$ & & & $\begin{array}{l}340.0 \\
230.0\end{array}$ & $\begin{array}{l}34.8 \\
52.5\end{array}$ \\
\hline & 161.5 & $\ldots \ldots \ldots$ & $\ldots \ldots$ & 570.0 & 40.3 \\
\hline & 603.3 & 468.4 & 134.6 & $1,738.0$ & $\overline{32.9}$ \\
\hline
\end{tabular}


TABLE 60.-Power-plant capacity for the superpower system, 1919, 1925, and 1930-Continued.

\begin{tabular}{|c|c|c|c|c|c|}
\hline Geographic division. & $\begin{array}{l}\text { Plant } \\
\text { capacity } \\
\text { (thousands } \\
\text { of kilo- } \\
\text { watts). }\end{array}$ & $\begin{array}{l}\text { Peak } \\
\text { demand } \\
\text { (thousands } \\
\text { of kilo- } \\
\text { watts). }\end{array}$ & $\begin{array}{c}\text { Plant } \\
\text { reserve } \\
\text { (thousands } \\
\text { of kilo- } \\
\text { watts). }\end{array}$ & $\begin{array}{l}\text { Output } \\
\text { (millions } \\
\text { of kilo- } \\
\text { watt- } \\
\text { hours). }\end{array}$ & $\begin{array}{l}\text { Capac- } \\
\text { ity } \\
\text { factor } \\
\text { (per } \\
\text { cent). }\end{array}$ \\
\hline 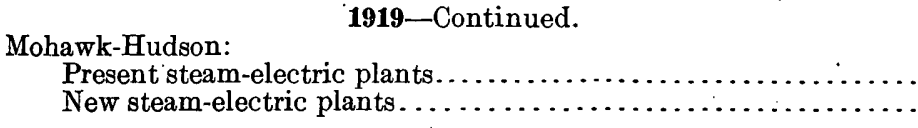 & $\begin{array}{r}45.7 \\
180.0\end{array}$ & & $\ldots \ldots \ldots$ & $\begin{array}{r}20.0 \\
605.0\end{array}$ & $\begin{array}{r}5.0 \\
38.3\end{array}$ \\
\hline & 225.7 & & & 625.0 & .31 .6 \\
\hline $\begin{array}{l}\text { Present hydroelectric plants } \ldots \ldots \ldots \ldots \ldots \ldots \ldots \ldots \\
\text { New hydroelectric plants. } \ldots \ldots \ldots \ldots \ldots \ldots \ldots \ldots\end{array}$ & $\begin{array}{l}124.9 \\
100.0\end{array}$ & & an. & $\begin{array}{l}361.0 \\
380.0\end{array}$ & $\begin{array}{l}32.9 \\
43.3\end{array}$ \\
\hline . & 224.9 & . $\ldots \ldots \ldots$ & . & 741.0 & 37.6 \\
\hline All plants...... & 450.6 & 321.7 & 129. 3 & $1,366.0$ & 34.5 \\
\hline $\begin{array}{l}\text { Metropolitan: } \\
\quad \text { Present steam-electric plants............. } \\
\quad \text { New steam-electric plants............ }\end{array}$ & $\begin{array}{l}1,130.5 \\
a 240.0\end{array}$ & an. & & $\begin{array}{r}2,960.0 \\
b 2,088.0\end{array}$ & $\begin{array}{l}30.0 \\
51.3\end{array}$ \\
\hline & $1,370.5$ & $\cdots \cdots \cdots$ & $\cdots \cdots$ & $5,048.0$ & 33.5 \\
\hline $\begin{array}{l}\text { Present hydroelectric plants. } \ldots \ldots \ldots \ldots \ldots \ldots \ldots \ldots \\
\text { New hydroelectric plants. } \ldots \ldots \ldots \ldots \ldots \ldots \ldots \ldots \ldots\end{array}$ & $\begin{array}{r}8.7 \\
183.0\end{array}$ & $\cdots \cdots \cdots$ & & $\begin{array}{r}22.0 \\
850.0\end{array}$ & $\begin{array}{l}28.8 \\
53.0\end{array}$ \\
\hline & 191.7 & …..... & $\ldots \ldots \ldots$ & 872.0 & 52.0 \\
\hline All plants....... & $1,562.2$ & $1,436.0$ & (c) & $5,920.0$ & 35.8 \\
\hline $\begin{array}{l}\text { Anthracite: } \\
\text { Present steam-electric plants... } \\
\text { New steam-electric plants.... }\end{array}$ & $\begin{array}{r}159.5 \\
d 450.0\end{array}$ & & & $\begin{array}{r}537.0 \\
e 1,950.0\end{array}$ & $\begin{array}{l}38.4 \\
75.0\end{array}$ \\
\hline$\cdot$ & 609.5 & . & & $2,487.0$ & 65.5 \\
\hline $\begin{array}{l}\text { Present hydroelectric plants............. } \\
\text { New hydroelectric plants. ............... }\end{array}$ & 5.1 & $\ldots \ldots \ldots$ & $\ldots \ldots$ & $\begin{array}{r}16.0 \\
\cdots \cdots\end{array}$ & $\begin{array}{rl}35.9 & 9 \\
\cdots \cdots & -1 \\
\cdots\end{array}$ \\
\hline & 5.1 & & & 16.0 & 35.9 \\
\hline All plants........... & 614.6 & 653.4 & (c) & $2,503.0$ & 65.3 \\
\hline $\begin{array}{l}\text { Southern: } \\
\text { Present steam-electric plants.... } \\
\text { New steam-electric plants..... }\end{array}$ & $\begin{array}{l}654.5 \\
450.0\end{array}$ & & & $\begin{array}{r}579.0 \\
2,923.0\end{array}$ & $\begin{array}{l}10.1 \\
74.2\end{array}$ \\
\hline & $1,104.5$ & & & $3,502.0$ & 36.2 \\
\hline 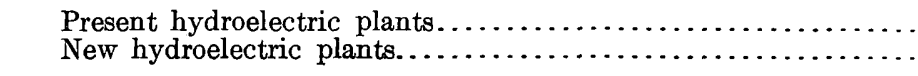 & $\begin{array}{l}105.3 \\
245.0\end{array}$ & $\cdots \cdots \cdots$ & & $\begin{array}{r}542.0 \\
1,434.0\end{array}$ & $\begin{array}{l}58.8 \\
66.8\end{array}$ \\
\hline . & 350.3 & $\cdots \cdot$ & $\cdots$ & $1,976.0$ & 64.3 \\
\hline All plants... & $1,454.8$ & $1,131.8$ & (c) & $5,478.0$ & 42.9 \\
\hline $\begin{array}{l}\text { Superpower zone: } \\
\quad \text { Present steam-electric plants.... } \\
\text { New steam-electric plants...... }\end{array}$ & $\begin{array}{l}2,676.6 \\
1,950.0\end{array}$ & & & $\begin{array}{r}4,689.0 \\
11,023.0\end{array}$ & $\begin{array}{l}20.0 \\
64.5\end{array}$ \\
\hline & $4,626.6$ & ... & & $15,712.0$ & 38.8 \\
\hline $\begin{array}{l}\text { Present hydroelectric plants... } \\
\text { New hydroelectric plants.... }\end{array}$ & $\begin{array}{l}451.5 \\
578.0\end{array}$ & & & $\begin{array}{l}1,550.0 \\
2,894.0\end{array}$ & $\begin{array}{l}39.2 \\
57.0\end{array}$ \\
\hline & $1,029.5$ & $\ldots \ldots \ldots$ & $\cdots \cdots$ & $4,444.0$ & 49.3 \\
\hline All plants. & $5,656.1$ & $4,854.0$ & 802.5 & $20,156.0$ & 40.5 \\
\hline
\end{tabular}

$a$ Does not include the portion of the Pittston plant capacity chargeable to the Metropolitan division.

c Joint reserve for Metropolitan, Anthracite, and Southern divisions, 1919, is 410,800 kilowatts.

$d$ Includes the total Pittston plant capacity.:

$e$ Is not the total output of the Pittston plant. 
TABLE 60.-Power-plant capacity for the superpower system, 1919, 1925, and 19s0-Continued.

\begin{tabular}{|c|c|c|c|c|c|}
\hline Geographic division. & $\begin{array}{l}\text { Plant } \\
\text { capacity } \\
\text { (thousainds } \\
\text { of kilo- } \\
\text { watts). }\end{array}$ & $\begin{array}{c}\text { Peak } \\
\text { demand } \\
\text { (thousands } \\
\text { of kilo- } \\
\text { watts). }\end{array}$ & $\begin{array}{c}\text { Plant } \\
\text { reserve } \\
\text { (thousands } \\
\text { of kilo- } \\
\text { watts). }\end{array}$ & $\begin{array}{l}\text { Output } \\
\text { (millions } \\
\text { of kilo- } \\
\text { watt- } \\
\text { hours). }\end{array}$ & $\begin{array}{l}\text { Capac- } \\
\text { ity } \\
\text { factor } \\
\text { (per } \\
\text { cent). }\end{array}$ \\
\hline 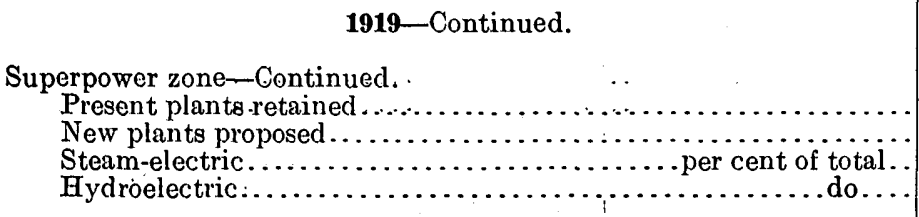 & $\begin{array}{r}3,128.1 \\
2,528.0 \\
81.8 \\
18.2\end{array}$ & $\begin{array}{l}\cdots \\
\cdots \\
\cdots \\
\cdots\end{array}$ & 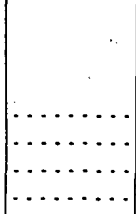 & $\begin{array}{r}6,239.0 \\
13,917.0 \\
78.2 \\
21.8\end{array}$ & $\begin{array}{r}22.7 \\
62.9 \\
\cdots \\
\cdots\end{array}$ \\
\hline 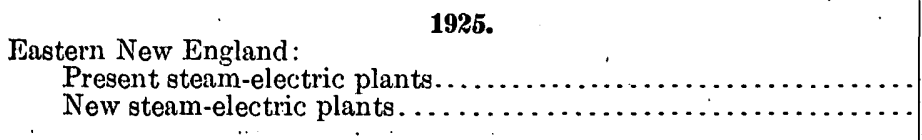 & $\begin{array}{l}514.6 \\
450.0\end{array}$ & & & $\begin{array}{r}516.0 \\
2,811.0\end{array}$ & $\begin{array}{l}11.5 \\
71.2\end{array}$ \\
\hline & 964.6 & $\cdots$ & & $3,327.0$ & 39.4 \\
\hline $\begin{array}{l}\text { Present hydroelectric plants } \ldots \ldots \ldots \ldots \ldots \ldots \ldots \ldots \ldots \ldots \ldots \ldots \ldots \ldots \\
\text { New hydroelectric plants. } \ldots \ldots \ldots \ldots \ldots \ldots \ldots \ldots \ldots \ldots\end{array}$ & \begin{tabular}{r|r|}
96.0 \\
$\cdots \cdots$
\end{tabular} & & & $\begin{array}{r}269.0 \\
\cdots \cdots\end{array}$ & $\begin{array}{r}32.0 \\
\cdots\end{array}$ \\
\hline . & 96.0 & & & 269.0 & 32.0 \\
\hline All plants. . . . . . . . . . . . . . . . . . . & $1,060.6$ & 918.0 & - 142.5 & $3,596.0$ & 38.7 \\
\hline 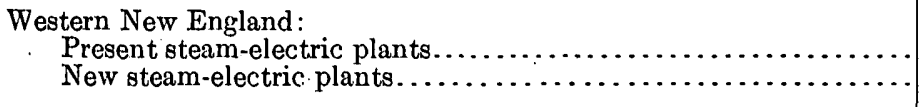 & $\begin{array}{l}\text { 171. } 8 . \\
300.0\end{array}$ & $\cdots$ & & $\begin{array}{r}77.0 \\
1,223.0\end{array}$ & $\begin{array}{r}5.1 \\
46.5\end{array}$ \\
\hline . & 471.8 & & $\cdots \cdot$ & $1,300.0$ & 31.4 \\
\hline $\begin{array}{l}\text { Present hydroelectric plants. } \ldots \ldots \ldots \ldots \ldots \ldots \ldots \ldots \ldots \ldots \ldots \ldots \ldots \ldots \ldots \\
\text { New hydroelectric plants. } \ldots \ldots \ldots \ldots \ldots \ldots \ldots \ldots \ldots\end{array}$ & $\begin{array}{r}111.5 \\
50.0\end{array}$ & & & $\begin{array}{l}340.0 \\
230.0\end{array}$ & $\begin{array}{l}34.8 \\
.52 .5\end{array}$ \\
\hline . & 161.5 & $\cdots$ & & 570.0 & 40.3 \\
\hline 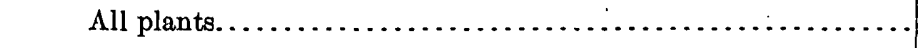 & 633.3 & 513.0 & 120.0 & $1,870.0$ & 33.7 \\
\hline $\begin{array}{l}\text { Mohawk-Hudson: } \\
\text { Present steam-electric plants. } \\
\text { New steam-electric.plants. } \ldots \ldots \ldots \ldots \ldots \\
\text { New. }\end{array}$ & $\begin{array}{r}45.7 \\
240.0\end{array}$ & & & $\begin{array}{r}20.0 \\
1,039.0\end{array}$ & $\begin{array}{r}5.0 \\
49.5\end{array}$ \\
\hline$\cdot$ & 285.7 & $\cdots$ & $\cdots$ & $1,059.0$ & 49.5 \\
\hline 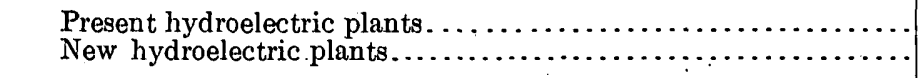 & $\begin{array}{l}124.9 \\
100.0\end{array}$ & & & $\begin{array}{l}361.0 \\
380.0\end{array}$ & $\begin{array}{l}32.9 \\
43.3\end{array}$ \\
\hline 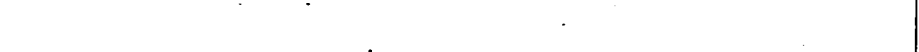 & 224.9 & $\ldots \ldots \ldots$ & $\ldots$. & 741.0 & 37.6 \\
\hline 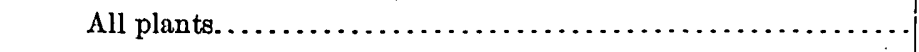 & . 510.6 & 415.0 & 96.0 & $1,800.0$ & 40.2 \\
\hline 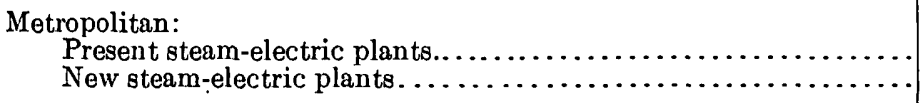 & $\begin{array}{l}1,130.5 \\
a 390.0\end{array}$ & \begin{tabular}{ll|}
$\cdots$ \\
$\cdots \cdots$ \\
$\cdots \cdots$
\end{tabular} & & $\begin{array}{r}2,960.0 \\
b 3,508.0\end{array}$ & $\begin{array}{l}30.0 \\
67.0\end{array}$ \\
\hline - & $1,520.5$ & $\ldots \ldots \ldots$ & $\ldots \ldots \ldots$ & $6,468.0$ & 39.4 \\
\hline $\begin{array}{l}\text { Present hydroelectric plants } \ldots \ldots \ldots \ldots \ldots \ldots \ldots \ldots \ldots \ldots \\
\text { New hydroelectric plants. } \ldots \ldots \ldots \ldots \ldots \ldots\end{array}$ & $\begin{array}{r}8.7 \\
183.0\end{array}$ & $-\ldots \cdots \cdots$ & \begin{tabular}{ll|}
$-\cdots$ \\
$\cdots \cdots$
\end{tabular} & $\begin{array}{r}22.0 \\
850.0\end{array}$ & $\begin{array}{l}28.8 \\
53.0\end{array}$ \\
\hline$\cdot$ & 191.7 & $\ldots \ldots \ldots$ & $\ldots$ & 872.0 & 52.0 \\
\hline . & $1,712.2$ & $1,730.0$ & $(c)$ & $7,340.0$ & 40.8 \\
\hline 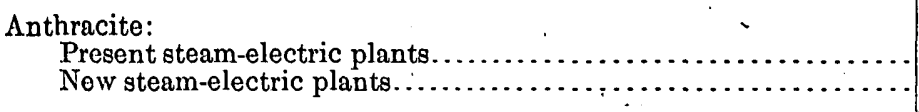 & $\begin{array}{r}159.5 \\
d 450.0\end{array}$ & $\ldots \ldots \ldots$ & & $\begin{array}{r}537.0 \\
e 1,735.0\end{array}$ & $\begin{array}{l}38.4 \\
75.0\end{array}$ \\
\hline . & 609.5 & $\cdots \cdots$ & $\ldots$ & $2,272.0$ & 65.5 \\
\hline
\end{tabular}
$a$ Does not include the portion of the Pittston plant capacity chargeable to the Metropolitan division.
$b$ Includes a portion of the output from the Pittston plant.

c Joint resorvo for Metropolitan, Anthracite, and Soththern divisions, 1925, is 255,000 kilowatts.

d Is not tho total output of the Pittston plant.

$63361^{\circ}-21-11$ 
TABLE 60.-Power-plant capacity for the superpower system, 1919, 1925, and 1930-Continued.

\begin{tabular}{|c|c|c|c|c|c|}
\hline Geographic division. & $\begin{array}{l}\text { Plant } \\
\text { capacity } \\
\text { (thousands } \\
\text { of kilo- } \\
\text { watts). }\end{array}$ & $\begin{array}{l}\text { Peak } \\
\text { demand } \\
\text { (thousands } \\
\text { of kilo- } \\
\text { watts). }\end{array}$ & $\begin{array}{l}\text { Plant } \\
\text { reserve } \\
\text { (thousands } \\
\text { of kilo- } \\
\text { watts). }\end{array}$ & $\begin{array}{l}\text { Output } \\
\text { (millions } \\
\text { of kilo- } \\
\text { watt- } \\
\text { hours). }\end{array}$ & $\begin{array}{l}\text { Capac- } \\
\text { ity } \\
\text { factor } \\
\text { (per } \\
\text { cent). }\end{array}$ \\
\hline \multirow[t]{2}{*}{ 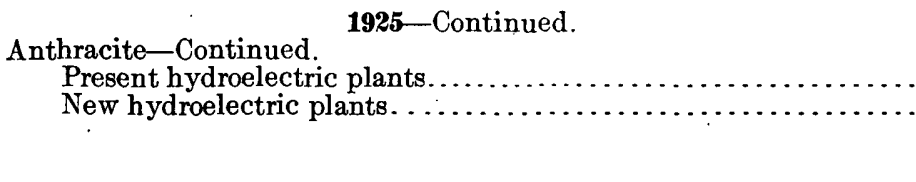 } & 5.1 & & & 16.0 & $\begin{array}{l}35.9 \\
\cdots\end{array}$ \\
\hline & 5.1 & $\cdots \cdots$ & & 16.0 & 35.9 \\
\hline 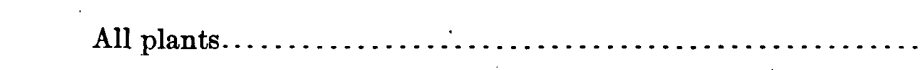 & 614.6 & 549.0 & $(a)$ & $2,288.0$ & 65.3 \\
\hline \multirow[t]{2}{*}{ 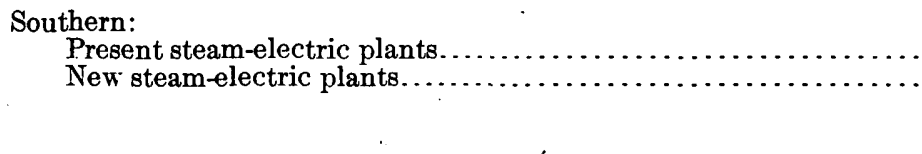 } & $\begin{array}{l}654.5 \\
690.0\end{array}$ & & & $\begin{array}{r}579.0 \\
4,365.0\end{array}$ & $\begin{array}{l}10.1 \\
72.2\end{array}$ \\
\hline & $1,344.5$ & & & 4., 944.0 & 42.0 \\
\hline \multirow[t]{2}{*}{ 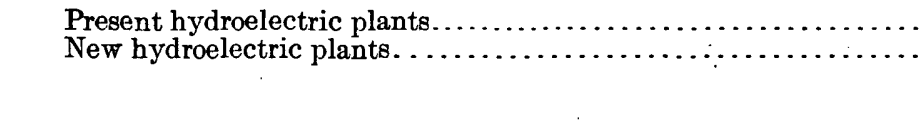 } & $\begin{array}{l}105.3 \\
245.0\end{array}$ & & & $\begin{array}{r}542.0 \\
1,434.0\end{array}$ & $\begin{array}{l}58.8 \\
66.8\end{array}$ \\
\hline & 350.0 & $\cdots$ & & $1,976.0$ & 64.3 \\
\hline \multirow{3}{*}{ 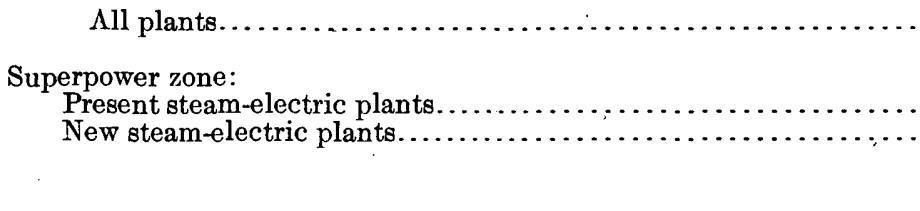 } & $1,694.8$ & $1,477.0$ & $(a)$ & $6,920.0$ & 46.7 \\
\hline & $\begin{array}{l}2,676.6 \\
2,520.0\end{array}$ & & & $\begin{array}{r}4,689.0 \\
14,681.0\end{array}$ & $\begin{array}{l}20.0 \\
66.4\end{array}$ \\
\hline & $5,196.6$ & & & $19,370.0$ & 42.5 \\
\hline \multirow[t]{2}{*}{ 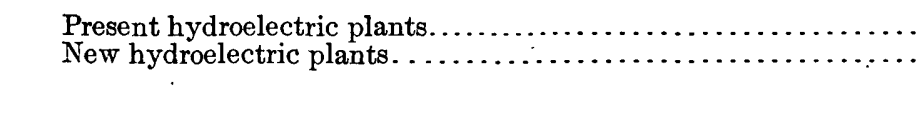 } & $\begin{array}{l}45] .5 \\
578.0\end{array}$ & & & $\begin{array}{l}1,550.0 \\
2,894.0\end{array}$ & $\begin{array}{l}39.2 \\
57.0\end{array}$ \\
\hline & $1,029.5$ & & & $4,444.0$ & 49.3 \\
\hline All plants.. & $6,226.1$ & $5,602.0$ & 624.5 & $23,814.0$ & 43.7 \\
\hline 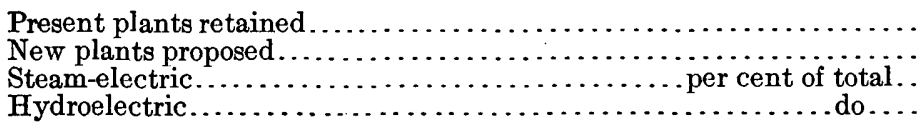 & $\begin{array}{r}3,128.1 \\
3,098.0 \\
83.5 \\
16.5\end{array}$ & & & $\begin{array}{r}6,239.0 \\
17,575.0 \\
81.5 \\
18.5\end{array}$ & $\begin{array}{r}22.8 \\
64.6 \\
\cdots \cdots\end{array}$ \\
\hline \multirow[t]{2}{*}{ 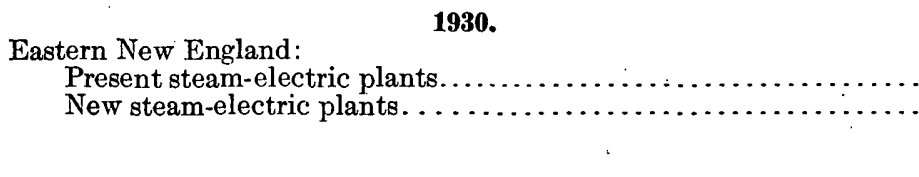 } & $\begin{array}{l}514.6 \\
810.0\end{array}$ & & & $\begin{array}{r}528.0 \\
4,148.0\end{array}$ & $\begin{array}{l}11.7 \\
58.3\end{array}$ \\
\hline & $1,324.6$ & & & $4,676.0$ & 40.3 \\
\hline \multirow[t]{2}{*}{ 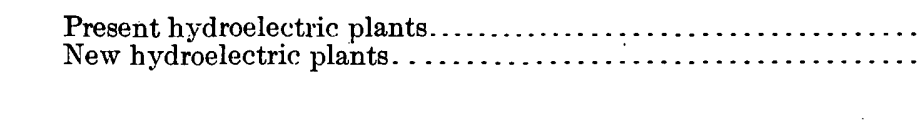 } & $\begin{aligned} 96.0 \\
\ldots \ldots\end{aligned}$ & & & 269.0 & 32.0 \\
\hline & 96.0 & & $\cdots$ & 269.0 & 32.0 \\
\hline 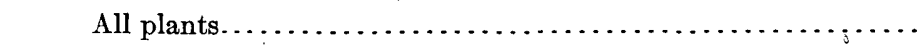 & $1,420.6$ & $12 \dot{4} .3$ & 177.5 & $4,945.0$ & 39.6 \\
\hline \multirow[t]{2}{*}{ 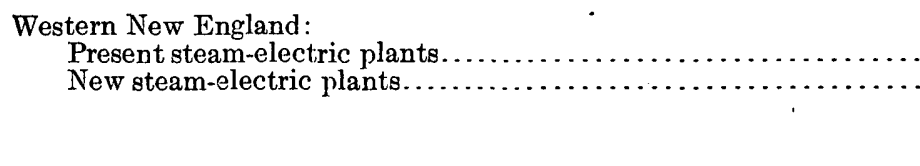 } & $\begin{array}{l}171.8 \\
390.0\end{array}$ & & & $\begin{array}{r}77.0 \\
1,237.0\end{array}$ & $\begin{array}{r}5.1 \\
36.2\end{array}$ \\
\hline & 561.8 & & & $1,314.0$ & 26.7 \\
\hline \multirow[t]{2}{*}{ 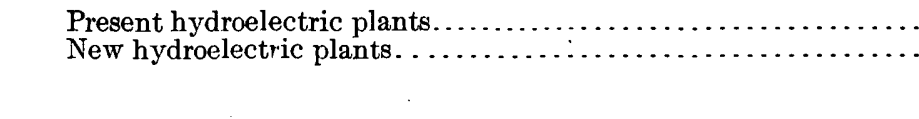 } & $\begin{array}{l}111.5 \\
165.0\end{array}$ & & & $\begin{array}{l}340.0 \\
760.0\end{array}$ & $\begin{array}{l}34.8 \\
52.5\end{array}$ \\
\hline & 276.5 & $\cdots \cdots$ & $\cdots \ldots$ & $1,100.0$ & 45.3 \\
\hline \multirow{3}{*}{ 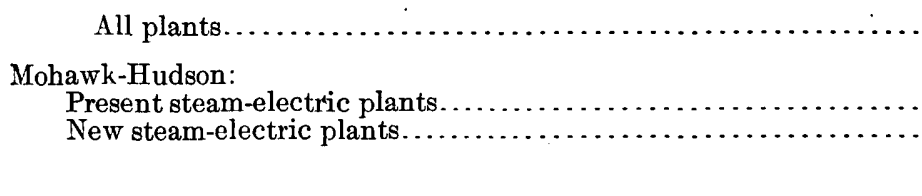 } & 838.3 & 652.0 & 186.0 & $2,414.0$ & 32.8 \\
\hline & $\begin{array}{r}45.7 \\
360.0\end{array}$ & & & $\begin{array}{r}20.0 \\
1,312.0\end{array}$ & $\begin{array}{r}5.0 \\
41.5\end{array}$ \\
\hline & 405.7 & ‥ & $\ldots \ldots \ldots$ & 1., 332.0 & 37.4 \\
\hline
\end{tabular}

$a$ Joint reserve for Metropolitan, Anthracite, and Southern divisions, 1925, is 265,000 kilowatts. 
TABLE 60.-Power-plant capacity for the superpower system, 1919, 1925, and 1930-Continued.

\begin{tabular}{|c|c|c|c|c|c|}
\hline $\begin{array}{c}\text { Geographic divișion. } \\
.\end{array}$ & $\begin{array}{c}\text { Plant } \\
\text { capacity } \\
\text { (thousands } \\
\text { of kilo-- } \\
\text { watts). }\end{array}$ & $\begin{array}{c}\text { Peak } \\
\text { demand } \\
\text { (thousands } \\
\text { of kilo- } \\
\text { watts). }\end{array}$ & $\begin{array}{c}\text { Plant } \\
\text { reserve } \\
\text { (thousands } \\
\text { of kilo- } \\
\text { watts). }\end{array}$ & $\begin{array}{l}\text { Output : } \\
\text { (millions } \\
\text { of kilo-: } \\
\text { watt- } \\
\text { hours). }\end{array}$ & $\begin{array}{l}\text { Capac- } \\
\text { ity } \\
\text { factor } \\
\text { (per } \\
\text { cent). }\end{array}$ \\
\hline \multirow{2}{*}{$\begin{array}{l}\text { Mohawk-Hudson-Continued. } \\
\text { Present hydroelectric plants................... } \\
\text { New hydroeleciric plants. . . }\end{array}$} & $\begin{array}{l}124.9 \\
150.0\end{array}$ & 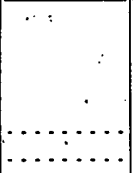 & & $\begin{array}{l}341.0 \\
900.0\end{array}$ & $\begin{array}{l}\because \cdot \\
\because \cdots !\end{array}$ \\
\hline & 274.9 & & & $1,241.0$ & 51.7 \\
\hline \multirow{3}{*}{ 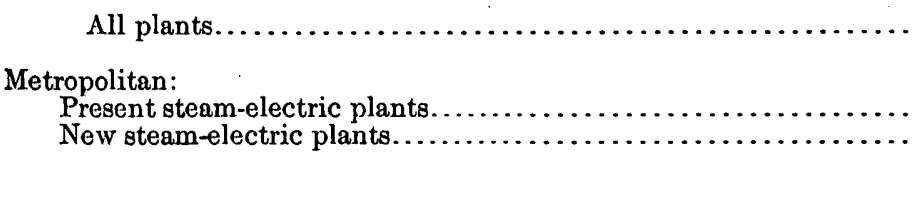 } & 680.6 & 591.0 & 90.0 & $2,573.0$ & 43.0 \\
\hline & $\begin{array}{r}1,130.5 \\
a 750.0\end{array}$ & & & $\begin{array}{r}2,276.0 \\
b 5,812.0\end{array}$ & $\begin{array}{l}23.0 \\
67.5\end{array}$ \\
\hline & $1,880.5$ & & & $8,088.0$ & 40.7 \\
\hline \multirow[t]{2}{*}{$\begin{array}{l}\text { Present hydroelectric plants } \ldots \ldots \ldots \ldots \ldots \ldots \ldots \ldots \ldots \ldots \ldots \ldots \ldots \ldots \\
\text { New hydroelectric plants. } \ldots \ldots \ldots \ldots \ldots \ldots \ldots \ldots\end{array}$} & $\begin{array}{r}8.7 \\
350.0\end{array}$ & & & $\begin{array}{r}22.0 \\
1,240.0\end{array}$ & $\begin{array}{l}28.8 \\
40.5\end{array}$ \\
\hline & 358.7 & & & $1,262.0$ & 40.2 \\
\hline \multirow{3}{*}{ 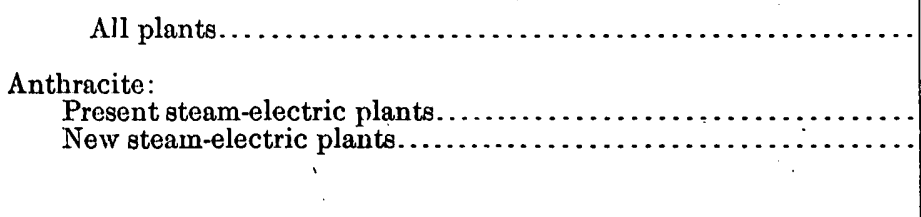 } & $2,239.2$ & $2,156.0$ & (c) & $9,350.0$ & 40.6 \\
\hline & $\begin{array}{r}159.5 \\
d 600.0\end{array}$ & & & $\begin{array}{r}537: 0 \\
a 2,571.0\end{array}$ & $\begin{array}{l}51.0 \\
75.0\end{array}$ \\
\hline & 759.5 & & & $3,108.0$ & $67: 3$ \\
\hline \multirow[t]{2}{*}{ 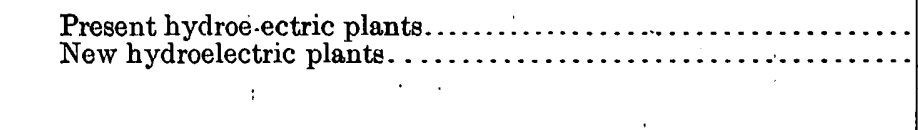 } & 5.1 & & & $\begin{array}{r}16.0 \\
\ldots \ldots\end{array}$ & $\begin{array}{r}35.9 \\
\cdots\end{array}$ \\
\hline & 5.1 & & & 16.0 & 35.9 \\
\hline 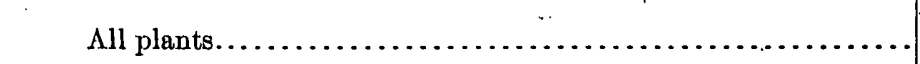 & 764.6 & 785.0 & (c) & $3,124.0$ & 67.1 \\
\hline \multirow[t]{2}{*}{ 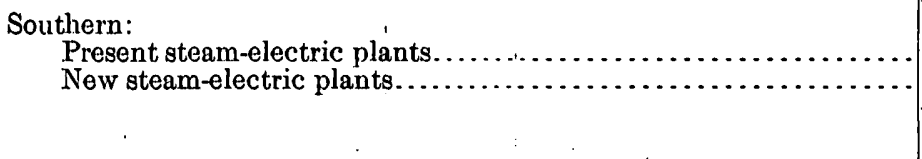 } & $\begin{array}{r}654.5 \\
1,020.0\end{array}$ & & & $\begin{array}{r}579.0 \\
6,219.0\end{array}$ & $\begin{array}{l}10.1 \\
69.5\end{array}$ \\
\hline & $1,674.5$ & & & $6,798.0$ & 46.2 \\
\hline \multirow[t]{2}{*}{ 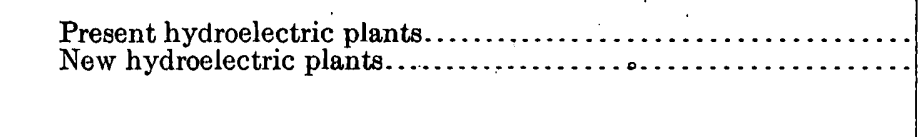 } & $\begin{array}{l}105.3 \\
385.0\end{array}$ & & & $\begin{array}{r}542.0 \\
2,180.0\end{array}$ & $\begin{array}{l}58.8 \\
64.5\end{array}$ \\
\hline & 490.3 & & & $2,722.0$ & 63.4 \\
\hline \multirow{3}{*}{ 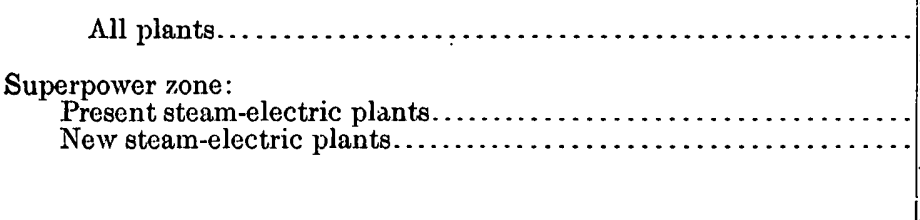 } & $2,164.8$ & $1,995.0$ & (c) & $9,520.0$ & 50.0 \\
\hline & $\begin{array}{l}2,676.6 \\
3,930.0\end{array}$ & & & $\begin{array}{r}4,017.0 \\
21,299.0\end{array}$ & 17. 1 \\
\hline & $6,606.0$ & & & $25,316.0$ & 43.7 \\
\hline \multirow[t]{2}{*}{$\begin{array}{l}\text { Present hydroelectric plants } \ldots \ldots \ldots \ldots \ldots \ldots \ldots \ldots \ldots \ldots \ldots \ldots \ldots \ldots \ldots \ldots \ldots \\
\text { New hydroelectric plants. } \ldots \ldots \ldots \ldots \ldots \ldots \ldots \ldots\end{array}$} & $\begin{array}{r}451.5 \\
1,050.0\end{array}$ & & & $\begin{array}{l}1,530.0 \\
5,080.0\end{array}$ & $\begin{array}{l}38.6 \\
55.2\end{array}$ \\
\hline & $1,501.5$ & & $\ldots$ & $6,610.0$ & 50.3 \\
\hline 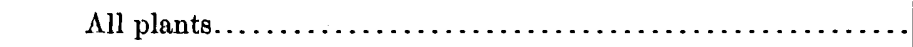 & $8,108.1$ & $7,422.0$ & 676.5 & $31,926.0$ & 45.0 \\
\hline 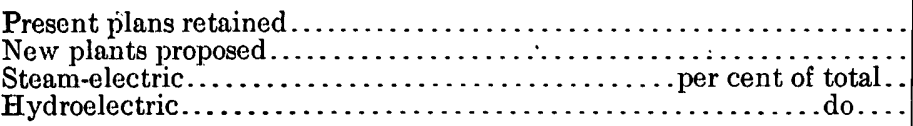 & \begin{tabular}{|c|}
, 128.1 \\
$4,980.0$ \\
81.5 \\
18.5
\end{tabular} & $\begin{array}{ll}\cdots \\
\cdots \\
\cdots\end{array}$ & $\cdots$ & $\begin{array}{r}5,547.0 \\
26,379.0 \\
79.2 \\
20.8\end{array}$ & $\begin{array}{r}20.2 \\
60.3 \\
\cdots \\
\cdots\end{array}$ \\
\hline
\end{tabular}

a Doos not includo the portion of the Pittston plant capacity chargeable to the Metropolitan division.

c Joint resorvo for Metropolitan, Anthracite, and Southern divisions 1930. is 233,000 kilowatts.

d Includes the total Pittston plant capacity.

Is not tho total output of the Pittston plant. 


\section{TRANSMISSION LINES.}

Table 61 gives the mileage of the transmission lines required for the superpower system for 1919,1925 , and 1930 .

Plates II and III (p. 14) show the proposed transmission lines for 1925 and 1930, respectively, and Plate III shows in addition proposed lines from the St. Lawrence and Niagara for 1932. These plates also show the approximate location for proposed new steam-electric and hydroelectric plants.

Reliable service is insured by the interconnecting network, as each principal load center is served by eight incoming lines, four from each direction, and a few favorably located load centers have even more.

TABLE 61.-Transmission lines for superpower zone in 1919, 1925, and 1930, in miles.

\begin{tabular}{|c|c|c|c|c|c|c|}
\hline \multirow{2}{*}{ : } & \multicolumn{3}{|c|}{220,000 -volt. } & \multicolumn{3}{|c|}{110,000 -volt. } \\
\hline & Route. & Tower. & Circuit. & Route. & Tower. & Circuit. \\
\hline 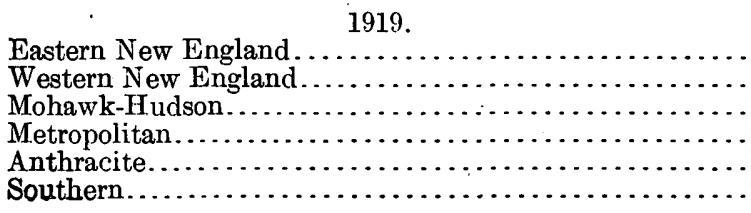 & $\begin{array}{r}0 \\
0 \\
0 \\
102 \\
35 \\
123\end{array}$ & $\begin{array}{r}0 \\
0 \\
0 \\
204 \\
70 \\
246\end{array}$ & $\begin{array}{r}0 \\
0 \\
0 \\
408 \\
\times 70 \\
492\end{array}$ & $\begin{array}{rr}20 & 207 \\
264 \\
237 \\
\\
283 \\
\ldots \quad 59 \\
\quad 314\end{array}$ & $\begin{array}{l}207 \\
415 \\
317 \\
393 \\
111 \\
463\end{array}$ & $\begin{array}{l}414 \\
630 \\
634 \\
786 \\
222 \\
926\end{array}$ \\
\hline 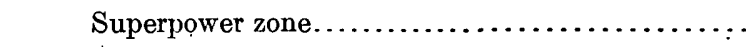 & 260 & 520 & 970 & 1,364 & 1,806 & 3,612 \\
\hline 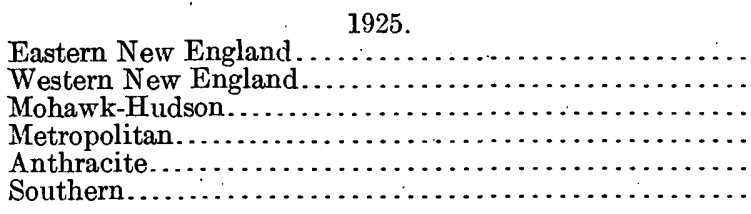 & $\begin{array}{r}0 \\
0 \\
0 \\
102 \\
35 \\
123\end{array}$ & $\begin{array}{r}0 \\
0 \\
0 \\
204 \\
70 \\
246\end{array}$ & $\begin{array}{r}0 \\
0 \\
0 \\
408 \\
70 \\
492\end{array}$ & $\begin{array}{r}262 \\
264 \\
237 \\
\because \quad 283 \\
70 \\
314\end{array}$ & $\begin{array}{l}262 \\
315 \\
317 \\
393 \\
133 \\
463\end{array}$ & $\begin{array}{l}524 \\
630 \\
634 \\
786 \\
266 \\
926\end{array}$ \\
\hline 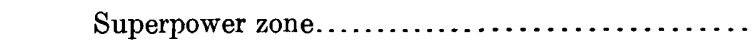 & 260 & 520 & 970 & $\cdots 1,4,430$ & 1,883 & 3,766 \\
\hline 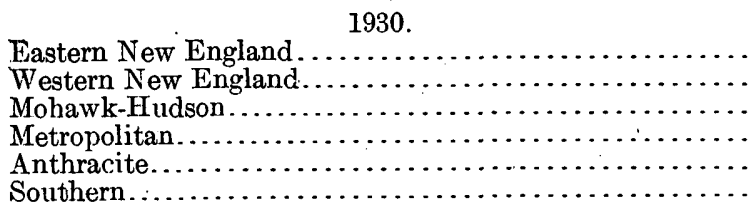 & $\begin{array}{r}0 \\
0 \\
0 \\
102 \\
35 \\
123\end{array}$ & $\begin{array}{r}0 \\
0 \\
0 \\
204 \\
70 \\
246 .\end{array}$ & $\begin{array}{r}0 \\
0 \\
0 \\
408 \\
70 \\
492\end{array}$ & $\begin{array}{r}262 \\
421 \\
262 \\
302 \\
70 \\
334\end{array}$ & $\begin{array}{l}262 \\
601 \\
418 \\
444 \\
140 \\
483\end{array}$ & $\begin{array}{r}524 \\
1,202 \\
836 \\
888 \\
280 \\
966\end{array}$ \\
\hline 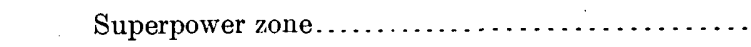 & 260 & 520 & 970 & 1,651 & 2,348 & 4,696 \\
\hline
\end{tabular}




\section{SUBSTATIONS.}

In Table 62 the transformer capacity does not include that installed in base-load steamelectric plants, and the synchronous-condenser capacity does not include the condenser effect of generators used as such, or of motor generator sets in the heavy-traction railroad substations.

TABLE 62.-Substation capacity for the superpower system in 191.9, 1925, and 1930, in thousands of kilovolt-amperes.

\begin{tabular}{|c|c|c|c|c|}
\hline \multirow[b]{2}{*}{ Geographic division. } & \multicolumn{2}{|c|}{ Transformers. } & \multirow[b]{2}{*}{$\begin{array}{c}\text { Synchro- } \\
\text { nous con- } \\
\text { densers. }\end{array}$} & \multirow[b]{2}{*}{$\begin{array}{l}\text { Frequency } \\
\text { changers. }\end{array}$} \\
\hline & $\begin{array}{c}220,000- \\
\text { volt } \\
\text { primary. }\end{array}$ & $\begin{array}{c}110,000- \\
\text { volt } \\
\text { primary. }\end{array}$ & & \\
\hline 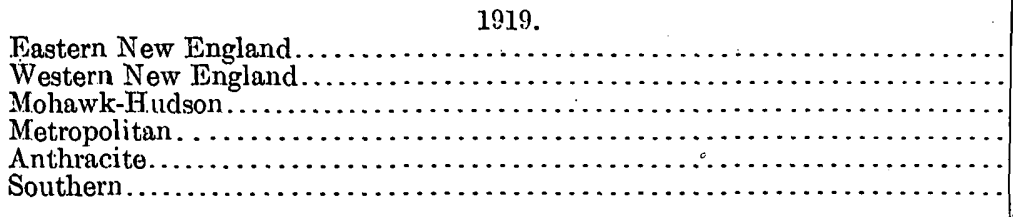 & $\begin{array}{r}0 \\
0 \\
0 \\
800 \\
125 \\
200\end{array}$ & $\begin{array}{l}325 \\
125 \\
300 \\
483 \\
425 \\
495\end{array}$ & $\begin{array}{r}150 \\
105 \\
45 \\
135 \\
90 \\
165\end{array}$ & $\begin{array}{r}0 \\
0 \\
30 \\
0 \\
0 \\
0\end{array}$ \\
\hline 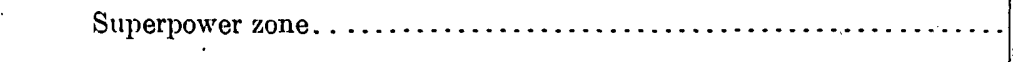 & 1,125 & 2,153 & 690 & 30 \\
\hline 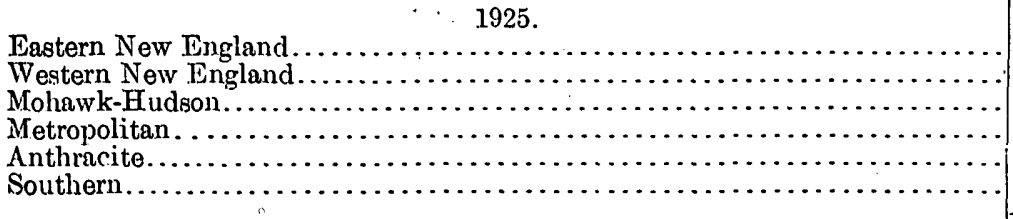 & $\begin{array}{r}0 \\
0 \\
0 \\
850 \\
50 \\
300\end{array}$ & $\begin{array}{l}475 \\
375 \\
350 \\
633 \\
500 \\
595\end{array}$ & $\begin{array}{r}150 \\
105 \\
45 \\
135 \\
90 \\
165\end{array}$ & $\begin{array}{r}0 \\
0 \\
30 \\
0 \\
0 \\
0\end{array}$ \\
\hline 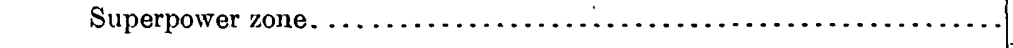 & 1,200 & 2,928 & 690 & 30 \\
\hline 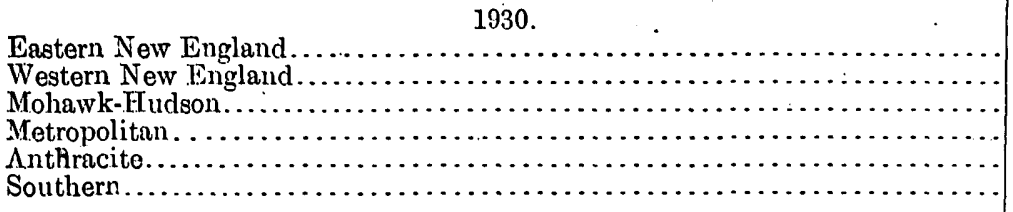 & $\begin{array}{r}0 \\
0 \\
0 \\
1,050 \\
75 \\
325\end{array}$ & $\begin{array}{l}550 \\
590 \\
475 \\
935 \\
675 \\
935\end{array}$ & $\begin{array}{r}180 \\
135 \\
60 \\
180 \\
150 \\
195\end{array}$ & $\begin{array}{r}0 \\
0 \\
60 \\
0 \\
0 \\
0\end{array}$ \\
\hline 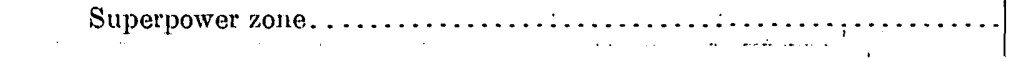 & 1,450 & 4,160 & 900 & 60 \\
\hline
\end{tabular}

FUEL REQUIREMENT.

Table 65 gives the fuel requirement for the superpower system for 1919, 1925, and 1930 . The estimated fuel saving by the superpower system to the electric public utilities is as follows:

TABLE 63.-Fuel saving by superpoiver system to electric public utilities.

\begin{tabular}{|c|c|c|c|}
\hline 。 & 1919 & 1925 & 1930 \\
\hline 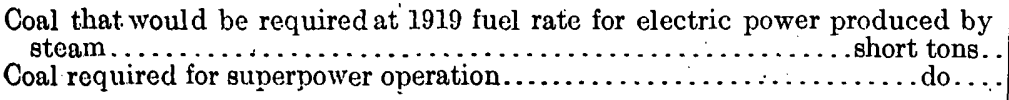 & $\begin{array}{l}24,600,000 \\
14,103,000\end{array}$ & $\begin{array}{l}29,600,000 \\
16,591,000\end{array}$ & $\begin{array}{l}39,700,000 \\
20,551,000\end{array}$ \\
\hline 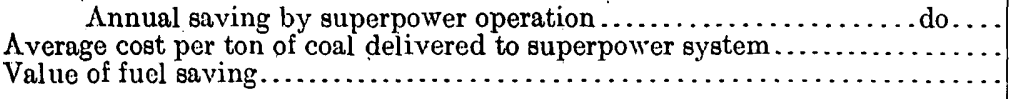 & $\begin{array}{r}10,497,000 \\
\$ 4.37 \\
\$ 45,872,000\end{array}$ & $\begin{array}{r}13,001.000 \\
\$ 5.25 \\
\$ 68,200,000\end{array}$ & $\begin{array}{r}19,149,000 \\
\$ 5.25 \\
\$ 100,500,000\end{array}$ \\
\hline
\end{tabular}

For independent operation the production of power by water has been taken at, 2,100,000,000 kilowatt-hour's for 1925 and 2,800,000,000 kilowatt-hours for 1930. These figures are based on growth of water power for the electric utilities indicated by data collected by the United States Bureau of the Census.

If in 1930 the superpower system were supplied with energy produced entirely from coal with the exception of that from existing hydroelectric plants the coal required would amount to $23,184,100$ short tons, and the fuel saving would be $2,633,100$ tons less than that effected by the proposed arrangement of superpower facilities for 1930 . 
TABLE 64.-Fuel rate for superpower operation and rate under independent operation in 1919, in pounds of coal per kilowatthour generated.

\begin{tabular}{|c|c|c|c|}
\hline$\because$ & 1919 & 1925 & 1930 \\
\hline 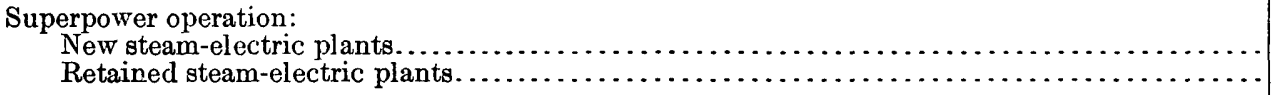 & $\begin{array}{l}1.47 \\
2.54\end{array}$ & $\begin{array}{l}1.45 \\
2.54\end{array}$ & $\begin{array}{l}1.43 \\
2.64\end{array}$ \\
\hline 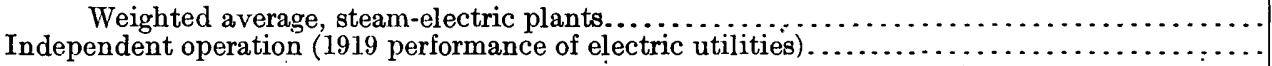 & $\begin{array}{l}\text { 1.. } 80 \\
2.73\end{array}$ & $\begin{array}{l}1.71 \\
2.73\end{array}$ & $\begin{array}{l}1.62 \\
2.73\end{array}$ \\
\hline
\end{tabular}

The average cost of fuel delivered to the new base-load steam-electric plants is lower than that for existing steam-electric plants because of the advantageous locations that can be selected for the new plants. (See Appendix F.) This difference is particularly marked in the comparison of the unit fuel cost for the electric utilities for 1919 (see p. 48) and that of the hypothetical superpower system for 1919, for which the cost of coal at the mine and the railroad freight rate have been assumed to be the same, the resulting cost to the utilities being $\$ 5.35$ per short ton, whereas that to the superpower system is $\$ 4.37$ per ton. For the same reason, despite the higher freight rates charged against coal to the superpower system for 1925 and 1930, the resulting unit cost to the superpower system is less than that to the electric utilities for 1919.

By the use of St. Lawrence power to the extent of 600,000 kilowatts at a load factor of 80 per cent in the Eastern New England, Western New England, and Mohawk-Hudson divisions in 1932 the annual coal requirement will be 2,234,000 tons less than the quantity which would be used were this amount of power generated by new steam-electric plants. By the use of Niagara power to the extent of 300,000 kilowatts at a load factor of 80 per cent in the Metropolitan division in 1932 the annual coal requirement will be $1,204,000$ tons less than the quantity which would be used were this amount of power generated by'new steam-electric plants.

TABLE 65.-Fuel requirements for superpower system for 1919, 1925, and 1930.

\begin{tabular}{|c|c|c|c|c|c|}
\hline Geographic division. & $\begin{array}{l}\text { Coal per } \\
\text { kilowatt-year } \\
\text { of capacity } \\
\text { (short tons). }\end{array}$ & $\begin{array}{l}\text { Total quantity } \\
\text { of coal per year } \\
\text { (thousands of } \\
\text { short tons). }\end{array}$ & $\begin{array}{l}\text { Cost per short } \\
\text { ton delivered. }\end{array}$ & $\begin{array}{l}\text { Total annual } \\
\text { cost. }\end{array}$ & $\begin{array}{c}0 \\
\text { Coal per } \\
\text { kilowatt-hour } \\
\text { (pounds). }\end{array}$ \\
\hline 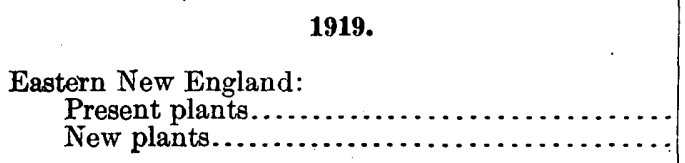 & $\begin{array}{l}\text { 1. } 31 \\
\text { 3.92 }\end{array}$ & $\begin{array}{r}673.2 \\
1,412.0\end{array}$ & $\because \quad \begin{array}{r}\$ 6.15 \\
6.10\end{array}$ & $\begin{array}{r}\$ 4,132,000 \\
8,620,000\end{array}$ & $\begin{array}{l}2.61 \\
1.20\end{array}$ \\
\hline & 2.39 & $2,085.2$ & 6. 11 & $12,752,000$ & 1.44 \\
\hline 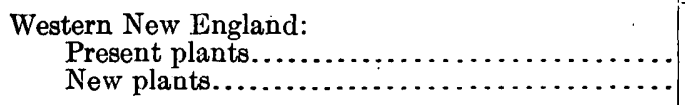 & $\begin{array}{r}.84 \\
2.70\end{array}$ & $\begin{array}{l}144.8 \\
729.0\end{array}$ & $\begin{array}{l}5.88 \\
5.67\end{array}$ & $\begin{array}{r}851,000 \\
4,130,000\end{array}$ & $\begin{array}{r}3.76 \\
\circ \quad 1.33\end{array}$ \\
\hline . & 1.97 & 873.8 & 5.70 & $4,981,000$ & 1. 50 \\
\hline 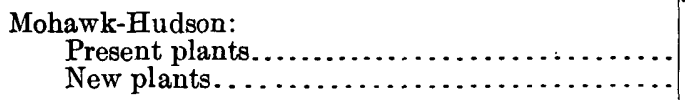 & $\begin{array}{l}1.12 \\
2.28\end{array}$ & $\begin{array}{r}51.2 \\
410.0\end{array}$ & $\begin{array}{l}\text { 5. } 32 \\
5.32\end{array}$ & $\begin{array}{r}272,000 \\
2,180,000\end{array}$ & $\begin{array}{l}\text { 5. } 12 \\
1.35\end{array}$ \\
\hline . & 2.04 & 461. 2 & 5. 32 & $2,452,000$ & 1.47 \\
\hline 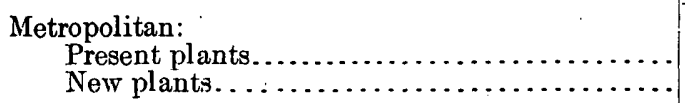 & $\begin{array}{l}2.80 \\
2.99\end{array}$ & $\begin{array}{r}3,170 \\
a 1,625\end{array}$ & $\begin{array}{l}5.22 \\
5.22\end{array}$ & $\begin{array}{r}16,550,000 \\
5,878,000\end{array}$ & $\begin{array}{l}2.14 \\
1.33\end{array}$ \\
\hline & 2.84 & 4,795 & 5. 22 & $22,428,000$. & 1.93 \\
\hline 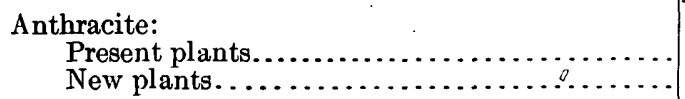 & $\begin{array}{l}6.80 \\
5.92\end{array}$ & $\begin{array}{r}1,085 \\
a 1,759.0\end{array}$ & $\begin{array}{l}2.53 \\
2.35\end{array}$ & $\begin{array}{l}2,752,000 \\
4,135,000\end{array}$ & $\begin{array}{l}4.04 \\
1.80\end{array}$ \\
\hline & 6.17 & $2,844.0$ & .2 .41 & $6,887,000$ & 2. 15 \\
\hline
\end{tabular}


TABLE 65.-Fuel requirements for superpower system for 1919, 1925, and 1980-Continued.

\begin{tabular}{|c|c|c|c|c|c|}
\hline Geographic division. & $\begin{array}{l}\text { Coal per } \\
\text { kilowatt-year } \\
\text { of capacity } \\
\text { (short tons). }\end{array}$ & $\begin{array}{l}\text { Total quantity } \\
\text { of coal per year } \\
\text { (thousands of } \\
\text { short tons). }\end{array}$ & $\begin{array}{l}\text { Cost per short } \\
\text { ton delivered. }\end{array}$ & $\begin{array}{l}\text { Total annual } \\
\text { cost. }\end{array}$ & $\begin{array}{l}\text { Coal per } \\
\text { kilowatt-hour } \\
\text { (pounds). }\end{array}$ \\
\hline 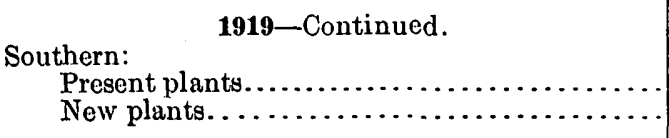 & $\begin{array}{l}\text { 1. } 29 \\
4.88\end{array}$ & $\begin{array}{r}845.8 \\
2,198.0\end{array}$ & $\begin{array}{r}\$ 5.05 \\
3.66\end{array}$ & $\begin{array}{r}\$ 4,270,000 \\
8,045,000\end{array}$ & $\begin{array}{l}2.93 \\
1.50\end{array}$ \\
\hline & 2.76 & $3,043.8$ & 4.05 & $12,315,000$ & 1. 73 \\
\hline 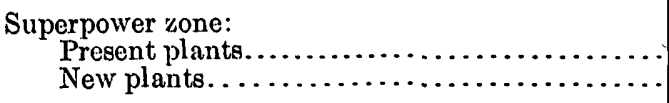 & $\begin{array}{l}2.23 \\
4.16\end{array}$ & $\begin{array}{l}5,969.8 \\
8,133.0\end{array}$ & $\begin{array}{l}4.84 \\
4.06\end{array}$ & $\begin{array}{l}28,827,000 \\
32,988,000\end{array}$ & $\begin{array}{l}2.54 \\
1.47\end{array}$ \\
\hline & 3.05 & $14,102.8$ & 4. 37 & $61,815,000$ & 1. 80 \\
\hline 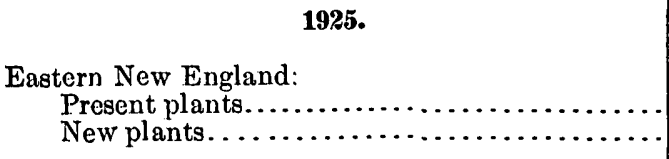 & $\begin{array}{l}1.29 \\
\text { 3. } 74\end{array}$ & $\begin{array}{r}665.3 \\
1,679.0\end{array}$ & $\begin{array}{l}7.40 \\
7.42\end{array}$ & $\begin{array}{r}4,928,300 \\
12,435,000\end{array}$ & $\begin{array}{l}2.58 \\
1.19\end{array}$ \\
\hline & 2.44 & $2,344.3$ & 7.40 & $17,363,300$ & 1. 41 \\
\hline 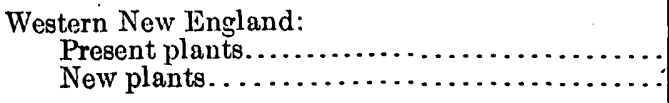 & $\begin{array}{r}.84 \\
2.72\end{array}$ & $\begin{array}{l}144.8 \\
816.0\end{array}$ & $\begin{array}{l}7.10 \\
6.86\end{array}$ & $\begin{array}{l}1,028,900 \\
5,600,000\end{array}$ & $\begin{array}{l}\text { 3. } 76 \\
1.33\end{array}$ \\
\hline . & 2.04 & 960.8 & 6.90 & $6,628,900$ & 1. 48 \\
\hline 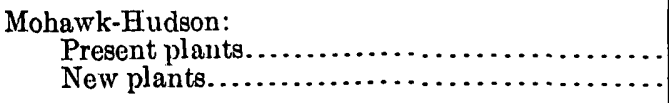 & $\begin{array}{l}1.12 \\
2.88\end{array}$ & $\begin{array}{r}51.2 \\
692.0\end{array}$ & $\begin{array}{l}6.33 \\
6.33\end{array}$ & $\begin{array}{r}324,000 \\
4,380,000\end{array}$ & $\begin{array}{l}5.14 \\
1.33\end{array}$ \\
\hline & 2. 60 & 743.2 & 6.33 & $4,704,000$ & 1.40 \\
\hline $\begin{array}{l}\text { Metropolitan: } \\
\quad \text { Present plants. } \ldots \ldots \ldots \ldots \ldots \ldots \ldots \ldots \ldots \ldots \ldots \ldots \ldots \\
\quad \text { New plants. } \ldots \ldots \ldots \ldots \ldots \ldots \ldots \ldots \ldots\end{array}$ & $\begin{array}{l}2.80 \\
3.84\end{array}$ & $\begin{array}{r}3,170.0 \\
a 2,598.0\end{array}$ & $\begin{array}{l}6.25 \\
6.25\end{array}$ & $\begin{array}{l}19,800,000 \\
12,190,000\end{array}$ & $\begin{array}{l}2.14 \\
1.32\end{array}$ \\
\hline & 3.06 & $5,768.0$ & 6.25 & $31,990,000$ & 1. 68 \\
\hline $\begin{array}{l}\text { Anthracite: } \\
\quad \text { Present plants. } \ldots \ldots \ldots \ldots \ldots \ldots \ldots \ldots \ldots \ldots \ldots \ldots \\
\quad \text { New plants. } \ldots \ldots \ldots \ldots \ldots \ldots \ldots \ldots\end{array}$ & $\begin{array}{l}6.80 \\
5.92\end{array}$ & $\begin{array}{r}1,085.0 \\
a 1,565.0\end{array}$ & $\begin{array}{l}2.81 \\
2.57\end{array}$ & $\begin{array}{l}3,046,000 \\
4,025,000\end{array}$ & $\begin{array}{l}4.04 \\
1.80\end{array}$ \\
\hline & 6. 17 & $2,650.0$ & 2.65 & $7,071,000$ & 2.15 \\
\hline 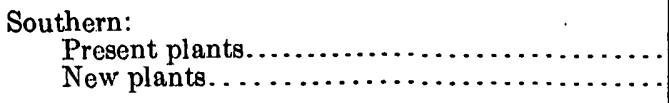 & $\begin{array}{l}1.29 \\
4.75\end{array}$ & $\begin{array}{r}845.8 \\
3,279.0\end{array}$ & $\begin{array}{l}5.89 \\
4.42\end{array}$ & $\begin{array}{r}4,979,000 \\
14,480,000\end{array}$ & $\begin{array}{l}2.93 \\
1.50\end{array}$ \\
\hline & 3. 06 & $4,124.8$ & 4. 72 & $19,459,000$ & 1. 67 \\
\hline 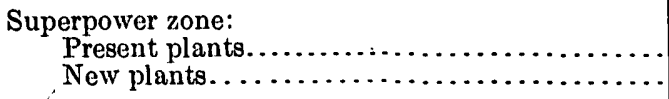 & $\begin{array}{l}2.23 \\
4.23\end{array}$ & $\begin{array}{r}5,962.1 \\
10,629.0\end{array}$ & $\begin{array}{l}5.72 \\
5.00\end{array}$ & $\begin{array}{l}34,106,200 \\
53,110,000\end{array}$ & $\begin{array}{l}2.54 \\
1.45\end{array}$ \\
\hline & 3.20 & $16,591.1$ & 5.25 & $87,216,200$ & 1. 71 \\
\hline 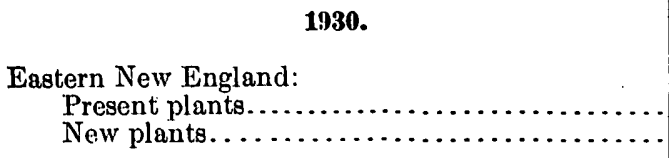 & $\begin{array}{l}1.30 \\
3.10\end{array}$ & $\begin{array}{r}673.2 \\
2,512.0\end{array}$ & $\begin{array}{l}7.43 \\
7.42\end{array}$ & $\begin{array}{r}4,995,000 \\
18,610,000\end{array}$ & $\begin{array}{l}2.55 \\
1.21 .\end{array}$ \\
\hline & 2.41 & $3,185.2$ & 7. 42 & $23,605,000$ & 1. 37 \\
\hline 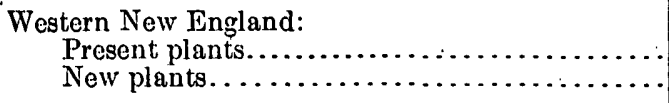 & $\begin{array}{r}.84 \\
2.17\end{array}$ & $\begin{array}{l}144.8 \\
846.0\end{array}$ & $\begin{array}{l}7.10 \\
6.87\end{array}$ & $\begin{array}{l}1,029,000 \\
5,810,000\end{array}$ & $\begin{array}{l}\text { 3. } 76 \\
\text { 1. } 37\end{array}$ \\
\hline & 1. 76 & 990.8 & 6.90 & $6,839,000$ & 1.. 51 . \\
\hline
\end{tabular}

$a$ Includes a portion of the coal burned in the Pittston plant. 
TABLE 65.-Fuel requirements for superpower system for 1919, 1925, and 1930-Continued.

\begin{tabular}{|c|c|c|c|c|c|}
\hline Geographic division. & $\begin{array}{l}\text { Coal per } \\
\text { kilowatt-year } \\
\text { of capacity } \\
\text { (short tons). }\end{array}$ & $\begin{array}{l}\text { Total quantity } \\
\text { of coal per year } \\
\text { (thousands of } \\
\text { short tons). }\end{array}$ & $\begin{array}{l}\text { Cost per short } \\
\text { ton delivered. }\end{array}$ & $\begin{array}{l}\text { Total annual } \\
\text { cost. }\end{array}$ & $\begin{array}{c}\text { Coal per } \\
\text { kilowatt-hour } \\
\text { (pounds). }\end{array}$ \\
\hline $\begin{array}{l}\text { 1930-Continued. } \\
\text { Mohawk-Hudson: } \\
\text { Present plants. } \ldots \ldots \ldots \ldots \ldots \ldots \ldots \ldots \ldots \ldots \ldots \ldots \ldots \\
\text { New plants. } \ldots \ldots \ldots \ldots \ldots \ldots \ldots \ldots \ldots \\
\end{array}$ & $\begin{array}{l}1.12 \\
2.47\end{array}$ & $\begin{array}{r}51.2 \\
888.0\end{array}$ & $\begin{array}{r}\$ 6.33 \\
6.33\end{array}$ & $\begin{array}{r}\$ 324 ; 000 \\
5,620,000\end{array}$ & $\begin{array}{l}5.14 \\
1.35\end{array}$ \\
\hline & 2.31 & 939.2 & 6.33 & $5,944,000$ & 1. 41 \\
\hline $\begin{array}{l}\text { Metropolitan: } \\
\quad \text { Present plants. } \ldots \ldots \ldots \ldots \ldots \ldots \ldots \ldots \ldots \ldots \ldots \ldots \\
\text { New plants. } \ldots \ldots \ldots \ldots \ldots \ldots \ldots \ldots \ldots\end{array}$ & $\begin{array}{l}2.23 \\
3.86\end{array}$ & $\begin{array}{r}2,522.0 \\
a 4,131.0\end{array}$ & $\begin{array}{l}6.25 \\
6.25\end{array}$ & $\begin{array}{c}: \\
15,763,000 \\
21,300,000\end{array}$ & $\begin{array}{l}2.22 \\
\text { 1. } 31\end{array}$ \\
\hline . & 2.88 & 6,653 & 6.25 & $37,063,000$ & 161. \\
\hline 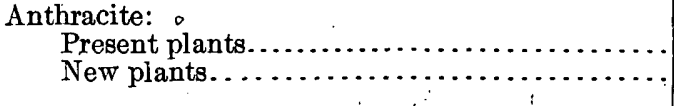 & $\begin{array}{l}6.80 \\
5.92\end{array}$ & $\begin{array}{r}1,85.0 \\
a 2,316.0\end{array}$ & $\begin{array}{l}2.81 \\
2.57\end{array}$ & $\begin{array}{l}3,046,000 \\
5,948,000\end{array}$ & $\begin{array}{l}4.04 \\
1.80\end{array}$ \\
\hline$\cdot$ & 6.10 & $3,401.0$ & 2.63 & 8,$994 ; 000$ & 2.07 \\
\hline 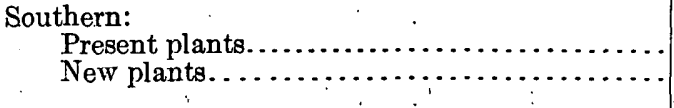 & $\begin{array}{l}1.29 \\
4.44\end{array}$ & $\begin{array}{r}845.8 \\
4,536.0\end{array}$ & $\begin{array}{l}5.89 \\
4.57\end{array}$ & $\begin{array}{r}4,979,000 \\
20,670,000\end{array}$ & $\begin{array}{l}2.93 \\
1.46\end{array}$ \\
\hline & 3. 21 & $5,381.8$ & 4. 77 & 25,$649 ; 0 \theta 0$ & 1.59 \\
\hline $\begin{array}{l}\text { Superpower zone: } \\
\quad \text { Present plants. } \ldots \ldots \ldots \ldots \ldots \ldots \ldots \ldots \ldots \ldots \ldots \ldots \ldots \\
\text { New plants. } \ldots \ldots \ldots \ldots \ldots \ldots \ldots \ldots \ldots\end{array}$ & $\begin{array}{l}1.98 \\
3.88\end{array}$ & $\begin{array}{r}5,322.0 \\
15,229.0\end{array}$ & $\begin{array}{l}5.67 \\
5.11\end{array}$ & $\begin{array}{l}30,136,000 \\
77,958,000\end{array}$ & $\begin{array}{l}2.64 \\
1.43\end{array}$ \\
\hline . & 3.11 & $20,551.0$ & $\because \cdots 5.25$ & $108,094,000$ & 1. 62 \\
\hline
\end{tabular}

$a$ Includes a portion of the coal burned in the Pittston plant.

\section{INVESTMENT COST.}

The total investment cost for the facilities of the superpower system for 1919,1925 , and 1930 is given in Table 68. The unit cost is shown below; the figures for the retained plants represent reproduction cost in midyear of 1919.

TABLE 66.-Unit investment cost of superpower system per kilowatt of installed plant capacity.

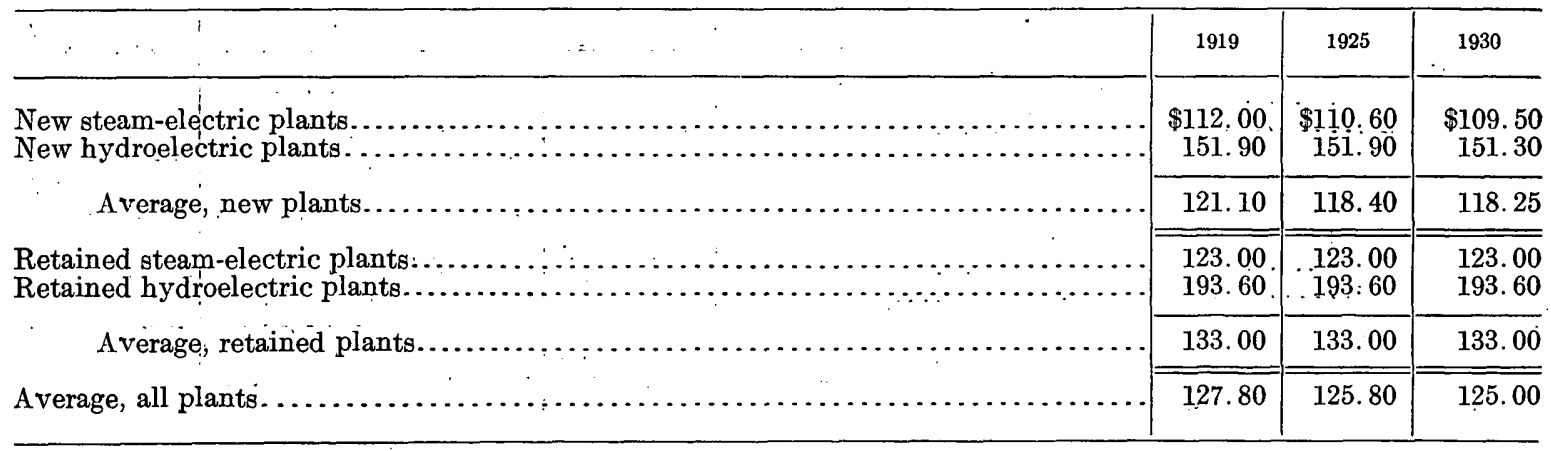

The greater unit cost of the plants retained is the result of their smaller individual capacity. The new hydroelectric plants for the superpower system are to be located only at the most economical sites and constructed largely to carry peak loads, and therefore they show a lower unit investment cost. 
TABLE 67.- Unit investment cost per kilowatt of demand for all facilities of superpower system. ·

\begin{tabular}{|c|c|c|c|}
\hline$+x^{\prime}$ & 1919 & 1925 & 1930 \\
\hline \multirow[t]{2}{*}{ 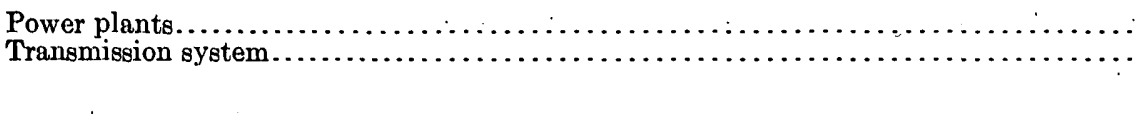 } & $\begin{array}{r}\$ 149.00 \\
16.00\end{array}$ & $\begin{array}{r}\$ 140.00 \\
.15 .40\end{array}$ & $\begin{array}{r}\$ 136.80 \\
14.05\end{array}$ \\
\hline & 165.00 & 155.40 & 150.85 \\
\hline
\end{tabular}

The reproduction cost of the power plants of the electric utilities in 1919 was $\$ 598,277,000$, or $\$ 196$ per kilowatt of demand.

The new money required for the superpower project is $\$ 453,143,000$ by 1925 and $\$ 693,218,000$ by 1930 , thus making it necessary to raise about $\$ 90,600,000$ annually for the first five years and $\$ 48,000,000$ annually for the succeeding five-year period. The early installation of the transmission network is responsible for the higher annual requirement for the first five years. This expenditure, however, is justified by the saving that will result through interconnection.

If the increase in demand to 1930 were provided for by independent systems such as were in existence in 1919 , a total of about $\$ 856,000,000$ would have to be expended, requiring financing to the extent of about $\$ 85,600,000$ annually. Accordingly, the construction of the superpower system should be accomplished with a saving in investment cost of about $\$ 163,000,000$ during the next 10 years.

TABLE 68.-Investment cost for the superpower system for 1919, 1925, and 1980, in thousands of dollars.

\begin{tabular}{|c|c|c|c|c|c|c|c|}
\hline & $\begin{array}{l}\text { Eastern } \\
\text { New } \\
\text { England. }\end{array}$ & $\begin{array}{l}\text { Western } \\
\text { New } \\
\text { England. }\end{array}$ & $\begin{array}{l}\text { Mohawk- } \\
\text { Hudson. }\end{array}$ & $\begin{array}{l}\text { Metro- } \\
\text { politan. }\end{array}$ & $\begin{array}{l}\text { Anthra- } \\
\text { cite. }\end{array}$ & Southern. & $\begin{array}{l}\text { Super- } \\
\text { power } \\
\text { zone. }\end{array}$ \\
\hline 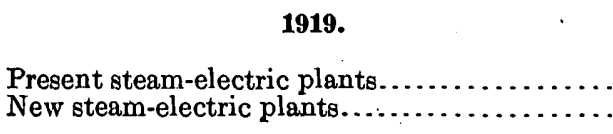 & $\begin{array}{l}66,235 \\
41,100\end{array}$ & $\begin{array}{l}24,550 \\
29,890\end{array}$ & $\begin{array}{r}7,200 \\
20,920\end{array}$ & $\begin{array}{l}129,105 \\
a 43,570\end{array}$ & $\begin{array}{r}22,586 \\
a 33,000\end{array}$ & $\begin{array}{l}79,543 \\
50,035\end{array}$ & $\begin{array}{l}329,219 \\
218,515\end{array}$ \\
\hline . & 107,335 & 54,440 & 28,120 & 172,675 & 55,586 & 129,578 & 547,734 \\
\hline 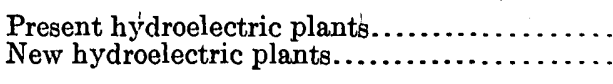 & $\begin{array}{r}16,501 \\
\ldots \ldots\end{array}$ & $\begin{array}{r}16,713 \\
9,000\end{array}$ & $\begin{array}{l}26,135 \\
20,124\end{array}$ & $\begin{array}{r}2,550 \\
25,700\end{array}$ & $\begin{array}{r}1,265 \\
\ldots\end{array}$ & $\begin{array}{l}23,963 \\
33,000\end{array}$ & $\begin{array}{l}87,127 \\
87,824\end{array}$ \\
\hline ' & 16,501 & 25,713 & 46,259 & 28,250 & 1,265 & 56,963 & 174,951 \\
\hline All power plants.............. & 123,836 & 80,153 & 74,379 & 200,925 & 56,851 & 186,541 & 722,685 \\
\hline 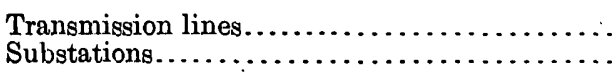 & $\begin{array}{l}4,131 \\
3,656\end{array}$ & $\begin{array}{l}6,343 \\
1,902\end{array}$ & $\begin{array}{l}6,108 \\
3,149\end{array}$ & $\begin{array}{l}13,345 \\
10,955\end{array}$ & $\begin{array}{l}3,635 \\
3,253\end{array}$ & $\begin{array}{r}15,009 \\
6,183\end{array}$ & $\begin{array}{l}48,571 \\
29,098\end{array}$ \\
\hline Transmission system........ & 7,787 & 8,245 & 9,257 & 24,300 & 6,888 & 21,192 & 77,669 \\
\hline 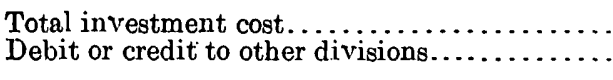 & $\begin{array}{l}131,623 \\
\ldots \ldots\end{array}$ & $\begin{array}{r}88,398 \\
\ldots \ldots\end{array}$ & $\begin{array}{r}83,636 \\
-3,800\end{array}$ & $\begin{array}{r}225,225 \\
+3,800\end{array}$ & $\begin{array}{r}63,739 \\
+2,655\end{array}$ & $\begin{array}{r}207,733 \\
-2,655\end{array}$ & $\begin{array}{r}800,354 \\
\ldots\end{array}$ \\
\hline $\begin{array}{l}\text { Total investment cost to division } \ldots \ldots \ldots \ldots \\
\text { Investment made as of midyear, } 1919 \ldots \ldots \ldots\end{array}$ & $\begin{array}{r}131,623 \\
82,736 .\end{array}$ & $\begin{array}{l}88,398 \\
41,263\end{array}$ & $\begin{array}{l}79,836 \\
33,335\end{array}$ & $\begin{array}{l}229,025 \\
131,655\end{array}$ & $\begin{array}{l}66,394 \\
23,851\end{array}$ & $\begin{array}{l}205,078 \\
103,506\end{array}$ & $\begin{array}{l}800,354 \\
416,346\end{array}$ \\
\hline New money required. & 48,887 & 47,135 & 46,501 & 97,370 & 42,543 & 101,572 & 384,008 \\
\hline 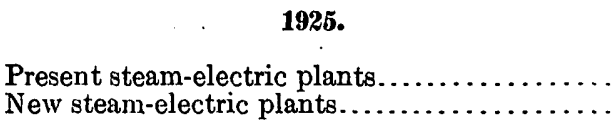 & $\begin{array}{l}66,235 \\
50,700\end{array}$ & $\begin{array}{l}24,550 \\
33,100\end{array}$ & $\begin{array}{r}7,200 \\
26,850\end{array}$ & $\begin{array}{l}129,105 \\
a_{6}, 700\end{array}$ & $\begin{array}{r}22,586 \\
a 29,420\end{array}$ & $\begin{array}{l}79,543 \\
76,120\end{array}$ & $\begin{array}{l}329,219 \\
278,890\end{array}$ \\
\hline & 116,935 & 57,650 & 34,050 & 191,805 & 52,006 & 155,663 & 608,109 \\
\hline 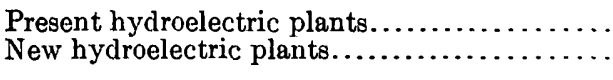 & $\begin{array}{r}16,501 \\
\cdots \cdots\end{array}$ & $\begin{array}{r}16,713 \\
9,000\end{array}$ & $\begin{array}{l}26,135 \\
20,124\end{array}$ & $\begin{array}{r}2,550 \\
25,700\end{array}$ & 1,265 & $\begin{array}{l}23,963 \\
33,000\end{array}$ & $\begin{array}{l}87,127 \\
87,824\end{array}$ \\
\hline & 16,501 & 25,713 & 46,259 & 28,250 & 1,265 & 56,963 & 174,951 \\
\hline All power plants........... & 133,436 & 83,363 & 80,309 & 220,055 & 53,271 & 212,626 & 783,060 \\
\hline
\end{tabular}


TABLE 68:-Investment cost for the superpower system for 1919, 1925, and 1930, in thousands of dollars-Continued.

\begin{tabular}{|c|c|c|c|c|c|c|c|}
\hline & $\begin{array}{c}\text { Eastern } \\
\text { New } \\
\text { England. }\end{array}$ & $\begin{array}{l}\text { Western } \\
\text { New } \\
\text { England. }\end{array}$ & $\begin{array}{l}\text { Mohawk- } \\
\text { Hudson. }\end{array}$ & $\begin{array}{l}\text { Metro- } \\
\text { politan. }\end{array}$ & $\begin{array}{l}\text { Anthra- } \\
\text { cite. }\end{array}$ & Southern. & $\begin{array}{l}\text { Super- } \\
\text { power } \\
\text { zone. }\end{array}$ \\
\hline 1925-Continued. & $\bullet$ & & & & & & . \\
\hline $\begin{array}{l}\text { Transmission lines................. } \\
\text { Substations.................. }\end{array}$ & $\begin{array}{l}5,186 \\
5,102\end{array}$ & $\begin{array}{l}6,346 \\
3,655\end{array}$ & $\begin{array}{l}6,108 \\
3,226\end{array}$ & $\begin{array}{l}13,345 \\
12,436\end{array}$ & $\begin{array}{l}4,085 \\
4,163\end{array}$ & $\begin{array}{r}15,009 \\
7,768\end{array}$ & $\begin{array}{l}50,079 \\
36,350\end{array}$ \\
\hline Transmission system.. & 10,288 & 10,001 & 9,334 & 25,781 & 8,248 & 22,777 & 86,429 \\
\hline $\begin{array}{l}\text { Total investment cost.................... } \\
\text { Debit or credit to other divisions.. }\end{array}$ & $\begin{array}{c}143,724 \\
\ldots \ldots \ldots\end{array}$ & $\begin{array}{r}93,364 \\
+5,980\end{array}$ & $\begin{array}{r}89,643 \\
-780\end{array}$ & $\begin{array}{l}245,836 \\
-5,200\end{array}$ & $\begin{array}{r}61,519 \\
+1,435\end{array}$ & $\begin{array}{l}235,403 \\
-1,435\end{array}$ & $\begin{array}{r}869,489 \\
\ldots \ldots\end{array}$ \\
\hline $\begin{array}{l}\text { Total investment cost to division } \ldots \ldots \ldots \ldots \\
\text { Investment made as of midyear, } 1919 . \ldots \ldots\end{array}$ & $\begin{array}{r}143,724 \\
82,736\end{array}$ & $\begin{array}{l}99,344 \\
41,263\end{array}$ & $\begin{array}{l}88,863 \\
33,335\end{array}$ & $\begin{array}{l}240,636 \\
131,655\end{array}$ & $\begin{array}{l}62,954 \\
23,851\end{array}$ & $\begin{array}{l}233,968 \\
103,506\end{array}$ & $\begin{array}{l}869,489 \\
416,346\end{array}$ \\
\hline New money required.. & 60,988 & 58,081 & 55,528 & 108,981 & 39,103 & 130,462 & 453,143 \\
\hline $\begin{array}{l}\qquad \mathbf{1 9 3 0 .} \\
\text { Present steam-electric plants..... } \\
\text { New steam-electric plants....... }\end{array}$ & $\begin{array}{l}66,235 \\
91,750\end{array}$ & $\begin{array}{l}24,550 \\
42,280\end{array}$ & $\begin{array}{r}7,200 \\
39,195\end{array}$ & $\begin{array}{r}129,105 \\
a 103,100\end{array}$ & $\begin{array}{r}22, \dot{586} \\
a 42,800\end{array}$ & $\begin{array}{r}79,543 \\
111,050\end{array}$ & $\begin{array}{l}329,219 \\
430,175\end{array}$ \\
\hline & 157,985 & 66,830 & 46,395 & 232,205 & 65,386 & 190,593 & 759,394 \\
\hline $\begin{array}{l}\text { Present hydroelectric plants.... } \\
\text { New hydroelectric plants...... }\end{array}$ & $\begin{array}{r}16,501 \\
\cdots \cdots \cdots\end{array}$ & $\begin{array}{l}16,713 \\
29,000\end{array}$ & $\begin{array}{l}26,135 \\
38,350\end{array}$ & $\begin{array}{r}2,550 \\
51,500\end{array}$ & $\begin{array}{r}1,265 \\
\cdots \cdots\end{array}$ & $\begin{array}{l}23,963 \\
40,000\end{array}$ & $\begin{array}{r}87,127 \\
158,850\end{array}$ \\
\hline & 16,501 & 45,713 & 64,485 & 54,050 & 1,265 & 63,963 & 245,977 \\
\hline All power plants... & 174,486 & 112,543 & 110,880 & 286,255 & 66,651 & 254,556 & $1,013,535$ \\
\hline $\begin{array}{l}\text { Transmission lines....... } \\
\text { Substations........... }\end{array}$ & $\begin{array}{l}5,186 \\
5,730\end{array}$ & $\begin{array}{r}11,840 \\
5,612\end{array}$ & $\begin{array}{l}7,956 \\
4,371\end{array}$ & $\begin{array}{l}14,369 \\
14,606\end{array}$ & $\begin{array}{l}4,310 \\
4,765\end{array}$ & $\begin{array}{r}16,440 \\
9,008\end{array}$ & $\begin{array}{l}60,101 \\
44,092\end{array}$ \\
\hline Transmission system. & 10,916 & 17,452 & 12,327 & 28,975 & 9,075 & 25,448 & 104,193 \\
\hline $\begin{array}{l}\text { Total investment cost.......................... } \\
\text { Debit or credit to other divisions... }\end{array}$ & $\begin{array}{l}185,402 \\
\cdots \cdots\end{array}$ & $\begin{array}{r}129,995 \\
+7,800 \\
\end{array}$ & $\begin{array}{r}123,207 \\
-480 \\
\end{array}$ & $\begin{array}{r}315,230 \\
-7,320 \\
\end{array}$ & $\begin{array}{r}75,726 \\
+18,340 \\
\end{array}$ & $\begin{array}{r}280,004 \\
-18,340 \\
\end{array}$ & $\begin{array}{l}1,109,564 \\
\cdots \cdots \cdots \cdots\end{array}$ \\
\hline $\begin{array}{l}\text { Total investment cost to division....... } \\
\text { Investment made as of midyear, } 1919 . .\end{array}$ & $\begin{array}{r}185,402 \\
82,736\end{array}$ & $\begin{array}{r}137,795 \\
41,263 \\
\end{array}$ & $\begin{array}{r}122,727 \\
33,335\end{array}$ & $\begin{array}{l}307,910 \\
131,655\end{array}$ & $\begin{array}{l}94,066 \\
23,851\end{array}$ & $\begin{array}{l}261,664 \\
103,506\end{array}$ & $\begin{array}{r}1,109,564 \\
416,346\end{array}$ \\
\hline New money required..... & 102,666 & 96,532 & 89,392 & 176,255 & 70,215 & 158,158 & 693,218 \\
\hline
\end{tabular}

a Includes a portion of the Pittston plant investment.

\section{COST OF POWER.}

Table 72 gives the annual production cost of the power plants for the superpower zone, Table 73 the annual transmission-system cost, and Table 74 the total cost of power delivered to load centers.

The costs given in Appendix B consider only production by the electric utilities and represent the cost of power at their bus bars. These costs, compared to the production cost of all the plants of the superpower system, are as follows:

- TABLE 69.-Production cost per kilowatt-hour net generated.

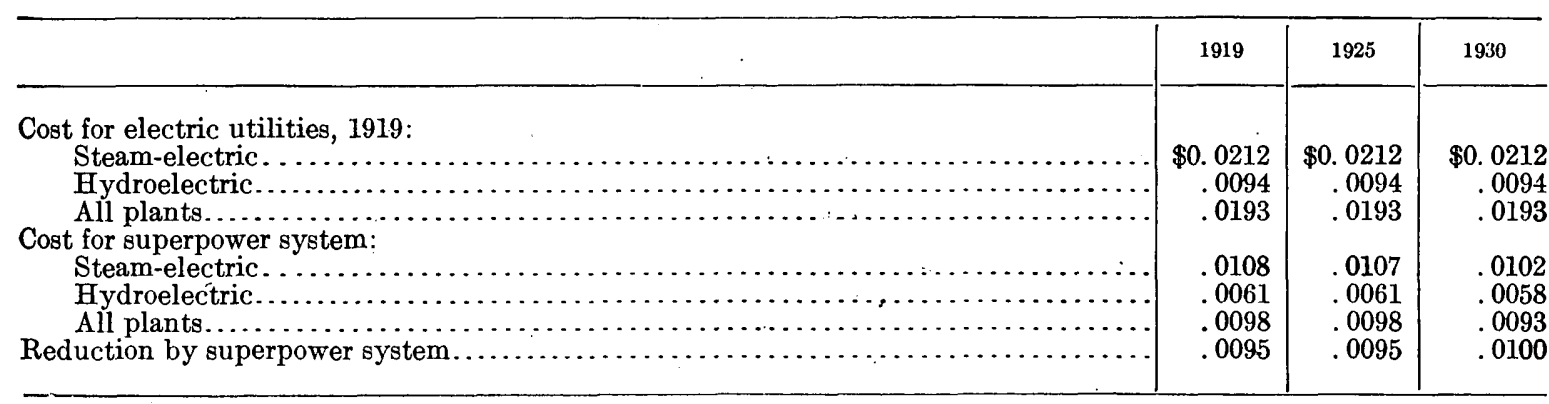


To the production cost of the superpower system must be added the transmission cost to determine the cost of power delivered at the load centers.

The average unit cost of power delivered by the superpower system to the load centers is stated below.

TABLE 70.-Unit cost of power delivered to load centers.

\begin{tabular}{|c|c|c|c|c|c|c|}
\hline \multirow[t]{2}{*}{. } & \multicolumn{2}{|c|}{1919} & \multicolumn{2}{|c|}{1925} & \multicolumn{2}{|c|}{1930} \\
\hline & $\begin{array}{c}\text { Per kilo- } \\
\text { watt-hour. }\end{array}$ & $\begin{array}{c}\text { Per kilo- } \\
\text { watt-year } \\
\text { of demand. }\end{array}$ & $\begin{array}{c}\text { Per kilo- } \\
\text { watt-hour. }\end{array}$ & $\begin{array}{c}\text { Per kilo- } \\
\text { watt-year } \\
\text { of demand. }\end{array}$ & $\begin{array}{c}\text { Per kilo- } \\
\text { watt-hour. }\end{array}$ & $\begin{array}{c}\text { Per kilo- } \\
\text { watt-year } \\
\text { of demand. }\end{array}$ \\
\hline 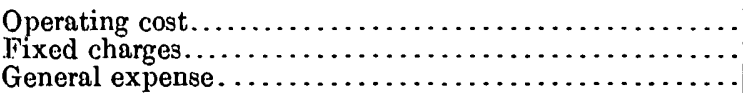 & $\begin{array}{r}\$ 0.0045 \\
.0064 \\
.0004\end{array}$ & $\begin{array}{r}\$ 17.85 \\
25.40 \\
1.55\end{array}$ & $\begin{array}{r}\$ 0.0050 \\
.0058 \\
.0004\end{array}$ & $\begin{array}{r}\$ 20.40 \\
24.00 \\
1.60\end{array}$ & $\begin{array}{r}\$ 0.0046 \\
.0056 \\
.0004\end{array}$ & $\begin{array}{r}\$ 19.10 \\
23.10 \\
1.60\end{array}$ \\
\hline & .0113 & 44.80 & .0112 & 46.00 & .0106 & 43.80 \\
\hline
\end{tabular}

TA ALE 71.-Annual cost for power delivered to load centers by superpower system and cost for independent operation under conditions of 1919 .

\begin{tabular}{|c|c|c|c|}
\hline & 1919 & 1925 & 1930 \\
\hline \multirow[t]{2}{*}{ 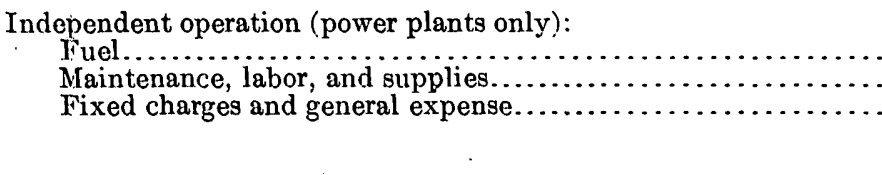 } & $\begin{array}{r}\$ 125,000,000 \\
47,905,000 \\
190,300,000\end{array}$ & $\begin{array}{r}\$ 151,000,000 \\
69,425,000 \\
227,150,000 \\
\end{array}$ & \multirow{2}{*}{$\begin{array}{r}\$ 203,800,000 \\
93,440,000 \\
305,900,000 \\
603,140,000\end{array}$} \\
\hline & $363,205,000$ & $447,575,000$ & \\
\hline 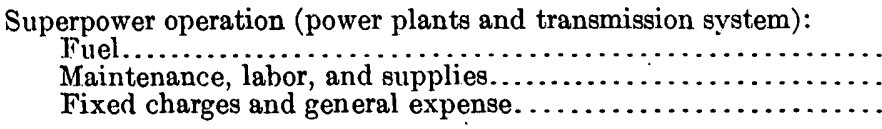 & $\begin{array}{r}61,815,000 \\
24,829,000 \\
130,511,000\end{array}$ & $\begin{array}{r}87,216,000 \\
27,451,000 \\
142,638,000\end{array}$ & $\begin{array}{r}108,094,000 \\
33,905,000 \\
182,608,000\end{array}$ \\
\hline & $217,155,000$ & $257,305,000$ & $324,607,000$ \\
\hline \multirow[t]{2}{*}{ 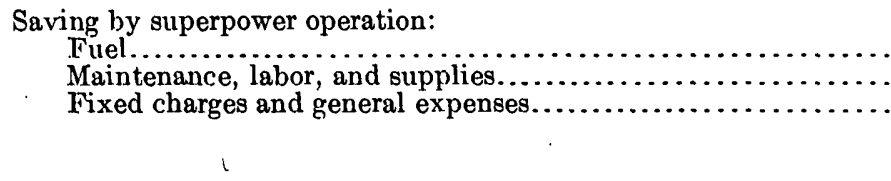 } & $\begin{array}{l}63,185,000 \\
23,076,000 \\
59,789,000 \\
\end{array}$ & $\begin{array}{l}63,784,000 \\
41,974,000 \\
84,512,000\end{array}$ & $\begin{array}{r}95,706,000 \\
59,535,000 \\
123,292,000\end{array}$ \\
\hline & $146,050,000$ & $190,270,000$ & $278,533,000$ \\
\hline
\end{tabular}

The estimated fuel saving for 1925 is very little greater in dollars than that for 1919, owing to the lower unit coal cost per ton for superpower operation in the earlier year. The cost of power for independent operation is computed on the 1919 unit cost given in Appendix B. The value of fuel saving as here stated will therefore not check with the value given on page 163, where a definite cost per ton has been used in obtaining the result.

The total inv'estment in electric-utility company plants in 1919, as shown by reproduction cost, was $\$ 598,277,000$. Plants to the value of $\$ 416,346,000$ are to be incorporated in the superpower system, leaving plants to be abandoned represented by a reproduction cost of $\$ 181,931,000$.

The net saving effected by the superpower system is arrived at by deducting from the gross saving the cost of money, taxes, insurance, and sinking fund on these abandoned plants, the investment in which must be gradually amortized. The cost of money, insurance, and taxes on the abandoned plants will amount to $\$ 21,800,000$ a year, and a sinking fund of $\$ 17,800,000$ a year will amortize the investment in these plants in about eight years on a 7 per cent annuity basis. The deduction from the gross saving is therefore $\$ 39,600,000$ a year, and the net savings are for $1919, \$ 106,450,000$; for $1925, \$ 150,670,000$; for $1930, \$ 238,933,000$.

If in 1930 the superpower zone were supplied with power from an interconnected system in which all the new power plants were of the steam-electric type and were located as close to the load centers as the available supply of condensing water would permit, the total investment in such a system would be $\$ 1,064,716,000$, and the annual cost of power delivered to the load 
centers would be $\$ 348,084,000$. The combination of base-load steam-electric plants located both at tidewater and in the anthracite mining region with hydroelectric plants increases the investment cost to $\$ 1,109,564,000$ but reduces the annual cost of power delivered to the load centers to $\$ 278,534,000-a$ saving of $\$ 69,550,000$ annually on an increased investment of $\$ 44,838,000$.

By taking advantage of the partial regional diversity existing between the Anthracite division and the Southern and Metropolitan divisions and by producing large blocks of power in the Sunbury, Nescopeck, and Pittston base-load steam-electric plants in connection with the development of the Delaware River project to carry peak loads, as recommended for 1930 , and by transmitting such of this power as is not absorbed by the Anthracite division to the Metropolitan and Southern divisions over the 220,000-volt transmission lines shown on Plates II and III, power could be delivered to these three divisions at the low average cost of 9.7 mills per kilowatt-hour. On the other hand, if the diversity existing between these divisions were ignored and the power were produced in steam-electric plants located as near the centers where it is used as the available supply of condensing water would permit, and if there were no transmissionline connection between the Anthracite and the Metropolitan and Southern divisions, the corresponding cost of power delivered to the load centers of these divisions would be 10.8 mills per kilowatt-hour.

As it will require about eight years to construct the proposed St. Lawrence hydroelectric works and about the same length of time to obtain additional capacity at Niagara Falls that could be released to the superpower zone, the load requirements of 1930 must be met by other facilities. However, if these developments were completed by 1930, the load growth in the Eastern New England, Western New England, and Mohawk-Hudson divisions should be sufficient to absorb the available output of the St. Lawrence by 1932, and that of the Metropolitan division should be sufficient to absorb 300,000 kilowatts at a load factor of 80 per cent from Niagara in the same year. It is believed from consultation with the best-informed authorities on these two projects that power could be purchased from them at not more than $\$ 20$ per horsepoweryear delivered at their bus bars, and accordingly this figure is used in determining their effect on the cost of power to those divisions of the superpower zone so supplied.

The estimated average cost for St. Lawrence power delivered in 1932. at Utica and Schenectady, N. Y., and Northampton, Mass., is 4.6 mills per kilowatt-hour for 600,000 kilowatts at a load factor of 80 per cent. The total annual cost for all power delivered in 1932 to the load centers of the Eastern New England, Western New England, and Mohawk-Hudson divisions with St. Lawrence power would be $\$ 130,273,000$. Were the excess energy requirement of 1932 over that of 1930 furnished by new steam-electric plants, the total cost would be $\$ 141,601,000$. The development of St. Lawrence River would therefore save $\$ 11,328,000$ annually to these geographic divisions. The total investment required for equipment to use St. Lawrence purchased power would be $\$ 24,826,000$ less than that required if new steam-electric plants were constructed to supply this excess energy. In the Eastern New England, Western New England, and Mohawk-Hudson divisions, which lie farthest from the coal fields, the cost of power generated by steam-electric plants is inherently high, and therefore the St. Lawrence development will be of very great benefit to these divisions.

The Metropolitan division by 1932 can absorb 300,000 kilowatts of Niagara power delivered at a load factor of 80 per cent. The cost of this power delivered at Paterson, N. J., will be about 5.7 mills per kilowatt-hour. - The total cost to the Metropolitan division for the power it will require in 1932, if Niagara power is used, will be $\$ 107,651,000$. If the growth in energy required between 1930 and 1932 were supplied from new steam-electric plants located in the Metropolitan division, the total cost for power to the division in that year would be $\$ 110,899,000$, showing a saving of $\$ 3,248,000$ in favor of Niagara power. Were the power purchased from the Niagara power interests, so that no investment by the superpower system in hydroelectric power plants at that location would be required, the total added investment for 1932 would be $\$ 5,080,000$ less than that which would be required if the Niagara power were displaced by steam-electric power. 
TABLE 72.-Total annual production cost for superpower system for 1919, 1925, and 1930.

\begin{tabular}{|c|c|c|c|c|c|c|c|}
\hline \multirow[b]{2}{*}{ - } & \multicolumn{4}{|c|}{ Annual operating cost. } & \multirow[b]{2}{*}{$\begin{array}{l}\text { Annual fixed } \\
\text { charges. }\end{array}$} & \multicolumn{2}{|c|}{ Annual production cost. } \\
\hline & Fuel. & $\begin{array}{l}\text { Labor, main- } \\
\text { tenance, and } \\
\text { supplies. }\end{array}$ & Total. & $\begin{array}{c}\text { Per kilo- } \\
\text { watt-hour. }\end{array}$ & & Total. & $\begin{array}{c}\text { Per kiln- } \\
\text { watt-hour. }\end{array}$ \\
\hline 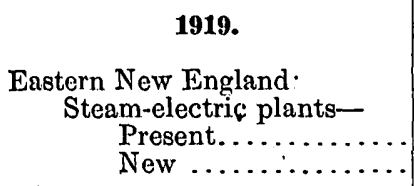 & $\begin{array}{r}\$ 4,132,000 \\
8,620,000\end{array}$ & $\begin{array}{r}\$ 2,655,000 \\
1,490,000\end{array}$ & $\begin{array}{l}\$ 6,787,000 \\
10,1.10,000\end{array}$ & $\begin{array}{r}\$ 0.0131 \\
.0043\end{array}$ & $\begin{array}{r}\$ 10,606,000 \\
6,580,000\end{array}$ & $\left\{\begin{array}{c}i \\
\ddots \\
\$ 17,393,000 \\
16,690,000\end{array}\right.$ & $\begin{array}{r}\$ 0.0336 \\
.0070 .\end{array}$ \\
\hline$\cdot$ & $12,752,000$ & $4,145,000$ & $16,897,000$ & .0058 & $17,186,000$ & $34,083,000$ & . . 01.18 \\
\hline $\begin{array}{l}\text { Hydroelectric plants- } \\
\text { Present } \ldots \ldots \ldots \ldots \ldots \ldots \\
\text { New } \ldots \ldots \ldots \ldots \ldots\end{array}$ & & $\begin{array}{r}388,000 \\
\ldots \ldots \ldots\end{array}$ & $\begin{array}{r}388,000 \\
\ldots \ldots \ldots\end{array}$ & $\begin{array}{c}.0014 \\
\ldots . . .\end{array}$ & $\begin{array}{c}2,394,000 \\
\ldots \ldots \ldots \ldots\end{array}$ & $2,782,000$ & $\begin{array}{r}. \\
.0104 \\
\ldots . \\
\end{array}$ \\
\hline . & $\ldots \ldots \ldots \ldots$ & 388,000 & 388,000 & .0014 & $2,394,000$ & $2,782,000$ & .0104 \\
\hline All plants............. & $12,752,000$ & $4,533,000$ & 17,$285 ; 000$ & .0055 & $19,580,000$ & $36,865,000$ & .0117 \\
\hline 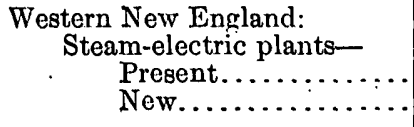 & $\begin{array}{r}851,000 \\
4,130,000\end{array}$ & $\begin{array}{r}942,000 \\
996,000\end{array}$ & $\begin{array}{l}1,793,000 \\
5,126,000\end{array}$ & $\begin{array}{l}.0233 \\
.0047\end{array}$ & $\begin{array}{l}3,928,000 \\
4,785,000\end{array}$ & $\begin{array}{l}5,721,000 \\
9,911,000\end{array}$ & $\begin{array}{l}.0743 \\
.0091\end{array}$ \\
\hline & $4,981,000$ & $1,938,000$ & $6,919,000$ & .0059 & $8,713,000$ & $15,632,000$ & .0133 \\
\hline 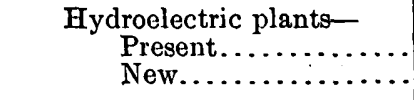 & & $\begin{array}{l}438,000 \\
100,000\end{array}$ & $\begin{array}{l}438,000 \\
100,000\end{array}$ & $\begin{array}{l}.0013 \\
.0004\end{array}$ & $\begin{array}{l}2,477,000 \\
1,156,000\end{array}$ & $\begin{array}{l}2,915,000 \\
1,2561000\end{array}$ & $\begin{array}{l}.0086 \\
.0055\end{array}$ \\
\hline & ............ & 538,000 & 538,000 & .0009 & $3,633,000$ & $4,171,000$ & .0073 \\
\hline All plants............. & $4,981,000$ & $2,476,000$ & $7,457,000$ & .0043 & $12,346,000$ & $19,803,000$ & .0114 \\
\hline 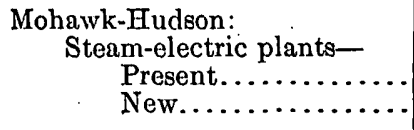 & $\begin{array}{r}272,000 \\
2,180,000\end{array}$ & $\begin{array}{l}212,000 \\
640,000\end{array}$ & $\begin{array}{r}484,000 \\
2,820,000\end{array}$ & $\begin{array}{l}.0242 \\
.0047\end{array}$ & $\begin{array}{l}1,153,000 \\
3,350,000\end{array}$ & $\begin{array}{l}1,637,000 \\
6,170,000\end{array}$ & $\begin{array}{l}.082 \\
.0102\end{array}$ \\
\hline . & $2,452,000$ & 852,000 & $3,304,000$ & .0053 & $4,503,000$ & $7,807,000$ & .0125 \\
\hline $\begin{array}{l}\text { Hydroelectric plants- } \\
\text { Present. . } \\
\text { New................... }\end{array}$ & & $\begin{array}{l}446,000 \\
200,000\end{array}$ & $\begin{array}{l}446,000 \\
200,000\end{array}$ & $\begin{array}{l}.0012 \\
.0005\end{array}$ & $\begin{array}{l}3,787,000 \\
2,615,000\end{array}$ & $\begin{array}{l}4,233,000 \\
2,815,000\end{array}$ & $\begin{array}{l}.0117 \\
.0074\end{array}$ \\
\hline & $\ldots \ldots \ldots \ldots$ & 646,000 & 646,000 & .0008 & $6,402,000$ & $7,048,000$ & .0095 \\
\hline All plants............. & $2,452,000$ & $1,498,000$ & $3,950,000$ & .0029 & $10,905,000$ & $14,855,000$ & .0109 \\
\hline 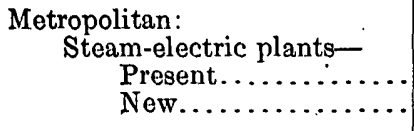 & $\begin{array}{r}16,550,000 \\
5,878,000\end{array}$ & $\begin{array}{l}6,343,000 \\
1,622,000\end{array}$ & $\begin{array}{r}22,893,000 \\
7,500,000\end{array}$ & $\begin{array}{l}.0077 \\
.0043\end{array}$ & $\begin{array}{r}20,657,000 \\
6,980,000\end{array}$ & $\begin{array}{r}43,550,000 \\
a 14,480,000\end{array}$ & $\begin{array}{l}.0147 \\
.0083\end{array}$ \\
\hline & $22,428,000$ & $7,965,000$ & $30,393,000$ & .0068 & $27,637,000$ & $58,030,000$ & .0 .130 \\
\hline 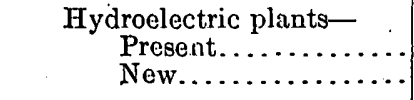 & & $\begin{array}{r}67,000 \\
350,000\end{array}$ & $\begin{array}{r}67,000 \\
350,000\end{array}$ & $\begin{array}{l}.003 \\
.0004\end{array}$ & $\begin{array}{r}370,000 \\
3,380,000\end{array}$ & $\begin{array}{r}437,000 \\
3,730,000\end{array}$ & $\begin{array}{l}.0198 \\
.0044\end{array}$ \\
\hline & $\ldots \ldots \ldots \ldots$ & 417,000 & 417,000 & .0005 & $3,750,000$ & $4,167,000$ & .0048 \\
\hline All plants... & $22,428,000$ & $8,382,000$ & $30,810,000$ & .0057 & $31,387,000$ & $62,197,000$ & .0115 \\
\hline 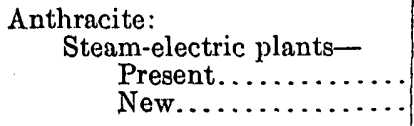 & $\begin{array}{l}2,752,000 \\
4,135,000\end{array}$ & $\begin{array}{l}1,007,000 \\
1,395,000\end{array}$ & $\begin{array}{l}3,758,000 \\
5,530,000\end{array}$ & $\begin{array}{l}.007 \\
.0028\end{array}$ & $\begin{array}{l}3,614,000 \\
5,280,000\end{array}$ & $\begin{array}{r}7,372,000 \\
a 10,810,000\end{array}$ & $\begin{array}{l}.0137 \\
.0055\end{array}$ \\
\hline & $6,887,000$ & $2,401,000$ & $9,288,000$ & .0035 & $8,894,000$ & $18,182,000$ & .0068 \\
\hline
\end{tabular}

a Includes a portion of tho annual production cost of the Pitston plant. 
TABLE 72.-Total annual production cost for superpower system for 1919, 1925, and 1980-Continued.

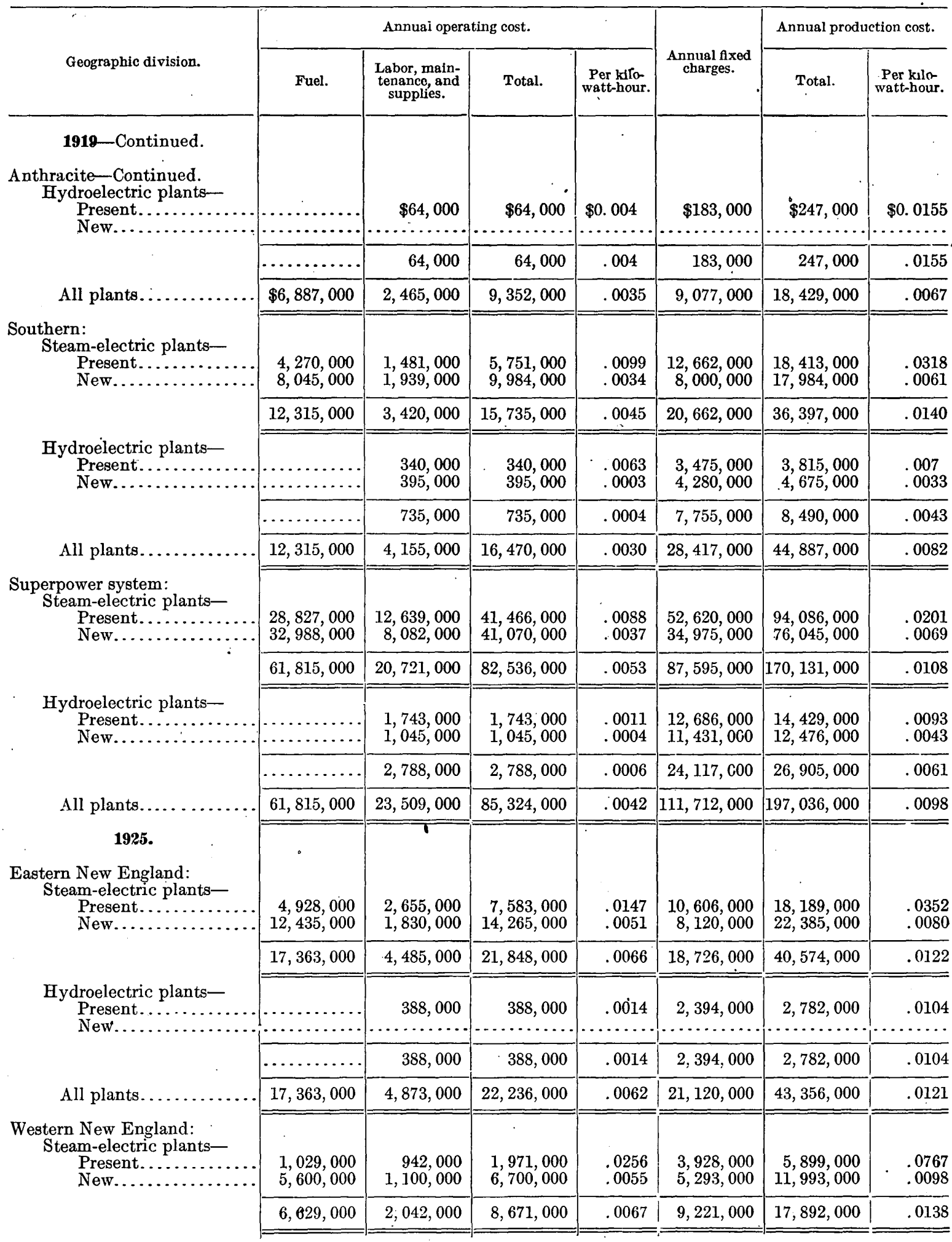


TABLE 72.-Total annual production cost for superpower system for 1919, 1925, and 1930-Continued.

\begin{tabular}{|c|c|c|c|c|c|c|c|}
\hline \multirow[b]{2}{*}{ Geographic division. } & \multicolumn{4}{|c|}{ Annual operating cost. } & \multirow[b]{2}{*}{$\begin{array}{c}\text { Annual fixed } \\
\text { charges. }\end{array}$} & \multicolumn{2}{|c|}{ Annual production cost. } \\
\hline & Fuel. & $\begin{array}{l}\text { Labor, main- } \\
\text { tenance, and } \\
\text { supplies. }\end{array}$ & Total. & $\begin{array}{c}\text { Per kilo- } \\
\text { watt-hour. }\end{array}$ & & Total. & $\begin{array}{c}\text { Per kilo- } \\
\text { watt-hour. }\end{array}$ \\
\hline 1925-Continued. & & & & & & & \\
\hline 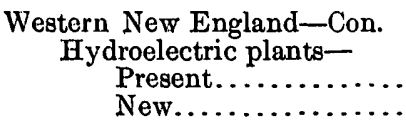 & & $\begin{array}{r}\$ 438,000 \\
100,000\end{array}$ & $\begin{array}{r}\$ 438,000 \\
100,000\end{array}$ & $\begin{array}{r}\$ 0.0013 \\
.0004\end{array}$ & $\begin{array}{r}\$ 2,477,000 \\
1,156,000\end{array}$ & $\begin{array}{r}\$ 2,915,000 \\
1,256,000\end{array}$ & $\begin{array}{r}\$ 0.0085 \\
.0055\end{array}$ \\
\hline & & 538,000 & 538,000 & .0009 & $3,633,000$ & $4,171,000$ & .0073 \\
\hline All plants. & $\$ 6,629,000$ & $2,580,000$ & $9,209,000$ & .0049 & $12,854,000$ & $22,063,000$ & .0118 \\
\hline 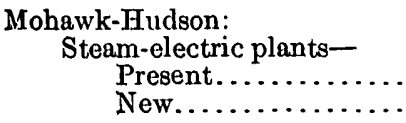 & $\begin{array}{r}324,000 \\
4,380,000\end{array}$ & $\begin{array}{l}212,000 \\
890 ; 000\end{array}$ & $\begin{array}{r}536,000 \\
5,270,000\end{array}$ & $\begin{array}{l}.0268 \\
.0051\end{array}$ & $\begin{array}{l}1,153,000 \\
4,296,000\end{array}$ & $\begin{array}{l}1,689,000 \\
9,566,000\end{array}$ & $\begin{array}{l}.0844 \\
.0092\end{array}$ \\
\hline & $4,704,000$ & $1,102,000$ & $5,806,000$ & .0055 & $5,449,000$ & $11,255,000$ & .0106 \\
\hline $\begin{array}{r}\text { Hydroelectric plants- } \\
\text { Present............ } \\
\text { New............. }\end{array}$ & & $\begin{array}{l}446,000 \\
200,000\end{array}$ & $\begin{array}{l}446,000 \\
200,000\end{array}$ & $\begin{array}{l}.0012 \\
.0005\end{array}$ & $\begin{array}{l}3,787,000 \\
2,615,000\end{array}$ & $\begin{array}{l}4,233,000 \\
2,815,000\end{array}$ & $\begin{array}{l}.0117 \\
.0074\end{array}$ \\
\hline & $\ldots \ldots \ldots \ldots$ & 646,000 & 646,000 & .0009 & $6,402,000$ & $7,048,000$ & .0095 \\
\hline All plants.. & $4,704,000$ & $1,748,000$ & $6,452,000$ & .0036 & $11,851,000$ & $18,303,000$ & .0102 \\
\hline 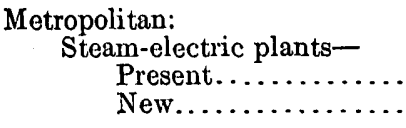 & $\begin{array}{l}19,800,000 \\
12,190,000\end{array}$ & $\begin{array}{l}6,343,000 \\
2,419,000\end{array}$ & $\begin{array}{l}26,143,000 \\
14,609,000\end{array}$ & $\begin{array}{l}.0088 \\
.0048\end{array}$ & $\begin{array}{l}20,657,000 \\
10,030,000\end{array}$ & $\begin{array}{r}46,800,000 \\
a 24,639,000\end{array}$ & $\begin{array}{l}.01 .58 \\
.077\end{array}$ \\
\hline & $31,990,000$ & $8,762,000$ & $40,752,000$ & .0071 & $30,687,000$ & $71,439,000$ & .0123 \\
\hline $\begin{array}{l}\text { Hydroelectric plants- } \\
\text { Present. } \\
\text { New................... }\end{array}$ & & $\begin{array}{r}67,000 \\
350,000\end{array}$ & $\begin{array}{r}67,000 \\
350,000\end{array}$ & $\begin{array}{l}.0030 \\
.0004\end{array}$ & $\begin{array}{r}370,000 \\
3,380,000\end{array}$ & $\begin{array}{r}437,000 \\
3,730,000\end{array}$ & $\begin{array}{l}.0198 \\
.0044\end{array}$ \\
\hline & n.......... & 417,000 & 417,000 & .0005 & $3,750,000$ & $4,167,000$ & .0048 \\
\hline All plants.. & $31,990,000$ & $9,179,000$ & $41,169,000$ & .0061 & $34,437,000$ & $75,606,000$ & .0112 \\
\hline 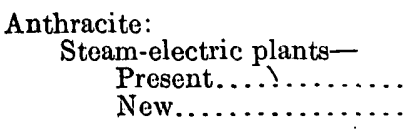 & $\begin{array}{l}3,046,000 \\
4,025,000\end{array}$ & $\begin{array}{l}1,006,000 \\
1,256,000\end{array}$ & $\begin{array}{l}4,052,000 \\
5,281,000\end{array}$ & $\begin{array}{l}.0075 \\
.0031\end{array}$ & $\begin{array}{l}3,614,000 \\
4,710,000\end{array}$ & $\begin{array}{r}7,666,000 \\
a 9,991,000\end{array}$ & $\begin{array}{l}.0143 \\
.0058\end{array}$ \\
\hline & $7,071,000$ & $2,262,000$ & $9,333,000$ & .0037 & $8,324,000$ & $17,657,000$ & .0071 \\
\hline 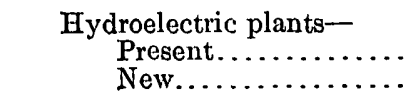 & & 64,000 & 64,000 & .0040 & 183,000 & 247,000 & .0155 \\
\hline & $\cdots \cdots \cdots, \cdots$ & 64,000 & 64,000 & .0040 & 183,000 & 247,000 & .0155 \\
\hline All plants. & $7,071,000$ & $2,326,000$ & $9,397,000$ & .0038 & $8,507,000$ & $17,904,000$ & .0071 \\
\hline $\begin{array}{l}\text { Southern: } \\
\text { Steam-electric plants- } \\
\text { Present........... } \\
\text { New............ }\end{array}$ & $\begin{array}{r}4,979,000 \\
14,480,000\end{array}$ & $\begin{array}{l}1,481,000 \\
2,960,000\end{array}$ & $\begin{array}{r}6,460,000 \\
17,440,000\end{array}$ & $\begin{array}{l}.0112 \\
.0040\end{array}$ & $\begin{array}{l}12,662,000 \\
12,175,000\end{array}$ & $\begin{array}{l}19,122,000 \\
29,615,000\end{array}$ & $\begin{array}{l}.0331 \\
.0068\end{array}$ \\
\hline & $19,459,000$ & $.4,441,000$ & $23,900,000$ & .0048 & $24,837,000$ & $48,737,000$ & .0099 \\
\hline 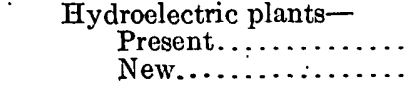 & & $\begin{array}{l}340,000 \\
395,000\end{array}$ & $\begin{array}{l}340,000 \\
395,000\end{array}$ & $\begin{array}{l}.0063 \\
.0003\end{array}$ & $\begin{array}{l}3,475,000 \\
4,280,000\end{array}$ & $\begin{array}{l}3,815,000 \\
4,675,000\end{array}$ & $\begin{array}{l}.007 \\
.0033\end{array}$ \\
\hline & . $\ldots \ldots \ldots \ldots$ & 735,000 & 735,000 & .0004 & $7,755,000$ & $8,490,000$ & .0043 \\
\hline All plants. & $19,459,000$ & $5,176,000$ & $24,635,000$ & .0035 & $32,592,000$ & $57,227,000$ & .0083 \\
\hline
\end{tabular}


TABLE 72.-Total annual production cost for superpower system for 1919, 1925, and 1930-Continued.

\begin{tabular}{|c|c|c|c|c|c|c|c|}
\hline \multirow{2}{*}{ Geographic division. } & \multicolumn{4}{|c|}{ Annual operating cost. } & \multirow[b]{2}{*}{$\begin{array}{l}\text { Annual fixed } \\
\text { charges. }\end{array}$} & \multicolumn{2}{|c|}{ Annual production cost. } \\
\hline & Fuel. & $\begin{array}{l}\text { Labor, main- } \\
\text { tenance, and } \\
\text { supplies. }\end{array}$ & Total. & $\begin{array}{l}\text { Per kilo- } \\
\text { watt-hour. }\end{array}$ & & Total. & $\begin{array}{l}\text { Per kilo- } \\
\text { watt-hour. }\end{array}$ \\
\hline \multirow{4}{*}{ 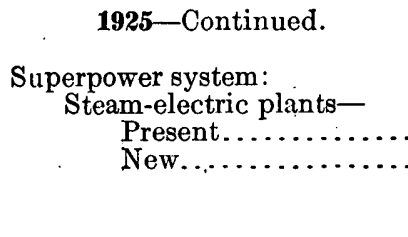 } & & & & & & & \\
\hline & & & & & & & \\
\hline & $\$ 34,106,000$ & $\$ 12,639,000$ & $\$ 46,745,000$ & $\$ 0.0100$ & $\$ 52,620,000$ & $\$ 99,365,000$ & $\$ 0.0212$ \\
\hline & & 23094000 & 110310000 & 0057 & 07244 & 207554 & 011 \\
\hline & & & & & & & C. \\
\hline \multirow{2}{*}{$\begin{array}{l}\text { Hydroelectric plants- } \\
\text { Present............ } \\
\text { New.............. }\end{array}$} & & $1,743,000$ & $1,743,000$ & .0011 & $12,686,000$ & $14,429,000$ & .0093 \\
\hline & & $1,045,000$ & $1,045,000$ & .0004 & $11,431,000$ & $12,476,000$ & .0043 \\
\hline New.................. & & $2,788,000$ & $2,788,000$ & .0006 & $24 ; 117,000$ & $26,905,000$ & .0061 \\
\hline All plants. & $87,216,000$ & $25,882,000$ & $113,098,000$ & .0048 & 121; 361,000 & $234,459,000$ & .0098 \\
\hline 1930. & & & & & . & - & \\
\hline \multirow{3}{*}{ 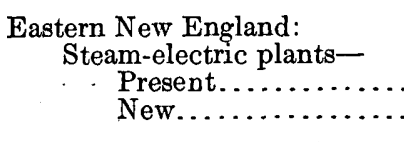 } & & & & & & & \\
\hline & $4,995,000$ & $2,852,000$ & $7,847,000$ & .0148 & $10,606,000$ & $18,453,000$ & .0350 \\
\hline & $18,610,000$ & $3,063,900$ & $21,675,000$ & .0052 & $14,685,000$ & $36,360,000$ & .0088 \\
\hline . & $23,605,000$ & $5,917,000$ & $29,522,000$ & .0063 & $25,291,000$ & $54,813,000$ &.$\quad .0117$ \\
\hline \multirow[t]{2}{*}{ 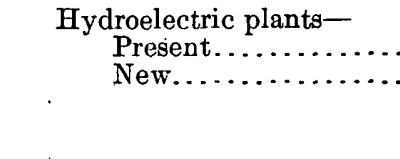 } & & 388,000 & 388,000 & .0014 & $2,394,000$ & $2,782,000$ & $\because .0104$ \\
\hline & & 388,000 & 388,000 & .0014 & $2,394,000$ & 2,782000 & .0104 \\
\hline All plants. & $23,605,000$ & $6,305,000$ & $29,910,000$ & .0061 & $27,685,000$ & $57,595,000$ & .0116 \\
\hline \multirow[t]{2}{*}{ 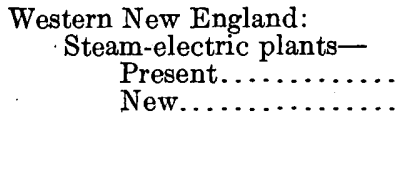 } & $\begin{array}{l}1,029,000 \\
5,810,000\end{array}$ & $\begin{array}{r}942,000 \\
1,370,000\end{array}$ & $\begin{array}{l}1,971,000 \\
7,180,000\end{array}$ & $\begin{array}{l}.0256 \\
.0058\end{array}$ & $\begin{array}{l}3,928,000 \\
6,775,000\end{array}$ & $\begin{array}{r}5,899,000 \\
13,955,000\end{array}$ & $\begin{array}{l}.0767 \\
.0113\end{array}$ \\
\hline & $6,839,000$ & 12,000 & 000 & .0070 & & & 0151 \\
\hline \multirow{2}{*}{$\begin{array}{l}\text { Hydroelectric plants- } \\
\text { Present........... }\end{array}$} & & & & & & & \\
\hline & & 438,000 & 438,000 & .0013 & $2,477,000$ & $2,915,000$ & .0086 \\
\hline & & & & .0004 & & $.4 ; 130,000$ & .0054 \\
\hline \multirow{2}{*}{ All plants............ } & & 768,000 & 768,000 & .0007 & $6,277,000$ & $7,045,000$ & .0064 \\
\hline & $6,839,000$ & $3,080,000$ & $9,919,000$ & .0041 & $16,980,000$ & $26,899,000$ & .0112 \\
\hline \multirow[t]{2}{*}{ 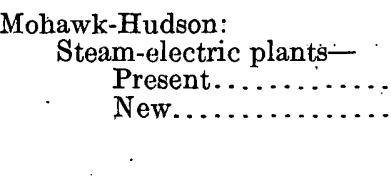 } & $\begin{array}{r}324,000 \\
5,620,000\end{array}$ & $\begin{array}{r}212,000 \\
1,300,000\end{array}$ & $\begin{array}{r}536,000 \\
6,920,000\end{array}$ & $\begin{array}{l}.0268 \\
.0053\end{array}$ & $\begin{array}{l}1,153,000 \\
6,270,000\end{array}$ & $\begin{array}{r}1,689,000 \\
13,190,000\end{array}$ & $\begin{array}{l}.0844 \\
.0100\end{array}$ \\
\hline & $5,944,000$ & $1,512,000$ & $7, .456,000$ & $\ldots 0056$ & $7,423,000$ & $14,879,000$ & .0112 \\
\hline $\begin{array}{c}\text { Hydroelectric plants - } \\
\text { Present. . . . . . . }\end{array}$ & & $\begin{array}{l}446,000 \\
300,000\end{array}$ & $\begin{array}{l}446,000 \\
300,000\end{array}$ & $\begin{array}{l}.0013 \\
.0003\end{array}$ & $\begin{array}{l}000 \\
000\end{array}$ & $\begin{array}{l}000 \\
000\end{array}$ & $\begin{array}{l}.0124 \\
.0058\end{array}$ \\
\hline & & 746000 & 746000 & 0006 & 8737000 & 0183000 & 0077 \\
\hline & $\cdots$ & 140,000 & 740,000 & .0000 & $8,737,000$ & $9,483,000$ & $.00 \pi$ \\
\hline All plants................ & $5,944,000$ & $2,258,000$ & $8,202,000$ & .0032 & $16,160,000$ & $24,362,000$ & .0095 \\
\hline
\end{tabular}


TABLE 72.-Total annual production cost for superpower system for 1919, 1925, and 1930-Continued.

\begin{tabular}{|c|c|c|c|c|c|c|c|}
\hline \multirow[b]{2}{*}{ Geographic division. } & \multicolumn{4}{|c|}{ Annual operating cost. } & \multirow[b]{2}{*}{$\begin{array}{l}\text { Annual fixed } \\
\text { charges. }\end{array}$} & \multicolumn{2}{|c|}{ Annual production cost. } \\
\hline & Fuel. & $\begin{array}{l}\text { Labor, main- } \\
\text { tenance, and } \\
\text { supplies. }\end{array}$ & Total. & $\begin{array}{l}\text { Per kilo- } \\
\text { watt-hour. }\end{array}$ & & Total. & $\begin{array}{l}\text { Per kilo: } \\
\text { watt-hour. }\end{array}$ \\
\hline \multirow{3}{*}{ 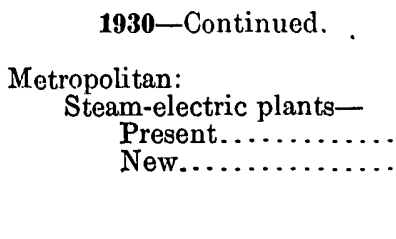 } & & & & & & & \\
\hline & $\begin{array}{r}\$ 15,763,000 \\
21,300,000\end{array}$ & $\begin{array}{r}\$ 5,992,000 \\
3,955,000\end{array}$ & $\begin{array}{r}\$ 21,755,000 \\
25,255,000\end{array}$ & $\begin{array}{r}\$ 0.0096 \\
.0047\end{array}$ & $\begin{array}{r}\$ 20,657,000 \\
16,485,000\end{array}$ & $\begin{array}{l}\$ 42,412,000 \\
a 41,740,000\end{array}$ & $\begin{array}{r}\$ 0.0186 \\
.0076\end{array}$ \\
\hline & $37,063,000$ & $9,947,000$ & $47,010,000$ & .0064 & $37,142,000$ & $84,152,000$ & .0103 \\
\hline \multirow[t]{2}{*}{$\begin{array}{l}\text { Hydroelectric plants- } \\
\quad \text { Present................... } \\
\text { New............. }\end{array}$} & & $\begin{array}{r}67,000 \\
650,000\end{array}$ & $\begin{array}{r}67,000 \\
650,000\end{array}$ & $\begin{array}{l}.003 \\
.0005\end{array}$ & $\begin{array}{r}370,000 \\
6,800,000\end{array}$ & $\begin{array}{r}437,000 \\
7,450,000\end{array}$ & $\begin{array}{r}.0198 \\
.0060\end{array}$ \\
\hline & 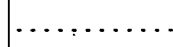 & 717,000 & 717,000 & .0005 & $7,170,000$ & $7,887,000$ & .0062 \\
\hline All plants.. & $37,063,000$ & $10,664,000$ & $47,727,000$ & .0055 & $44,312,000$ & $92,039,000$ & .0094 \\
\hline \multirow[t]{2}{*}{ 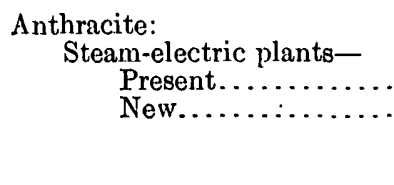 } & $\begin{array}{l}3,046,000 \\
5,948,000\end{array}$ & $\begin{array}{l}1,006,000 \\
1,892,000\end{array}$ & $\begin{array}{l}4,052,000 \\
7,840,000\end{array}$ & $\begin{array}{l}.0075 \\
.0031\end{array}$ & $\begin{array}{l}3,614,000 \\
6,855,000\end{array}$ & $\begin{array}{r}7,666,000 \\
a 14,695,000\end{array}$ & $\begin{array}{l}.0143 \\
.0057\end{array}$ \\
\hline & $8,994,000$ & $2,898,000$ & $11,892,000$ & .0036 & $10,469,000$ & $22,361,000$ & .0067 \\
\hline \multirow[t]{2}{*}{ 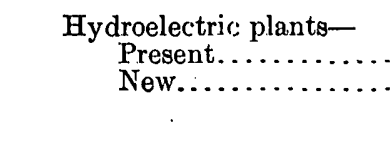 } & & $\begin{array}{l}64,000 \\
\ldots \ldots \ldots \ldots\end{array}$ & $\begin{array}{r}64,000 \\
\cdots \cdots \\
\ldots \ldots\end{array}$ & .004 & 183,000 & $\begin{array}{c}247,000 \\
\ldots \ldots \ldots\end{array}$ & $\begin{array}{l}.0155 \\
\cdots \cdots\end{array}$ \\
\hline & & 64,000 & 64,000 & .004 & 183,000 & 247,000 & .0155 \\
\hline All plants............. & $8,994,000$ & $2,962,000$ & $11,956,000$ & .0036 & $10,652,000$ & $22,608,000$ & .0067 \\
\hline \multirow[t]{2}{*}{ 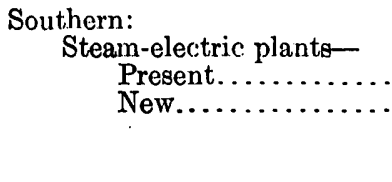 } & $\begin{array}{r}4,979,000 \\
20,670,000\end{array}$ & $\begin{array}{l}1,481,000 \\
4,310,000\end{array}$ & $\begin{array}{r}6,460,000 \\
24,980,000\end{array}$ & $\begin{array}{l}.0112 \\
.0040\end{array}$ & $\begin{array}{l}12,662,000 \\
17,765,000\end{array}$ & $\begin{array}{l}19,1.22,000 \\
4.2,745,000\end{array}$ & $\begin{array}{l}.0331 \\
.0069\end{array}$ \\
\hline & $25,649,000$ & $5,791,000$ & $31,440,000$ & .0046 & $30,427,000$ & $61,867,000$ & .0091 \\
\hline \multirow[t]{2}{*}{$\begin{array}{r}\text { Hydroelectric plants- } \\
\text { Present.............. } \\
\text { New............ }\end{array}$} & & $\begin{array}{l}340,000 \\
6 \approx 5,000\end{array}$ & $\begin{array}{l}340,000 \\
625,000\end{array}$ & $\begin{array}{l}.0006 \\
.0003\end{array}$ & $\begin{array}{l}3,475,000 \\
6,526,000\end{array}$ & $\begin{array}{l}3,815,000 \\
7,151,000\end{array}$ & $\begin{array}{l}.0070 \\
.0033\end{array}$ \\
\hline & & 965,000 & 965,000 & .0004 & $10,001,000$ & $10,966,000$ & .0040 \\
\hline All plants. & $25,649,000$ & $6,756,000$ & $32,405,000$ & .0034 & $40,428,000$ & $72,833,000$ & .0077 \\
\hline \multirow[t]{2}{*}{ 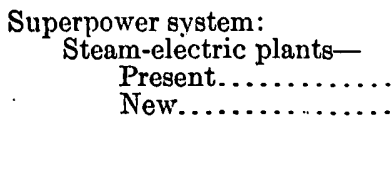 } & $\begin{array}{l}30,136,000 \\
77,958,000\end{array}$ & $\begin{array}{l}12,485,000 \\
15,892,000\end{array}$ & $\begin{array}{l}42,621,000 \\
93,850,000\end{array}$ & $\begin{array}{l}.0106 \\
.0044\end{array}$ & $\begin{array}{l}52,620,000 \\
68,835,000\end{array}$ & $\begin{array}{r}95,241,000 \\
162,685,000\end{array}$ & $\begin{array}{l}.0238 \\
.0076\end{array}$ \\
\hline & $108,094,000$ & $28,377,000$ & $136,471,000$ & .0054 & $121,455,000$ & $257,926,000$ & .0102 \\
\hline \multirow[t]{2}{*}{$\begin{array}{r}\text { Hydroelectric plants- } \\
\text { Present............. } \\
\text { New.............. }\end{array}$} & & $\begin{array}{l}1,743,000 \\
1,905,000\end{array}$ & $\begin{array}{l}1,743,000 \\
1,905,000\end{array}$ & $\begin{array}{l}.0011 \\
.0004\end{array}$ & $\begin{array}{l}12,686,000 \\
22,076,000\end{array}$ & $\begin{array}{l}14,429,000 \\
23,981,000\end{array}$ & $\begin{array}{l}.0094 \\
.0047\end{array}$ \\
\hline & … & $3,648,000$ & $3,648,000$ & .0006 & $34,762,000$ & $38,4.10,000$ & .0058 \\
\hline All plants. & $108,094,000$ & $32,028,000$ & $140,119,000$ & .0044 & $156,217,000$ & $296,336,000$ & .0093 \\
\hline
\end{tabular}

a Includes a portion of the annual production cost of the Pittston plant. $63361^{\circ}-21-12$ 
TABLE 73.-Annual cost of transmission system for superpower system, 1919, 1925, and 1990.

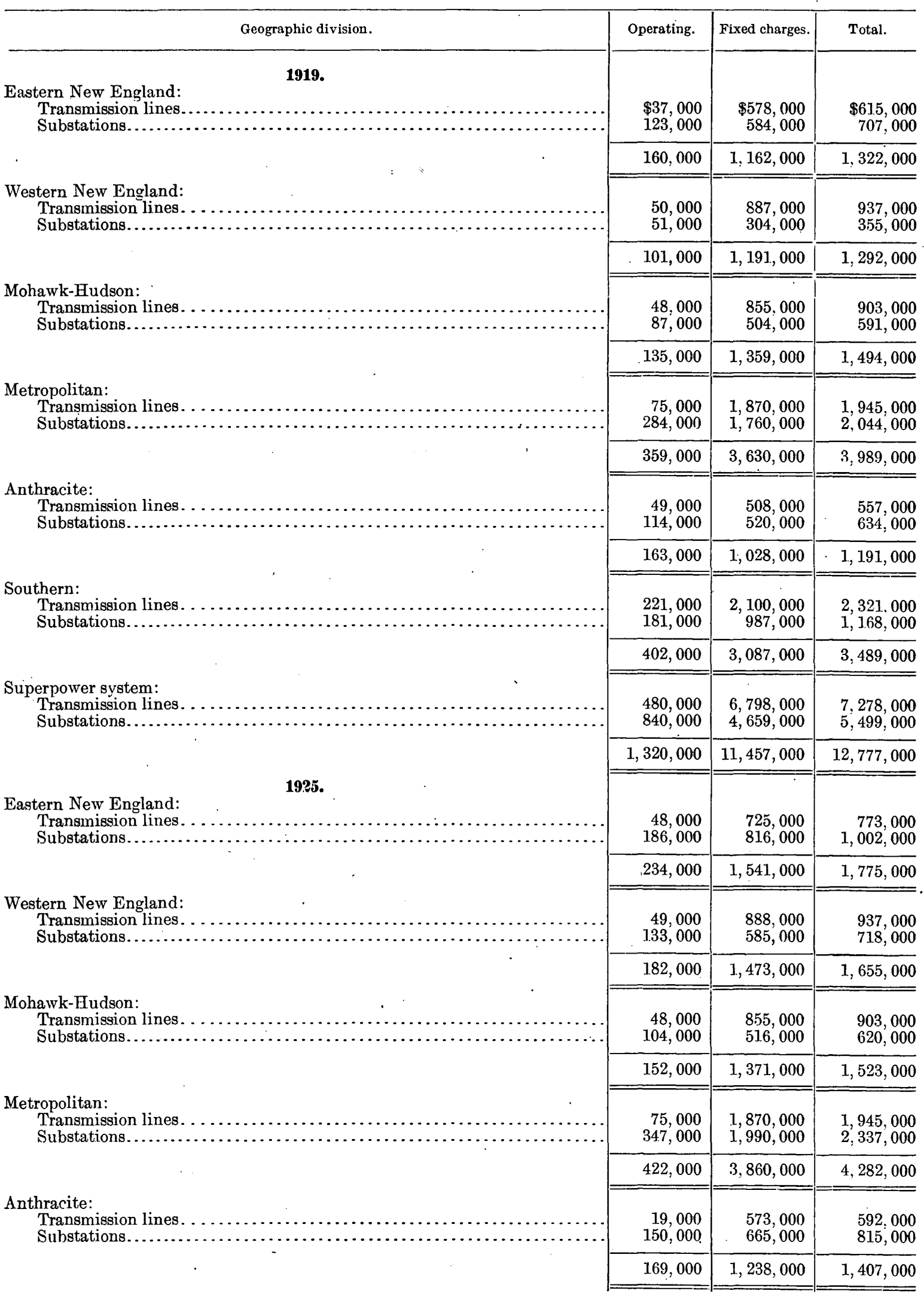


TABI.E 73.-Annual cost of transmission system for superpower system, 1919, 1925, and 1980-Continued.

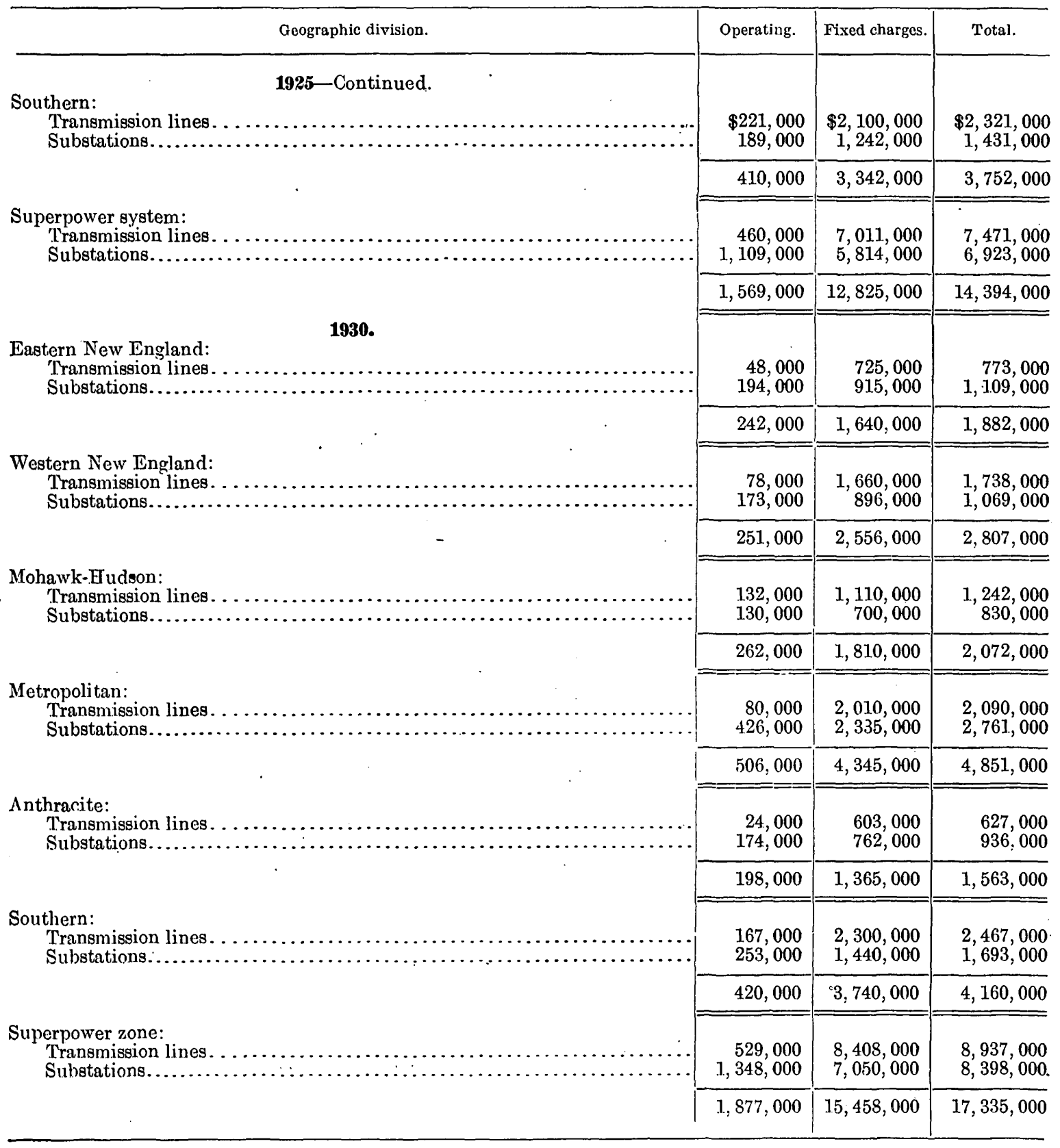


TABLE 74.-Annual cost of delivered power for the superpower system, 1919, 1925, and 1930.

\begin{tabular}{|c|c|c|c|c|c|c|}
\hline \multirow{2}{*}{ Geographic division. } & \multicolumn{2}{|c|}{ Operating cost. } & \multirow{2}{*}{$\begin{array}{c}\text { Fixed } \\
\text { charges. }\end{array}$} & \multirow{2}{*}{$\begin{array}{l}\text { General } \\
\text { expense. }\end{array}$} & \multicolumn{2}{|c|}{ Cost of delivered power. } \\
\hline & Total. & $\begin{array}{c}\text { Per kilo- } \\
\text { watt-hour. }\end{array}$ & & & Total. & $\begin{array}{c}\text { Per kilo- } \\
\text { watt-hour. }\end{array}$ \\
\hline 1919. & & & & & & \\
\hline $\begin{array}{l}\text { Eastern New England: } \\
\text { Cost of power produced............ } \\
\text { Debit or credit to other divisions. }\end{array}$ & $\$ 17,445,000$ & & $\$ 20,742,000$ & $\begin{array}{r}\$ 1,333,000 \\
0\end{array}$ & $\begin{array}{r}\$ 39,520,000 \\
0\end{array}$ & \\
\hline Net cost. . & $17,445,000$ & $\$ 0.0058$ & $20,742,000$ & $1,333,000$ & $39,520,000$ & $\$ 0.0131$ \\
\hline $\begin{array}{l}\text { Western New England: } \\
\text { Cost of power produced............ } \\
\text { Debit or credit to other divisions. }\end{array}$ & $\begin{array}{r}7,558,000 \\
0\end{array}$ & & $\begin{array}{r}13,537,000 \\
0\end{array}$ & $\begin{array}{r}740,000 \\
0\end{array}$ & $\begin{array}{r}21,835,000 \\
0\end{array}$ & \\
\hline Net cost. & $7,558,000$ & .0045 & $13,537,000$ & 740,000 & $21,835,000$ & .0131 \\
\hline $\begin{array}{l}\text { Mohawk-Hudson: } \\
\text { Cost of power produced........... } \\
\text { Debit or credit to other divisions.. }\end{array}$ & $\begin{array}{r}4,085,000 \\
+540,000\end{array}$ & … & $\begin{array}{r}12,264,000 \\
+560,000\end{array}$ & $\begin{array}{r}572,000 \\
+60,000\end{array}$ & $\begin{array}{r}16,921,000 \\
+1,160,000\end{array}$ & \\
\hline Net cost... & $4,625,000$ & .0035 & $12,824,000$ & 632,000 & $18,081,000$ & .0137 \\
\hline $\begin{array}{l}\text { Metropolitan: } \\
\text { Cost of power produced............. } \\
\text { Debit or credit to other divisions... }\end{array}$ & $\begin{array}{r}31,169,000 \\
-540,000\end{array}$ & & $\begin{array}{r}35,017,000 \\
-560,000\end{array}$ & $\begin{array}{r}2,320,000 \\
-60,000\end{array}$ & $\begin{array}{r}68,506,000 \\
-1,160,000\end{array}$ & \\
\hline Net cost. . & $30,629,000$ & .0055 & $34,457,000$ & $2,260,000$ & $67,346,000$ & .0120 \\
\hline $\begin{array}{l}\text { Anthracite: } \\
\text { Cost of power produced........... } \\
\text { Debit or credit to other divisions }\end{array}$ & $\begin{array}{r}9,515,000 \\
+3,000,000\end{array}$ & & $\begin{array}{r}10,105,000 \\
+3,200,000\end{array}$ & $\begin{array}{r}687,000 \\
+470,000\end{array}$ & $\begin{array}{r}20,307,000 \\
+6,670,000\end{array}$ & \\
\hline Net cost.. & $12,515,000$ & .0042 & $13,305,000$ & $1,157,000$ & $26,977,000$ & .0090 \\
\hline $\begin{array}{l}\text { Southern: } \\
\text { Cost of power produced.......... } \\
\text { Debit or credit to other divisions }\end{array}$ & $\begin{array}{r}16,872,000 \\
-3,000,000\end{array}$ & & $\begin{array}{r}31,504,0 \Theta 0 \\
-3,200,000\end{array}$ & $\begin{array}{l}1,690,000 \\
-470,000\end{array}$ & $\begin{array}{r}50,066,000 \\
-6,670,000\end{array}$ & \\
\hline Net cost. . & $13,872,000$ & .0029 & $28,304,000$ & $1,220,000$ & $43,396,000$ & .0093 \\
\hline Superpower system... & $86,644,600$ & .0045 & $123,169,000$ & $7,342,000$ & $217,155,000$ & .0113 \\
\hline $\begin{array}{l}1925 . \\
\text { Eastern New England: } \\
\text { Cost of power produced........... } \\
\text { Debit or credit to other divisions. }\end{array}$ & $\begin{array}{r}22,470,000 \\
0\end{array}$ & & $\begin{array}{r}22,661,000 \\
0\end{array}$ & $\begin{array}{r}1,580,000 \\
0\end{array}$ & $\begin{array}{r}46,711,000 \\
0\end{array}$ & \\
\hline Net cost... & $22,470,000$ & .0065 & $22,661,000$ & $1,580,000$ & $46,711,000$ & .0135 \\
\hline $\begin{array}{l}\text { Western New England: } \\
\text { Cost of power produced............ } \\
\text { Debit or credit to other divisions. }\end{array}$ & $\begin{array}{l}9,391,000 \\
+680,000\end{array}$ & & $\begin{array}{r}14,327,000 \\
+710,000\end{array}$ & $\begin{array}{r}830,000 \\
+25,000\end{array}$ & $\begin{array}{r}24,548,000 \\
+1,415,000\end{array}$ & \\
\hline Net cost... & $10,071,000$ & .0053 & $15,037,000$ & 855,000 & $25,963,000$ & .0136 \\
\hline $\begin{array}{l}\text { Mohawk-Hudson: } \\
\text { Cost of power produced............. } \\
\text { Debit or credit to other divisions... }\end{array}$ & $\begin{array}{r}6,604,000 \\
+190,000\end{array}$ & & $\begin{array}{r}12,957,000 \\
++210,000\end{array}$ & $\begin{array}{r}685,000 \\
+15,000\end{array}$ & $\begin{array}{r}20,246,000 \\
+415,000\end{array}$ & \\
\hline Net cost..... & $6,794,000$ & .0038 & $13,167,000$ & 700,000 & $20,661,000$ & .0117 \\
\hline $\begin{array}{l}\text { Metropolitan: } \\
\quad \text { Cost of power produced.............. } \\
\text { Debit or credit to other divisions... }\end{array}$ & $\begin{array}{r}41,591,000 \\
-870,000\end{array}$ & & $\begin{array}{r}38,297,000 \\
-910,000\end{array}$ & $\begin{array}{r}2,800,000 \\
-40,000\end{array}$ & $\begin{array}{r}82,688,000 \\
-1,820,000\end{array}$ & \\
\hline Net cost...... & $40,721,000$ & .0059 & $37,387,000$ & $2,760,000$ & $80,868,000$ & .0117 \\
\hline $\begin{array}{l}\text { Anthracite: } \\
\text { Cost of power produced............ } \\
\text { Debit or credit to other civisions. }\end{array}$ & $\begin{array}{r}9,566,000 \\
+960,000\end{array}$ & & $\begin{array}{r}9,745,000 \\
+980,000\end{array}$ & $\begin{array}{r}677,000 \\
+165,000\end{array}$ & $\begin{array}{r}19,988,000 \\
+2,105,000\end{array}$ & \\
\hline Net cost. & $10,526,000$ & .0040 & $10,725,000$ & 842,000 & $22,093,000$ & .0085 \\
\hline
\end{tabular}


TABLE 74.-Annual cost of delivered power for the superpower system, 1919, 1925, and 1930—Continued.

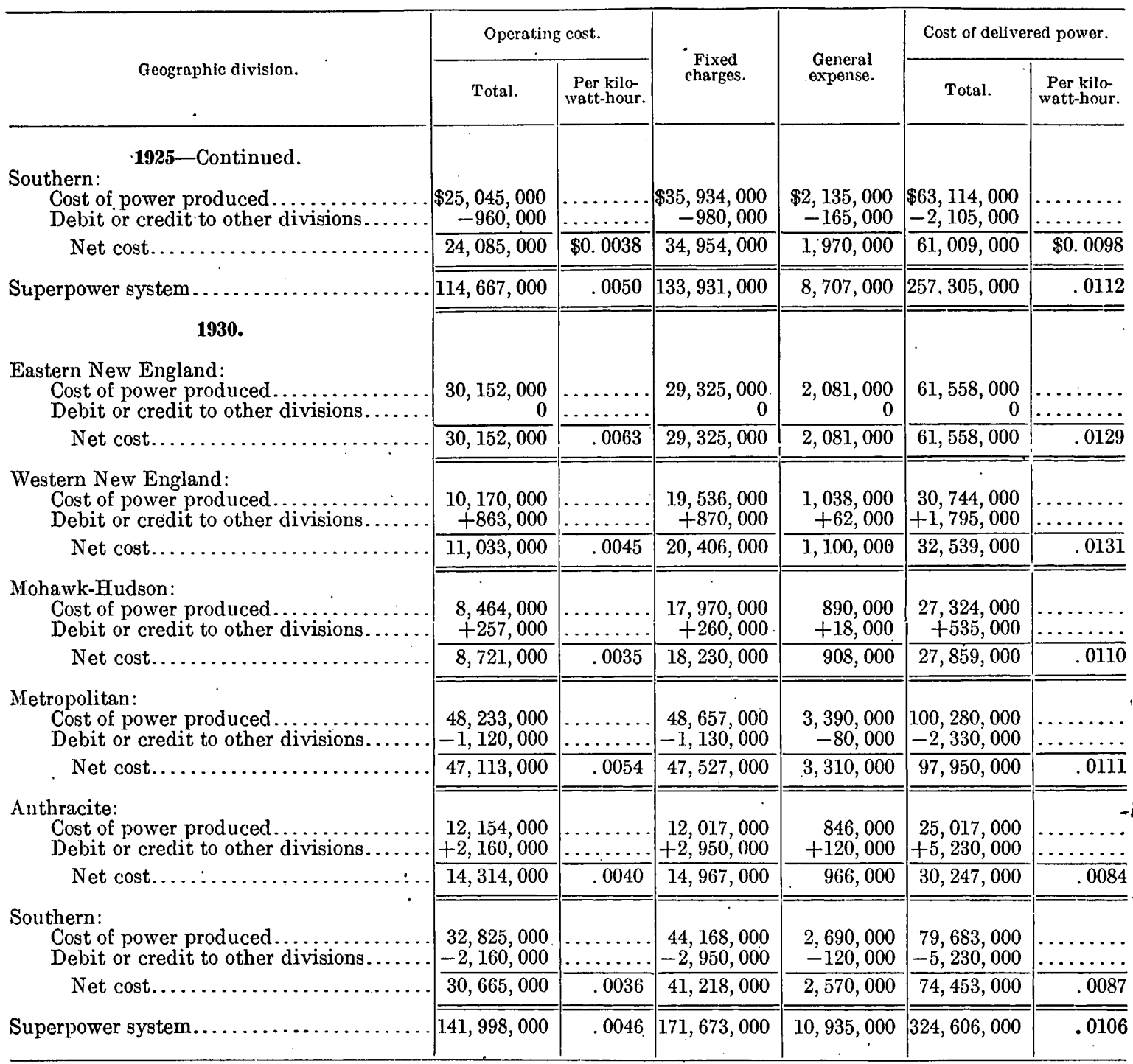

\section{COST OF POWER DELIVERED TO THE LOAD CENTERS FROM THE NEW POWER PLANTS AND THE. TRANSMISSION SYSTEM OF THE SUPER- POWER SYSTEM.}

The superpower system as analyzed in the preceding sections comprises two distinct elements-(1) the present power plants incorporated into the system and (2) the new power plants and the transmission system. The amount of new power-plant capacity required is as follows:

TABLE 75.-New power-plant capacity for superpower system, in kilowatts.

\begin{tabular}{|c|c|c|c|}
\hline Geographic division. . & 1919 & 1925 & 1930 \\
\hline 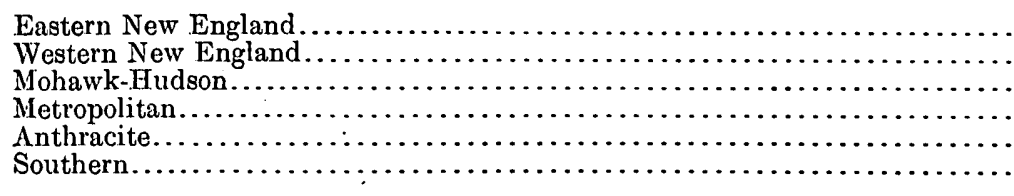 & $\begin{array}{l}350,000 \\
320,000 \\
280,000 \\
423,000 \\
450,000 \\
695,000\end{array}$ & $\begin{array}{l}450,000 \\
350,000 \\
340,000 \\
573,000 \\
450,000 \\
935,000\end{array}$ & $\begin{array}{r}810,000 \\
555,000 \\
510,000 \\
1,100,000 \\
600,000 \\
1,405,000\end{array}$ \\
\hline Superpower zone.... & $2,528,000$ & $3,098,000$ & $4,980,000$ \\
\hline
\end{tabular}


The investment cost for the new facilities given in Table 76 is 52.2 per cent of the total investment cost for the superpower system in 1925 and 62.5 per cent of the total in 1930 .

The cost of power delivered to the load centers from the new facilities of the superpower system is shown by Table 77 to be 54.3 per cent of the total cost for the superpower system in 1925 and 65 per cent of the toual in 1930.

The present power plants proposed for incorporation in the superpower system will be a very important factor in the earlier stages of its being. Although theoretically power could be generated more cheaply and a greater amount of coal could be conserved by abandoning practically every steam-electric power plant now located within the zone, this procedure is not desirable, practicable, or financially possible.

If the power plants retained are operated by the utilities as set forth on pages 157-161, the average cost of power purchased from the new facilities of the superpower system would be $\$ 0.0084$ per kilowatt-hour measured at the receiving busses of the electric utilities at the load centers. To obtain this result, however, it is essential that all power plants within the zone be so operated that the resulting cost to all concerned will be the lowest. This end can be accomplished only by the operation of the older, less efficient plants for peak load and by the operation of the new, highly efficient plants for base load at high' capacity factors.

TABLE 76.-Investment cost for new power plants and transmission system of the superpower system, 1919, 1925, and 1930, in thousands of dollars.

\begin{tabular}{|c|c|c|c|c|c|c|c|}
\hline & $\begin{array}{l}\text { Eastern New } \\
\text { England. }\end{array}$ & $\begin{array}{c}\text { Western New } \\
\text { England. }\end{array}$ & $\begin{array}{l}\text { Mohawk- } \\
\text { Hudson. }\end{array}$ & $\begin{array}{l}\text { Metropoli- } \\
\text { tan. }\end{array}$ & Anthracite. & Southern. & $\begin{array}{c}\text { Superpower } \\
\text { zone. }\end{array}$ \\
\hline 1919. & & & & & & & \\
\hline 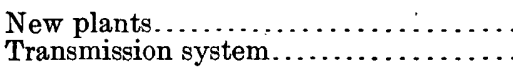 & $\begin{array}{r}41,100 \\
7,787\end{array}$ & $\begin{array}{r}38,890 \\
8,245\end{array}$ & $\begin{array}{r}41,044 \\
9,257\end{array}$ & $\begin{array}{r}a 69,270 \\
24,300\end{array}$ & $\begin{array}{r}a 33,000 \\
6,888\end{array}$ & $\begin{array}{l}83,035 \\
21,192\end{array}$ & $\begin{array}{r}306,339 \\
77,669\end{array}$ \\
\hline Debit or credit to other divisions... & $\begin{array}{l}48,887 \\
\ldots \ldots \ldots\end{array}$ & $\begin{array}{r}47,135 \\
\ldots \ldots\end{array}$ & $\begin{array}{r}50,301 \\
-3,800\end{array}$ & $\begin{array}{r}93,570 \\
+3,800\end{array}$ & $\begin{array}{r}39,888 \\
+2,655\end{array}$ & $\begin{array}{r}104,227 \\
-2,655\end{array}$ & $\begin{array}{r}384,008 \\
\ldots \ldots \ldots\end{array}$ \\
\hline Net investment. & 48,887 & 47,135 & 46,501 & 97,370 & 42,543 & 101,572 & 384,008 \\
\hline 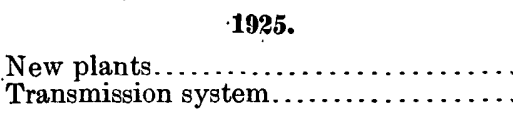 & $\begin{array}{l}50,700 \\
10,288\end{array}$ & $\begin{array}{r}42,100 \\
10,001\end{array}$ & $\begin{array}{r}.46,974 \\
9,334\end{array}$ & $\begin{array}{r}a 88,400 \\
25,781\end{array}$ & $\begin{array}{r}a 29,420 \\
8,248\end{array}$ & $\begin{array}{r}109,120 \\
22,777\end{array}$ & $\begin{array}{r}366,71.4 \\
86,429\end{array}$ \\
\hline Debit or credit to other divisions.. & $\begin{array}{c}60,988 \\
\ldots \ldots\end{array}$ & $\begin{array}{r}52,101 \\
+5,980\end{array}$ & $\begin{array}{r}56,308 \\
-780\end{array}$ & $\begin{array}{l}114,181 \\
-5,200\end{array}$ & $\begin{array}{r}37,668 \\
+1,435\end{array}$ & $\begin{array}{r}131,897 \\
-1,435\end{array}$ & $\begin{array}{l}453,143 \\
\cdots \cdots \cdots\end{array}$ \\
\hline Net investment. & 60,988 & 58,081 & 55,528 & 108,981 & 39,103 & 130,462 & 453,143 \\
\hline $\begin{array}{c}1930 . \\
\text { New plants................... } \\
\text { Transmission system............. }\end{array}$ & $\begin{array}{l}91,750 \\
10,916\end{array}$ & $\begin{array}{l}71,280 \\
17,452\end{array}$ & $\begin{array}{l}77,545 \\
12,327\end{array}$ & $\begin{array}{r}a 154,600 \\
28,975\end{array}$ & $\begin{array}{r}a 42,800 \\
9,075\end{array}$ & $\begin{array}{r}151,050 \\
25,448\end{array}$ & $\begin{array}{l}589,025 \\
104,193\end{array}$ \\
\hline Debit or credit to other divisions. . & 102,666 & $\begin{array}{r}88,732 \\
+7,800\end{array}$ & $\begin{array}{r}89,872 \\
-480\end{array}$ & $\begin{array}{r}183,575 \\
-7,320\end{array}$ & $\begin{array}{r}51,875 \\
+18,340\end{array}$ & $\begin{array}{r}176,498 \\
-18,340\end{array}$ & 693,218 \\
\hline Net investment. & 102,666 & 96,532 & 89,392 & 176,255 & 70,215 & 158,158 & 693,218 \\
\hline
\end{tabular}

a Includes a part of the investment in the Pittston plant. 
TABLE 77.-Cost of power delivered from new power plants and transmission system of superpower system for 1919, 1925, and 1990.

\begin{tabular}{|c|c|c|c|c|c|c|c|}
\hline & $\begin{array}{l}\text { Eastern New } \\
\text { England. }\end{array}$ & $\begin{array}{c}\text { Western New } \\
\text { England. }\end{array}$ & $\begin{array}{l}\text { Mohawk- } \\
\text { Hudson. }\end{array}$ & $\begin{array}{l}\text { Metropoli- } \\
\text { tan. }\end{array}$ & Anthracite. & Southern. & $\begin{array}{l}\text { Superpower } \\
\text { zone. }\end{array}$ \\
\hline 1919. & & & & & & & \\
\hline $\begin{array}{l}\text { Power (millions of kilowatt-hours): } \\
\text { Delivered to division............... } \\
\text { Generated by old plants. } . . . \ldots\end{array}$ & $\begin{array}{r}3,016 \\
785\end{array}$ & $\begin{array}{r}1,671 \\
417\end{array}$ & $\begin{array}{r}1,313 \\
381\end{array}$ & $\begin{array}{l}5,590 \\
2,982\end{array}$ & $\begin{array}{r}3,005 \\
553\end{array}$ & $\begin{array}{l}4,669 \\
1,121\end{array}$ & $\begin{array}{r}19,264 \\
6,239\end{array}$ \\
\hline Delivered from new facilities. & 2,231 & 1,254 & 932 & 2,608 & 2,452 & 3,548 & 13,025 \\
\hline 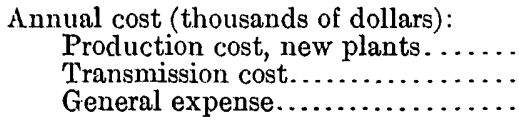 & $\begin{array}{r}16,690 \\
1,322 \\
630\end{array}$ & $\begin{array}{r}11,167 \\
1,292 \\
438\end{array}$ & $\begin{array}{r}8,985 \\
1,494 \\
358\end{array}$ & $\begin{array}{r}a 18,210 \\
3,989 \\
782\end{array}$ & $\begin{array}{r}a 10,810 \\
1,191 \\
420\end{array}$ & $\begin{array}{r}22,659 \\
3,489 \\
915\end{array}$ & $\begin{array}{r}88,521 \\
12,777 \\
3,543\end{array}$ \\
\hline Debit or credit to other divisions.. & $\begin{array}{r}18,642 \\
\cdots \cdots\end{array}$ & $\begin{array}{r}12,897 \\
\ldots \ldots \ldots\end{array}$ & $\begin{array}{r}10,837 \\
+1,160\end{array}$ & $\begin{array}{r}22,981 \\
-1,160\end{array}$ & $\begin{array}{r}12,421 \\
+6,670\end{array}$ & $\begin{array}{r}27,063 \\
-6,670\end{array}$ & $\begin{array}{l}104,841 \\
\ldots \ldots\end{array}$ \\
\hline 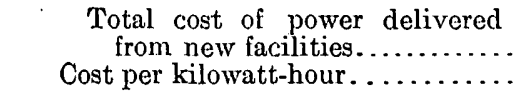 & $\begin{array}{r}18,642 \\
\$ 0.0084\end{array}$ & $\begin{array}{r}12,897 \\
\$ 0.0103\end{array}$ & $\begin{array}{r}11,997 \\
\$ 0.0129\end{array}$ & $\begin{array}{r}21,821 \\
\$ 0.0084\end{array}$ & $\begin{array}{r}19,091 \\
\$ 0.0078\end{array}$ & $\begin{array}{r}20,393 \\
\$ 0.0057\end{array}$ & $\begin{array}{l}104,841 \\
\$ 0.0080\end{array}$ \\
\hline 1925. & & & & & & & \\
\hline $\begin{array}{l}\text { Power (millions of kilowatt-hours): } \\
\text { Delivered to division. } . . . . . . \\
\text { Generated by old plants....... }\end{array}$ & $\begin{array}{r}3,458 \\
\quad 785\end{array}$ & $\begin{array}{r}1,909 \\
417\end{array}$ & $\begin{array}{r}1,767 \\
381\end{array}$ & $\begin{array}{l}6,903 \\
2,982\end{array}$ & $\begin{array}{r}2,600 \\
553\end{array}$ & $\begin{array}{l}6,233 \\
1,121\end{array}$ & $\begin{array}{r}22,870 \\
6,239\end{array}$ \\
\hline Delivered from new facilities.: & 2,673 & 1,492 & 1,386 & 3,921 & 2,047 & 5,112 & 16,631 \\
\hline 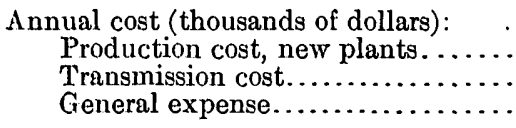 & $\begin{array}{r}22,385 \\
1,775 \\
845\end{array}$ & $\begin{array}{r}13,249 \\
1,655 \\
522\end{array}$ & $\begin{array}{r}12,381 \\
1,523 \\
487\end{array}$ & $\begin{array}{r}a 28,369 \\
4,282 \\
1,140\end{array}$ & $\begin{array}{r}a 9,991 \\
1,407 \\
398\end{array}$ & $\begin{array}{r}34,290 \\
3,752 \\
1,330\end{array}$ & $\begin{array}{r}120,665 \\
14,394 \\
4,722\end{array}$ \\
\hline Debit or credit to other divisions.. & $\begin{array}{l}25,005 \\
\cdots \cdots\end{array}$ & $\begin{array}{r}15,426 \\
+1,405\end{array}$ & $\begin{array}{r}14,391 \\
+415\end{array}$ & $\begin{array}{r}33,791 \\
-1,820\end{array}$ & $\begin{array}{r}11,796 \\
+2,105\end{array}$ & $\begin{array}{r}39,372 \\
-2,105\end{array}$ & 139,781 \\
\hline $\begin{array}{l}\text { Total cost of power' delivered } \\
\text { from new facilities............... } \\
\text { Cost per kilowatt-hour. . . . . }\end{array}$ & $\begin{array}{r}25,005 \\
\$ 0.0093\end{array}$ & $\begin{array}{r}16,831 \\
\$ 0.0113\end{array}$ & $\begin{array}{r}14,806 \\
\$ 0.0107\end{array}$ & $\begin{array}{r}31,971 \\
\$ 0.0082\end{array}$ & $\begin{array}{r}13,901 \\
\$ 0.0068\end{array}$ & $\begin{array}{r}37,267 \\
\$ 0.0073\end{array}$ & $\begin{array}{l}139,781 \\
\$ 0.0084\end{array}$ \\
\hline 1930. & & & & & & & \\
\hline $\begin{array}{l}\text { Power (millions of kilowatt-hours) } \\
\text { Delivered to division } . . . . \ldots \ldots \\
\text { Generated by old plants........ }\end{array}$ & $\begin{array}{r}4,755 \\
797\end{array}$ & $\begin{array}{r}2,477 \\
417\end{array}$ & $\begin{array}{r}2,526 \\
361\end{array}$ & $\begin{array}{l}8,781 \\
2,296\end{array}$ & $\begin{array}{r}3,606 \\
553\end{array}$ & $\begin{array}{l}3,567 \\
1,121\end{array}$ & $\begin{array}{r}30,712 \\
5,547\end{array}$ \\
\hline Delivered from new facilities. & 3,958 & 2,060 & 2,165 & 6,485 & 3,053 & 7,446 & 25,165 \\
\hline $\begin{array}{l}\text { Annual cost (thousands of dollars): } \\
\text { Production cost, new plants. } \\
\text { Transmission cost.................. } \\
\text { General expense.............. }\end{array}$ & $\begin{array}{r}36,360 \\
1,882 \\
1,330\end{array}$ & $\begin{array}{r}18,085 \\
2,807 \\
795\end{array}$ & $\begin{array}{r}18,440 \\
2,072 \\
735\end{array}$ & $\begin{array}{r}a 49,190 \\
4,851 \\
1,835\end{array}$ & $\begin{array}{r}a 14,695 \\
1,563 \\
755\end{array}$ & $\begin{array}{r}49,896 \\
4,160 \\
1,700\end{array}$ & $\begin{array}{r}186,666 \\
17,335 \\
7,150\end{array}$ \\
\hline Debit or credit to other divisions.. & $\begin{array}{r}39,572 \\
\ldots \ldots \ldots\end{array}$ & $\begin{array}{r}21,687 \\
+1,795\end{array}$ & $\begin{array}{r}21,247 \\
+535\end{array}$ & $\begin{array}{r}55,876 \\
-2,330\end{array}$ & $\begin{array}{r}17,013 \\
+5,230\end{array}$ & $\begin{array}{r}55,756 \\
-5,230\end{array}$ & $\begin{array}{l}211,151 \\
\ldots \ldots \ldots\end{array}$ \\
\hline $\begin{array}{l}\text { Total cost of power delivered } \\
\text { from new facilities................ } \\
\text { Cost per kilowatt-hour......... }\end{array}$ & $\begin{array}{r}39,572 \\
\$ 0.0100\end{array}$ & $\begin{array}{r}23,482 \\
\$ 0.0114\end{array}$ & $\begin{array}{r}21,782 \\
\$ 0.0101\end{array}$ & $\begin{array}{r}53,546 \\
\$ 0.0083\end{array}$ & $\begin{array}{r}22,243 \\
\$ 0.0073\end{array}$ & $\begin{array}{r}50,526 \\
\$ 0.0068\end{array}$ & $\begin{array}{l}211,151 \\
\$ 0.0084\end{array}$ \\
\hline
\end{tabular}

$a$ Includes a part of the annual production cost of the Pittston plant. 


\section{APPENDIX F. STEAM-ELECTRIC PLANTS FOR THE SUPERPOWER SYSTEM.}

By Henry Flood, jr., and others of the engineering staff.

\section{EXIsting PLANTS TO BE RETAINED. CAPACITY AND PERFORMANCE.}

The principal factor in determining whether or not a given plant shall be incorporated in the superpower system is fuel performance. Other factors, however, are strategic location for regulation of voltage and the adaptability of the plant to expansion. The total effective capacity to be retained, as shown by Table 78, is 79 per cent of the total effective capacity of the steam-electric plants on December 31, 1919.

TABLE 78.-Capacity and performance in 1919 of steam-electric plants to be retained in the superpower system.

\begin{tabular}{|c|c|c|c|c|c|}
\hline Division. & $\begin{array}{c}\text { Effective } \\
\text { capacity } \\
\text { (kilowatts). }\end{array}$ & $\begin{array}{l}\text { Output } \\
\text { (millions of } \\
\text { kilowatt- } \\
\text { hours). }\end{array}$ & $\begin{array}{l}\text { Fuel used } \\
\text { (thousands } \\
\text { of short } \\
\text { tons). }\end{array}$ & $\begin{array}{l}\text { Effectivo } \\
\text { capacity } \\
\text { factor } \\
\text { (per cent). }\end{array}$ & $\begin{array}{l}\text { Coal used per } \\
\text { kilowatt-year } \\
\text { of effective } \\
\text { capacity } \\
\text { (short tons). }\end{array}$ \\
\hline \multirow[t]{2}{*}{ 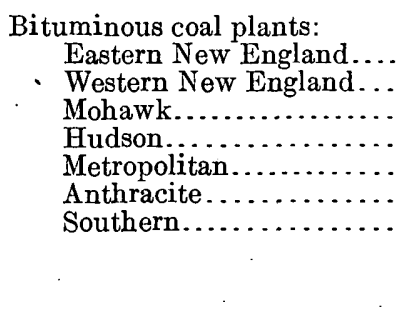 } & $\begin{array}{r}514,580 \\
171,800 \\
31,750 \\
14,000 \\
1,130,500 \\
48,000 \\
632,800\end{array}$ & $\begin{array}{r}1,290.4 \\
294.4 \\
21.1 \\
33.1 \\
3,474.1 \\
164.3 \\
2,141.3\end{array}$ & $\begin{array}{r}1,318.5 \\
330.8 \\
52.0 \\
45.5 \\
3,734.0 \\
234.9 \\
1,887.9\end{array}$ & $\begin{array}{r}28.6 \\
19.5 \\
7.6 \\
26.8 \\
35.0 \\
39.2 \\
38.6\end{array}$ & $\begin{array}{l}2.56 \\
1.93 \\
1.64 \\
3.25 \\
3.30 \\
4.90 \\
2.98\end{array}$ \\
\hline & $2,543,430$ & $7,418.7$ & $7,603.6$ & 33.2 & 2.90 \\
\hline \multirow[t]{2}{*}{$\begin{array}{l}\text { Anthracite plants: } \\
\text { Anthracite.................. } \\
\text { Southern } . . . \ldots \ldots \ldots \ldots\end{array}$} & $\begin{array}{r}111,500 \\
21,700\end{array}$ & $\begin{array}{r}480.2 \\
22.0\end{array}$ & $\begin{array}{r}979.5 \\
44.3\end{array}$ & $\begin{array}{l}29.1 \\
11.5\end{array}$ & $\begin{array}{l}8.78 \\
2.04\end{array}$ \\
\hline & 133,200 & 502.2 & $1,023.8$ & 42.8 & 7. 68 \\
\hline Grand total. & $2,676,630$ & $7,920.9$ & $8,627.4$ & 33.8 & 3.23 \\
\hline
\end{tabular}

Figure 26 shows the estimated average fuel performance during 1919 of plants using anthracite and bituminous coal. The plants to be retained that burn bituminous coal are those that use not over 50 per cent more than the plants of type B-3 (see p. 185) and those to be retained that burn anthracite are those that use not over 125 per cent more coal than the plants of type A-3 (see p. 185).

\section{ESTIMATED INVESTMENT COST.}

In 1919 there were in operation in the superpower zone 400 steam-electric public-utility plants. Most of these plants were built so long ago that their cost can not readily be estimated. A knowledge of the investment made in existing plants is required for the purpose of computing the fixed charges and the total cost of energy. In comparing the total cost of power produced under a superpower system with the cost of that produced under independent operation the investment cost for each element of both systems must be computed in the same manner. 
Figure 27 shows the estimated unit investment cost required for effective plant capacity and for excess generator capacity. Many of the existing plants have insufficient boiler capacity

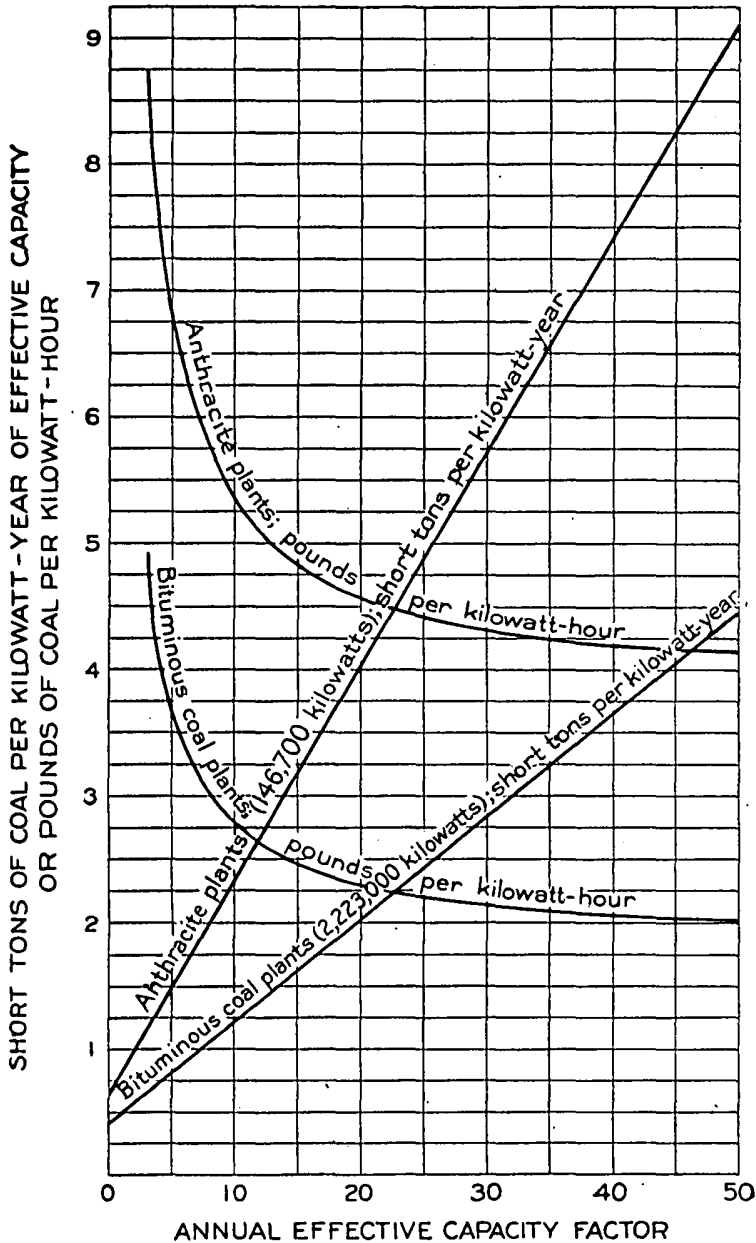

FraURE 26.-Average performance of existing steam-electric plants to be retained in the superpower system. for the entire prime-mover installation, so that it is necessary to estimate the cost of excess generator capacity. These estimates are the result of an examination in detail of the items of cost of plants having capacities between 500 and 175,000 kilowatts. To insure the use of fair cost values authorities on this subject have been consulted freely.

The estimated cost of constructing, in midyear of 1919 , the steam-electric plants to be retained in the superpower system is as follows:

Eastern New England................... \$66,235, 000 Western New England................ 24,550,000 Mohawk.......................... 5, 030,000

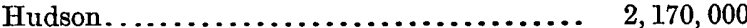
Metropolitan.......................... 129, 105, 000 Anthracite ............................. 22, 586,000

Southern......................... 79, 543, 000

Superpower zone. $\overline{329,219,000}$

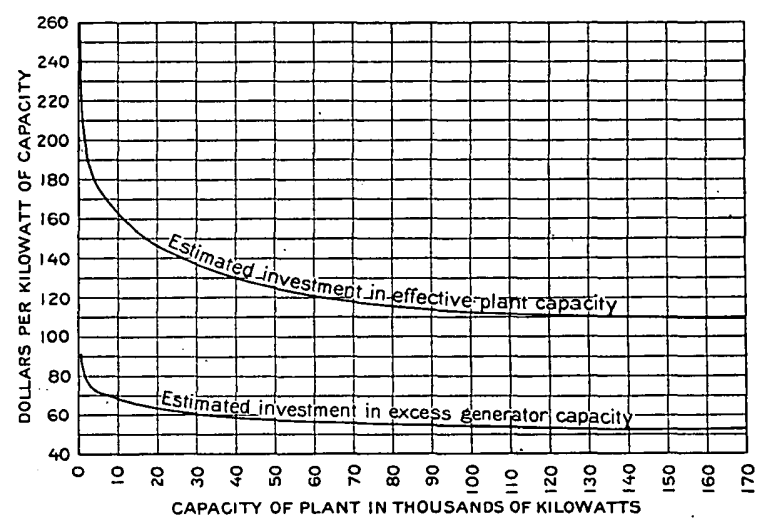

FIGURE 27.-Estimated unitinvestment for existingsteam-electric plants as if constructed in midyear of 1919 .

ESTIMATED ANNUAL PRODUCTION COST.

The fixed charges for the plants to be retained, computed at 16 per cent of the investment cost given above, are stated below. (See also Appendix L.) The cost in 1919 for maintenance, labor, and supplies has been used, and the cost of coal as given in Appendix $\mathfrak{J}$.

Eastern New England.................. $\$ 10,606,000 \mid$ Anthracite....................... $\$ 3,614,000$

Western New England................ 3,928,000 Southern...................... 12,662,000

Mohawk....................... $\quad 805,000 \quad$ Superpower zone............... $52,620,000$

Hudson........................... 348,000

Metropolitan......................... 20,657,000

Figures 28 and 29 give the average production cost of all existing steam-electric plants to be retained in the superpower system, and in Table 79 the operating cost, fixed charges, and total production costs of these plants are compared to the estimated annual cost of base-load steam-electric plants. 


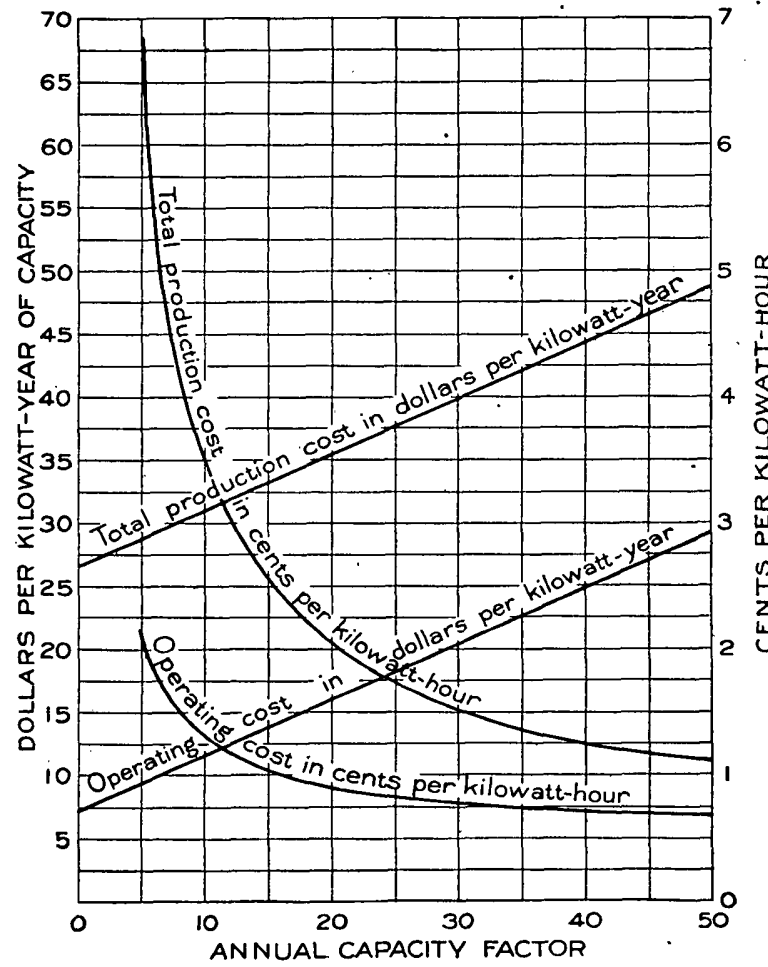

Figure 28.-Estimated average production and operating costs for existing steam-electric plants burning bituminous coal to be retained in superpower system. Coal figured at $\$ 5.30$ per short ton in bunkers.

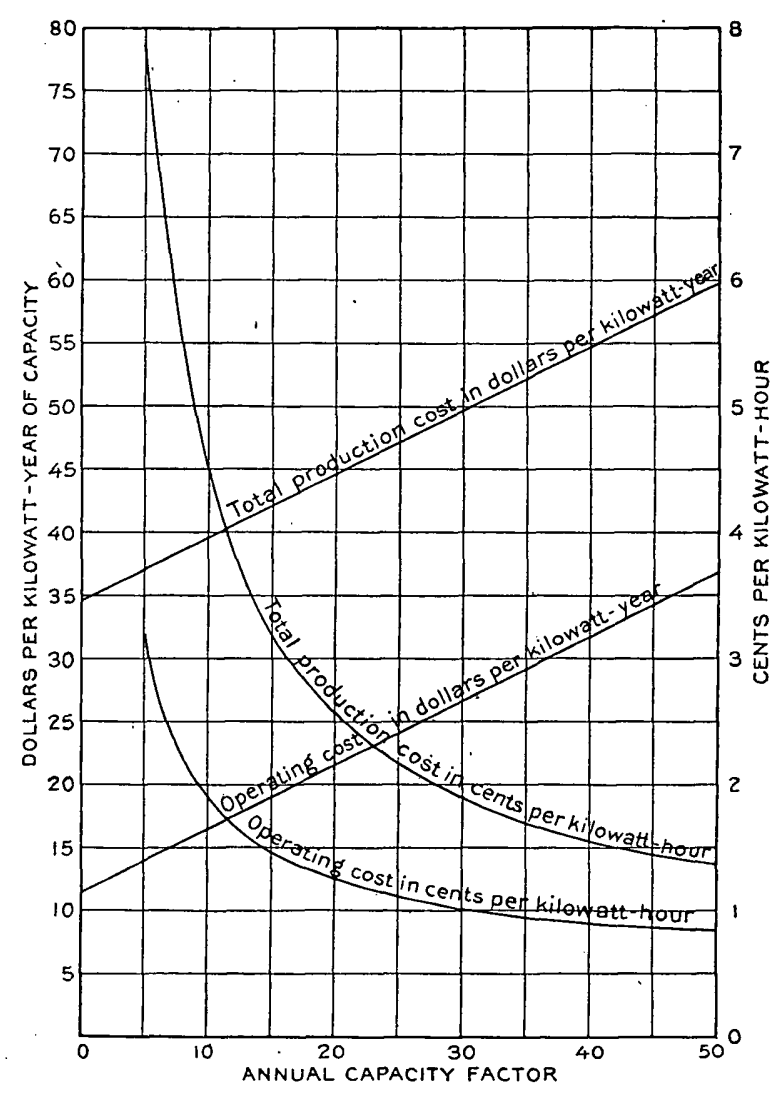

FIGURE 29.-Estimated average cost of production and operation for existing steam-electric plants burning anthracite to be retained in superpower system. Coal figured at $\& 3$ per long ton.

TABLE 79.-Costs for new and retained steam plants, at an annual capacity factor of 30 per cent, in cents per kilowatt-hour.

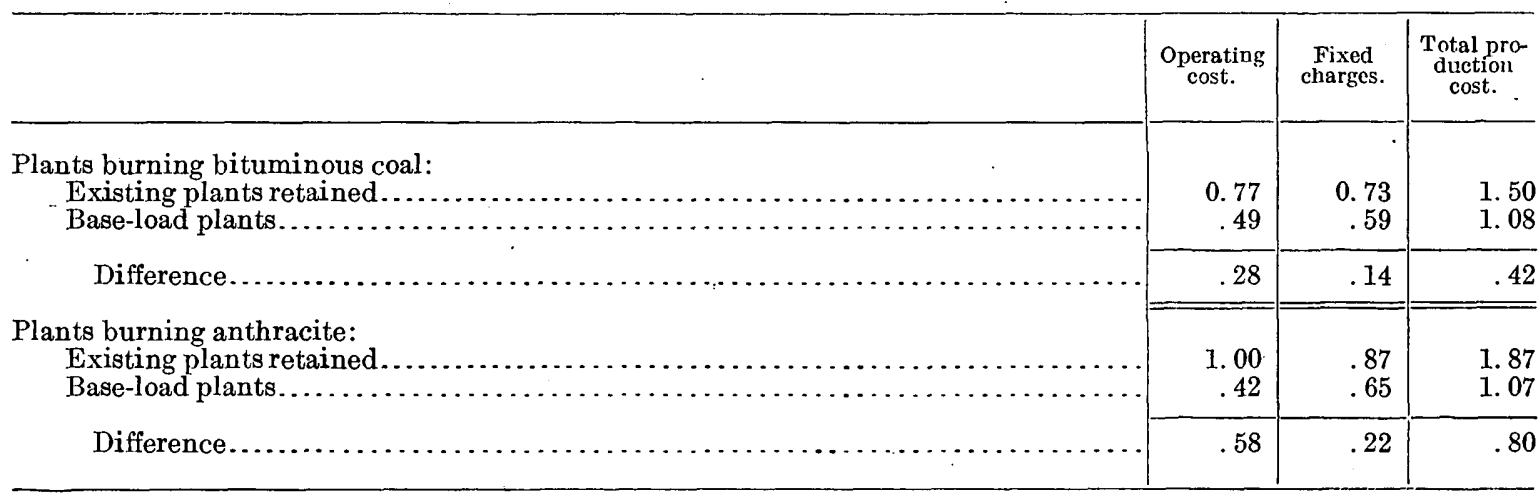

NEW BASE-LOAD PLANTS.

LOCATION, CHARACTER, SIZE, AND DESIGN.

The location of the new base-load steam-electric plants will be determined largely by the availability of condensing water and the convenience and cost of coal delivery and storage.

Except as qualified by character of load and relation to existing hydroelectric and steamelectric plants, the new plants will be operated at high annual capacity factors. To provide flexibility in design and cost the plants will be constructed in multiples of 30,000 kilowatts and may therefore use single-cylinder turbines of 30,000 kilowatts or multiple-cylinder turbines of 60,000 kilowatts. 
The maximum size of steam-electric station has been fixed at 360,000 kilowatts. This limit has been determined by considering on the one hand the ability to transmit energy away from the plant and on the other the hazard incident to the possibility of destruction through unusual catastrophe.

It is desirable to standardize as far as may be possible all the units or elements that enter into the construction of a plant, such as boiler equipment, turbines, transformers, and switch gear, in order to reduce the cost of maintenance, to obviate the need of carrying many small parts, and thus, by making quick repairs possible, to insure continuity of service.

After consultation with many representatives of manufacturers of equipment and with designing and operating engineers, the following basic operating requirements for base-load sterm-electric plants have been selected:

Steam pressure at turbine throttle, 300 pounds per square inch.

Superheat at turbine throttle, $230^{\circ} \mathrm{F}$.

Final temperature at turbine throttle, $652^{\circ} \mathrm{F}$.

Absolute pressure at turbine exhaust nozzle, 1 inch of mercury.

These requirements have been thoroughly tried, and conformity with them should assure reliability of service.

Base-load steam-electric plants are of two general types-type A, using anthracite, and type $B$, using bituminous coal. The two types in turn have been subdivided into three classesclass 1, stokers, boilers, economizers, and air preheaters; class 2, stokers, boilers, and economizers; class 3 , stokers and 20-tube high boilers. The stokers for type A are chain grate; those for type $B$ are underfeed. The relative performance of these types, the relative investments, and the relative production costs are discussed in the following sections of this appendix.

The load to be carried on these plants will not include sudden peaks of short duration. Such peaks as they will have to carry will be of long duration. Accordingly, a liberal boiler capacity has been planned for the turbines, ranging from about 4 kilowatts per boiler-horsepower for a plant of class 3 to about 4.65 kilowatts for a plant of class 1 . The boiler plant can thus operate at a very high efficiency over the entire range of load. Plants of class 1 can carry about 175 per cent of their rating at normal loads and 215 per cent on sustained peaks; plants of class 3 can carry about 160 per cent on normal loads and 190 per cent on sustained peaks. The boiler and stoker arrangement is so planned, however, that 300 per cent rating can readily be obtained if necessary for peaks of short duration. Large combustion chambers are used, $3 \frac{1}{2}$ cubic feet per boiler-horsepower having been allowed.

Should the burning of pulverized or process fuels become profitable in conjunction with the production of power, it will be possible to install the necessary apparatus with little expense, as this contingency has been considered in designing the boiler plant.

With 30,000-kilowatt turbines surface condensers having approximately 50,000 square feet of surface will be used. This amount of surface may be varied at different localities because of local water conditions. Under average conditions of obtaining condensing water for the entire zone this amount of condenser capacity will be ample.

Base-load stations will be located outside of congested centers of population.

\section{ESTIMATED PERFORMANCE.}

The estimated performance for base-load steam-electric plants is shown in Plate VIII for plants of types $\mathrm{A}-3, \mathrm{~B}-1, \mathrm{~B}-2$, and $\mathrm{B}-3$.

It is not considered advisable to use pressures or temperatures higher than those indicated above, which are in successful use to-day, despite the fact that fuel economy may be increased by higher pressures and temperatures.

The estimate of the performance of plants of type A was based upon the use of No: 3 buckwheat coal having approximately the following characteristics:

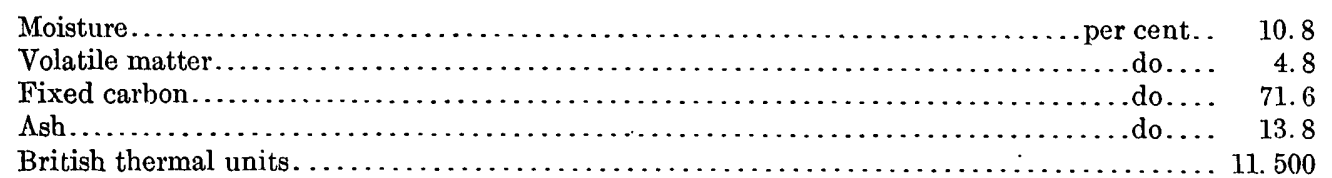


The estimate of the performance of plants of type B was based upon the use of coal from the central Pennsylvania fields having the following characteristics:

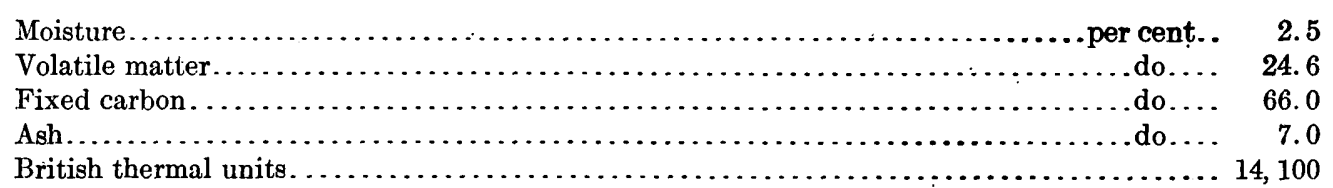

The curves in Plate VIII show two performances, one called "acceptance test conditions," meaning the best possible performance that may be expected from the plant, and one called

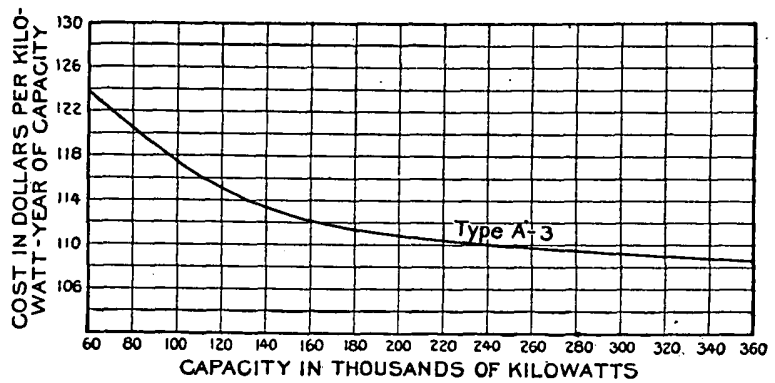

FIGURE 30.-Estimated unit investment cost of base-load steam-electric plants burning anthracite. Based on prices prevailing in midyear of 1919. Type A-3, chain-grate stokers and boilers.

"annual," meaning the performance considered throughout a year. The "annual" performance was estimated according to actual operating conditions, under which the boilerroom equipment can not be kept clean enough to maintain test results, the turbines are lapped at about 75 to 80 per cent load to protect service, the vacuum varies, inferior coal must be used at times, and the boilers are banked when necessary. These actual operating conditions have a large effect on performance: It is planned to operate the base-load plants with a uniform daily load by shifting the load swings either to the existing steam-electric plants or to such hydroelectric plants as may be found suitable for peak-load operation. On the assumption that the thermal efficiency will increase up to 1930 at the present rate the annual performance represented by these estimates is a fair average for expected performance between 1920 and 1930.

\section{UNIT INVESTMENT COST.}

The unit investment costs of plants of the several types.considered in figures 30 and 31 are based on the prices of material and labor in the midyear of 1919. These costs will provide sufficient land for a 360,000 -kilowatt plant as well as for coal storage and a process coal plant. The main coal-handling system and the main intake and discharge tunnels are adapted to a plant having a minimum capacity of 180,000 kilowatts. Intake and discharge laterals will be added to each unit as turbines are installed. The cost of a 60,000 kilowatt plant therefere includes land sufficient for its development to 360,000 kilowatts and coal-handling facilities and main condenser tunnels for its development to 180,000 kilowatts.

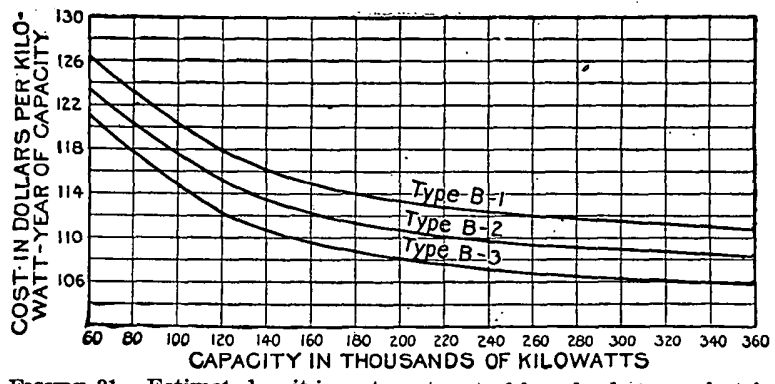

FraURE 31.-Estimated unit investment cost of base-load steam-electric plants burning bituminous coal. Based on prices prevailing in midyear of 1919. Type B-1, underfeed stokers, boilers, economizers, and preheaters; B-2, underfeed stokers, boilers, and economizers; B-3, underfeed stokers and bollers.

Table 80 shows the estimated cost of three sizes and four types of base-load plants, including the cost of superintendence, engineering, contingencies, and interest during construction. 
U. 9. GEOLOGHOAL SURVEY

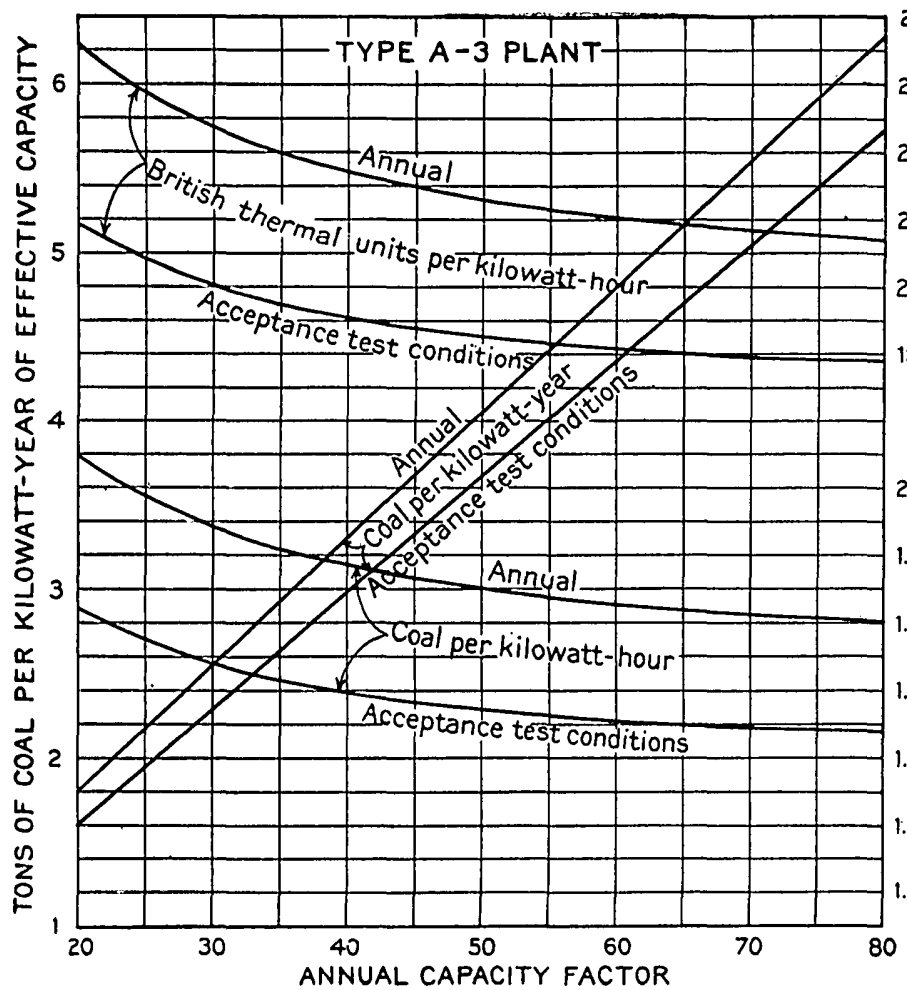

ṖR̄ofiessional PAPER 123 PLATE Vimi

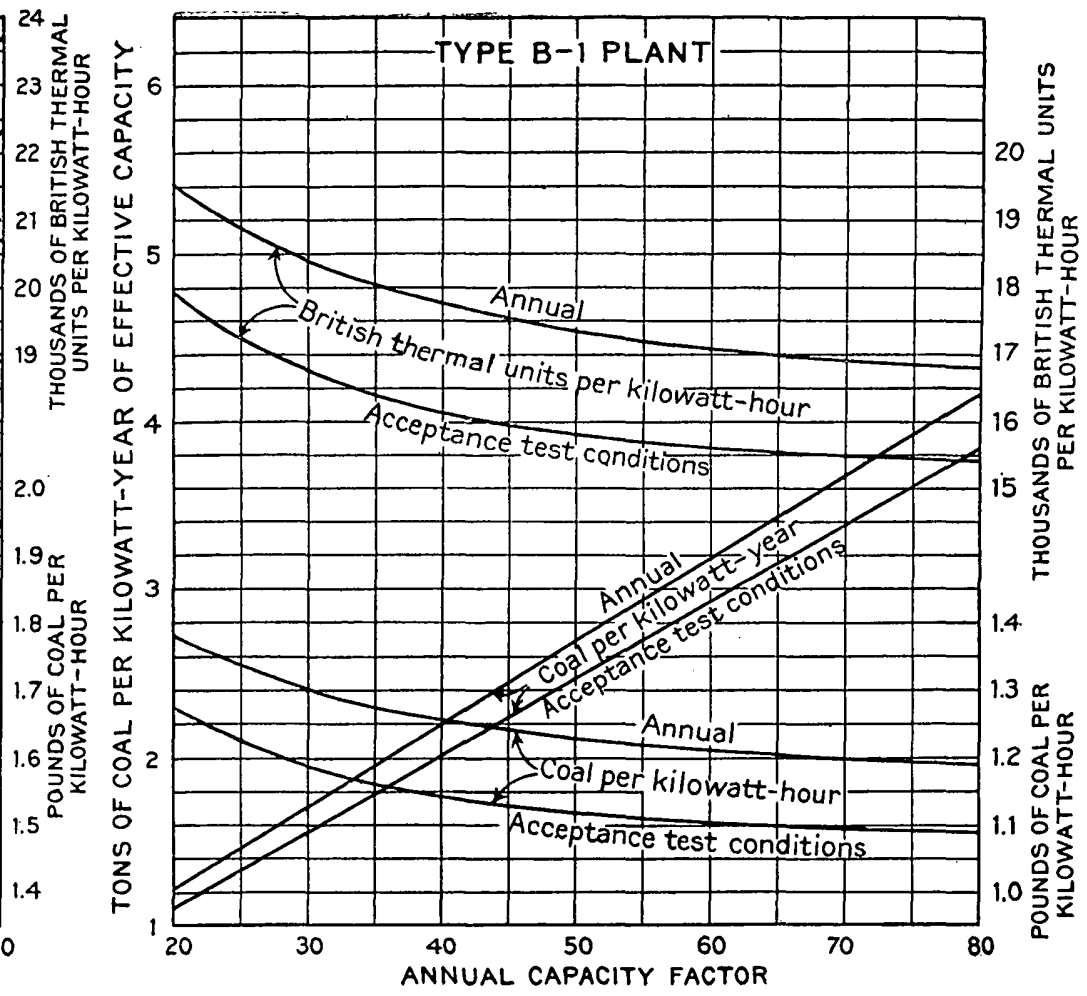

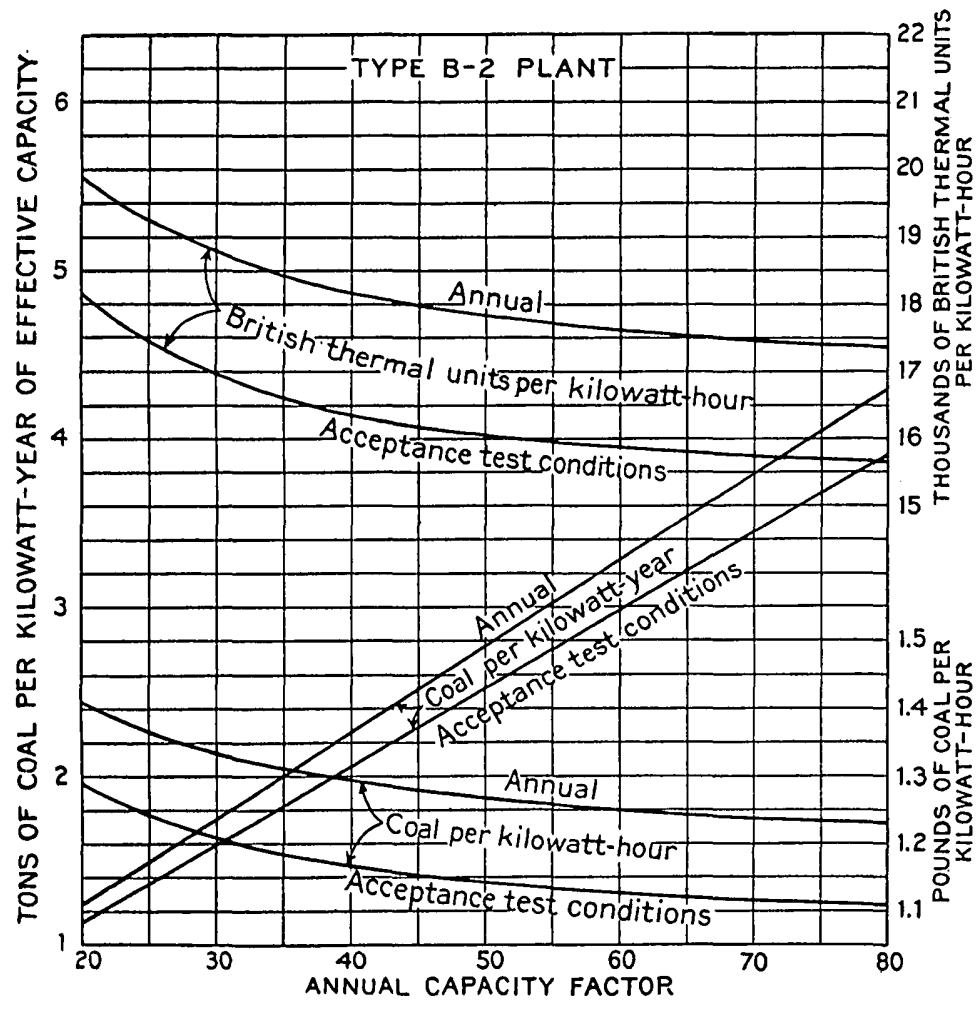

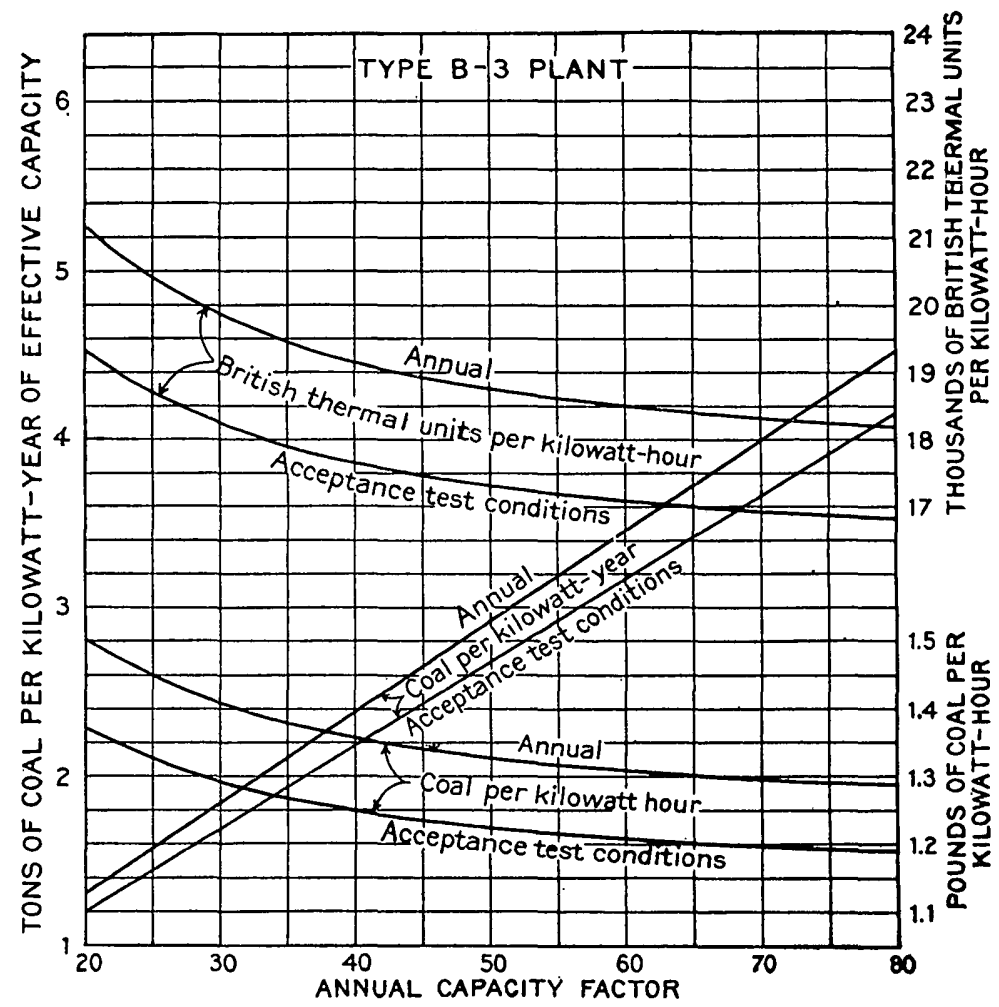

ESTIMATED UNIT PERFORMANCE OF BASE-LOAD STEAM-ELECTRIC PLANTS.

Q3361 ${ }^{\circ}-21$. (Face page 186.) 
TABLE 80.-Estimated unit investment per kilowatt of capacity for base-load steam-electric plants in midyear, 1919.

\begin{tabular}{|c|c|c|c|c|c|}
\hline Type of plant and capacity in kilowatts. & $\begin{array}{c}\text { Real estate } \\
\text { and sea- } \\
\text { sonal coal } \\
\text { storage. }\end{array}$ & $\begin{array}{l}\text { Boiler } \\
\text { house, } \\
\text { complete. }\end{array}$ & $\begin{array}{l}\text { Turbine } \\
\text { house, } \\
\text { complete. }\end{array}$ & $\begin{array}{l}\text { Switching } \\
\text { and } \\
\text { feeders. }\end{array}$ & Total. \\
\hline 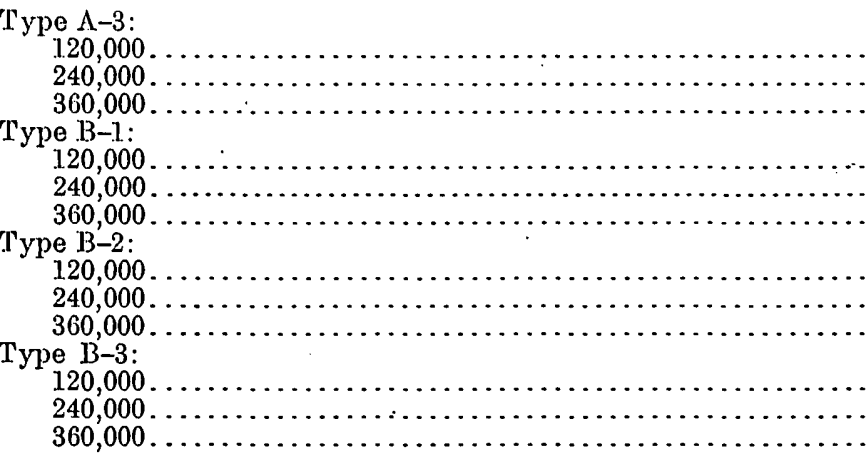 & $\begin{array}{r}\$ 3.00 \\
2.10 \\
1.80 \\
\\
3.00 \\
2.10 \\
1.80 \\
3.00 \\
2.10 \\
1.80\end{array}$ & $\begin{array}{r}\$ 47.65 \\
44.34 \\
43.78\end{array}$ & $\begin{array}{r}\$ 57.20 \\
56.79 \\
55.00\end{array}$ & $\begin{array}{r}\$ 7.39 \\
7.37 \\
7.36 \\
7.39 \\
7.37 \\
7.36\end{array}$ & $\begin{array}{r}\$ 115.24 \\
110.60 \\
107.94 \\
117.69 \\
112.89 \\
110.29 \\
115.04 \\
110.32 \\
107.66\end{array}$ \\
\hline
\end{tabular}

UNIT PRODUCTION COST.

Unit production costs are subdivided into operating costs (fuel, maintenance, labor, and supplies) and fixed charges. The costs of maintenance, labor, and supplies for plants using bituminous and anthracite coal, as shown in figure 32 , have been determined by detailed analyses of the operations of the largest steam-electric plants in the superpower zone.

The total production cost varies with the type and size of plant and the cost of fuel. Typical costs are shown by the curves in figures 33 and 34 for types B-3 and A-3. The cost of bituminous coal has been fixed at $\$ 5.30$ per short ton delivered to the plant bunkers, this being the weighted cost for the zone in 1919 . The cost of anthracite for plants type A-3 has been fixed at

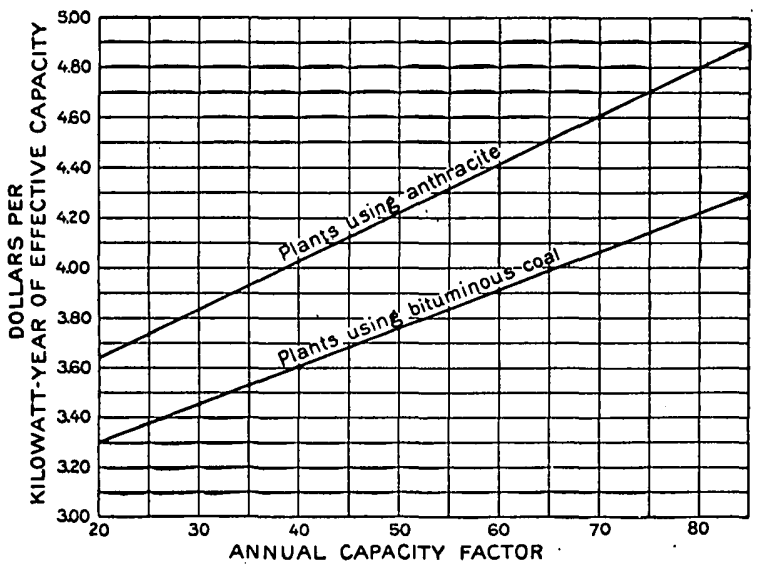

Figure 32.-Estimated annual cost of maintenance, labor, and sup plies for base-load steam-electric plants. Based on prices prevailing in 1019.

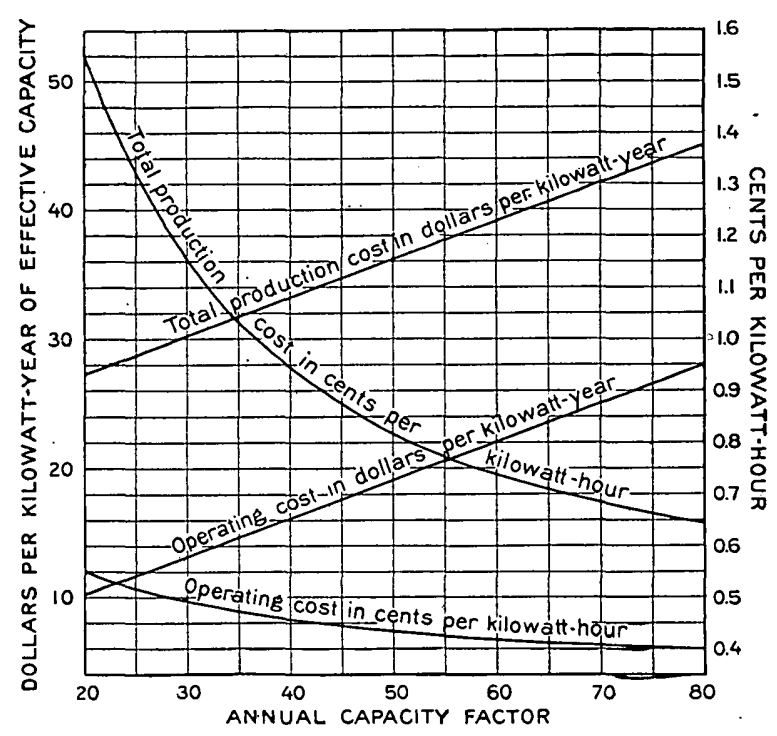

FIGURE 33.-Estimated annual production and operating costs for a plant of type B-3, capacity 300,000 kilowatts. Fuel figured at $\$ 5.30$ per short ton in bunkers.

$\$ 3$ per long ton delivered to the plant bunkers, this being approximately the cost at the anthracite mines plus the freight charge.

Greater fuel economy would be gained by installing plants of high efficiency, but such plants (of classes 1 and 2) cost more per unit, and unless the saving in operating cost is so great as to bring a large return on the additional investment their installation is not warranted. By taking a return of 30 per cent on the additional capital required for plants of classes 1 and 2 over that required for plants of class 3 as the point where the installation of plants of classes 
1 and 2 is justified, any notable change in conditions that may occur-such as a large reduction in the cost of coal, the development of water power, or the development of much more efficient methods of power production - is largely discounted, for the additional investment will be counterbalanced in three or four years by the 30 per cent additional return on it.

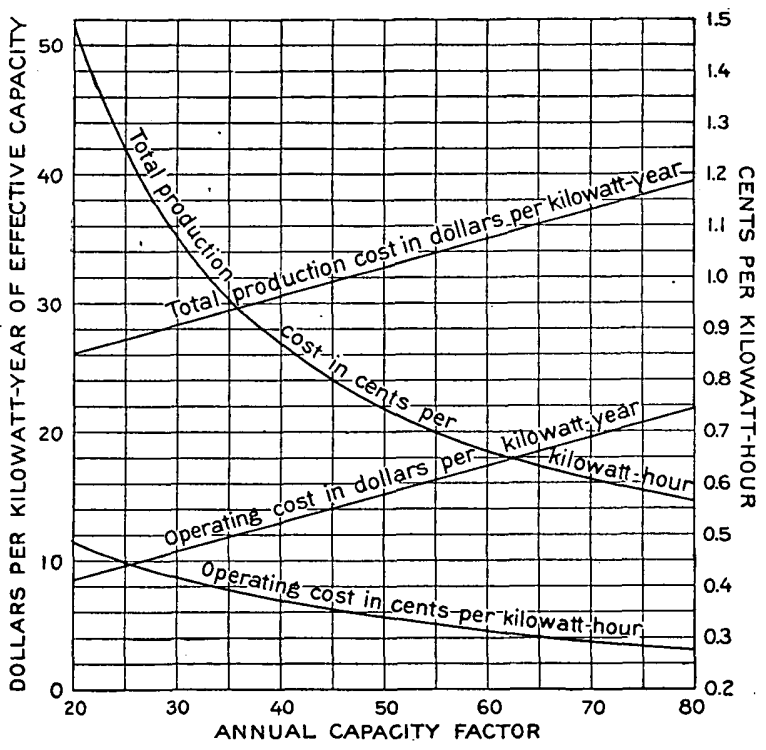

Figure 34.-Estimated annual production and operating costs for a plant of type A-3, capacity 300,000 kilowatts. Fuel figured at $\$ 3$ per long ton in bunkers.

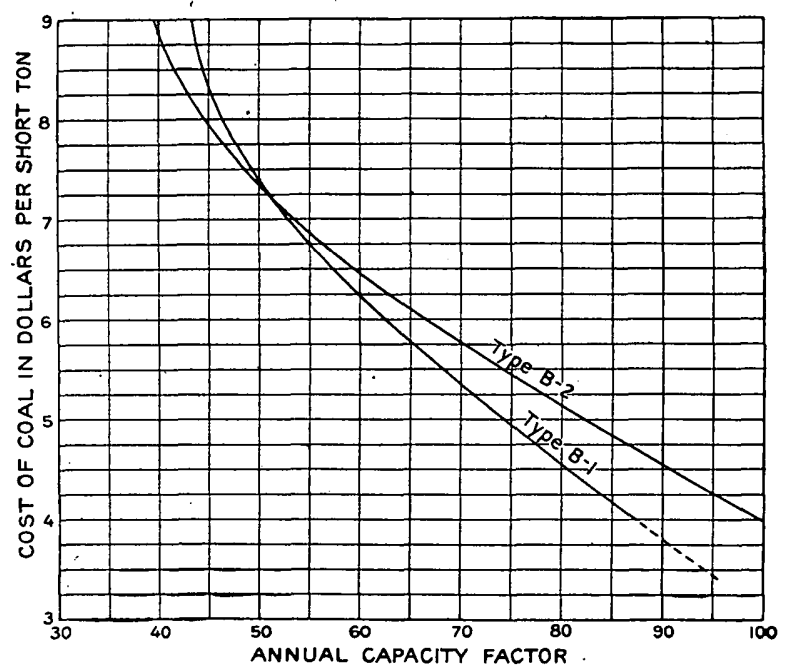

FIgURE 35.-Conditions justifying the use of a plant of type B-1 or B-2 instead of a plant of type B-3. Based on a return of 30 per cent on the additional investment required.

The adoption of plants of different types at different locations has been decided according to the curves in figure 35. The authorities on this subject are of two schools, one advocating a lesser return and the other a greater return than 30 per cent. Figure 35, based upon a 30 per cent return, expresses the average opinion of these two schools.

\section{LOCATION AT TIDEWATER AND ON INLAND RIVERS.}

The new base-load steam-electric plants for the superpower system have been so located as to obtain full advantage of low freight rates, available coal-delivery routes, and ample condensing water.

TABLE 81.-Location and capacity of new base-load steam-electric plants.

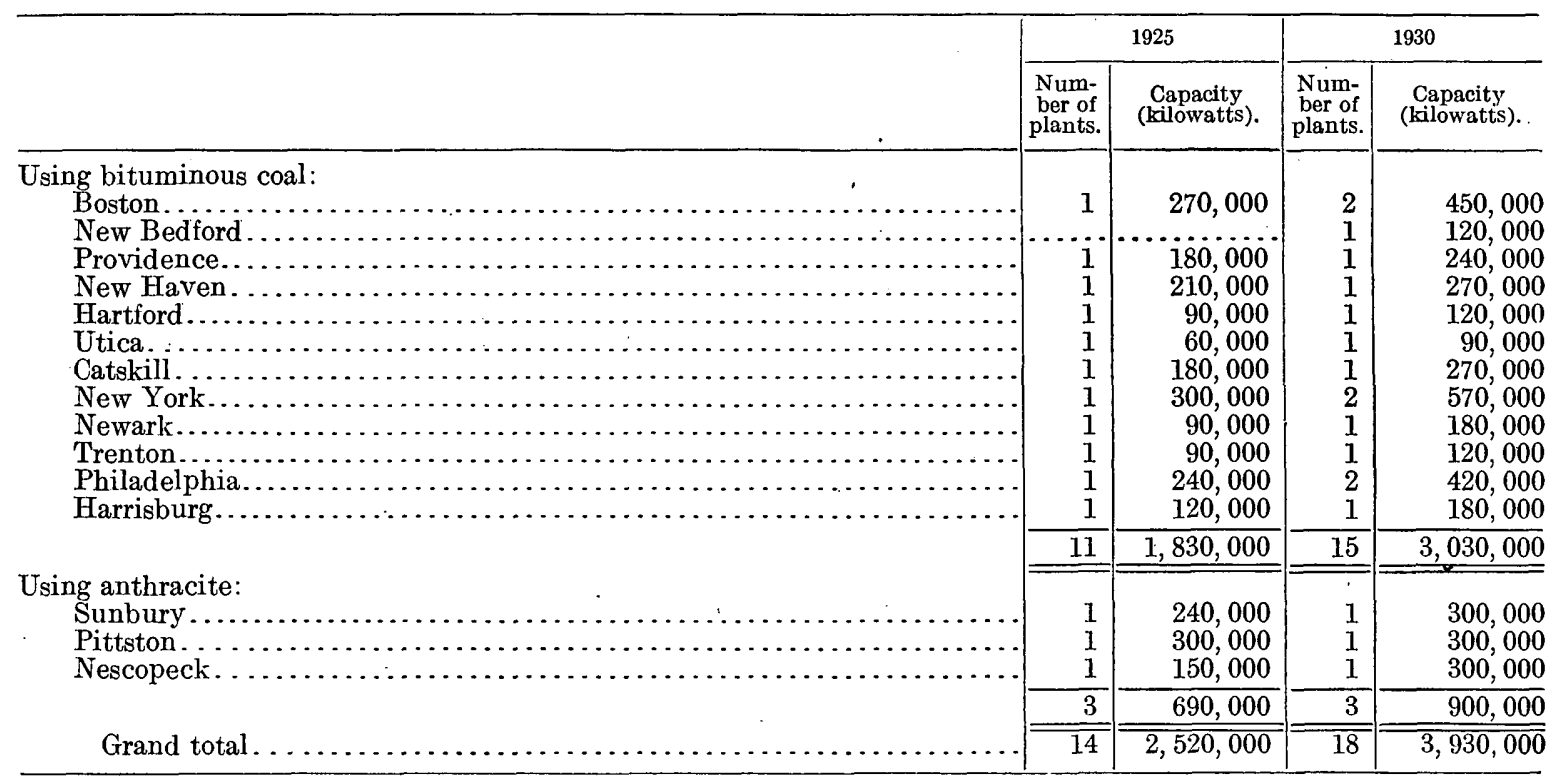


Reference to Appendix E (pp. 164-166) shows that the cost of coal per ton delivered to these proposed new base-load steam-electric plants is lower than to either the steam-electric plants retained or to the electric public utilities for 1919.

The plant locations for 1930 are shown on Plate X (p. 220) with reference to the coal-mining districts, the available coal-delivery routes, and the supply of condensing water. Their locations with respect to the transmission system for both 1925 and 1930 are shown on Plates II and III (p. 14).

For the Anthracite, Metropolitan, and Southern divisions the capacities of the steamelectric power plants have been so determined as to obtain the most economical combination with the hydroelectric plants on Potomac, Susquehanna, and Delaware rivers. Furthermore, the diversity in demand existing between the Anthracite and the Southern and Metropolitan divisions has been considered in determining the capacity of the plants to be installed.

It would have been possible to supply the same amount of power from a smaller number of steam-electric plants having a capacity of about 300,000 kilowatts each, but in order to insure continuity of service the plants have been more widely distributed at a slight increase of cost. However, with such a distribution of plant capacity future demand can be partly met by the enlargement of these plants.

The procedure to be adopted for the development of the hydroelectric resources of the zone has a very important bearing upon the amount of steam-electric capacity to be installed. For instance, in the Mohawk-Hudson division it is proposed to start the development of Hudson River on the assumption of a high load factor, steam-electric plants being used to carry the peak load. This plan calls for the early installation of a relatively large amount of new steamelectric capacity for that division. However, when power from St. Lawrence River is supplied to this division the economical procedure will be to continue the development of Hudson River to handle peak loads and to install practically no further steam-electric capacity until the ultimate limit of development of St. Lawrence and Hudson rivers has been reached.

\section{PLANTS IN THE MINING REGIONS.}

The development of electric power within the coal regions is justified when the freight charges on the corl to the points of consumption are greater than the value of the electric energy lost in transmission plus the fixed and operating charges on the transmission system, allowance being made for the saving in capitalization on generating equipment that will be permitted by diversity in loads between the interconnected load centers.

\section{ANTHRACITE FIELDS. \\ SIZE AND QUALITY OF ANTHRACITE.}

Investigation shows that buckwheat No. 3. is the most economical size of anthracite for use on the stokers of superpower plants. The firing of powdered anthracite is being developed but has not yet been brought to the commercial stage. The quality of anthracite from different mines varies, especially as to its ash content. Improved boiler efficiency justifies the cost of ash removal by washing down to a content of about 15 per cent. The performance of steam-electric plants using anthracite is based upon coal having the following analysis: Moisture 9.8 per cent, volatile matter 4.6 per cent, fixed carbon 71.6 per cent, ash 13.8 per cent, British thermal units 11,500 .

QUANTITY OF ANTHRACITE AVAILABLE.

Doubtless the peak of production of anthracite was reached during the World War, the output from the mines during that period being reinforced by washeries which reclaimed great quantities of the finer sizes of coal from culm banks. Most of the coal of size No. 3 has now been removed from the banks. There is no indication, however, that there will be any considerable falling off in the production of freshly mined coal for many years, and there is no reason for any appreciable change in the ratio of the smaller sizes to the total output. The statistics of the last few years are therefore a reliable indication of the quantity of buckwheat 
No. 3 available for many years. The table given below is taken from a report of the United States Geological Survey on the production of Pennsylvania anthracite in 1919, by F. G. Tryon, supplemented by data obtained from the Anthracite Bureau of Information. The figures in the last column are a close approximation of the total output of buckwheat No. 3 , for although no complete records are available upon the size of the fuel used by the mines, data obtained from individual mines indicate that it is almost exclusively buckwheat No. 3 .

TABLE 82.-Anthracite produced in 1916-1919, in long tons.

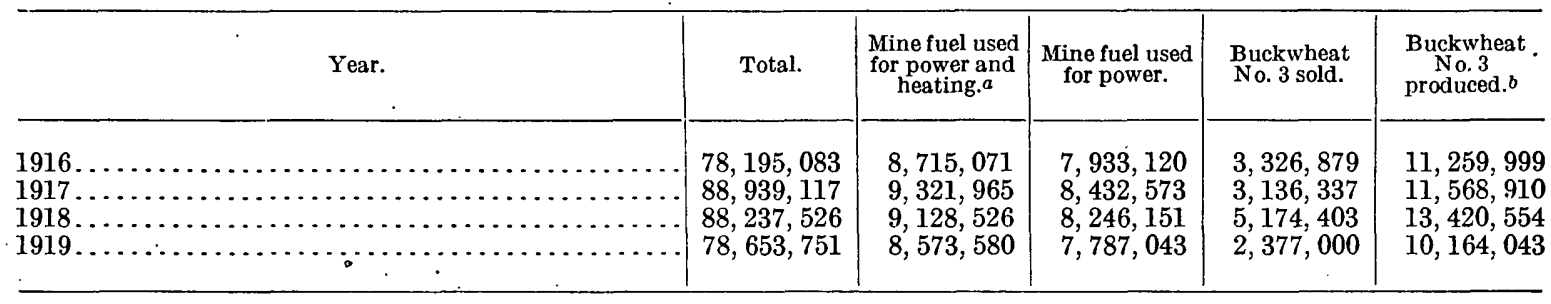

a Probably almost exclusively buckwheat No. 3. $\quad b$ Determined by assuming that all the mine fuel used for power is buckwheat No. 3.

Estimates of the future supply of buckwheat No. 3 will show some reduction from the above figures, which include coal from washeries. Tryon in the report cited above states that $1,650,000$ tons of freshly mined buckwheat No. 3 was sold and 7,721,545 tons of freshly mined fuel was used for mine operations in 1919. It is estimated that the annual production of this size for the next 10 years should average about $9,000,000$ tons.

If all the mines are electrified, the coal thus released will be sufficient to serve all the demands for power at the mines and in addition to operate at their full capacity all the public-utility plants that now serve New York City, New Jersey, and the Philadelphia district.

\section{POSSIBLE SITES IN THE ANTHRACITE REGION.}

The following streams within the anthracite region have been investigated with reference to their suitability for supplying condensing water: Portions of Susquehanna, Schuylkill, Lackawanna, and Lehigh rivers; Shamokin, Mahonoy, Mahantango, Wiconisco, Wapwallowpen, Nescopeck, Catawissa, and Roaring creeks. All except the Susquehanna have been eliminated because of low flow, contamination, or both. Three sites on Susquehanna River are suggestedone north of Pittston, one near the mouth of Nescopeck Creek, and the third south of Sunbury. At each of these points the water conditions are favorable for a 300,000-kilowatt plant. An adequate supply of suitable coal can be obtained within a radius of 25 miles. The length of haul is a minimum at Pittston.

COST OS ENERgy From PLANTS IN THE ANTHRACITE REgION.

Appendix $\mathrm{E}$ shows that by 1930 the total energy requirements of the Anthracite division should reach $3,606,000,000$ kilowatt-hours, corresponding to a maximum demand of 785,000 kilowatts. The total generating capacity of the public-utility companies now serving the division is 230,000 kilowatts. Minimum operating cost would be obtained by carrying the entire load from the superpower system, but in order to conserve capital the more efficient of the present plants will be retained.

The sizes of the plants and their location in the Anthracite division, together with their relation if interconnected with Delaware River, are discussed in Appendix E. The combination of the plants in the coal-mining region with Delaware River shows the greatest economic possibility to the Anthracite, Metropolitan, and Southern divisions. In view of the fact that the Anthracite division load reaches a maximum in the morning and falls off rapidly after 3 o'clock in the afternoon, there is considerable diversity between this load and the loads in adjacent territories. Furthermore, the anthracite mines operate on an average only 225 days in the year, so there is further diversity between the mines. If there were an interconnected system between the Anthracite and the other divisions considerable off-peak capacity would be available in the Anthracite division for supplying power to the Metropolitan and Southern divisions. 
BITUMINOUS COAL FIELDS.

GENERAL CONDITIONS.

On account of the adequate stream flow and the proximity of the Anthracite division to the superpower zone, steam-electric power in that division is an economic possibility. These favorable conditions, however, do not prevail in the bituminous coal region, nor will the power requirement of the southern load centers by 1930 be sufficiently high to permit the economical transmission of power from the bituminous coal fields.

POSSIBLE SITES IN THE BITUMINOUS COAL REGION.

Only three large streams flow from the eastern slope of the Allegheny Mountains-the West Branch of the Susquehanna, the Juniata, and the Potomac. The highest point on Susquehanna River deserving consideration in this connection is at Keating, where Sinnemahoning Creek joins the river. This point is about 20 miles from the Clearfield district, the nearest locality at which an adequate supply of coal can be obtained. The flow at Keating derived from stream-flow records at Renovo indicates that the output during dry periods would be limited to less than 100,000 kilowatts.

Below the junction of the Frankstown and Raystown branches of Juniata River, near Huntingdon, the water supply is. insufficient for a plant of a capacity exceeding 180,000 kilowatts. At either Huntingdon or Mount Union railroad facilities are available for obtaining coal from the Broad Top field with a maximum haul of 30 miles, and the distance from Huntingdon to the Philipsburg district is 45 miles.

The West Branch of Potomac River reaches the coal fields near Cumberland, Md: At this point the local power company has a steam plant whose ultimate capacity is limited by the supply of water to about 30,000 kilowatts. About 30 miles below Cumberland, near Green Spring, the South Branch adds a large volume of water, which will permit increasing the capacity to 180,000 kilowatts.

A condition precedent for the economical transmission of power to tidewater is a capacity for delivered power of about 300,000 kilowatts, with transmission at a very high load factor. Sufficient condensing water is not available for the production of this amount of power on any of the streams in the eastern bituminous coal region. This fact, however, does not preclude the future development of power capacity with proper regulation of these rivers by storage. On Potomac River hydroelectric developments are contemplated at Great Falls, near Washington, which involve controlling the river flow by means of large reservoirs on the South Branch. When this plan is carried out the stream flow at the proposed site will be adequate for a $300,000-$ kilowatt steam plant. Coal for such a plant would come largely from the Georges Creek field, with an average haul of about 35 miles.

Ultimately steam-electric power plants may be profitably developed at sites near the bituminous mines, especially after the electrification of railroads has been extended sufficiently to create considerable demand for power within economical transmission distances from these sites.

$63361^{\circ}-21-13$ 


\section{APPENDIX G. HYDROELECTRIC PLANTS FOR THE SUPERPOWER SYSTEM.}

By L. E. Imlay, L. A. Whitsit, B. J. Peterson, and others of the engineering staff.

THE USE OF HYDROELECTRIC PLANTS.

The installation of hydroelectric plants is justified where the interest on the investment plus the cost of operation amounts to less than that for steam-electric plants, so that the economical proportions of water and steam development must depend upon the cost of money, coal, and labor.

Hydroelectric plants can be classified as of three types, the type depending upon the character of the stream flow, namely:

1. Uniform stream flow by which the output may be maintained for 24 hours a day.

2. Variable stream flow without storage. A hydroelectric plant of this type is especially useful in a large interconnected system, but less so if it supplies a single system, for then the economical use of water is most difficult, if not impossible. The flow curve of such a river is as clearly defined as the load curve of the power market, and evidently power must be wasted unless either the load curve of the market is coincident with the flow of the river or the market load is sufficiently large to absorb the entire hourly output of the plant. It is obvious that the load of a large interconnected system can absorb the hourly output of a plant of this type.

3. Variable stream flow with storage, which provides water for carrying peak loads. The maximum attainable load factor for the superpower system will probably be 50 per cent. With such a load factor 14 per cent of energy (in kilowatt-hours) will carry a 50 per cent peak load (in kilowatts). It is therefore apparent that the value of water storage will lie in the utilization of the stored kilowatt-hours for carrying peak load, inasmuch as, after the dam and head works of the hydroelectric plant have been installed, the investment in generator capacity is but half as much as that for a complete steam-electric plant. In other words, stored water should be held in reserve for peak load.

\section{POTENTIAL HYDROELECTRIC DEVELOPMENTS.}

GENERAL CONSIDERATIONS.

The investigation of potential hydroelectric development is limited to the major hydroelectric resources of the superpower zone and to such outside sources of hydroelectric energy as may be reasonably expected to contribute to. it. The principal rivers involved are the Potomac, Susquehanna, Delaware, Hudson, Black, Raquette, Connecticut, St. Lawrence, and Niagara. (See Pl. IX.) The Niagara at Niagara Falls contains the largest single potential hydroelectric power development on the North American continent. It is within transmission distance of the superpower zone, but its development beyond what is already provided for is prevented for an indefinite time by international treaty. All the power resources of the zone are not included in these studies, those below 5,000 kilowatts in capacity being disregarded except where contiguous sites of smaller capacity aggregate more than that amount. These small powers will be developed as local conditions warrant, and the plants will be connected to the superpower system through the facilities of the electric public-utility companies. The superpower system will permit the earlier construction of the smaller plants by providing a market for energy not required locally. 


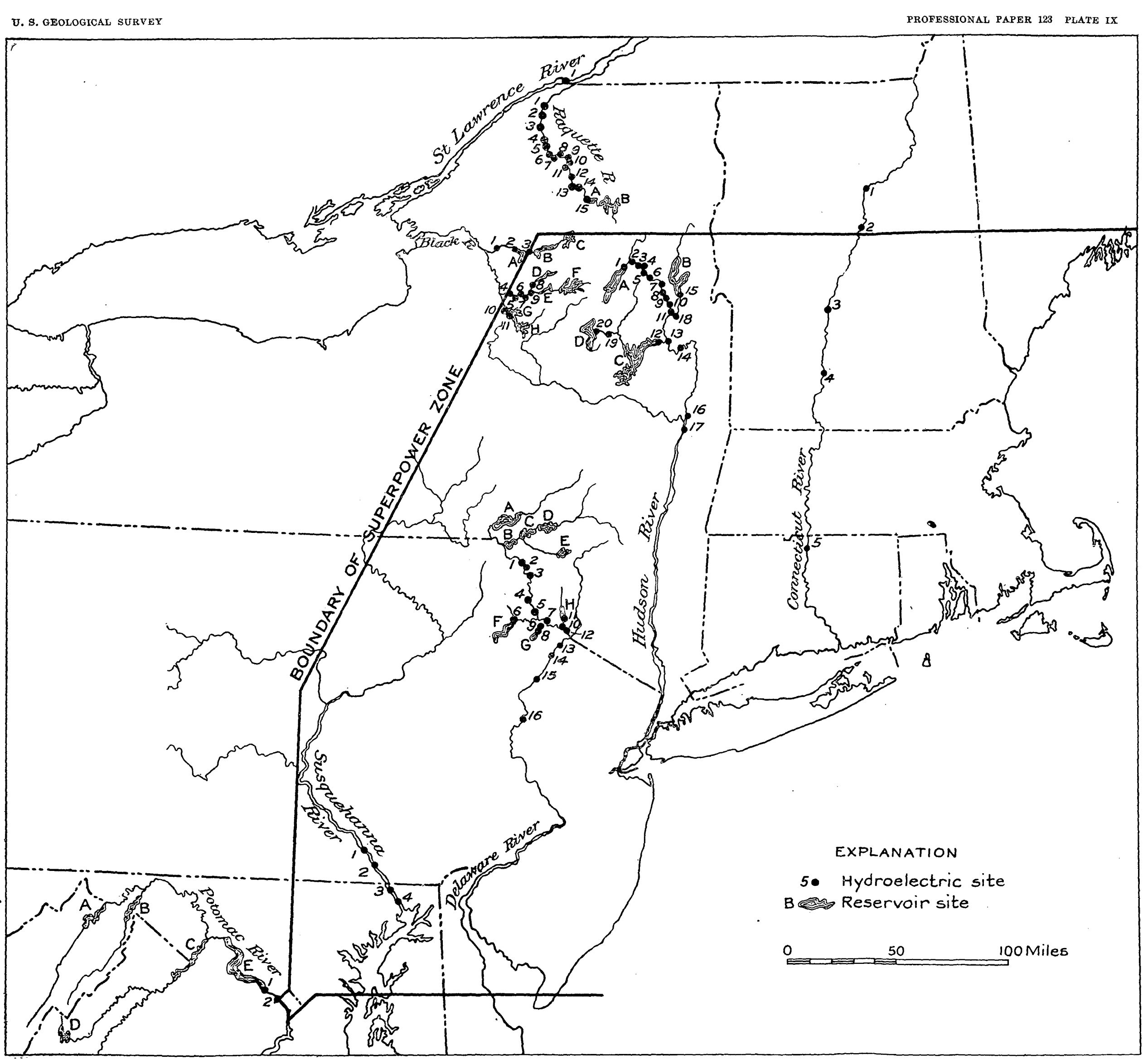

Power site.
1. Gereat Falls.
2. Chain Bridge.

POTOMAC RIVER.

B. Great Cacapon.
C. Shenandoah River.
D. North Fork of Shenandoah River.
E. Great Falls.

1. Conestoga

SUSQUEEHANNA RIVER

Conowingo
Port Deposit.

A. Cannonsville
Iower Hankius

Upper Narrowsburg. C. East Branch.

$\begin{array}{lll} & \text { E. Lower Narrowsburg. } & \text { E. Livingston Nanor } \\ \text { 5. Wallenpaupack. } & \text { W. Wallewpaupack- }\end{array}$

$\begin{array}{ll}\text { Barryville. } & \text { G. Shohola. } \\ \text { Upper Shohola. } & \text { H. Mongaup. }\end{array}$

10. Knights Eddy.

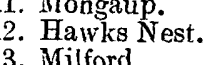

4. Dinomans Ferry.
5. Wallpack.

Belvider

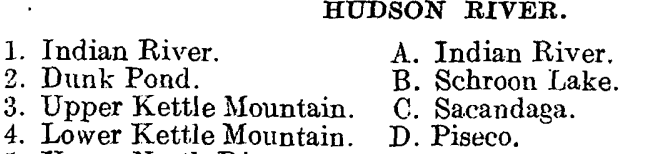

Lower North River.

Miill Creek.

9. Millington Brook

12. Sacandaga.

Palmerton Mountain.

: Alder Brook.
: Waterford.

18. Wrarenguburg.

seco Outlet.

1. High Falls.
2. Sort thaple Dam.
Noshieo Creek,

Iloshioe Creed
Fowlersville.
C.

6. Mroose River.
6. Lower McKeeve

Lower Mhckeever.
Minnhehaha.

Leyden Bridg.

RAQUETTE RIVER $\begin{array}{ll}\text { 1. Raymondville. } & \text { A. Piercefield. } \\ \text { 2. East Nortolk. } & \text { B. Oxbow. }\end{array}$

4. Hewittville.
Loper Hannawa Falls.
Connawa Falls

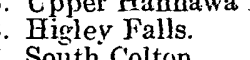

G. Gaintwist Falls.

9. Sittle
Blake.

11. Stark.

Jamestown Falls.

Piercefield. COXXECTICCT RIVER

PRTNCIPAL HYDROELECTRICAL RESOLRCES OF SLPERPPOWER ZONE

1. Fiiteen Xile Falls.

BLACK RIVER.

A. Beaver Lake.

C. Lake Lila:
D. Middle fork

E. Panther. Pr.

Higley Mountain
Hawkinsville.

Forestport.

Piermont.
Dechee Falls. 4. Beelones Falls.
Windsor Locks 
The following table gives a general idea of the characteristics that affect the availability of the rivers for power:

TABLE $83 .-C h a r a c t e r i s t i c s$ of rivers that may furnish power in the superpower zone.

\begin{tabular}{|c|c|c|c|c|c|c|}
\hline . & Point of record. & $\begin{array}{l}\text { Natural } \\
\text { run-off } 50 \\
\text { per cent of } \\
\text { the time } \\
\text { in year } \\
\text { of average } \\
\text { stream } \\
\text { flow. } \\
\text { (second- } \\
\text { feet). }\end{array}$ & $\begin{array}{l}\text { Lowest } \\
\text { recorded } \\
\text { daily } \\
\text { run-off } \\
\text { (second- } \\
\text { feet). }\end{array}$ & $\begin{array}{l}\text { Possible } \\
\text { continuous } \\
\text { regulated } \\
\text { flow in } \\
\text { average } \\
\text { year } \\
\text { (second- } \\
\text { feet). }\end{array}$ & $\begin{array}{l}\text { Total } \\
\text { drainage } \\
\text { area } \\
\text { (square } \\
\text { miles). }\end{array}$ & $\begin{array}{l}\text { Fall avail- } \\
\text { 8ble for } \\
\text { power de- } \\
\text { velopment } \\
\text { (feet). }\end{array}$ \\
\hline $\begin{array}{l}\text { Potomac......... } \\
\text { Susquehanna... } \\
\text { Delaware........ } \\
\text { Hudson.......... } \\
\text { Raquette........ } \\
\text { Connecticut..... } \\
\text { St. Lawrence.... } \\
\text { Niagara........... }\end{array}$ & 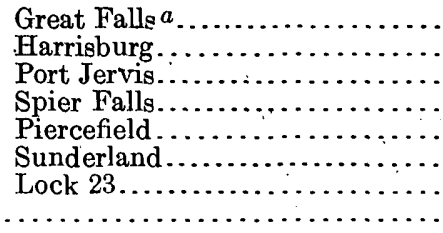 & $\begin{array}{r}6,500 \\
19,500 \\
3,100 \\
3,000 \\
900 \\
8,160 \\
235,000 \\
212,000\end{array}$ & 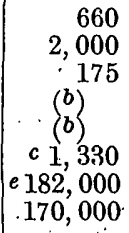 & $\begin{array}{r}7,650 \\
4,600 \\
4,200 \\
1,430 \\
\ldots \ldots \ldots\end{array}$ & $\begin{array}{r}11,500 \\
24,100 \\
3,100 \\
2,800 \\
\quad 723 \\
8,000 \\
285,000 \\
254,700\end{array}$ & $\begin{array}{r}215 \\
220 \\
600 \\
1,500 \\
. \quad 1360 \\
\text { d } 378 \\
85 \\
310\end{array}$ \\
\hline
\end{tabular}

a Flow at Creat Falls detormined from records of flow of Potomac River at Point of Rocks, Md., and Monocacy River near Frederick, Md. $b$ Stroam flow allected by operation of power plant.

c Mean of low week September, 1894, determined from records of flow at Holyoke. Flow somewhat affected by existing plants.

d Net head used in report.

All these streams except the St. Lawrence and Niagara rise in the Appalachian Mountains. The fall indicated as available for power development in most of the rivers is but a small fraction of the total fall. The developments proposed are practical.

The following table indicates the hydroelectric power resources that are considered economical for supplying the energy requirements of the superpower zone in 1930 :

TABLE 84.-Hydroelectric power resources for 1930.

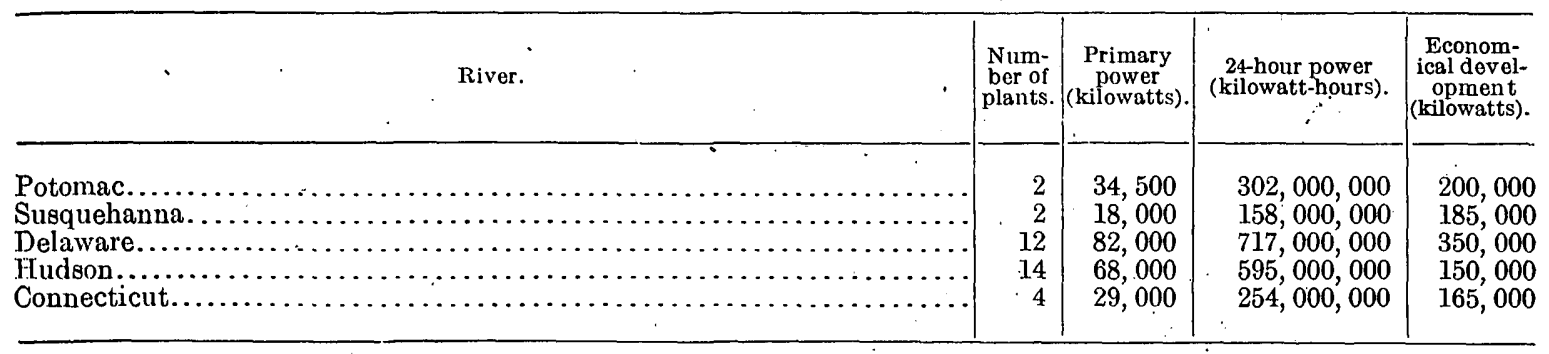

The quantity of water available for the production of power at the several sites was determined from stream-flow measurements made by the United States Geological Survey or by the State governments. The period of record used for most of the poyer estimates was 15 years and extended from October 1, 1904, to September 30, 1919. The power and reservoir sites were located from State reports, reports of private engineers, topographic drawings, and personal investigation by the engineering staff. Stream-flow and power-duration curves for reservoir and power sites were plotted for average and minimum years.

Development of primary power on all the streams under consideration, except the Niagara and St. Lawrence, involves the provision of large storage-reservoir capacity. There must be in addition ample forebay capacity at each power plant for peak-load operation. The construction of hydroelectric plants for base-load operations results in the lowest investment and production cost, and additional capacity for peak-load operation is obtained at about one-half the cost of an equivalent amount of steam-generating capacity.

The developments proposed in the estimates for 1925 and 1930 can be justified only if they are included in an interconnected system, as otherwise their output can not be economically absorbed by the power market. 
For the rivers that are not included in the 1921-1930 program estimates are given showing the resources that can be developed in average years, together with the investment and production costs.

At practically all sites where hydroelectric plants are designed for peak-load operation there are considerable periods during each year when there is sufficient water to generate energy in excess of peak-load requirements. At such times the hydroelectric plants will be operated at full capacity, thus saving coal that would otherwise be burned in the steam plants of the system.

The recommended capacity for most of the proposed hydroelectric plants is larger than has been recommended in the past for use with individual electric public-utility systems. This is possible only through the interconnected system, which permits full advantage to be taken of peak-load development and of secondary power from hydroelectric plants.

In estimating the over-all efficiency of hydroelectric plants 80 per cent has been taken as the combined efficiency of turbines, generators, and auxiliary equipment and is applied to the net operating head between forebay and tail race.

\section{POTOMAC RIVER.}

The Potomac rises in the mountains of West Virginia and flows into Chesapeake Bay. It is not regulated to any appreciable extent, and the flow at Great Falls ranges from 653 to 248,000 second-feet and averages 11;900 second-feet. The drainage area is 11,500 square miles, and the annual rainfail is between 35 and 40 inches. The fall from Point of Rocks, Md., to tidewater near the boundary line of the District of Columbia is 204 feet, of which 151 feet is below the aqueduct dam at Great Falls, 10.5 miles above the District line.

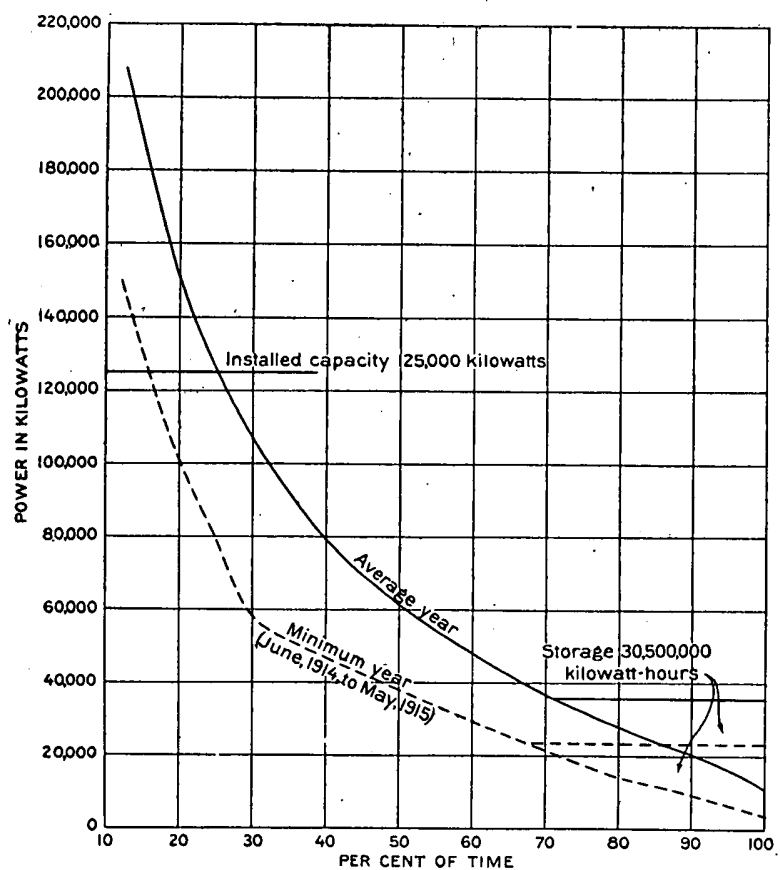

FIGURE 36.-Estimated power available from proposed hydroelectric development of Potomac River for 1925. Total power, average year, 634,000,000 kilowatt-hours; minimum year, 480,000,000 kilowatt-hours. Power site 1 (Pl. IX).

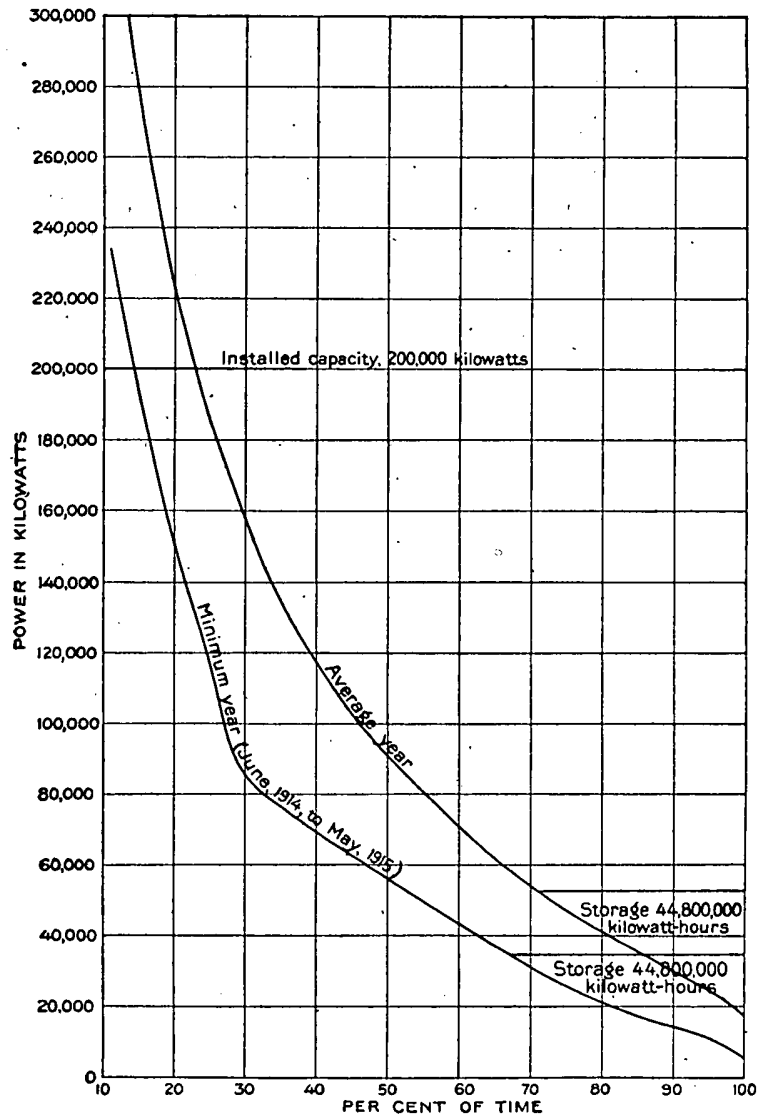

FIGURE $67-$ Estimated power available from proposed hydroelectric de velopment of Potomac River for 1930. Total power, average year, 950,000,000 kalowatt-hours; minimum year, 725,000,000 kilowatt-hours. Power sites 1 and 2 (Pl. IX).

There are sites available for storage reservoirs on Great Cacapon River, a tributary stream, where the capacity is $\mathbf{1 5 . 6}$ billion cubic feet; on North Fork of Shenandoah River near Brocks Gap, where the capacity is 4.8 billion cubic feet; farther downstream on Shenandoah River, where the capacity is 11.2 billion feet; and on the South Branch of the Potomac near its junction 
with the main rivor, where the capacity is 20.2 billion cubic feet. Furthermore, the dam at Great Falls will provide a combined storage reservoir and forebay with a capacity of 13.1 billion cubic feet, making a total storage capacity of 65 billion cubic feet.

The most favorable locations for power development are at Great Falls and Chain Bridge, where, by the construction of two dams, a head of 215 feet may be utilized. (For duration of flow expressed in kilowatts at these power sites see figs. 36 and 37.) The following table gives the essential data on this project, which includes the two plants, with necessary reservoir capacity:

TABLE 85.-Power development on Potomac River.

\begin{tabular}{|c|c|c|c|}
\hline & \multicolumn{2}{|c|}{ Proposed development. } & \multirow{2}{*}{$\begin{array}{l}\text { Possible ultimato } \\
\text { development. }\end{array}$} \\
\hline & 1925 & 1930 & \\
\hline 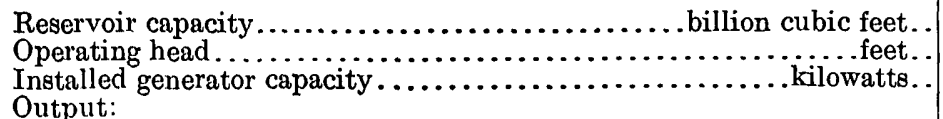 & $\begin{array}{r}13.07 \\
139.5 \\
125,000\end{array}$ & $\begin{array}{r}13.07 \\
205 \\
200,000\end{array}$ & $\begin{array}{r}64.97 \\
205 \\
600,000\end{array}$ \\
\hline 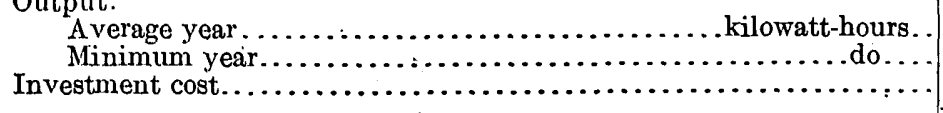 & $\begin{array}{l}634,000,000 \\
480,000,000 \\
\$ 15,000,000\end{array}$ & $\begin{array}{l}950,000,000 \\
725,000,000 \\
\$ 22,000,000\end{array}$ & $\begin{array}{r}1,370,000,000 \\
1,030,000,000 \\
\$ 60,000,000\end{array}$ \\
\hline 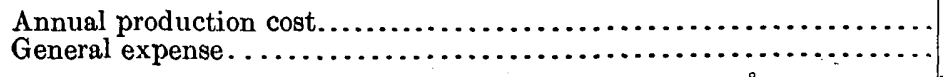 & $\begin{array}{r}\$ 2,165,000 \\
75,000\end{array}$ & $\begin{array}{r}\$ 3,190,000 \\
110,000\end{array}$ & $\begin{array}{r}\$ 8,790,000 \\
310,000\end{array}$ \\
\hline 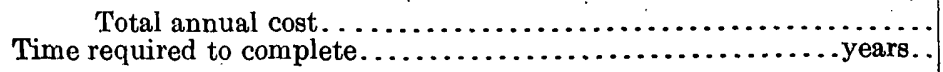 & $\begin{array}{r}2,240,000 \\
2\end{array}$ & $\begin{array}{r}3,300,000 \\
2\end{array}$ & $\begin{array}{r}9,100,000 \\
3\end{array}$ \\
\hline
\end{tabular}

\section{SUSQUEHANNA RIVER.}

The Susquehanna has its headwaters in southern New York and in the highlands of northwestern Pennsylvania and empties into Chesapeake Bay. The drainage area above Harrisburg is 24,100 square miles, and the flow at that point ranges from 2,000 to 700,000 second-feet and averages 19,500 second-feet. The average annual rainfall on the area is 40 inches. In the lower 35 miles of the course of the river there is a fall of 220 feet so distributed that most of it may be utilized for power at four points-Conestoga, Holtwood, Conowingo, and a point about 2 miles above Port Deposit. There is already a power plant at Holtwood, which may be advantageously enlarged when the demand for power justifies it. (For duration of flow expressed in second-feet per square mile at Harrisburg, see fig. 38.)

The Susquehanna has no favorable sites for storage reservoirs and therefore must be developed for "run of river" power. Power development at the Conowingo site is hampered by the fact that the railroad parallels the stream just above high-water level, and thus large expenditure would be required for relocating railroad tracks.

The following table gives the data on development of the river at the four points above mentioned:

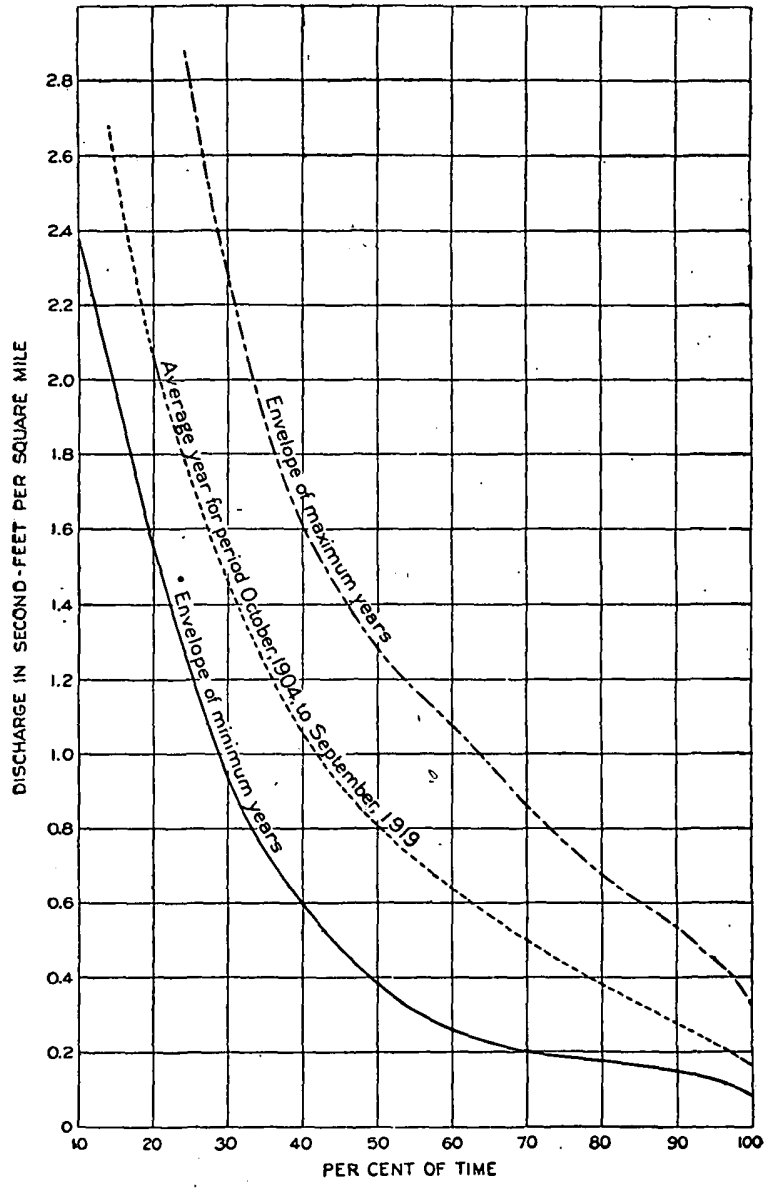

Figure 38.-Curves showing duration of flow of Susquehanna River at Harrisburg, $\mathrm{Pa}$. Drainage area, 24,100 square miles. 
TaBle 86.-Power development on Susquehanna River.

\begin{tabular}{|c|c|c|c|}
\hline & \multicolumn{2}{|c|}{ Proposed developmenț. } & \multirow{2}{*}{$\begin{array}{l}\text { Possible ultimate } \\
\text { development. }\end{array}$} \\
\hline & 1925 & 1930 & \\
\hline $\begin{array}{l}\text { Total operating head, including Holtwood } \ldots \ldots \ldots \ldots \ldots \ldots \ldots \ldots \ldots \ldots \ldots \ldots \text { kilowatts. } \\
\text { Installed new generating capacity } \ldots \ldots \ldots \ldots \ldots \ldots \ldots \ldots \\
\text { Output: }\end{array}$ & 120,000 & 185,000 & 620,000 \\
\hline 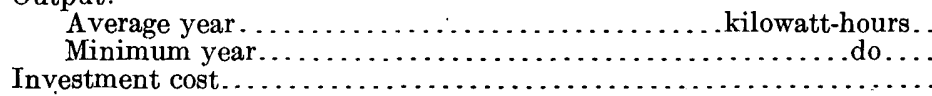 & $\begin{array}{l}800,0 \supset 0,000 \\
580,000,000 \\
\$ 18,000,000\end{array}$ & $\begin{array}{r}1,230,000,000 \\
900,000,000 \\
\$ 28,000,000\end{array}$ & $\begin{array}{l}2,700,000,000 \\
1,850,000,000 \\
\$ 64,000,000\end{array}$ \\
\hline $\begin{array}{l}\text { Annual production cost. . . . . . . . . . . . . } \\
\text { General expense. . . . } \ldots \ldots\end{array}$ & $\begin{array}{r}\$ 2,510,000 \\
90,000 \\
\end{array}$ & $\begin{array}{r}\$ 3,961,000 \\
139,000 \\
\end{array}$ & $\begin{array}{r}\$ 9,484,568 \\
335,432 \\
\end{array}$ \\
\hline $\begin{array}{r}\text { Total annual cost. } \ldots \ldots \ldots \ldots \ldots \ldots \ldots \ldots \ldots \ldots \\
\text { Time required to complete. } \ldots \ldots \ldots \ldots \ldots \ldots \ldots \ldots\end{array}$ & $\begin{array}{r}2,600,000 \\
2\end{array}$ & $\begin{array}{r}4,100,000 \\
2\end{array}$ & $\begin{array}{r}9,820,000 \\
2\end{array}$ \\
\hline
\end{tabular}

DELAWARE RIVER.

The headwaters of Delaware River are in the Catskill Mountains, and it empties into Delaware Bay: The drainage area above Port Jervis is 3,100 square miles, and the natural stream flow at that point ranged from 175 second-feet in September, 1908, to a maximum of 108,000 second-feet in February, 1909. The average annual rainfall on the area is about 40 inches.

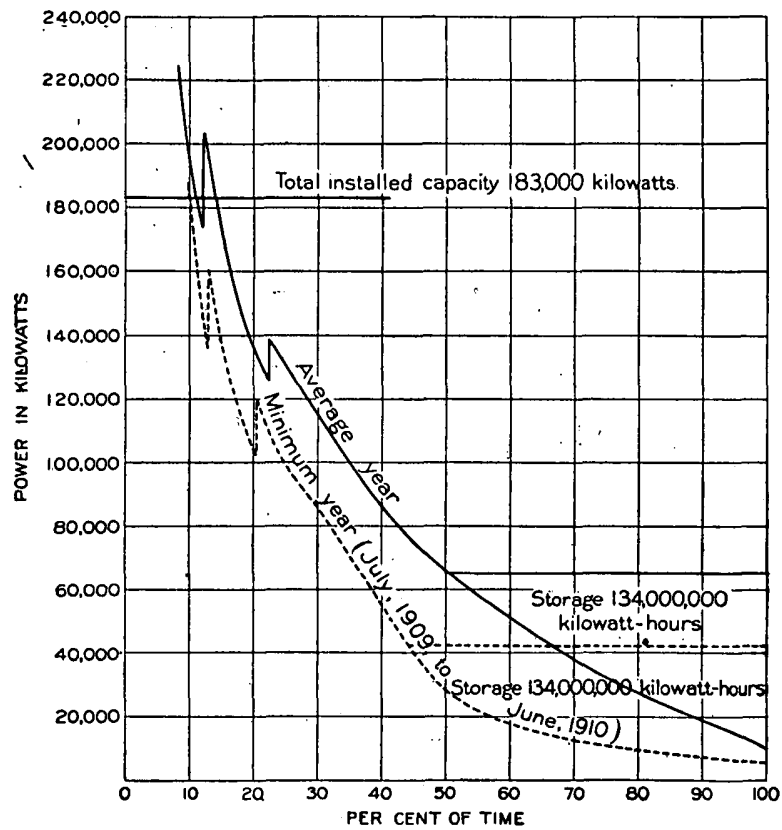

Frgure 39.-Estimated power available from proposed hydroelectric development of Delaware River for 1925. Total power, average year, $850,000,000$ kilowatt-hours; minimum year, 650,000,000 kilowatt-hours. Reservoir A (Pl. IX), 12 billion cubic feet. Power sites 6 (storage 7.5 billion cubic feet), 7, 10, 12, 13, 15, 16 (Pl. IX).

Between Hancock and Belvidere, a distance of 125 miles, there is a fall of 600 feet. The development proposed is to be effected by means of a series of dams, each of which will back up the water to the next site above. It is proposed ultimately to develop 12 sites on the main river, one on Wallenpaupack Creek, one on Shohola Creek, and one on Mongaup River. On the Delaware also power development is hampered by the presence of railroad tracks along the banks of the stream, but in the proposals for development the height of dams has been restricted 
so that only at one site will the grade of the railroad have to be changed. The power plants on the Delaware will be located at the dams, but for those on the three tributary streams tunnels will be required.

Owing to the wide variation in the flow of this river storage reservoirs will be absolutely necessary in its development. There are a number of favorable sites on the east and west branches above Hancock, and also one on each of the tributary streams on which developments are proposed. A capacity of 50 billion cubic feet can be provided in eight reservoirs, which are shown on Plate IX. Practically all the sites have a forebay capacity which will enable the plants to be operated on peak loads at a low capacity factor. (For duration of flow expressed in kilowatts at these power sites see figs. 39 and 40.)

The following table gives the data on development of Delaware River and its tributaries:

TABLE 87.-Power development on Delaware River.

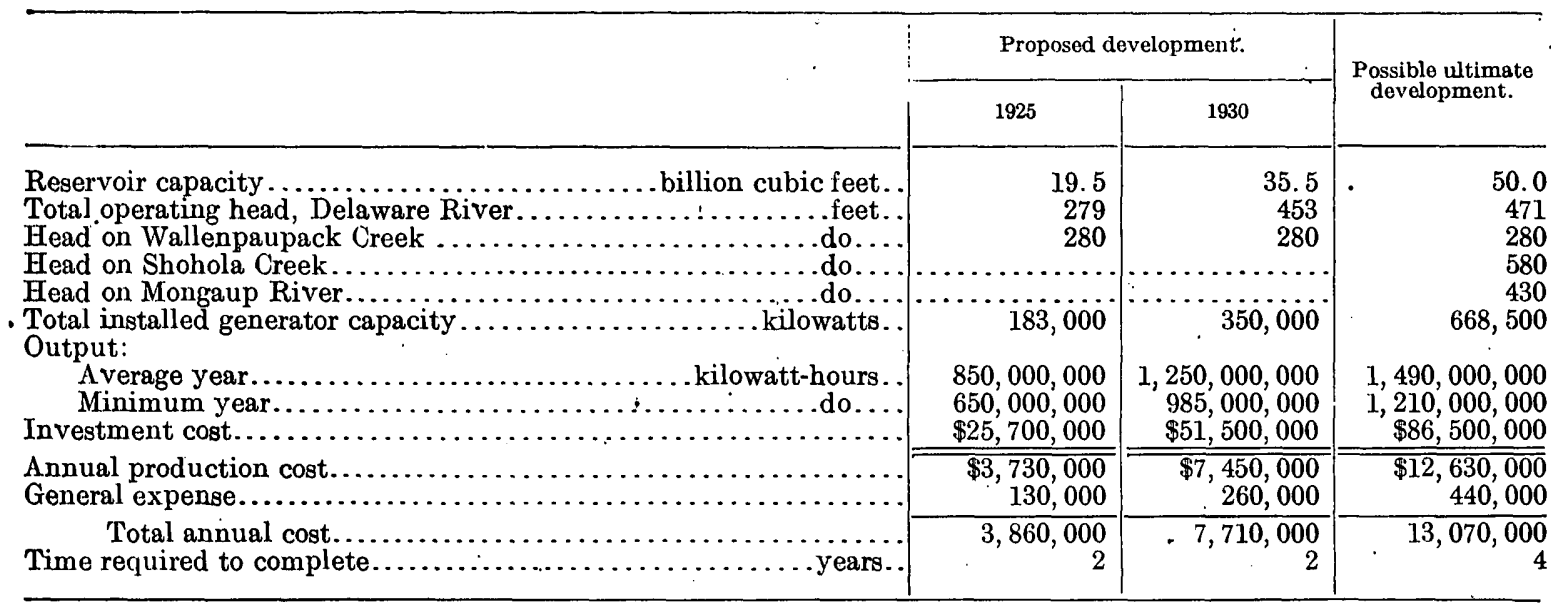

HUDSON RIVER.

Hudson River rises in the Adirondack Mountains and empties into the Atlantic Ocean at New York. The drainage area at Spier Falls is 2,800 square miles and at Troy 8,100 square miles. The stream flow at Spier Falls ranged from 660 second-feet, the mean for the low week in September, 1913, to 84,200 second-feet in March, 1913. The average annual rainfall on the area is about 45 inches. There is a gross fall of 975 feet between Ort Falls and Hadley. A large number of hydroelectric plants have been built on the Hudson, and complete development would involve about 16 new plants and reconstruction or replacement of 14 existing plants. (For duration of flow expressed in kilowatts at these power sites see figs. 41 and 42, p. 198.)

There are four available storage reservoir sites-Lake Piseco, 4.3 billion cubic feet; Sacandaga River at Conklingville, 37 billion cubic feet; Schroon Lake at Alder Brook, 12 billion cubic feet; and Indian River at Bullhead Pond, 10 billion cubic feet; total, 63.3 billion cubic feet.

TABLE. 88.-Power development on Hudson River.

\begin{tabular}{|c|c|c|c|}
\hline & \multicolumn{2}{|c|}{ Proposed development. } & \multirow{2}{*}{$\begin{array}{l}\text { Possible ultimate } \\
\text { development. }\end{array}$} \\
\hline & 1925 & 1930 & \\
\hline 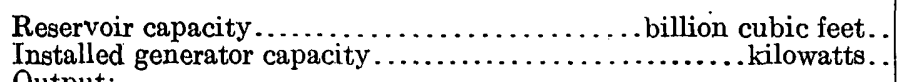 & $\begin{array}{r}a 10 \\
100,000\end{array}$ & $\begin{array}{r}a 10 \\
150,000\end{array}$ & $\begin{array}{r}a 63.3 \\
430,000\end{array}$ \\
\hline 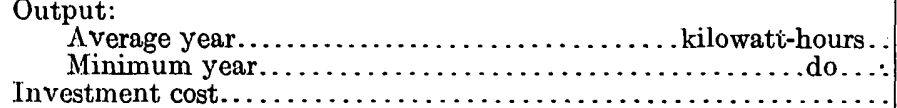 & $\begin{array}{l}380,000,000 \\
330,000,000 \\
\$ 20,124,000\end{array}$ & $\begin{array}{l}900,000,000 \\
800,000,000 \\
\$ 38,350,000\end{array}$ & $\begin{array}{r}1,560,000,000 \\
1,370,000,000 \\
\$ 74,384,000\end{array}$ \\
\hline 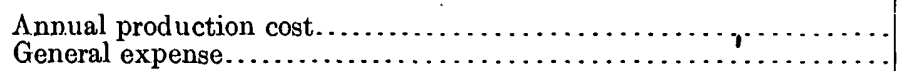 & $\begin{array}{r}\$ 2,815,000 \\
99,000\end{array}$ & $\begin{array}{r}\$ 5,250,000 \\
200,000\end{array}$ & $\begin{array}{r}\$ 10,520,000 \\
370,000\end{array}$ \\
\hline 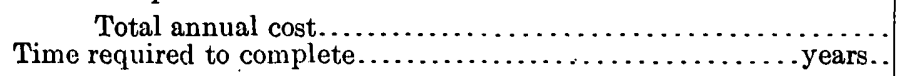 & $2,914,000$ & $\begin{array}{r}5,450,000 \\
2\end{array}$ & $10,890,000$ \\
\hline
\end{tabular}

a Gross capacity including present storage of 4.6 billion cubic feet. 


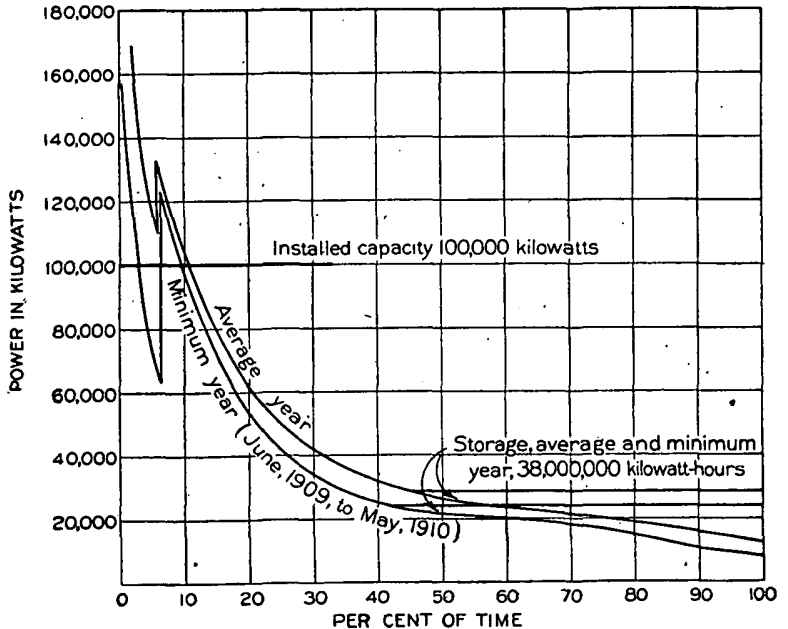

FiguRE 41.-Estimated power available from proposed hydroelectric development of Hudson River for 1925. Total power, average year, $380,000,000$ kilowatt-hours; minimum year, 330,000,000 kilowatt-hours. Reservoir A (Pl. IX), net increased storage 5.1 billion cubic feet. Power sites 7, 8, 9, 10, 11 (Pl. IX):

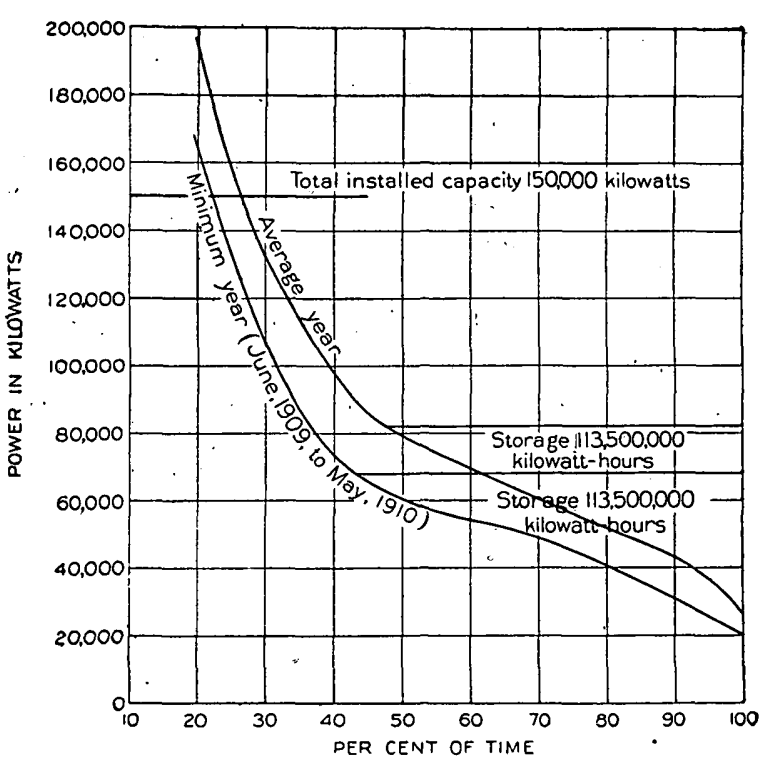

FIGURE 42.-Estimated power available from proposed hydroelectric development of Hudson River for 1930 . Total power, average year, $900,000,000$ kilowatt-hours; minimum year, 800,000,000 kilowatthours.' Reservoir A (P1.IX), net increased storage 5.1 billion cubic feet. Power sites $1,2,3,4,5,6,7,8,9,10,11,14,16,17$ (Pl. IX).

\section{RAQUETTE RIVER.}

Raquette River rises in the Adirondack Mountains and empties into the St. Lawrence near Cornwall. The drainage area at Raymondsville is 1,070 square miles, and the stream flow at Piercefield ranged from 58 second-feet, the mean for the low two-week period in September, 1913, to 6,970 second-feet in April, 1913. The average annual rainfall on the area is 48 inches. In 72 miles of this river between Piercefield and Raymondsville there is a fall of 1,350 feet.

The drainage area of Raquette River contains a number of natural lakes, which may be developed into storage reservoirs by the construction of dams at their outlets. It is estimated that 16 billion cubic feet of water may be stored in this manner.

The following statement gives the data of development for Raquette River at 15 sites, at some of which reconstruction of existing plants will be required.

\section{TABLE 89.-Possible ultimate power development on Raquette River.}

Reservoir caparity . ................................ billion cubic feet.

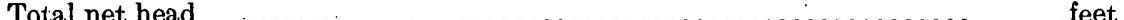

'New installed generator capacity . . . . . . . . . . . . . . . . . . . . . kilowatts..

Net output:

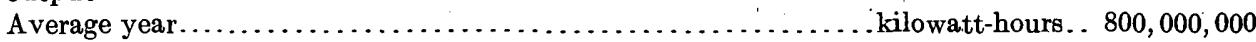

Minimum year................................................ $670,000,000$

Investment cost............................................... $\$ 26,500,000$

Annual production cost.......................................... $\$ \$ \$ 3,745,000$

General expense................................................... 130,000

Total annual cost...................................... $3,875,000$

\section{BLACK R.IVER.}

Black River rises in the Adirondack Mountains, flows westward, and empties into Lake Ontario near Sacketts Harbor. The drainage area above Felt Mills is 1,851 square miles. The stream flow is affected by artificial regulation and has ranged from 400 second-feet, the mean for the low week, to 32,166 second-feet. The average annual rainfall on the area is about 45 inches. On Black River proper the main fall is one of 480 feet between Dexter and Carthage, a distance of 31 miles. Beaver River, a tributary, has a fall of 1,024 feet in 55 miles, and Moose. River, another tributary, has a fall of 1,087 feet in 45 miles. 
A large number of small lakes in the Adirondack Mountains form natural storage reservoirs, and it is proposed to improve these at six sites on Black River and its tributaries to provide an ultimate storage capacity of 21.5 billion cubic feet.

There are 33 existing power plants in this drainage basin, most of which are used for making paper pulp. There are 11 undeveloped sites on Black River and its tributaries.

The following statement gives the data on these developments and includes estimates for the reconstruction of such existing plants as may be justified and for increasing the reservoir capacity 20 billion cubic feet.

TABLE 90.-Possible ultimate power development on Black River.

Reservoir capacity (including 1.5 billion cubic feet of existing storage),

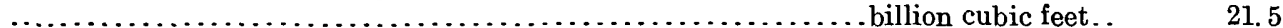

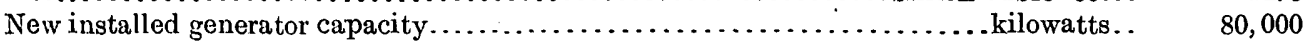
Output:

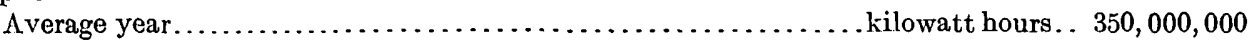

Minimum year ........................................... 315,000,000

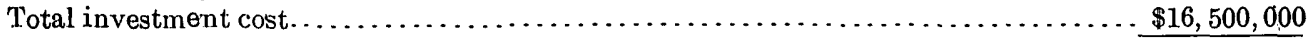

Annual production cost. . . . . . . . . . . . . . . . . . . . . . . . . . .

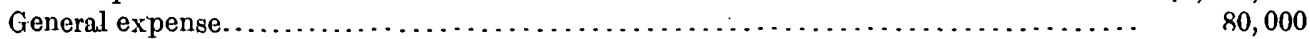

Total annual cost. ...................................... $2,370,000$

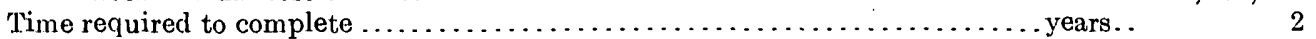

CONNECTICUT RIVER.

- Connecticut River rises in the Province of Quebec, Canada, and flows into Long Island Sound about 60 miles east of New Haven. The drainage area is 8,000 square miles, and the stream

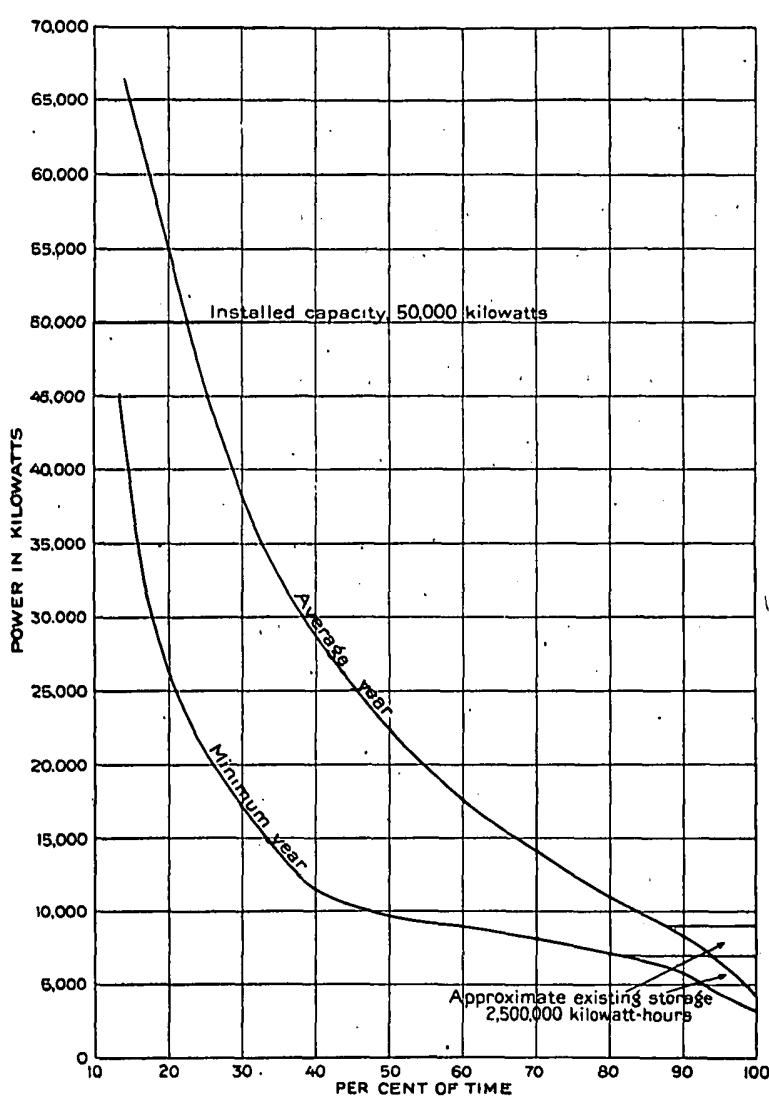

FiguRE 43.-Estimated power available from proposed hydroelectric development of Connecticut River for 1925. Total power, exclusivo of storago, average year, 230,000,000 kilowatt-hours; minimum year, $150,000,000$ kilowatt-hours. Power site 5 (Pl. IX). flow at Sunderland, Mass., ranged from 1,330 second-feet, the mean for the low week in September, 1894, to 110,000 second-feet in April, 1895. Between Fifteen Mile Falls, N. H., and

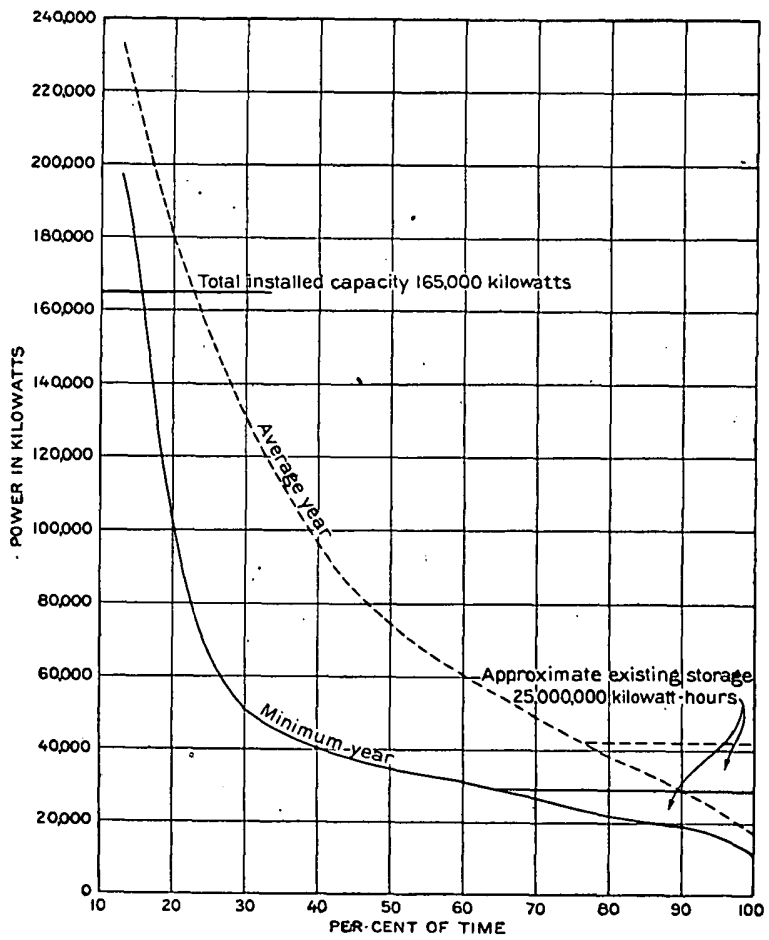

FIGURE 44.-Estimated power available from proposed hydroelectric development of Connecticut River for 1930. Tota] power, exclusive of storage, average year, 760,000,000 kilowatt-hours; minimum year, $510,000,000$ kilowatt-hours. Power sites 1, 3, 4, 5 (Pl. IX)

Windsor Locks, Conn., there is an aggregate usable fall of 428 feet, including redevelopment of the Bellows Falls site but excluding other developed sites. This fall is divided as follows: Fifteen 
Mile Falls, 250 feet; Piermont, 50 feet; Quechee.Falls, 45 feet; Bellows Falls, 50 feet; Windsor Locks, 33 feet. (For duration of flow expressed in kilowatts at these power sites see figs. 43-45.)

A small amount of storage has been developed and is now used for logging operations and for the development of power. The conditions are favorable for the development of additional storage, which will not only benefit new plants but greatly improve operating conditions at existing plants.

The following table gives data on potential developments at five power sites, which include redevelopment of the Bellows Falls site. The statement does not include additional reservoir capacity:

TABLE 91.-Power development on Connecticut River.

\begin{tabular}{|c|c|c|c|}
\hline \multirow{2}{*}{ - } & \multicolumn{2}{|c|}{ Proposed development. } & \multirow{2}{*}{$\begin{array}{l}\text { Possible ultimate } \\
\text { development } \\
\text { without storage. }\end{array}$} \\
\hline & 1925 & 1930 & \\
\hline 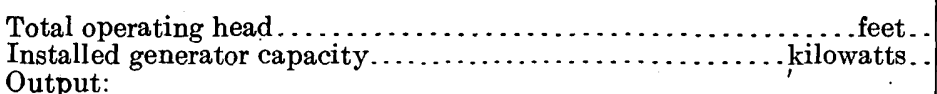 & $\begin{array}{r}33 \\
50,000\end{array}$ & $\begin{array}{r}428 \\
165,000\end{array}$ & $\begin{array}{r}428 \\
165,000\end{array}$ \\
\hline 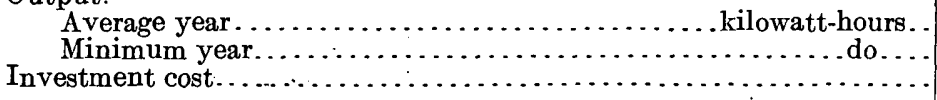 & $\begin{array}{r}230,000,000 \\
150,000,000 \\
\$ 9,000,000\end{array}$ & $\begin{array}{l}760,000,000 \\
510,000,000 \\
\$ 29,000,000\end{array}$ & $\begin{array}{r}760,000,000 \\
510,000,000 \\
\cdot \quad \$ 29,000,000\end{array}$ \\
\hline $\begin{array}{l}\text { Annual production cost....... } \\
\text { General expense............ }\end{array}$ & $\begin{array}{r}\$ 1,256,000 \\
44,000\end{array}$ & $\begin{array}{r}\$ 4,130,000 \\
140,000\end{array}$ & $\begin{aligned} \quad & \$ 4,130,000 \\
\therefore \quad & 140,000\end{aligned}$ \\
\hline Total annual cost. & $1,300,000$ & $4,270,000$ & $4,270,000$ \\
\hline
\end{tabular}

ST. LAWRENCE RIVER.

The portion of St. Lawrence River here considered lies between Lake Ontario and a point near Cornwall, where the international boundary diverges from the river in an easterly direc-

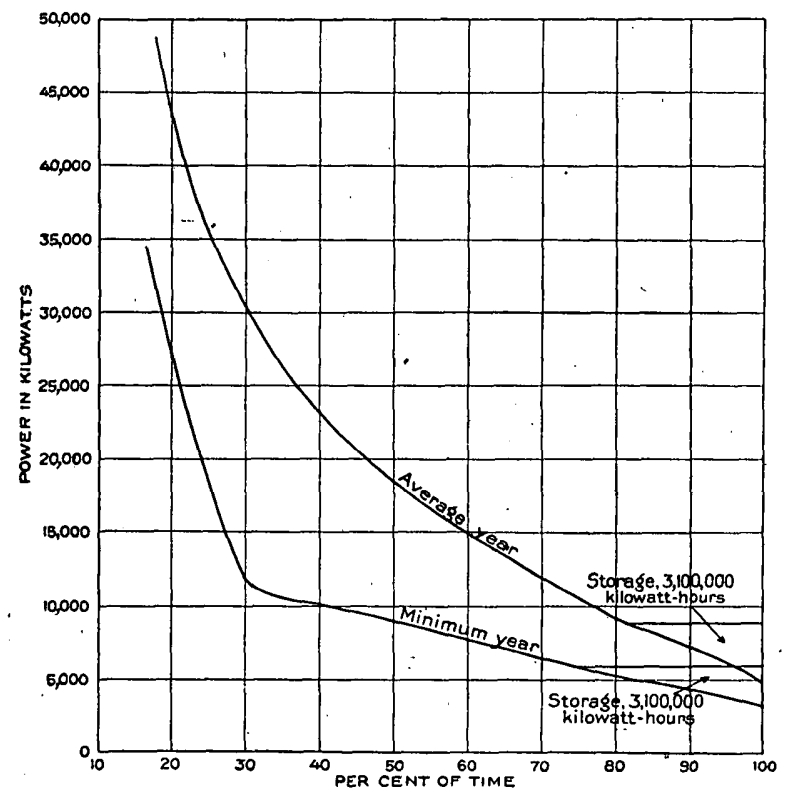

Figure 45.-Curves showing duration of power on Connecticut River at Bellows Falls, vt. tion. An investigation is now being made by engineers of the United States and Canadian governments looking to the development of the river in the vicinity of Long Sault and Barnhardts Island. The fall available is about 80 feet, and it is estimated that generating capacity of about $1,200,000$ kilowatts can be installed to yield an annual output of more than $10,000,000,000$ kilowatt-hours. It is assumed that the ownership of one-half of this output will be allocated to the United States Government. The outstanding feature of this development is that the storage capacity of the Great Lakes, which drain an area of 278,700 square miles, furnishes almost complete regulation of the river flow. The lowest recorded average flow for a month is 186,000 second-feet, which is about 80 per cent of the average continuous flow.

No estimate of the cost of development will be given here, as such an estimate is now being made by the engineers of the two governments. The cost, however, should be lower per unit than that of any of the developments on which estimates are given in this report, on account of the size of the development and because a large portion of the expenditure will be made for the improvement of navigation. 
NIAGARA RIVER.

Niagara River is about $30^{\circ}$ miles in length and drains Lake Erie into Lake Ontario. The difference in elevation between these two lakes is about 330 feet. The fall between Lake Erie and the river level at the beginning of the rapids above the main falls is 9 feet, between this point and the middle'pool below the falls 220 feet, and between the middle pool and Lake Ontario 101 feet. The characteristics of stream flow are much the same as those of the St. Lawrence, but the flow is subject to daily variations due to wind.

The water that can be diverted at Niagara Falls for the generation of power is now limited by international treaty to 20,000 second-feet on the American side of the river and to 36,000 second-feet on the Canadian side. Practically the whole of this permitted diversion has been made, and no further developments are possible so long as the present treaty is in force. It may be abrogated on one year's notice from either party.

The question of additional diversion of water from the river for power is somewhat complicated with the navigation of Lake Erie, as any large increase in diversion will tend to lower the lake level. By the construction of remedial works at the outlet of Lake Erie, however, it will be practicable to increase the amount of water diverted for power without impairing the navigability of the lake. The scenic beauty of the falls may be preserved by constructing works that will distribute the flow more uniformly over the crest. This power would- probably be cheaper to develop than St. Lawrence power and would be equally available for use in the superpower zone.

\section{THE RIVERS OF MAINE.}

In addition to the resources described above there is considerable undeveloped power in the State of Maine which is within transmission distance of the northeastern part of the superpower zone. As hydroelectric energy. generated in Maine can not, under the present laws of that State, be transmitted outside its boundaries, these potential developments have not been analyzed in detail.

The following figures taken from the report of a special water-power investigation by the Public Utilities Commission of Maine for 1918 give an idea of the magnitude of these resources:

TABLE 92.-Water-power resources of Maine.

[Horsepower available for 95 per cent of an average year.]

\begin{tabular}{|c|c|c|c|c|c|c|}
\hline \multirow{2}{*}{ River. } & \multicolumn{3}{|c|}{ Present conditions. } & \multicolumn{3}{|c|}{ Conditions after regulation. } \\
\hline & Developed. & $\begin{array}{l}\text { Unde- } \\
\text { veloped. }\end{array}$ & Total. & Developed. & $\begin{array}{c}\text { Unde-- } \\
\text { veloped. }\end{array}$ & Total. \\
\hline 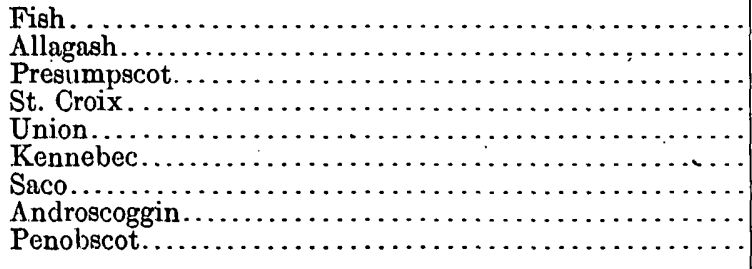 & $\begin{array}{r}5,400 \\
13,000 \\
1,600 \\
26,000 \\
11,000 \\
77,800 \\
92,000\end{array}$ & $\begin{array}{r}3,600 \\
3,600 \\
3, \ldots 00 \\
4,00 \\
50,000 \\
7,000 \\
28,000 \\
47,000\end{array}$ & $\begin{array}{r}3,600 \\
3,600 \\
5,400 \\
17,000 \\
1,600 \\
76,000 \\
18,000 \\
1.05,800 \\
139,000\end{array}$ & $\begin{array}{r}10,000 \\
14,000 \\
5,000 \\
56,000 \\
24,000 \\
85,000 \\
110,000\end{array}$ & $\begin{array}{r}6,400 \\
8,600 \\
\cdots, 000 \\
4,00 \\
105,000 \\
15,000 \\
31,000 \\
67,000\end{array}$ & $\begin{array}{r}6,400 \\
8,600 \\
10,000 \\
18,000 \\
5,000 \\
161,000 \\
39,000 \\
115,000 \\
177,000\end{array}$ \\
\hline : & 226,000 & 143,200 & 370,000 & 310,000 & 237,000 & 547,000 \\
\hline
\end{tabular}

CAPACITY AND OUTPUT OF EXISTING HYDROELECTRIC PLANTS.

The following table shows the location of hydroelectric generating capacity in operation in the superpower zone and its output for 1919. The table gives an estimate of the capacity that can be furnished for the annual peak under low-water conditions and the annual output for the average and minumum year. 
TABLE 93.-Hydroelectric plants in superpower zone.

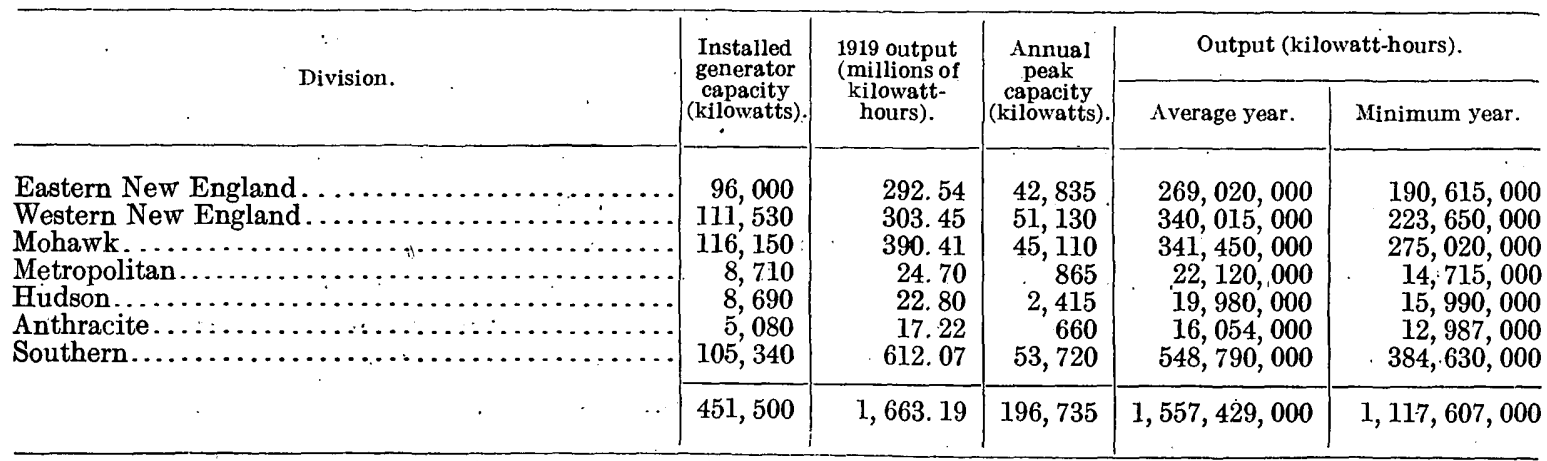

\section{UNIT AND TOTAL INVESTMENT COST.}

The unit investment cost for hydroelectric generating equipment is given in figure 46 for operating heads of $20,40,80,120$, and 400 feet and for generating units ranging in size from

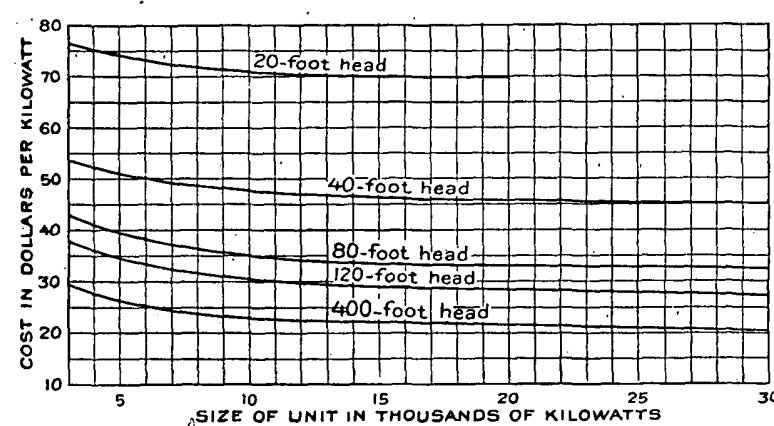

Fraure 46.-Unit cost for complete hỷdroelectric equipment installed, for different operating heads in midyear of 1919. Includes turbines, generators, low-tension switch gear and wiring, interest during construction, superintendence, engineering, and contingencies. $A$ development charge of 8 per cent against the first unit should be added. 5,000 to 30,000 kilowatts. These unit costs are based on prices in the midyear of 1919 and include turbines, generators, low-tension switch gear, wiring erected, interest during construction, superintendence, engineering, and contingent expenses. They are applicable to all units except those first installed, for which 8 per cent must be added to cover development charges. The unit costs were compiled from information furnished by the principal manufacturing companies in this country.

In estimating the reproduction cost of the existing hydroelectric generating plants as shown below consideration was given to the size of the plant, the operating head, and the other characteristics of individual plants, and the estimates were checked by data furnished by the owners.

Eastern New England.

Western New England...................16,713,000

Metropolitan.
$16,713,000$
$24,442,000$ $2,550,000$
Hudson $\ldots \ldots \ldots \ldots \ldots \ldots \ldots \ldots \ldots \ldots \ldots \ldots . \$ 1,693,000$

Anthracite....................... $1,265,000$

Southern.......................... $23,963,000$

$87,127,000$ 


\section{ANNUAL OPERATING COST PER UNIT.}

In order to determine annual unit operating costs, comprehensive records of 58 hydroelectric plants were selected for analysis. Figure 47 shows the cost per kilowatt-year of total generator capacity plotted against the size of the unit. Figure 48 shows the cost per kilowattyear of total generator capacity plotted against the capacity of the plant. The use of these two curves in conjunction gives operating cost for power plants employing units of different sizes.

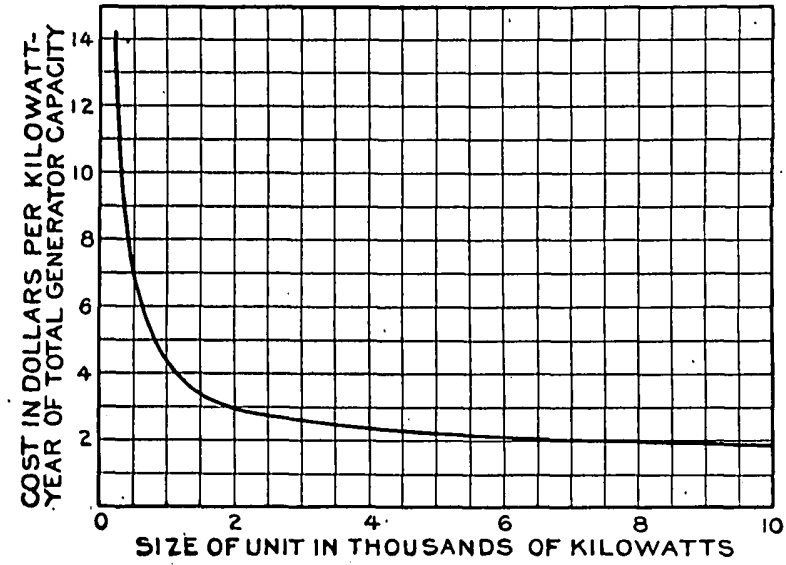

Fioure 47.-Unit operating cost of 58 selected hydroelectric plants in the superpowor zone, 1919, according to size of unit.

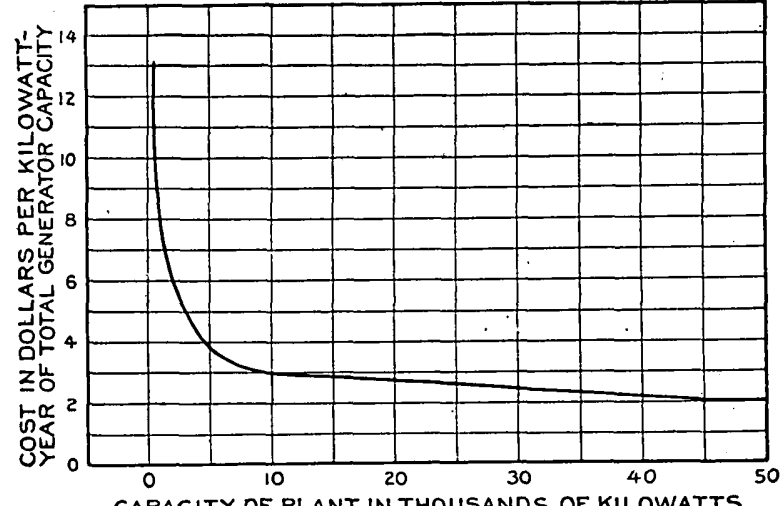

CAPACITY OF PLANT IN THOUSANDS OF KILOWATTS

FIGURE 48.-Unit operating cost of 58 selected hydroalectric plants in the superpower zone, 1919, according to capacity of plant. 


\title{
APPENDIX $\mathrm{H}$. THE SUPERPOWER TRANSMISSION SYSTEM.
}

\author{
By L. E. ImLAY. \\ EXISTING TRANSMISSION SYSTEMS.
}

The mileage of the transmission lines above 30,000 volts in the superpower zone in 1919 amounted to 1,200 miles, 37 at 110,000 volts, 813 at 66,000 volts, 36 at 44,000 volts, and 314 at 33,000 volts. Of these 1,200 miles New England has 778, indicating that considerable interconnection has already been established in that region. The high-voltage lines in other parts of the superpower zone are used mainly to transmit energy from sources where it is produced cheaply to points where it is used.' The superpower system will multiply these sources of cheap production and will use the existing transmission lines as vehicles of distribution rather than of transmission. Accordingly, the present 33,000 to 66,000 volt transmission systems will be expanded for the distribution of the additional power made availablerby the superpower system.

\section{CHARACTERISTICS OF THE SUPERPOWER TRANSMISSION SYYTEM.}

The proposed transmission lines of the superpower system (see Pls. II, III, p. 14) are of two general classes-interconnecting lines between load centers, operating at 110,000 volts, and high-tension lines of large capacity, operating at 220,000 volts.

\section{INTERCONNECTING IINES.}

The interconnecting lines are to be used (1) to transfer energy from one load center to another in order to take care of small increments of growth in demand until additions to local generating 'plants are justified; (2) to provide means by which reserve capacity at centers of distribution in one part of the system may be made available for use in adjacent centers; (3) to equalize the load between the generating plants of the system or to distribute it among them as economy or policy may direct; (4) to transmit energy from power plants that are not at load centers and that are not provided with separate high-tension lines of transmission.

Any scheme for distributing load between generating centers over tie lines presupposes the automatic operation of governors on prime movers to maintain proper speed under all variations of load up to the full capacity of the generating units. An ideal interconnecting system would function automatically, for when an overload comes on any part of the system the prime mover of that part tends to slow down and lower the frequency, and its slowing down causes the generating units' of the part affected to become somewhat out of phase with those of the rest of the system and produces a flow of energy from the lightly loaded to the more heavily loaded part of the system. Owing to physical and economic limitations, however, lines having considerable resistance and reactance can be automatically controlled only within rather narrow limits of load transfer between two load centers several miles apart, so that automatic regulation of voltage is not possible, except through a comparatively small range, without the use of special regulating equipment, for it presupposes a very low reactance circuit with relatively low resistance.

Under ordinary conditions energy may be transferred through a tie line so as to maintain the same bus voltage at all distributing points in a system by varying either the voltage or the impedance volts of the line. The voltage. may be varied by shifting to different taps on the transformers, by the use of synchronous boosters, or by the use of some form of regulator. The induction regulator is probably the most satisfactory, and it should be manipulated by hand, 
as no device yet contrived can automatically distinguish between a variation due to a short circuit and one due to a change in demand. The impedance volts may be varied by the use of synchronous condensers at the receiving station.

In varying either the voltage or the impedance volts of the tie lines the limitations of synchronizing power and of corona effect should be considered. If a regulator is used a conductor of a size that will insure economy must be selected, and if synchronous condensers are used a design should be selected that will insure regulation rather than prevent loss of power.

If the tie lines are not long and if they are to carry relatively little energy the load can generally be carried by providing lines having low resistance. If the governors and the voltage regulators function properly they will automatically tend to distribute the energy as demanded if the fields in the generators in the station receiving energy are strengthened. If the demand is so great that the capacity to which the generator fields can be strengthened is exhausted before normal voltage is reached the deficiency must be supplied by providing synchronous-condenser capacity.

Consideration has been given to the effect of short circuits that may occur on the network of lines of the superpower system. Obviously, to insure the maximum economy an ideal system should be interconnected and operated as a unit. Studies of the possible concentration of energy resulting from short circuits at critical points in an ideal superpower system indicate, as was expected, that the short-circuit currents would exceed the rupturing capacity of any circuit breaker now available. In planning the interconnecting system contemplated in this report the limitations of the circuit breakers now available and the operating conditions to be provided for have been fully considered. If a short circuit occurs the system will be automatically separated at selected points into several systems that are complete in themselves, in order to limit the energy interrupted to amounts that can be readily handled. The feeders affected by the short circuit are thus automatically disconnected from the system, with minimum disturbance to the service. The rapid improvement in circuit breakers within the last few years leads us to expect that future improvement may produce apparatus that will permit much greater concentration of power, so that by the time the superpower system has grown to a size requiring circuit breakers of larger capacity they will probably be obtainable.

No insuperable difficulty is expected in obtaining rights of way for tie lines in the outlying districts of the superpower zone, where overhead circuits will be used, but rights of way in the congested parts of the large cities, where underground lines operated at comparatively low voltage are necessary, may not be obtained so easily. 'In New York City, for example, the generating stations are not now sufficiently provided with tie lines to insure the most economical operation on account of the prohibitive cost of conduits or conduit space for high-tension cables. Tie-line connection between New York and the industrial district of New Jersey is still more difficult to obtain and is even more necessary. Particular attention is called to the necessity of providing ample conduit space for tie lines in the new vehicular tunnel under the Hudson between New York and Jersey City.

\section{TRANSMISSION LINES.}

The principal elements to be considered in designing transmission lines are length of line, amount of energy to be transmitted, frequency, voltage, corona, resistance, reactance, conductance, susceptance, value of energy lost, cost of money, cost of operation, and value of energy delivered at the receiving end, of the line. Kelvin's law is applicable here if the conductors are large enough to escape corrona and if the investment in conductors includes the cost of other apparatus, which varies with the sizes of the conductors considered.

Length of line is determined by location of power plant with respect to market for power.

The amount of energy transmitted on a line may be limited either by the size of the generating plant or by the extent of the market. If a power plant is capable of an increase in capacity, the transmission line should have a margin of capacity to cover the increase or should be susceptible of additions at minimum cost. 
The maximum practicable potential used for transmission to-day is 220,000 volts, and in the study of transmission to and within the superpower zone this and lower potentials are used.

Corona fixes one of the limits to economical long-distance transmission at very high voltages. There is a critical disruptive voltage for each size of cable, depending on spacing and arrangement of conductors, elevation above sea level, and meteorologic conditions. Rain, fog, and snow tend to lower the critical voltage. Up to 2,000 feet above sea level the minimum diameter of conductors for operation at 110,000 volts is about 0.45 inch and the minimum diameter of conductor for operation at 220,000 volts is about 0.95 inch.

The fundamental characteristics that determine the losses and the performance of a line are resistance, reactance, conductance, and susceptance. Resistance depends upon the size and length of the conductor and the material of which it is composed. Reactance varies with the frequency employed and with the length, size, arrangement, and spacing of the conductors. Conductance varies with the effect of corona and with insulation of line. Susceptance determines the charging current of the line and depends on the spacing, diameter, and arrangement of conductors, the frequency employed, and the length of circuit.

For lines of moderate length, say up to 350 miles, energy can be transmitted at 60 cycles, the prevailing frequency in the superpower zone. For longer lines it may be desirable to transmit at a lower frequency on account of the limitations' of reactance and susceptance, but energy for use in the superpower zone will probably never be transmitted farther than 350 miles.

Kelvin's law is applicable to the design of high-tension transmission lines if account is taken of all the factors, which vary with variations in the conductors considered. The effect of these factors is subject to constant change, and the adoption of a particular design can be justified only if the cost of all the elements that may affect it are known. The cost of money, the cost of material, and the value of energy at the receiving end of the line are the principal elements involved.

The structural features of designs of existing transmission lines have been carefully worked out, and the designs for the transmission lines proposed involve no new problems. It may be economical, however, to use a type of tower construction for long lines that is different from the type used for comparatively short lines that transmit the same amounts of energy. For conductors of moderate size to be used under the usual limiting conditions the most economical tower spacing will be as follows: For hard-drawn copper, about 800 feet; for steel-reinforced copper, about 1,000 feet; for steel-reinforced aluminum cable, 1,200 to 1,500 feet.

The principal elements to be considered in spacing towers economically are (1) the character of the cable (weight, tensile strength, elastic limit, and temperature coefficient of linear expansion); (2) the clearance from the ground; (3) the assumed loading by ice and wind pressure; and (4) the cost of towers, foundations, insulators, and labor.

All 110,000 and 220,000 volt systems should be star connected with grounded neutral. The 110,000-volt lines may be provided with overhead ground wires where A-frame construction is used, but the 220,000-volt lines should not be provided with either ground wires or lightning arresters, for they will probably cause more trouble than they will prevent.

The entire superpower zone lies within an area that is occasionally subject to severe sleet storms, and authentic records show that sleet $1 \frac{1}{2}$ inches in radial thickness has been formed on line conductors. The cost of building transmission lines to withstand so heavy an accumulation of sleet would be prohibitive. The remedy is to keep the lines so warm during a sleet storm that ice will not collect on them, either by transmitting sufficient energy over them or by shortcircuiting them and sending enough current through them at low voltage.

\section{RIGHTS OF WAY.}

The importance of adequate rights of way for transmission lines can hardly be overestimated. Many of the troubles on existing long-distance lines are due to crooked lines, which introduce hazardous construction. The service rendered to the public over many power lines is greater than the service rendered by some railroads, and these public lines should have rights of way commensurate with the value of their service. It is therefore an imperative 
public necessity that companies operating transmission systems should be granted rights of way through the exercise of the right of eminent domain. A 220,000-volt transmission system consisting of two tower lines, each containing two circuits, should have a right of way. 240 feet wide and as straight as it can be made.

Transmission and tie lines should be so located as to avoid interference with service over" communication circuits. In anticipation of the necessity of cooperation to avoid such interference conference was had with the engineers of the American Telephone \& Telegraph Co., who have furnished the superpower survey a complete set of maps, consisting of 331 topographic sheets, fully indexed, showing the location of the toll lines of that company and its subsidiaries in the superpower zone. The preparation of these maps involved an enormous amount of work by the telephone company, and the set is too large for incorporation in this report, but it may be examined at the office of the United States Geological Survey at Washington.

\section{PERFORMANCE OF TRANSMISSION LINES.}

The performance of a transmission line may be determined graphically by the use of vector diagrams indicating currents and voltages at the ends of the circuit and applying the auxiliary constants of the circuit which account for the distribution effect. Figures 49-55 show the performance of a proposed transmission line from St. Lawrence River to a point in central New England. This line will be 225 miles long, will operate at 220,000 volts and 60 cycles, and has been designed to transmit 300,000 kilowatts and supply a distributing system that operates at a power factor of 85 per cent. The transmission system will consist of two tower lines, each supporting two circuits. The conductors are steel-reinforced aluminum cables measuring in cross section 605,000 circular mils and having a diameter of 0.953 inch. Each circuit will transmit 75,000 kilowatts under normal conditions and 150,000 kilowatts in an emergency. Additional data are given on the diagrams.

The diagrams show fully the graphic method of solution and also the mathematical solution. These solutions take into account the leakage and the local impedance of the raising and lowering transformers as well as the effect of these in reducing the effective synchronous-condenser capacity required under load. The mathematical solution given involves the values of the auxiliary constants determined by the employment of hyperbolic functions and is rigorously correct.

Figure 49 shows the conditions existing at no load, with normal load connections and with line and lowering transformers energized. With 220,000 volts at the receiving end of the line, measured at the low-voltage side of lowering transformers, a synchronous-reactor capacity of about 30,000 kilovolt-amperes will be required to hold the voltage at the sending end at 230,000 volts. A synchronous-reactor capacity of about 20,000 kilovolt-amperes will be required to maintain 220,000 volts at both the receiving and the sending ends of the line.

Figure 50 shows the performance of the system at a normal load of 75,000 kilowatts per circuit and 220,000 volts at the receiving end of the line. A synchronous-condenser capacity of about 42,000 kilovolt-amperes will be required to hold the receiving voltage at 220,000 volts with a load having a power factor of 85 per cent. If the voltage at the sending line is held at 220,000 volts the synchronous-condenser capacity required will be about 53,000 kilovoltamperes.

Figure 51 shows the performance of the system with an emergency load of 150,000 kilowatts on each circuit, a condition that may exist for short intervals while one tower line is out of service for repair. Under these conditions a condenser capacity of 173,000 kilovolt-amperes will be required to hold voltage constant at 220,000 volts at both ends of the line.

Figure 52 shows the amount of energy that may, be delivered over this line under various conditions of sending-end voltage to an 85 per cent power-factor load, with 220,000 volts at the receiving end.

Figure 53 shows the synchronous-condenser capacity required for various loads at the three sending-end voltages that are most likely to be used.

$63361^{\circ}-21-14$ 


\section{A SUPERPOWER SYSTEM FOR THE REGION BETWEEN BOSTON AND WASHINGTON.}

Figure 54 shows the voltage on each side of the raising transformers corresponding to condenser loads of various capacities in parallel with a load of 75,000 kilowatts at a power factor of 85 per cent. The vertical distance between the two voltage lines is the voltage drop or voltage rise through the raising transformers. For condenser loads up to 15,000 kilovolt-

\section{KV PROBLEM-ZER'́ LOAD}

(THIS CORRESPONDS TO NORMAL LOAD CONNEOTIONS)

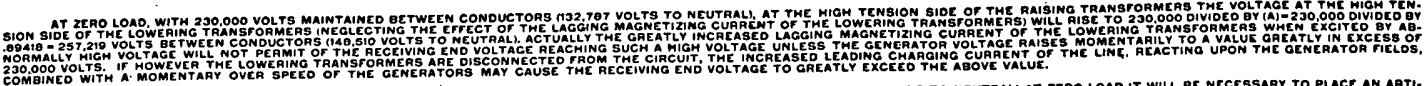

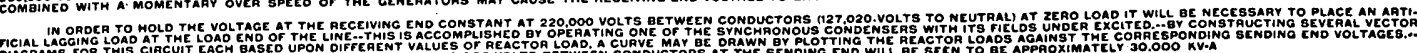

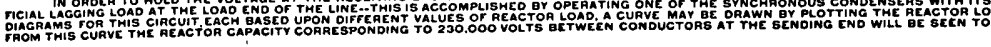

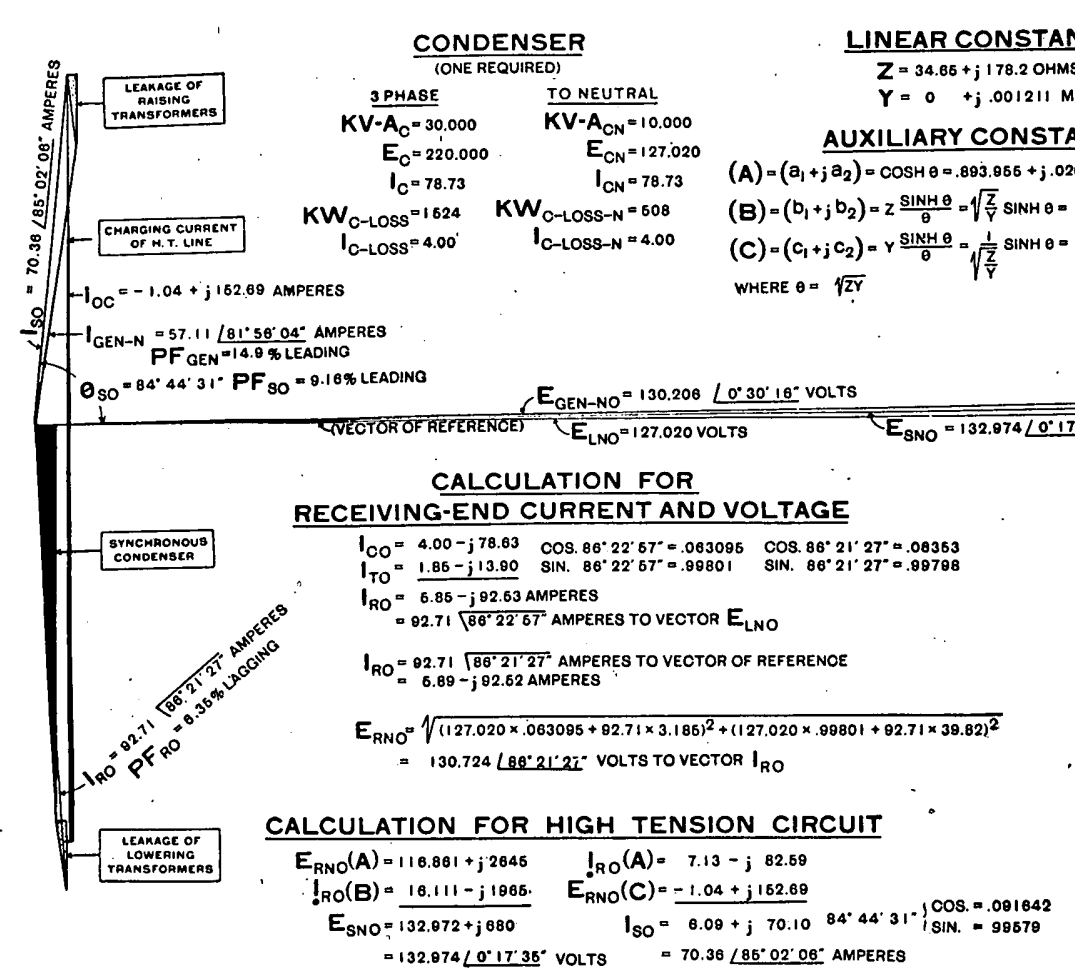

CALCULATION FOR GENERATOR VOLTAGE AND CURRENT

$\cos .81^{\circ} 25^{\circ} 48^{\circ} \cdot ., 14902$

$=130.200 \angle 84^{\circ} 31^{\circ} 50^{\circ}$ VOLTS TO VECTOR $I_{\text {SO }}$

$=.130 .206 L^{\circ} 30^{\circ} 10^{\circ}$ VOLTS $\quad 84^{\circ} 31^{\prime} 60^{\circ}\left\{\begin{array}{l}\text { COS. }=.095315 \\ \text { SIN. }=.98545\end{array}\right.$

$70.36(.095315+j .89545)$

$=6.71+j 70.04$
$=1.80-j 13.57$ (LEAKAGE OF RAISING TRANSFORMERS

$I_{\text {OEN }-N}=8.51+j 56.47$

$=67.11 \angle 81 \cdot 25^{\circ} 48^{*}$ AMPERES TO VECTOR $\mathrm{E}_{\text {GEN-NO }}$

$=67.11 \angle 1^{\circ} 56^{\circ} 04^{-}$AMPERES

KV-A SO $_{S O}=132.974 \times 70.38 \times 3=28.068$ PER 3 PHASE CIRCUN

$K V-A_{\text {GEN-O }}=130.208 \times 57.11 \times 3=22.308$ PER 3 PHASE GIRCUIT

KV-A $A_{C O}=132.974(.001168 \times 148,510) \times 3=68.107$ PER 3 PHASE CIROUIT

FIGURE 49.-Vector diagram for 225-mile transmission line with no load.

amperes there is a drop in voltage through the raising transformers. For condenser loads above 15,000 kilovolt-amperes there is a rise in voltage through the raising transformers.

Figure 55 is a general diagram showing a possible arrangement of generating, transforming, and transmitting equipment for the St. Lawrence-New England project. 


\section{KV PROBLEM-NORMAL LOAD}

\section{(COMPLETE SOLUTION)}

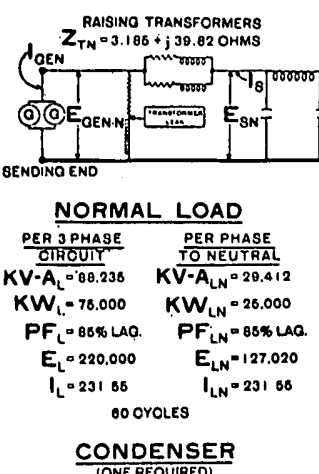

LLOW TENSION VALUES REFERRED TO THE MIGH TENSION CIRCUIT

HIGH TENSION LINE $Z$ ' $34.66+j 178.2$ OHMS

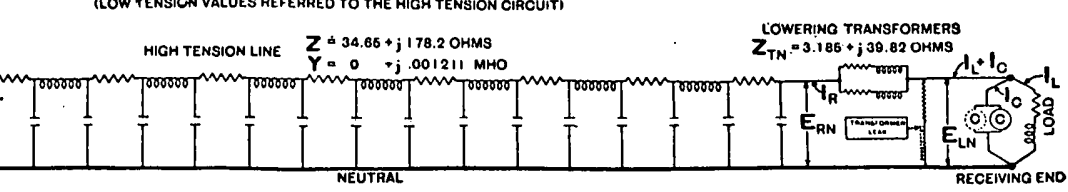

$$
\begin{aligned}
& \text { NORMAL LOAD } \\
& \text { TONEUTAA } \\
& K W_{L}=78.000 \quad K W_{L N}=25.000
\end{aligned}
$$

$\frac{\text { 3PHASE }}{K V \cdot A_{0}=45.000} \frac{\text { TO NEUTRAL }}{K V-A_{C N}=16.000}$

$E_{0}=220.000 \quad E_{C N}=127.020$

$I_{C}=118.09 \quad I_{C N}=118.00$

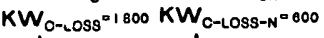

$I_{\text {C-LOS8 }}=4.78 \quad \mathrm{I}_{\mathrm{C}-\text { LOSS-N }}=4.72$

NOTE - THE CONDENSER INDICATED.BY BROKEN LINE OIRCLE SEAVES AS.A SPARE DURING NORMAL
OPERATION BUT IS REQUIREO FOR THE EMERGENCY

\section{LINEAR CONSTANTS \\ $Z=34.65+j 178.2$ OMMS \\ $Y=0+j .001211$ MHO}

\section{AUXILIARY CONSTANTS}

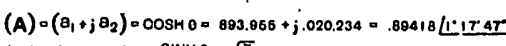

(B) $=\left(b_{1}+j b_{2}\right)=2 \frac{\text { SINH } \theta}{\theta}=\sqrt{\frac{Z}{Y}}$ SINH $\theta=32.188+j 172.084$ OHMS (C) $\circ\left(c_{1}+j C_{2}\right)=r \frac{\operatorname{SiNH} \theta}{\theta}=\frac{1}{\sqrt{\frac{2}{\gamma}}} \operatorname{siNH} \theta=-.000 .008+j .001 .188$ MHO
WHERE $\theta=\sqrt{2 Y}$

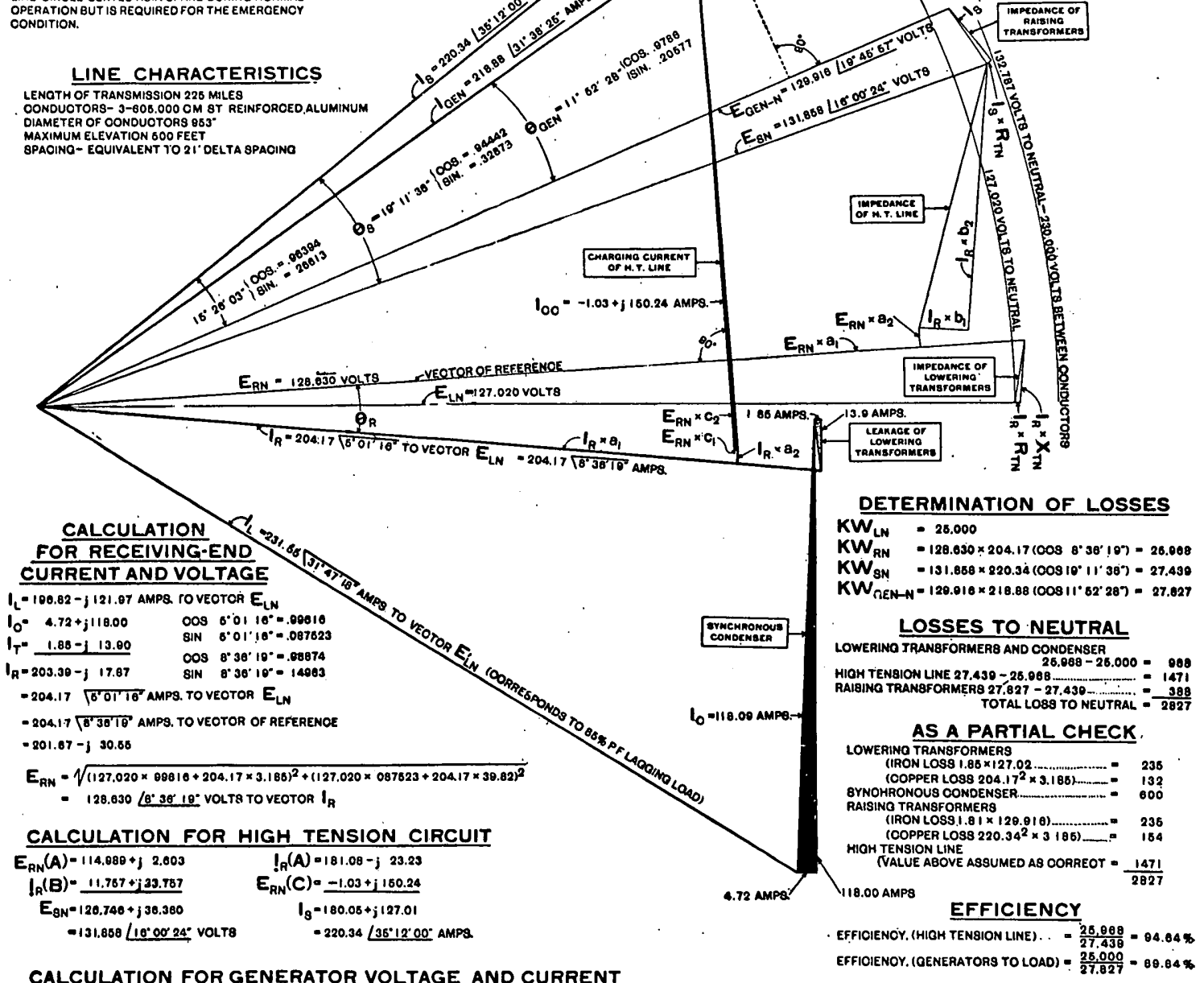

CALCULATION FOR GENERATOR VOLTAGE AND CURRENT

$E_{\text {OEN-N }}-\sqrt{(131.888 \times .84442+220.34 \times 3.186)^{2}+(131.858 \times 32870-220.34 \times 38.82)^{2}} \quad 220.38(.08394+j .26813)$

$-120.916 \angle 16^{\circ} 28^{\circ}$.05. VOLTS TO VEOTOR $\mathrm{I}_{8}$

- $120.010 \angle 10^{\circ} 46^{\circ} 6 T^{\circ}$ VOLTS

$K V-A_{8}=131.858 \times 220.34 \times 3=87.103$ PER 3 PHASE QARCUIT

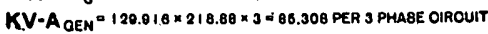

$K V$-A $A_{0}=131888 \times 180.24 \times 3=50.431$ PER 3 PHASE OAROUIT

$=212.38+j 58.64$
$=1.81-j 13.60$ (LEAKAGE. OF RAUSING TRANBFORMERS)

$I_{\text {GEN-N }}=214.20+j 46.00$

$=218.88411 .62^{2} 28^{\circ}$ AMPEREs TO VECTOR E

$=218.88 \angle 31^{\circ} 38^{\circ} 20^{\circ}$ AMPERES

FYaURE 50.-Vector diagram for 225-mile transmission line with normalload of 75,000 kilowatts on each circuit. 


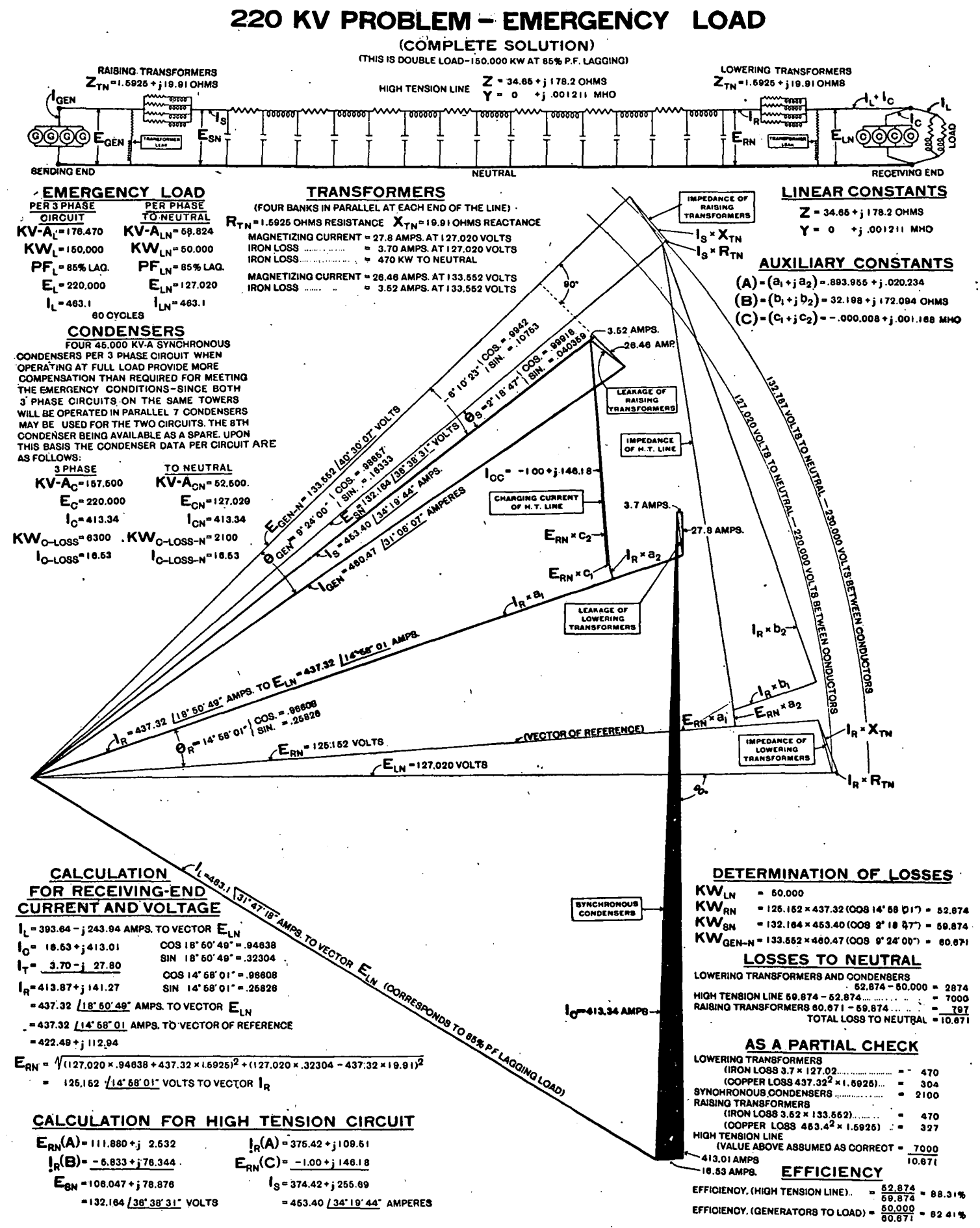

CALCULATION FOR GENERATOR VOLTAGE AND CURRENT

\section{$E_{G E N-N}=\sqrt{(132.164 \times .08918+453.4 \times 1.5926)^{2}+(132.164 \times .040359+463.4 \times 10.01)^{2}}$ \\ $=133.652 \angle 0^{\circ} 10^{\circ} 3^{\circ}$ VOLTS TO VECTOR IS - $133.652 \angle 40^{\circ} 30^{\circ}$ or VOLTS}

KV- $A_{8}=132.164 \times 463.40 \times 3=170.769$ PER 3 PHASE CIRCUIT KV-A $A_{G E N}=133.652 \times 4860.47 \times 3=184.480$ PER 3 PHASE CIRCUIT KV-A $O C=132.184 \times 140.18 \times 3=57.068$ PER 3 PHASE CIRCUIT

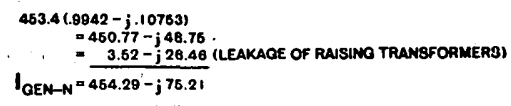

\footnotetext{
FiaURE 51.-Vector diagram for 225-mile transmission line with emergency load of 150,000 kilowatts on each circuit.
} 


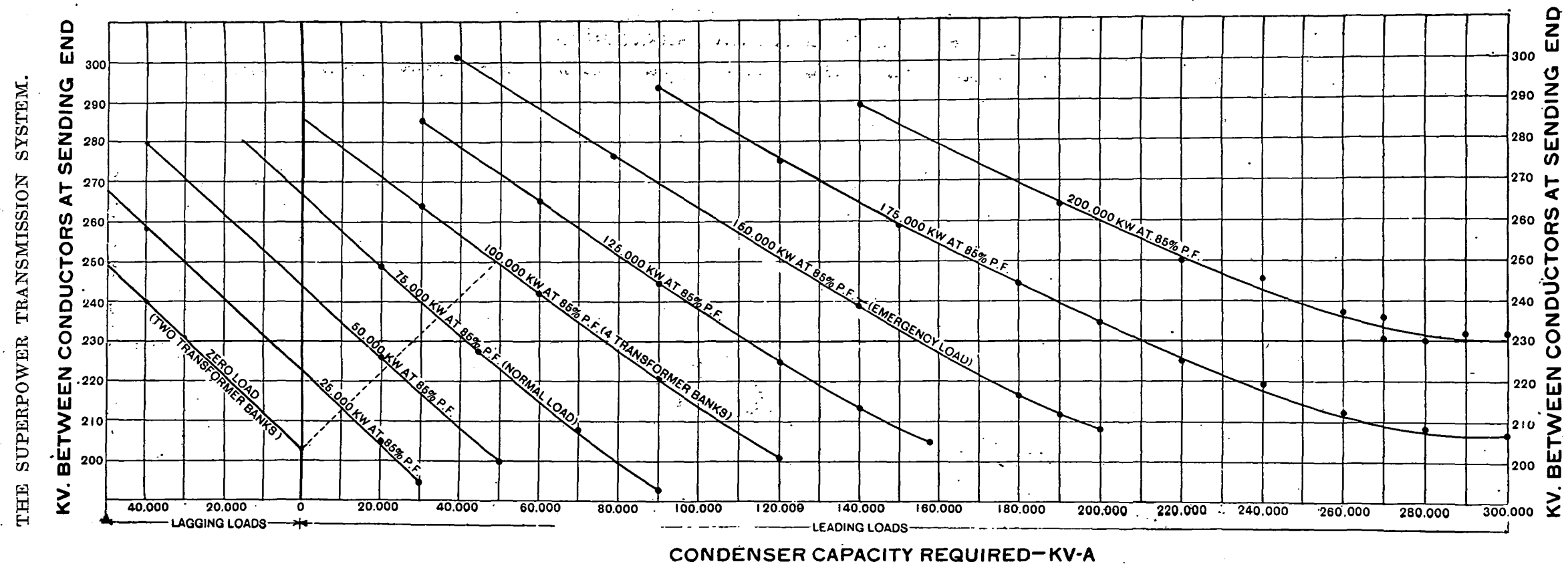

FTGuRE 52.-Energy delivered over 225-mile transmission line. ·

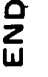




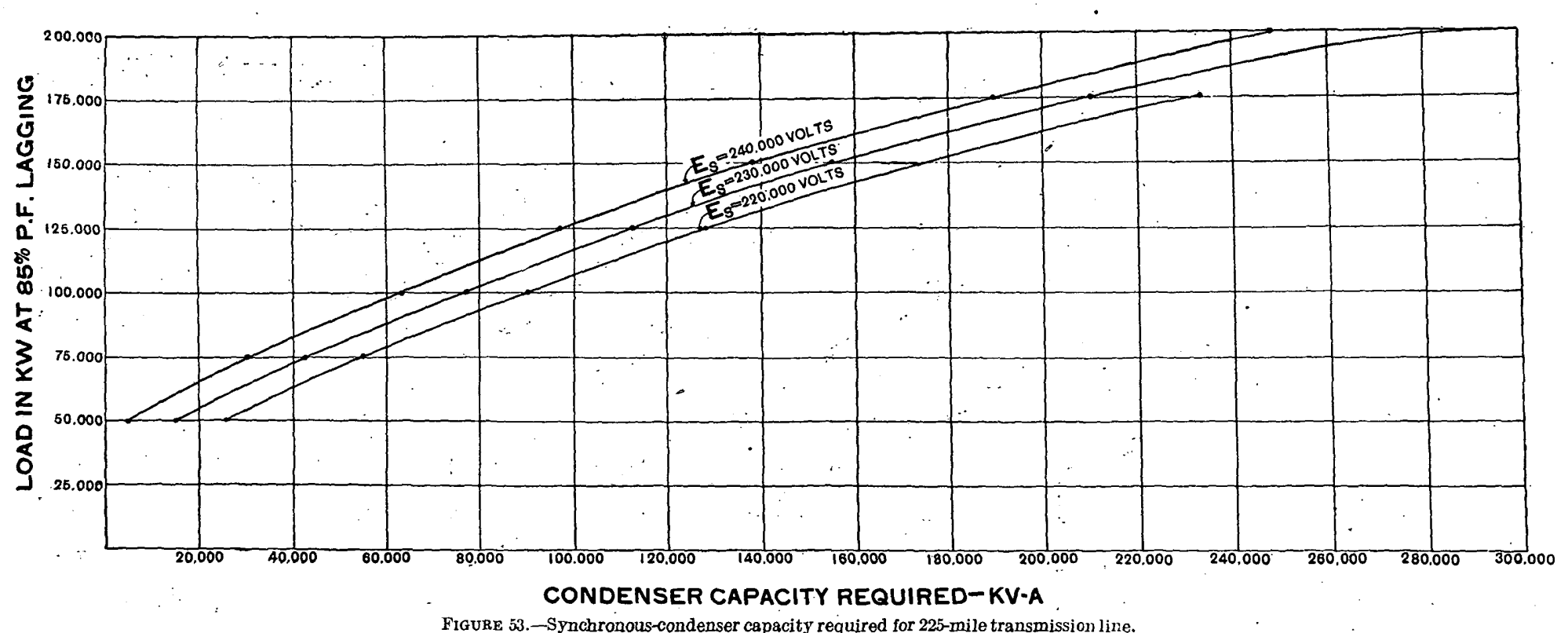

FiauRE 53-Synchronous-condenser capacity required for 225-mile transmission line. 


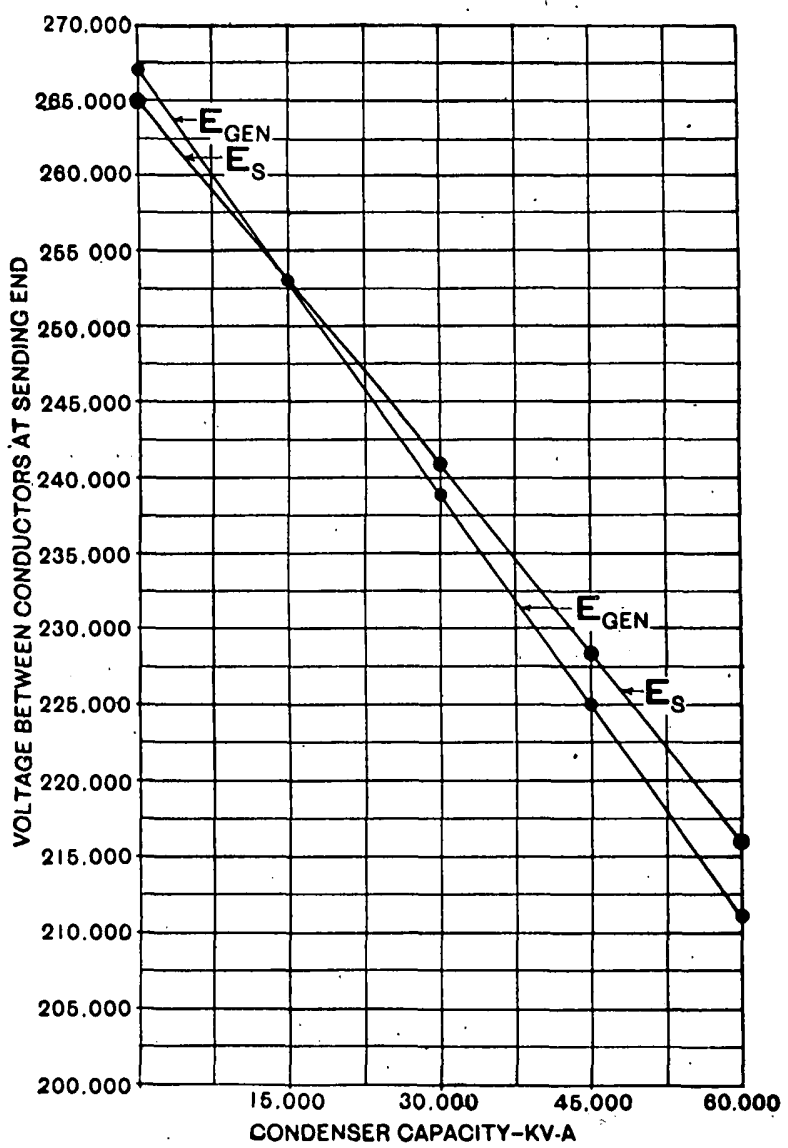

FIGURE 54.-Voltage on raising transformers for 225-mile transmission line.

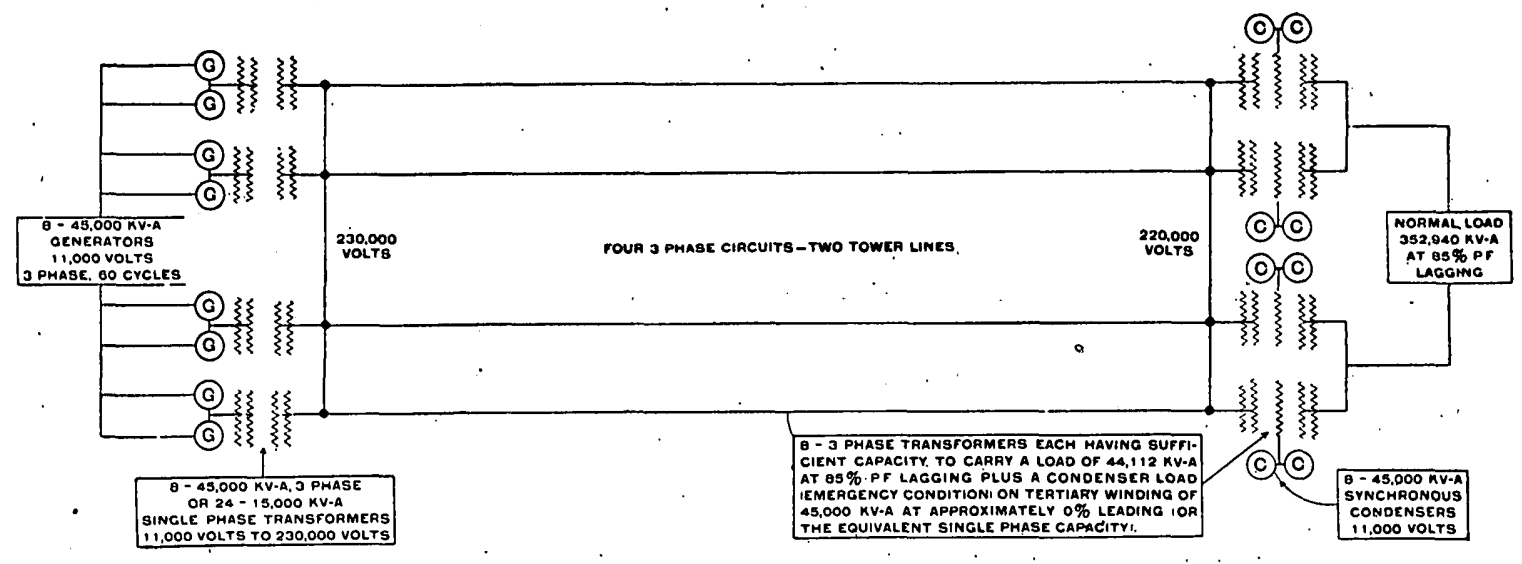

NOTE- SWITCHING EOUIPMENT PERMITS OF THE ENTIRE LOAO BEING I AANSMITTED OVEA ONE TOWER UNE (TWO CIRCUITS)

FIGURE 55.-Possible arrangement of equipment for St. Lawrence-New England project. 
TABLE 94.-Character and performance of lines that have been considered as sources of energy for the superpower zone.

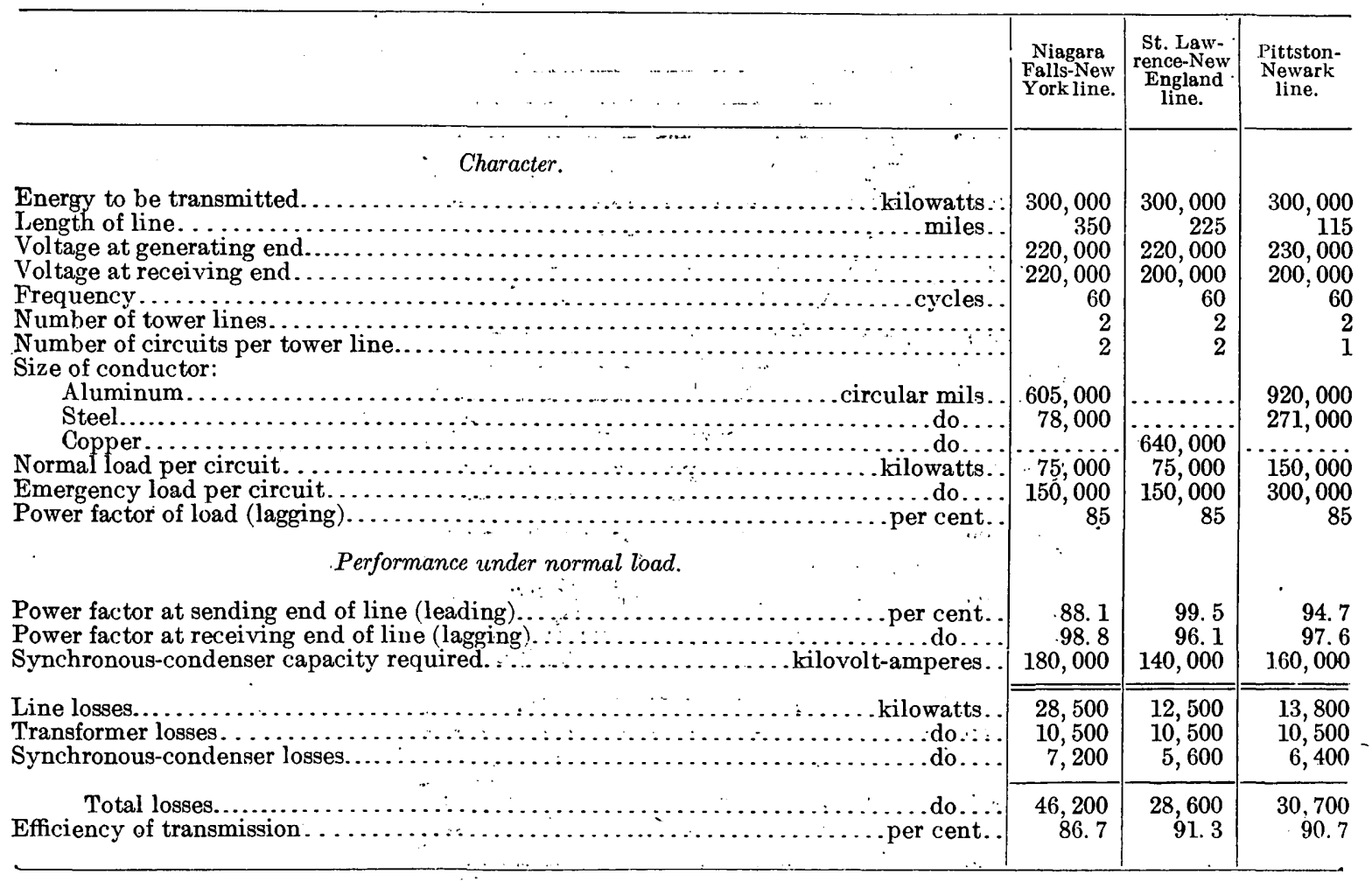

\section{COMMUNICATION LINES.}

The superpower system can be operated successfully only through absolute unity of operating control. Relations must be established between the different parts of the system to insure unquestioning and immediate response to the directions of some central authority. This requirement involves facilities for instant communication between all the generating and distributing stations. Most of the existing transmission systems provide lines of communication that parallel the lines of transmission and that are supported by the transmission-line towers or by poles erected on the right of way. These lines of communication, supplemented in reserve by the Bell telephone systems for use between important centers, furnish adequate service.

The maintenance of lines of communication on the right of way of a high-tension transmission line that parallels power circuits, where they are particularly exposed to electrostatic and electromagnetic induction, is considered very undesirable by the power company, but it is employed as the surest means of maintaining communication between power plants and distributing. stations. The commercial telephone systems have been so greatly improved and augmented that the telephone companies in the superpower zone now have great resources in trunk lines and alternate routes and exceptional facilities for maintaining their plants.

The operation of transmission lines by means of radio telephones or telegraph is being rapidly developed and will probably increase in the near future, particularly as radio communication is free from the effect of interference by high tension circuits.

\section{SUBSTATIONS.}

Outdoor substations of standard design, except as the design may be affected by higher voltages, will be used. Synchronous condensers will be installed in the substations to reduce investment and operating cost. 


\section{UNIT INVESTMENT COSTS.}

TRANSMISSION IINES.

In the following table, showing the unit investment cost per mile for the different types of transmission lines used in existing systems, the cost includes rights of way and is based on prices in midyear of 1919 .

TABLE 95.-Unit investment cost for transmission lines.

\begin{tabular}{|c|c|c|c|c|c|}
\hline \multirow{2}{*}{$\begin{array}{c}\text { Line } \\
\text { voltage. }\end{array}$} & \multicolumn{2}{|l|}{ Conductors. } & \multirow{2}{*}{$\begin{array}{l}\text { Number } \\
\text { of tower } \\
\text { lines. }\end{array}$} & \multirow{2}{*}{$\begin{array}{l}\text { Total } \\
\text { number of } \\
\text { circuits. }\end{array}$} & \multirow{2}{*}{$\begin{array}{l}\text { Cost per } \\
\text { mile. }\end{array}$} \\
\hline & Material. & $\begin{array}{l}\text { Area (cir- } \\
\text { cular mils). }\end{array}$ & & & \\
\hline 220,000 & 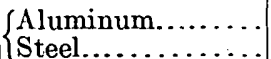 & $\begin{array}{r}605,000 \\
78,000\end{array}$ & 1. & 2 & $\$ 27,328$ \\
\hline 220,000 & 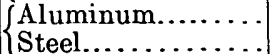 & $\begin{array}{r}605,000 \\
78,000\end{array}$ & 2 & 4 & 54,056 \\
\hline 220,000 & 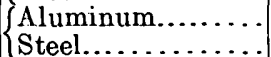 & $\begin{array}{r}605,000 \\
78,000\end{array}$ & 1 & $\mathbf{L}^{*}$ & 18,760 \\
\hline $2 \dot{20}, 000$ & 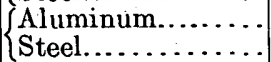 & $\begin{array}{r}605,000 \\
78,000\end{array}$ & 2 & 2 & 36,920 \\
\hline 220,000 & 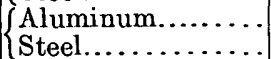 & $\begin{array}{l}920,000 \\
212,000\end{array}$ & 1 & 1 & 22,330 \\
\hline 220,000 & 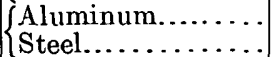 & $\begin{array}{l}920,000 \\
212,000\end{array}$ & 2 & 2 & 44,060 \\
\hline 110,000 & Copper............ & No. 000 & 1 & 2 & 19,160 \\
\hline 110,000 & 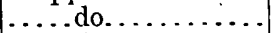 & No. 000 & 2 & 4 & 37,070 \\
\hline 110,000 & $\ldots \ldots$ do........... & 350,000 & 1 & 1 & 16,780 \\
\hline 110,000 & $\ldots \ldots$ do........... & 350,000 & 2 & 2 & 32,310 \\
\hline 110,000 & 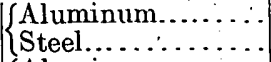 & $\begin{array}{r}450,000 \\
58,500\end{array}$ & 1. & 2 & 20,945 \\
\hline 110,000 & 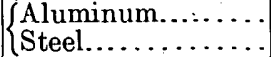 & $\begin{array}{r}450,000 \\
58,500\end{array}$ & 2 & 4 & 40,640 \\
\hline $1 \dot{1} 10,000$ & 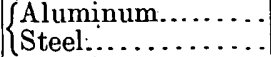 & $\begin{array}{l}920,000 \\
212,000\end{array}$ & 1 & 2 & 33,440 \\
\hline 110,000 & 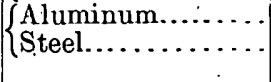 & $\begin{array}{l}920,000 \\
212,000\end{array}$ & 2 & 4 & 65,630 \\
\hline
\end{tabular}

Figure 56 shows the unit cost of 110,000-volt substations with low-tension secondaries in midyear of 1919. This cost includes transformers, structures, and switch gear to accommodate two, four, six, or eight incoming 110,000-rolt lines.

Figure 57 shows the unit cost of 220,000-volt substations with low-tension secondaries in midyear of 1919. This cost includes transformers, structures, and switch gear to accommodate two or four incoming 220,000 -volt lines.

Figure 58 shows the unit cost of 220,000-volt substations with 110,000-volt secondaries in midyear of 1919. This cost includes transformers, structures, and switch gear to accommodate two, four, or six incoming 220,000-volt circuits and six outgoing 110,000-volt circuits.

\section{SYNCHRONOUS-CONDENSER STATIONS.}

Figure 59 shows the unit cost of synchronous-condenser stations at midyear of 1919 . This cost includes buildings, synchronous condensers, transformers, and switching and regulating equipment. For the operation of synchronous condensers on 110,000-volt circuits independent transformers are provided; for 220,000-volt circuits a tertiary winding is added to the main transformers.

\section{FREQUENCY-CHANGER STATIONS.}

Figure 60 shows the unit cost of frequency-changer stations at midyear of 1919 . This cost includes building, frequency changers, transformers, and switching and regulating equipment. 


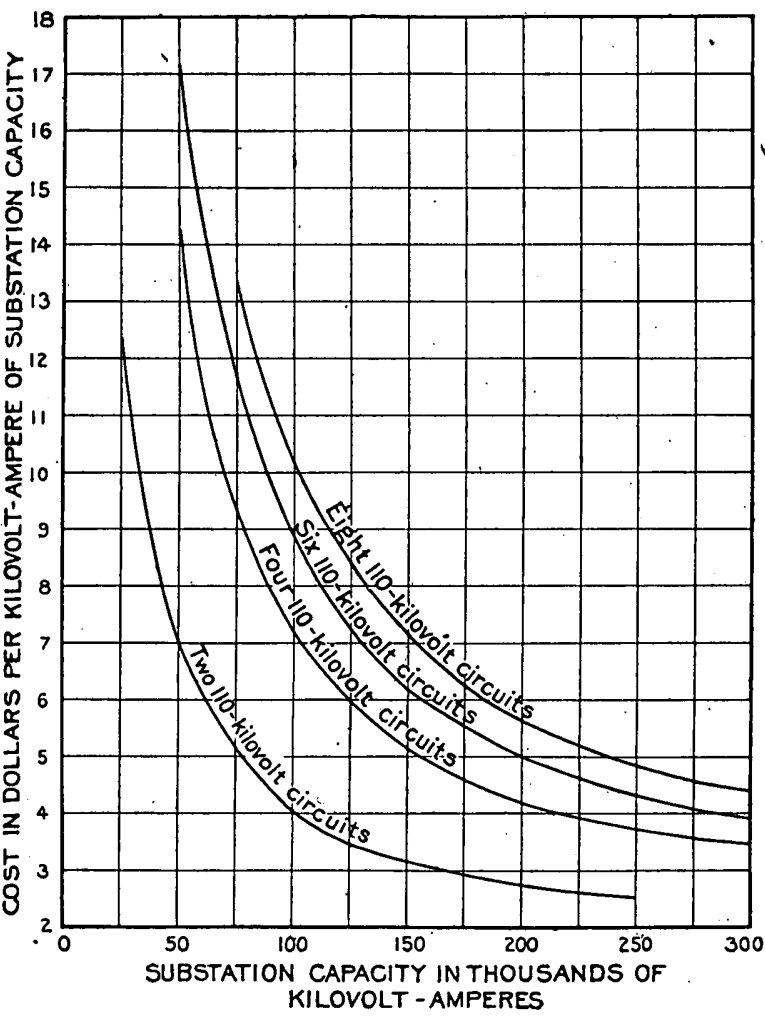

Fioure 56.-Unit cost of 110,000 -volt 60-cycle substations with low-tension secondaries in midyear of 1919.

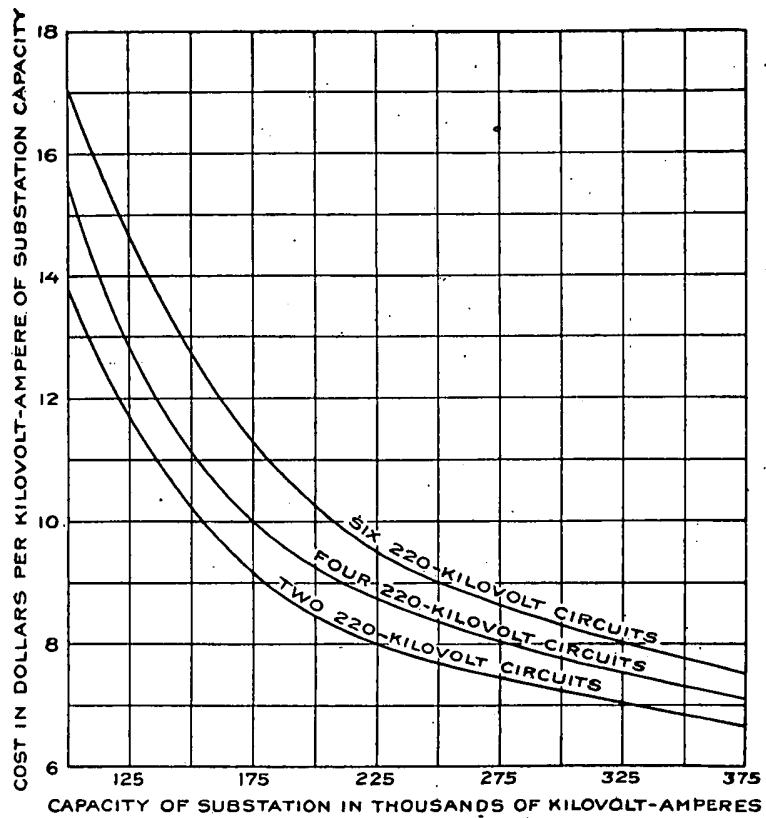

Figure 58.-Unit cost of 220,000-volt 60-cycle substations with $110,000-$ volt secondaries in midyear of 1919 .

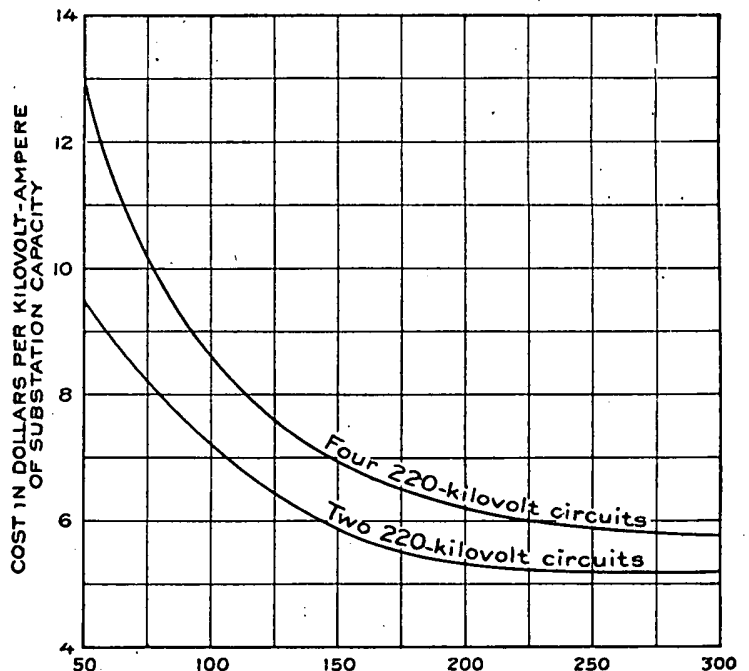

CAPACITY OF SUBSTATION IN THOUSANDS OF KILOVOLT-AMPERES FIGURE 57.-Unit cost of 220,000 -volt 60-cycle substations with lowtension secondaries in midyear cf 1919.

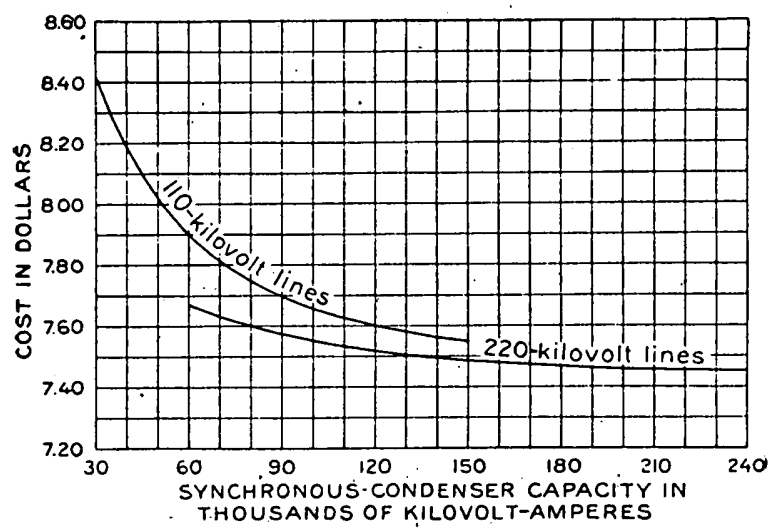

FIGURE 59.-Estimated cost per lilovolt-ampere of capacity of 60 cycle synchronous condensers in midyear of 1919.

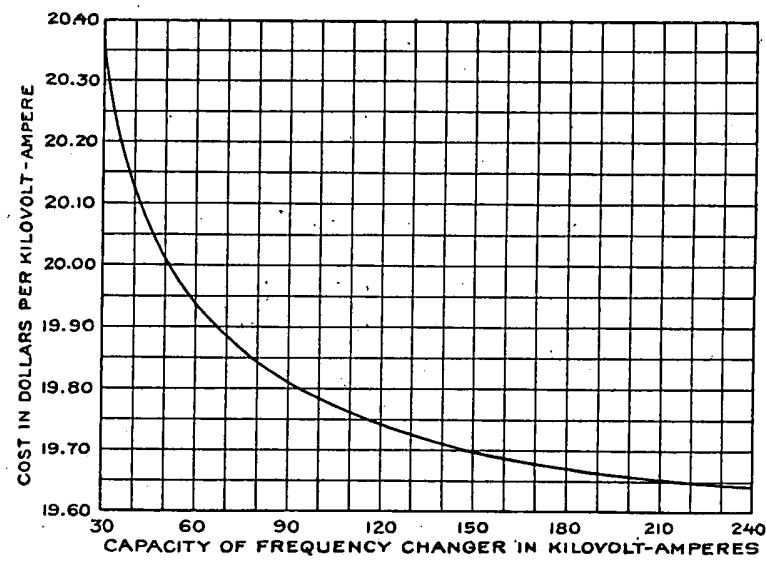

FIGURE 60.-Unit cost of frequency-changer stations in midyear of 1919. Applies to installations of 110,000 or 220,000 volts, 25 or 60 cycles. 
THE SUPERPOWER TRANSMISSION SYSTEM.

\section{OPERATING COST OF TRANSMISSION SYSTEM.}

TRANSMISSION IINES.

The following estimated operating cost for transmission lines includes maintenance, labor, and supplies and is based on the actual cost of operating long-distance lines:

TABLE 96.-Operating cost for transmission lines.

\begin{tabular}{|c|c|c|c|}
\hline Line voltage. & $\begin{array}{l}\text { Number } \\
\text { of tower } \\
\text { lines. }\end{array}$ & $\begin{array}{c}\text { Total } \\
\text { number of } \\
\text { circuits. }\end{array}$ & $\begin{array}{l}\text { Operating } \\
\text { cost per } \\
\text { mile per } \\
\text { year. }\end{array}$ \\
\hline $\begin{array}{c}220,000 \ldots \ldots \ldots \ldots \ldots \ldots \ldots \\
. \\
110,000 \ldots \ldots \ldots \ldots \ldots \ldots\end{array}$ & $\left\{\begin{array}{l}1 \\
1 \\
2 \\
2 \\
1 \\
1 \\
2 \\
2\end{array}\right.$ & $\begin{array}{r}1 \\
2 \\
\cdot \quad 2 \\
4 \\
1 \\
2 \\
2 \\
2 \\
4\end{array}$ & $\begin{array}{r}\$ 1.75 \\
200 \\
225 \\
250 \\
125 \\
150 \\
200 \\
250\end{array}$ \\
\hline
\end{tabular}

SUBSTATIONS.

The annual cost of maintenance and supplies has been fixed at 2 per cent of the total first cost of the substation. For the annual cost of labor $\$ 12,000$ is used for substations having a capacity of 150,000 kilovolt-amperes or less, $\$ 18,000$ for those having capacities between 150,000 and 300,000 kilovolt-amperes, and $\$ 24,000$ for those having capacities of more than 300,000 kilovolt-amperes. 


\section{A.PPENDIX I. RELIABILITY OF SERVICE.}

By L. E. ImLAY and others of the engineering staff.

Reliability of service is of first importance. A superpower system with interconnection through many load centers and with provision for obtaining power from several sources can insure continuous service."

Modern power plants, which use large units, are simple compared to power plants built a decade ago. The tendency to locate the plants outside of centers of population has done much to simplify former complicated switching and feeder arrangements.

The principal causes of power-plant interruption, outside of fluctuations in coal supply, are in the coal-handling, boiler, turbine, condenser, and electrical apparatus. Provision is made against such interruptions in the superpower. system.-

Coal-handling equipment is now provided either in duplicate or of sufficient capacity so that the coal supply will not be in danger of exhaustion. To the popular mind boiler explosions are regarded as one of the greatest dangers to be apprehended in steam plants, but since the advent of the water-tube boiler there is, so far as explosions are concerned, no limitation to the number and capacity of boilers that may be placed in one plant.

Large steam turbines of recent development have excellent records for continuous operation over long periods. It is true that during the World War considerable trouble was experienced with a number of large turbines, but the cause of this particular trouble has been accurately ascertained and eliminated.

The operating records of turbine units in a number of large plants show that these units are available for service more than 90 per cent of the time, and the margin is within the reserve capacity of the plant.

It is difficult in a well-operated plant to justify interruptions from condenser troubles.

Failures in modern electric generators are no longer frequent. The perfection of oil switches and the complete isolation of the phases and reactance applications have resulted in the elimination of the disastrous effects of short circuits.

Superpower transmission will involve capacities of 300,000 kilowatts and maximum distances of 350 miles. Consultation and exhaustive discussion with the principal transmission authorities of this country regarding a proper support and circuit arrangement led to the conclusion that these transmission systems should consist of two tower lines, each supporting two circuits and each tower line being capable of transmitting the entire load.

Load centers in the past have usually been dependent upon a single transmission line. By virtue of its interconnecting network the superpower system will eliminate the hazard of interruption or disaster from the use of a single line.

The transmission systems for the superpower system will be of entirely different dimensions from those to which we have become accustomed. Appendix H-2 brings out the features of their construction. Their reliability will be of the same order as that prevailing within the best modern power plants. They can thus be considered as merely high-tension extensions of the power-plant busses.

The inherent characteristic of the superpower system, therefore, is adequate provision for reserves through its entire structure. 


\section{APPENDIX J.}

\section{THE RELATION OF COAL AND COAL-DELIVERY ROUTES TO THE SUPERPOWER SYSTEM.}

By C. E. Lesher, F. G. Tryon, and others.

\section{DISTRIBUTION AND USE OF COAL IN THE SUPERPOWER ZONE IN 1919.}

Table 97 shows that the coal used by central stations is only about 9 per cent of the total used in the superpower zone; that used for locomotive fuel and other railroad purposes and by industries, mines, Government institutions, waterworks, and the central stations amounts to nearly 71 per cent of the total.

TABLE 97.-Distribution and use of coal in superpower zone for 1919, in short tons.

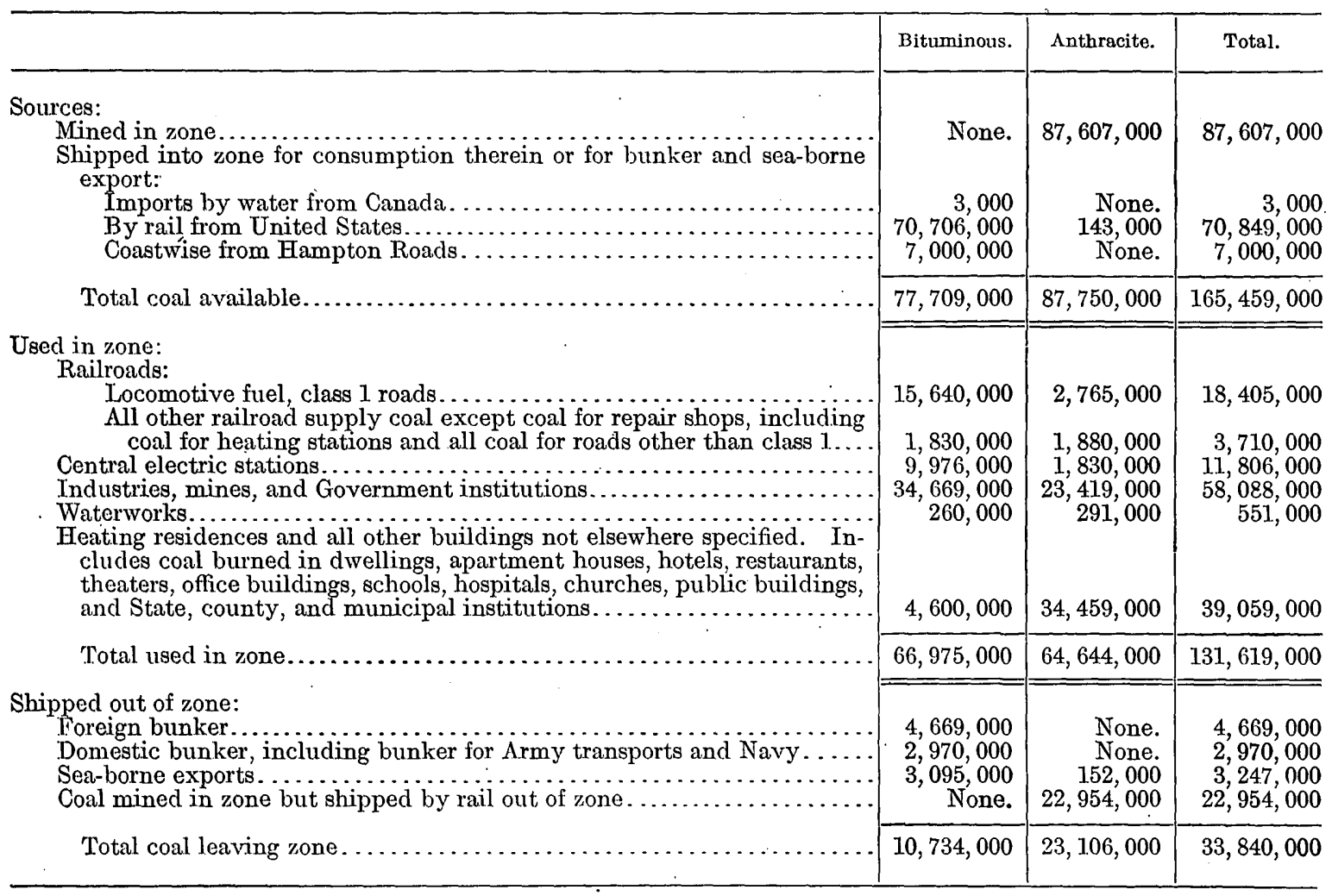

COAL DISTRICTS AND COAL DELIVERY ROUTES.

The bituminous-coal districts tributary to the superpower zone are the Clearfield, Somerset, Windber, Greensburg, Westmoreland, Pittsburgh, Fairmont, Georges Creek, Pocahontas, New River, and Kanawha.

The Clearfield, Somerset, and Windber districts lie nearest, and the freight rate from them is the lowest, but they are within the thin-seam regions, where the production cost is high.

The Westmoreland, Greensburg, Pittsburgh, and Fairmont districts are in the thicker-seam region, where production costs are lower, but the freight rates from them are higher.

About half of New England's coal has heretofore been supplied from the Pocahontas, New River, and Kanawha districts. These districts are the chief sources of coal for export, and when the export demand is large the demand in New England must compete with it. 
The selection of sites for base-load steam-electric plants is dependent upon the availability of sufficient condensing water, the cost of coal delivered, and the relation of the plant site to the coal-delivery routes from the mines.

Power plants at tidewater in New England east of New London have a reliable coal supply, as they can obtain fuel from the greatest number of sources, having the option of either allrail or rail and water delivery. The two particular difficulties in the free movement of coal to New England are congestion at times at the Hudson River gateways, due to weather and traffic conditions, and the shortage of bottoms at certain periods for the movement of coal from Baltimore, Philadelphia, and Hampton Roads to eastern New England ports.

The principal bituminous-coal carriers to the superpower zone are the Pennsylvania, the Baltimore \& Ohio, the New York Central, and the Western Maryland. These railroads are also the principal carriers of all other traffic to that zone, and at times the traffic demand exceeds their capacity. At certain points on these lines, such as the classification yards at Cumberland, Altoona, Williamsport, and Harrisburg, congestion has occurred through either the traffic conditions or the topographic conditions; at others congestion is due primarily to the necessity of transfer between the railroads, as at Troy, Albany, Maybrook, and Harlem River.

Plants on Hudson River as far north as Troy can readily receive coal, either through Albany or by river barges from New York Harbor. Between New York and Washington there are a number of good locations for steam-electric power plants. Sites are available along New York Bay, Hackensack River, Passaic River, Raritan Bay, Raritan River, Delaware River as far north as Trenton, Delaware Bay, Chesapeake Bay, and Potomac River as far west as Cumberland. In the inland region Susquehanna River and its branches offer excellent sites for the location of base-load steam-electric plants.

The principal difficulty in the location of steam-electric plants in the bituminous mining districts comes from lack of condensing water. (See Appendix F.)

Plate $\mathrm{X}$ shows the location of available coal-mining districts, principal rail routes, and location of base-load steam-electric plants for 1930. Anthracite is not discussed at this time, for plants constructed to burn anthracite will be located in the mining region, and rail delivery will consist only in gathering the coal for them. Power can be delivered to the Newark and Philadelphia load centers from plants to be constructed in the anthracite region more cheaply than power can be generated at these centers. (See Appendix F.)

\section{COST OF COAL.}

\section{COST OF COAL AT THE MINES.}

Bituminous coal.-The average price for bituminous coal at the mine has been taken at. $\$ 2.90$ per short ton for the three years considered $(1919,1925$, and 1930) and was determined by the weighted average cost of bituminous coal for 1919 to the fuel-using industries in the superpower zone. This price applies to fuels that take the Clearfield freight rate. The Greensburg, Westmoreland, Pittsburgh, and Fairmont districts, which ship coal to the superpower zone by rail and water, as well as by all-rail routes, sell at a price about 50 cents a short ton lower than the Clearfield district. - The Pocahontas, New River, and Kanawha fields supply large amounts of coal to eastern New England by boat, delivered from Hampton Roads. This coal commands a premium of about 50 cents a short ton at the mine over that of the Clearfield district.

Although the cost of labor may be reduced by modification of the present wage scale, which terminates in 1922, the cost of coal tends to increase gradually from the necessity of developing mines in thinner seams and deeper veins and of extending underground haulage in existing mines.

Anthracite.-The price for buckwheat No. 3 coal at the mines has been taken at $\$ 1.75$ per long ton for the three years considered $(1919,1925$ and 1930): This price is based on records of sales made in 1919 and on the competitive relation between anthracite and.bituminous coal at tidewater delivery points. 


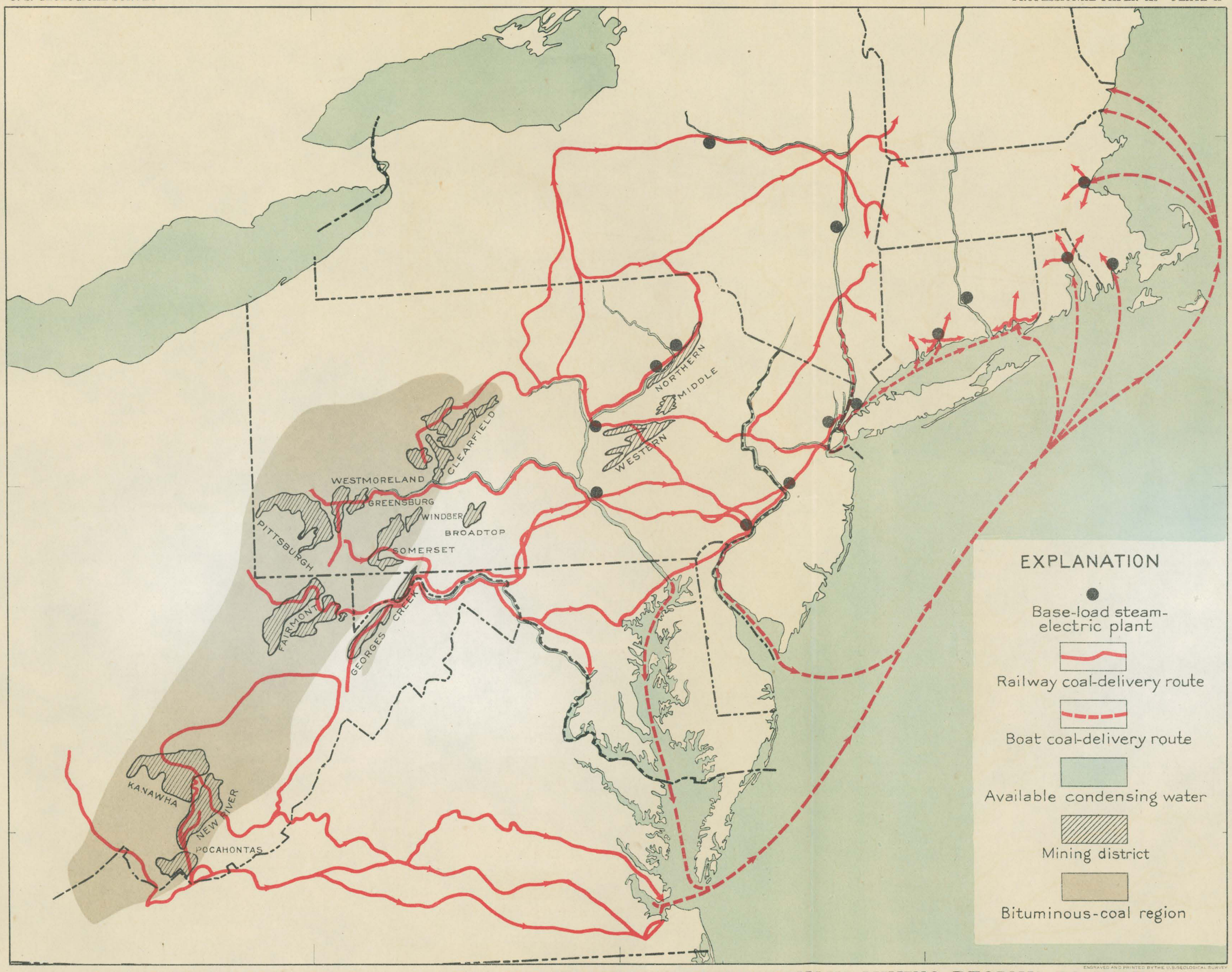

LOCATION OF PRINCIPAL COAL-DELIVERY ROUTES FROM BITUMINOUS MINING REGIONS TO BASELOAD STEAM ELECTRIC PLANTS IN 1930. 
Between 1911 and 1917 the ratio of the cost of buckwheat No. 3 coal at New York Harbor to the cost of low-volatile bituminous coal increased from 53 to 56 per cent. In 1918 it jumped to about 67 per cent, but in 1919 it fell to 66 per cent. The large increase in 1918 and 1919 was due to the fact that bituminous coal was then under governmental regulation, while buckwheat No. 3 coal was not, and it was further due to the difficulty of obtaining deliveries of bituminous coal. The New York Harbor price of buckwheat No. 3 coal has been taken at approximately 63 per cent of the price of low-volatile bituminous. Although this ratio is somewhat higher than that in existence before the war, it is considered reasonable, as the demand for buckwheat No. 3 coal has increased through the development of anthracite stokers and better knowledge of the use of this coal gained during the war.

United States Geological Survey records show that 78,501,931 long tons of anthracite was mined in 1919. Of this total $67,817,284$ tons was shipped out of the anthracite district and $8,576,850$ tons was used for fuel by the mines themselves. Local sales account for the remainder. The total quantity of buckwheat No. 3 and smaller sizes of anthracite shipped in 1919 was $3,759,000$ tons.

Large base-load steam-electric plants located in the anthracite region will require approximately 1,600,000 long tons of buckwheat No. 3 and smaller sizes of anthracite for each 300,000kilowatt plant, which is nearly one-half of the total of those sizes shipped in 1919. However, a large proportion of the mines that now have their own steam plants would be electrified when such power plants were constructed, thus releasing, owing to the higher efficiency of the power plants, a larger amount of the small steam sizes than would be required for the operation of these base-load plants. Under such conditions the demand will not be in excess of the supply. (See Appendix F.)

\section{COST OF COAL DELIVERED TO THE STEAM-ELECTRIC PLANTS.}

The cost of fuel at the power plants has been determined by the cost of coal from the Clearfield district.

Coal from the Westmoreland, Greensburg, Pittsburgh, and Fairmont districts costs 50 cents a short ton less than Clearfield coal but is lower in calorific value. Coal from the Pocahontas, New River, and Kanawha fields has a higher calorific value than that of Clearfield, but its mine price is 50 cents a short ton higher. When all charges to the destination point are considered, the number of British thermal units obtained for each dollar expended is nearly the same for coal from all the fields, and the use of the Clearfield prices and freight rates as a basis both for fuel cost and plant performance gives a representative average.

The current freight rates of 1919 are used in the calculations for that year and those existing on January 1, 1921, for the 1925-1930 period.

Table 98 gives the cost of bituminous coal at specified destination points from those fields that are tributary to them.

TABLE 98.-Cost of bituminous coal per short ton at destination points in the superpower zone.

\begin{tabular}{|c|c|c|c|c|c|}
\hline Load center. & Mining district. & Period. & $\begin{array}{l}\text { Price at } \\
\text { mines. }\end{array}$ & $\begin{array}{l}\text { Freight, } \\
\text { taxes, in- } \\
\text { surance, } \\
\text { and sea- } \\
\text { sonal coal } \\
\text { storage. }\end{array}$ & $\begin{array}{l}\text { Total cost } \\
\text { in plant } \\
\text { bunkers. }\end{array}$ \\
\hline \multirow[t]{3}{*}{ Boston... } & Clearfield...$\ldots \ldots \ldots \ldots \ldots$ & 1919 & $\$ 2.90$ & $\$ 3.16$ & $\$ 6.06$ \\
\hline & Fairmont & $\begin{array}{l}1925-1930 \\
1925-1930\end{array}$ & $\begin{array}{l}2.90 \\
2.45\end{array}$ & $\begin{array}{l}4.45 \\
4.68\end{array}$ & $\begin{array}{l}7.35 \\
7.13\end{array}$ \\
\hline & Pocahontas $\ldots \ldots \ldots \ldots \ldots$ & $1925-1930$ & 3.35 & 5. 40 & 8.75 \\
\hline \multirow[t]{3}{*}{ Providence. . } & Clearfield... & 1919 & 2.90 & 3.24 & 6.14 \\
\hline & Fairmont... & $\begin{array}{l}1925-1930 \\
1925-1930\end{array}$ & $\begin{array}{l}2.90 \\
2.45\end{array}$ & $\begin{array}{l}4.59 \\
4.81\end{array}$ & $\begin{array}{l}7.49 \\
7.26\end{array}$ \\
\hline & Pocahontas. & $1925-1930$ & 3.35 & $\begin{array}{l}4.01 \\
5.15\end{array}$ & 8.50 \\
\hline \multirow[t]{4}{*}{ New London. } & Clearfield... & 1919 & 2.90 & 2.79 & 5.69 \\
\hline & $\ldots$ do $\ldots \ldots \ldots \ldots$. & $1925-1930$ & 2.90 & 3.93 & 6.83 \\
\hline & Fairmont............. & $1925-1.930$ & 2.45 & 4. 16 & 6.61 \\
\hline & Pocahontas........ & 1925-1930 & 3. 35 & 5.40 & 8.75 \\
\hline
\end{tabular}


TABLE 98.-Cost of bituminous.coal per short ton at destination points in the superpower zone-Continued.

\begin{tabular}{|c|c|c|c|c|c|}
\hline Load center. & Mining district. & Period. & $\begin{array}{l}\text { Price at } \\
\text { mines. }\end{array}$ & $\begin{array}{l}\text { Freight, } \\
\text { taxes, in- } \\
\text { surance, } \\
\text { and sea- } \\
\text { sonal coal } \\
\text { storage. }\end{array}$ & $\begin{array}{l}\text { Total cost } \\
\text { in plant } \\
\text { bunkers. }\end{array}$ \\
\hline \multirow[t]{3}{*}{ New Haven ....................... } & Clearfield................... & 1919 & $\$ 2.90$ & $\$ 2.68$ & $\$ 5.58$ \\
\hline & $\ldots$ do $\ldots \ldots \ldots \ldots \ldots \ldots \ldots$ & $1925-1930$ & 2.90 & 3.81 & 6.71 \\
\hline & 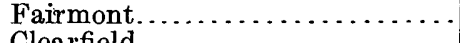 & $1925-1930$ & 2.45 & 4. 18 & 6.63 \\
\hline \multirow{2}{*}{ Hartford.... . } & ' & $1925-1930$ & $\begin{array}{l}2.90 \\
2.90\end{array}$ & $\begin{array}{l}3.06 \\
4.33\end{array}$ & $\begin{array}{l}5.96 \\
7.23\end{array}$ \\
\hline & Fairmont.................. & $1925-1930$ & 2.45 & 4.55 & 7.00 \\
\hline \multirow[t]{3}{*}{ 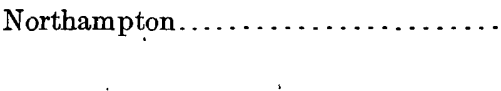 } & Clearfield. & 1919 & 2.90 & 3. 42 & 6.32 \\
\hline & $\ldots \ldots$ do................. & $1925-1930$ & 2.90 & 4. 83 & 7. 73 \\
\hline & 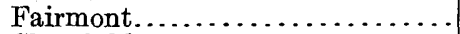 & $1925-1930$ & 2. 45 & 5.07 & 7.52 \\
\hline \multirow[t]{2}{*}{ Albany and Poughkeepsie........... } & Clearfield $\ldots \ldots \ldots \ldots \ldots \ldots \ldots$ & 1919 & 2.90 & 2.42 & 5. 32 \\
\hline & $\ldots$ do $\ldots \ldots \ldots \ldots \ldots \ldots \ldots \ldots \ldots$ & $1925-1930^{\circ}$ & 2.90 & 3.43 & 6. 33 \\
\hline \multirow{3}{*}{$\begin{array}{l}\text { New York, Newark, and New Bruns- } \\
\text { wick. }\end{array}$} & Clearfield................. & $\begin{array}{c}1920-1950 \\
1919\end{array}$ & $\begin{array}{l}2.45 \\
2.90\end{array}$ & $\begin{array}{l}3.80 \\
2.32\end{array}$ & $\begin{array}{l}6.25 \\
5.22\end{array}$ \\
\hline & $\ldots \ldots$ do...................... & $1925-1930$ & 2.90 & 3.35 & 6.25 \\
\hline & Fairmont.............. & $1925-1930$ & 2.45 & 3.66 & 6.11 \\
\hline \multirow{3}{*}{ Trenton $\ldots \ldots \ldots \ldots \ldots \ldots \ldots \ldots$} & Clearfield....................... & 1919 & 2.90 & 2.23 & 5.13 \\
\hline & 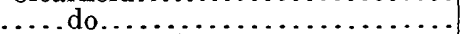 & $1925-1930$ & 2.90 & 3.17 & 6. 07 \\
\hline & Fairmont........ & $1925-1930$ & 2.45 & 3.40 & 5.85 \\
\hline \multirow[t]{3}{*}{ Harrisburg. . . . . . . . . . . . . . . } & Clearfield................ & 1919 & 2.90 & 1. 77 & 4. 67 \\
\hline & $\because \because$ й. & $1925-1930$ & 2.90 & 2.53 & 5.43 \\
\hline & 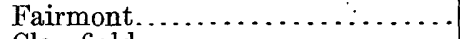 & $1925-1930$ & 2.45 & 2.77 & 5. 22 \\
\hline \multirow{2}{*}{$\begin{array}{l}\text { Philadelphia, Wilmington, Baltimore, } \\
\text { and Washington. }\end{array}$} & Clearfield $\ldots \ldots \ldots \ldots \ldots \ldots \ldots \ldots$ & 1919 & 2.90 & 2.15 & 5.05 \\
\hline & 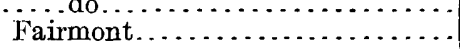 & $\begin{array}{l}1925-1930 \\
1925-1930\end{array}$ & $\begin{array}{l}2.90 \\
2.45\end{array}$ & $\begin{array}{l}3.05 \\
3.27\end{array}$ & $\begin{array}{l}\text { 5. } 95 \\
4.72\end{array}$ \\
\hline
\end{tabular}

\section{OWNERSHIP OF COAL MINES.}

No advantage has been found in the ownership of coal mines by the power company to offset the elimination of the flexibility of supply, the increase in initial investment, the additional administrative cost, and the hazard common to mining enterprises.

\section{COAL STORAGE.}

A 360,000-kilowatt plant at an annual capacity factor of 60 per cent will use 1,260,000 short tons of bituminous coal a year. Storage of six months' coal supply for such a plant will therefore require 630,000 tons. Coal storage in this amount might appear excessive, but the following advantages are evident: (1) It would absolutely prevent interruption of service due to lack of fuel. (2) It would permit the purchase of coal at the lowest market price. Where facilities for coal storage are scanty, the purchase of coal'in the spot market at times of shortage and without regard to quality results in an excessive expense, which would more than offset the cost of adequate storage facilities. (3) It would effect partial stabilization of the mining and the transportation industries through bringing about a more uniform demand for fuel and thus tending to increase the operating load factor of these two industries. It is equally obvious that this would be a step toward reducing the price of fuel to the consumer because it would be a step in the reduction of cost of mining and transportation.

There has been some discussion with regard to the ownership by the superpower system of either coal cars or railroad routes or both, but it has been concluded that the superpower system should confine its activities to the production of power and the storage of coal.

The cost of coal storage is included in the production cost of the superpower system. 


\section{APPENDIX K. \\ USE OF PROCESS FUELS AND PULVERIZED COAL FOR BASE-LOAD STEAM- ELECTRIC PLANTS.}

By O. P. Hoon and others of the engineering staff.

\section{CONCLUSIONS RELATIVE TO THE USE OF PROCESS FUELS.}

In considering the use of process fuels by base-load steam-electric stations it has been necessary to fix certain limitations to the study, which must necessarily be a general one covering the entire superpower zone. The study was therefore confined to processes that had reached the stage of commercial development. The fixed charges against the investment cost in the by-product plants have invariably been taken at 20 per cent-10 per cent for the cost of money, 8 per cent for depreciation and obsolescence, and 2 per cent for taxes and insurance. At the same time the operating costs have been taken at $\$ 1.35$ per ton of coal carbonized, and the prices credited for by-products are those given below.

In a base-load steam-electric plant under present conditions coal must generally be used in the raw form in order to produce cheap power. Local conditions will justify certain exceptions to this practice. At large centers of population it may be found profitable to install process-fuel plants in conjunction with base-load. steam-electric stations if the gas produced by the plants can be sold at a profit, particularly where a process is used that will yield gas which has a very high heating value and which can be used to enrich water gas made by the gas companies.

Coal is subjected to a preliminary process for two purposes-to place its energy in a more desirable form and to recover valuable products. If power is produced by the use of either coke or gas from process-fuel plants the value of the remaining products, when credited to the cost of such fuels, is not sufficient to reduce the cost below that of raw coal. As certain by-products are essential in time of war regardless of cost, however, it is desirable in selecting a site for a superpower plant. to provide space for a processing plant.

Accordingly, provision is made in the estimated costs for base-load steam-electric plants both for the location of process-fuel plants and for boiler-room construction that will permit the use of process fuel at a later date if it is found advisable.

\section{SOURCES OF PROCESS FUELS.}

Four sources of process fuels for base-load steam-electric plants have been consideredby-product coke-oven plants furnishing coke, by-product coke-oven plants furnishing gas, low-temperature distillation plants furnishing semicarbocoal, and bituminous gas producers furnishing gas.

The credits used for by-products are as follows:

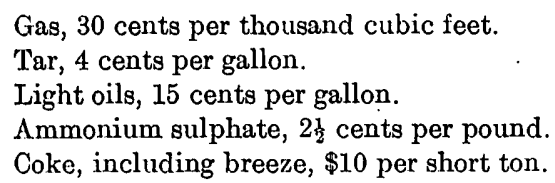

The base-load steam-electric plants for which process fuel will be furnished are assumed to be 300,000-kilowatt plants having an annual capacity factor of 70 per cent. Sufficient process-fuel plant capacity must be provided to meet variations in the load of the steam-electric plants.

$63361^{\circ}-21-15$ 
The average cost of gas coal for carbonization is taken at $\$ 6.11$ per short ton; the cost of Clearfield coal used directly in the power plant is taken at $\$ 6.25$ per short ton.

For process-fuel plants the unit operating cost exclusive of fuel has been placed at $\$ 1.35$ per short ton of coal carbonized, and the fixed charges have been taken at 20 per cent.

Table 99 gives the result of this study: With the exception of gas from by-product cokeoven plants, process fuel is shown to cost more than coal: Moreover, the heavy investment required for a coke-oven plant producing gas as the process fuel, combined with the transportation difficulties in distributing the by-products, makes its use as a source of process fuel impracticable. The coke produced by one such plant would amount to 26 per cent of the total present coke requirement of the superpower zone, and even if the existing coke-producing facilities in the zone are ignored, it would require only four plants of this size to satisfy the entire coke demand of the zone. Furthermore, over 760 special railroad cars daily would be required to distribute the coke output of one such plant to its market and at the same time about 590 cars additional to bring the coal to the plant. Compared to this, only about 70 cars a day would be needed to convey coal to the 300,000-kilowatt steam-electric plant burning raw coal.

For low-temperature distillation plants the by-products have been credited at $\$ 4.22$ per short ton of coal carbonized, which is 28 cents less than the credits claimed by the Carbo Coal Co., but this difference is immaterial, because to make this process profitable under present conditions more than $\$ 5.15$ per short ton of coal carbonized must be realized from the byproducts. Although the carbocoal process has been selected for analysis, as it is further advanced technically than any of the, other low-temperature distillation processes, semicarbocoal has not yet been used extensively in large power plants.

It is fundamentally necessary, where the processing of fuel is combined with the production of power, that a minimum number of heat units be lost to the steam-electric plant. Tar, oils, and ammonium sulphate contain relatively few heat units, and therefore in the recovery of these by-products a large portion of the original heat units remain available for making steam.

The results set forth above justify the conclusions given in the preceding section.

\section{USE OF GAS FROM PROCESS-FUEL PLANTS IN INTERNAL-COMBUSTION ENGINES.}

Gas engines have a higher thermal efficiency than prime movers that use steam, but they are so deficient in other characteristics that they can not at present be considered for superpower plants. The gas engine has not been developed in units of a size comparable with steam turbines, and investment and production costs for gas engines are much higher. These disadvantages outweigh the advantage gained by their higher thermal efficiency.

\section{PULVERIZED COAL.}

Pulverized coal has been successfully used in cement kilns and metallurgic furnaces for some time, but it is only in recent years that sufficient progress has been made in its adaptation to boiler furnaces to warrant its consideration. However, no large power plants have used this form of fuel long enough to give a reliable indication of the results.

As the future development of firing pulverized fuel may warrant its substitution for stokers, provision is made in the power station for sufficient combustion-chamber volume to allow the installation to be quickly and cheaply changed. 
Cost.

TABLE 99.-Relative cost of process fuel and of coal for $300,000-k i l o w a t$ base-load steam-electric plants for the superpower system.

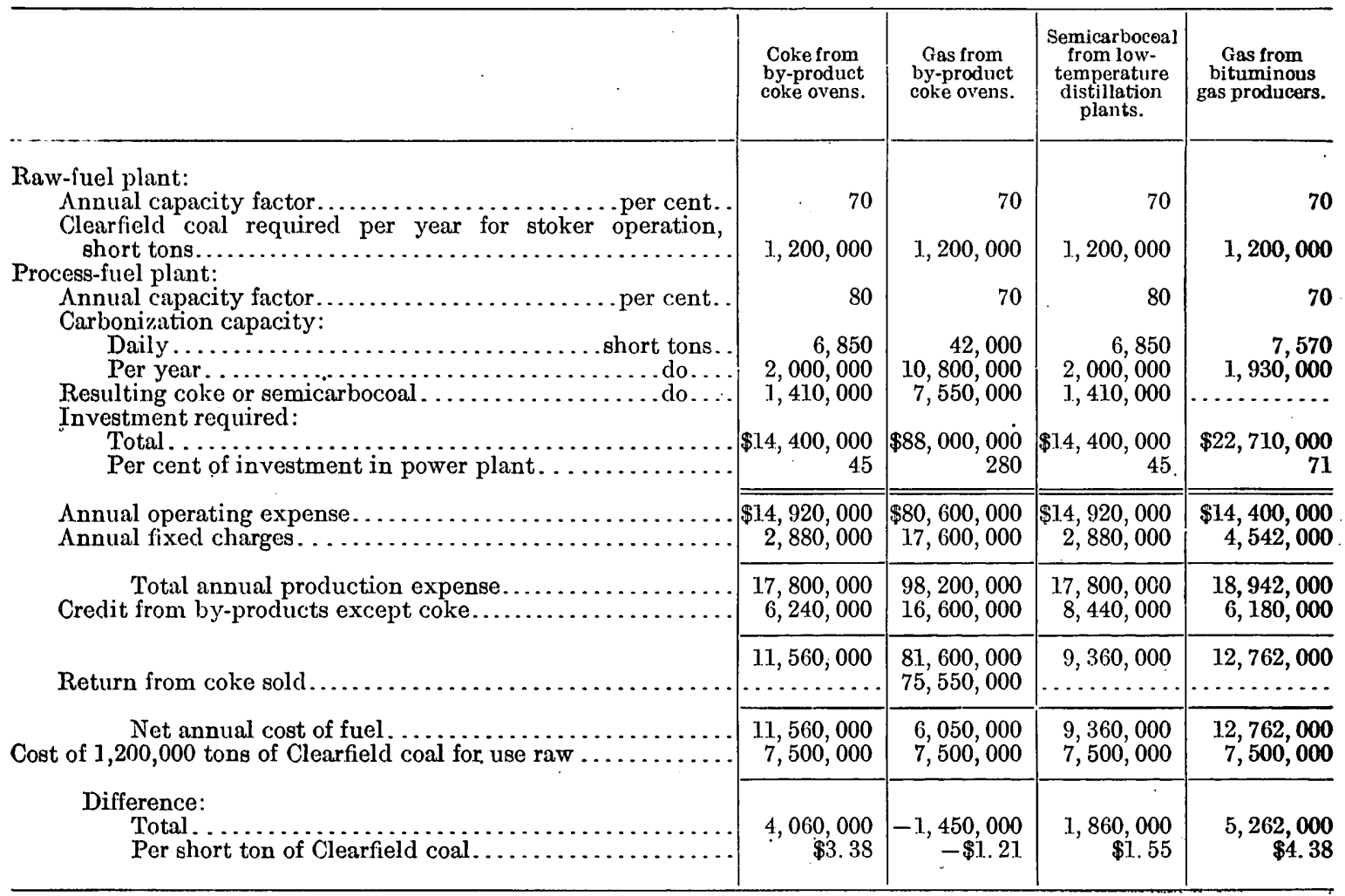




\title{
APPENDIX L. \\ BASIC COSTS.
}

\author{
By the engineering staff.
}

\section{CONSTRUCTION COSTS.}

The costs for labor and materials in construction prevailing at midyear of 1919 are used unless otherwise specified.

\section{FIXED CHARGES AGAINST INVESTMENT:}

Fixed charges against investment have been subdivided into cost of money, depreciation and obsolescence, and taxes and insurance.

Cost of money.-Ten per cent has been taken as the cost of money for investments of all classes. The term "cost of money" is used to express the allowable return upon investment; it includes the rate of interest, discounts, and profit. The resulting final costs are the price at which energy can be sold by the superpower system with proper return upon its investment.

Depreciation and obsolescence.- The charge for depreciation and obsolescence is varied to provide reserves on an annuity basis for the several classes of investment against which it

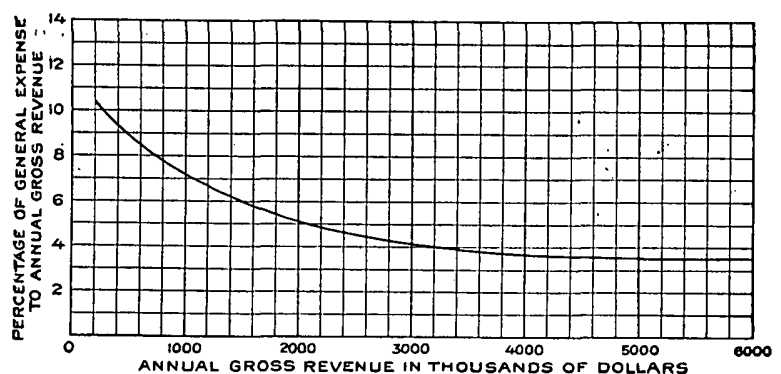

FIGURE 61.-Relation of general expense to annual gross revenue for 60 electric-utility companies in the superpower zone. Amortization fund, interest, taxes, and miscellaneous adjustments have been deducted. is figured. The percentages used are as follows:

Steam-electric power plant ......................... Per cent. Hydroelectric power plants .................. 3 Hydraulic works ........................ 1

Transmission lines ...................... 2

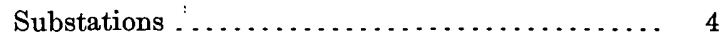

Taxes and insurance.-The following percentages have been used for taxes and insurance:

Steam-ele Per cent.

Complete hydroelectric developments $\ldots \ldots \ldots . . . . .2$

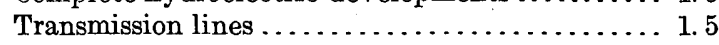

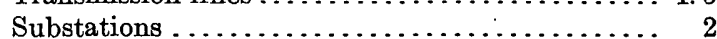

GENERAL EXPENSE.

General expense includes provision for salaries and expenses of administrative officers, engineers, and legal counsel, salaries of clerks, claims, general stationery, printing; and store and stable expenses. Amortization, taxes, and insurance have been included under fixed charges rather than under general expense.

An examination of public-service commission records for 60 electric-utility companies in the superpower zone showed that general expense ranges from about 10.5 per cent for a gross annual revenue of $\$ 200,000$ to about 3.5 per cent for a gross annual revenue of $\$ 5,000,000$ or more, as is shown by figure 61 .

\section{OVERHEAD CHARGES AGAINST CONSTRUCTION.}

The rate used for interest during construction is $7 \frac{1}{2}$ per cent, and this rate applied to the construction period for different classes of work results in the following charges: Steam-electric plants, $4 \frac{1}{2}$ per cent; hydroelectric plants, 6 per cent; transmission lines and substations, 3 per cent. Taxes during construction are figured at 1 per cent. Superintendence, engineering, and contingencies are figured at 15 per cent. 


\title{
APPENDIX M. \\ STATIONS AND TRANSMISSION LINES OF ELECTRIC-POWER COMPANIES ENGAGED IN PUBLIC SERVICE.
}

\author{
By A. H. Horton.
}

The information given on Plate XI (in pocket) has been obtained from the power companies in the following manner: A proof map showing the stations and transmission lines of the public-utility companies in each State included in the superpower zone was prepared from the best information that could be obtained. A section of this map showing the stations and transmission lines operated by each company was sent to that company, which was requested to examine the map and report to the Geological Survey any errors detected or any changes that should be made. From the corrections and additions thus received a revised map of each State was prepared. The location of the power stations and transmission lines of those companies which did not reply to requests for information was determined from available published sources.

The maps were prepared to be published as separate State maps, and the accompanying map of the northeastern United States has been produced from these State maps by photolithography. The general outline of the superpower zone is shown on the map. In some of the congested areas in and around the large cities it was not possible to show all the power stations and transmission lines! However, the names and addresses of the companies that produce electricity for public use are shown in the following list, which includes the names of all companies in each State, even though only a portion of the State is shown on the map. The information on the map for New England and New York represents conditions in 1919; for Pennsylvania, New Jersey, Maryland, the District of Columbia, and Delaware, 1920; and for Virginia, 1921.

In this list the names of the operating companies are arranged in alphabetic order, and the corresponding file numbers assigned to them are in general arranged in numerical order. These file numbers are those used by the Geological Survey in its list of public utilities engaged in the production or distribution of electric energy. Where the numerical order conflicts with the alphabetic order the latter is followed, but the file number is repeated in the proper place, with the name of the operating company. Disarrangement of the numerical order is due to changes in the ownership of companies and to the inclusion in the list of certain manufacturing companies which sell for public use a part of the current they generate for manufacturing and which are distinguished by a different system of file numbers. The generating stations of a company that operates more than one station are indicated by letters (A, B, C, etc.) placed after the file numbers, as 5905-A; the substations of a company that operates more than one substation are indicated by prefixing figures $(1,2,3$, etc.) to the file numbers, as 1-5985. The file number assigned to a company added to the list after consecutive numbers had been assigned to companies preceding and following it consists of the preceding number with a figure added, as 5985-1. A file number that contains more than four digits indicates a company that is not engaged primarily in producing electric power or not operated as a public utility. 
TABLE 100.-Electric-power companies engaged in public service. in the States in which the superpower: zone is situated.

Connecticut.

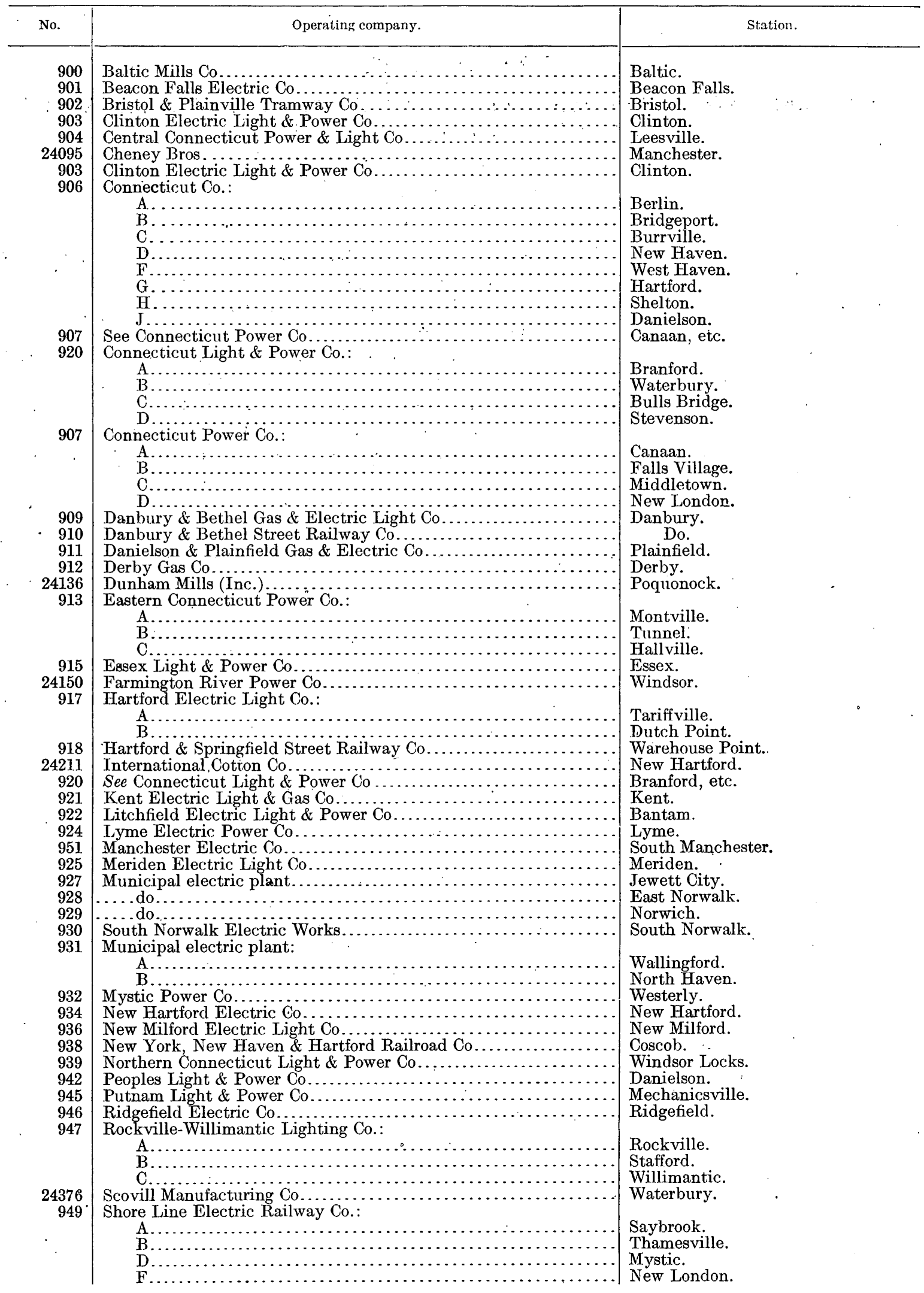


TABLe 100.-Electric-power companies engaged in publịc service in the States in. which the superpower zone is situated-Con.

Connecticut-Continued.

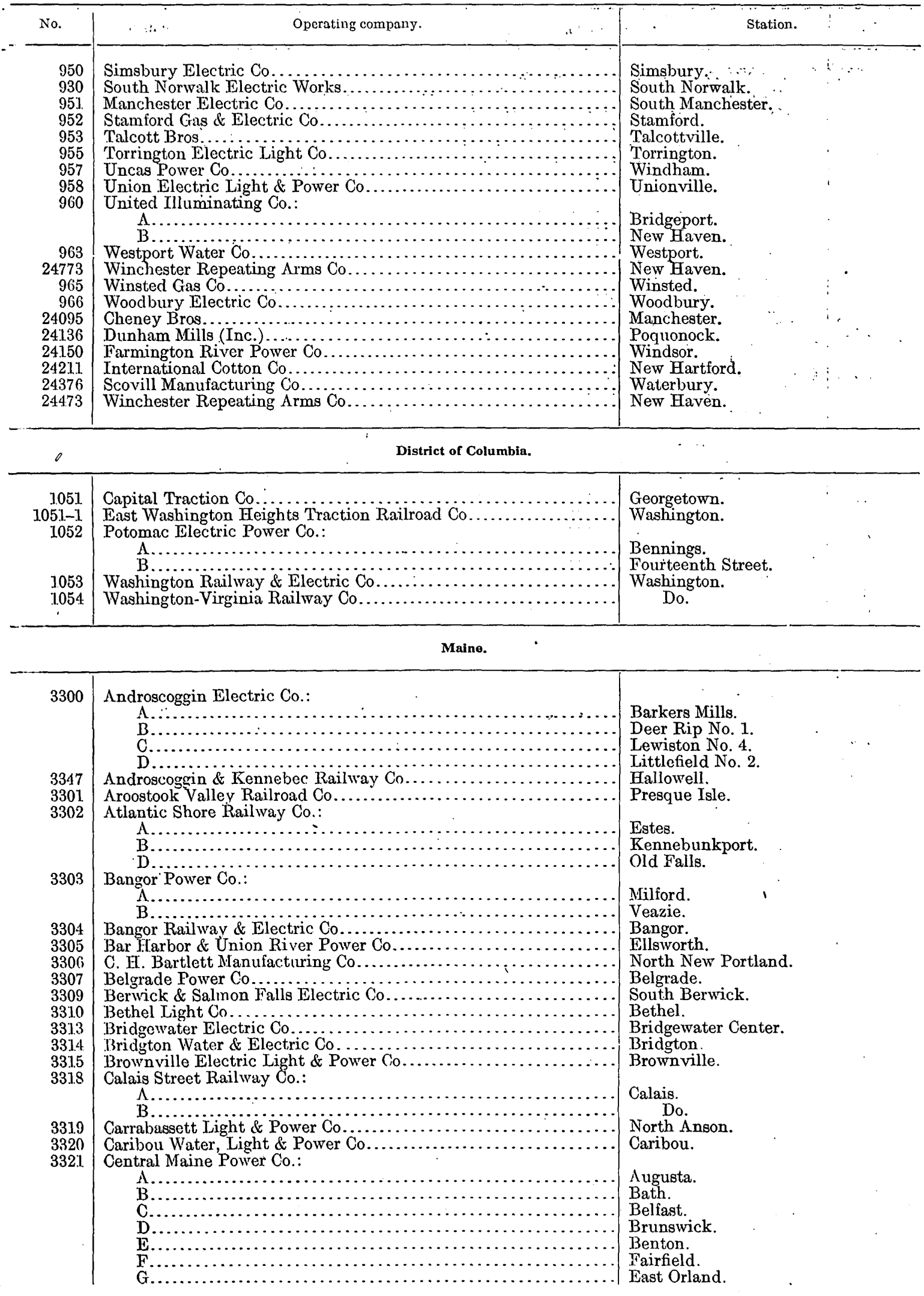




\section{A SUPERPOWER SYSTEM FOR THE REGION BETWEEN BOSTON AND WASHINGTON.}

TABLE 100.-Electric-power companies engaged in public service in the States in which the superpower zone is situated-Con.

Maine-Continued.

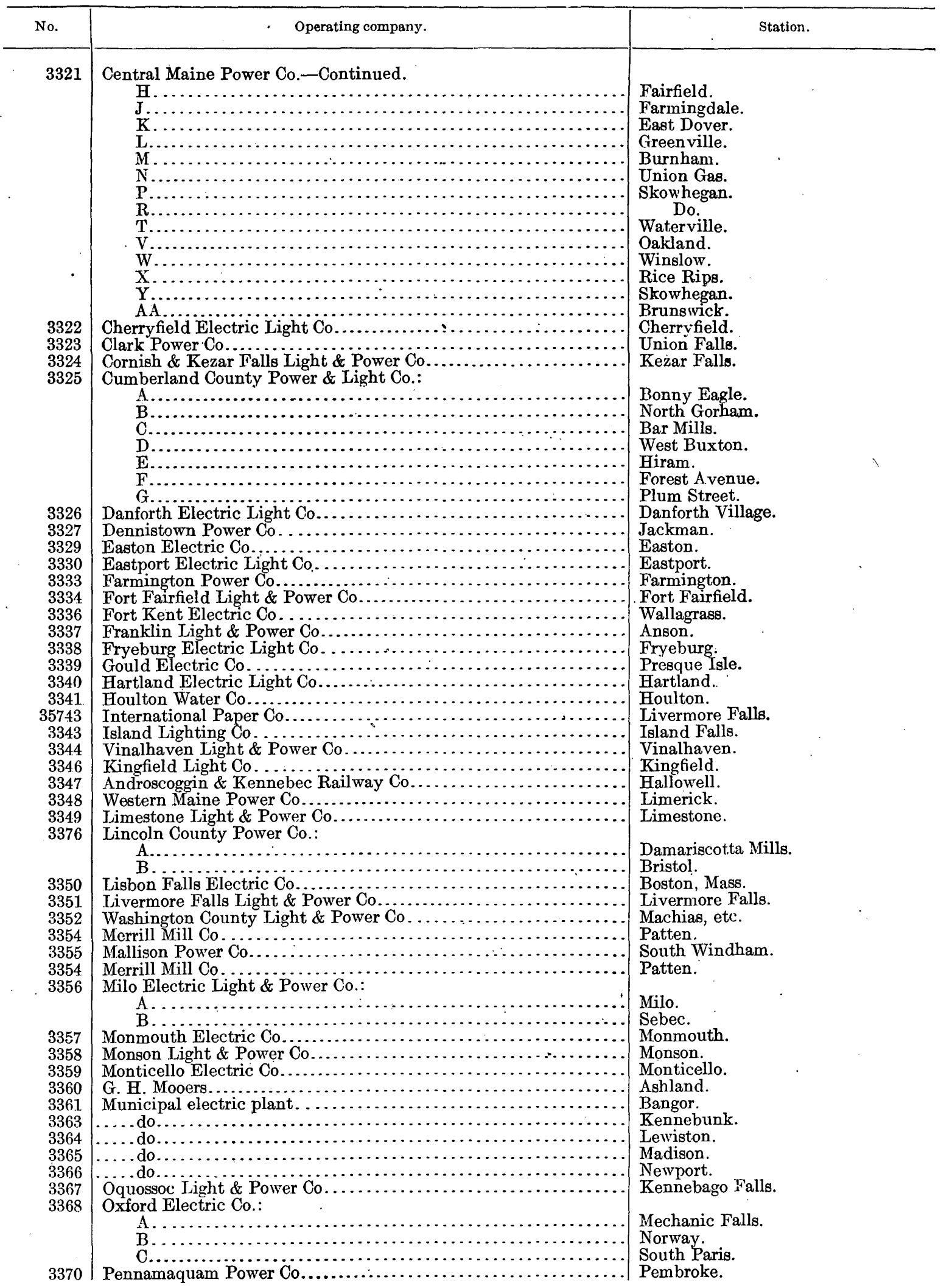


TABLE 100.-Electric-power companies engaged in public service in the States in which the superpower zone is situated-Con.

Maine-Continued.

\begin{tabular}{|c|c|c|c|}
\hline No. & Operating company. & Station. & \\
\hline $\begin{array}{r}3379 \\
3382 \\
3383 \\
3385 \\
3388 \\
3389 \\
3390 \\
3391 \\
3391-1 \\
3392 \\
3344 \\
3352\end{array}$ & 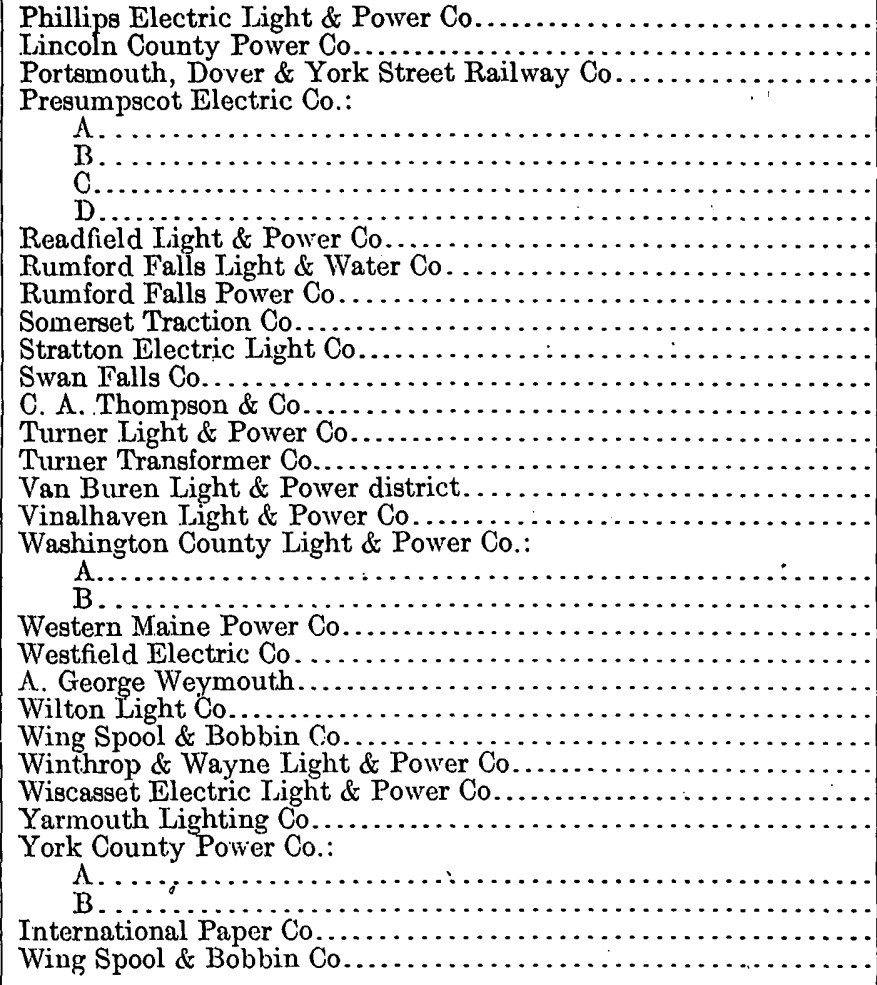 & $\begin{array}{l}\text { Phillips. } \\
\text { Damariscotta Mills, etc. } \\
\text { Kittery Point. } \\
\text { Dundee. } \\
\text { Eel Weir. } \\
\text { Saccarappa. } \\
\text { Smelt Hill. } \\
\text { Readfield. } \\
\text { Rumford. } \\
\text { Do. } \\
\text { Skowhegan. } \\
\text { Eustis. } \\
\text { Pryeburg. } \\
\text { New Sharon. } \\
\text { Turner. } \\
\text { South Turner. } \\
\text { Van Buren. } \\
\text { Vinalhaven. } \\
\\
\text { Machias. } \\
\text { Pleasant River. } \\
\text { Limerick. } \\
\text { Westfield. } \\
\text { Farmington Falls. } \\
\text { Wilton. } \\
\text { Kingfield. } \\
\text { Winthrop. } \\
\text { Wiscasset. } \\
\text { Yarmouth. } \\
\text { Biddeford. } \\
\text { Sanford. } \\
\text { Livermore Falls. } \\
\text { Kingfield. }\end{array}$ & . \\
\hline $\begin{array}{l}3500 \\
3501 \\
3502 \\
3504 \\
3505 \\
3506 \\
3508\end{array}$ & 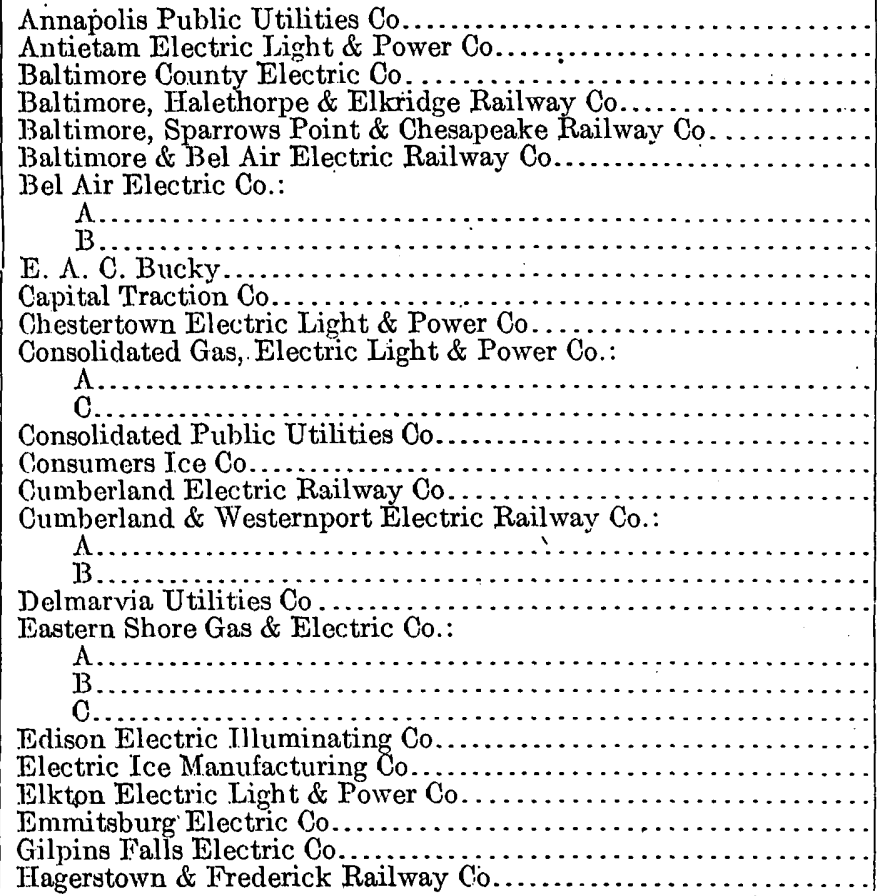 & $\begin{array}{l}\text { Annapolis. } \\
\text { Breathedsville. } \\
\text { Baltimore. } \\
\text { Do. } \\
\text { Do. } \\
\text { Bel Air. } \\
\text { Bel Air No. 1. } \\
\text { Bel Air No. } 2 . \\
\text { Union Bridge. } \\
\text { Chevy Chase. } \\
\text { Chestertown. } \\
\text { Ilchester. } \\
\text { Westport. } \\
\text { Westminster. } \\
\text { Crisfield. } \\
\text { Cumberland. } \\
\text { Clarysville. } \\
\text { Reynolds. } \\
\text { Ocean City. } \\
\text { Denton (hydroelectric). } \\
\text { Salisbury. } \\
\text { Denton (steam). } \\
\text { Cumberland. } \\
\text { Pocomoke City. } \\
\text { Elkton. } \\
\text { Emmitsburg. } \\
\text { Gilpins Falls. } \\
\text { Security. }\end{array}$ & \\
\hline
\end{tabular}


TABLE 100.-Electric-power companies engaged in public service.in the States in. which the superpower zone is situated-Con.

Maryland-Continued.

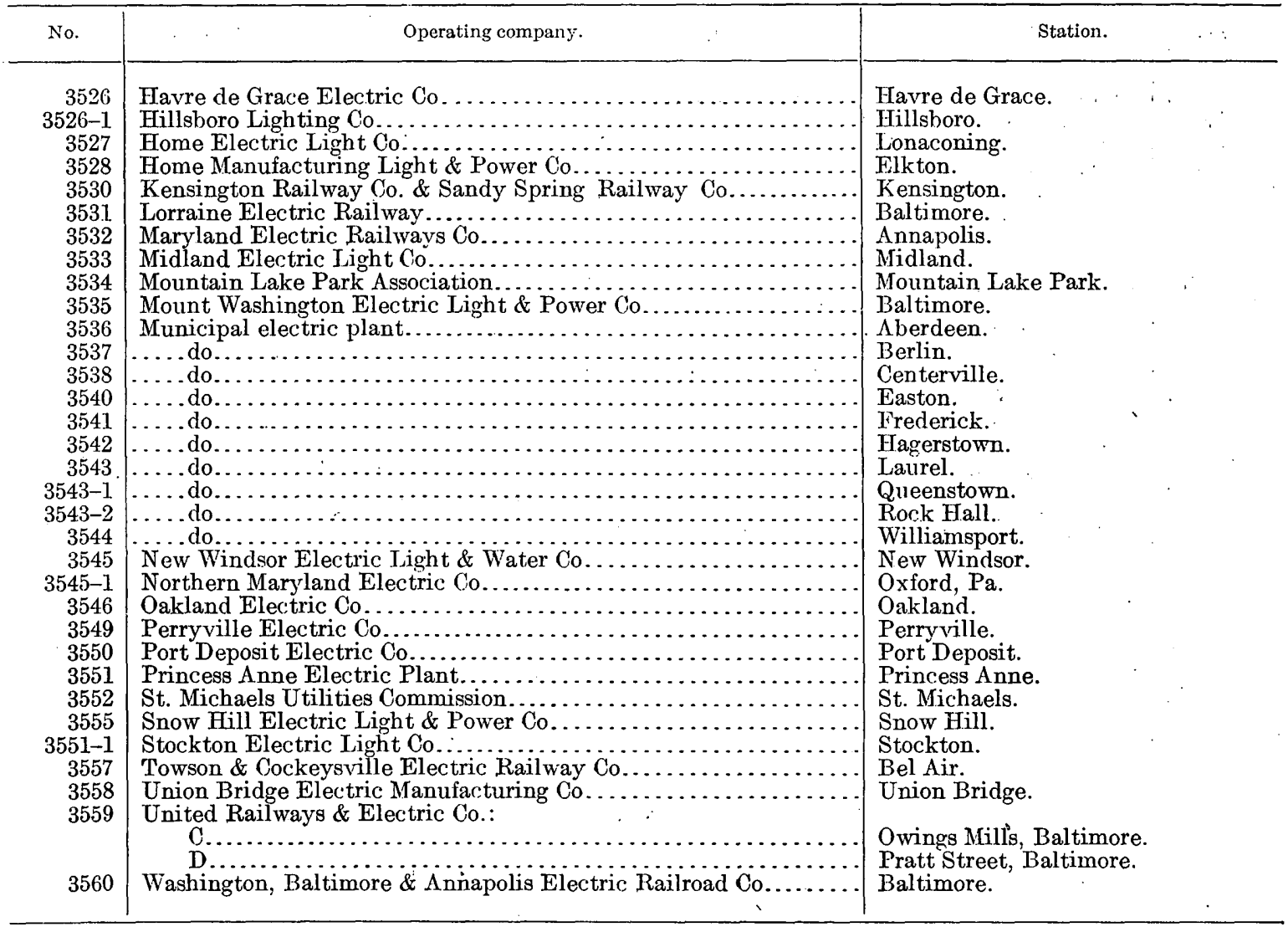

Massachusetts.

\begin{tabular}{|c|c|c|}
\hline 3601 & Agawam Electric Co. & Springfield. \\
\hline 3602 & American Woolen Co.... & Maynard. \\
\hline 3603 & Amesbury Electric Light Co......... & Amesbury. \\
\hline 3604 & Amherst Gas Co............... & Amherst. \\
\hline 3605 & Athol Gas \& Electric Co.: & \\
\hline & B... & Wendell Depot. \\
\hline & C... & Farley. \\
\hline 3607 & Attleboro Steam \& Electric Co. & Attleboro. \\
\hline 3608 & Ayer Electric Light Co.................... & Ayer. \\
\hline 3609 & Eastern Massachusetts Street Railway Co.............. & Byfield, etc. \\
\hline 3610 & Berkshire Street Railway Co.: & \\
\hline & B... & \\
\hline 3611 & Beverly Gas \& Electric Co... & erly. \\
\hline 3612 & Blackstone Electric Light Co.. & Blackstone. \\
\hline 3614 & Blue Hill Street Railroad Co.... & Canton. \\
\hline 3616 & Boston Elevated Railway Co.: & Control \\
\hline & A. & $\begin{array}{l}\text { Central. } \\
\text { Charlestown. }\end{array}$ \\
\hline & & hester. \\
\hline & D. & ridge. \\
\hline & E.. & Li \\
\hline & F. & h Boston. \\
\hline 3618 & Boston \& Worcester Street Railroad Co.... & ingham. \\
\hline 3620 & uth Street Railway Co..... & \\
\hline 3621 & rds Bay Electric Co..... & Fal \\
\hline 3622 & lge Electric Light Co. . & idge. \\
\hline $440-1$ & Cold St & etown \\
\hline 3623 & ic Co.. & rdvill \\
\hline 3626 & Power Co... & iont. \\
\hline 3627 & & WII. \\
\hline
\end{tabular}


TABLE 100.-Electric-power companies engaged in public service in the States in which the superpower zone is situated-Con.

Massachusetts-Continued

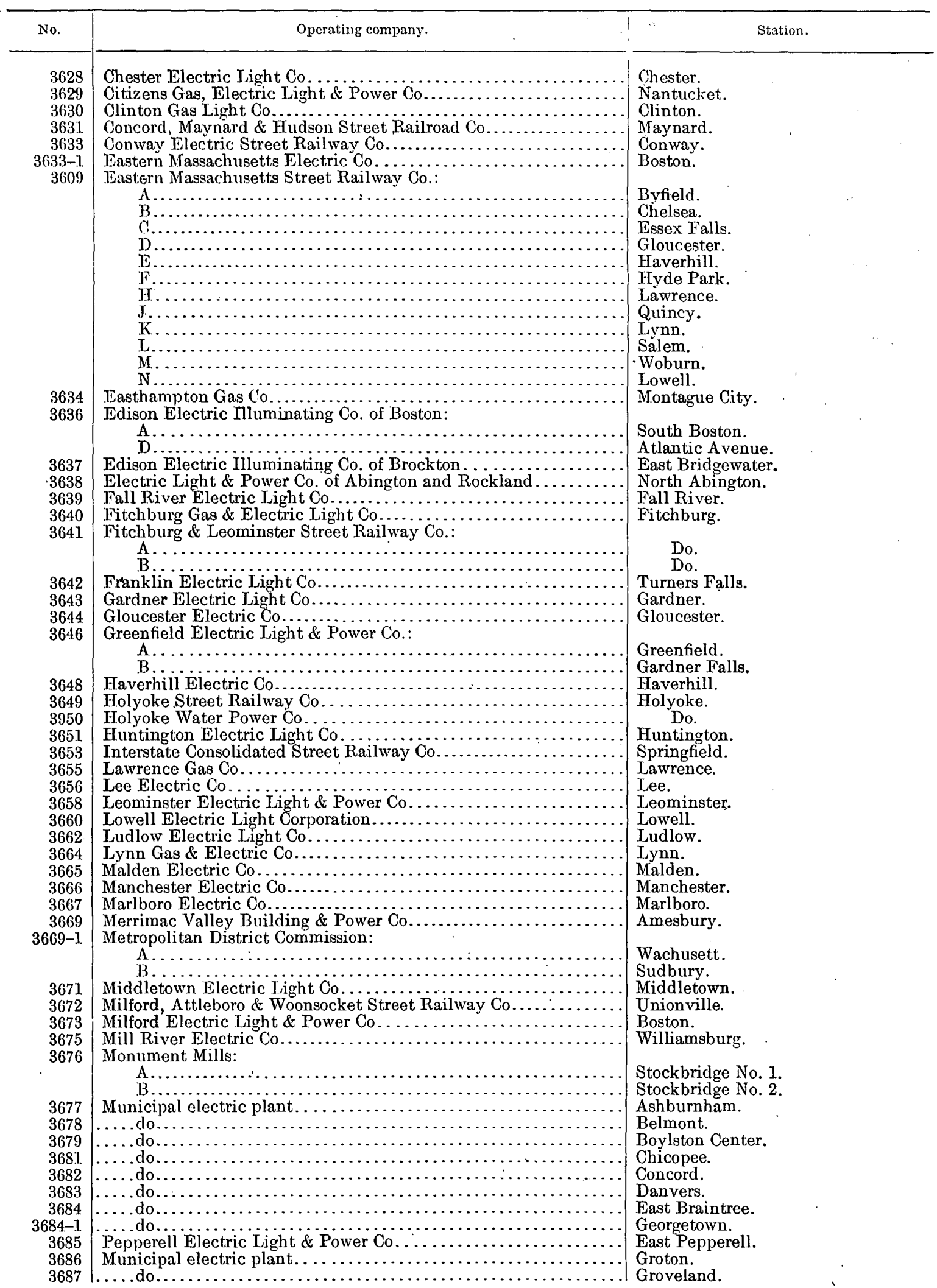


TABLE 100.-Electric-power companies engaged in public service in the States in which the superpower zone is situated-Con.

Massachusetts-Continued.

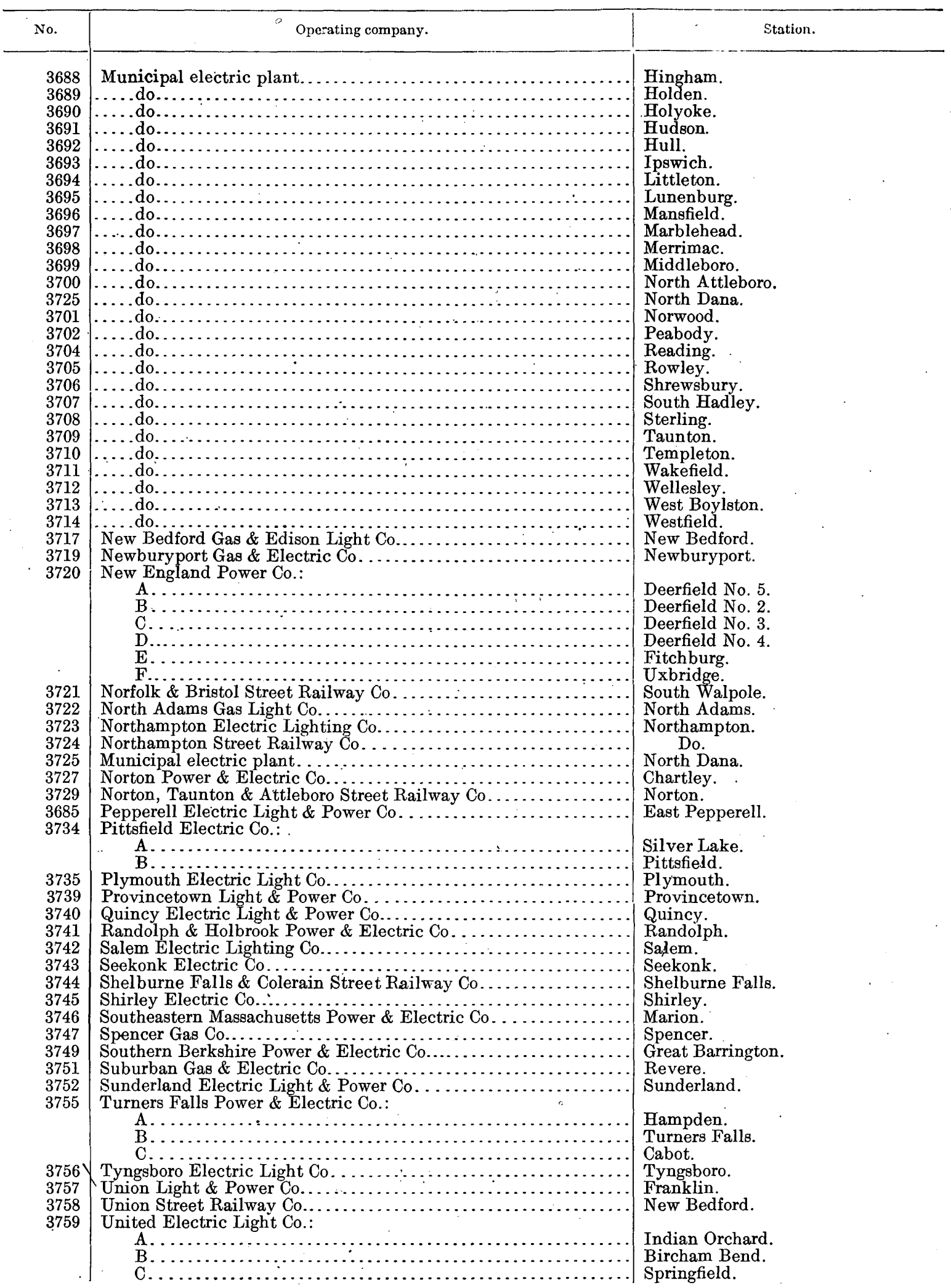


TABLE 100.-Electric-power companies engaged in public service in the States in which the superpower zone is situated-Con.

Massachusetts-Continued.

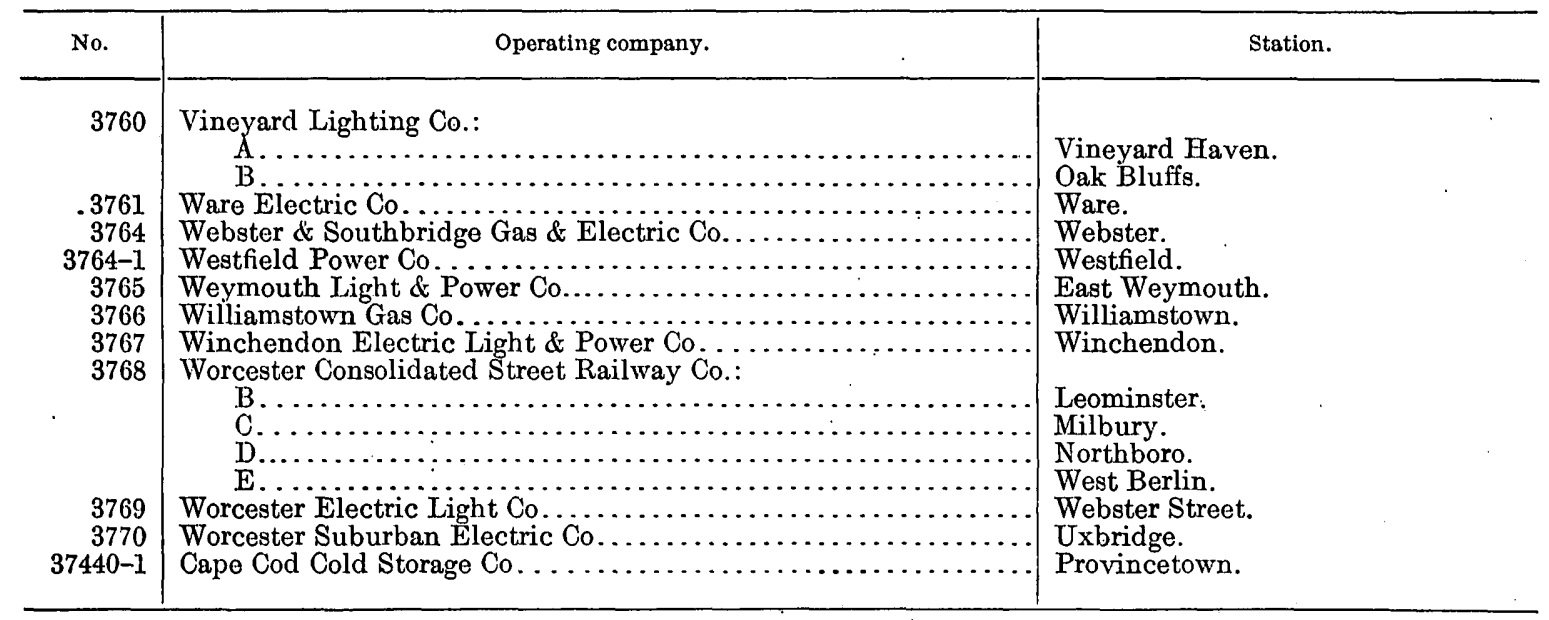

New Hampshire.

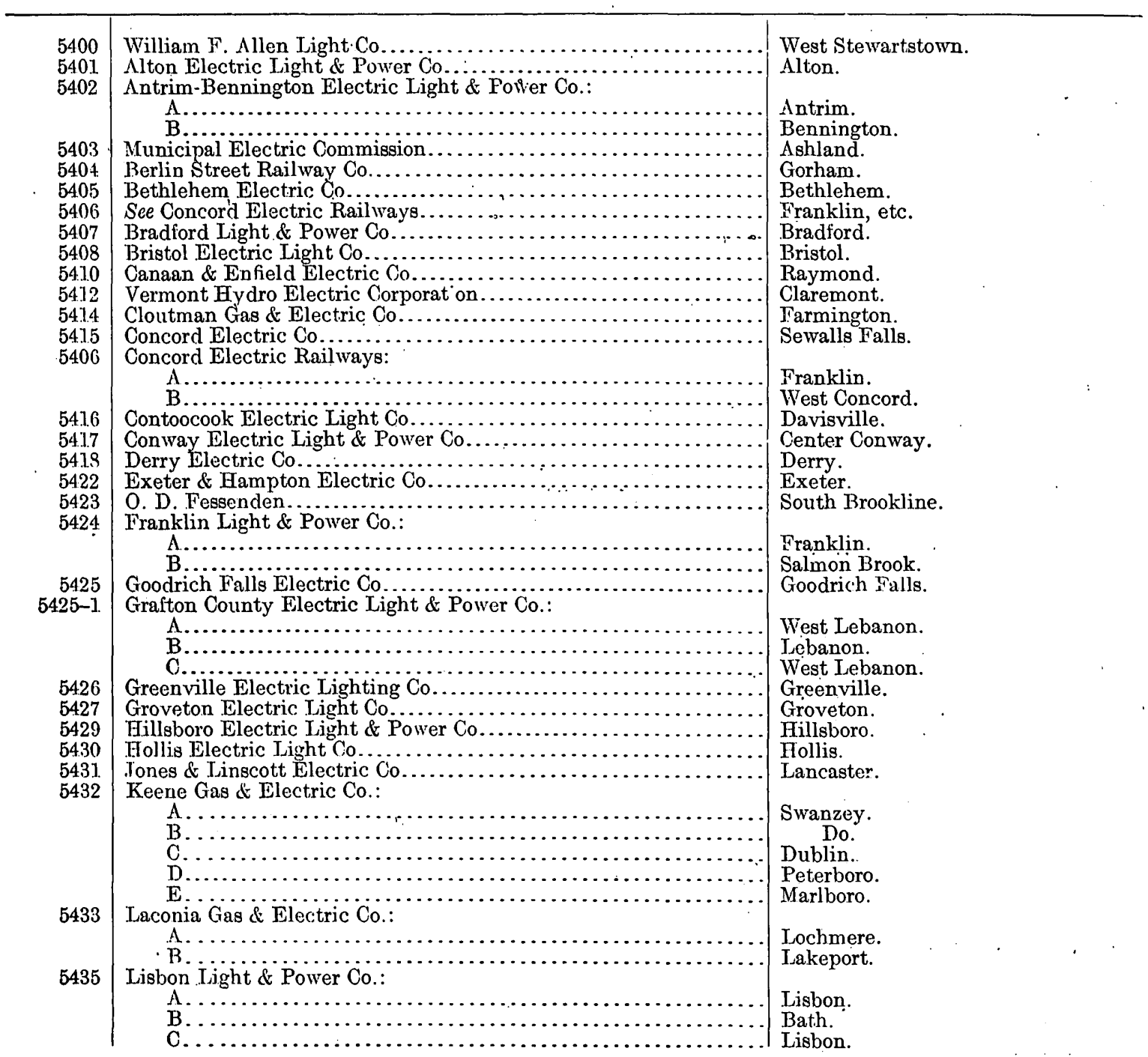


TABLE 100.-Electruc-power companies engaged in public service in the States in which the superpower zone is situated-Con.

New Hampshire-Continued.

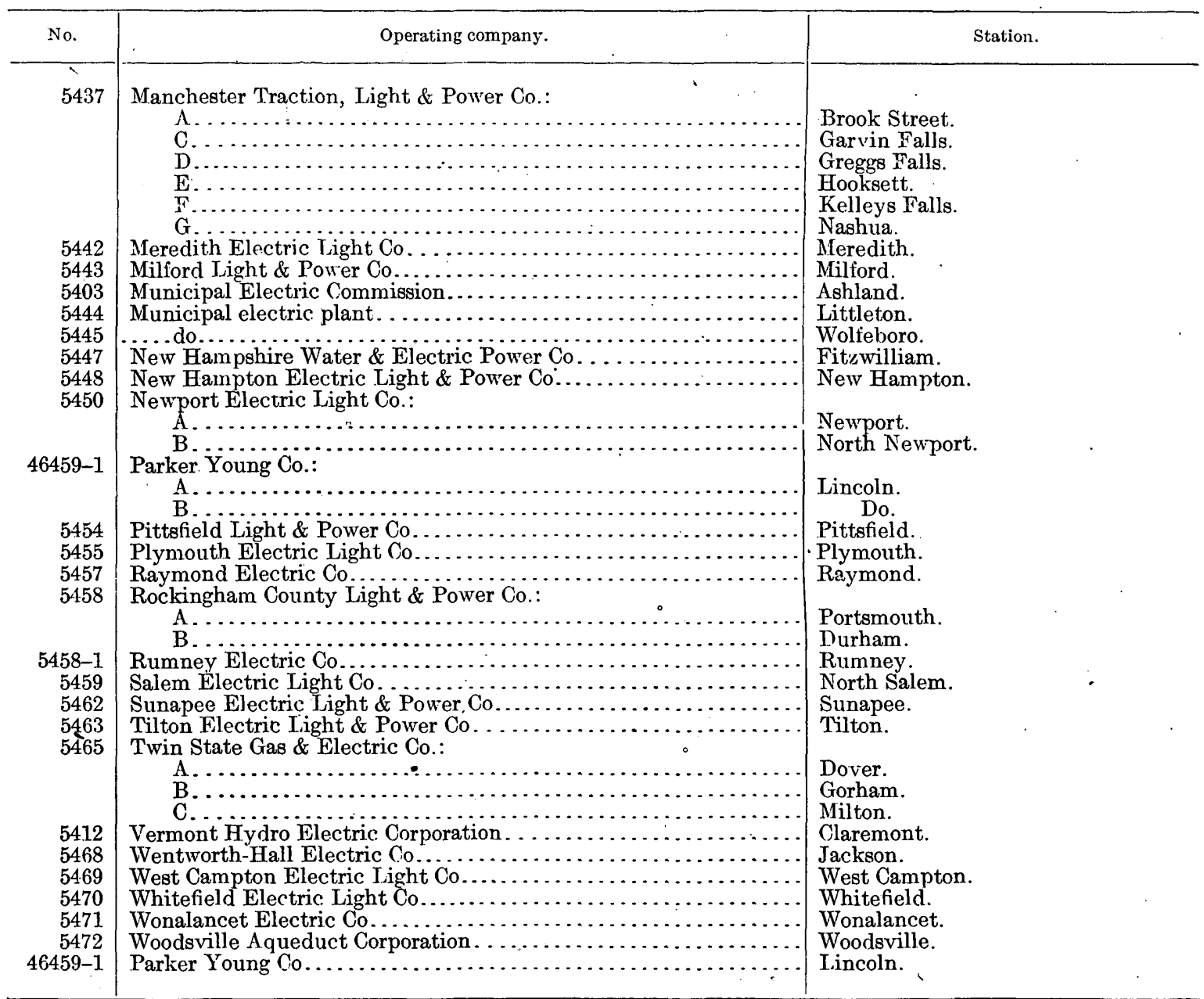

New Jersey.

5500

5502

5503

5504

5505

$5506-1$

5507

5508

5509

5511

5513

5514

5593

5515

5517

5594

5519

5520

5522
Atlantic City Electric Co.:

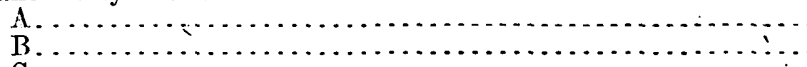

C.

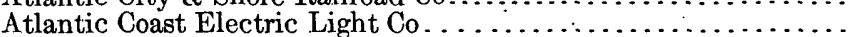

Atlantic Coast Electric Railway Co.

Atlantic County Electric Co...

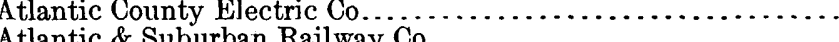

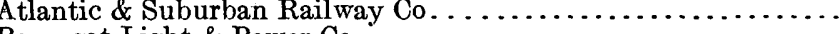

Barnegat Light \& Power Co.

Blair Electric Iight Co

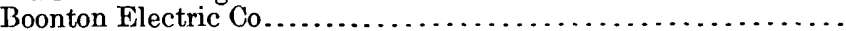

Branchville Electric Power, Water \& Lighting Co..............

Bridgeton \& Millville Traction Co.

Burlington County Transit Co.

Califon Flectric Light \& Power Co...

Cape May Court Hount \& Power Co

Cape May Light \& Power Co.

Central Passenger Railway Co

E. R. Collins \& Son:

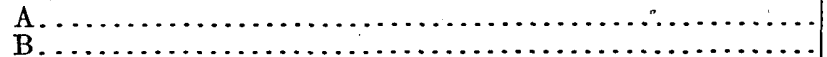

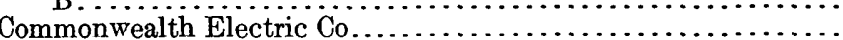

Consolidated Gas Co. of New Jersey

Pennsylvania Utilities Co.
Atlantic City.

Ocean City.

Pleasantville.

Atlantic City

Asbury Park.

Allenhurst.

Egg Harbor.

Pleasantville

Seaside Heights.

Blairstown.

Boonton.

Branchville.

Bridgeton.

Hainesport.

Califon.

Cape May Court House

Cape May.

Atlantic City.

Market Street, Belvidere.

South Water Street, Belvidere

Summit.

Long Branch.

Columbia. 
TABle 100.-Electric-power companies engaged in public service in the States in which the superpower zone is situated-Con.

New Jersey-Continued.

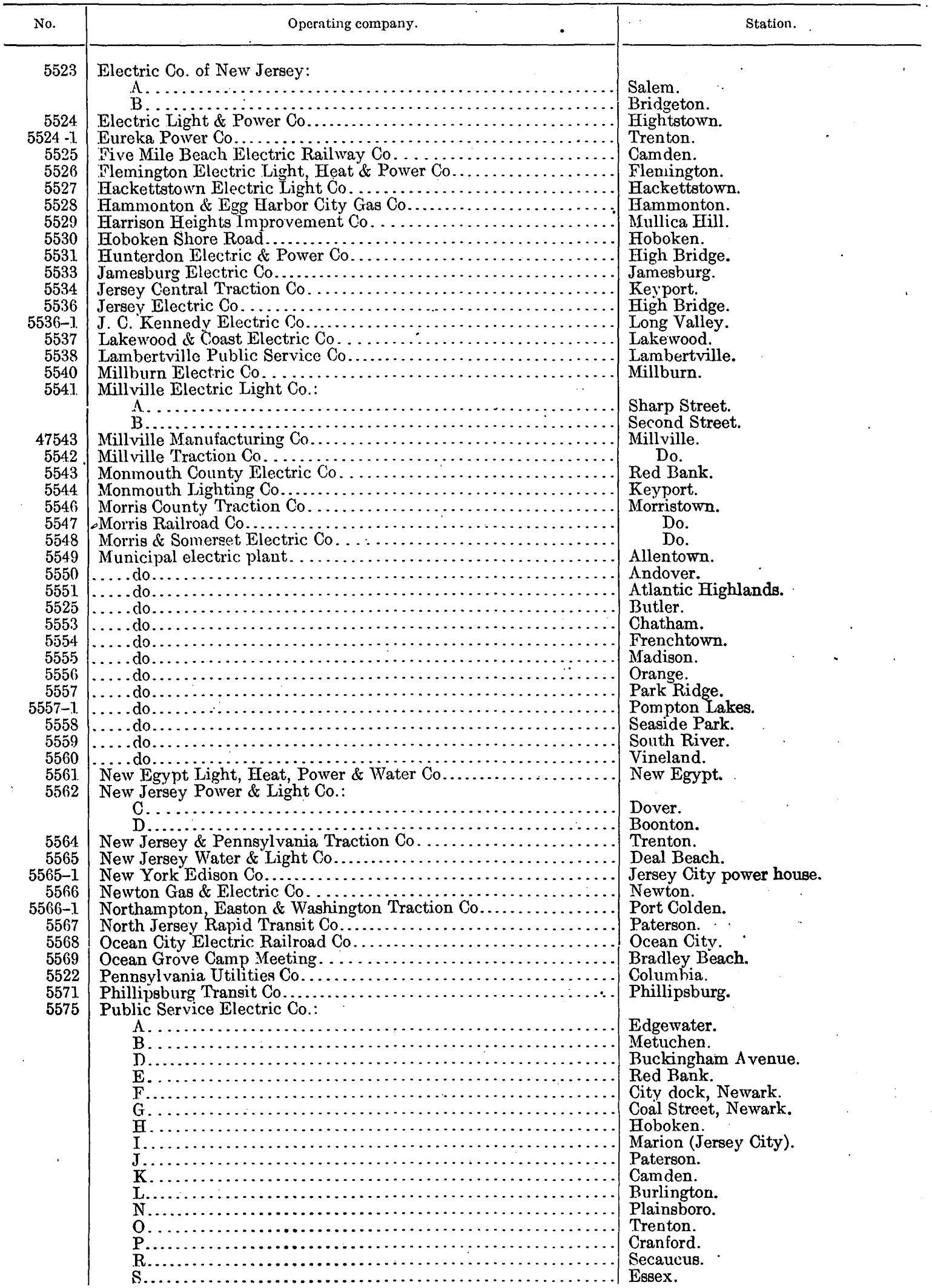


TABLE 100.-Electric-power companies engaged in public service in the States in which the superpower zone is situated-Con. New Jersey-Continued.

\begin{tabular}{|c|c|c|}
\hline No. & Operating company. & Station. \\
\hline 5576 & Public Service Railway Co...................... & Newark: \\
\hline 5577 & Rockland Electric Co. of New Jersey & Gloucester. \\
\hline 47551 & Sayre \& Fisher Co. & Sayreville. \\
\hline 5580 & Sayreville Electric Light \& Power Co......................... & Do. \\
\hline 5581. & 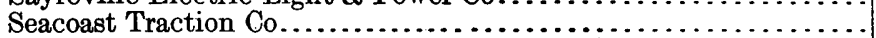 & Seagirt. \\
\hline 5582 & Sea Isle City Electric Light, Power \& Water Co. . . . . . . . . . . . . & Sea Isle City. \\
\hline 5584 & Stone Harbor Electric Light \& Power Co..................... & Stone Harbor. \\
\hline 5587 & Toms River Electric & Toms River. \\
\hline 5588 & Trenton, Lakewood \& Seacoast Railway . . . . . . . . . . . . . . . & Trenton. \\
\hline 5589 & Trenton, Iawrenceville \& Princeton Railroad Co................. & Do: \\
\hline 5590 & Trenton \& Mercer Co. Traction Corporation. . . . . . . . . . . . & Do. \\
\hline 5591 & Trenton Street Railway Co. . . . . . . . . . . . . . & Do. \\
\hline 5598 & 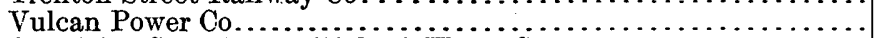 & Netcong. \\
\hline 5593 & Cape May Court House Light \& Water Co......... & Cape May Court House. \\
\hline 5594 & $\begin{array}{r}\text { E. R. Collins \& Son: } \\
\text { A. } \ldots \ldots \ldots \ldots \ldots \ldots \ldots \ldots \\
\text { B }\end{array}$ & $\begin{array}{l}\text { Market. Street, Belvidere. } \\
\text { South Water Street, Belvidere. }\end{array}$ \\
\hline 5595 & Washington Electric Co. & Washington. \\
\hline 5596 & West Jersey Electric Co............. & Wildwood. \\
\hline 5597 & West Jersey \& Seashore Railroad Co............. & Westville. \\
\hline 5598 & Vulcan Power Co $\ldots \ldots \ldots \ldots \ldots \ldots \ldots \ldots \ldots \ldots$ & Netcong. \\
\hline 5600 & Woodbine Land \& Improvement Co......... & Woodbine. \\
\hline 5601 & Woodbourne Electric Light, Heat \& Power Co. & Woodbourne. \\
\hline 47543 & 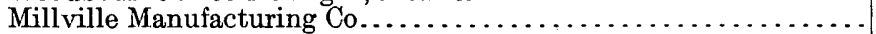 & Mill ville. \\
\hline 47551 & 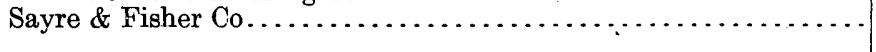 & Sayreville. \\
\hline
\end{tabular}

New York.

5800 Adams Electric Light Co

5801

6180

Addison Electric Light \& Power Co.

Adirondack Power \& Light Corporation

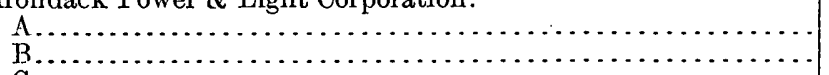

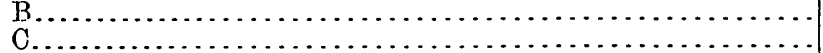

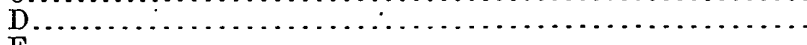

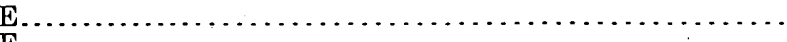

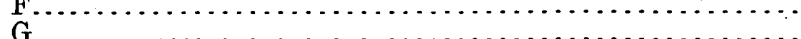

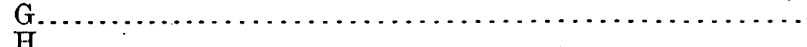

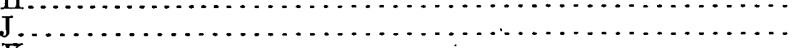

K

L

5804

5805

5806

5807

5809

5811

5812

5813

5814

5817

5946

5821

5822

5823

5824

5825-1

5826

5827

5828

5893

5832

5833

583
Adrian Kinitting Co

Afton-Windsor Light, Heat \& Power Co. (Inc.) ... . . . . . . . . .

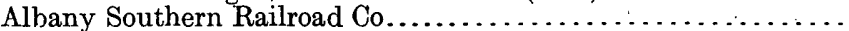

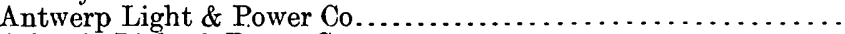

Atlantic Light \& Power Co.

Auburn \& Syracuse Electric Railroad. . . . . . . . . . . . . . . . . .

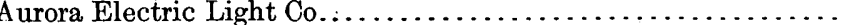

Ausable Valley Light, Heat \& Power Co.....................

Avon Electric Co...

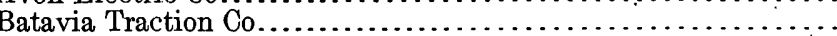

Berkshire Street Railway Co

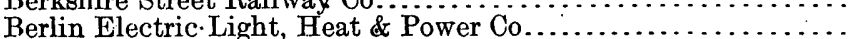

Binghamton Light, Heat \& Power Co.:

A.

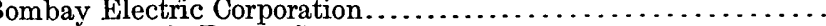

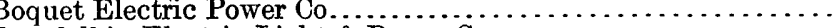

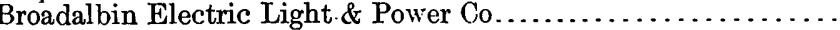

Bronx Gas \& Electric Co. . . . . . . . . . . . . . . . . . . . . . . .

Brooklyn Edison Co.

Brooklyn Rapid Transit Co.:

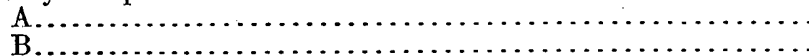

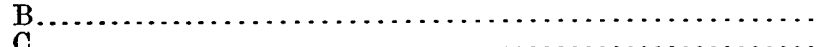

ryant Power Co. (Inc.).

Buffalo General Electric Co
Adams.

Addison.

Johnsonville.

Schaghticoke.

East Creek.

Inghams Mills.

Mechanicsville.

Schoharie Falls.

Spier Falls.

Utica.

Kanes Falls.

North Granville.

Granville.

Sanquoit.

Center Village.

Stuyvesant Falls.

Antwerp.

Coeymans.

Syracuse.

Aurora.

Keene.

Avon.

Batavia.

Walloomsac.

Berlin.

Binghamton.

Johnson City.

Binghamton.

Watertown.

Bombay.

Essex.

Broadalbin.

Bronx.

Gold Street.

Central Power.

Williamsburg.

Ninth Street.

Buffalo.

Do. 
TABLE 100.-Electric-power companies engaged in public service in the States in which the superpower zone is 'stuated-Con.

New York-Continued.

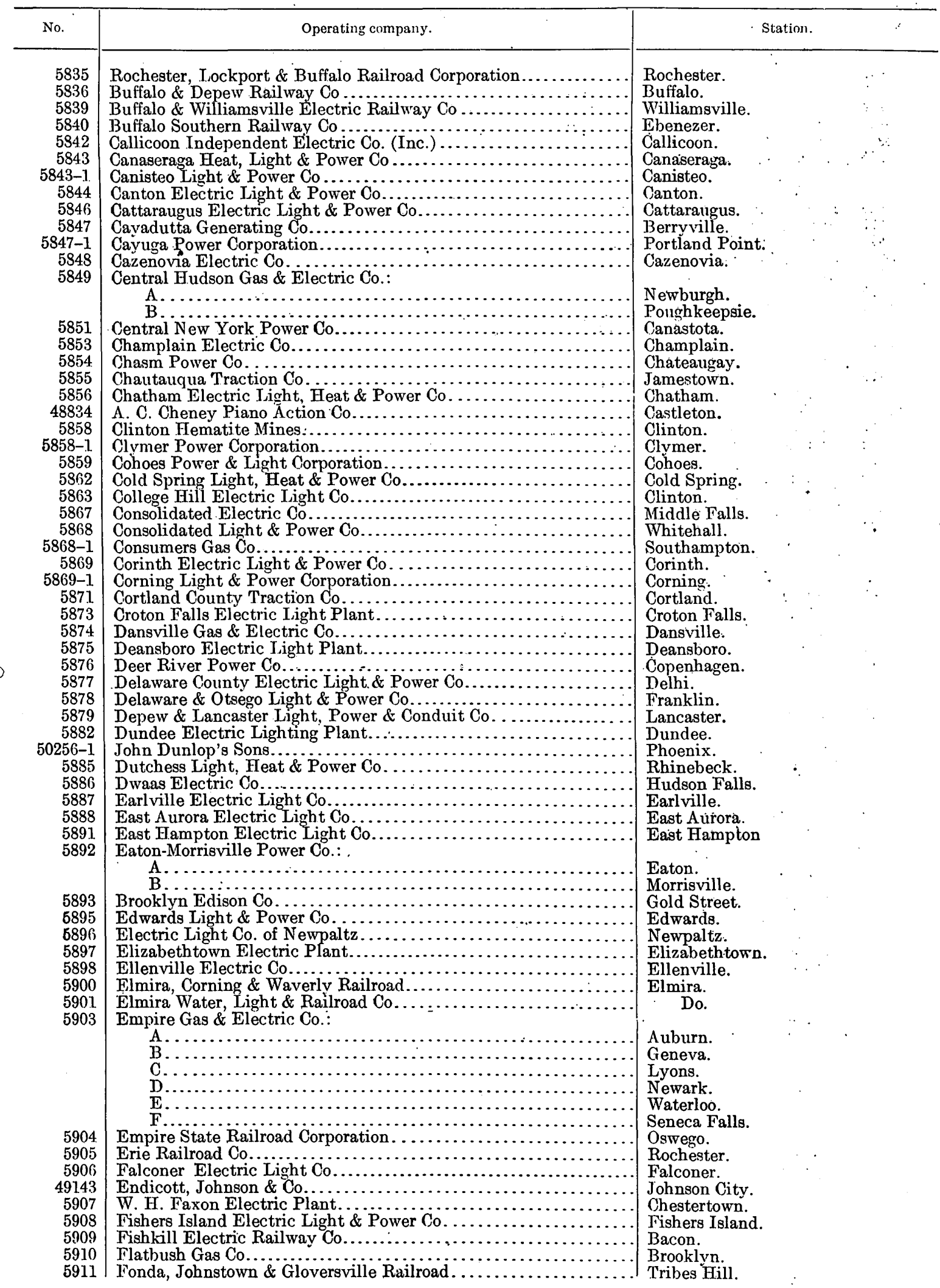

$63361^{\circ}-21-16$ 
TABLE 100.-Electric-power companies engaged in public service in the States in which the superpower zone is situated-Con.

New York-Continued.

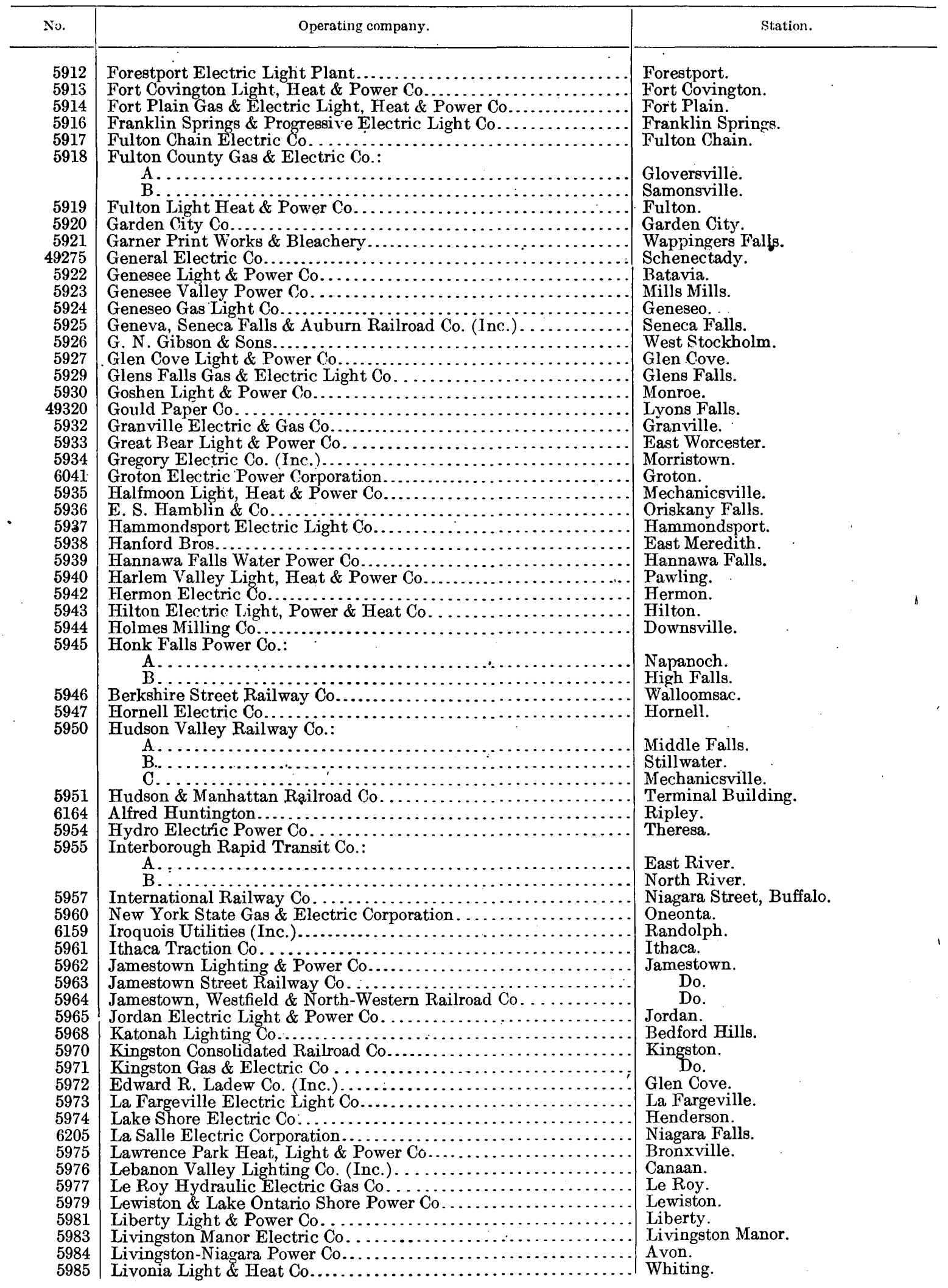


'TABLE 100.-Electric-power companies engaged in public service in' the States in whrch the superpower zone is situated-Con.

New York-Continued.

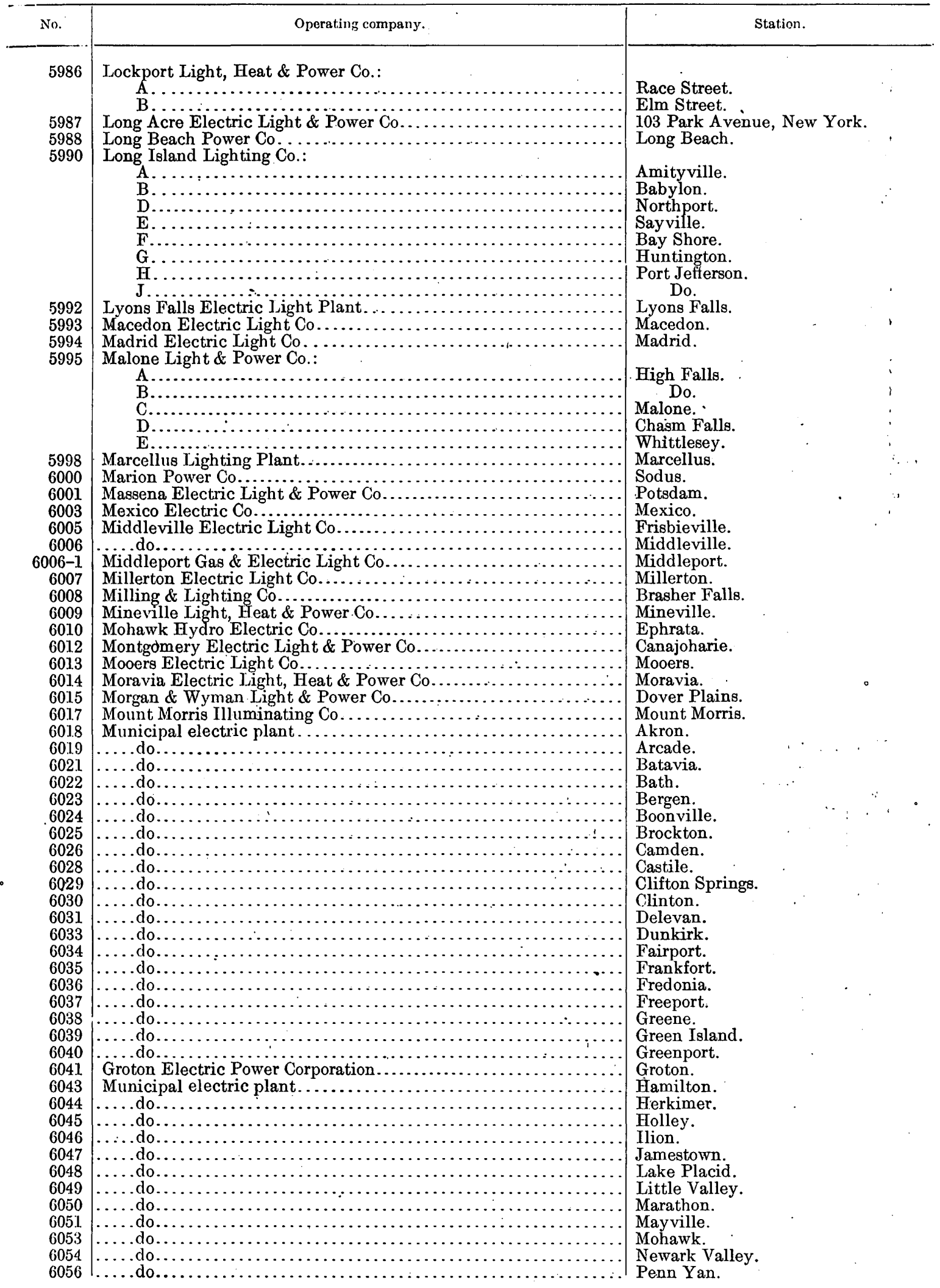


TABLE 100.-Electric-power compantes engaged in public service in the States in which the superpower zone is situated-Con.

New York-Continued.

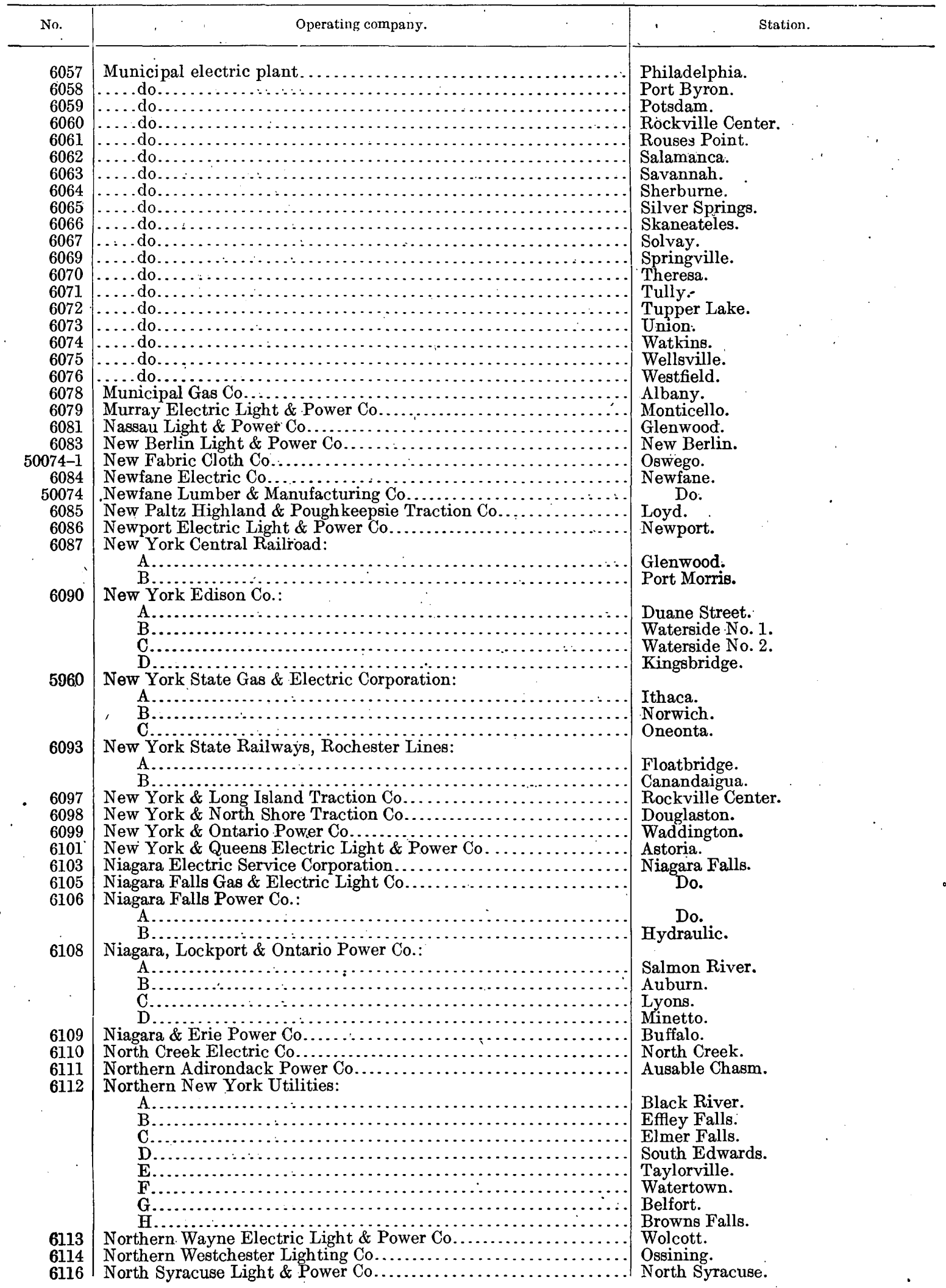


TABLE 100.-Electric-power companies engaged in public service in the States in which the superpower zone is situated-Con.

New York-Continued.

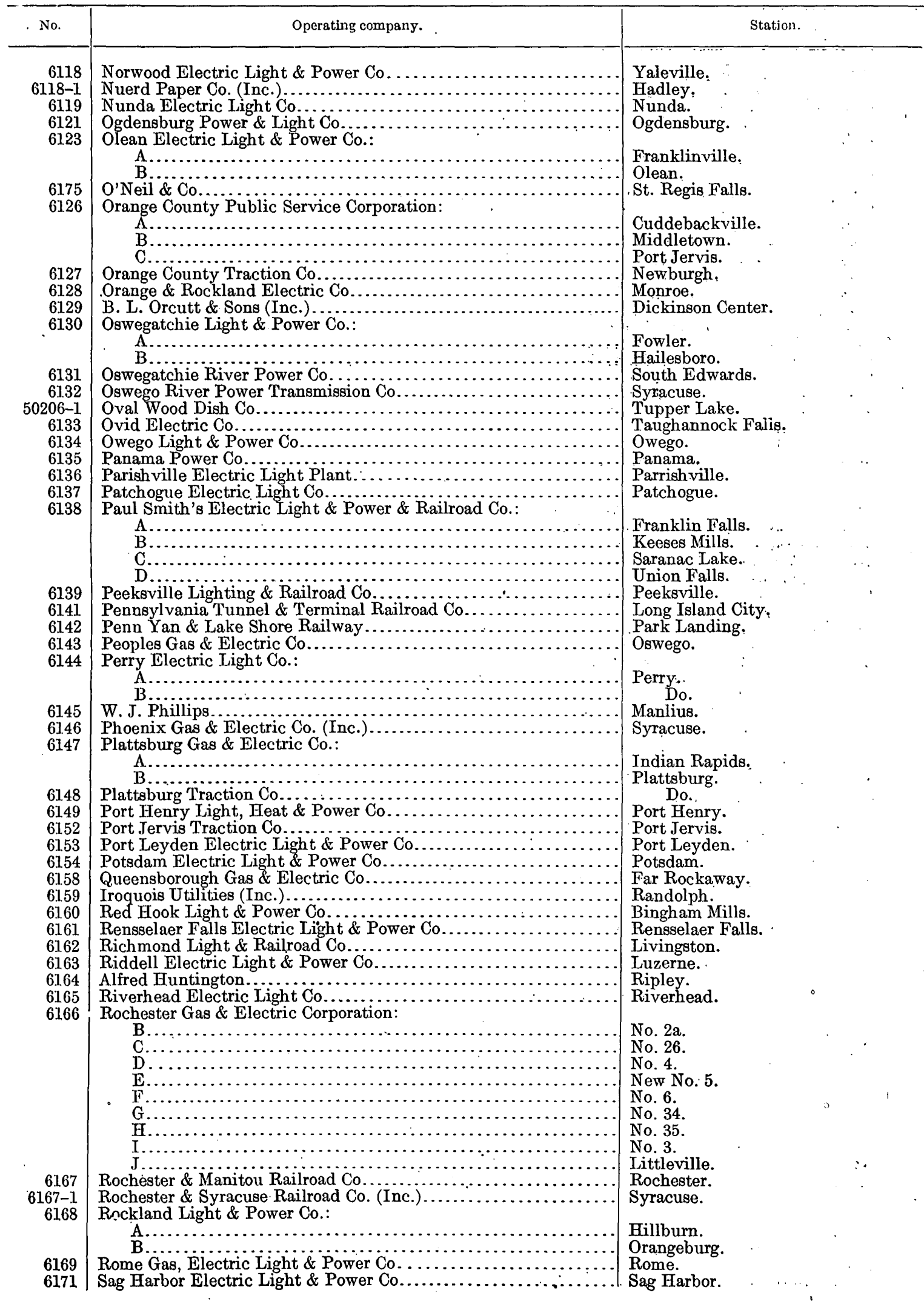


TABLE 100.-Electric-power companies engaged in public service in the States in which the superpower zone is situated-Con.

New York-Continued.

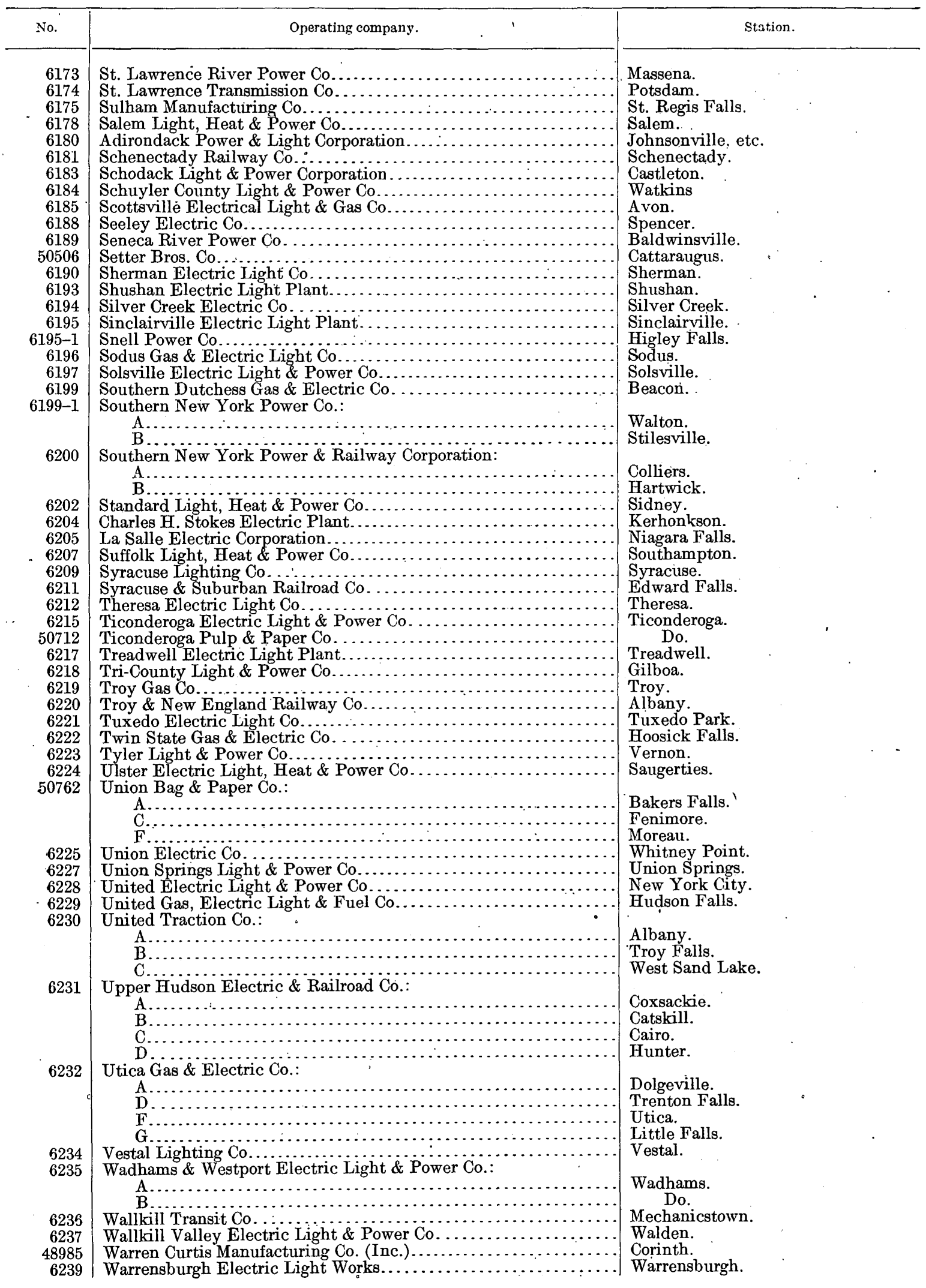


TABLE 100.-Electric-power companies engaged in public service in the States in which the superpower zone is situated-Con.

New York-Continued.

\begin{tabular}{|c|c|c|c|c|}
\hline No. & Operating company. & \multicolumn{3}{|c|}{ Station. } \\
\hline 6240 & Warsaw Gas \& Electric Co..... & \multicolumn{3}{|l|}{ Warsaw. } \\
\hline 6242 & Waterville Gas \& Electric Co.. & \multicolumn{3}{|l|}{ Waterville. } \\
\hline $6242-1$ & 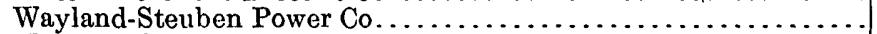 & \multicolumn{3}{|l|}{ Wayland. } \\
\hline 6243 & Waverly, Sayre \& Athens Traction Co.................... & \multicolumn{3}{|l|}{ Waverly. } \\
\hline 6244 & Wayland Light \& Power Co. (Inc.) $\ldots \ldots \ldots \ldots$ & \multicolumn{3}{|l|}{ Wayland. } \\
\hline $6242-1$ & 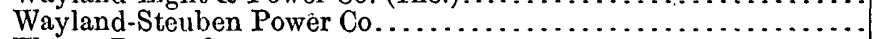 & Do. & & - \\
\hline 6245 & 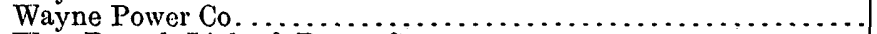 & \multicolumn{3}{|l|}{ Sodus. } \\
\hline 6246 & West Branch Light \& Power Co.: & \multirow{2}{*}{\multicolumn{3}{|c|}{ Stamford. }} \\
\hline & 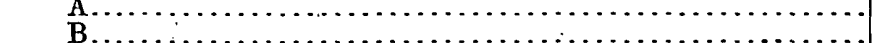 & & & \\
\hline 6248 & Westchester Lighting & \multicolumn{3}{|l|}{ New Rochelle. } \\
\hline 6250 & Western New York Electric Co. & \multicolumn{3}{|l|}{ Jamestown. } \\
\hline 6251 & Western New York Utilities Co.: & \multirow{2}{*}{\multicolumn{3}{|c|}{ Medina. }} \\
\hline & 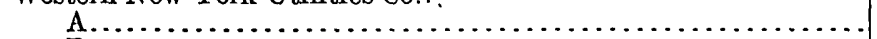 & & & \\
\hline & B............. & \multicolumn{3}{|l|}{ Waterport. } \\
\hline$\cdot$ & 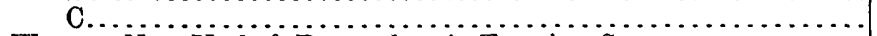 & \multicolumn{3}{|l|}{ Medina. } \\
\hline 6252 & Western New York \& Pennsylvania Traction Co.......... & \multirow{2}{*}{\multicolumn{3}{|c|}{$\begin{array}{l}\text { Ceres. } \\
\text { Carvers Falls }\end{array}$}} \\
\hline $6252-1$ & Western Vermont Power \& Light Co................... & & & \\
\hline 6254 & 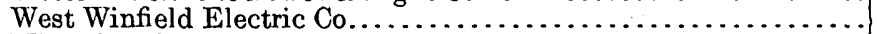 & \multicolumn{3}{|l|}{ West Winfield. } \\
\hline 50946 & Witherbee-Sherman Co.: & \multirow{2}{*}{\multicolumn{3}{|c|}{ Port Henry. }} \\
\hline & 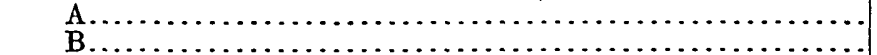 & & & Mineville. \\
\hline 6256 & Worcester Electric Light Plant. & \multicolumn{3}{|l|}{ Worcester. } \\
\hline 6257 & 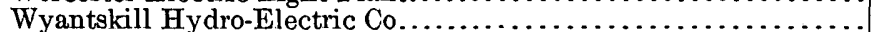 & \multicolumn{3}{|l|}{ Wyantskill. } \\
\hline 6258 & 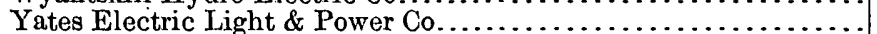 & \multicolumn{3}{|l|}{ Seneca Mills. } \\
\hline $6258-1$ & 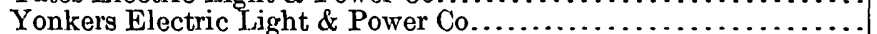 & \multicolumn{3}{|l|}{ New York City. } \\
\hline 48834 & 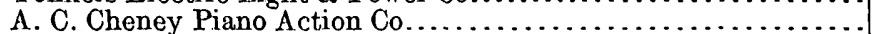 & \multicolumn{3}{|c|}{ Castleton. } \\
\hline 48895 & Warren Curtis Manufacturing Co. (Inc.) $\ldots \ldots \ldots \ldots \ldots \ldots$ & \multicolumn{3}{|c|}{ Corinth. } \\
\hline 49143 & 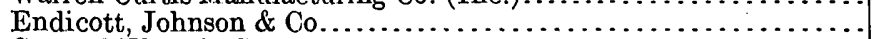 & \multicolumn{3}{|l|}{ Johnson City. } \\
\hline 49275 & 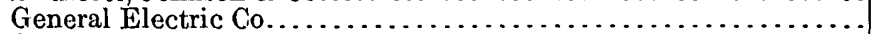 & \multicolumn{3}{|l|}{ Schenectady. } \\
\hline 49320 & 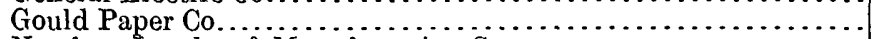 & \multicolumn{3}{|l|}{ Lyons Falls. } \\
\hline 50074 & Newfane Lumber \& Manufacturing Co. . ..... & \multicolumn{3}{|l|}{ Newfane. } \\
\hline $50074-1$ & 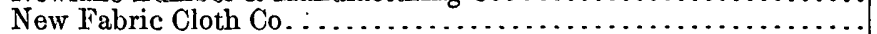 & \multicolumn{3}{|l|}{ Oswego. } \\
\hline 50206 & 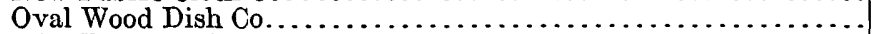 & Tupper Lake. & & \\
\hline $50256-1$ & 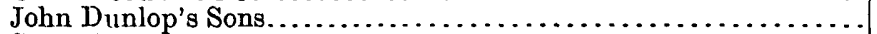 & Phoenix. & & \\
\hline 50506 & 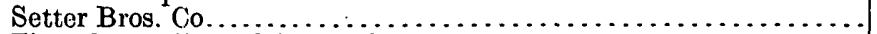 & Cattaraugus. & & \\
\hline 50712 & Ticonderoga Pulp \& Paper Co...................... & Ticonderoga. & & \\
\hline 50762 & 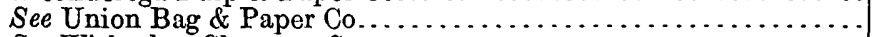 & Bakers Falls, etc. & & \\
\hline 50946 & 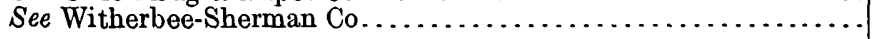 & Port Henry, etc. & & \\
\hline
\end{tabular}

Pennsylvania.

Abington Electric Co

Allegheny Valley Light Co.

Allentown \& Reading Traction Co.

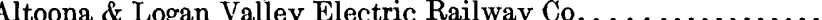

Ambler Electric Light, Heat \& Motor Co. . . . . . . . . . . . . . . .

Annville \& Palmyra Electric Light Co . . . . . . . . . . . . . . . .

Anthracite Power Co

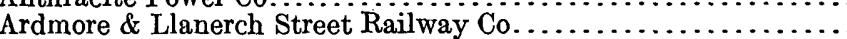

Arendtsville Roller Mills.

Barnor

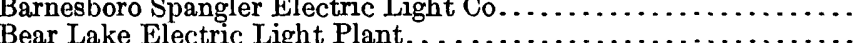

Beaver County Light Co.

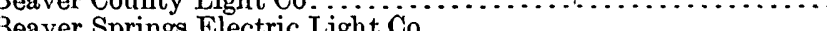

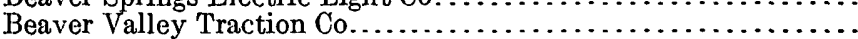

Bedford Electric Light, Heat \& Power $\mathrm{Co}_{\ldots} \ldots \ldots \ldots \ldots \ldots \ldots \ldots \ldots \ldots$

Bala \& Merion Electric Co.

Benton Hydroelectric Co.:

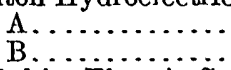

Berkshire Electric Co..........

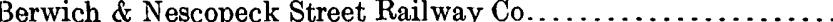

Bethlehem \& Nazareth Passenger Railway Co.................

Big Spring Electric Co. . . . . . . . . . . . . . . . . . . . .

Birdsboro Electric Co.

Blossburg Electric Light \& Power Co

Blue Mountain Electric Co.
Laplume.

Creighton.

Pittsburgh.

Bethlehem.

Reading.

Altoona.

Ambler.

Annville.

Hazleton.

Upper Darby.

Arandtsville.

Bangor.

Barnesboro.

Bear Lake.

Pittsburgh.

Beaver Springs.

New Brighton.

Bedford.

Philadelphia.

Benton

Hydroelectric.

Sinking Spring.

Berwick.

Bethlehem.

Newville.

Birdsboro.

Blossburg.

Bethel. 


\section{A SUPERPOWER. SYSTEM FOR THE REGION BETWEEN BOSTON AND WASHINGTON.}

TABLE 100.-Electric-power companies engaged in public service in the States in which the superpower zone is situated-Con.

Pennsylvania-Continued.

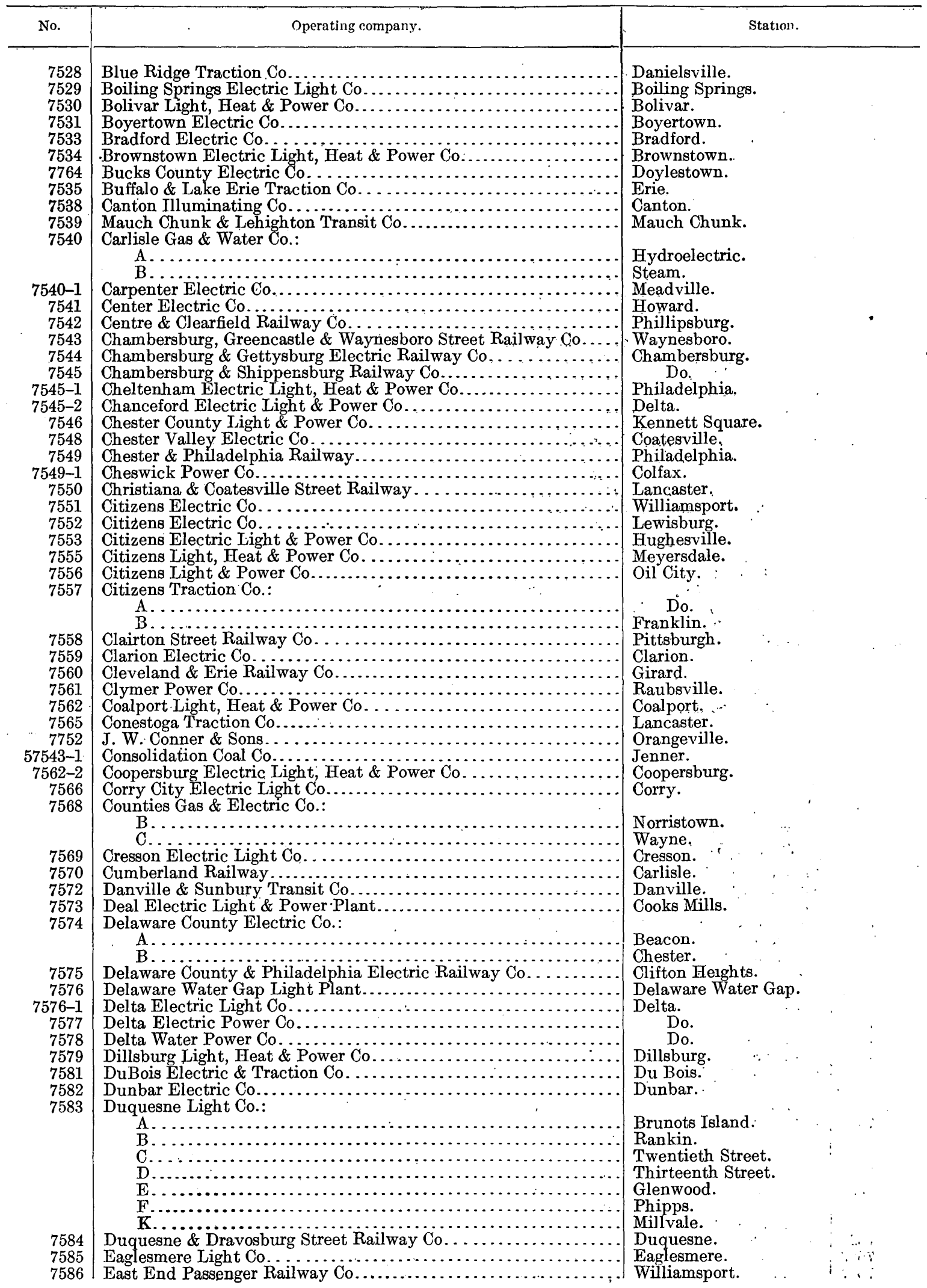


TABLE 100.-Electra-power companies engaged in public service in the States in which the superpower zone is. situated-Con.

Pennsylvania-Continued.

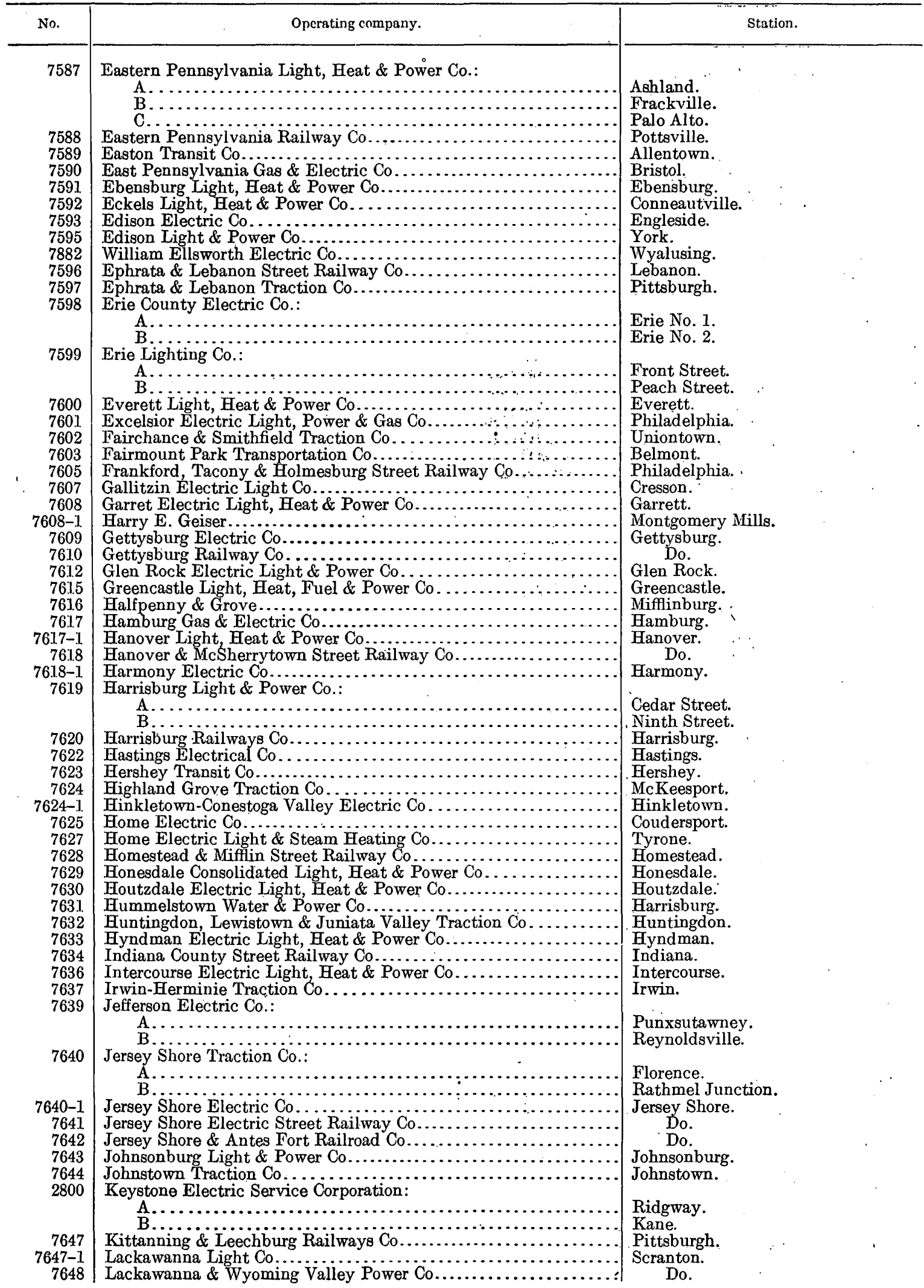


248 A SUPERPOWER SYSTEM FOR THE REGION BETWEEN BOSTON AND WASHINGTON.

TABLE 100.-Electric-power companies engaged in public service in the States in which the superpower zone is situated-Con. Pennsylvania-Continued.

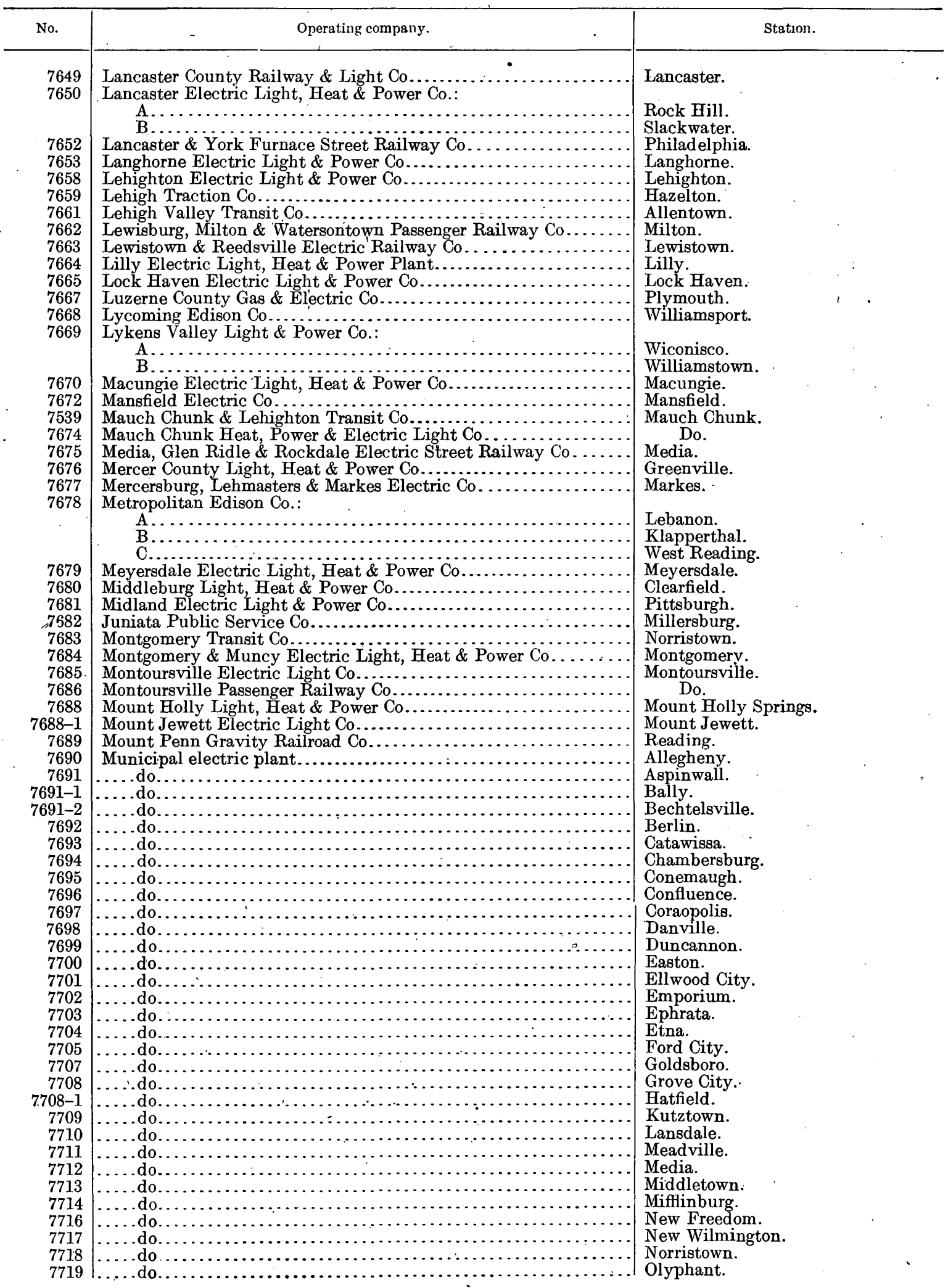


TABLE 100.-Electric-power companies engaged in public service in the States in which the superpower zone is situated-Con.

Pennsylvania-Continued.

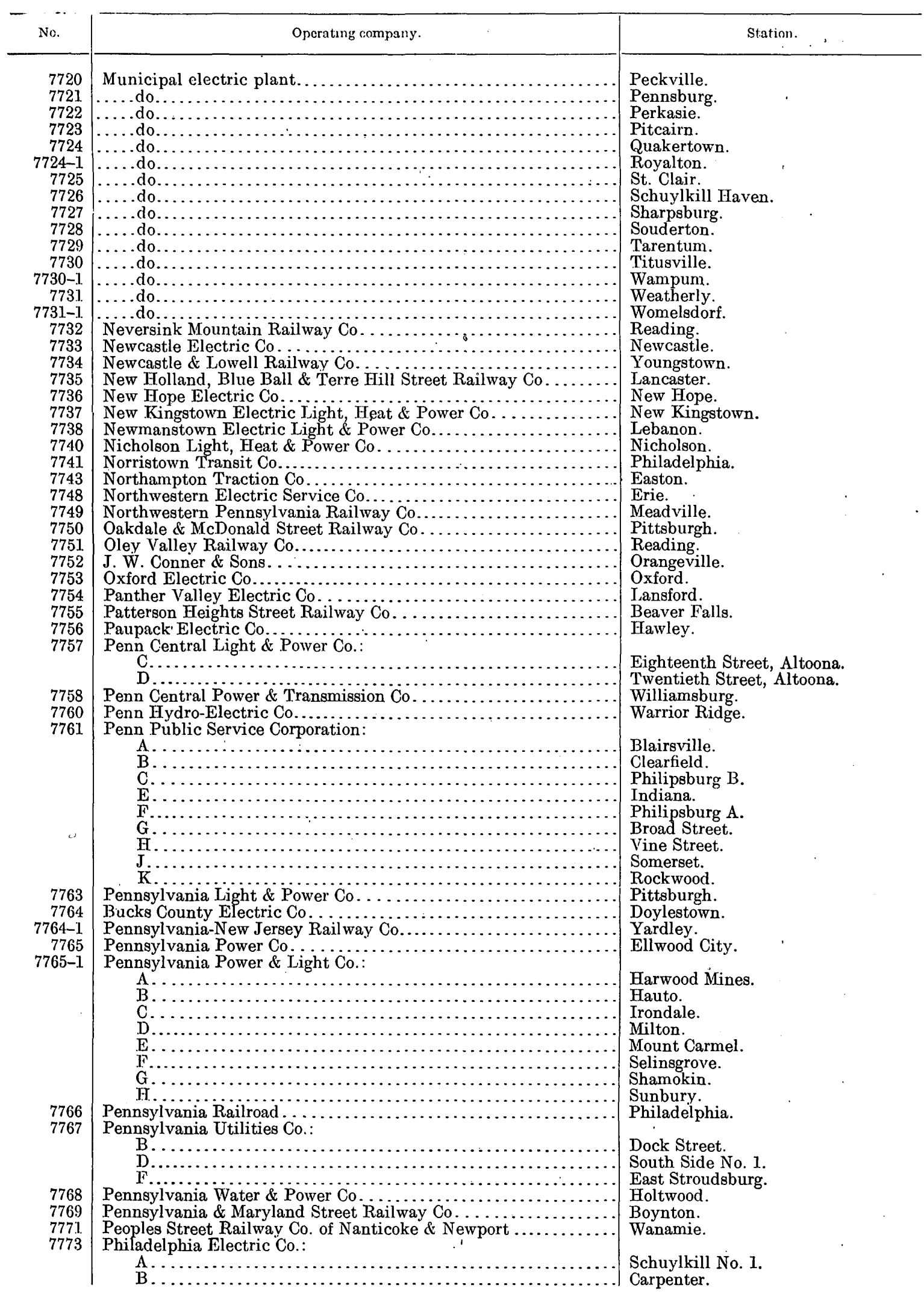


TABLE 100.-Electric-power companies engaged in public service in the States in which the superpower zone is situated-Con.

Pennsylvania-Continued.

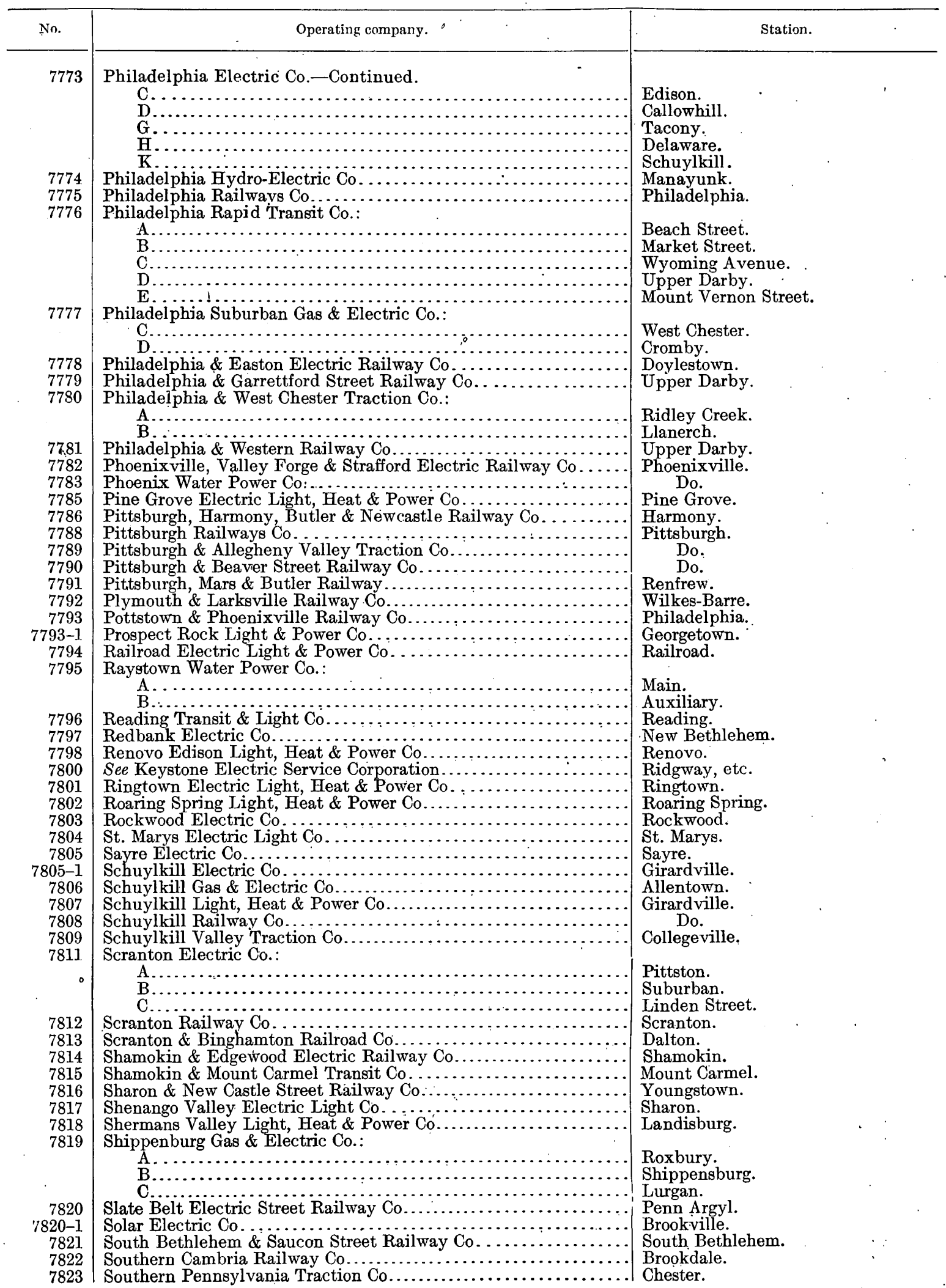


TABLE 100.-Electric-power companies èngaged in public service in the States in which the superpower zone is situated-Con.

Pennsylvania-Continued.

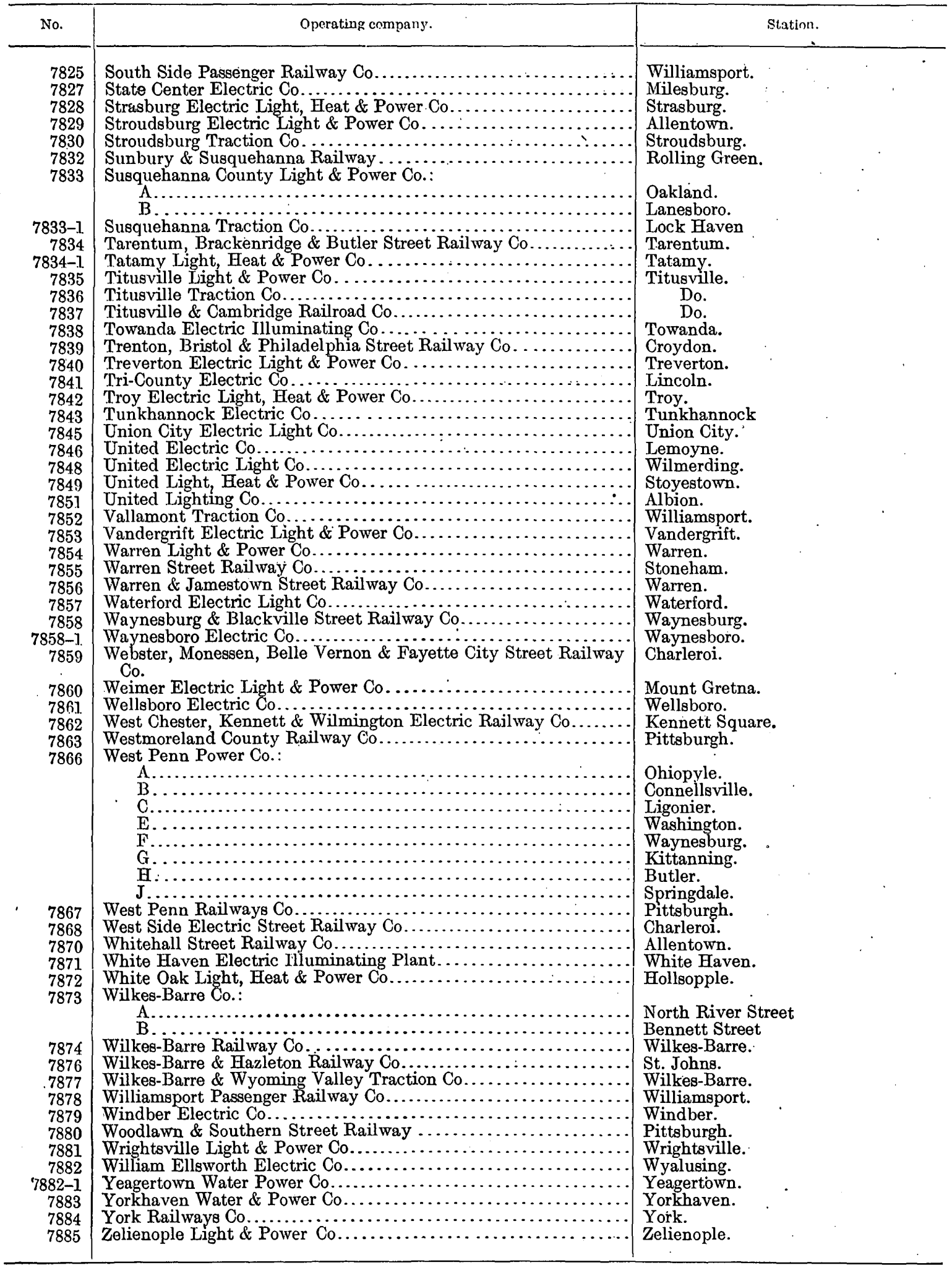


TABLE 100.-Electric-power companies engaged in publuc service in the States in which the superpower zone is situated-Con.

Rhode Island:

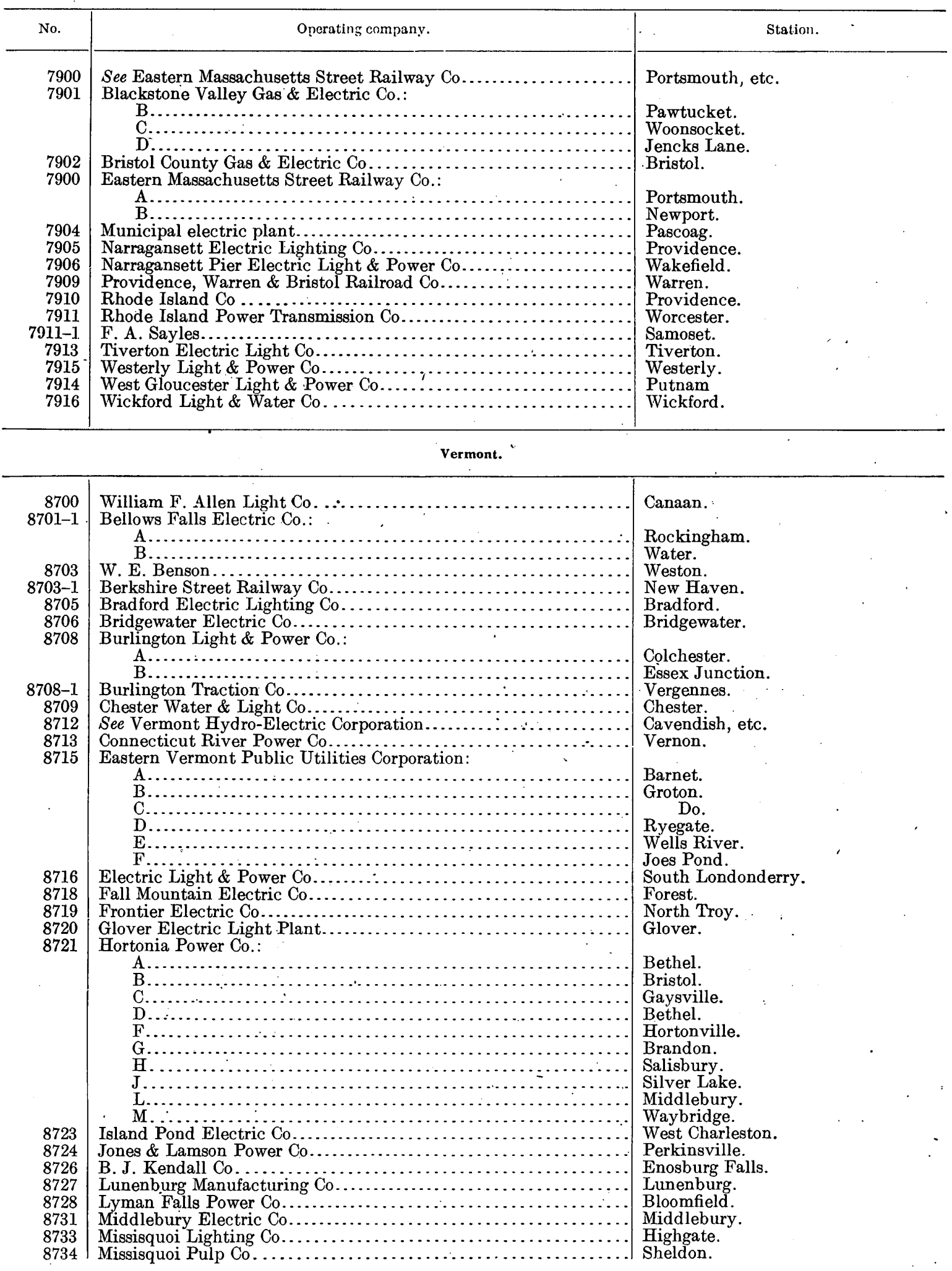


TABLE 100.-Electric-power companies engaged in public service in the States in which the superpower zone is situated-Con.

Vermont-Continued.

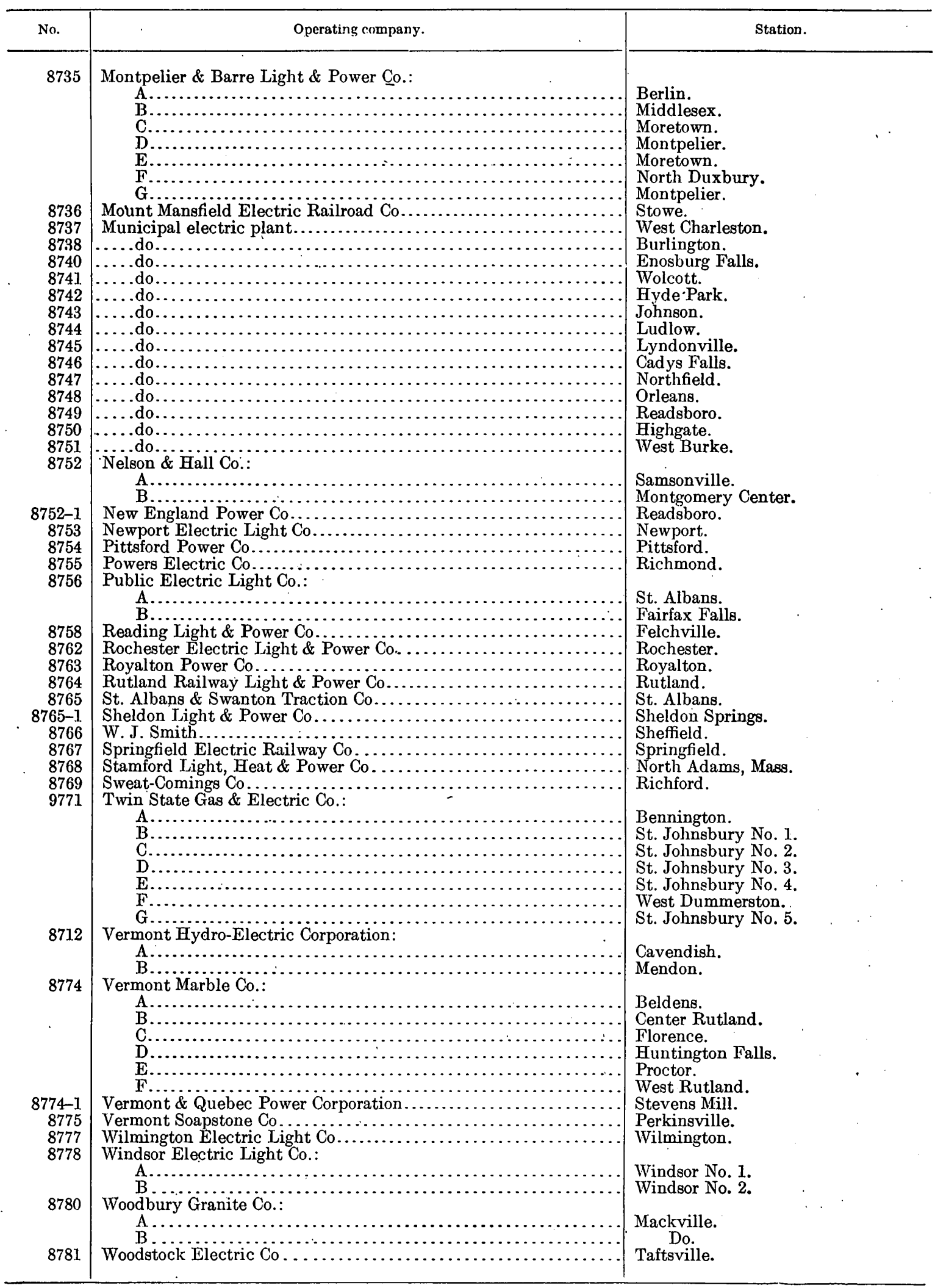


TABLE 100.-Electric-power companies engaged in public service in the States in which the superpower zone is situated-Con. Virginia.

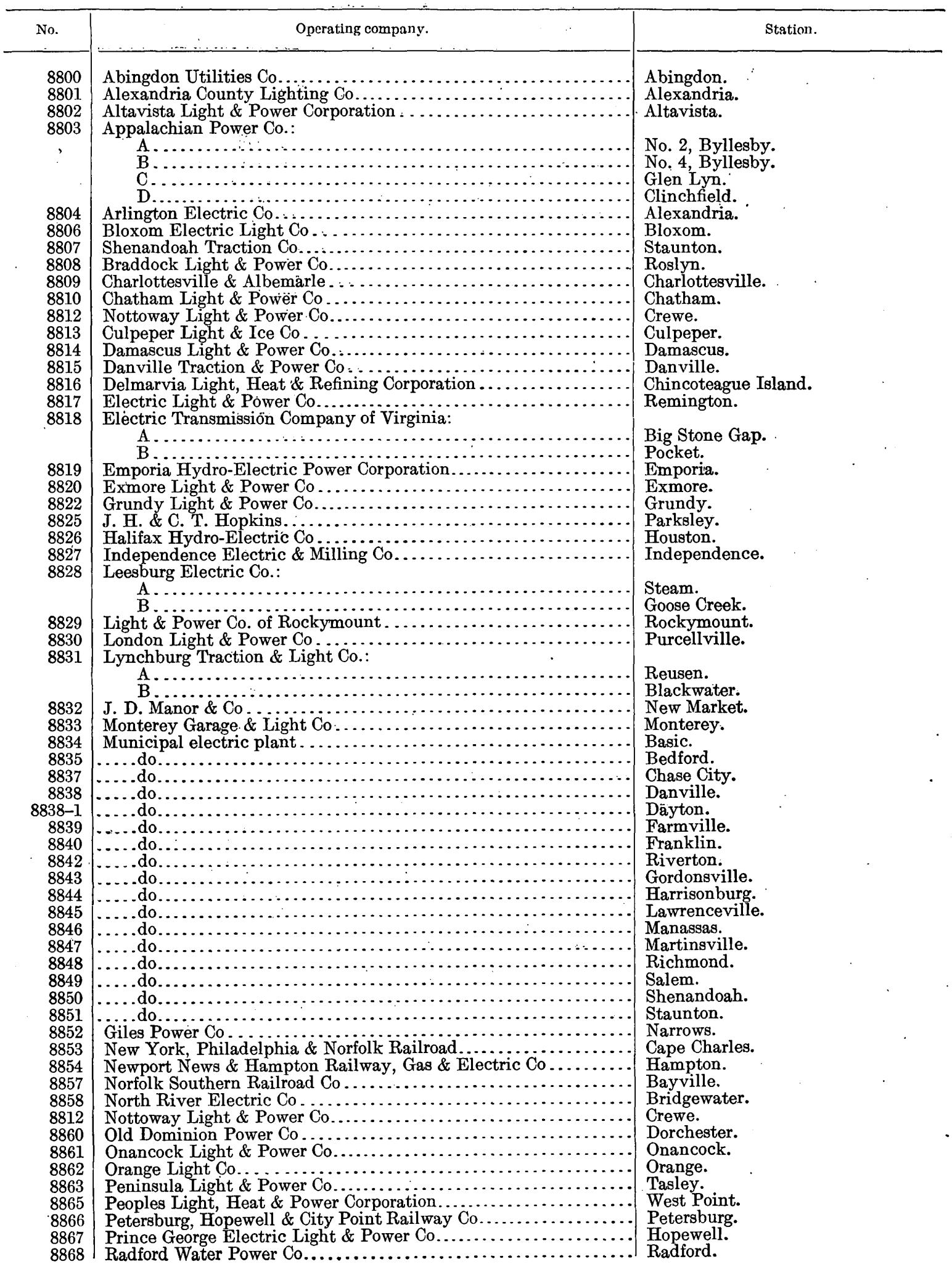


TABLE 100.-Electric-power compunies engaged in public service in the States in which the superpower zone is situated-Con.

Virginia-Continued.

\begin{tabular}{|c|c|c|}
\hline No. & Operating company. & Station. \\
\hline 8869 & 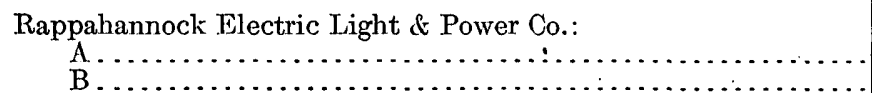 & $\begin{array}{l}\text { Steam, Fredericksburg. } \\
\text { Hydroelectric, Fredericksburg. }\end{array}$ \\
\hline 8871 & 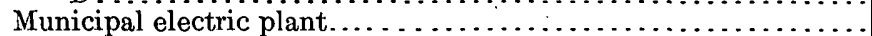 & Richland. \\
\hline $8871-1$ & Richmond-Ashland Railway $\mathrm{Co} . . . . \cdots \cdots$ & Richmond. \\
\hline 8872 & Richmond \& Chesapeake Bay Railway Co. & Do. \\
\hline 8876 & Riverside Light \& Power Co................ & Waynesboro. \\
\hline 8877 & $\begin{array}{l}\text { Roanoke Railway \& Electric Co.: } \\
\text { A } \ldots \ldots \ldots \ldots \ldots \ldots \ldots \ldots\end{array}$ & $\begin{array}{l}\text { Niagara. } \\
\text { Roanoke. }\end{array}$ \\
\hline 8880 & 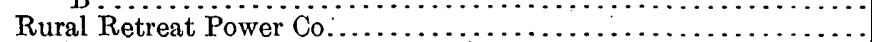 & Rural Retreat. \\
\hline 8881. & Shenandoah River Light \& Power Corporation. & Luray. \\
\hline 8807 & Shenandoah Traction Co................... & Staunton. \\
\hline 8882 & Smithfield Light \& Power Co..... & Smithfield. \\
\hline 8883 & South Boston Power Co........... & South Boston. \\
\hline 8884 & South Fill Manufacturing Co.... & South Hill. \\
\hline 8885 & Spottsylvania Power Co........... & Fredericksburg. \\
\hline 8886 & Stanley Milling Co............... & Stanley. \\
\hline 8887 & Staunton Lighting Co . . . . . . . . . & Staunton. \\
\hline 8889 & Tazewell Electric Light \& Power Co.... & Tazewell. \\
\hline 8890 & Tazewell Street Railway Co........... & Do. \\
\hline $8890-1$. & Victoria Ice, Light \& Power Co... & Victoria. \\
\hline 8891. & Valley Light \& Power Co........ & Woodstock. \\
\hline 8892 & $\begin{array}{r}\text { Virginia Alberene Corporation: } \\
{ }_{A}^{A}{ }_{B} \\
C \\
C\end{array}$ & $\begin{array}{l}\text { No. 1, Schuyler. } \\
\text { No. 2, Schuyler. } \\
\text { No. 3, Schuyler. }\end{array}$ \\
\hline 8898 & Warrenton Electric Light \& Power Co & Warrenton. \\
\hline 8899 & Washington \& Old Dominion Railroad Co....... & Rosslyn. \\
\hline 9899-1. & 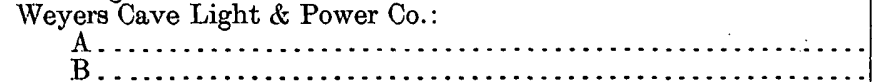 & $\begin{array}{l}\text { Rockland. } \\
\text { Grottoes. }\end{array}$ \\
\hline $8899-2$ & Woodstock Electric Light \& Power Co $\ldots \ldots \ldots \ldots \ldots \ldots \ldots \ldots \ldots \ldots \ldots \ldots \ldots$ & Woodstock. \\
\hline 8899-3 & Waverly Light \& Power Co $\ldots \ldots \ldots \ldots \ldots \ldots \ldots \ldots \ldots \ldots \ldots \ldots \ldots \ldots \ldots \ldots$ & Waverly. \\
\hline
\end{tabular}

$63361^{\circ}-21-17$ 


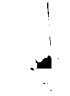




\section{INDEX.}

A. Page.

Acknowledgments for aid and information........ 10,20,25,28-31, 58 $\begin{array}{ll}\text { Advisory board, appointment and work...................... } & 10 \\ \text { Alexander, Magnus W., service on the advisory board.......... } & 27\end{array}$ Allentown, Pa. See load centers in tables.

Altornating-current system, advantages and disadvantages..... 18 Anthracito coal. See Coal, anthracite.

Anthrncito coal fields, steam-electric plants in, character and quantity of coal available..................... 189-190

steam-clectric plants in, cost of energy.

$$
\text { sites suitable. }
$$

Anthracite

Anthracite division, diversity from Metropolitan and Southern divisions.......

Approprintion, Government, amount and conditions............ 9,31

Archbold,. Area to be supplied, limits ....................................

Armstrong, A. H., expert service..

Assigned locomotives, definition ............................

Automobilo manufactories, power-supply equipment and fuel $112-113,142$

\section{B.}

Bakcries, power-supply equipment and fuel used. $90-91,142$

Baltiniore, M.d., hydroelectric plant needed near................. See also load conters in tables.

Barstow, W. S., expert service..............................

Base-load plant defined

Baso loads, new plants to carry

coal fiolds, steam-electric plantsa ot now leasible...

sites for future steam-electric plants. ...

Black River, hydroelectric development................... 198-199

Blast furnaces, isolated, saving of waste gases................. 144 power-supply equipment and fuel used................ 98-99, 142

Boston, Mass., steam-electric power plant needed near............ 13 Sce also load centers in tables.

Bradford, H. B., expert service.............................

Breckonridgo, Lester P., member of committee appointed by Engineering Council.

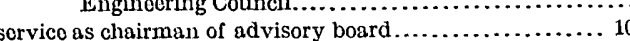
Bridgoport, Conn., steam-electric plantneeded near............... Sce also load centers in tables.

Brockton, Mass. Sec load centers in tables.

Buckland, Edward G., service on the advisory board. suggested superpower survey

(n.......................

Butler, Henry $W$, service as a division ongineer.

Goodwin, H., jr., and others, industry in the superpower zone.

$$
\text { - }
$$

c.

Capacity, effoctive, defined

Capacily factor defined ................................. Capital, amounts required in 1919, 1925, and $1930 \ldots \ldots 12,17,21-22,166,168$ estimated earnings................................. 12 intorest cost.....................................20,220 See also Investment.

Car manufacturing not by railroads, power-supply equipment and fucl used............................... 114-115, 142 Carpet and rug industries, power-supply equipment.and fuel used ................................... 94-95, 142

Catenary system, cost of installation . . . . . . . . . . . . . . . . . $68-69$ Cement industries, power-supply equipment and fuel used ... 108-109, 142 saving of conl.

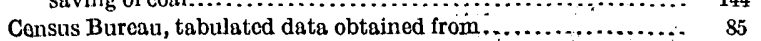

Page.

fixed, percentages.................................. 220 Chemical industries not otherwise specified, power-supply equipment and fuel used....................... 108-109, 142 Clay industries, power-supply equipment and fuel used..... 110-111, 142 Clothing industries, power-supply equipment and fuel used.... 96-97, 142 Coal, availability

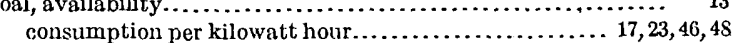

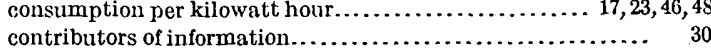
equivalent, meaning and estimates..................... 63 ownership of mines and facilities for delivery . . .......... 25, 222 pulverized, provision for use........................... 224 pulverized, provision for use................................... 46,48

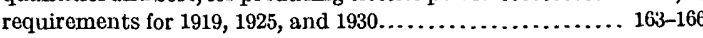
saving expected................................. 12,62-63, 163 saving in cement industry........................... 144 storage $\ldots$ anthracite, cost and quantity required for steam-electric plants...

$25,220-221$ distribution and use................................. 219 quantity available for steam-electric plants.......... 189-190 bituminous, cost........................ 25, 220, 221-222 cost, how determined ................................. cost, how determined
distribution and use......................................... districts and delivery routes....................... 219-220 map showing power plants using, performance and operating cost.......46,47 See also Fuel.

Coal by-products, contributors of information................ 30 Coal mines, anthracite, fuel used ......................... 144 ownership..................................... 222 Coke ovens, power-supply equipment and fuel used.......... 106-107, 14 Communication, facilities. ................................. 214 Conclusions summarized . ................................ 12-13 Connecticut, electric-power companies engaged in public service. 228-229 power-supply equipment of industries. . ............... 126-129 Connecticut River, hydroelectric development. . . . . . . . . . . 24, 199-200 Construction, overhead charges............................. 220

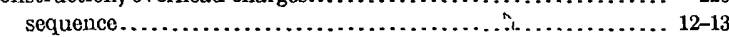
Contributions of money, acceptance authorized.............. amount............................................ 10 Cost, operating, defined..................................... 15

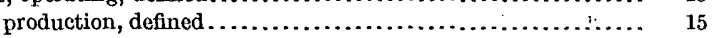
reproduction, defined ................................... 15 transmission system, defined .......................... 16 Cost of power, use of term .............................. 12 Cost of power delivered, definition. ........................ 15 Cost of power produced by steam-electric plants in the anthraciteCost of power produced by the superpower system compared with cost if produced by independent electric utilities. 22, 168-181 Cost of the superpower system..................... 20-22, 148-181 Cotton goods, small wares, and lace industries, power-supply equipment and fuel used................... 92-93, 142 D.

Definitions of terms used........................... 15-16 Delaware, power-supply equipment of industries.............. 138-139, Delaware River, hydroelectric development............ 13, 24, 196-197 Delivery routes for coal in 1930 , map showing.................... 220 Demand for power, Franklin K. Lane on........................ 9

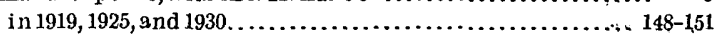
Depreciation and obsolescence........................... 226 Direct-curren t system, advantages and disadvantages............ is District of Columbia, electric-power companies engaged in public service..................................... 229 water-supply equipment of industries............... 138-139 
Diversity range and Page. three kinds defined.

Diversity economy, defined. importance.

Divisions, geographic.

Dyeing and finishing industries, power-supply equipment and fuel usēd.

Economy, expectation from coordinating electric utilities expectation from electrifying railroads $2-63,66-67,75-78,80,81-83$

expectation in industries $2,19-20,144,145-147$ means for attaining

Economy, diversity, defined

Edgar, Charles L., service on the advisory board ..................

Electric power, alternating-current and direct-current systems compared.

cost to railrogds.

Electric-power companies engaged in public service, names and addresses................................ 227-255

Electric power plants, future, proper locations.................

Electric utility load, distribution.

distribution, plate showing

growth.

plate showing.

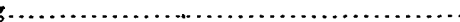

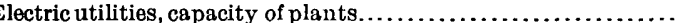
capital required

existing, status in 1919 .

steam plants to be retained in the superpower system

Electrical machinery industries, power-supply equipment and fuel used .............................. 118-119, 142

Electrification of heavy-traction railroads, advantages......... 51-52

Energy. See Power.

Engineering'staff, personnel selection.

Equipment, motive-power, standardization for railroads

Expense, general, defined.

general, items included..

relation to gross revenue ........................... 26,226

Explosives manufactories, power-supply equipment and fuel used................................ 106-107, 112

F.

Fabrics and materials not otherwise specified, manufactories of, power-supply equipment and fuel used:........ 96-97, 142

Factor, capacity, defined

diversity, defined

load, defined

Factories. See Industries.

Finance, contributors of information.............

Fixed charges, definition. percentages.

Flood, Henry, jr., service as engineer-secretary.

and others, Steamielectric plants for the sur

Wellwood, A. R., and others, Performance and cost of the superpower system..

Flour-mill and grist-mill industries, power-supply equipment and fuel used ............. 90-91, 142

Foods not otherwise specified, manufactories of, power-supply equipment and fuel used ................... 92-93, 142

Foran, George, expert service.

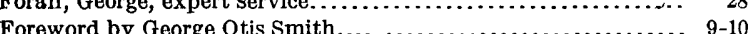

Frequency, cost of equipment for 60-cycle and 25-cycle......... 153 standard, considerations affecting choice...........16, 21, 152-153

Frequency-changer stations, cost..................... 215-216

Fuel, process, employment . . . . . . . . . . . . . . . . 25. 223 process, provision for use ........................... 185 sources and cost..................................... 223, 225 See also Coal.

Funds. Sce Appropriation, Money.

Furniture and lumber products not otherwise specified, manufactories of, power-supply equipmentand fuei used. 100-101,142
Page.

Gas, use in internal combustion engines $\ldots$ Gas-works, power-supply equipment and fuel used...... 106-107, 142 Generating capacity required under independent and under superpower operation ....................... 17, 46

Glass industries, power supply equipment and fuel used.. 110-111, 142 Goodwin, Harold, jr., service as an assistant division engineer.. 27 Butler, H. W., and others, Industry in the superpower zone 85-147 Government institutions, power-supply equipment and fuel

$$
\text { used. }
$$

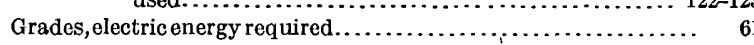
Grover, N. C., service as hydraulic engineer and in administration 10,27 $\mathrm{H}$.

Hanker, F. C., expert service............................

Hardin, A braham T., service on the advisory board ...............

Harrisburg, $\mathrm{Pa}$. See load centers in tables.

Hartford, Conn. See load centers in tables.

Hazleton, Pa. See load centers in tables.

Hood, O. P., service as member of engineering staff......... 10,27 and others, Use of process fuels and pulverized coaI for base-

load steam-electric plants...................223-225

Hoover, Herbert, service on the advisory board.................

Horton, A. H., Stations and transmission lines of electric-power

Hudson River, hydroelectric development.............. 24, 197-198

Hudson River region, power plants needed ................. 13

Hunt, F. L., expert service ............................. 28

Hutchinson, Dr. Cary T., service as a division engineer........... McPherson, N. C., and others, Proposed electrification of heavy-traction railroads in the superpower zone.....50-83

Hydroelectric plants, advisability . ...................... 192, 193 investment cost................................. 24, 202 types...................................................... 192 existing, capacity and output................................. operating cost.............................. 203 percentage of total power-plant capacity............. 153

performance......................... 43-45

Hydroelectric power, economy from joint use with steam-electric power.................................... 21-22

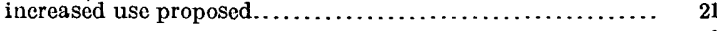
resources......................................... 13

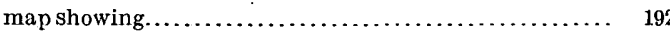

Ice manufacturing, power-supply equipment and fuel used. 118-119, 142 Imlay, Lorin E., service as a division engineer............... 27 The superpower transmission system.................... 204-217 and others, Reliability of service..................... 218 Rutherford, T. B., and others, Electric utilities in independent operation in the superpower zone in $1919 \ldots \ldots . .32-49$ Whitsit, L. A., Peterson, B. J., and others, Hydròclectric plants for the superpower system............... 192-203

Industries, by-product power. .............................. 20 capital required for superpower equipment ............. 12 conservation of coal possible...................19, 20,85, 143,144 contributors of information . ......................... 29-30 economy possible, in cost of power.......... 12, 19, 20, 143-144, 147

in heating and process work...................... 143, 144

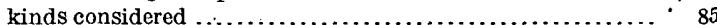
Iocations, plate showing. ................................ 86 miscellaneous, power-supply equipment and fuel used.. 120-121, 142 power, cost.................................. 145-147 quantities developed, purchased, and used ............. 19, 20 power plants, isolated, map showing .................. 86 power-supply equipment used, past and predicted future.... 145 power-supply equipment and fuel used, by character of power supply .................................. 88-89 by industry subgroups......................... 90-123,142 by size of plant................................... $88-89$ summary and analysis ......................... 143-144 statistics affected by changes......................... 86

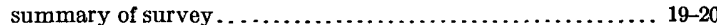
tables, purpose and scope. . ........................ 87

waterworks not included.$\ldots \ldots \ldots \ldots \ldots \ldots \ldots \ldots \ldots \ldots \ldots$ Insull, Samuel, early contention that power for railroads should be obtained from electric utility plants

\section{.} .

(1)


Insurance, estimate.

Interest, rate necessary to attract capital

Page.

See also Capital.

Iron and stcel industries not otherwise specified, power-supply cquipment and fuel used........... 100-101, 142

Iron smelters, saving of waste gases.

J.

Jackson, D. C., momber of committee appointed by Engineering Counctl.

\section{$\mathrm{K}$.}

Kelly, Col. William, service on the advisory board

Knitting industries, power-supply equipment and fuel used.. 92-93, 142$$
\text { L. }
$$

Lanc, Franklin K., conference with on the demand for power.

recommended appropriation for survey

Loundries, power-supply equipment

Law, contributors of information. ....................... 30-31

Leather-goods industries, power-supply equipment.and fuel used. 102-

Leather production; power-supply equipment and fuel used . 102-103,142 Lee, Nlisha, service on the advisory board.

Leeper, John B., expert service.

.............. Council.

Lesher, C. E., Tryon, F. G., and others, The relation of coal and coal-delivery routes to the superpower system......219-222

Lincoln, P. M., expert service.

Liquor and beverage industries, power-supply equipment and fuel used ................................. 104-105, 142

Little, Arthur D., service on the advisory-board................ 27

Load, decentralization possible.

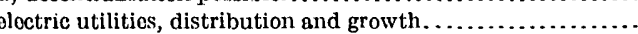
distribution and growth, plates showing.............. 34,35

growth, annual rate ................................. 16 past and estimated future.......................... 154

Load centers, location.

Load factor, defined.

trond, past and ostimated future.

Locomotives, assigned, definition......................... 15

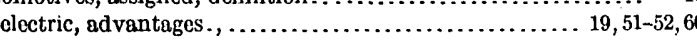
classes....................................... 52-53 cost...................................................... cost of maintenance..............................65-66 energy used ......................................... locomotive hours.

mileage.

number required for service as in $1919 \ldots \ldots \ldots \ldots \ldots . . . .70$

not by railroads, power-supply equipment and fuel used.. 98-99, 142

steam, cost of maintenance..........................64-65 disadvantages. .............................. 51-52,60

locomotivo hours.............................. $71-72$

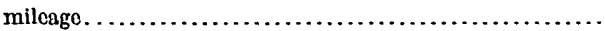

reloased value.

weight on drivers.

.

Sec also load centers in tables.

Lumber industries, power-supply equipment and fuel used .. 100-101, 142 M.

McGraw, James H., service on the advisory board.

MacLaren, Malcolm, service as an assistant division engineer.....

McPherson, Norman C., service as an assistant division engineer..

Futchinson, Cary T., and others, Proposed electrification of

heavy-traction railroads in the superpower zone..... 50-83

Maine, eloctric-power companies engaged in public service...... 229-231

water-power resources............................... 201

Manufactures. See Industries.

Market for superpower energy in 1930 .

Maryland, olectric-power companios engaged in public power-supply equipment of industries................. 140-141 Massachusetts, eloctric-power companies engaged in public service. 232

power-supply equipment of industries.
Metal-product manufactories, miscellaneous, power-supply equipPage. ment and fuel used........................116-117, 142

other than iron and steel, power-supply equipment and fuel used................................... 112-113, 142 Metal smelters other than iron and steel, power-supply equipment and fuel used........................... 110-111, 142

Mines, except anthracite, and quarries, power-supply equipment and fuel used............................. 122-123.142

Mining regions. See Anthracite coal fields and Bituminous coal fields.

Money for superpower survey, amount appropriated....... 31

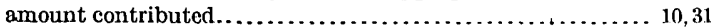
See also Capital.

Murray, W. S., appearance before House Committee on Appropriations

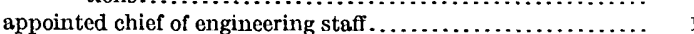

report on Organization

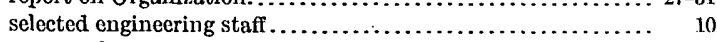

suggested superpower survey........................... 9

Summary report $\ldots \ldots \ldots \ldots \ldots \ldots \ldots \ldots \ldots \ldots \ldots \ldots \ldots, \quad 11-26$

N.

Nesbit, William, expert service.

Newark, N. J. See load centers in tables.

New Bedford, Mass. See load centers in tables.

.New Brunswick, N. J. See load centers in tables.

Newburyport, Mass., steam-electric power plant needed near..... 13 See also load centers in tables.

New England Power Co., equipment..........................

New Hampshire, electric-power companies engaged in public service.................................... 235-236 power-supply equipment of industries..................... 124-125 New Haven. Conn., steam-electric plant needed near............ 13 See also load centers in tables.

New Jersey, electric-power companies engaged in public service. 236-238 power-supply equipment of industries................ 132-135

Newlin, E. M., service as an assistant division engineer. . . . . . 27

New York, electric-power companies engaged in public service.. 238-245 power-supply equipment of industries................. 128-133

New York City, concentration of load.......................... 16 diversity among four utility companies.................. 154 See also load centers in tables.

New York Central Railroad, early provisions for electromotive power.....................................

New York, New Haven \& Hartford Railroad, early provisions for

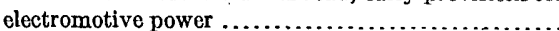

New York, Ontario \& Western Railway omitted from survey .... 75

Niagara River, additional development..................... 201

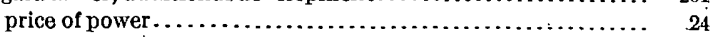
use of power in $1932 \ldots \ldots \ldots \ldots \ldots \ldots \ldots \ldots \ldots \ldots \ldots \ldots . \ldots \ldots \ldots \ldots \ldots \ldots, 164,170$

Northampton, Mass. See load centers in tables.

Norwich, Conn., steam-electric plant needed near ............ $\quad 13$ See also load centers in tables.

O.

Obsolescence and depreciation............................ 226

Oil, use for power to remain small...........................

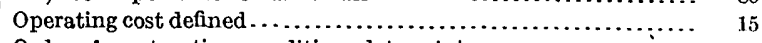

Order of construction, conditions determining.................. 12

schedule advised $. . . \ldots \ldots \ldots \ldots \ldots \ldots \ldots \ldots \ldots \ldots \ldots \ldots, 13$

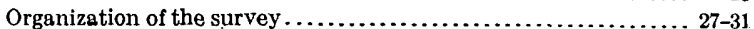

$P$.

Paper and wood-pulp mills, power-supply equipment and fuel

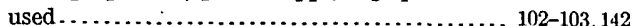
Paper manufactures, power-supply equipment and fuel used. 104-105, 142 Pardee, John H., service on the advisory board.............. 27 Parsons, William Barclay, expert service.................. 28

Paterson, N. J. See load centers in tables.

Pattison, Hugh, expert service..................... 28

Payne, John Barton, appointed advisory board................... 10 Peak demand, volume in 1919, 1925, and 1930......... 148-149, 157-161

Peak-load plant defined $\ldots \ldots \ldots \ldots \ldots \ldots \ldots \ldots \ldots \ldots \ldots \ldots \ldots \ldots, 15$

Peak loads, excess of capacity ............................. 17

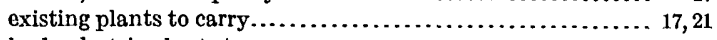
hydroelectric plants to carry ............................. 24 small requirements of energy $\ldots \ldots \ldots \ldots \ldots \ldots \ldots \ldots \ldots \ldots, 16-17$

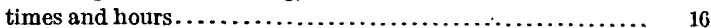


Pennsylvania, electric-power companies engaged in public service...................................... 245-251 power-supply equipment of industries................. 136-139 Performance of the superpower system ...........20-22,148-181 Perkins, Henry C., service on the advisory board............ 27 Peterson, B. J., service as an assistant division engineer.......... Imlay, I. E., Whitsit, L. A., and others, Hydroelectric plants for the superpower system.

. Philadelphia, $\mathrm{Pa}$. See load centers in tables.

Philadelphia Electric Co., Delaware station.

Pittsfield, Mass power plant needed near.... Sce also load centers in tables.

Pittston, Pa., steam-electric plant needed near................ Plant, base-load, defined. peak-load, defined.

Plants, electric, average capacity ......................... 16 existing hydroelectric, capacity and cost......... 14, 156-161, 201-203 reproduction cost............................. 17,49 existing industrial, map showing...................... 86 existing steam-electric, capacity and cost..... 14, 21, 156-161, 182-184 reproduction cost . . . . . . . . . . . . . . . . . . . . . . . 17,49 retention in the superpower system............. 22-23, 182-184 inefficient, elimination . ............................ 157, 169 proposed hydroelectric, location, capacity, and cost....... 24, posed steam-electric, location, capacity, and cost........ 14,

Port Jervis, N. Y. See load centers in tables.

Potomac River, condensing-water supply for a steam-electric plant.................................... 191 hydroelectric development...................... 13, 24, 191, 194-195 Pottery. Sce Clay industries.

Pottsville, Pa. See load centers in tables.

Poughkeepsie, N. Y., power plant needed near................. See also load centers in tables.

Power, advances in the art of production. capacity of present and new steam-electric and hydro-electric plants................................21,156-16 cost per kilowatt hour.

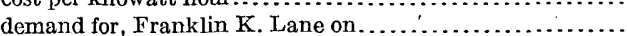
hydroelectric, production cost.......................... 48-49 kilowatt hours required by isolated industries in 1919...... 144-145 kilowatt hours required in 1919,1925 , and $1930 \ldots \ldots \ldots \ldots$. $148-151$ purchase by industries . ........................... 19-20 relative cost of producing by large and small units......... 17 steam-electric, production cost....................... 48-49

Power delivered, cost of, defined .

Power plants. Sce Plants, hydroelectric, and Plants, steamelectric.

Power stations used in public service, map of northeastern United States showing........................... In pocket. Poxer-supply equipment by counties . . . . . . . . . . . Pragst, Ernest W., expert service.

Printing and publishing, power-supply equipment and fuel used ............................ 104-105, 142

Production, contributors of information.......................... $28-29$ present and future facilities ........................... 156-161

Production cost, defined ............................... 15 under independent and under superpower operation.........

Providence, R. I. See load centers in tables:

Purchase of power, economy.

R.

Radio communication.

Railroad, electric, repair shops, power-supply equipment "and fuel used. steam, repair shops, power-supply equipment and fuel used.. 114-

Railroads, class 1, coal used by steam locomotives............. 58 class 1 , defined ...................................... electric operation on selected divisions $\ldots . \ldots 0,81,82$ inquiries concerning........................... 54-56 ist. . map showing principal data.
Railroads, steam locomotives in service. class 1 , steam-operated tracks. steam operation on selected divisions............. $79,81,82$

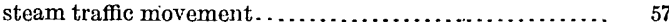
track mileage of selected divisions .................... 79 electric street, percentage of power demand used .............. heavy traction, advantages of electrification............. $51-52$ advantages of unified operation .................... $50-51$ allowance for contingencies in electrification........... 75

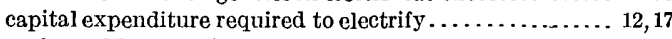
coal saved by electric operation................ 12,62-63,80 contributors of information....................... 30 cost of direct-current feeders........................ $\quad 70$ cost of electric catenary system.................. 6 $68-69$ cost of electric locomotives and number required........ 70 cost of electric substations......................... 69 cost of electrification, total................. 12, 17,67,74 cost of maintaining electric distribution system........ 66 cost of maintaining electric substations................. 66 early experience in electrification................... 17-18 economy, expectation from electrifying. ........ 12, 19,66-67,82 obtained on electrified divisions............... $75-78,80,81$ efficiency of electric operation......................... energy required for electric operation................. $60-61$ electrification proposed........................ 17-19,50-83 extensions and betterments, annual cost................ 19 inquiries concerning electric operation............. 55-56 mileage to be electrified . . ........................ 17 motive power, imminent necessity for increase......... 19 purchase of electric power advised ................. 18, 19 scope of investigation. . ............................. $53-54$ standardizing of motive-power equipment........ 18,52-53 switcherserviec, steam and electric, coal consumption. . 61-62,67 Raquette River, hydroelectric development.................. 198 Reading, $\mathrm{Pa}$. See load centers in tables.

Reliability of superpower service........................ 25, 218

Reproduction cost, defined.

of electric-utility plants compared with cost of superpower

plants.......................................... 17

Rhode Island, electric-power companies engaged in public service. $\quad 252$ power-supply equipment of industries................. 126-127

Rights of way, requirements . . . ......................... 206-207

Rivers, development beyond primary power................. 24 resources for hydroelectric power....................... 192-194 Rubber goods manufacturing, power-supply equipment and fuel used...........................116-117, 142 Rushmore, David B., expert service......................... 28 Rutherford, T. B., service as an assistant division engineer........ 27 Imlay, L. E., and others, Electric utilities in independent operation in the superpower zone in $1919 \ldots \ldots \ldots \ldots \ldots . . . .32-49$

St. Lawrence River, hydroelectric development.............. 200

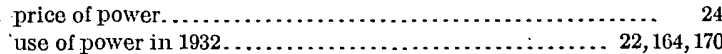
Savings. See Economy.

Schenectady, N. Y., power plant needed near................. 13 See also load centers in tables.

Scranton, Pa. See load centers in tables.

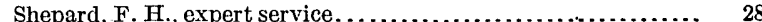
Shipbuilding, power-supply equipment and fuel used...... 118-119, 142 Short circuits, provisions concerning .................... 205 Silk industries, power-supply equipment and fuel used...... 94-95, 142 Sloan, Matthew S., service on the advisory board............. 27 Slaughtering industries, power-supply equipment and fuel used $9 C_{-}$ Smith, George Otis, appearance before House Committee on Appropriations. Foreword by Standardization of motive power equipment for railroads...... 18,52-53 Steam-electric plants, cost in proportion to size................ 23 economy from joint use with hydroelectric plants.......... 21-22 existing, annual production cost...................... 183-184 . capacity and performance.................. 43-45, 46,48, 182 investment cost............................... 182-183 quantities and cost of coal used.................... 46,48 that use bituminous coal nerformance and operating cost. 46,47 
Page.

Stoam-electric plants, new base-load, character location, in the coal-mining regions ................. 189-191 number required in 1925 and in $1930 \ldots \ldots \ldots \ldots \ldots .23$ performance.................................. 185-18 diagrams showing........................... 186 unit investment cost. ........................ 23, 186-187 unit production cost.......................... 23,187-188

Stecl works and rolling mills, power-supply equipment and fuel used ................................... 98-99, 142

Stevens, John A., expert service..........................

Stone products not otherwise specified, power-supply equipment and fuel used............................ 108-109, 142

Stroet railroads, electric, percentage of power demand used........ electric, use of 25 -cycle energy ...........................

Substations, elcctric, capacity requirements for 1919,1925 , and 1930.

eloctric, design and equipment. investment cost.

operating cost.

Sugar reftneries, power-supply equipment and fuel used..... 92-93,142

Summary of appendixes, by W. H. Murray .................. 16-26

Summary report.

Sunbury, Pa., steam-electric plant needed near

Superpower, origin of the term.

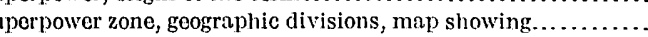

limits.......................................... 13,55

map of the northeastern United States showing........... 12

Susquehanna River, condensing-water supply for a steam-electric plant................................... 191

hydroelectric development. .... $13,24,195-196$

System, electric, choice for railroads.

T.

Tapping of transmission system, minimum load. .

Taxes, estimate.

Terms used, definitions.

Territory covered by the survey.

Textile industries not otherwise specified, power-supply equipmont and fuel used.......................... 98-99,

Thomns, Percy H., expert service.

Timo occupied by the survey

113,142
$112-$

Ton-miles, total, defined 16

trniling, defined.

Traction, heavy, contributors of information................ 30

Traflic, donsity, a controlling factor in railroad electrification......

Transmission, contributors of information.................. 2\$-29

Transmission lines, existing, inquiries concerning.

existing, map of northeastern United States showing.... In pocke mileage and utilization........................... 24, 20

superpower, design............................. 205-206 mileage and routes needed in 1919,1925 , and $1930 \ldots \ldots \ldots .162$ porformance, methods of calculating................ 207-214

Trausmission system, superpower, extent and capacity ......... 24-25

superpower, in 1925 and 1930, maps showing.

interconnecting lines. . . investment cost, percentage of investment cost of super-

power system
operating cost...

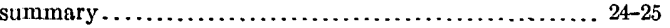

unit investment cost.

$215-216$
Transmission system cost, definition.

Page. Trenton, N. J. See load centers in tables.

Tryon, F. G., Lesher, C. E., and others, The relation of coal and coal delivery routes to the superpower system...... 219-222

U.

Ulster \& Delaware Railroad omitted from survey.

Unit investment cost of power plants...

United Flectric Light \& Power Co. early contract with, lor plo for New Haven road................................. Hell Gate station.

United States Geological Survey, water-resources branch of, administrative work

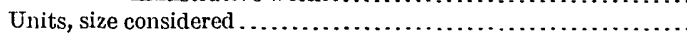

Users of power, number, in the superpower zone ................

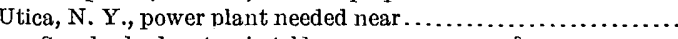
See also load centers in tables.

Utilities, electric, existing, capacity of power plants........... 42 electric, existing, demand for power...................... 32,33

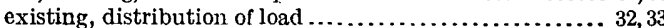

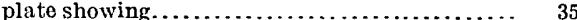

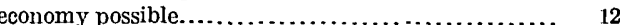

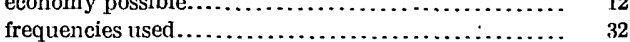

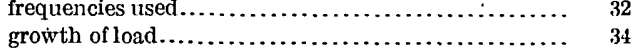
plate showing............................. 34 loads carried on typical days, Saturdays, and Sundays. 34-41 number of power-generating units of different sizes... 42,43 number of power plants of different capacities....... 42,43 output of power............................. 32 performance of power plants.................... 43-46 production cost of power provision for peak loads $\ldots \ldots \ldots \ldots \ldots \ldots \ldots \ldots \ldots \ldots \ldots \ldots, \quad 34,49$ quantities and cost of coal used in power plants...... 46, 48 reproduction cost of power plants ............... 17,49 $\checkmark$.

Varney, Theodore, expert service............................ 28 Vehicle manufacturing not otherwise specified, power-supply equipment and fuel used .................. 114-115, 142 Vermont, electric-power companies engaged in public service... 252-253 power-supply equipment of industries............... 124-125 Virginia, electric-power companies engaged in public service.... 254-255 voltages selected. W.

Washington, D. C., hydroelectric plant needed near............ 13 See also load centers in tables.

Waterbury, Conn., steam-electric plant needed near............ 13

See also load centers in tables.

Water-resources branch of United States Geological Survey, administrative work............................ 10

Water power. See Hydroelectric power.

Waterworks, fuel used . ................................. 144

Webster, Hosea, expert service............................ ${ }_{28}$

Wellwood, Arthur R., service as an assistant division engineer.... 27

Flood, Henry, jr., and others, Performance and cost of the superpower system

Western Mryland Railway omitted from survey ............ 148-181

Whitsit, Lyle A., service as an assistant division engineer........... 27

Imlay, L. E., Peterson, B. J., and others, Fydroelectric plants for the superpower system............... 192-203

Wilkes-Barre, Pa. See load centers in tables.

Wilmington, Del. See load centers in tables.

Withington, Sidney, expert service.

Woolen industries, power-supply equipment and fuel used . . . $94-95,142$

Worcester, Mass. See load centers in tables. 